\title{
Developmental State:
}

\section{The Politics of Business, Poverty, and Economic Empowerment} from the New Deal to the New Democrats

\author{
Randall Brentson Cebul \\ Brooklyn, New York
}

Master of Arts, University of Virginia, 2008

Bachelor of Arts, Hamilton College, 2003

A Dissertation presented to the Graduate Faculty

of the University of Virginia in Candidacy for the Degree of

Doctor of Philosophy

Department of History

University of Virginia

August 2014 
Cebul

\section{Table of Contents}

Table of Contents 1

Acknowledgments $\quad 2$

List of Abbreviations $\quad 4$

Introduction Defining the Developmental State 5

Section I: Building the Developmental State, 1932-1965

Chapter 1 Working for New Deal and Wartime Development in Georgia 44

Chapter 2 The Best Location in the Nation: Cleveland's Elite in New Deal and War 126

Chapter 3 “It Didn’t Just Happen:” Planning for Growth in Northwest Georgia 201

Chapter 4 Renewal and Revolt: The Boundaries of the Developmental State 277

Section II: Deregulating the War on Poverty, 1965-1975

Chapter $5 \quad$ Deregulating the War on Poverty in Cleveland 341

Chapter $6 \quad$ Deregulating the War on Poverty in Georgia 409

Section III: Business Producerism and Developmental States, 1965-1995

Chapter 7 Business Producerism / Urban Populism in Cleveland 466

Chapter 8 Competitive Federalism: The Southern Growth Policies Board, the Politics of Inflation, and the Origins of "New" Democrats 522

Chapter $9 \quad$ Cleveland's Public-Private Governance in an Era of Market Speak 577

Chapter 10 Developmental States: New Democrats and the New Economy 641

$\begin{array}{ll}\text { Epilogue } & 709\end{array}$

$\begin{array}{ll}\text { Bibliography } & 738\end{array}$ 


\section{Acknowledgments}

A number of institutions generously supported my research and writing. These include the Gerald R. Ford Presidential Library, the John Anson Kitridge Educational Fund, the Bankard Fund for Political Economy, the Institute of the Humanities and Global Cultures, the Hagley Museum and Library, the Eisenhower Institute, and the Miller Center. The Corcoran Department of History and U.Va.'s Graduate School of Arts and Science also provided critical summer research funds.

I have been fortunate to have a number of wonderful intellectual homes at the University of Virginia. In the History Department, Jennifer Burns, Peter Onuf, Edmund Russell, Mark Thomas, and Olivier Zunz have been inspiring teachers, generous readers, and incisive commenters. Claudrena Harold is a powerful teacher, probing questioner, and always a breath of fresh air. Conversations with Grace Elizabeth Hale rank among the most stimulating and inspiring moments of graduate school, and she quite literally set me on the course that resulted in this dissertation. At critical moments, Michael Holt and Philip Zelikow delivered generous support for and outsized faith in this project. Jenni Via always had the answer. At the Institute for Advanced Studies in Culture, Josh Yates and the Thriving Cities and New Spirits of Capitalism teams continue to challenge me and inspire new ways of thinking about historical problems. The Miller Center's many scholars and staff have been essential for my intellectual development. Since my first year in graduate school, Guian McKee has been a generous reader and friend. Sidney Milkis and Vesla Weaver helped introduce me to the world of APD. Connections to and collaborations with years of Miller Center Fellows have enriched my work in incalculable ways. Most importantly, however, the Miller Center is home to the most indefatigable, supportive, good-humored, and astute advisor a graduate student could wish for. Though he warned me against producing yet "another history of conservatism," Brian Balogh's encouragement of both the project and my professional development has been steadfast. Having read every word I've produced, Brian continues to be an unmatched resource, advocate, confidant, mentor, model, and friend. I am so grateful to him.

This project would never have come together were it not for the generosity of many many friends and family members who offered couches and guest rooms - and, most importantly, wonderful diversions when I slunk in from the archives. Justin Bain and Brooks Batcheller, in particular, repeatedly welcomed me into their homes in Los Angeles and Atlanta for literally weeks on end. On shorter research trips and on the conference circuit, I looked forward to spending evenings 
Cebul

with so many: Dan and Adrienne, Dan and Annie, Dennis and Lisa, Doug and Dani, Fabrizio, John and Eleanor, Sasha, Scott and Julie, and the Zieglers. In Cleveland, Taras Szmagala spent hours with me explaining the city's white ethnic politics, his family's history, and making vital connections. Likewise, George and Irene Harper welcomed me into their home in Rome, Georgia, told so many stories, and introduced me to many other Romans. Thank you all.

I have greatly benefitted from the insights and criticism of many scholars who have read and commented on my work. These include Lizabeth Cohen, Gareth Davies, David Freund, Lily Geismer, Louis Hyman, Richard John, Matthew Lassiter, Suleiman Osman, Kim Phillips-Fein, Bruce Schulman, and Ben Waterhouse. Joe Crespino and Jim Sparrow deserve extra thanks for their willingness to read the bulk of the project and offer critical insights and advice for transitioning this behemoth into a book manuscript some humans might actually want to read.

In both Charlottesville and New York, I have enjoyed the camaraderie of a great group of confederate historians including Jaime Allison, Michael Brenes, Bart Elmore, Chris Loomis, Andrew McGee, Laura Phillips-Sawyer, Mason Williams, and Kelly Winck. For the duration, no one has been more important than Stephen Macekura. He helped me maintain my sanity (except during a particular Cavs-Celtics series) and simultaneously played an extraordinary role in my intellectual development. I don't think I would have made it through grad school without our intellectual partnership and our friendship.

I undertook my first historical project in elementary school when I interviewed my grandfather about his experiences in World War II. Without the love and support of my family, and of my grandparents in particular, Bob and Cheer, Ray and Alice, I would never have completed the dissertation, let alone started it. My parents, Mary-Scott and Randy, supported me in every way imaginable, and their love and encouragement inspired me to stick with it - at one precarious moment in particular. They are each models of active and engaged scholars who don't simply seek to understand the world but to make it a better place. It was wonderful to have my brother Kerry in DC, near Charlottesville, and it's even better now that he's just down the street in New York. His dogged work ethic and good humor are a constant source of wonder and inspiration, his friendship a vital source of sustenance and joy. Finally, Katherine Treppendahl has enriched my life in ways I could have hardly fathomed. To have a partner blessed with such grace, encouragement, energy, understanding, intellect, and cheer has been my life's greatest gift. This project is for my family, all of whom I love so much. 
Cebul

\section{List of Abbreviations}

Advanced Technology Development Center, Georgia Tech (ATDC)

Advisory Commission on Intergovernmental Relations (ACIR)

Aid to Families with Dependent Children (AFDC)

Agricultural and Industrial Development Board of Georgia (AIDB)

Appalachian Regional Commission (ARC)

Area Redevelopment Administration (ARA)

Better Home Towns (BHT)

Buckeye Woodland Community Congress (BWCC)

Citizens to Bring Broadway Back (CBBB)

Civil Works Administration (CWA)

Civilian Conservation Corps (CCC)

Cleveland Advanced Manufacturing Program (CAMP)

Cleveland Development Foundation (CDF)

Cleveland Electric Illuminating (CEI)

Community Action Program (CAP)

Community Development Block Grants (CDBG)

Congress of Racial Equality (CORE)

Coosa Alabama River Improvement Association (CARIA)

Coosa Valley Area Planning and Development Commission (CVAPDC)

Council of Economic Advisors (CEA)

Cuyahoga County Relief Administration (CCRA)

Democratic Leadership Council (DLC)

Economic Development Administration (EDA)

Electric Home and Farm Authority (EHFA)

Engineering Experiment Station, Georgia Tech (EES)

General Revenue Sharing (GRS)

Greater Cleveland Growth Association (GCGA)

Health, Education and Welfare, Department of (HEW)

Housing and Urban Development, Department of (HUD)

Helping Our People Educationally (HOPE)

Industrial Development Branch of Georgia Tech (IDB)

Metropolitan Applied Research Center (MARC)

National Association for the Advancement of Colored People (NAACP)

National Association of Manufacturers (NAM)

National Industrial Recovery Act (NIRA) 
Cebul

National Peoples Action (NPA)

National Resources Planning Board (NRPB)

Northwest Georgia Branch of Georgia Tech's Engineering Experiment Station (NGB)

Office of Economic Opportunity (OEO)

Office of Management and Budget (OMB)

President's Appalachian Regional Commission (PARC)

Public Works Administration (PWA)

Reconstruction Finance Corporation (RFC)

Rome Vocational School (RVS)

Small Business Administration (SBA)

Southern Growth Policies Board (SGPB)

Southern Technology Council (STC)

Tennessee Valley Authority (TVA)

Ukrainian National Association (UNA)

Urban Development Action Grants (UDAG)

Waterloo Beach Homeowners Association (WBHA)

West Central Georgia Area Planning and Development Commission (WCAPDC)

Works Progress Administration (WPA) 
Cebul

\section{Introduction:}

\section{Defining the Developmental State}

In the wake of the 2008 financial crisis, conservatives blasted the Obama Administration for devoting part of its stimulus package to funding green energy startups. This limited industrial policy - what conservatives disparaged as government choosing market "winners and losers" backfired for the President when Solyndra, a solar energy company, went bankrupt despite \$536 million in federal loan guarantees. ${ }^{1}$ Appearing outside Solyndra's shuttered headquarters in Freemont, California, 2012 Republican Presidential nominee Mitt Romney called the building "a symbol of gross waste." He blasted President Obama for failing "to understand the basic nature

of free enterprise in America."2 As Romney’s running mate, Wisconsin Rep. Paul Ryan told Fox News, “This is industrial policy and crony capitalism at its worst." Said Paul, "We shouldn’t be picking winners and losers in Washington."3

This was not the first time in American history that conservatives advocating limited government, ostensibly speaking for a broad business constituency, decried foolhardy and anti-

\footnotetext{
${ }^{1}$ For a representative example of the right's criticism of Barack Obama's green energy policy, see, for instance, the online blog of the Heritage Foundation, and in particular, "President Obama's Taxpayer-Backed Green Energy Failures," The Foundry, October 18, 2012. Accessed online: http://blog.heritage.org/2012/10/18/president-obamastaxpayer-backed-green-energy-failures/

2 “Two Locations Chosen to Annoy the Other Side," New York Times, May 31, 2012.

3 Paul Ryan on Fox News Sunday, September 18, 2011, online at: https:/www.youtube.com/watch?v=4G66rI959J8
} 
Cebul

American governmental efforts to steer domestic economic development and industrial

innovation. Just such an outcry killed FDR's National Resources Planning Board. ${ }^{4}$ Forty years

later, another outpouring of laissez-faire sentiment in opposition to national industrial policy

wrought the demise of the Humphrey-Hawkins full employment bill. ${ }^{5}$ As we settle in to the

twenty-first century, and as Americans gaze warily at a European market seemingly in perpetual

crisis, the lesson for many appears to be that, despite its rough patches, the United States'

postwar political economy constituted a resounding victory for an American version of

democratic capitalism. That triumph was forged through limited government and free markets

buoyed by individual entrepreneurial initiative rather than state planning or wealth redistribution.

"Developmental State" argues the opposite. The growth, innovation, and productivity that

characterized many of the heights of the post-New Deal political economy were fundamentally

built through public private partnerships that invited just such government intervention and

redistribution - interventions that local and regional businesspeople sought, shaped, and often

\footnotetext{
${ }^{4}$ On the NRPB, see Alan Brinkley, The End of Reform: New Deal Liberalism in Recession and War (New York: Vintage, 1995); and Philip Funigiello, The Challenge to Urban Liberalism: Federal-City Relations during World War II (Knoxville; University of Tennessee Press, 1978), 163-86.

${ }^{5}$ On Humphrey-Hawkins and the Carter Administration's refusal to pursue industrial policy, see especially Jefferson Cowie, Stayin' Alive: The 1970s and the Last Days of the Working Class (New York: The New Press, 2010), 26288; and Judith Stein, Pivotal Decade: How the United States Traded Factories for Finance in the Seventies (New Haven: Yale University Press, 2010), 165-92.
} 
Cebul

administered. ${ }^{6}$ The largely untold story of the twentieth century American political economy is

one of highly porous boundaries between the public and private sectors and of vigorous but

decentralized, regional, business-led industrial policies. ${ }^{7}$

By exploring the actions of local businesspeople and their political allies in regions

generally taken to be historiographical antipodes - the declining Rustbelt and the ascendant

Sunbelt - "Developmental State" illuminates the halting interregional convergence upon a

common vision of public private partnerships on behalf of growth. ${ }^{8}$ But, the project also

demarcates the highly racialized and normative boundaries that delineated the Developmental

State. From the New Deal to the New Democrats, a local bipartisan consensus reigned that

\footnotetext{
${ }^{6}$ Economists and economic historians have begun to identify the ways governmental intervention, though rarely systematic or transparent, underwrote and protected industrial and economic development throughout the developed world in the $19^{\text {th }}$ and $20^{\text {th }}$ centuries. See Ha-Joon Chang, Kicking Away the Ladder: Development Strategy in Historical Perspective: Policies and Institutions for Economic Development in Historical Perspective (London: Anthem Press, 2002); and Fred Block and Matthew R. Keller, eds., State of Innovation: The US Government's Role in Technology Development (Boulder, CO: Paradigm, 2011). On the many ways in which federal policies absorbed private sector risk and underwrote innovation and growth in the United States, see David A. Moss, When All Else Fails: Government as the Ultimate Risk Manager (Cambridge: Harvard University Press, 2002).

${ }^{7}$ For a thorough introduction into the diverse business history literature that also suggests "the porous boundary" between the public and private sectors, see Philip Scranton and Patrick Friedenson, Reimagining Business History (Baltimore: Johns Hopkins University Press, 2013), 92-6. On businesspeople bringing state provision into their business models, see Stephen B. Adams, Mr. Kaiser Goes to Washington: The Rise of a Government Entrepreneur (Chapel Hill: University of North Carolina Press, 1997); and Bartow J. Elmore, Citizen Coke: The Making of Coca Cola Capitalism (New York: Norton, forthcoming 2014). See also, Kim McQuaid, Uneasy Partners: Big Business in American Politics, 1945-1990 (Baltimore: Johns Hopkins University Press, 1994).

${ }^{8}$ The canonical volume that counterpoises the rise of Sunbelt conservatism and the fall of Rustbelt liberalism is Steve Fraser and Gary Gerstle, eds., The Rise and Fall of the New Deal Order (Princeton: Princeton University Press, 1989).
} 
Cebul

consistently resisted redistribution to address the structural causes of endemic poverty and

unemployment. Instead, Republicans and Democrats argued that growth, individual initiative,

and empowering private sector actors were the best remedies for declining regions and poverty. ${ }^{9}$

By arguing for the antipoverty efficacy of market and nongovernmental actors, they invoked

flimsy tropes of "free markets" and "positive business climates" that fundamentally obfuscated

their policy preferences. ${ }^{10}$ This rhetoric obscured a much more vigorous role for targeted market

\footnotetext{
9 "Developmental State" links the history of post-New Deal developmental politics with the literature on liberals' often ambivalent and halfhearted efforts to address structural and racialized poverty. On poverty and social welfare policy, see Alice O'Connor, Poverty Knowledge: Social Science, Social Policy, and the Poor in Twentieth-Century U.S. History (Princeton: Princeton University Press, 2001); Adolph Reed, Jr., ed., Without Justice for All: The New
} Liberalism and Our Retreat from Racial Equality (Boulder: Westview Press, 1999); Daryl Michael Scott, Contempt and Pity: Social Policy and the Image of the Damaged Black Psyche, 1880-1996 (Chapel Hill: University of North Carolina Press, 1997); and Alyosha Goldstein, Poverty in Common: The Politics of Community Action During the American Century (Durham, NC: Duke University Press, 2012). On the interaction of federalism, development politics, and social welfare provisions, see especially, Ira Katznelson, When Affirmative Action was White: An Untold History of Racial Inequality in Twentieth-Century America (New York: Norton, 2005). On normativity and social provision, see Michael B. Katz, The Undeserving Poor: From the War on Poverty to the War on Welfare (New York: Pantheon Books, 1989).

${ }^{10}$ Because historians have focused on rhetoric, the rise of 'neoliberal' intellectuals, or Ronald Reagan's election in 1980 to explain the rise of the New Right, they have reinforced popular notions that businesspeople and conservatives prefer non-state policies while Democrats, when true to "liberalism," prefer statist solutions. For a similar critique, see Matthew Lassiter, "Political History Beyond the Red Blue Divide," Journal of American History (2011) 98 (3): 760-764. On the rise of market based discourse and ideas, see especially, Angus Bergin, The Great Persuasion: Reinventing Free Markets since the Depression (Cambridge: Harvard University Press, 2012); and Daniel Rodgers, Age of Fracture (Cambridge: Belknap, 2012). Biographers have had more success in linking intellectual or discursive trends with habits and practice, though they generally focus on individuals who generate ideas rather than the ways ideas reflect political action and lived experience. See, for instance, Jennifer L. Burns, Goddess of the Market: Ayn Rand and the American Right (New York: oxford University Press, 2009). For narratives of political history that keep policymaking in view and thus leaven political rhetoric and ideologies, see Brian Balogh, “Making Pluralism 'Great:' Beyond a Recycled History of the Great Society,” in Sidney M. Milkis 
Cebul

interventions, infrastructure spending and direct subsidies, University research and development, and public to private technology transfers that drove innovation and productivity for a broad range of business interests, from entrepreneurs to established firms, while denying public assistance for the poor and marginalized. ${ }^{11}$

While recent works of history and political science point out the vast role government has played in shaping markets, they do not in any systematic way identify how local actors came to "naturalize" or submerge such extensive public interventions. ${ }^{12}$ The primary questions animating

and Jerome M. Mileur, eds., The Great Society and the High Tide of Liberalism (Amherst, MA, 2005), Gareth Davies, See Government Grow: Education Politics from Johnson to Reagan (Lawrence: University Press of Kansas, 2007), and Paul Pierson, Dismantling the Welfare State?: Reagan, Thatcher and the Politics of Retrenchment (New York, 1995).

${ }^{11}$ There is growing interest in public investment in research and development and the turn to a high technology, "knowledge economy." So far, however, these studies have focused mainly on the Universities themselves and less on the broader political justification for the investments and the private sector adjuncts to these University-driven development projects. See especially, Margaret O'Mara, Cities of Knowledge: Cold War Science and the Search for the Next Silicon Valley (Princeton: Princeton University Press, 2005). On business and University research, see also Elizabeth Tandy Shermer Sunbelt Capitalism: Phoenix and the Transformation of American Politics (Philadelphia: University of Pennsylvania Press, 2013), 200-19.

${ }^{12}$ On this dilemma, see especially, William J. Novak, "The Myth of the 'Weak' American State," American Historical Review, 113, no. 3 (June 2008): 752-772. This project offers new insights into a growing body of literature in Policy History, Political Science, and American Political Development that describe as "hidden" or "submerged" federal policies that underwrite a broad range of social and economic goods. See, Brian Balogh, $A$ Government Out of Sight: The Mystery of National Authority in Nineteenth Century America (New York: Cambridge University Press, 2010); Suzanne Mettler, The Submerged State: How Invisible Government Policies Undermine American Democracy (Chicago: University of Chicago Press, 2011); Christopher Howard, The Hidden Welfare State: Tax Expenditures and Social Policy in the United States (Princeton: Princeton University Press, 1999); and Jacob Hacker, The Divided Welfare State: The Battle over Public and Private Social Benefits in the United States (New York: Cambridge University Press, 2002). 
Cebul

this project, then, address significant gaps in the flourishing literatures on conservatism, political economy and capitalism, and the mobilization of business. ${ }^{13}$ How, on the one hand, did businesspeople justify, reconcile, and understand their unprecedented empowerment within the state as well as their contributions to increased state capacity, while, on the other hand, they consistently called for federal retrenchment and free markets? Put another way, how and why have businesspeople and politicians propagated an idealized myth of a weak American state while simultaneously pursuing growth policies that underscore just how mythical that state is?

In answering these questions, "Developmental State" identifies a critical flaw in the Obama Administration's attempts to stimulate a green economy. It did so through highly visible and direct federal expenditures. In contrast, the twentieth century developmental state, with its origins in the New Deal, was constructed through an indirect model of cooperative, intergovernmental fiscal federalism that filtered national tax revenues through state and local governments and across a wide array of policy areas - from overt economic and community development programs to defense spending and antipoverty and regional planning initiatives.

\footnotetext{
${ }^{13}$ In his 2012 presidential address to the Business History Association, Kenneth Lipartito called for renewed attention to business peoples' cultural and material practices. Lipartito, "Connecting the Cultural and Material in Business History," Enterprise \& Society, December 2013, Vol. 14, No. 4, 686-704. For incisive introductions to the historiography of American conservatism that identify the need to investigate political mobilization within the broader contexts of political economy and policymaking, see Kim Phillips-Fein, "Conservatism: A State of the Field," Journal of American History (December 2011, Vol. 98, No. 3), and Julian E. Zelizer, "Reflections:

Rethinking the History of American Conservatism," Reviews in American History (June 2010, Vol. 38, No. 2).
} 
Cebul

Conventionally, analysts often point to Congress' defunding of the NRPB in 1943 as the end of a version of activist government economic and industrial planning - the "end of reform."14 To be sure, the "Social Keynesians" who advocated active and centralized federal policies such as public works, natural resource development, jobs programs, and national economic planning were soon marginalized in national politics in favor of consumer Keynesianism. ${ }^{15}$ But, local politicians and businesspeople who so greatly appreciated New Deal and wartime development spending and strategic regional planning did not end their mobilization or lower their expectations for public support. ${ }^{16}$ Instead, they continued to lobby for federal spending wherever they could get it and, in so doing, created a decentralized arrangement of local, state, and regional economic planning institutions that partnered with business and Universities to deliver the kinds of industrial policy and planning that had been pioneered by the New Deal and Warfare States. $^{17}$

\footnotetext{
${ }^{14}$ Alan Brinkley, The End of Reform. See also, James T. Kloppenberg, The Virtues of Liberalism (New York: Oxford University Press, 1998), 100-123.

${ }^{15}$ Brinkley, The End of Reform; and Lizabeth Cohen, A Consumer's Republic: The Politics of Mass Consumption in Postwar America (New York: Vintage, 2003).

${ }^{16}$ Referring to New Deal works programs as economic or community development programs is an anachronism, but, as Jason Scott Smith has argued, in practice, these programs were important precedents for later programs that were defined more explicitly as "development" initiatives. Smith, Building New Deal Liberalism: The Political Economy of Public Works: 1933-1956 (New York: Cambridge University Press, 2006).

${ }^{17}$ Few historians have recognized the persistence of preferences for industrial policy or of full employment liberalism at the local level. One significant exception is Guian A. McKee, The Problem of Jobs: Liberalism, Race, and Deindustrialization in Philadelphia (Chicago: University of Chicago Press, 2008). As early as 1971, sociologist Robert Nisbet bemoaned the rise of "academic capitalism." See Nisbet, The Degradation of the Academic Dogma:
} 
Cebul

The Developmental State was obscured because it blended federal tax receipts with

decentralized public administrative authority and the agency and interests of local private actors.

Such an arrangement enabled Democrats and Republicans alike during the Cold War to plausibly

invoke wizened tropes such as American exceptionalism, the fight against creeping socialism,

and the notion of the "American Way." "This ad hoc, regional, and "associative" model of state

building empowered local elites to control generous federal tax revenues and to steer them

toward the development of local and regional industrial and economic strengths. ${ }^{19}$ Seen from this

vantage point, local politicians and business people in burgeoning "Cities of Knowledge" who

yoked federal research and development spending to the particular industrial or academic assets

of Silicon Valley, Atlanta, suburban Boston, or Philadelphia acted in remarkably similar ways to

The University in America, 1945-1970 (New York: Basic, 1971). On the creation and legitimization of new forms of state capacity during World War II, see James T. Sparrow, Warfare State: World War II Americans and the Age of Big Government (New York: Oxford University Press, 2011).

${ }^{18}$ On the political construction of American exceptionalism and the "American Way" in the context of the Cold War, see Wendy Wall, Inventing the "American Way": The Politics of Consensus from the New Deal to the Civil Rights Movement (New York: Oxford University Press, 2008); Ellen Schrecker, Many are the Crimes: McCarthyism in America (New York: Little Brown, 1998); and Donald T. Critchlow, Phyllis Schlafly and Grassroots Conservatism: A Woman's Crusade (Princeton: Princeton University Press, 2005).

${ }^{19}$ Southern defense contracting well fits this model of state building. For a concise and illuminating account of these developments in one locality in South Carolina, see Kari Fredrickson, Cold War Dixie: Militarization and Modernization in the American South (Athens: University of Georgia Press, 2013). On associative or associational state building, see David M. Hart, "Herbert Hoover's Last Laugh: The Enduring Significance of the 'Associative State' in the United States," Journal of Policy History, Volume 10, Issue 04, October 1998, 419-444. See also, Joanna Grisinger, The Unwieldy American State: Administrative Politics Since the New Deal (New York: Cambridge University Press, 2012); and Ellis Hawley, "Hebert Hoover, the Commerce Secretariat, and the Vision of an 'Associative State,"' Journal of American History 61 (1974): 116-40. 
Cebul

businesspeople who organized in Southern California or Arizona in pursuit of the economic growth that came along with federal defense contracts and infrastructure dollars. ${ }^{20}$ They were all developmental state builders who, on behalf of local prerogatives, very often disparaged state building. While historians generally consider states rights and localism as barriers to national state building, in the case of the developmental state, preferences for local control helped build and conceal - growth-oriented national state capacity.

Over decades of structural economic change, this developmental state model of federalism and regional industrial policy maintained and refashioned a plausible appearance of "free market" activity by emphasizing the private fruits of public private partnerships. Neither wholly liberal nor wholly conservative, the developmental state was fundamentally a creature of American federalism: localism, majoritarian values, and thin but staunchly majoritarian invocations of "community" contributed to its resilience and also help explain its relative invisibility. ${ }^{21}$ The federal structure resided within an even deeper set of historical concerns about

\footnotetext{
${ }^{20}$ O'Mara, Cities of Knowledge; Lisa McGirr, Suburban Warriors: The Origins of the New American Right (Princeton: Princeton University Press, 2001); Shermer, Sunbelt Capitalism; Frederickson, Cold War Dixie; and Michael Brenes, "For Right and Might: The Militarization of the Cold War and the Remaking of American Democracy" (PhD. Diss., The City University of New York, 2013).

${ }^{21}$ On the power for electoral majorities and elites of "community" discourse to flatten distinctions between competing groups and to thus marginalize minority interests, see Iris Marion Young, "The Ideal of Community and the Politics of Difference," in Penny A. Weiss and Marilyn F. Friedman, eds., Feminism and Community (Philadelphia: Temple University Press, 1995).
} 
Cebul

the dangers of centralized authority reaching back to the earliest days of the American republic. ${ }^{22}$

Neither cyclical narratives of waning liberalism or ascendant conservatism provide an analytical

or ideological framework that makes sense of this decentralized system of public inducements

for local growth and economic development. ${ }^{23}$ Rather, as Thomas Sugrue has suggested, these

politics were instead "ineluctably a politics of place," and localism and regionalism, rather than

liberalism or conservatism, must drive analyses of developmental politics and the twentieth

century political economy. $^{24}$

The Obama Administration's highly visible efforts to empower green companies like

Solyndra, a newcomer in a field dominated by entrenched carbon-based energy interests, also

${ }^{22}$ On the power of federalism to mitigate fears of national overreach while subtly expanding the national state's capacity during the founding era, for instance, see Max Edling, A Revolution in Favor of Government: Origins of the U.S. Constitution and the Making of the American State (New York: Oxford University Press, 2008); and Patrick Griffin, American Leviathan: Empire, Nation, and Revolutionary Frontier (New York: Hill and Wang, 2008).

${ }^{23}$ Scholars of American Political Development have challenged the "cycles of reform" framework of American political history. See especially, Brian Balogh, Between the Cycles: Essays on the Evolution of Twentieth-Century American Governance (University of Pennsylvania Press, forthcoming); Paul Pierson, Politics in Time: History Institutions, and Social Analysis (Princeton: Princeton University Press, 2008); and Paul Pierson and Theda Skocpol, eds. The Transformation of American Politics: Activist Government and the Rise of Conservatism (Princeton: Princeton University Press, 2007). In the field of political history, Matthew Lassiter called for historical analysis that challenges rigid binaries between liberalism and conservatism. See, Lassiter, "Political History beyond the Red-Blue Divide."

24 Thomas J. Sugrue, “All Politics is Local: The Persistence of Localism in Twentieth Century America,” in The Democratic Experiment, eds., Meg Jacobs, William J. Novak, and Julian Zelizer (Princeton: Princeton University Press, 2003). Jefferson Cowie has powerfully emphasized the importance of localist concerns in shaping both the rise and fragmentation of twentieth century organized labor. See Cowie, Capital Moves: RCA's Seventy-Year Quest for Cheap Labor (New York: The New Press, 2001), esp. ch. 7. 
Cebul

illuminates another fundamental feature of the developmental state - its boundaries. Indeed, when the Administration explicitly sought to expand the developmental state to benefit newcomers, the reaction among entrenched interests, many of which had historically benefited from federal subsidies themselves, was swift. Between 1950 and 2010, the federal government provided the oil and gas industries with nearly $\$ 500$ billion in subsidies. Ongoing subsidies total $\$ 50$ billion annually. ${ }^{25}$ By attacking green subsidies, these interests deployed free market rhetoric not as a statement of ideological preference but as a ploy to protect their material interests.

Similarly, in an earlier era, the War on Poverty advanced a highly visible form of federalism that bypassed local elites and established political hierarchies and, in so doing, punctured the majoritarian and highly racialized assumptions embedded in the developmental state. While many businesspeople and their political allies eagerly sought public redistribution and market intervention in order to stimulate local economic development, they vociferously opposed similar redistributional approaches to structural poverty that seemed to threaten their dominant positions. In so doing, they invoked hollow tropes of rugged individualism, "self help," and free market opportunity to delegitimize poverty programming. In relation to the meager degree to which their developmental authority had actually been challenged, local and regional

\footnotetext{
${ }^{25}$ National Public Radio offered an overview of the history of government energy subsidies stretching back to early investments in oil and gas exploration in 1918. See http://www.npr.org/2011/11/16/142364037/solyndra-highlightslong-history-of-energy-subsidies
} 
Cebul

business people's reaction was grossly overstated and contributed to a misguided but potent

antistatism that increasingly and inaccurately posited a zero sum relationship between the public

and private sectors. ${ }^{26}$ Over the 1970s, this antipathy toward government was fueled by public

sector scandals such as Watergate, the failure in Vietnam, and the government's seeming

inability to handle the various financial crises of the decade, from oil shocks to stagflation. ${ }^{27}$ In

this roiling political climate, business leaders locally and nationally sought to burnish business'

reputation as community shepherds, job producers, and protectors of essential American values

on behalf of their exclusive right to guiding - and benefitting from - developmental policies.

These political cultural trends played a critical role in submerging and ultimately

undermining federal support for the developmental state. During the 1970s and into the 1980s,

amidst a crisis of faith in public institutions, businesspeople more forcefully claimed the

\footnotetext{
26 "Developmental State" contributes to a growing history of the local war on poverty that suggests just how involved the private sector was in steering and ultimately blunting federal antipoverty initiatives. See especially, Annelise Orleck and Lisa Gayle Hazirjian, eds., The War on Poverty: A New Grassroots History (Athens, GA: University of Georgia Press, 2011).

${ }^{27}$ Frustration over governments' litany of failures, perceived and real, was a crucial and generally overlooked push factor for Americans' rhetorical embrace of free market or conservative politics. Alan Brinkley has urged historians to investigate this aspect of the 1970s. See Brinkley, "Conservatism as a Growing Field of Scholarship," Journal of American History (2011) 98 (3): 748-751. See also, Greta R. Krippner, Capitalizing on Crisis: The Political Origins of the Rise of Finance (Cambridge: Harvard University Press, 2011). For an excellent overview of the 1970s from a variety of policy perspectives, see David Brian Robertson, ed., Loss of Confidence: Politics and Policy in the 1970s (University Park, PA: Pennsylvania State University Press, 1998). See also, Niall Ferguson, Charles S. Maier, Erez Manela, and Daniel J. Sargent, The Shock of the Global (Cambridge: Belknap, 2010); and Joseph S. Nye, Jr., Philip Zelikow, and David C. King, eds., Why People Don't Trust Government (Cambridge: Harvard University Press,
} 1997). 
Cebul

producerist mantle. As Michael Kazin has argued, the "producer ethic" legitimizes those who produce wealth in tangible ways as the best protector of the nation's or a community's values and opportunities. ${ }^{28}$ Faced with insurgent minority groups backed by federal antipoverty dollars, attacked by consumer advocates such as Ralph Nader, and squeezed by the 1970s' debilitating inflation, businesspeople across a wide spectrum and scale embraced a self-styled underdog persona and mounted a rearguard political mobilization. ${ }^{29}$ In so doing, they embraced a hardedged version of a business brand of the producer ethic. Businesspeople - not labor, neighborhood associations, mobilized minority groups, or their allies in bloated government were fiscally responsible job producers, the guarantors of local opportunity and healthy communities.

At first, the salience of antigovernment rhetoric and "free market" politics was based on business peoples' pious sense of entitlement to state provision - not a clear-cut call for separating the public and private sectors. Over time, however, as reflected in Newt Gingrich's 1994 “Contract with America," a partisan and cynical version of business producerism and antistatism

\footnotetext{
${ }^{28}$ Michael Kazin, The Populist Persuasion: An American History (Ithaca: Cornell University Press, 1995). On the political potency of populism as well as its malleability, see Sophia Rosenfeld, Common Sense: A Political History (Cambridge: Harvard University Press, 2011). Shane Hamilton dubbed working class and small business peoples' antistatism of the 1970s "neopopulism." Hamilton, Trucking Country: The Road to America's Wal-Mart Economy (Princeton: Princeton University Press, 2008), see esp., 207-31.

${ }^{29}$ In this political cultural rather than ideological construction of business politics, I take a cue from Grace Elizabeth Hale's history of middle class whites' cultivation of outsider self-conceptions. Hale, A Nation of Outsiders: How the White Middle Class Fell in Love with Rebellion in Postwar America (New York: Oxford University Press, 2011).
} 
Cebul

flowered that genuinely sought to substitute private action for public policies. A new generation

of conservative politicians had come of age in the tumultuous 1970 s and sought to act on the

increasingly zero sum rhetoric. If the Democratic Party from the New Deal to the New

Democrats sought to knit together pragmatic local growth-based concerns by stimulating the decentralized developmental state, Newt Gingrich and the New Majority built an electoral coalition based on abstract national grievances that ultimately undermined the developmental state. After decades of their own rhetorical attacks on government, on minority empowerment, and an embrace of "market speak" - privileging private sector outputs rather than public inputs advocates of public private partnerships were fundamentally complicit in the politics that undermined public funding in support of developmental state building. The low tax politics of austerity that emerged in the 1980 s profoundly limited the public sector's ability to back innovative partnerships and significantly narrowed the range of federally backed developmental state policies. As a result, business interests turned to state governments, where they helped create a number of developmental states across the country.

The Politics Federalism Makes:

Public Private Partnerships, Regionalism \& Multiple Political Orders

“Developmental State” advances a comparative analysis of regional political economies and politics often invoked together but rarely explored within a shared narrative: the declining 
Cebul

Rustbelt and the emerging Sunbelt. By focusing on Cleveland's region of Northeastern Ohio and Southern developmental politics through the lens of rural Northwest Georgia, based in and around Rome, the project answers a call from political historians to more carefully probe notions of Southern exceptionalism. ${ }^{30}$ By moving between the regions and focusing on business and politicians' growth strategies, the project highlights important regional distinctions and convergences: in terms of interest group politics; the significance of race and minority enfranchisement for equity and development policy; the promise of regionalism; the constraints of democratic access on developmental decision-making; and for distinctions in the development and goals of durable public private partnerships.

While public private partnerships have a long history in American politics, particularly in the area of social provision, the post-New Deal turn toward institutionalized private sector administration of and influence on publicly underwritten economic development policies was genuinely new in both substance and scale. ${ }^{31}$ Urban historians have long identified the role of

\footnotetext{
${ }^{30}$ Matthew D. Lassiter and Joseph Crespino, eds., The Myth of Southern Exceptionalism (New York: Oxford University Press, 2010).

${ }^{31}$ Historians and political scienctists have developed a rich literature on public private partnerships in the policy domains of social provision and charitable organizations. For recent examples, see especially, Axel R. Schaefer, Piety and Public Funding: Evangelicals and the State in Modern America (Philadelphia: University of Pennsylvania Press, 2012); and Politics and Partnerships: The Role of Voluntary Associations in America's Political Past and Present, Elisabeth S. Clemens and Doug Guthrie, eds. (Chicago: University of Chicago Press, 2010). Though it understates how local politicians capitalized on business in favor of a more one-sided account of private 'capture' of public institutions, the most comprehensive work to date on business oriented public private partnerships is Gregory D. Squires, ed., Unequal Partnerships: The Political Economy of Urban Redevelopment in Postwar America (New
} 
Cebul

"growth coalitions" in postwar urban history, but they have not situated this trend within a

broader story of federalism, regionalism, and the national political economy. ${ }^{32}$ Indeed, according

to the National Council for Public Private Partnerships, the average city or municipality today

delivers over a third of its basic municipal services through such partnerships and many more

have brought the private sector into city planning functions, meaning that private interests have a

strong influence on publicly administered programs across local governments, urban or rural. ${ }^{33}$

The public private partnership model of local governance was a significant development

for a number of reasons. First, these partnerships institutionalized the private sector's influence

on local government, shaping the means and ends of local policymaking that very often served as

the administrative endpoint for generous and loosely regulated federal spending. Second, public

private partnerships often developed in response to moments when the federal role in local

affairs was expanding. During the New Deal in the South, for instance, regional leaders forged

inter-jurisdictional partnerships to steer the shared developmental goals of federal and regional

Brunswick, NJ, 1989). In political science, see especially Clarence N. Stone, Regime Politics: Governing Atlanta, 1946-1988 (Lawrence, Kansas, 1989).

${ }^{32}$ For variations on the concept of-growth coalitions, see John H. Mollenkopf, The Contested City (Princeton, NJ: Princeton University Press, 1983); John R. Logan and Harvey L. Molotch, Urban Fortunes: The Political Economy of Place (Berkeley: University of California Press, 1987); Clarence Stone, Regime Politics: Governing Atlanta, 1946-1988 (Lawrence: University Press of Kansas, 1989); and Alan Harding, "Elite Theory and Growth Machines," in Theories of Urban Politics, ed. David Judge, Gerry Stoker and Harold Wolman (London: Sage, 1995), 35-53.

${ }^{33}$ National Council for Public Private Partnerships, 2013 Press Kit, accessed online, http://www.ncppp.org/wpcontent/uploads/2013/03/PressKit_2013_WEB.pdf. 
Cebul

interests both to win more aid and to block those aspects of federal intervention they found

threatening (i.e., national wage rates or equal racial access) ${ }^{34}$ A similar state of affairs played out across the country, particularly in the industrial North, during the War on Poverty when partnerships promised to mitigate for local business leaders the less desirable aspects of minority empowerment or the progressive designs of community development programs such as Community Action or Model Cities. ${ }^{35}$ For businesspeople in urban and rural areas alike, these partnerships promised to protect local power structures and assuaged fears of national overreach, all while shepherding support for the kinds of industrial planning, physical renewal, and research and development many businesspeople so appreciated during the New Deal and WWII.

Local businesspeople often construed as "self help" the hard, often frustrating work that went into mobilizing federal support. ${ }^{36}$ These political cultural rather than ideological perspectives speeded their naturalization of an outsized federal role in regional market growth. ${ }^{37}$ Indeed, business people's deployment of antistatist rhetoric was often the result of their day-to-

\footnotetext{
${ }^{34}$ Katznelson, When Affirmative Action was White; and Fear Itself: The New Deal and the Origins of Our Time (New York: Liveright, 2013).

${ }^{35}$ A new generation of scholars is illuminating the on-the-ground struggles over War on Poverty programs. See especially, McKee, The Problem of Jobs; and Orleck and Hazirjian, eds., The War on Poverty. On the Great Society from a national perspective, see Gareth Davies, From Opportunity to Entitlement: The Transformation and Decline of Great Society Liberalism (Lawrence, KS: University of Kansas Press, 1996).

${ }^{36}$ In exploring frontiersmen's calls for greater national sovereignty on behalf of their efforts to settle the frontier and clear Native Americans, Patrick Griffin identifies a similar political cultural rather than ideological process at work. Griffin, American Leviathan, esp., introduction and ch. 1.

${ }^{37}$ Lipartito, "Connecting the Material and the Cultural in Business History."
} 
Cebul

day relationship with sluggish bureaucracies, the constant specter of onerous regulations, and the litany of seemingly inequitable funding decisions that benefited other regions, unworthy constituencies, or other businesses. For local business people, disparaging the state was very often part and parcel of their demands for state support.

Public private partnerships also helped legitimize new forms of state capacity. ${ }^{38}$ For politicians across the federal system, inviting in the private sector offered useful political cover against claims of creeping socialism or national governmental overreach. In this sense, partnerships gained credence because they offered solutions to social and economic problems that aligned with American values of limited government. Likewise, while federal spending elsewhere was often construed as wasteful and market-distorting Washington pork, in their own communities, business leaders' stewardship of local programs legitimized new forms of government action by habituating businesspeople and their political allies to an outsized - but locally managed - role for the national government.

This reading of business politics offers a sharp contrast to recent studies of the rise of 'neoliberalism' or of business' intrinsically conservative mobilization, pointing instead towards a history of business-state interaction that operates "beyond the red blue divide." 39 Recent

\footnotetext{
${ }^{38}$ James Sparrow offers a rich discussion of both threats to and the legitimation of new forms of state capacity. Sparrow, Warfare State, 9-12, and 100-59.

${ }^{39}$ Lassiter, "Political History Beyond the Red Blue Divide."
} 
Cebul

accounts of the 'neoliberal turn' describe how, blessed with an innovative, new "thought

collective," businesspeople and their conservative allies increasingly emphasized "market based

solutions," targeted deregulation, and sought to replace or augment public sector programs with

private alternatives. ${ }^{40}$ As this project and recent studies of "submerged" state policies suggest,

however, the federal government had for decades - indeed, for over a century - filtered its

capacity through decentralism, partnership with private actors, emphasized contracting rather

than the creation of new bureaucracies, and offered targeted tax and regulatory policies. ${ }^{41}$ To

take just the case of "supply side" tax liberalization, between 1929 and 1981, the years of the

"New Deal Order," Congress passed over fifty tax code revisions offering corporate tax credits,

deductions, and carryover periods. ${ }^{42}$ As this project reveals, at the very moment when

Congressional Republicans and the Reagan Administration were fashioning their version of

\footnotetext{
${ }^{40}$ Indeed, in the former case, intellectual historians have understandably credited the power of ideas for the rise of neoliberalism. See, for instance, Bergen, The Great Persuasion. Another account of the rise of neoliberal ideas as translated into policy can be found in Daniel Stedman Jones, Masters of the Universe: Hayek, Friedman, and the Birth of Neoliberal Politics (Princeton: Princeton University Press, 2012). On neoliberal policymaking, see for instance, Monica Prasad, The Politics of Free Markets: The Rise of Neoliberal Economic Policies in Britain, France, Germany, and the United States (Chicago: University of Chicago Press, 2006). See also, Philip Mirowski and Dieter Plehwe, eds., The Road from Mont Pelerin: The Making of the Neoliberal Thought Collective (Cambridge: Harvard University Press, 2009).

${ }^{41}$ Balogh, A Government out of Sight; Mettler, The Submerged State; Howard, The Hidden Welfare State; and Hacker, The Divided Welfare State. On the "associational state," see Ellis Hawley, "Hebert Hoover, the Commerce Secretariat, and the Vision of an 'Associative State," Journal of American History 61 (1974): 116-40.

${ }^{42}$ Michael I Luger, "Federal Tax Incentives as Industrial and Urban Policy," in Larry Sawers and William K. Tabb, eds., Sunbelt / Snowbelt: Urban Development and Regional Restructuring (New York: Oxford University Press, 1984), 204-9.
} 
Cebul

"supply side" politics, many within the Republican Party worried their efforts would be

perceived as borrowing from the Democrat's playbook. ${ }^{43}$

Historians have missed the developmental state's decentralized system of public private economic planning partnerships and supply side inducements for a number of reasons. Some have focused on local business peoples' conservative political expression and confined their narratives to discrete regions or single case studies, explaining away local business advocacy of federal aid as exceptions to conservative mobilization rather than constitutive of a national, albeit decentralized process. ${ }^{44}$ In contrast, "Developmental State" highlights the degree to which liberal policymakers well understood that programs, from Truman's Urban Renewal to Kennedy's Area Redevelopment Administration and Carter's Urban Development Action Grants, empowered local businesspeople, often in the name of fighting poverty or blight. Scholars have also focused on national lobbying associations such as the U.S. Chamber of Commerce or the National Association of Manufacturing, mapping their diffusion of antistatist sentiment and mobilization for "free markets." 45 These accounts, however, miss the ways in which local affiliates pursued a

\footnotetext{
43 "Developmental State," ch. 10.

${ }^{44}$ By focusing on the local side of business-government relations, for instance, Elizabeth Tandy Shermer's rich account of "grasstops" politics in Phoenix misses the way national policymakers explicitly sought to partner with the local actors she describes. Shermer, Sunbelt Capitalism.

${ }^{45}$ Kimberly Philips Fein, Invisible Hands: The Making of the Conservative Movement from the New Deal to Reagan (New York: W.W. Norton, 2009); Benjamin Waterhouse, "Mobilizing for the Market: Organized Business, WagePrice Controls, and the Politics of Inflation, 1971-1974,” Journal of American History, (September 2013, Vol. 100, No. 2, September 2013), and “The Corporate Mobilization Against Liberal Reform: Big Business Day, 1980,” in
} 
Cebul

growth-based agenda that diverged in fundamental ways from their national lobbyists, often

actively undermining their limited government agenda. Finally, the literature on twentieth

century conservatism has overlaid many of its narratives on studies of liberalism that reify a

"Rise and Fall of the New Deal Order" periodization that overstates the ideological clarity of the conservative coalition by flattening the diverse manifestations of twentieth century liberalism. In short, Democratic policymaking and party building efforts were much more diverse phenomena than has recently been recognized. ${ }^{46}$ By reexamining "liberal" politics and statecraft, we can better understand the ways in which key actors in the "rise of conservatism" were deeply enmeshed in the political developments they seemingly repudiated.

"Developmental State" illuminates a strain of Democratic liberalism that, above all, emphasized economic growth. While it rejected social or economic structural reform as a solution for poverty or tearing down racial barriers to economic opportunity, it embraced structural economic inducements that enhanced the promise of technological innovation, individualist solutions to poverty such as education reform and vocational training, supply side

What's Good For Business: Business and American Politics since World War II, eds., Kim Phillips-Fein and Julian E. Zelizer (New York: Oxford University Press, 2012).

${ }^{46}$ On a potent strain of mid-century liberalism - growth liberalism - often overlooked by scholars of conservatism, see Robert Collins, More: The Politics of Economic Growth in Postwar America (New York: Oxford University Press, 2000), 61-76. On the variety of competing "liberalisms" see Robert Self, American Babylon: Race and the Struggle for Postwar Oakland (Princeton: Princeton University Press, 2003). For a concise overview of twentieth century liberalism, see McKee, The Problem of Jobs, introduction. 
Cebul

stimulus, and the fantastic possibilities for social reform and racial reconciliation through

growth. This brand of Democratic liberalism held intrinsic 'producerist' and supply side appeal

for business and was perhaps the most salient feature in the high water marks of national

Democratic political success during the Kennedy-Johnson years of the early 1960s. This brand of

Democratic policymaking also helps explain Democrats' control of Congress and Southern

statehouses well into the era of Reagan's Revolution. ${ }^{47}$ While recent accounts of the "New

Democrat" politicians such as Arkansas' Bill Clinton or Georgia's Sam Nunn suggest that their

embrace of 'neoliberalism' constituted a capitulation to ascendant conservative values,

"Developmental State" directly links the "New Democrats" to this venerable strand of growth

liberalism. $^{48}$

Ultimately, however, "Developmental State" argues for the explanatory power of

localism and makes an appeal for political historians to look afresh at the United States' system

\footnotetext{
${ }^{47}$ To be sure, incumbency and periodic redistricting played a role as well. Nevertheless, this is a fact that political scientists have long wrestled with and one that political historians, overwhelmingly focused on fitting local stories to national narratives, have overlooked. See, for instance, Charles S. Bullock III and Mark J. Rozell, ed., The New Politics of the Old South: An Introduction to Southern Politics (Lanham, MD: Rowman and Littlefield, 2007), and Earl Black and Merle Black, The Rise of Southern Republicans (Cambridge: The Belknap Press of Harvard University Press, 2002).

${ }^{48}$ This is the central argument of the only monograph to date on the rise of the Democratic Leadership Council. Kenneth Baer, Reinventing Democrats: The Politics of Liberalism from Reagan to Clinton (Lawrence, KS: University Press of Kansas, 2000). For a conventional appraisal of Clinton and the New Democrat's retreat from a purported Democratic consensus on structural approaches to poverty and racial justice, see, for instance, Philip A. Klinkner, "Bill Clinton and the Politics of the New Liberalism," in Adolph Reed, Jr., ed., Without Justice for All.
} 
Cebul

of federalism. For too long, American political historians have either downplayed or ignored

federalism or have relied upon an overly functionalist reading of America's intergovernmental

arrangements. ${ }^{49}$ In contrast, as political scientist Margaret Weir has argued, the United States is a

"layered polity in which federal initiatives" have been "overlaid on state political systems that

operated with different administrative capacities and political logics." ${ }^{, 50}$ Seen through the lens of

federalism, American politics have evolved into a highly fragmented, competing, and overlaid

set of policies, institutional arrangements, and crosscutting political perspectives. What emerged

is an institutional state of affairs political scientists have by turns characterized hopefully as

having "multiple orders" or at worst have dubbed "The Rube Goldberg State.", ${ }^{\circ 1}$ Historicizing

${ }^{49}$ The best work on American federalism often focuses on the founding era or the New Deal or has been written by political scientists and is, as a result, not often cited by American historians. See especially, Martha Derthick, "How many communities? The evolution of American federalism," in Derthick, ed., Dilemmas of Scale in America's Federal Democracy (Cambridge: Woodrow Wilson Center Press and Cambridge University Press, 1999), Paul E. Peterson, City Limits (Princeton: Princeton University Press, 1980), and The Price of Federalism (Washington: Brooking Institution Press, 1995); Timothy Conlan, From New Federalism to Devolution (Washington, D.C.: Brookings Institution Press, 1998). On historians' appraisal of American federalism, see Edling, A Revolution in Favor of Government; Peter Onuf, Jefferson's Empire: The Language of American Nationhood (Charlottesville: University of Virginia Press, 2000); Balogh, A Government Out of Sight; and Smith, Building New Deal Liberalism.

${ }^{50}$ Margaret Weir, "States, Race, and the Decline of New Deal Liberalism," Studies in American Political Development Vol. 19, no.2 (October 2005): 157-72.

${ }^{51}$ See Weir, "States, Race, and the Decline of New Deal Liberalism," and “'Beyond the Plant Gates': Postwar Labor and the Organizational Structure of Liberalism," Institute for Research on Labor and Employment Working Paper Series, University of California, Berkeley, 2009, Karen Orren and Stephen Skowronek, The Search for American Political Development (New York: Cambridge University Press, 2004), and Rogers M. Smith, "Which Came First, the Ideas or the Institutions? Toward a Synthesis of Multiple Traditions and Multiple Orders," accessed online at www.yale.edu/coic/smith.doc. 
Cebul

localism enables us to more clearly see past ideological expression and to better understand how

local interests within the competitive opportunity structures of federalism and market capitalism

have shaped state capacity and political rhetoric in ways that don't easily map onto narratives of

liberalism or conservatism.

Overview of the Project

"Developmental State" is organized into three chronologically ordered and thematically

linked sections that offer parallel chapters focused on business and development in Cleveland,

Ohio and rural Northwest Georgia, in and around Rome. The first section, "Building the

Developmental State" illuminates how developmentally minded business leaders of local

Chambers of Commerce and business associations learned to accept and ultimately demand a robust federal presence on behalf of growth during the New Deal and Second World War. The four chapters in this section explore the locally contingent ways they did so and periodizes their progress, highlighting the New Deal's works programs, wartime defense spending, and post-war Urban Renewal development programs. The section explores the ways in which post-war development policies reinforced local class and racial hierarchies and folkways, creating new opportunities for local business leaders to extend New Deal-style industrial planning and 
Cebul

economic development in a manner that ensured elite control. ${ }^{52}$ Indeed, the early developmental

state's relatively light and inconspicuous federal regulatory apparatus - one that embraced

cooperative federalism as the most effective way to deliver services and shore up local support -

propped up localism and business peoples' myths of rugged individualism.

The first chapter explores the emergence of public private developmental regionalism in Northwest Georgia and Northeastern Alabama. Based in Rome, the region's businesspeople retailers, distributors, and "community development" experts at Georgia Power, the private electric utility - joined together to lobby Washington, D.C. for generous subsidies for river and transportation infrastructure to enhance their key industries, textile manufacturing and logging. Far from simply a story of Washington pork meant to cobble together a Democratic coalition, regional businesspeople across the south competed in a market of federal aid, driving hesitant bureaucrats' national funding decisions. ${ }^{53}$ The chapter illuminates the ways in which the quest

\footnotetext{
${ }^{52}$ The reluctance of national policymakers to confront segregation or deal with significant structural issues during the New Deal has most often been told from the national perspectives and have quite rightly emphasized more progressive forms of liberalism closed off by New Deal Democrat's dependence upon Southern Congressmen. For the national story, see especially, Alan Brinkley, "The New Deal and Southern Politics," in The New Deal and the South, ed., James C. Cobb and Michael Namorato (Jackson: University of Mississippi Press, 1984), Ira Katznelson, Fear Itself, and When Affirmative Action Was White.

${ }^{53}$ This chapter offers local and social context that challenges some of the assumptions about the top-down nature of southern industrialization in the two major works on the subject. It also emphasizes state and local political developments that emerged as part of the quest for economic development. See Bruce J. Schulman, From Cotton Belt to Sunbelt: Federal Policy, Economic Development, and the Transformation of the South, 1938-1980 (Raleigh: Duke University Press, $2^{\text {nd }}$ ed. 1994), and James C. Cobb, The Selling of the South: The Southern Crusade for Industrial Development, 1936-1990 (Urbana, IL: University of Illinois Press, 2nd ed., 1993).
} 
Cebul

for federal aid also spurred new forms of local and state-based state capacity on behalf of

growth. ${ }^{54}$ It examines as well the ways in which Georgia Power, a subsidiary of Wendell

Willkie's Commonwealth and Southern, which famously battled the Tennessee Valley

Authority's David Lilienthal, learned to emulate key elements of the TVA. As a result, Georgia

Power emerged from the New Deal and war more competitive and developmentally sophisticated

than ever.

The second chapter moves to Cleveland, Ohio, where nationally elite businesspeople -

industrialists, bankers, and lawyers - were far more closely aligned with the perspectives of their

national lobbying associations than were capital poor rural business people. Indeed, a number of

Cleveland's business elites served in leadership roles with the National Association of

\footnotetext{
${ }^{54}$ In describing the modern turn toward bureaucratically and expert managed public and private institutions, little work was done by historians of the "organizational synthesis" on southern state governments' persistent lack of complexity, bureaucratization, management and expertise, which lasted well into the twentieth century. Seen from this angle, business leaders' emphasis on public-private partnerships became an effective means of blending and enhancing each sector's developmental capacity. For a recent account that also identifies the importance of public private partnerships in Southern political development, see Joan Malczewki, "Weak State, Stronger Schools: Northern Philanthropy and Organizational Change in the Jim Crow South," The Journal of Southern History, Vol. 75, No. 4. Richard Franklin Bensel argues for the importance of sectionalism in shaping laggard political development in the South in Sectionalism and American Political Development, 1880-1980 (Madison, 1984). On the organizational synthesis more broadly, see, Robert H. Wiebe, The Search for Order, 1877-1920 (New York, 1967); Louis Galambos, “The Emerging Organizational Synthesis in Modern American History,” Business History Review, 44 (Autumn 1970), 279-90; Samuel P. Hays, “The Social Analysis of American Political History, 18801920,” Political Science Quarterly, 80 (September 1965), 373-94; and Brian Balogh, "Reorganizing the Organizational Synthesis: Federal-Professional Relations in Modem America," Studies in American Political Development, 5 (Spring 1991), 119-72.
} 
Cebul

Manufacturers and the U.S. Chamber of Commerce. Instead of directly engaging with local

politics and politicians, Cleveland's Chamber members initially sought voluntary means to shape the city's response to the Depression. ${ }^{55}$ Over time, however, the opportunity to steer federal works programs and wartime contracts, which could help placate the city's restive working class population and maintain business leaders' social and political standing, were too great to pass up, especially as elites began to recognize the extent to which interregional rivals were seizing these new opportunities. But, as the wartime boom restored prosperity, the city's business leaders disavowed the federal programs they had previously administered, returning to a more familiar form of elites' limited government political orthodoxy.

Chapter three illuminates the degree to which, following the war, Southern regional businesspeople took the opposite approach. Rather than renounce federal partnerships, capital poor Southern businesspeople organized durable public private partnerships to stimulate growth and recruit business and industry. In Georgia, the result was the establishment of the Area Planning and Development Commissions (APDCs), publicly subsidized, private led regional associations that partnered with Georgia Tech engineers to offer industrial recruits and residents "technical assistance" - a bland term that included everything from publicly subsidized product

\footnotetext{
${ }^{55}$ Following the progressive era, Cleveland was home to a variety of competing interest groups that made local politics an often messy and inefficient process. Indeed, Margaret Weir has argued that the progressive era's legacy of mobilized interest groups played a subtle but important role in hampering New Deal economic development policies throughout the industrial North. Weir, "States, Race, and the Decline of New Deal Liberalism."
} 
Cebul

designs and shop floor layout, to new industrial processes and technologies ${ }^{56}$ Immediately

following the national turn away from industrial policy, Georgia's businesspeople thus sought

public subsidies and support to create regional industrial policy. But, as growth came to Rome,

this period of cooperative interregional development failed entirely to consider the perspectives

of African Americans who were almost wholly invisible in the era's developmental policy. ${ }^{57}$

Instead, thanks to Jim Crow and restrictive labor practices, Georgia's businesspeople enjoyed a

far freer hand to shape liberal developmental programming than did Northern politicians and

businesspeople, who struggled with significant interest group jockeying. Indeed, comparing

Northern and Southern developmental politics identifies significant tension between democracy

and development. ${ }^{58}$

The chapter concludes by examining the direct ways Georgia's effective partnerships

ultimately shaped national liberal developmental policies, too, when Rome's regional Planning

\footnotetext{
${ }^{56}$ On this trend more broadly, see Elizabeth Popp Berman, Creating the Market University: How Academic Science Became an Economic Engine (Princeton: Princeton University Press, 2012).

${ }^{57}$ On the power of regionalism as an economic and political force, see Nicole Mellow, The State of Disunion: Regional Sources of National Partisanship (Baltimore: Johns Hopkins University Press, 2008), esp. ch. 1. See also, Paul Krugman, Geography and Trade (Cambridge: MIT Press, 1991). For a political introduction to regionalism, particularly Southern regionalism, see Lassiter and Crespino, eds., The Myth of Southern Exceptionalism, 8-13.

${ }^{58}$ For how relatively few competing interest groups smoothed business-led economic development of the South, see Mancur Olson, "The Causes and Quality of Southern Growth," in E. Blaine Liner and Lawrence K. Lynch, eds., The Economics of Southern Growth (Durham, NC: Southern Growth Policies Board, 1977). For Olson's argument about interest groups and development in an international context, see The Rise and Decline of nations: Economic Growth, Stagflation, and Social Rigidities (New Haven: Yale University Press, 1982).
} 
Cebul

and Development Commission became a principal model for the Kennedy and Johnson

Administrations' Appalachian Regional Commission. The ARC was a billion dollar program

meant to fight poverty, but, based on policymakers' emphasis on private sector administration,

the result was even greater federal spending routed through business partnerships.

The fourth chapter moves back to Cleveland, where comparing the North and South

during the high tide of growth liberalism suggests the importance of local politics in the story of

Sunbelt ascension, Rustbelt decline, and structural economic shifts. ${ }^{59}$ Southern businesspeople

made better strategic use of federal aid than did their Northern counterparts who were

complacent in the face of increasing signs of structural change, waning productivity, and

interregional competition. Instead of using federal developmental state funds to spur innovative

partnerships with government and Universities, Cleveland's businesspeople largely focused on

boosterism, slum clearance, and physical revitalization of the city, moves which simultaneously

failed to spur industrial innovation while also generating staunch opposition from the city's

African American and working class ethnic communities. Suburbanites themselves, Cleveland's

business leadership also struggled to cohere a sense of regionalism as suburbanization and

suburban tax flight offered their businesses short term tax advantages and cheap land, further

\footnotetext{
${ }^{59}$ This adds Northern political agency to the robust literature that emphasizes low wage rates and hostility to Unions. See especially, Cowie, Capital Moves. See also, Tami J. Friedman, "Exploiting the North-South Differential: Corporate Power, Southern Politics, and the Decline of Organized Labor after World War II," Journal of American History, September 2008, 323-346.
} 
Cebul

fragmenting the region's political economy and enervating the city's budget. ${ }^{60}$ The city's

business leaders and its racially and fiscally conservative white ethnic Democrats also worried that African Americans, increasingly empowered through War on Poverty and philanthropic programming, would subvert local political and social hierarchies. Their fears were realized when, following significant riots in 1966 , Cleveland became the first major city to elect an African American Mayor, Carl Stokes. By that time, Cleveland's businesspeople were awakening to the significant strains their city faced. They looked south for new strategies.

Section two, "Deregulating the War on Poverty, 1965-1975" explores how more closely regulated categorical War on Poverty programs and new minority claimants to national developmental largesse challenged the unstated assumptions undergirding New Deal federalism and mid-century growth liberalism, generating fierce intergroup competition over developmental state programming. Chapter five stays in Cleveland and illuminates this intergroup struggle in the city's Model Cities program where mobilized African Americans clashed with a populist, white ethnic Republican mayor, while businesspeople searched for new ways to generate political influence. The chapter explores local efforts to "deregulate" the war on poverty in Cleveland and examines the Nixon Administration's success in doing the same through his New

\footnotetext{
${ }^{60}$ Indeed, this was not merely a Northern story. Robert Self illuminates similar trends in postwar Oakland. Self, American Babylon. On the political economic and legal structure that underpin regional fragmentation around many American cities, see especially, Gerald Frug, City Making: Building Communities without Building Walls (Princeton: Princeton University Press, 1999).
} 
Cebul

Federalism reforms. The policy articulation of Nixon's "silent majority" appeals, New

Federalism bundled together funding for some of the most controversial War on Poverty

programs such as Community Action and Model Cities, deregulated their use, and sent the funds

to mayors rather than the poor and disfranchised. In so doing, Nixon reestablished the

developmental state's model of cooperative rather than categorical federalism.

Chapter six returns to Georgia and tracks the deregulation of the War on Poverty in the rural South through Jimmy Carter's and other rural business people's deep involvement in federal poverty programming. When War on Poverty funding arrived in Georgia, the state simply made its public private regional Planning and Development Commissions - one of which Carter established in his west central region of the state - the poverty program administrators. While African Americans mobilized to secure access to federally guaranteed developmental programs, entrenched business interests consistently thwarted their efforts. In Rome, ongoing barriers to democratic access and economic opportunity ultimately resulted in racial violence, which only served to further legitimize business' self-perception as the community's rightful leaders. Jimmy Carter played into these majoritarian concerns in his successful run for governor, promising to restore government to "the people." Like white ethnic Democrats, Democratic mayors, and businesspeople across the North, Carter had no vested interest in minority enfranchisement 
Cebul

within the developmental state. Like Nixon, he actively worked to restore local administrative autonomy within and business influence upon developmental programming.

\section{Section three, "Business Producerism and the Rise of Antigovernment Governance"}

explores the consequences of the rise of antistatist rhetoric that belied business people's ongoing interest in developmental state programming. Chapter seven focuses on the rise of business producerism nationally as well as through the lens of business people's frustration in Cleveland with a fiscally conservative, anti-corporate Republican white ethnic mayor. It also emphasizes the profoundly enervating fiscal climate of the 1970s for municipal budgets. As inflation pushed the cost of services ever higher, outmigration and deindustrialization shriveled city tax bases. ${ }^{61}$

These trends ultimately encouraged the mayor's acquiescence in a business-led downtown, abatement-based developmental scheme, embracing "neoliberalism by default." 62 But, in a

\footnotetext{
${ }^{61}$ The revenue raising capabilities of local v. state v. the federal government emerges as a significant theme. Faced with inflation, recession, or deindustrialization, local municipalities, which overwhelmingly rely on property and sales taxes for basic services and for funding major public works, experience much greater fiscal hardship much faster than do other levels of government. On this issue, see especially Peterson, City Limits. See also, David Brunori, Local Tax Policy: A Federalist Perspective (Washington, DC: The Urban Institute Press, 2007).

${ }^{62}$ Political Scientist Timothy Weaver deployed this phrase to describe the process by which Philadelphia's politicians, white and black, embraced business friendly policies. See, Timothy Weaver, "Ideas, Coalition Building, and Political Development in the City: Urban Policy and Politics in the U.S. and the U.K., 1976-2000,” APSA 2011 Annual Meeting Paper, August 15, 2011, accessed online, http://papers.ssrn.com/sol3/papers.cfm?abstract_id=1903162. See also, Timothy Paul Ryan Weaver, "Neoliberalism in the trenches: Urban policy and politics in the United States and the United Kingdom" (January 1, 2012). Dissertations available from ProQuest. AAI3542903. http://repository.upenn.edu/dissertations/AAI3542903 Other scholars previously used this phrase to describe this pragmatic, sometimes desperate, rather than ideological embrace of business friendly politics. See, for instance, Steffen Ganghof, "The Politics of Tax Structure," in Ian
} 
Cebul

majority working class and minority city, populist discontent flared, and business leaders found

themselves in a war with an insurgent anti-corporate, populist Mayor, Dennis Kucinich, who

rode a wave of neighborhood-based, Saul Alinsky-style confrontational organizing to office. For

a moment, Kucinich's mayoralty seemed to auger a high-water mark for a new brand of anti-

corporate, "good government" populism led nationally by groups like Nader's Raiders. The

results, however, of a war between business interests and local government - which triggered a

much more muscular business producerism and ultimately the city's 1978 default on its bonds -

would determine the city's developmental future.

Chapter eight returns to northwest Georgia and the South where, in explicit contrast to

flagging, polluted, and acrimonious Northern industrial centers, "progressive" New South

governors like Jimmy Carter joined together to develop a new industrial development strategy,

one based on high tech innovation, new forms of venture capital, clean industry, and middle class

quality of life concerns. Founded in 1971, two years after Cleveland's Cuyahoga River famously

caught fire, the Southern Growth Policies Board, based at North Carolina's Research Triangle

Park, was established to pool regional funds to generate this new industrial policy for the South's

sunny "post-racial" future. The chapter also highlights how the Board became embroiled in

national squabbles between Northern and Southern groups in the late 1970s in the Sunbelt-

Shapiro, Peter A. Swenson, and Daniela Donno Panayides, eds., Divide and Deal: The Politics of Distribution in Democracies (New York: NYU Press, 2008). 
Cebul

Frostbelt war, which pitted the regions in a battle over federal developmental program dollars.

Although staked on antigovernment grounds - arguing that government wasted taxpayer dollars

by supporting undeserving regions and constituencies - the battle instead hinged on repudiating government waste in order to legitimize one region's exclusive rights to federal largesse. In contrast to their overwhelmingly supply-side uses, politicians learned to invoke a region's relative poverty to justify federal subsidies, explicitly linking supply side economic development with fighting poverty.

As they deregulated and decentralized federal poverty programs, national policymakers, too, argued that antipoverty goals would be better realized through the efficacy of local government, free markets, and private enterprise - as if that had not been the local model all along. In so doing, policymakers explicitly merged the domains of poverty alleviation and economic development. Republicans and Democrats alike sped a shift toward venerating business actors as the key to ensuring the nation's and local communities' welfare. This framing, written in to policies such as Nixon's Community Development Block Grants and Carter's Urban Development Action Grants, reinforced businesses' pious and producerist sense that their interests were naturally in the best interests of the community and nation.

Chapter nine, the final chapter in Cleveland, explores business leaders' efforts over the 1980s to at last create durable public private partnerships to tap into the federal developmental 
Cebul

state. Enervated labor groups, moribund neighborhood associations, and decreasing minority

electoral participation cleared the way for business' stewardship of the city's developmental

politics. Indeed, the interest group landscape had come to more closely resemble the postwar

South. With Republican Mayor George Voinovich in office for most of the decade promising to

“run government like a business," business leaders employed ascendant "market speak" to justify

their use of massive federal and city subsidies to radically redevelop the city's downtown. Meant

to recapture suburban tax dollars and based on promises that downtown development would

trickle down to poor neighborhoods, the projects instead diverted valuable public aid away from

the struggling neighborhoods they were ostensibly meant to support. At last, the state of Ohio

and the city of Cleveland began to partner to create their own developmental state, albeit one

that, as in the South, aimed to use regional industrial policy to grow the economy from the

middle out and which employed vigorous structural reforms to benefit business - not the poor.

Chapter ten illuminates how Georgia's focus on a high tech, innovation economy and

declining developmental state dollars fragmented the regionalism that had once been a key

source of strength. Rural county residents looked with increasing suspicion at growth strategies

they saw were bypassing them, policies that accelerated the trend toward "Two Georgias" -

metropolitan areas and rural counties. Framed as an antipoverty / economic development policy,

Governor Zell Miller pushed through significant education reform, but, thanks to decades of 
Cebul

"market speak" and antigovernment rhetoric, he opted against taxation and instead developed a

state lottery to fund public University education for top high school performers. With each

innovative policy, the state's developmental emphasis moved further away from the kinds of jobs

that supported a broader range of Georgians and toward more highly skilled employees who

often came from outside the state. Similarly, Miller's University education program

disproportionately benefited the middle class, while rural and impoverished regions sunk deeper

into entrenched poverty and chronically low wages, their lotto tickets subsidizing higher

achieving and predominantly better off middle class and white students. While the state's well-

trained middle class enjoyed the benefits of state support and of a well paying, high tech

innovation economy, poor and rural residents competed in an increasingly globalized system of

low wage work.

Ultimately, "Developmental State" argues that Americans and American business

developed a highly fragmented political rhetoric that narrowed the range of feasible

developmental policies despite local leaders' strong preferences for stimulative government

spending and targeted industrial policy. Indeed, as the state of Georgia turned from blue to red,

politicians like Newt Gingrich cited the state's track record for growth as an example of the kind

of limited government, free market politics that might get the country moving again. 'It's the

places like Cobb" County "that are entrepreneurial," said Gingrich, "that have a strong work 
Cebul

ethic, that are going to do well."63 Beneath the rhetoric, however, the state's public-private

bureaucracy and state level growth liberalism had brought public largess seamlessly into the

workings of the market, driving Georgia's growth since the New Deal. Indeed, in 1992, Cobb

County, the bulk of Gingrich's district, received more federal aid than any non-urban county in the country - nearly $\$ 3.4$ billion in federal spending. While Gingrich blasted New York City’s "culture of waste," its addiction to the federal dole, Cobb County received nearly twice as much federal spending per capita than did New York City residents. ${ }^{64}$ Similarly, in 2009, while Paul Ryan blasted the Obama Administration's highly visible failure with Solyndra, when it came to securing federal stimulus for local governments and businesses in his district, Ryan wrote strongly supportive letters. As he put it, a town in his district deserved further funding for a major infrastructure project that had "created jobs." For "a Village whose entire operational budget is typically 1.5 million annually," Ryan explained, "this 1.3 million project was a huge undertaking, and the Village has indicated they were only able to complete this project as a result of the . . grant award." To deny them future funding, Paul wrote, "would be economically devastating to this small community." 65 Ryan's support of public aid suggests how fragmented

\footnotetext{
${ }^{63}$ Peter Applebome, Dixie Rising: How the South is Shaping American Values, Politics, and Culture (New York: Random House, 1997), ch. 2.

64 “Traditions and Ideas of Old South Make a Political Comeback,” Chicago Tribune, February 26, 1997.

${ }^{65}$ Paul Ryan to Lisa P. Jackson, December 2, 2009, accessed online at: http://www.huffingtonpost.com/2012/10/12/paul-ryan-stimulus-funds_n_1962163.html
} 
Cebul

our federal system and political discourse has become. But it also suggests the developmental state persists. 
Cebul

\section{Section I}

\section{Building the Developmental State: Cooperative Federalism and Public-Private Partnerships}

In 1935, Works Progress Administration director Harry Hopkins explained just how important local leaders were to New Deal programs. "We would have been damned fools if we thought for a minute that we have either the power or the ability to go out and set up 100,000 work projects ... without the complete cooperation of local and state officials. We couldn't do it if we wanted to." The WPA's work, Hopkins said, was overwhelmingly carried out "not on Federal property but on city and county and state property ... [I]t is work that is going to be of interest to the local taxpayers and local people and we couldn't if we wanted to develop these projects, organize them or prosecute them for that matter, without bringing the cities and the counties and states into a complete partnership." "Ninety per cent of this," Hopkins told his staff, "depends on the people we have to run it." In townships, municipalities, cities and counties, the people the administration relied upon to run its programs were local elites who often moved seamlessly between the public and private sectors.

\footnotetext{
${ }^{1}$ Hopkins quoted in Jason Scott Smith, Building New Deal Liberalism, 105.
} 
Cebul

\section{Chapter 1}

\section{Working for New Deal and Wartime Development in Georgia}

\section{Introduction}

The New Deal in the South has garnered much scholarly attention. Excellent accounts describe the New Deal's profound impact on the modernization of Southern agriculture, rising southern wages, the construction of massive transportation and power infrastructure, and Southern Congressmen's role in limiting more progressive national reforms. ${ }^{1}$ Throughout nearly all of these narratives, however, lurk figures as mysterious as they seem influential - local businessmen and boosters. Though not articulated with theoretical sophistication or in particularly systematic terms, local political and business elites in the rural South had developed a proto-Keynesianism that was already in place by 1933. Moreover, they were unencumbered by the panoply of competing interests that mobilized across the urban North during the progressive era. With Jim Crow suppressing African American mobilization and with a relatively quiescent white labor force, Southern businessmen enjoyed distinctive advantages in directing the federally

\footnotetext{
${ }^{1}$ Bruce J. Schulman, From Cotton Belt to Sun Belt, Numan V. Bartley, The Creation of Modern Georgia, George Tindall, The Emergence of the New South, Michael S. Holmes, The New Deal in Georgia, Ira Katznelson When Affirmative Action was White and Fear Itself: New Deal Democracy in a Southern Cage.
} 
Cebul

underwritten local agenda. ${ }^{2}$ As a result, they were well positioned to take advantage of, and, as

Harry Hopkins suggested, steer the New Deal's wide-ranging development policies. $^{3}$

Prior to the Depression, local political and business leaders, especially in the capital poor

South, focused laser-like on a single economic imperative: growth. Long before Keynes

theorized the power of government spending, infrastructure improvements, and the importance

of wages and consumer demand to even out the business cycle, local business interests clamored

for public "improvements" that promised to grow the local economy. ${ }^{4}$ As a result, while

businessmen's national lobbying associations stridently opposed the New Deal by invoking often

abstract free market ideologies, the interests they represented - business people operating at the

local level enmeshed in very concrete socio-political contexts - had markedly different

experiences with New Deal policies. Though not articulated with theoretical sophistication or in

particularly systematic terms, local political and business elites in the rural South had developed

a proto-Keynesianism that was already in place by $1933 .{ }^{5}$ While agents of national government

\footnotetext{
${ }^{2}$ On the way relatively few competing interest groups might positively affect economic development, see Mancur Olson, “The Causes and Quality of Southern Growth,” in E. Blaine Liner and Lawrence K. Lynch, eds., The Economics of Southern Growth, Durham, NC: Southern Growth Policies Board, 1977. On the ways in which the legacies of interest group formation during the progressive era stymied New Deal development in the urban North, see Margaret Weir, "States, Race, and the Decline of New Deal Liberalism," Studies in American Political Development, September 2005, 19(02): 157-172.

${ }^{3}$ Smith, Developming New Deal Liberalism, 105.

${ }^{4}$ On local businessmen and public improvements, see Balogh, A Government Out of Sight.

${ }^{5}$ Michelle Brattain, The Politics of Whiteness: Race, Workers, and Culture in the Modern South (Athens, Georgia: University of Georgia Press, 2001), ch. 1.
} 
Cebul

honed a variety of methods to legitimize for Americans a growing governmental presence, local developments and outlooks - the inherently associational nature of New Deal federalism played a crucial role in Americans' ambivalent embrace of an aggrandized state. In practice and in stark contrast to their national lobbying associations, local business leaders became adjuncts to the New Deal state through a variety of points of contact: through federal contracts; through their influence on local and state government; and through their role in shaping and comprising the new public authorities that administered so many of the New Deal's programs.

Business' interests were, of course, far from monolithic. ${ }^{6}$ Their scale and sector shaped their perceptions of federal programs, just as the bevy of state policies shaped the tone and timing of their various political mobilizations. ${ }^{7}$ The way a railroad man viewed WPA and Army Corps improvements to waterways for shipping was understandably different than local merchants or industrialists' views. Likewise, the promise of lower electrical rates and broader,

\footnotetext{
${ }^{6}$ On businesses' strained attempts to forge a political and competitive consensus prior to the New Deal, see Colin Gordon, New Deals: Business, Labor, and Politics in America, 1920-1935 (New York: Cambridge University Press, 1994), ch. 4. On the structural roots of small business' political fragmentation, see McGee Young, "The Political Roots of Small Business Identity,” Polity, 40:4 (October 2008).

${ }^{7}$ On business' reciprocal relationship with federal policymaking see, especially, Jacob S. Hacker and Paul Pierson, "Business Power and Social Policy: Employers and the Formation of the American Welfare State," Politics and Society 30 (April 2004), Jacob Hacker, The Divided Welfare State: The Battle over Public and Private Social Benefits in the United States (Cambridge, 2002), Richard Franklin Bensel, The Political Economy of American Industrialization, 1877-1900 (New York, 2001), Martin Sklar, The Corporate Reconstruction of American Capitalism, 1890-1916: The Market, the Law, and Politics (New York, 1988), Robert Weibe, The Search for Order,
} 1877-1920 (New York, 1967). 
Cebul

more reliable service was greeted with enthusiasm by many businesses, but Georgia's private

electric utility, Georgia Power, reasonably understood the Tennessee Valley Authority to be a

mortal threat. But, while some national lobbying associations like the Liberty League and

outspoken free marketeers repudiated the New Deal wholesale, local businessmen and local

branches of national businessmen's associations such as the Chamber of Commerce adapted to,

appropriated and ultimately demanded New Deal developmental support. ${ }^{8}$ And, even a company

such as Georgia Power, a subsidiary of Wendell Willkie's Commonwealth and Southern, gained

much from the New Deal.

In short, local businessmen - whether regional merchants in the rural South or major

industrialists in the urban North - had much to gain and much to fear from the array of New Deal

policies. These of crosscutting forces shaped their perceptions of their relationship with federal

government. Even supporters of a new public works program that might improve a waterway and

drive down transportation costs knew federal aid was imperiled thanks to their competition in the

market of federal aid with other communities, regions, and states. Mobilizing to win and

administer a grant - working with the dizzying number of new federal agencies and commissions

or hiring and overseeing massive workforces - was, in the end, hard work. The setbacks,

\footnotetext{
${ }^{8}$ Hacker and Pierson show that, while business interests initially opposed Social Security, once its passage was assured, they sought to shape the program and to reorient their business models to maximize their own benefits. Hacker and Pierson, Business Power and Social Policy."
} 
Cebul

denials, diversions and trips to Washington, D.C. all conspired to obscure the very source of these funds: the federal government. And, thanks to competition with other states and localities, they often perceived winning or losing federal support in relative terms. Some other town or region or business was always more favored. As well, business peoples' painstaking mobilization and the stymieing federal bureaucracy encouraged businesspeople to emphasize their own initiative, obscuring the fundamentally galvanizing role played by new federal instruments and spending. And, though business leaders accommodated and appropriated much that the New Deal had to offer, they loudly objected to those aspects they found threatening. As a result of the confluence of these perceptual forces, local leaders often considered New Deal support justified, underwhelming, and the result of their own hard work. In so doing, politicians and business leaders localized the root causes of the benefits of federal spending and nationalized the burdens of federal programs, entrenching localism at the same time that they expanded their expectations for federal support. By the end of World War II, businesspeople across the country had naturalized their role in building a massive new developmental state - some to lobby for greater involvement and others to deny they ever had.

Varieties of New South Economic Development

Labor Day festivities in Rome, Georgia usually included grand fireworks, Boy Scout swimming and diving contests, motor boat races on the Coosa River ("the biggest speed boat 
Cebul

regatta held in the South"), and a citywide picnic featuring terrapin races. The terrapin, contest

rules mandated, "must be a native of this section," and "must measure between three to six

inches across the back." ${ }^{\prime 9}$ Each year, Rome's leading citizens organized the festivities that were

voluntarily funded by local businesses. But, in the deteriorating economic climate of 1931,

business leaders struggled to muster sufficient resources. As J.L. Storey, President of the Rome

Chamber of Commerce and Chairman of the city's Labor Day Committee put it, that year's

"effort to raise funds for the Labor Day Program was a flop.","10

The increasingly dire economic climate, however, also triggered some debate among

Rome's leading men over whether cash prizes for turtle races and diving contests were sound

uses for dwindling resources when so many Romans were out of work and struggling to feed

their families. Judge John W. Bale entreated Storey to consider how “'Labor Day' in Rome this

year can't be made an occasion for real enjoyment for those the day was created to honor, the

laboring man - many of whom are hungry." Rather than the usual fireworks display, Bale

suggested the funds be "equitably apportioned between the whites and colored" to "give the

\footnotetext{
${ }^{9}$ Terrapin Race Feature of Labor Day Program, September 7, 1931, Box 1, Rome Chamber of Commerce Papers, Sarah Hightower Special Collections, Rome-Floyd County Library, Rome, Georgia (hereafter RCCP), and George Magruder Battey, Jr., A History of Rome and Floyd County, 1540-1922, 484.

${ }^{10}$ J.L. Storey to General Committee, Labor Day Program, August 6, 1931, Box 1, RCCP.
} 
Cebul

hungry unemployed and their families 'a full tummie' with which they can fully enjoy 'Labor

Day." $" 11$

Squeezed by hard economic times and without elite consensus, the 'New South' ideal of

business leadership, civic-minded localism, and industrial paternalism was on shaky ground. ${ }^{12}$

Indeed, the Chamber's failure to host a successful Labor Day celebration revealed the ways the

Depression challenged paternalism, an essential feature of Southern industry's competition with

the North: cheap and pliant labor. ${ }^{13}$ Since Reconstruction, corporate paternalism had greased the

wheels of Southern industrial development, from the region's burgeoning textile mills, which

ringed Rome and its cousin to the North, Dalton, to the handful of new manufacturing plants that

dotted the North Georgia hills. ${ }^{14}$ Fewer hours and creeping furloughs made the prospect of

unionization, federally backed in 1933's Wagner Act, an attractive option. By the end of 1933,

unions had already formed in some of Rome and Dalton's textile mills. ${ }^{15}$

${ }^{11}$ John W. Bale to JR Storey, August 5, 1931, Box 1, RCCP.

${ }^{12}$ On the ways the Depression threatened traditional southern socio-economic structure, see especially, Douglas

Flamming, Creating the Modern South: Millhands and Managers in Dalton, Georgia, 1884-1984.

${ }^{13}$ On the signal importance of cheap labor in Southern industrial recruitment, see James C. Cobb, Industrialization and Southern Society, 1877-1984 (Lexington, KY, 1984), 148-9.

${ }^{14}$ On the development of North Georgia corporate paternalism, see especially, Flamming, Creating the Modern South, chs. 6-8. For the effect of the Great Depression on corporate paternalism, see Flamming, ch. 9. For corporate paternalism more broadly across the South, see Jacqueline Dowd Hall, Like a Family: The Making of a Southern Cotton Mill World (Chapel Hill, 1987).

${ }^{15}$ Brattain, The Politics of Whiteness, 61-3, and Flamming, Creating the Modern South, 195-7. 
Cebul

Such developments directly challenged the social and economic hierarchy that had defined the 'New South' ethos. Long before he became the chief spokesman of the "New South creed," Henry Grady built his early career in Rome, cultivating the themes that quickly stood for an entire region's developmental outlook. As a young boy in Athens, Georgia, Grady often visited his uncle who, for a time, was Rome's mayor. At 19, Grady returned to the region, this time as part of a small press junket organized by the superintendent of the W\&A Railroad. The 1869 excursion aimed to highlight the natural and human resources of southeast Tennessee, northwest Georgia, and northeast Alabama. An aspiring journalist and a freelancer for the newly formed Atlanta Constitution (founded in 1868), Grady jumped at the chance to write about a region he knew and loved. The "excursionists," as an early historian of Rome put it, assessed soil and mineral quality, spoke with farmers and evaluated agricultural "potentialities." The junket returned to Rome at the "unearthly" hour of 1:30 on a Friday morning. The editor of the Rome Courier anxiously awaited the group. He had reserved space in that morning's paper for a column on the mission, but Grady was so taken by all he had seen that by the time the train pulled into Rome's station he had composed a characteristically verbose feature-length article. "Mr. Grady," Rome’s first historian wrote in 1922, "declared a column would hardly start the story he bore," so the editor scrapped "some of his livest news and no doubt a few 
Cebul

advertisements." That morning, Romans awoke to find a prototypical 'New South' narrative,

penned by Henry Grady, on the front page of the Rome Courier:

Every citizen of Cherokee Georgia has long been convinced that our mineral resources are unsurpassed, and all that was wanting was for someone to make a start, and induce men of means to come along, to aid in developing the same ... Our brothers of the quill will now have something interesting to write about and for a while, at least, will devote their time to something more substantial than politics, and of infinitely more advantage to our bankrupt people. It is refreshing to see men of all political shades quietly traveling together, and for once making a united effort to forget political differences, and to lend their efforts to the more laudable cause of developing the great wealth that nature had bestowed upon us ... ${ }^{16}$

The Courier promptly hired Grady as an associate editor, but Grady and the paper's managing editor had just as fast a falling out. Grady formed his own paper, the Southerner and Commercial, and for three years in Rome, he honed his New South creed. Grady vigorously evangelized for local businesses, placing articles across the state touting the Coosa River Valley region's human and natural resources.

In addition to his boosterism, Grady was an outspoken opponent of Reconstruction and was a leading member of Rome's Ku Klux Klan. ${ }^{17}$ When, in 1871, Congress passed the Ku Klux Klan Act, Grady's Southerner and Commercial published a vigorous denunciation of federal intervention in local affairs. Grady urged friends of the paper "who have any connection with

\footnotetext{
${ }^{16}$ Battey, A History of Rome, 246.

${ }^{17}$ Bartley, The Creation of Modern Georgia, p. 84.
} 
Cebul

secret orders to remain perfectly quiet and orderly, for the present at any rate. Let there be no suspicion of disorder or lawlessness; let there be no parading of disguised men ... Let us be quiet and bide our time; a passion chained down is a more fearsome and nobler thing than a passion gratified." "Remember, brothers and sisters," Grady reminded his white allies, "that the strength and power ... rest in the attribute of mystery and hidden force, and in the fact that upon a thousand hills of our country a legion of brave hearts that are throbbing quietly can be called together by a tiny signal, and when the work is done can melt away into the shadowy nothing . . .${ }^{18}$ In his time in Rome, Grady honed the two most distinctive features of his nascent New South creed: vigorous local development on behalf of the social and racial status quo that he defined in stark contrast to federal or northern tyrants who aimed to extract southern capital and impose northern mores.

While Grady remained strictly a 'booster' in the sense that his efforts were almost entirely promotional, the local business and political elites he left behind when he moved to Atlanta three years later set about realizing their own vision of local development. Rome's business leaders established a Chamber of Commerce and soon reformed the institutions of local government, creating a City Commission that would work more seamlessly with business leaders. Indeed, the Commission was almost wholly comprised of local business interests. ${ }^{19}$ In

\footnotetext{
${ }^{18}$ Grady quoted in Roger Aycock, All Roads to Rome, 152.

${ }^{19}$ Battey, A History of Rome, 397.
} 
Cebul

rural regions like Rome's Floyd County, which lacked accumulated public or private capital, any hope for sustained industrial growth depended upon infrastructure development. As a result, regional development hinged upon collective initiative that could only be financed and coordinated by local public institutions. Dynamic competition between Southern towns also drove boosters and their developmental agendas. The results of a regional mineral and agricultural exposition are suggestive of Romans sense of competitiveness. "That our county secured the first premium against the efforts of boastful Birmingham [AL], ambitious Anniston [AL], hopeful Gadsden [AL], and other pretentious cities and counties . . . in the mineral districts of North Alabama and Tennessee," would surely speed "the anxious inquiry of Eastern investors." "Since the exposition," the author noted, "a large amount of money has flowed into the county." ${ }^{20}$ Indeed, in 1896, the Massachusetts Mill Company opened a branch in nearby Lindale, operating 30,000 spindles run by 600 employees. By the turn of the century, the Massachusetts Mills expanded to over 2,500 workers. The Trion Mill in Rome, opened in 1888, employed 550 workers and, by 1902, it too had expanded its workforce to $1,200 .^{21}$

Most essential to attracting industry were transportation infrastructure, natural resource management and extraction, energy production, and the development of basic social services. In and around Rome, these public initiatives on behalf of growth paid some dividends. Rome's first

\footnotetext{
${ }^{20}$ Battey, 325.

${ }^{21}$ Aycock, 164-5.
} 
Cebul

historian, George Magruder Battey, Jr., described in his 1922 book how, by 1886, "the people

awakened" to Rome's need to attract "more people, more industries, more prosperity." "The

idea," Battey wrote, "spread like the measles. Everybody took it up, especially the financial

leaders." Over the ensuing decade, the private Rome Land Company solicited Northern capital

and played an important role in attracting a number of small industries. ${ }^{22}$ Though their success

was halting at best, business leaders between the end of Reconstruction and the Great Depression

made concerted efforts to create partnerships and to use local government to develop a baseline

of local infrastructure. ${ }^{23}$

In the late $19^{\text {th }}$ century, a new entrant on the booster scene spurred the placement of

branches of Northern businesses across the South: private power companies. In Georgia, Henry

M. Atkinson, a Massachusetts carpetbagger and Harvard-trained lawyer, was an early pioneer of

private utility-led boosterism, and between 1883 and the early 1920s, he expanded his small

electric light company across the state, particularly in the North, where river-powered sources of

energy were in abundance. Atkinson, and his new President and partner, Atlanta attorney Preston

S. Arkwright, recognized the advantage to the Company of rural, decentralized development. In

\footnotetext{
${ }^{22}$ Brattain, 29-32.

${ }^{23}$ See especially, Robert McMath, "Infrastructure for the New South: Dalton Utilities and the Development of an Industrial City," unpublished conference paper in author's possession. See also, McMath, et al., eds., Engineering the New South: Georgia Tech, 1885-1985 (Atlanta: Georgia Institute of Technology Press, 1986), and Gavin Wright, Old South, New South.
} 
Cebul

1928, Atkinson distilled his vision of rural development before the Georgia Association in a speech titled "Agriculture and the Decentralization of Industry in the Development of Georgia."

As recently as fifteen years prior, Atkinson explained, "the business of Georgia Power Company

did not extend outside the limits of Atlanta and its immediate suburbs." ${ }^{24}$ By 1928, however, the

Company served two thirds of the state with over 5,000 miles of transmission lines. And he

pointed to Rome for an example. "Last week," he said, "the corner stone was laid of [sic] a

$\$ 4,000,000$ artificial silk mill at Rome, Georgia, which is regarded as merely the beginning of

the development of this industry on a large scale in Georgia." Rome's new corporate resident,

the Tubize Chatillon Company, produced rayon and was a subsidiary of an Italian Company.

(Benito Mussolini donated the cornerstone for the new Mill, sending it "From Old Rome to New

Rome.”) Said Atkinson,

The Georgia Power Company is bending every energy at its command to bring about the location of new industries throughout Georgia .... [T]he smaller towns and rural districts of Georgia are in position to offer to new industries coming to the State many comparative advantages over those offered by the larger cities. This will bring to the rural districts the benefits of decentralized industry, such as increased opportunity for employment, larger home markets for the products of the farm, opportunity for more diversified farming, increased profits for the farm itself, and better farm living conditions.

\footnotetext{
${ }^{24}$ Henry M. Atkinson, "Agriculture and Decentralization of Industry in the Development of Georgia,” May 16, 1928, Preston Arkwright Speeches \& Early Company Collection, Georgia Power Corporate Archives, Atlanta, Georgia [hereafter GPCA].
} 
Cebul

And, of course, with greater development in further flung areas, Georgia Power would benefit from greater sales and new customers. The catch, though, was that the power company hoped business and industry would commit to decentralized development before the company expended its resources to deliver increased lode in the hinterlands. Sensibly, the company aimed to spread the risks of rural development among its industrial partners. ${ }^{25}$

As Georgia Power grew - thanks in part to expanded demands generated through the war effort - it formalized and institutionalized its recruitment efforts, creating an independent Department of Community and Industrial Development in 1927. The department operated from industrial recruitment offices one block west of Wall Street on Broadway in New York City and another in Atlanta. As Arkwright explained it, they were focused on "making surveys and gathering statistical information of conditions and available industrial sites, and then presenting the story of Georgia natural resources and other advantages to eastern and northern plant executives contemplating changes in location or establishment of new plants." ${ }^{26}$ By 1929, thanks in part to Georgia Power's boosterism, fourteen new industries relocated to the company's service area, providing jobs for 5,125 workers and, the company asserted, a total capital investment of $\$ 11,950,000$. As Arkwright put it, "Both because we are interested selfishly in

\footnotetext{
${ }^{25}$ For a similar approach to rural Southern utility development, see Kenneth Lipartito, The Bell System and Regional Business: The Telephone in the South, 1877-1920 (Baltimore: Johns Hopkins / AT\&T Series in Telephone History, 1989).

${ }^{26}$ More Industries for Georgia," February 1930, Preston Arkwright Speeches \& Early Company Collection, GPCA.
} 
Cebul

attracting new customers and because it is part of our business to assist in building up the state,

the Company is glad to work with any community it serves in bringing new industries to

Georgia. ${ }^{, 27}$ Local newspapers noticed. The Tri-County Advertiser in Clarksville called the

Company "a priceless asset," and the Athens Banner-Herald noted, "Many of the industries

secured for this state have been due directly to the efforts of representatives of the Georgia

Power Company." The Company, wrote the Brunswick Pilot, "should receive the full

appreciation of the people." 28 By 1930, a majority of the state's labor force was employed in non-agricultural pursuits. The son of a farmer who left the fields for the Tubize Mill in 1930

recalled the remarkable turn of events: "We moved in to the village, into a brand new house,

with lights in the bathroom. Boy, we thought we were rich and we was ... We thought we were

in hog heaven." 29

With new industry and relative wealth came new challenges. Indeed, the proliferation of

automobiles and a burgeoning car and truck economy demanded not just regulations but new and better roads. Georgia's business leaders' road building bonanza was overwhelmingly funded by state and local resources, which, during the 1920s (despite some efforts to raise local property

\footnotetext{
27 Ibid.

${ }^{28}$ Binder 1, Early Economic Development, GPCA.

${ }^{29}$ Quoted in Brattain, 43.
} 
Cebul

taxes) remained exceedingly modest. ${ }^{30}$ State and municipal financing for social welfare programs

and infrastructure development came from the same limited sources: relatively low property

taxes, local levies, municipal bonds, a small state sales tax on fuel oil, and an automobile

registration fee. ${ }^{31}$ Because local levies or bonds delivered so much of the financing for road infrastructure, other realms of public service - especially education - suffered commensurately when road spending increased. Between 1880 and 1910, education spending as a percentage of total state expenditure increased from 6.9 percent to 38.8 percent, but, from 1910 to 1930 , banner decades for road construction in Georgia, that figure slumped back to 19.8 percent. Meanwhile, highway construction soared from 0 percent of public expenditures in 1910 to 16.2 percent in 1920 and 45.1 percent in 1930 . The benefits of state spending, however, were allocated unevenly and only heightened interregional competition. From 1924 to 1929, just 32 miles of "first class" roads were paved in Floyd County. Meanwhile, 1,500 miles of "second class roads" were constructed of gravel or chert rock - a good start, but a type of road that Romans felt risked leaving Rome and Floyd County behind competitors like Augusta or Macon. ${ }^{32}$

\footnotetext{
${ }^{30}$ Ann Short Chirhart, "Gender, Jim Crow, and Eugene Talmadge," in Elna C. Green, ed., The New Deal and Beyond: Social Welfare in the South since 1930 (Athens, GA: University of Georgia Press 2003), 74-5.

${ }^{31}$ Bartley, Creation of the New South, p. 160. The financing of road building was much the same across the country. See James Patterson, The New Deal and the States, 15.

32 "Number Miles of Road Paved in Past Five Years in Floyd County," undated (in a folder of papers from 1929), Box 2, RCCP.
} 
Cebul

Rome's business leaders kept the pressure on the Chamber of Commerce and the City

Commission, often comparing local infrastructure development to neighboring counties and

states. After taking a Saturday tour on a number of regional roads, A.C. Hogg, the vice president

of Rome's Hanks Stove and Range Company, complained to the Chamber President: "If a man

will drive his car at the rate of thirty miles per hour over . . these highways," he wrote, "he will

be in shape for a Doctor and a Nurse."

If I were living in Cherokee County, Alabama or in the city of Cave Springs and had to make a decision as to which place I would go to market my stuff . . . I certainly would not damage my car to the amount of $\$ 25.00$ every trip or load a truck with cotton to the amount $\$ 25.00$ or $\$ 50.00$ on every trip. There is positively no excuse for . . . these roads being in their present condition ... You will do the people of Rome and Floyd County quite a favor both from a financial standpoint and also save a nervous wreck of the motorists of this county . . . by demanding that these roads have immediate attention ... ${ }^{33}$

Chambers of Commerce led the charge, as one local president put it, for "a movement to get [roads] paved." 34 The Rome Chamber created a Roads group that met regularly. At one meeting, members noted, "the Primrose Tapestry Company had complained of the condition of the road to their plant." 35 Wyatt Foster, Rome's Chamber President, wrote to the state's roads commissioner, pointing out that part of the road to Primrose was "in a boggy condition and ...

\footnotetext{
${ }^{33}$ A.C. Hogg to W.O. Walden, July 30, 1929, Box 2, RCCP.

${ }^{34}$ President, Bainbridge Chamber of Commerce to W.H. Foster, March 30, 1931, Box 2, RCCP.

35 Roads Group, Meeting Minutes, February 15, 1929 Box 2, RCCP.
} 
Cebul

they have had some trouble with trucks bogging down, carrying machinery and supplies."

"These people," Foster complained, "have put their own money into this plant ... and they feel they should have some consideration in the up-keep of the road to their plant, and we thoroughly agree with them ${ }^{, 36}$ Increasingly, businesspeople viewed state and local public support for road building not merely as a competitive advantage but as a right of business citizenship.

Interregional competition for state funding thus raised the stakes in local road-building initiatives. Representatives from chambers across the state lobbied the State Highway Board in Atlanta for a bevy of projects and all hoped that major developments could be routed through their towns. ${ }^{37}$ Wherever possible, these business leaders were anxious to avoid the expenditure of local funds. As Foster put it in a letter to a chamber ally in Summerville in neighboring Chattooga County, "we are still interested in completing paved highway from Rome to Chattanooga, through Summerville. Quite a few of our people feel that the unfinished portion through Chattooga County should be built by State and Federal money, without the participation of Chattooga County." 38

As the nation slumped into Depression, however, a 1929 local bond initiative fell through, and the Chamber's plans for Route 1 - the Henry Grady Highway - were mothballed.

\footnotetext{
${ }^{36}$ W.H Foster to O.N. Richardson, February 26, 1929, Box 2, RCCP.

${ }^{37}$ See, for instance, William J. Harris to W.H. Foster, February 23, 1929, Box 2, RCCP.

${ }^{38}$ W.H. Foster to Wesley Shropshire, January 12, 1931, Box 2, RCCP.
} 
Cebul

The inability to raise local funds only heightened local chambers' frustration with the State

Highway Commission's laser like focus on Atlanta to the detriment of other regions. Columbus

Roberts, president of the Columbus, Georgia Coca-Cola Bottling Company, complained to

Foster that "it seems that we will never get a [Highway] Commissioner from the West side of the

State. It now seems to be the policy to build only roads leading in and out of Atlanta." Alabama

to the west, he grumbled, "has built a highway from Huntsville into our State entering at

Columbus and we have no outlet for it in any direction. I am anxious that we do something . .."39

While the Depression had hampered local initiative, shelving road building efforts as well as

labor day festivities, Franklin Roosevelt's election as president augured new avenues for growth.

New Deal Economic Development

"There is one outstanding governmental principle which the vast majority of businessmen in the United States unanimously support," argued the April 1929 edition of the Executives Services Bulletin to which the Rome, Georgia Chamber of Commerce subscribed. The newsletter, published "in the interests of better management" by the Metropolitan Life Insurance, Co., explicated this principle: "the Government should not go into private business operations," and bring public institutions into "competition with private capital." While wartime necessity

\footnotetext{
${ }^{39}$ Columbus Roberts to W.H. Foster, May 6, 1930, Box 2, RCCP.
} 
Cebul

could justly bend this rule for a time, by 1929 , that eventuality was "now long past." ${ }^{40}$ The article specifically targeted government-subsidized or operated barge lines on publicly developed inland waterways, which undermined the competitiveness of private rail lines.

But, with the arrival of Franklin Roosevelt and the New Deal, these principles would be challenged anew and nowhere more directly than by the Tennessee Valley Authority. Passed on May 18, 1933, the Tennessee Valley Authority Act brought the federal government into the business of power development, distribution and sales. The Authority aimed to capitalize on the underutilized Wilson Dam power infrastructure at Muscle Shoals in North Alabama and to extend electrification throughout the broader Tennessee River Valley. But, the program, which would eventually extend to portions of Tennessee, Mississippi, Alabama, Georgia, North Carolina and Virginia, aimed to do more than merely diffuse cheap and reliable power. The TVA's early administrators hoped to use the Authority as an experiment in "grass roots," democratic administration. That is, administrators hoped to foster local control of power utilities through the creation of community-based power cooperatives. In turn, as these cooperatives invited in the TVA and its federally subsidized sub-market rates, the TVA would force its private competitors to lower their own rates. The new federal agency identified Tupelo, Mississippi as its first "yardstick" community, the benchmark municipality whose region would jumpstart the

\footnotetext{
${ }^{40}$ Executives Services Bulletin, Vol. VII, No. 4., April, 1929, Box 2, RCCP.
} 
Cebul

public-private rates competition. ${ }^{41}$ Indeed, the TVA was just one example of how the New Deal sought to use federal funding to empower local development.

But David Lilienthal, the young Wisconsin utility commissioner brought in to administer the new Authority, had still bigger plans. He saw that competition with low, federally subsidized rates alone might not convince the private utilities of the efficacy of lowering their own rates. Indeed, in 1933, private power utilities were, in terms of net capital invested, the nation's largest industry, but the vast majority of companies stayed afloat through a complex process of rolling over debt that many never seriously expected to retire. ${ }^{42}$ Lowering rates was the last thing most companies considered. More pragmatically, he also recognized the need to find some common ground for partnership with the local private utilities since, in 1933, Georgia Power and Alabama Power were his Authorities' biggest customers. As Lilienthal put it, "here we have a picture of a complete business stalemate." ${ }^{43}$ Lilienthal had to prove to them that the price elasticity of demand for power was significantly larger than that which private companies supposed. As Lilienthal put it in a letter to the White House, "we sought to devise some means of increasing

\footnotetext{
${ }^{41}$ There is a rich historical literature that explores the Tennessee Valley Authority's developmental and democratic goals. See especially, Philip Selznick, TVA and the Grass Roots: A Study in the Sociology of Formal Organization (Berkeley, 1949), Thomas McCraw, TVA and the Power Fight, 1933-1939 (Philadelphia, 1971), Erwin C. Hargrove, Prisoners of Myth: The Leadership of the Tennessee Valley Authority, 1933-1990 (Princeton, 1994) and Patrick D. Reagan, Designing a New America: The Origins of New Deal Planning, 1890-1943 (Amherst, 1999).

${ }^{42}$ McCraw, TVA and the Power Fight, 6-10 and 60-2.

${ }^{43}$ Gregory B. Field, “'Electricity for All': The Electric Home and Farm Authority and the Politics of Mass Consumption, 1932-1935," The Business History Review, Vol. 64, No. 1 (Spring, 1990), 36.
} 
Cebul

the demand for electricity so as to make room for the existing [private] systems as well as the system which we are creating. We concluded that this can only be done by large-scale distribution of appliances, and the lowering of rates. ${ }^{, 44}$ Lilienthal determined that Tennessee Valley residents would have to consume more power. Years before the Roosevelt administration reached "the end of reform" and embraced a consciously expansionist political economy based on mass consumption, Lilienthal sought to forge just such a political economy throughout the Tennessee Valley. ${ }^{45}$

The vehicle Lilienthal created to stimulate consumer demand was the Electric Home and Farm Authority (EHFA), a sub-agency of the TVA, which Roosevelt established through an executive order on December 19, 1933. While Lilienthal hoped for an Authority that was nationwide in scope, Roosevelt limited the experiment to the TVA-region and delivered far less capitalization than Lilienthal had imagined: $\$ 1$ million of direct funds and $\$ 100$ million of credit with the Reconstruction Finance Corporation. The EHFA was thus established as a federal credit agency that offered low interest loans for the purchase of home appliances: refrigerators, stoves and heaters, mainly. In addition, the EHFA partnered with a range of appliance manufacturers to bring to market EHFA-certified goods that were sold at lower prices than were the

\footnotetext{
${ }^{44}$ Lilienthal quoted in McCraw, 61-2.

${ }^{45}$ Field, “'Electricity for All': The Electric Home and Farm Authority and the Politics of Mass Consumption, 19321935." For the Roosevelt administration's turn to emphasizing a mass consumption / full employment political economy, see Brinkley, The End of Reform, esp. 230-3.
} 
Cebul

manufacturers' usual line of products. The EHFA conducted demonstrations across the region, educating and enticing consumers to modernize their kitchens and farms. As a result, Lilienthal hoped, lower retail prices combined with EHFA credit would stimulate the kind of consumer demand that could actually make lower electricity rates an attractive option for the private utilities. Six months into the TVA experiment, the federal government was not only directly competing with private power companies, but it had partnered with a segment of the appliance manufacturing and retail sales industry to drive down those prices as well. As the New York Times put it, "the Roosevelt administration is enabled to engage in virtually any form of business

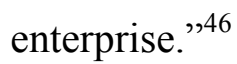

The ensuing furor and among conservatives and nation business associations in particular has been well documented. ${ }^{47}$ Indeed, 41-year-old attorney Wendell Willkie made a national name for himself as the president of Commonwealth and Southern, the billion-dollar holding company whose subsidiaries included Georgia Power, Alabama Power and other private utilities threatened by the TVA's incursions. Yet, the peculiar arrangements between public and private utilities in the TVA area necessitated some sort of rapprochement. The TVA's biggest customers, the source of the Wilson Dam and the TVA's greatest revenue, were Commonwealth and Southern subsidiaries. Willkie and Lilienthal met in Washington in the fall of 1933 to try to

\footnotetext{
${ }^{46}$ Quoted in Field, 45.

${ }^{47}$ See especially, Phillips-Fein, Invisible Hands, 3-34.
} 
Cebul

forge a consensus. Though they came to no agreement that day ("I recall," wrote Lilienthal several years later, "that we were too exceedingly cagey fellows who met at lunch that noon.”), Willkie understood the potential benefit to C\&S of increasing consumer's energy use. Though the ensuing years certainly witnessed overheated rhetoric between Willkie and Lilienthal, by January 1934, Commonwealth and Southern had committed to "use their utmost endeavors" to increase consumer demand and had signed on to sell EHFA-approved low cost appliances at their local retail outlets. ${ }^{48}$ (Local appliance retailers in Georgia were not pleased that the power utility had partnered with the TVA and worried they would be muscled out of their own market. Some even brought suit against the "monopolistic" arrangement. ${ }^{49}$ ) Just as quickly, however, C\&S was back to trying to roll back the TVA. Indeed, historian Thomas McCraw argued that the January agreement "marked the high point in good feeling between the public and private traditions in the Tennessee Valley." ${ }^{50}$ Nevertheless, competition with the TVA would prove to be a profoundly important factor in the development of at least one of C\&S's chief subsidiaries,

Georgia Power.

This was not immediately apparent to Georgia Power's president, Preston Arkwright. In late 1934, Arkwright joined Willkie for a lengthy meeting with President Roosevelt to discuss

\footnotetext{
${ }^{48}$ Field, 47 and 50, and McCraw, 62.

${ }^{49}$ The Washington Post, December 14, 1934.

${ }^{50} \mathrm{McCraw}, 62$.
} 
Cebul

the "power question." Afterward, the businessmen expressed gratitude to Roosevelt for meeting but were adamant that their industry could not operate at the low rates being delivered by the TVA. ${ }^{51}$ Still, Arkwright expressed measured enthusiasm for expanding appliance sales, and Georgia Power, he noted, was doing better business in these areas, enjoying a degree of new income from retail sales and increased energy use. ${ }^{52}$ Nevertheless, both Arkwright and Willkie were resolute that the TVA "stay where it is" and not expand its operating area. They flatly dismissed the possibility of dramatic rate cuts. ${ }^{53}$

While the TVA's main areas of operation and power generation were at a considerable distance from what Georgia Power called its "principle" territory in and around Atlanta, the company was concerned that the federal agency was attempting "to induce some of the farmers and small towns situated in the northwestern part of the State ... to apply to the TVA to build lines and take electric current from the TVA in preference to Georgia Power Company.",54 Indeed, by 1936, as the company's Annual Report put it, the TVA had "invaded this State for the purpose of competing with the Georgia Power Company in furnishing electric service in eight Northwest Georgia Counties." In an editorial, Arkwright blasted the encroachment of the TVA in Northwest Georgia, and he outlined why the New Deal in general and the TVA in particular

\footnotetext{
${ }^{51}$ New York Times, December 14, 1934.

52 Wall Street Journal, December 14, 1934.

${ }^{53}$ The Washington Post, December 14, 1934.

${ }^{54}$ Annual Report of the Georgia Power Company, 1935, 8, GPCA.
} 
Cebul

imperiled the region's economic development. "Will the new industries that are coming follow

their predecessors and seek out locations in Northwest Georgia . . . [o]r will they avoid

Northwest Georgia?" The answer, he wrote, hinged on whether Georgians repelled the "invasion

... by TVA and its creature-corporation, the" North Georgia Electric Membership Corporation,

a Rural Electrification Administration backed cooperative. One of their goals, Arkwright argued,

"is to drive the Georgia Power Company out of Northwest Georgia. If this could be

accomplished would it make the section more inviting to new industries?" Quite the opposite.

"Many of the industries now considering locations in Georgia," he explained, "are doing so

because of the strife, the disturbance, the harassment to which they have been subjected in their

present locations. Certainly they don't want to jump out of the frying pan and into the fire." If

"these new industries ... find that in one section of the state the biggest industry in Georgia, the

Georgia Power Company, is being subjected to strife, disturbance and harassment, will that make

the new industries wish to locate in that particular section?" The TVA, moreover, typified the

New Deal's slippery statist slope, since, "if the government invades the electric business, how

long will it be before the government invades all other businesses?" Logical businessmen, he

concluded, will "stay as far away as possible from sections where the people believe in the 
Cebul

doctrine of government ownership ... They avoid such sections like the plague." ${ }^{.55}$ Public and private competition was bad for business, he argued, positing a zero sum developmental game.

Yet, local businessmen in North Georgia looked with optimism to the increased service and lower rates promised by the TVA and REA. Indeed, between 1928 and 1930, businesses from Macon to Rome expressed frequent frustration with Georgia Power's performance. The company's oft-shifting rates, frequent black or brownouts, and the confounding variation between residential, commercial, and industrial rates rankled business leaders who sought, above all else, predictability. ${ }^{56}$ The investment division of Mackubin, Goodrich and Co., based in Baltimore (which later became Legg Mason), represented the interests of a number of Georgia Power investors. In the fall of 1933, they reached out to Georgia Chambers of Commerce to make "a detailed investigation of the public relations of this company and just what effect the Federal Government's development of the Tennessee Valley will have on its earnings." ${ }^{57}$ Rome's Chamber President Wyatt Foster responded that Georgia Power had "generally satisfactory" relations with the public in and around Rome. The only complaint, he noted, was "a feeling, especially among small concerns, that ... rates are too high.” Foster noted the salutary

\footnotetext{
${ }^{55}$ Preston Arkwright, "Who Builds Georgia?" undated editorial (likely 1936), Preston Arkwright Speeches \& Early Company Collection, GPCA.

${ }^{56}$ Lincoln McConnell, Jr., Macon Chamber of Commerce to W.H. Foster, December 10, 1930, Macon Chamber of Commerce, "Road Report,” August 20, 1928, Box 2, RCCP.

${ }^{57}$ J.G. Bent, Jr. to W.H. Foster, September 19, 1933, Box 2, RCCP.
} 
Cebul

effects the TVA could have for Georgia Power's image: "It is the personal opinion of the writer that should the Georgia Power Company establish rates equal to that of the Tennessee Valley Authority, that there will be no effort made by the local authorities of the public to advocate municipal ownership or make application to the Authority." ${ }^{58}$ Pressure to adopt the TVA's rates came not just from the public utility, but also from businesspeople.

While Arkwright and Willkie made it clear in December 1934 that lower rates were a near-impossibility, the company soon deployed a development strategy to increase their customers' energy consumption. Prior to the New Deal, Georgia Power's business development initiatives had focused almost entirely on wooing new industries to the state. In 1935, however, Georgia Power's new Home Service Department essentially replicated the goals of the TVA's EHFA - the timing was no coincidence. The Home Service Department hired female "home economists" in towns across the state and trained them in the art of home improvement. As that year's Annual Report noted, the 62 "home economists" were providing "information on the selection, care and operation of electric household equipment, making proper home lighting recommendations, [and] repairing equipment in customers' homes . . . They conducted or assisted in 1,423 lecture demonstrations on rates, lighting and the use of household equipment, with total attendance aggregating 112,734." In addition to the lectures, the Home Services

\footnotetext{
${ }^{58}$ W.H. Foster to J.G. Bent, Jr., September 21, 1933, Box 2, RCCP.
} 
Cebul

Department operated two "traveling demonstration kitchen coaches" that advertised the

advantages of "an all-electric kitchen." The coach was equipped with a small "auditorium" that

could seat twenty women who watched as the home economist demonstrated the kitchen's

electric range, refrigerator, water heater and pump, dishwasher and sink as well as a number of

other smaller appliances. "The results so far," concluded the Report, "have been gratifying.",59

Indeed, the Company had established its own appliance sales division that marketed EHFA-

certified goods, and 1935 was the company's best sales year on record. The next year was even

better, and the Company hired 26 more home economists, bringing the total to 88 . That year,

they conducted 548 demonstrations of the traveling kitchen in "rural communities and small

towns where the Company does not maintain offices." 60

Promotion alone, however, failed to deliver the appliance sales for which the Company

had hoped (from 1934 to 1937 annual sales growth were respectable, though, varying between 5

and 6 percent) and Georgia Power adopted other tactics pioneered by the EHFA. In 1935,

Lilienthal had extended EHFA credit to all appliance models produced by manufacturers of

EHFA-rate goods, creating a broader interest-based revenue stream for the agency. ${ }^{61}$ But, when

the Supreme Court invalidated the NIRA, the executive order establishing the EHFA was also

\footnotetext{
59 Annual Report of the Georgia Power Company, 1935, 4-5, GPCA.

${ }^{60}$ Annual Report of the Georgia Power Company, 1936, 4, GPCA.

${ }^{61}$ Annual Report of the Georgia Power Company, 1937, 4, GPCA; and Field, 50.
} 
Cebul

invalidated, forcing Lilienthal to go to Congress for enabling legislation to save his credit

agency. Congress instead reestablished the EHFA as a subsidiary of the Reconstruction Finance

Corporation, taking control from Lilienthal and delivering it to a seven-member board of

directors. The new EHFA had vastly expanded territory but was forced to curb much of its

promotional activities. By 1942, as wartime manufacturing priorities curtailed appliance

production, the EHFA was dissolved. ${ }^{62}$

The diminution and ultimate dissolution of the EHFA created an opportunity for Georgia

Power. Beginning in 1938, the Company partnered with the Commercial Credit Company to create the Economy Purchase Plan, "a cooperative installment and finance arrangement" for selling appliances that replicated the EHFA's credit financing model. ${ }^{63}$ As the EHFA withdrew from the retail credit markets, Georgia Power hoped to increase its share and, in so doing, continue to drive up demand for its primary product, electricity.

By the end of the decade, Georgia Power's growth vindicated Lilienthal's and the TVA's hunch about market elasticity and rates. Between 1930 and 1939, the amount of energy sold by Georgia Power - 90 percent of the energy used in Georgia - increased from 758,000,000-

kilowatt hours to $1,611,838,000$, an upsurge of 112 percent. Meanwhile the state's population only increased by seven percent during that period, suggesting the degree to which the state's

\footnotetext{
${ }^{62}$ Field, 54-5.

${ }^{63}$ Annual Report of the Georgia Power Company, 1937, 4.
} 
Cebul

energy demand was driven almost solely by increased per capita consumption and expanding industrial uses. ${ }^{64}$ The Company’s total electricity sales soared from a little over $\$ 19$ million in 1935 to $\$ 29.9$ million in 1941 . While the company's net income did not experience parallel growth, after 1935, its annual profit never dropped below $\$ 4.5$ million. ${ }^{65}$ Most significantly, from 1927 to 1942, Georgia Power's electricity customers out-consumed national consumers of electricity by a staggering margin. While the Company’s average kilowatt hours sold per customer was similar in 1927 to the nation's (481 kilowatt hours annually per customer versus 429 nationally), by 1942, it had ballooned to $1,536 \mathrm{kwh}$ (versus $1,022 \mathrm{kwh}$ nationally). To be sure, Georgia's pre-TVA rates of consumption were impressive, but the rate of increase after the arrival of the federal agency was especially dramatic, besting national growth by $66 \%$ between the TVA's arrival in earnest in 1934 and 1942, when the EHFA was phased out. ${ }^{66}$ Suggesting its newfound faith in lowering rates, over the same period, Georgia Power decreased its rates at a more rapid pace and to a lower level than the national averages, sinking from 7.6 cents per $\mathrm{kWh}$ to 2.72 cents (versus 6.8 to 3.67 cents nationally; the TVA rate was just slightly lower than Georgia Power's). ${ }^{67}$ In under a decade, its competition with and emulation of the TVA had

\footnotetext{
64 “Georgia Plans Water Resources Development,” Georgia Progress, June 1, 1946, Binder 1, Economic Development, GPCA.

${ }^{65}$ Figures compiled from Georgia Power Annual Reports, 1935, 1936, 1937, 1941, 1942 and 1943, GPCA.

${ }^{66}$ Annual Report of Georgia Power Company, 1942, GPCA.

${ }^{67}$ Annual Report of Georgia Power Company, 1942, 6, GPCA.
} 
Cebul

revolutionized Georgia Power's business model from one focused on conservative development geared toward industry to one that increasingly looked to individual consumers and households to drive a significant portion of growth.

Nevertheless, the Company's influential and outspoken president Preston Arkwright continued to take aim at government overreach. Much of the blame, he contended, for government's invasion of the private sphere fell on shortsighted businessmen themselves. Business' political interests were too fragmented and myopically self-interested (Arkwright conveniently forgot the small retailers' ire at his partnership with the EHFA). "We decry strict, repressive regulation of our own business by the government," he said in a 1940 speech, "but we don't object if it is applied to somebody else's business. Indeed, I venture to say that most of the repressive regulations have been imposed because of the complaints of other business people, who thought they themselves would escape." This is because, he said, "We have no cohesion. Each business man looks after himself alone and is quite willing to join in any attack on another business man, generally for his own selfish advantage.” Big and small businesses, workers and farmers, he argued, "are all dependent on the same things" and upon each other. The solution was that "business men and professional men [must] give their talents and their abilities to politics and political offices. ${ }^{\circ 68}$ Arkwright pressed his employees to get involved in state and

\footnotetext{
${ }^{68}$ Preston Arkwright, “You Can’t Be Beaten Until You Give Up,” October 17, 1940, Preston Arkwright Speeches \& Early Company Collection, GPCA.
} 
Cebul

local government and regional civic associations. Indeed, the Company strongly encouraged its employees to join local branches of Kiwanis or Rotary and it expected its managers and development experts to become active members of their Chambers of Commerce. The Company, in fact, paid its employees' dues. ${ }^{69}$ The solution, then, was not necessarily less government. The solution was more business influence on government.

After the war, the company took the EHFA 'home-modernization' template for mass consumption and applied it to entire communities. In the 1940s, Georgia Power debuted its Better Home Towns Division (the utility also ran a similar program geared toward farm modernization called the Agricultural and Industrial Development Board, which published a monthly newsletter called Georgia Progress). ${ }^{70}$ The company divided the towns and cities of the state by population classifications, and the Division awarded cash prizes to towns that installed new streetlights, improved their roads, pursued beautification programs, or passed levies on behalf of schools or improved social services - collective efforts that would both demand more energy and, the Company hoped, ultimately attract new business and industry. ${ }^{71}$ The Company hired Deal de Ovies, "beloved minister and well-known writer," to host a radio program

\footnotetext{
${ }^{69}$ Author interview with Ken Cormany, August 2, 2012, Rome, Georgia.

${ }^{70}$ On the Agricultural and Industrial Development Board and Georgia Progress, see Binder 1, Early Development Efforts, GPCA.

71 “Griffin and Cleveland are Acclaimed Champion Home Towns of Georgia," Atlanta Constitution, December 12, 1948, Binder 1, Early Economic Development, GPCA.
} 
Cebul

broadcast throughout the state. As a 1945 ad for the show put it, de Ovies' weekly 15 minute

"This is Your Georgia!" "gives the all-important 'local touch"” by featuring "a Georgia town that has done something new and noteworthy, both for itself and the state. Listen in! You'll find that the people of Georgia are up and doing!"”2 What the company called "community development" was quickly becoming a central piece of Georgia Power's business model.

By institutionalizing competition over municipal development, Georgia Power also sought to alter the structure and aims of local governments. Local Better Home Towns branches offered Georgia Power-trained Community Development consulting services to local civic leaders. The division also published a Better Home Towns Committee Working Manual that communities could use to identify projects and carry out improvements. The Company recommended each town establish a series of committees and subcommittees "for each specific MAJOR job." "For instance:

it's up to the Education Sub-Committee to foster a plan for establishing a vocational training school, or to work with school officials and teachers toward a more effective program of instruction. The Business \& Industry Sub-Committee, on the other hand, will work with merchants toward improvements of store fronts will help local industries expand in the proper direction. ${ }^{73}$

\footnotetext{
72 “This is Your Georgia!,” advertisement, 1945, Preston Arkwright Speeches \& Early Company Collection, GPCA.

${ }^{73}$ Working Manual for Georgia Better Home Towns Committees, Better Towns Materials, GPCA.
} 
Cebul

In addition to providing instructions on the types of committees and their specific goals, the Better Home Towns Division provided "analysis" sheets to help towns identify their needs. Towns were to assess their highways and roads, streets and sidewalks, railroad and bus facilities, airfield service, a variety of municipal utilities, health facilities, educational institutions recreational facilities, and the degree to which the town had a tourist trade. Georgia Power asked towns to assess their social and economic institutions as well. Up for analysis were civic associations, religious institutions, housing stock, factories and industrial plants, agriculture, and the full range of the towns' retail trade and professional services (from music teachers and barbers to the town's lawyers and optometrists). The Company suggested the Advertising and Publicity sub-committees "keep BHT representatives of the Georgia Power Company informed such information will be given state-wide publicity, whenever possible., ${ }^{, 74}$ Deal de Ovies then broadcast successful innovations on "This is Your Georgia!" Of course, the information had other applications, too. By collecting reports on everything from the number of dentists in town to a municipalities' plans to expand its sewage system, the BHT program enabled Georgia Power to deliver steadier service, to forecast future needs, and to provide fine-grained community profiles to potential industries looking to make the move to Georgia. Indeed, Better Home Town teams worked in lock step with the company's

\footnotetext{
${ }^{74}$ Ibid.
} 
Cebul

Industrial Development branch, supplying valuable information for the Company's community profiles, which it distributed to potential recruits from its offices in New York and Atlanta. Interested companies were encouraged to contact Georgia Power or to go directly to local Chambers of Commerce, Kiwanis Clubs, or Mayors. ${ }^{75}$ Highly rational, rooted in communities' self-interest, and tied to economic development, Georgia Power's Better Home Towns was a public relations and business development coup.

Many Georgians deeply appreciated the support and attention provided by their state's private electric utility. In Cleveland, a North Georgia mountain town, Jim Davidson, the editor of the local paper, worried about the town's WWII veterans. "I got to thinking that this town wasn't much of a place for them to come back to." Temp Davis, a regional Georgia Power development official agreed. "Cleveland was just a wide place in the road ... Nobody ever stopped on purpose." The town had no water system nor sidewalks and only a handful of electric lights. Three of the town's four hotels had burned, and the only bank had closed years earlier. So Davis and Davidson rallied the town to make improvements. Following the Georgia Power BHT guidelines, they set aside days to clean the streets, developed and carried out a plan to modernize the town's square, and organized community painting of city businesses and public buildings. "Later," the Rome News Tribune reported, when a new "bank opened, its president ... got out

\footnotetext{
${ }^{75}$ See, for example, Community Profiles of Lawrenceville, Adairsville, Acworth, Monroe, Calhoun, Fairburn, Canton and Cedartown in Binder 5, Advertisements and Community Development, GPCA.
} 
Cebul

with a rake or paint brush." Soon, Cleveland had constructed a new water system, freshly paved its streets, and was sprouting telephone polls that carried not only the new communication technology but also the town's first street lights. The Chief of Police even got an expensive new uniform, which cost a whopping $\$ 157.50$. But, the News Tribune noted, "the chief needs a lot of uniform. He stands 7 feet 4, [and] weighs in at 336 [pounds]. ${ }^{, 76}$ Cleveland won $\$ 1,000$ Better Hometown contests in 1948 and 1952, and, with Georgia Power's assistance, the Talon Fastener Corporation of Meadville, Pennsylvania soon opened a factory in town. "As most other communities have done, Cleveland acquired the land and built the plant on a leasing basis." The next year, Ames Textiles of Lowell, Massachusetts opened a branch factory on a knoll overlooking Cleveland. Mrs. John B. Edwards had been raised on a nearby farm and had always planned to be a homemaker, but when her husband, a carpenter, was injured, she got a job in one of the new factories. Her employment, she reported, was "providential." "I do about half the housework before I go to work," she reported, and "I do the other half when I get home in the afternoon." When asked what her female coworkers did with their paychecks, she said "They're buying stoves and rugs ... most of the money they earn goes into the home." When asked about televisions and radios, she replied quickly: "Oh, yes - many of them ... It's just the most wonderful thing that ever happened to us." ${ }^{\text {77 }}$

\footnotetext{
76 “South Turning Brightest Corner In History With Industrial Growth,” RNT, August 30, 1953.

77 “South Turning Brightest Corner In History With Industrial Growth,” RNT, August 30, 1953.
} 
Cebul

The Company diversified its consumption contests, as well, re-entering Georgians'

homes by extending the work of its nearly-all female Home Services Department, the original development branch modeled on the TVA’s EHFA. In 1949, Mrs. John H. Butler won the Monroe County Living Room Improvement Contest, which had been entered by over 600 "farm wives." She'd placed second in the previous year's kitchen improvement contest and reported that she saw the contests as a great opportunity to provide her 12 year old son Gerald with a home to which he'd be proud to invite his friends. "We had no living room for many years," Mrs. Butler told the Macon Telegraph and News' Farm Editor. "Our house had four rooms and [a] small hallway. We used the little hallway for the living room." Mrs. Butler described how, to win the contest, she "cut the entrance hall in half, made two closets of the space at the rear of the house and left the front space for an entrance hall." She "carefully followed suggestions from the score sheet ... She reworked the fireplace, which had been made of concrete; put in a hardwood floor; used sheet rock for the walls and ceiling." The Power Company's lighting expert pointed out that her inclusion in the living room of a floor lamp and three table lamps was "perfect.",78

Thousands of Georgia homemakers entered these contests over the 1940s. According to the Atlanta Journal, in 1948 alone, over "15,000 farm women improved their kitchen" by

\footnotetext{
78 “Son Main Reason Home Made Over,” Macon Telegraph and News, November 13, 1949, Better Communities Scrap Book, GPCA.
} 
Cebul

entering Georgia Power's regional kitchen improvement contests. ${ }^{79}$ Winners received prizes such as washing machines, lamps, or cash. While the material rewards and public recognition were important to these women, the contestants, like the contest's sponsors, linked the value of home improvement to family values. Prize winners gathered at the Bainbridge, Georgia Presbyterian Church, for instance, were commended for the efforts since "a beautiful and pleasant home would help to solve the juvenile delinquency problem as it would encourage children to stay at home." ${ }^{80}$ Indeed, Monroe County’s Mrs. Butler had gone to such strenuous length to improve her home, as she put it, "Not so much for myself, but for my son." ${ }^{81}$ Women from across the state wrote to Georgia Power to express their appreciation for the company's assistance and for recognizing their hard work (all entrants in one year's contests had received a corsage). Though she hadn't won her local contest, Mrs. Irwin Everett felt compelled to write Elizabeth Parker, the Atlanta-based Director of Georgia Power's Home Services Department. "It seems more like a dream to get all these lovely and wonderful gifts from you and Georgia Power, for 'fixing up my own kitchen.' When one works in their own home they don't expect pay. But then when it comes

\footnotetext{
79 "Polk County Woman is District Winner in '49 Kitchen Contest," The Daily Standard, November 1, 1949; “15,000 Farm Women Improve Kitchens Due to Contest,” Atlanta Journal, September 26, 1949; “Awards and Prizes Awarded to Winners of Kitchen and Living Room Contests," Bainbridge Post Searchlight, November 17, 1949, Better Communities Scrap Book, GPCA.

80 “Awards and Prizes Awarded to Winners of Kitchen and Living Room Contests," Bainbridge Post Searchlight, November 17, 1949, Better Communities Scrap Book, GPCA.

81 “Son Main Reason Home Made Over,” Macon Telegraph and News, November 13, 1949, Better Communities Scrap Book, GPCA.
} 
Cebul

to being awarded for it - well!!! I can't see why every one wouldn't want to get to work at once, especially with a concern as large as GA. Power Co. backing them.. ${ }^{, 82}$ Indeed, the U.S. Chamber of Commerce took note of the popular program, devoting a feature length article to Better Home Towns in a 1951 edition of its periodical, Nation's Business. ${ }^{83}$ For many Georgia women, Georgia Power was truly living up to its longstanding slogan: "A Citizen Wherever We Serve."

$$
* * *
$$

Georgia Power enjoyed extraordinary growth thanks in large part to competition with and their adoption and extension of the practices of the TVA. Meanwhile, other businessmen in Northwest Georgia - indeed, some who worked as development officers with Georgia Power sought direct partnership with the New Deal developmental state on behalf of regional development.

The TVA itself was greeted with a degree of enthusiasm from local merchants and industrialists. In 1934, Wyatt Foster, the chairman of the Rome Chamber of Commerce, who suggested early on that Georgia Power adopt TVA rates, responded enthusiastically to a request from the TVA to identify potential recreational sites that might be developed as part of Authority

\footnotetext{
${ }^{82}$ Mrs. Irwin Everett to Elizabeth Parker, November 17, 1949, Better Communities Scrap Book, GPCA.

${ }^{83}$ Nation's Business, November 1951, accessed online, Hagley Museum and Library Digital Collections, http://www.hagley.org/2012/04/digital-collections-nations-business-online.
} 
Cebul

water and energy infrastructure projects. ${ }^{84}$ Such outreach to local business interests by the TVA was typical of the New Deal agency, which sought explicitly to encourage regional land use planning. ${ }^{85}$ As he evangelized for his agency, Lilienthal became a familiar face in the Coosa Region. In a speech in nearby Chattanooga, Lilienthal touted the rate savings already enjoyed by local businesses thanks to TVA projects. A variety of businesses from a cotton mill to an ice cream company enjoyed 20 - 30 percent reductions in their monthly energy bills. One exceptional case, he noted, was the Tupelo Cotton Mill's 40.4\% reduction while, at the same time, the Mill actually expanded its energy consumption by 26 percent. ${ }^{86}$ The Rome Chamber, too, worked with the TVA to identify private companies in and around the Coosa region that could use timber generated by the massive federal power infrastructure projects. As a result, a number of manufacturing, supply and processing companies benefited from a new supply of cheap timber. $^{87}$

Across the country, local business leaders greeted the early New Deal with wary acceptance and pragmatism. As historian Robert M. Collins has argued, a "spirit of cooperation"

\footnotetext{
${ }^{84}$ W.H. Foster to Sam Brewster, TVA, July 20, 1934, Box 2, RCCP.

${ }^{85}$ McCraw and Selznick.

${ }^{86}$ David E. Lilienthal, Address Before the Tennessee Valley Institute of the University of Chattanooga, April 21, 1934, Box 2, RCCP.

${ }^{87}$ W.H. Foster to L.N. Allen, April 4, 1934, Box 2, RCCP.
} 
Cebul

defined the "early halcyon days of the NRA." In a speech before the national Chamber of

Commerce in May 1933, Roosevelt laid out what he hoped could be a shared vision:

You and I acknowledge the existence of unfair methods of competition, of cutthroat prices and of general chaos. You and I agree that this condition must be rectified and that order must be restored. The attainment of that objective depends upon your willingness to cooperate with one another to this end and also your willingness to cooperate with your Government. ${ }^{88}$

Far from recoiling at Roosevelt's call for planning, the national Chamber of Commerce rushed to press its influence on the NIRA's corporatist version of cooperation, planning, and managed competition. ${ }^{89}$ As the New York Times reported, "the President's speech was received with an enthusiasm which can hardly be overemphasized." Henry Harriman, President of the U.S. Chamber, underscored the President's sentiments in a speech before the Philadelphia Chamber of Commerce. "Laissez faire," he said, "must be replaced by a philosophy of planned national economy." ${ }^{90}$ Indeed, even before the NIRA passed Congress, the national Chamber set to work drafting codes and preparing implementation guidelines for its local branches. Nation's Business, a leading trade periodical, endorsed the sea change: "Some ancient cornerstones of

\footnotetext{
${ }^{88}$ Roosevelt quoted in Robert M. Collins, The Business Response to Keynes (New York: Columbia University Press, 1981), 29.

${ }^{89}$ Ibid, 29-31. See also, Ellis Hawley, “The Discovery and Study of a 'Corporate Liberalism,"” Business History Review (Autumn 1978), 52:312.

${ }^{90}$ Ibid., 30 .
} 
Cebul

business undoubtedly are being moved ... but there is strong sentiment that they are landing on solider ground."

Though business leaders still emphasized the sanctity of balanced budgets, some business leaders pragmatically countenanced increased public works spending and strategic economic planning. "Inevitably under such a system there will be some ill-considered action, some errors, and perhaps some regrets," opined Nation's Business. "But ... there is evident a conscious attempt to reduce mistakes to a minimum and to make expended funds produce maximum results." President Roosevelt, after all, "has done a fine job." ${ }^{91}$ While the vast majority of businessmen regretted the need for a New Deal between business and the state, early on, many accepted the Roosevelt administration's good faith effort to get the nation's economy moving again.

Though there were grumblings about the NRA's clumsy start, in a speech before the Southeastern Divisional Meeting of the Chamber of Commerce in Atlanta in the fall of 1933, Chamber President Harriman underscored his organization's commitment to the colossal effort:

For four years we were sliding down hill and it will take several years to recover. Mistakes have been made. More will probably be made, but mistakes are inevitable in a program of such magnitude... We may now have reached the limits of extensive development, but the vast field of intensive or internal improvement lies ahead to challenge our resourcefulness and to test our courage. Better homes, more education and leisure, shorter hours of work, higher pay, a balanced production to consumption, a wider

\footnotetext{
${ }^{91}$ Ibid., 31.
} 
Cebul

diffusion of wealth, a more equitable system of taxation, protection against sickness, unemployment, and old age - these mark the steps toward the economic security which our well-being demands, and which is our ULTIMATE GOAL [emphasis in original]. ${ }^{92}$

For Harriman, as for many of the economic planners in the first Roosevelt administration, the task before the nation's civic leaders was restoring balance to the business cycle. ${ }^{93}$ While other industrialists and businessmen offered cautionary warnings against labor organization, on the whole, the meeting was characterized by pragmatism. ${ }^{94}$ The promise and peril of the New Deal were apparent to Southern business leaders from the start.

Local businessmen, however, had different complaints about nationally driven planning and worried that new labor rates would unfairly stymie Southern recovery and growth. The final report on the NRA issued by the Chamber's Southeastern Division described the regionally skewed pressures NRA labor codes exerted against the South. The national wage scales, they contended, resulted "in comparatively negligible increases in labor costs to northern and eastern industries," while in the South, "they have and will result in increases . . f from $50 \%$ to $150 \%$." Such wage hikes, "will imperil the actual existence of many industrial and manufacturing

\footnotetext{
${ }^{92}$ Henry I. Harriman, “The New Deal to Date," in Summary of the Proceedings of the Southeastern Divisional Meeting of the Chamber of Commerce of the United States, November 20 and 21, 1933, Box 1, RCCP.

${ }^{93}$ On the distinctions between the early New Deal's emphasis on restoring economic balance and the late New Deal's pivot to Keynesian growth policies and full employment, see Robert M. Collins, More, esp., Prologue and Ch. 1, and Alan Brinkley, The End of Reform, esp. chs. 2, 10 and Epilogue.

${ }^{94}$ John A. Law, "Southern Aspects of Industrial Recovery," in Summary of the Proceedings of the Southeastern Divisional Meeting of the Chamber of Commerce of the United States, November 20 and 21, 1933, Box 1, RCCP.
} 
Cebul

operations in the South ... [and] will make it impossible for southern manufacturers to

overcome freight differentials on both raw and finished materials." Their report recommended "a supplemental basic code to provide that minimum hourly wages in industry and business in the

South be fixed at levels equal to those existing in July 1929" and, which, "in no instance shall . .

. be greater than $70 \%$ of the minimum wages for the North and East under the code governing a similar classification of business or industry." 95 Southern businessmen sought to make sure that, in comparison to their Northern competitors, the New Deal for the South was a fair one as well.

Rome Chamber leader Wyatt Foster appealed to his regional NRA official for guidance on wage rates for the "farm women and the women in the small towns" whom, he wrote, "work at their leisure time - in other words - after their household duties are performed and as they catch time during the day or evening." Manufacturers, he explained, delivered spreads stamped with the outline of a design, which "the woman fills in ... and gets paid for the number of ounces of the tufting thread that she sews into the spread." "I am sure," Foster wrote, "that if you have travelled from Atlanta to Chattanooga, via Calhoun and Dalton, you have seen a great many of these spreads and mats hanging out along the sides of the road in front of their homes." Rather than take a combative tone at national intervention in local labor markets, Foster concluded with an appeal for guidance: "This industry is so entirely different from work done in the factory, so

\footnotetext{
95 "Southern Wage Differential," in Summary of the Proceedings of the Southeastern Divisional Meeting of the Chamber of Commerce of the United States, November 20 and 21, 1933, Box 1, RCCP.
} 
Cebul

many hours per week, that it seems to us that your office might get in direct touch with this work and determine whether . . those engaged in this tufting are being sufficiently paid."96

While Foster hoped to carve out a degree of local autonomy in federal labor policy, NRA codes, the Wagner Act, and, later, the Fair Employment Practices provided business leaders with easy examples of invasive federal policies. The Rome Chamber was dead set against collective bargaining rights for workers, and corresponded periodically with "labor experts" on ways to defuse "industrial disturbances." 97 The Chicago-based labor expert Henry Curran Wilbur wrote frequently to Georgia Chambers even prior to the New Deal, warning them in one case that "an organizer for the National Textile Workers Union, the Communist organized, controlled, and guided union in the textile field, is soon to start for Rome, Ga., to form branch groups there." 98 The organizers' chief goal, Wilbur counseled, “on orders of the Communist International . . . is to form military groups for use in connection with the ultimate Communist plans."99

During the war, the Fair Employment Practices Commission especially drew the ire of Rome's newspaper editorial pages, which castigated the federal agency for threatening to overturn the racial status quo. The paper published a photo of the local FEPC officer, noting "the

\footnotetext{
${ }^{96}$ WH Foster to DB Lasseter, March 20, 1934, Box 1, RCCP.

${ }^{97}$ Henry Curran Wilbur to R.A. Palmer, August 9, 1929, attached to Benj. B. Barker to W.H. Foster, August 16, 1929, Box 2, RCCP.

${ }^{98}$ Henry Curran Wilbur to R.A. Palmer, July 15, 1929, Box 2, RCCP.

${ }^{99}$ Henry Curran Wilbur to R.A. Palmer, July 15, 1929, Box 2, RCCP.
} 
Cebul

person second from the left is a 'Chocolate Drop' from Chicago, while the one fifth from the left is a big "Tar Baby." Later, in a front-page editorial, the paper commended Alabama Governor Frank Dixon for railing against the federal incursion. Dixon, the paper opined, had mounted "one of the noblest defenses of white supremacy that has resounded throughout the South for many a moon." His defense of local labor and racial practices was a "bold utterance, worthy of the best that ever fell from the lips of great Southern leaders like Robert Toombs, Alexander Stephens, John B. Gordon, Henry Grady and other immortals." ${ }^{100}$ Indeed, Rome's boosters opposed federal meddling in labor markets (their main competitive advantage over the North) and their social and racial hierarchy, but the archival record suggests that the vast majority of the Rome Chamber's efforts were geared toward lobbying local, state and national government to deliver more developmental spending. The Rome Chamber hoped to roll back or contain certain aspects of the New Deal state, but they were keenly interested in others.

Indeed, there were many aspects of the New Deal rural businesspeople embraced wholeheartedly. At the same meeting of the Southeastern Chambers, the businessmen held a meeting to discuss ways to "speed public works." "The records of the Public Works Administration," they found, "show that the presentation and approval of projects in the

\footnotetext{
${ }^{100} R N T$, July 23, August 10, and September 4, 1942; Brattain, 101.
} 
Cebul

Southeastern territory is proceeding at a rate far behind that of the remainder of the country.,"101

The "submission and approval of proper projects," they found, must "be expedited." ${ }^{102}$ Delegates acknowledged that some of the responsibility rested with themselves and their local political leadership. They explored ways to exert their influence on local projects. Winning federal development support was a competitive sport, and they so far had few points on the board. The delegates from Georgia, however, had a particularly significant impediment to winning New Deal public works spending: Governor Eugene Talmadge. From the moment he assumed the governorship in 1933, Talmadge waged war on Roosevelt's New Deal. "If the government keeps handling relief, manicuring nails and giving relief people cars to ride around in," he fumed, "it will stifle religion in the country and all religion will just dry up. Let the communities take care of relief through their religious organizations." Likewise, Talmadge assailed wage and price controls and called farm price supports "the first move toward making peons of the farmers of America." Talmadge's intransigence led the Roosevelt administration to federalize Georgia's relief efforts, and Talmadge reciprocated by refusing to participate in old age assistance, aid to dependent children, and other federal welfare programs. As he put it, these wage controls threatened to "add on nearly every Negro of a certain age in the county to this

\footnotetext{
101 "To Speed Public Works," in Summary of the Proceedings of the Southeastern Divisional Meeting of the Chamber of Commerce of the United States, November 20 and 21, 1933, Box 1, RCCP.

${ }^{102}$ Ibid.
} 
Cebul

pauper's list" and, in so doing, "eradicate state lines and centralize all power in Washington."103

While Georgia benefitted from some federal programs, Talmadge's obduracy limited their

breadth and impact.

Georgia's business leaders watched with frustration as the state's neighbors surpassed

them in winning federal funds. In Alabama, just a few miles to the west of Rome, governor Bibb

Graves seized upon the New Deal; indeed, he had been one of Hoover's leading critics,

complaining in 1930, "I want not only suggestions but help before these people get to suffering. I

want to do something to add to their buying power."104 In contrast, Talmadge's refusal to expend state capital on behalf of federal grant matching requirements meant that, between 1933 and 1939, Georgia received the second lowest per-capita federal spending (North Carolina ranked last). ${ }^{105}$ Pressed by forward-looking business constituents who hoped to bypass the governor altogether, members of the state legislature attempted to change the state's strict limits on borrowing (neither the state government nor local units could borrow more than seven percent of their potential tax revenues and the state was unable to borrow against future years' revenue). ${ }^{106}$ Talmadge blocked all of their efforts. As a result, in 1933, the state qualified for only 43 projects in just 24 of its 159 counties. Without the ability to raise local funds to apply for federal works

\footnotetext{
${ }^{103}$ Bartley, 173-4.

${ }^{104}$ Quoted in Patterson, The New Deal and the States, (Princeton: Princeton University Press, 1969$), 28$.

${ }^{105}$ Gavin Wright, Old South, New South, 260.

${ }^{106}$ Holmes, The New Deal in Georgia, 168-9.
} 
Cebul

projects, many counties and local governments opted against applying for any projects at all

until, in its 1935 Congressional reauthorization, the PWA increased its funding portion of local

projects from 30 to 45 percent for material and labor costs. ${ }^{107}$ By the next summer 188 new

projects were completed. ${ }^{108}$ Indeed, despite constant bickering between Talmadge and the

Federal Roads Bureau, road construction in Georgia eventually became the most significant use

of PWA funds and labor. ${ }^{109}$ Still, Talmadge's impact on the state's underutilization of federal

funds, even in the area of road construction, is clear when comparing Georgia to its neighbor to

the west. In 1930, Georgia had just under 15,000 miles of paved roads, and between 1935 and

1943, the state constructed 9,000 miles of new roads. During the same period, Alabama

constructed over 20,000 miles of roads, more than doubling its 1930 total. ${ }^{110}$

Businessmen sensed that federal policies were unfairly meted out, and interregional

competition within the state only deepened local boosters' worries that they were being left

behind. Wyatt Foster wrote to the Macon Chamber to enquire about the number of relief jobs the central Georgia city had been allotted. "What I am all 'hot and bothered' about," wrote Foster, "is that I am given to understand by our City Manager that Rome and Floyd County is being discriminated against in the allotment of jobs. For a population around 50,000," he fumed,

\footnotetext{
${ }^{107}$ Holmes, 169.

${ }^{108}$ Holmes, 174.

${ }^{109}$ Holmes, 175.

${ }^{110}$ Gavin Wright, "The New Deal and the Modernization of the South,” Federal History, $2010,59$.
} 
Cebul

“Floyd County has been allotted 674." He'd heard, however, "that there are counties in Georgia with possibly less than half the population of Floyd County, that are being allotted 1000 or more jobs, and also that the [federal] Government is paying for equipment, such as small tools and materials on the projects, whereas they are desiring of us that this be paid for by us locally."111 Whether the rumored discrepancy was fact or fiction, Foster's response reveals the importance local business leaders attached to federal spending in jumpstarting local economies.

One of the major projects for which Foster and the Rome Chamber pursued New Deal funding was to improve Floyd County's airport. Federal funds were the linchpin to these local developments, and local business leaders, not local politicians, led the pursuit of WPA support for the Rome Airport. Beginning in 1935, the WPA made improving the nation's air infrastructure a major focus. In eight years, the New Deal agency built more than 480 airports and made improvements to another $470 .{ }^{112}$ Prior to the New Deal, Rome's business leadership worked with the federal government to construct the county's first landing strip and aggressively lobbied the Department of Commerce and the office of the Postmaster General to designate Rome an airmail post office or to establish at Rome an emergency field for the Atlanta-Chicago air mail line. ${ }^{113}$ Earlier in the decade, the CWA contributed $\$ 80,000$ to an initial expansion of the

\footnotetext{
${ }^{111}$ W.H. Foster to Lincoln McConnell, December 13, 1933, Box 2, RCCP.

112 Smith, Building New Deal Liberalism, 208.

${ }^{113}$ W.H. Foster to W.F. MacCracken, Jr., July 16, 1928 and John K. Ottley, Jr. to W.H. Foster, July 14, 1928, Box 1, RCCP.
} 
Cebul

city's two airstrips, but without modern lighting on the runway, the field was not up to the

Commerce Department's regulations for landing passenger or mail planes (indeed, when visiting

a business man flew into Rome, the Chamber offered to "have a man guide you in" from another plane). ${ }^{114}$ The head of Rome's Airport Association (a committee of the Chamber of Commerce) corresponded frequently with the WPA's North Georgia Area Engineers, the Department of Commerce and the Civil Aeronautics Authority. Rome's business leaders were invested in the project, he wrote, but because of the poor "financial conditions of both City of Rome and Floyd County ... none of the officials of the either the City or County have taken a great deal of interest in" the airport. ${ }^{115}$ Indeed, insomuch as they were interested at all, it was the prospect of federal support that made possible the entire endeavor. As the President of the Rome Airport Association put it, "unless you feel that we have a worthy WPA project, it's going to be hard to interest the City of County officials in going further with us." ${ }^{116}$ The Chamber even explored the possibility that, once the improvements had been completed with WPA funds, they could use the "Preparedness Program" to turn over to the federal government the day-to-day responsibilities for maintaining the airport. ${ }^{117}$ As the nation pivoted to war, Rome's business leaders got their

\footnotetext{
${ }^{114}$ W.H. Foster to W. Irving Glover, Second Assistant Postmaster General, July 16, 1938, Phillips Moore to W.H. Foster, March 8, 1938, and U.N. Howell to J.D. Keever, July 13, 1938, Box 1, and President, Rome Airport Corporation to W.V.M. Robertson, Jr., July 16, 1928, Box 1, RCCP.

${ }^{115}$ U.N. Howell to Phillips Moore, November 19, 1938, Box 1, RCCP.

${ }^{116}$ U.N. Howell to W.J. Greene, January 6, 1939, Box 1, RCCP.

${ }^{117}$ Phillips Moore to U.N. Howell, November 22, 1938, Box 1, RCCP.
} 
Cebul

federally funded airport improvements. ${ }^{118}$ In 1942, Georgia's WPA administrator put a fine point on the crucial role WPA funding played in developing the state's air infrastructure, linking the developments to the war effort: "Cancel out the work of the WPA in the past six years and, I assure you, it would seem that Hitler's Luftwaffe had suddenly visited us in the night."119 Forward-looking Georgians' realization that their state was lagging its neighbors in seizing the benefits of New Deal spending slowly transformed the state's electoral politics as well. Indeed, while Eugene Talmadge did his best to block outside influence in state affairs, New Deal programs and national foundation spending trickled into Georgia (the Rosenwald Fund, he said, delivered "Jew money for niggers"), giving Georgians a glimpse of newfound developmental possibilities. ${ }^{120}$ In 1936, Talmadge reached his term limit, and voters turned out in unusually high numbers to choose E.D. Rivers in the all-white Democratic primary over Talmadge's handpicked successor (Talmadge was defeated in his bid for U.S. Senate by Richard B. Russell, a cautious supporter of the New Deal). Relative to other states, Rivers was hardly a revolutionary figure (he frequently reminded voters of his commitment to white supremacy), but he promised to pass legislation and constitutional amendments necessary for Georgia to fully participate in the New Deal. Once in office, Rivers set out on a 'little New Deal' for Georgia,

\footnotetext{
${ }^{118}$ Cite the history of the Rome airport on its web page.

${ }^{119}$ Quoted in Smith, 210.

${ }^{120}$ Bartley, The Creation of Modern Georgia, 194.
} 
Cebul

resulting in, as one wag put it, "the bill passin'est session since Oglethorpe climbed out on Yamacraw Bluff." Many of the progressive measures he passed reflected business leaders' moderate developmental agenda: the creation of the state's first economic planning board, increased spending for schools, and, most significantly, cooperation with federal relief and highway officials by circumventing the stringent constitutional limits on state debt through the creation of independent highway and road authorities that could sell their own bonds. ${ }^{121}$ To fund these efforts, Rivers increased personal and corporate income taxes. These levies, however, were often insufficient to meet federal matching requirements. As President Roosevelt bluntly put it on a trip to Warm Springs, "this state cannot raise money . . because there is nothing to tax." Georgia was soon on the verge of bankruptcy, and chaos descended on the capital. Rivers was forced to declare martial law in order to impound $\$ 2.5$ million from the state highway fund to direct it toward more urgent emergencies. Though Rivers had the will and, for a time the support of the voters, without public revenue, he had no way to secure the kind of little New Deal developments enacted in other states. ${ }^{123}$ In 1940, Talmadge was reelected as governor on a platform emphasizing racial and moral platitudes, local control, and balanced budgets.

\footnotetext{
${ }^{121}$ Bartley, 191.

${ }^{122}$ Ibid., 176.

${ }^{123}$ Patterson, The New Deal and the States, 142 - 154.
} 
Cebul

Despite the collapse of Rivers' Little New Deal, his two terms enhanced local-federal partnerships. As federal funding and development projects arrived in and around Rome, the region's business leaders set their sights higher than merely improving the modest infrastructure they already enjoyed. ${ }^{124}$ Located at the convergence of three rivers, Romans had long imagined the potential economic boom that would come from improving the region's waterways. But, the rivers also overflowed their beds, threatening commerce, agriculture and future development. Indeed, in his book, George Magruder Battey, Rome's progressive era historian, included plates depicting the rivers titled: "Some Day Man Will Conquer Water" and "Dame Nature Makes Romans Step Lively." "125 A cataclysmic 1886 "freshet," as he termed the flood, jolted Rome's civic leaders to the realization that any development they pursued was contingent upon their ability to manage the rivers. City boosters dreamed of linking flood control measures with a 360mile canal project to that would connect the Coosa River to the Gulf of Mexico at Mobile. ${ }^{126}$ Yet, as of Battey's 1922 account, despite a number of halting attempts at fund-raising and state

\footnotetext{
${ }^{124}$ Though it, too, was not without significant tension. Roosevelt halted PWA aid to Georgia in 1938 when Rivers failed to endorse Roosevelt's candidate against Senator Walter George. See Schulman, From Cotton Belt, pp. 52-4. In Rome, civic leaders eagerly deployed the WPA to build parks and bridges, to modernize streets and highways and to build a community center. ${ }^{124}$

${ }^{125}$ Battey, A History of Rome and Floyd County, 323 and 332.

${ }^{126}$ Mississippi Valley Association, “The Alabama-Coosa River Project,” undated pamphlet, Box 2, RCCP.
} 
Cebul

lobbying, no progress had been made on Romans' vast inland waterway and flood control

project. ${ }^{127}$ Nevertheless, successive generations of Rome businessmen kept the dream alive.

Alabama and Georgia businessmen made periodic attempts to win the support of their state governments, but a project of such magnitude, stretching across hundreds of municipalities, counties and jurisdiction, was a political nonstarter. In the 1920s, regional interests joined the Mississippi Valley Association (MVA). Founded in 1922, the MVA was an organization of "farsighted Valley business men" from Alabama to Minnesota who sought public support for infrastructure improvements along the nation's longest artery. The MVA showed little interest in their proposed Alabama-Coosa River project (the name given to the canal and its corresponding improvements), but they offered guidance on an increasingly professionalized art: lobbying. ${ }^{128}$ Local Chamber of Commerce members took the MVA's advice and fanned out across the region to galvanize the leading businessmen's associations - the burgeoning Kiwanis and Rotary Clubs, chief among them. ${ }^{129}$ Following the MVA model, development boosters used these speaking tours to raise public and private funds to support the "movement." In addition to soliciting $\$ 1,500$ from interests in Rome, in Alabama, the organization targeted Gadsden, Anniston, and Selma ( $\$ 1,500$ each), $\$ 3,000$ from Montgomery, $\$ 4,000$ from Mobile, and, $\$ 2,000$ from each of

\footnotetext{
${ }^{127}$ See Battey, 315-332.

${ }^{128}$ E.L. May to C.O. Walden, June 13, 1929, Box 2, RCCP.

${ }^{129}$ See, for instance, W.H. Foster to W.H. Butler, June 26, 1929, Box 2, RCCP.
} 
Cebul

the twenty counties most likely to benefit. The $\$ 53,000$ they secured underwrote the research,

publicity, and lobbying that became, in 1929, the Coosa Alabama River Improvement

Association (CARIA). ${ }^{130}$ In 1930, Wyatt Foster articulated their vision: it "should not require a

very vivid imagination to grasp the many advantages to Rome and this section [of developing the

Coosa] - cheaper transportation, development of latent resources, location of additional

industries, [and] enormous saving to agriculture by reason of flood control."131 As the Secretary

of the National Rivers and Harbors Association put it in a 1929 letter to Foster, were the

Alabama-Coosa to be "open to navigation ... where [the region's] people 'are dipping up

pennies in a tin cup, they would then be scooping gold eagles with a shovel.",132

The Talmadge administration limited their progress, however, and, by 1936, one CARIA

member recalled, "it looked as if the proposition was quite dead." ${ }^{133}$ Nevertheless, an important

project on a smaller scale represented a significant breakthrough. In 1936, the president of the

Rome Chamber teamed with H.H. Keel, the chairman of the City Commission, to create a City

Levee Committee made up entirely of Chamber of Commerce and City Commissioners. They

sought federal support for a new levee to protect the city's growing downtown fringe from the

\footnotetext{
${ }^{130}$ J. A. Fox to W.F (sic) Foster, June 27, 1929, Box 2, RCCP.

${ }^{131}$ W.H. Foster, untitled speech before the Rotary Club, July 1930, Box 2, RCCP.

${ }^{132}$ E.L. May to W.H. Foster, June 13, 1929, Box 2, RCCP.

133 'Coosa Certain Success,' Meighan Says on Return: Emergency Nature of Situation Will Speed Money Allocation for River Work, He Adds," Gadsden Times, November 9, 1941, Box 1, RCCP.
} 
Cebul

temperamental waters of the Coosa and Oostanaula Rivers. The committee soon met with representatives from the Army Corps of Engineers at Mobile, Alabama and requested a federally funded feasibility study for the new floodwall for the city. Working with the Corps, Keel's committee designed a levy that was 100 feet wide at its base, averaged eighteen feet high and extended for two miles between the river and Rome's Second Avenue. The city's downtown merchants were abuzz, but residents of the city's south and west sides strongly opposed the proposed development. They abutted the equally-flood prone Etowah River and feared the massive levee would wall them off and subject them to even higher floodwaters. After a year of wrangling, however, the committee struck an agreement with concerned residents. Rather than choose one project or the other (or neither), because Uncle Sam was being so generous, Keel and his allies at the Chamber doubled down on their requests. They would pursue an additional project to manage the Etowah's levels. With final federal approval, the Army Corps contracted with a private construction company, and, by February 1938 , work had begun on the $\$ 400,000$ project. By the summer of 1938 , the company's payroll averaged $\$ 75,000$ a month, employing between 125 and 200 men at any time; almost all were drawn from Floyd County relief rolls, a significant boon for the region's economy. More than man-hours, however, the levee was comprised of over 400,000 pounds of Alabama steel and nearly 4,000 cubic yards of concrete. The levee project put men to work, stimulated the local economy through their renewed 
Cebul

purchasing power, and stimulated the region's industrial output. The frigid ribbon cutting in

February 1939 was declared a local holiday and was attended by thousands of Romans.

Airplanes soared overhead as representatives from the Chamber and the Commission christened

the floodwall the "H.H. Keel Levee." ${ }^{134}$ Within three years, the federally funded floodwall

enabled the construction of a new (federally underwritten) park and the $\$ 200,000$ Floyd County

Hospital, which, the Rome News Tribune boasted upon its 1942 opening, had beds for "sixty-five white patients, fifteen colored patients, and fifteen babies." $" 135$

The arrival of the Rivers administration augured new developmental possibilities, but the major factor that revived their hope was President Roosevelt's adoption of their developmental dreams for the South. Indeed, the prescriptions for the South's 'colonial economy' adduced in the administration's Report on the Economic Conditions of the South echoed those of Henry Grady a half century earlier: industrialization, tapping natural resources, and developing local consumer markets would help the South become economically self-sustaining, and in so doing, remedy what Roosevelt later called “the Nation's No. 1 economic problem.” The result was accelerated approval of Southern development projects. Indeed, the number of Georgians employed by the WPA exploded. In December 1937 just 24,272 Georgians were employed on

\footnotetext{
${ }^{134}$ Aycock, 420-24.

${ }^{135}$ Rome News Tribune, July 3, 1942; Aycock, 487-8.
} 
Cebul

projects; one year later, the total was 67,203 , nearly tripling the number of workers. In contrast, the national total had not even doubled. ${ }^{136}$

In 1938, inspired by the success of the Rome Levee and the infusion of new federal

dollars, H.H. Keel turned to J.J. McDonough, the new Rome Chamber President and a regional Georgia Power administrator, to resuscitate the Alabama-Coosa project. McDonough reached out to CARIA members, but, most significantly, called on his friend, Congressman Malcolm Tarver. From Washington, Tarver advised McDonough that the consulting engineers and budget analysts of the House Rivers and Harbors Committee had nagging "doubts as to whether [the] estimated costs of construction" were worth the "amount of economic benefits which may be anticipated." ${ }^{137}$ By 1939, as the nation began to plan for war, the rationale for massive development projects began to shift. While McDonough organized letter-writing campaigns at Kiwanis, Rotary and Chamber meetings, Tarver extended his lobbying to the White House. In 1940, his efforts paid off, and Roosevelt personally wrote the Georgia Congressman, assuring him that the project would receive judicious consideration from the National Defense Advisory Council, the Corps of Engineers and the Federal Power Commission, and the Army Corps. ${ }^{138} \mathrm{~A}$ representative of the Corps conveyed the good news to Tarver: given "the recent directive of the

\footnotetext{
${ }^{136}$ Figures in Holmes, The New Deal in Georgia, 333.

${ }^{137}$ MC Tarver to JJ McDonough, April 19, 1941, Box 1, RCCP.

${ }^{138}$ Franklin D. Roosevelt to M.C. Tarver, December 26, 1940, Box 1, RCCP.
} 
Cebul

President," the "department will expedite its further consideration" of the Allatoona Reservoir and Etowah River projects. ${ }^{139}$ The result was a new round of hearings on the project scheduled for April 1941.

McDonough convened a meeting of the CARIA in nearby Gadsden, Alabama to unify the boosters' lobbying efforts and to plan their trip to Washington to appear in support of the bill that would become the Flood Control Act of $1941 .{ }^{140}$ The vast majority of the Coosa area's business leaders enthusiastically responded, though the development would have to overcome the strenuous objection of the region's railroad interests, who viewed enhanced river infrastructure as a threat. ${ }^{141}$ On April 28, 1941, the Southern business leaders packed into thirty rooms at the Wardman Park Hotel outside Washington, DC ${ }^{142}$ Representatives from Georgia alone hailed from Acworth, Atlanta, Calhoun, Carrollton, Cartersville, Cedartown, Chatsworth, Dalton and Rome. Following their trip, the businesspeople built a contingency fund "with which to meet any emergencies that may arise in the quick prosecution of the campaign ... we must strive for quick and positive action before the Federal Power Commission and the National Resources Commission, as well as the White House - bending every energy to get these hurdles out of the

\footnotetext{
${ }^{139}$ Thomas M. Robbins to M.C. Tarver, January 6, 1941, Box 1, RCCP.

140 “Coosa Meeting Caled April 16," Rome News Tribune, April 3, 1941, Box 2, RCCP.

141 “Coosa Waterway Action Gladdens Local Citizens," Gadsden Times, November 9, 1941, Box 1, RCCP.

${ }^{142}$ JR Hornady to JJ McDonough, April 21, 1941, Box 1, RCCP.
} 
Cebul

way in time to have the project" passed by Congress. ${ }^{143}$ By August, Congressman Tarver

received assurances of support from the director of the Office of Production Management, who

wrote that the OPM was doing everything "possible to accelerate completion of the project so

that the power supply thereby made available will be of maximum utility in our defense

effort." ${ }^{144}$ To that end, the OPM director wrote a personal letter to the Undersecretary of War,

Judge Robert P. Patterson. ${ }^{145}$ While the Office of the Chief of Engineers had long been hesitant

to fund the Allatoona Dam project, as a result of this new pressure and the slide toward a war

footing, their calculus changed. By the end of the summer of 1941, their reluctance became

enthusiasm. "You may be assured that the Department recognizes the importance of the

Allatoona project for flood control and the development of hydroelectric power," the Chief of

Engineers wrote to Tarver, "and that it is fully prepared to undertake the design and construction

of the Allatoona Dam without delay when funds for those purposes become available."146

The project was ultimately funded under the guise of defense preparedness, but local

businessmen well understood where the real benefits would be. The Flood Control Act of 1941

included \$3.3 million for opening the "Mobile River Basin."147 Federal engineers recommended

\footnotetext{
143 JR Hornady to Henry W. Pyne, May 8, 1941, Box 1, RCCP.

${ }^{144}$ William S. Knudsen to M.C. Tarver, August 1, 1941, Box 1, RCCP.

${ }^{145}$ William S. Knudsen to Robert P. Patterson, August 1, 1941, Box 1, RCCP.

${ }^{146}$ John J. Kingman to M.C. Tarver, August 29, 1941, Box 1, RCCP.

${ }^{147}$ Public Law 228, $77^{\text {th }}$ Congress, $1^{\text {st }}$ Session, HR 4911, accessed online at the website of the United States Fish and Wildlife Service, http://www.fws.gov/habitatconservation/wrda.html.
} 
Cebul

a total amount, once the $\$ 3.3$ million was used to get the project under way, of $\$ 13$ million of future spending be allocated for the project. ${ }^{148}$ By October, when an omnibus rivers and harbors bill was passed, the federal government had committed an astonishing $\$ 60,000,000$ to develop the power and water infrastructure in the Coosa-Alabama region (among the 236 projects authorized in the bill was \$192 million for the Great Lakes-St. Lawrence Seaway project and \$197 million for a ship canal in Florida, for which the WPA had already committed \$5.4 million). ${ }^{149}$ A Gadsden retailer called the federal measure "one of the grandest achievements taking place in the history of the city ... We can't exactly realize what it means to our city ...

Once we are in the swing of this, I can visualize a great city in one of the greatest industrial areas in our country." Louis Loveman, a local merchant recalled that, "When I came here 49 years ago the main topic of discussion was the Coosa river development, and now, almost half a century later, it is gratifying to learn" that the project would be a reality. ${ }^{150}$ Similarly, when Romans had lobbied their Washington delegation, they rarely mentioned the war effort as a prime motivator for funding. I.M. Levinson, the President of the Rome Retail Merchants Association said the project would be "the greatest asset that Rome has ever had." Levinson, like M.D. Daniel,

\footnotetext{
148 “House Committee Favors Start on River Project,” News Clipping, May 30, 1941, Box 1, RCCP.

${ }^{149}$ JR Hornady to Friends and Supporters, January 7, 1942, Box 1, RCCP; "House to Get 900 Million Waterways Measure Next Week," Washington Post, October 24, 1941 and "Seaway Plan Gets Approval of House Group: But Minority Fights It as Waste," Chicago Tribune, November 22, 1941.

150 “Coosa Waterway Action Gladdens Local Citizens,” Gadsden Times, November 9, 1941, Box 1, RCCP.
} 
Cebul

incoming president of the Rome Chamber, never mentioned the war effort in their telegrams to their Washington representatives. ${ }^{151}$ When Rome's Kiwanis President mentioned the looming war, he emphasized the potential economic benefit for the region. "Not only," he wrote to Georgia's delegation, “do we feel this to be essential as a defense measure but [it will also be] our greatest forward stride in the industrial development of the southeast. We are counting on you." ${ }^{\prime 52}$ Upon passage, Congressman Tarver wrote to convey the good news to a Georgia CARIA-member. At the bottom of his typed letter, Tarver scrawled a note, cheekily punching up the link between war and local economic development: "The Blitz has hit our Uncle Sam - and our Aunt Airy Craft. They need our help. We are in the army now."153

The hard work local business leaders put in to lobbying the federal administrators and bureaucrats contributed to their sense that these programs were justified, natural and, in some cases, underwhelming compared to their own herculean efforts amidst rumors of other regions' winnings. Indeed, while the region's business leaders enthusiastically pursued federal support for the development projects, they and their allies in the regional press often framed their relationship with the federal government in competitive terms. An editorial in the Rome News Tribune brought readers up to speed on the status of the project prior to the April hearings. It did

\footnotetext{
${ }^{151}$ IM Levinson to Sen. Walter F. George and Senator Richard Russell, undated (Dec. 1941), Box 1, RCCP.

${ }^{152}$ Ed L. Cantrell to Walter F. George and Richard B. Russell, December 6, 1941, Box 1, RCCP.

${ }^{153}$ MC Tarver to CA Milhollin, December 4, 1941, Box 1, RCCP.
} 
Cebul

so, however, by framing local development goals and federal bureaucrats in oppositional terms.

"The score is tied, so to speak," and, "the district and division engineers" who know the local

score have "recommended the improvement." The "board of engineers in Washington,"

however, "must be convinced of its economic importance to the state of the nation." "Teams

entering this vitally important contest" from across the region "will be fully represented...

when the chief of engineers [in Washington] calls 'Batter Up." "154 Those laboring for these

improvements, the News Tribune argued, "are not only serving their own communities but also

serving the nation."

Publicly, boosters argued that developing local resources was the patriotic thing to do, and, though the federal government provided the crucial funding, its engineers and bureaucrats became construed as the major impediment to the development. On the one hand, federal support habituated local leaders to federal programs - and a significantly larger scale of spending.

Meanwhile, the rhetoric surrounding New Deal projects - especially in the slide toward war endowed parochial developmental goals with an inflated sense of national purpose and patriotism. Local boosters recognized the utility of draping longstanding developmental dreams in nationalistic and patriotic bunting. ${ }^{155}$ On the other hand, the inflation of national purpose and the hard work that local development-minded business put into winning federal support, helped

\footnotetext{
154 “Crucial Event April 28,” Rome News Tribune, April 22, 1941, Box 2, RCCP.

${ }^{155}$ On this trend nationally, see James Sparrow, Warfare State, 166-173.
} 
Cebul

naturalize and obscure federal spending at the local level. Indeed, Northwest Georgia's and

Northeast Alabama's business leaders felt their efforts to develop the region deserved

commensurate attention - i.e. development spending - from the federal government. As

founding CARIA member J.R. Hornady put it, "The Coosa, on which so much has been spent by

private enterprises and which has added so much to the wealth of the South, certainly deserves

much better treatment in the future than it has in the past." "I am fearful," he warned, " that if we

do not get this improvement started now when so many outlays are being made that it will mean

an indefinite postponement." ${ }^{156}$ Competition with other regions, business leaders' own hard

work, and the sense that the federal government's bureaucrats threatened to impede justifiable

federal support all contributed to business people's sense that unprecedentedly large federal

spending was natural, earned, and essential to the proper development of the region's latent

economic potential.

In contrast to local business leaders' sense that federal developmental spending could be a win-win if allocated judiciously, national business elites increasingly sought to diffuse a zerosum interpretation of public and private action. Indeed, local businessmen's appreciation of federal programs became submerged by new forms of political mobilization by national business associations, which, while initially pragmatic and accepting of increased state action, quickly

\footnotetext{
${ }^{156}$ J.R. Hornady to M.C. Tarver, April 5, 1941, Box 1, RCCP.
} 
Cebul

soured on the New Deal spending and regulatory regime. ${ }^{157}$ Indeed, at the same time that

Northwest Georgia's and Northeast Alabama's leading businessmen sought and won huge

outlays of federal support, the national association to which they all belonged and paid dues - the

U.S. Chamber of Commerce - sought to lead them in the opposite direction. Their national association aimed to inspire its local branches to evangelize on behalf of a more ideologically

pure vision of free markets, limited government intervention, curbing wasteful spending, and, in

so doing, "bring 'American Business out of the dog house." ${ }^{\prime 58}$ National Chamber elites

explicitly aimed to cultivate a "producerist" ethos among its member-branches. ${ }^{159}$ Businessmen,

the Southern regional association of Chambers of Commerce explained, "must realize that

American Business as we know it ... is the backbone" of American life. ${ }^{160}$

The U.S. Chamber took an even harder line, arguing for a zero sum appraisal of public

and private initiative. In 1939, for instance, the U.S. Chamber distributed to local chapters radio

scripts for 3, 5, and 10 minute programs titled "So that you may tell the story . ." One script

from January 1939 was called "Taxes - and the Stockholder." In three minutes, the reader

explained to listeners that "you have a stake in American government [since the] money it

spends is your money." "For the past nine years," "the greatest of all corporations - the

\footnotetext{
${ }^{157}$ See especially, Phillips-Fein, Invisible Hands, 3-33.

158 “Southern Secretary,” December 1937, Box 2, RCCP.

${ }^{159}$ On producerism, see especially, Michael Kazin, The Populist Persuasion, Introduction and Ch. 1.

${ }^{160}$ Ibid.
} 
Cebul

Government of the Unites States," "has been going deeper into debt at the rate of $\$ 7,000,000$ a day - and is still going. If you were a stockholder in a private business corporation that made such a report, you'd probably wonder if you could get better returns by putting your money into something else." Unfortunately, this deficit spending had consequences for private corporations. Since 25 cents of every Americans' dollar went to government spending, "only 75 cents is available for private enterprise ... In other words, the more government you buy, the less money you will have for business enterprise. The longer the political payrolls grow, the shorter are the business payrolls." "You have the choice," the reader explained, "of investing your earnings in productive business enterprise or in nonproductive government enterprise. You can spend it for what you think you need or desire or you can turn it over to your political representatives to spend it for what they think you out to have." ${ }^{\prime 161}$ In the five-minute version, the Chamber described how government is, "for the most part, nonproductive. It does not originate or create much of anything. Instead of making and distributing goods, it lays down rules prescribing how they may be made, how they may be bought and sold. But, you can't eat or wear regulations or feed chickens with statutes." "Good Government," the US Chamber concluded with considerable vagueness, "is a profitable investment if it helps business and by helping business it helps you." 162

\footnotetext{
${ }^{161}$ Radio Script No. 1-A, Taxes - and the Stockholder, U.S. Chamber of Commerce, January 1939, Box 2, RCCP.

${ }^{162}$ Radio Script No. 1-B, Taxes - and the Stockholder, U.S. Chamber of Commerce, January 1939, Box 2, RCCP.
} 
Cebul

At the local level, however, businessmen's understanding of "government's proper role" in practice couldn't have been more distinct from the U.S. Chamber's zero sum version. A survey of the Southern Secretary during 1937 and 1938 reveals a fraternal group of business leaders engaged in collegial networking and jockeying for publicly supported economic development successes. ${ }^{163}$ The December 1937 edition published a tongue-in-cheek letter to Santa Claus, revealing much about these local leaders' state-centered development dreams:

So, Nick, let's get down to business - the business of giving." "I sure would like to see you give little BEN MOOMAW, Roanoke, a fine new municipal airport to take care of the biggest planes . . FRED WEEDE, up in Asheville, just like HOD LEWIS, over in Little Rock, wants a new auditorium ready for business. A soil conservation program, perfect team work and enthusiasm are wanted most by JOHN MALONE at Shawnee, Okla. . . . J.E. BELL, Corpus Christi, wants a $\$ 350,000$ yacht basin. BOB BLANTON, Paris, Texas, can use a new Junior College building . . . More tourists and better roads will make RUSS DYMOND happy at Daytona.

“And while you're in Florida, give HORACE SMITH, Ocala, an athletic field, an air mail passenger line, a municipal auditorium and a five-year agricultural program - a whale of an order, I'll grant, but isn't Horace one of the most loyal of all SOUTHERN members?' Not to be outdone, "BILL BLANTON, Houston, gave us such a wonderful convention at Houston last year that he deserves a whole flock of gifts, so how about giving him a flood prevention program, finishing up his airport, a street improvement plan, four-lane highways, more conventions and

\footnotetext{
${ }^{163}$ See, for instance, the "Whirligig" section of the Southern Secretary, in which local leaders report their successes and poke fun at one another. Southern Secretary, August 1938, October 1938, and November 1938, Box 2, RCCP.
} 
Cebul

industries?"164 “'”I hope I haven't been piggish, Nick, with all these requests for my friends,"

John L. Morris, the new president of the SCSA concluded. "They're good fellows, you see, and

fine secretaries all, and really they are deserving." The businessmen's Christmas wish list

continued, totaling four single spaced pages. Santa Claus, however, would not provide the vast

majority of the wished-for items. The gifts would be delivered from the taxpayers to private

interests, which increasingly construed such public action as natural and right.

Economic \& Political Development in Georgia After the New Deal \& War

Business leaders' heightened expectations for government triggered significant political change in Georgia. In the early 1940s, Governor Ellis Arnall offered an alternative to the Talmadge "era of crackers and wool-hat politics." 165 When he won the governor's mansion in 1942, Arnall opposed the extremist politics of his predecessor, Eugene Talmadge, and spoke hopefully of social progress, improved public education, sound governance and economic development. Arnall pursued a number of developmental measures that won him national acclaim. In 1945, Life described how he'd lifted "his state from the benightedness of Tobacco Road to the position of runner-up to North Carolina for the title of 'most progressive southern state." "166 Despite the fact that the Rome News-Tribune endorsed Talmadge, Arnall won Floyd

\footnotetext{
164 “Southern Secretary,” December 1937, Box 2, RCCP.

${ }^{165}$ Stephen N.G. Tuck, Beyond Atlanta: The Struggle for Racial Equality in Georgia, 1940-1980, 42.

${ }^{166}$ Ibid.
} 
Cebul

County, along with the majority of the state's other mid-sized counties and all of its large urban counties. In Floyd's working class (and unionized) town Lindale, for instance, Arnall defeated Talmadge 277 to 163 . In Rome, where he won 1,809 to 876, Arnall's support was even more decisive. ${ }^{167}$ Developmental vision and developmental state spending were linking the interests of business and the white working class.

Arnall hoped to address, as he put it, "obstacles created by our own lack of vision." "168 A moderate Democrat, Arnall emphasized progressive management of the state's economy and reformed institutions of state government on behalf of economic growth. Arnall shepherded through the legislature a bill to establish fifteen vocational schools, which, once passed in 1945 , were established across the state. ${ }^{169}$ Arnall's efforts to develop the state's political and economic institutions met with mixed success but reflected an ascendant sense across the state that the Governor and state government had a key developmental role to play. "Georgia," Arnall argued, "must develop an industrial-agrarian economy that will provide a high standard of living for all our citizens." To do so, in 1943, the General Assembly established the Agricultural and Industrial Development Board (AIDB), which, as Arnall described it, would "plan [the] ordered and comprehensive development of the state and its resources." The Board was made up of

\footnotetext{
${ }^{167}$ Brattain, 105-7.

168 “Governor Arnall Points the Way to Greater Progress in Georgia,” Georgia Progress, September 15, 1944, Binder 1, Economic Development, GPCA.

${ }^{169}$ Numan V. Bartley, The Creation of Modern Georgia, 196-7.
} 
Cebul

representatives from government, agriculture, business and industry. In a nod toward the move

toward embracing expert planning, the Board was headquartered at the University of Georgia,

and its first executive director was a member of the University faculty. With input from across

these sectors, the board would coordinate development efforts and recommend new policies. One

initiative that Board members were particularly enthusiastic about was the creation of a state

version of the Reconstruction Finance Corporation, or "little RFC" as they came to call it.

Arnall's and the Board's original plan for Georgia's RFC would have authorized up to

$\$ 100,000,000$ in state loans to new, relocating or expanding businesses within the state and to

more rapidly develop the state's ports and waterways. ${ }^{170}$ The Board, in effect, aimed to become

an NRPB or TVA planning commission for the state of Georgia.

Though Arnall's plans for a little RFC floundered in a legislature still wary of big

spending, the AIDB played an important role in institutionalizing expectations for the state's role

in economic development, and Georgia Power was one of the Board's greatest supporters. ${ }^{171}$ The

Board identified nine districts and held meetings in each to introduce the AIDB's goals. "Each of

the district meetings," the AIDB's newsletter reported, "was attended by approximately two

hundred citizens from communities in the area." Throughout 1944, two hundred communities

\footnotetext{
170 “Governor Arnall Points the Way to Greater Progress in Georgia,” Georgia Progress, September 15, 1944, Binder 1, Economic Development, Georgia Power Corporate Archives, Atlanta, Georgia; and Bartley, 196-7.

${ }^{171}$ The best work on industrial development in Georgia, for instance, spends less than one page on the work of the AIDB. Ibid.
} 
Cebul

across Georgia held "mass meetings for the purpose of organizing permanent committees on industrial development." ${ }^{, 172}$ In Rome, former Chamber of Commerce president and regional Georgia Power administrator J.J. McDonough chaired the district meeting, suggesting the degree to which Arnall's associative vision, what we might today call a public-private partnership, was embraced at the local level. "Georgia," the Washington Post wrote, "is receiving many compliments these days on the progressive policies that the state is inaugurating." Magazine Digest went further: “Georgia's status has been raised from that of one of the most politically backward states, even by Southern standards, to one of the most progressive, even by Northern measurements." 173

Arnall's Industrial Development Board drew on a legacy of the progressive era, development of and reliance upon scientific expertise, on a New Deal scale. ${ }^{174}$ Though it was established in 1919, the Georgia Institute of Technology's Engineering Experiment Station (EES) was not actually funded by the state legislature until 1934. That year, the EES took its first steps toward fulfilling its mandate to " . . aid in the promotion of engineering and industrial

\footnotetext{
172 “Industry Panel Program Goes Forward At Meetings in 200 Georgia Towns,” Georgia Progress, January 1, 1945, Binder 1, Economic Development, GPCA.

173 "What Others Say About Georgia," Georgia Progress, December 1, 1945, Binder 1, Economic Development, GPCA.

${ }^{174}$ For the emphasis on cultivating scientific expertise in the progressive era and, later, on behalf of an associative vision of state building, see David M. Hart, “Herbert Hoover's Last Laugh: The Enduring Significance of the 'Associative State' in the U.S.,' Journal of Policy History, and Hart, Forged Consensus: Science, Technology, and Economic Policy in the United States, $1921-1953$ (Princeton: Princeton University Press, 1998).
} 
Cebul

research, and for the more complete development and utilization of the natural resources of

Georgia, and for the encouragement or industries and commerce, and insuring the public welfare

of the people of Georgia consistent with modern progress and preparedness." ${ }^{175}$ In 1938, Georgia

Power partnered with the EES and the state University system to create the Industrial

Development Council, an advisory board of business and industrial interests which sought to

guide the EES's research contracting. ${ }^{176}$

In 1943, the same year Congress defunded the National Resources Planning Board, under

Ellis Arnall (and eight years before the national Council of Economic Advisers began its own

version of regional studies), the Station's regional economic researchers forged its first

partnership with a local Chamber when it conducted for the Macon branch a survey of its 26

county trade area. ${ }^{177}$ The next year, the EES received funding from the AIDB and completed a

similar report on the 31 counties surrounding Augusta. It soon had contracts from the Chambers

in Albany, Rome, Valdosta and Waycross to deliver findings on everything in their regions from

the local labor force and natural resources, to recommendations for improvements to

transportation, energy and water infrastructure. The EES reports also cataloged existing

\footnotetext{
${ }^{175}$ Richard S. Combes and William J. Todd, "From Henry Grady to the Georgia Research Alliance: A Case Study of Science-Based Development in Georgia," undated, p. 8., Binder 1, Economic Development, GPCA.

${ }^{176}$ Richard Snyder Combes, “Origins of Industrial Extension: A Historical Case Study in Georgia,” Unpublished MA Thesis, June 1992, Georgia Institute of Technology, p. 42, folder EES-Industrial Extension Division, GTA

Subject File, Georgia Institute of Technology Archives, Atlanta, Georgia [hereafter GTA].

${ }^{177}$ On the CEA, see Collins, More, 35-6.
} 
Cebul

industries and public utilities and community services in order to make recommendations for best-fit industries and the kinds of industry-targeted improvements local government might make. "Included in such a canvas," the AIDB's newsletter reported, "is a determination of possible sites, of water supply and nature of water, of housing facilities, and potential labor supply." Finally, the EES offered another invaluable set of recommendations for nurturing local economies. "For example, if a community wants to set up a factory to manufacture viscose rayon" - a highly technical process likely lost on the local development team - "it would be the function of the Station to determine what are the necessary raw materials, the extent to which they are found locally, and the amount which would be required to manufacture . . . the product." ${ }^{178}$ This service, blandly referred to as "technical assistance" would, in the post-war years, become a crucial weapon in Georgia's now perpetual and statewide campaign for economic development. In the years to come, the EES's greatest private ally would be Georgia Power. By 1946, the EES began publishing a bi-monthly newsletter, “The Research Engineer," which summarized and disseminated the EES's findings. ${ }^{179}$ Georgia had begun to develop its own state funded, regionally based industrial policy.

\footnotetext{
178 “Economic - Industrial Research at Tech,” Georgia Progress, January 1, 1945, Binder 1, Economic Development, GPCA.

${ }^{179}$ Richard Snyder Combes, “Origins of Industrial Extension: A Historical Case Study in Georgia,” Unpublished MA Thesis, June 1992, Georgia Institute of Technology, p. 43, folder EES-Industrial Extension Division, GTA Subject File, GTA.
} 
Cebul

Arnall's political moderation, however, stopped at the color line, and his political style played upon traditional southern mistrust of the federal government. Indeed, Arnall's politics of progress entrenched notions of Southern exceptionalism by keying on fears of federal discrimination. The Governor advanced his 'progressive' call for improved local government and expanded social services by recasting traditional states' rights sentiment. Rather than call for less federal intervention in local affairs, Arnall made great political hay of the fact that Georgia had been discriminated against in the lavish spending of the New Deal. Even before his election as Governor, Arnall introduced legislation in the state house "assailing the federal government for allegedly depriving Georgians of administrative jobs in the state" by importing outsiders to fill FERA posts. Arnall demanded the Georgia legislature "put an end to this new era of carpetbag days. ${ }^{\prime 180}$ He castigated federal agencies in hopes that they would employ more Georgians. The state's FERA administrators met Arnall's challenge almost immediately, conducting an internal investigation that found that of 3,998 administrative employees, 3,894 (97.4 percent) were Georgians. Fifty-two of the 104 non-Georgians were, in fact, Southerners, and, FERA pointed out for good measure, that 3,301 of the employees had been pulled in from the state's relief rolls. Nevertheless, Arnall stuck to his fed-bashing guns.

\footnotetext{
${ }^{180}$ Holmes, The New Deal in Georgia, 83.
} 
Cebul

Likewise, from the start of his administration, Arnall highlighted the ways federal regulations and programs discriminated against the emerging South. As he put it, "Certain debris ... must be cleared away before we can erect such an edifice to house the Georgians of the future. This consists of obstacles put in our way by others and of obstacles created by our own lack of vision. The former," he noted, "are more important." In one case, Arnall brought suit over the federal government's discriminatory freight rates, which, he argued, favored railroads (in violation of federal antitrust statutes) to the detriment of small businesses. In 1945, the Supreme Court agreed to hear Arnall's case, but, in May, the Interstate Commerce Commission mandated uniform rates, rendering moot Arnall's suit. The Governor saw bias against the South in other areas of federal policies. The mandate that states match federal spending for certain social programs, Arnall argued, discriminated against the poorer South. Georgia's Governor contented that federal spending should be based on need rather than the amount a state could put up to match a federal grant. As a result, he claimed Southerners had not gotten their fair share of New Deal spending. Though Arnall argued in 1944 that "discriminations practiced against Georgia and the other southern states . . must be eliminated," the tide had already begun to turn. ${ }^{181}$ The year 1940, two years before his election, was the last in which southern states paid

\footnotetext{
181 "Governor Arnall Points the Way to Greater Progress in Georgia," Georgia Progress, September 15, 1944, Binder 1, Economic Development, GPCA.
} 
Cebul

more in federal taxes than they received in federal spending programs. ${ }^{182}$ By keying on specific cases of federal discrimination and yoking them to southern whites' well-primed sense of grievance, Arnall perpetuated the general mood of anti-federal sentiment on behalf of greater federal involvement through spending in local affairs.

When the Talmadge clan reclaimed the governor's mansion for the "wool hat boys" in 1946, political analysts in Georgia and across the country decried the return to the old-style politics, but Arnall had succeeded in transforming the institutions and intentions of state government in ways that resisted Talmadge-ite meddling. Indeed, technical expertise combined with public infrastructure improvements resulted in a flurry of private development during the second half of the 1940s and into the 1950s. In 1948, Georgia's Department of Commerce, for instance, began analyzing the state's commodities markets and made recommendations on new business opportunities. ${ }^{183}$ But state agencies did much more than merely advise companies on where to expand. The Funkhouser Company, for instance, had long produced slate granules for the roofing trade. But, when a geologist with the Georgia Department of Mining and Geology (working alongside a TVA geologist) discovered "a new and unusual type of mica deposit," state

\footnotetext{
${ }^{182}$ Bartley, The Creation of Modern Georgia, 196.

${ }^{183}$ For instance, the Department reported the state "ginned" 760,000 cotton bales while its industries consumed 2,033,000 bales: there was an opportunity for expanded cotton production. "Industrial Development in Georgia Shows Continued Progress," Industrial Newsletter, Vol. 1, No. 1, June 20, 1949, Binder 1, Economic Development, GPCA.
} 
Cebul

analysts quickly released a report indicating the deposit's commercial possibilities. Within

months, Funkhouser was invited to mine and mill the new mica. The state even assisted with

financing their new mill, which, according to Georgia's Commerce Department, would soon

"have a capacity of 100 tons per day." ${ }^{184}$ Indeed, the newfound technical and analytical capacity

of the state's agencies and bureaus - from the AIDB and Commerce Department to the expanded

Departments of Labor and Mining and Geology - provided municipal and county governments

as well as Chambers of Commerce and expanding and growing businesses with the kind of data

and technical expertise they needed to develop new opportunities. The postwar years would see

an explosion of such publicly derived research and development for private growth.

\section{"Good Government is Good Business in Georgia"}

"It has been charged that I am a friend of big business," said Ellis Arnall. "I admit it. I am

also a friend of moderate business and little business. I want to make it possible for my boy or

your boy to own his own business." In 1944, the governor's words topped a full-page

advertisement placed by Georgia Power in newspapers across the country, including the New

York Times, the Chicago Tribune, the Detroit Free Press and the Wall Street Journal. The

company’s pre-New Deal advertisements had once solely emphasized the region's cheap "native

\footnotetext{
184 “A New Mica Industry in Georgia,” Industrial Newsletter, Vol. 1, No. 1, June 20, 1949, Binder 1, Economic Development, GPCA.
} 
Cebul

born" labor, its climate and abundant natural resources. But, by 1944, the chief selling point for

Georgia Power was the state's government: "Good Government is Good Business in Georgia," read the advertisement's heading. "Under the able and broad-visioned leadership of Governor

Ellis Arnall," the ad read, "Georgia has become one of the best governed states in the nation.

Good business principles are being applied to government. Finances are in sound condition.

There has been no increase in taxes. Enlightened education reforms have been effected. Farsighted programs for the development of the state's huge industrial and agricultural resources are under way." In short, "The people of Georgia and their government believe in and cooperate with business enterprise." Only then, did Georgia Power's narrative go on to tout the region's climate and "native-born" labor. Indeed, Georgia Power's turn toward good government had ironically been catalyzed in its competition with the federal government.

Georgia Power's emphasis on the benefits to private business of "good government" reflected the quiet revolution that had occurred in Georgia in a little under two decades. Indeed, in the 1920s, Georgia's business leaders dreamed of massive infrastructure improvements but competed jealously for modest road improvements. Within ten years, Rome's leaders had secured $\$ 60,000,000$ of federal support to open the region to the global economy through a canal to the Gulf of Mexico. Nevertheless, businesses' embrace of key aspects of the liberal state were tempered by a strong sense of localism and producerist privilege - they deserved this support 
Cebul

after decades of hard work and individual initiative, which, as the nation went to war, became increasingly cast in nationalistic and patriotic terms. The regulatory or labor-related excesses of the liberal state, too, encouraged skepticism and lent legitimacy to businesses' small government posturing. Nevertheless, private business interests had never before looked to government for so much.

While Ellis Arnall took the first steps toward robust public-private institutions on behalf of economic development, the decades to come would see a massive expansion and reorganization of the state's economic and community development departments. These changes, however, would first take root not in Atlanta, but in the Chambers of Commerce in Rome and Dalton. Led by a local merchant and a development officer at Georgia Power, a veteran of the Coosa Alabama River Improvement Association, the Coosa Valley Area Planning and Development Commission would change the way businesses, the state of Georgia, and the federal government pursued growth and development. 
Cebul

\section{Chapter Two}

The Best Location in the Nation:

Cleveland's Elite in New Deal and War

The scion of one of Cleveland's leading families, Samuel Mather, died in 1931. Samuel

was descended from the New England Mathers, one of the first families to divvy up and sell the land upon which Cleveland was built, land that had comprised the state of Connecticut's

"Western Reserve."1 Like other leading Clevelanders, Mather shepherded the city's affairs through a mix of charity, associationalism, and self-interest. For a time, just after the turn of the century, Cleveland's repentant capitalist and Progressive mayor Tom L. Johnson and his invigorated constituency of workers and recent immigrants made life difficult for Cleveland's elites, pushing, for instance, for municipal ownership of utilities. ${ }^{2}$ But the teens and twenties saw the return of "caretaker" mayors who steered clear of radicalism and reform. Upon his death, Samuel's estate included a number of substantial bequests to the various causes for which he had advocated - a handful of social service organizations as well as educational and medical

\footnotetext{
${ }^{1}$ Among Samuel's forbears was Cotton Mather, the Puritan minister. For a discussion of the Mather family, see The Mathers, an online exhibit of the Tracy W. McGregor Library, the University of Virginia Library, accessed online: http://explore.lib.virginia.edu/exhibits/show/mcgregor75/americanhistories/mathers

${ }^{2}$ On Tom L. Johnson's years as mayor, see Dominc Candeloro, "The Single Tax Movement and Progressivism, 1880-1920," American Journal of Economics and Sociology, Vol. 38, No. 2 (Apr. 1978). See also, Thomas S. Hines, “The Paradox of 'Progressive’ Architecture: Urban Planning and Public Building in Tom Johnson's Cleveland.” American Quarterly, Vol. 25, No. 4 (Oct., 1973).
} 
Cebul

institutions. The staggering drop in the stock market, however, withered Mather's portfolio to such a degree that his estate was unable to meet its obligations. As a keen chronicler of Cleveland's history put it, "To the careful observer it seemed that both an era and a tradition"of a city led through a mixture of patrician prerogatives and generosity - "had died" along with Samuel Mather. ${ }^{3}$

Mather's estate was neither the only nor nearly the most significant example of the crisis of Cleveland's, indeed the nation's, elite. In 1934, Harper's ran a feature explaining the onset of the Depression by narrating the intertwined downfall of two of Cleveland's most glittering institutions: the real estate and railroad empire forged by the Van Sweringen brothers and the city's most august bank, Union Trust Company. Oris and Mantis Van Sweringen worked their way up from newsboys to real estate moguls, buying and selling the land that became one of the nation's first and best known suburbs, Shaker Heights. In the 1920s, Shaker Heights had the highest per capita income of any municipality in the United States. ${ }^{4}$ Linking Shaker with Cleveland familiarized the brothers with railroads, and, using cheap debt and capital from Union Trust and other major east coast banks, the brothers leveraged one purchase into another. As

Harper's put it, "This operation introduced them to two powerful weapons which they were to

\footnotetext{
${ }^{3}$ John Grabowski, Introduction to the Second Edition, William Ganson Rose, Cleveland: The Making of a City (Kent, Ohio: Kent State University Press, 1990), vi.

${ }^{4}$ Barney Warf and Brian Holly, "The Rise and Fall and Rise of Cleveland," Annals of the American Academy of Political and Social Science, Vol. 552 (May, 1997), 210.
} 
Cebul

use with compelling effect. One of these was the holding company. The other was the use of other people's money in banks." It was the "perfection and abuses of these two implements which have brought capitalistic America to the verge of despair."

By shuttling loans and preferred and common stock offerings through a handful of holding companies, the Van Sweringens acquired numerous railroads, often without putting up a single penny of their own. These railroads included such venerable lines as the Nickel Plate, the Chesapeake and Ohio, the Erie, the Pere Marquette, and the Missouri-Pacific, extending the brothers' reach all the way to the west coast. Soon, they gobbled up coal and shipping companies, hotels, and trolley lines, all knitted together in a nearly inscrutable arrangement of debt-laden holding companies. At their peak in 1930, the brothers controlled at least 150 corporations that operated 23 railroads, 10 real estate companies, and a hodgepodge of other entities. ${ }^{5}$ Later, when he was called to testify before a Senate Committee, Oris Van Sweringen admitted that even he could not keep track of their holdings.

On the eve of the stock market crash and its subsequent bank runs, the brothers and their business partners held loans of at least \$24 million from Union Trust alone, more than the entire capital stock of the bank at the time (for comparison, at the time of its December 1930 failure,

\footnotetext{
${ }^{5}$ Louis B. Seltzer, The Years Were Good: The Autobiography of Louis B. Seltzer (1956), 150, accessed online at http://www.clevelandmemory.org/ebooks/tywg.
} 
Cebul

the much larger Bank of the United States in New York held \$286 million in savings). ${ }^{6}$ Among the first institutions bailed out by President Hoover's Reconstruction Finance Corporation were the Van Sweringens and the Cleveland banks upon whose loose lending they'd built their empire. Union Trust received a \$10 million federal bailout. Following Franklin Roosevelt's election, however, and the subsequent bank holiday, Union Trust was still overleveraged and was forced to shutter. As the Van Sweringens retired to their Shaker Heights mansion, they left behind a city and financial institutions in ruins, not to mention millions in lost savings for average Clevelanders. Oris Van Sweringen died in his sleep in 1936 at age fifty-seven in a Nickel Plate Railroad Pullman Car as it pulled in to Hoboken, New Jersey. One imagines Oris was headed to meet with some of his east coast financiers. Indeed, the following year, a Cleveland Probate Court received a statement of claims and debts pegging Oris' indebtedness at $\$ 80,733,566.45$ against an estate appraised at \$534,994. "“And this,” Harper's concluded, “is what happened to your town, wherever it is.",

The arrival of the New Deal's regulated prices, public works projects, competitive wages, and its planning and industrial policy, recent histories of business and politics argue, constituted

\footnotetext{
${ }^{6}$ David Kennedy, Freedom From Fear: The American People in Depression and War, 1929-1945 (New York: Oxford University Press, 1999), 67.

${ }^{7}$ Seltzer, 152.

${ }^{8}$ John T. Flynn, “The Betrayal of Cleveland,” Harper's, January, 1934.
} 
Cebul

a period of bitter medicine for business elites such as the Mathers and the Van Sweringens. ${ }^{9}$

Certainly much of the era's increasingly nasty antigovernment rhetoric emanating from the

National Association of Manufacturers, the Liberty League, or the Chamber of Commerce of the

United States would suggest as much. Indeed, elite men who shared the Mathers and Van

Sweringens' rarified socioeconomic status led these organizations, which fought to turn the tide

of public opinion against key pieces of the New Deal. Missing from these narratives is the degree to which New Deal programs also relied upon and empowered local business elites. ${ }^{10}$

Faced with paralyzed capital markets, overburdened bond markets, and strong headwinds against new forms of taxation, the New Deal and wartime model of cooperative fiscal federalism effectively restored elites' community stewardship through a model of associational governance: the fruits of federal taxing power was administered through local public-private partnerships.

Viewing the urban New Deal through this associational lens offers new historiographical insights. In particular, "growth machine" analyses of urban politics and political economy argue that business leaders seized privileged positions in city politics in the decades following New Deal and war as a mobilization of their rational economic self-interest: both to shape favorable

\footnotetext{
${ }^{9}$ See, for instance, Elizabeth Tandy Shermer, Sunbelt Capitalism: Phoenix and the Transformation of American Capitalism, ch. 1, Kimberly Phillips-Fein, Invisible Hands, ch. 1, and Donald T. Critchlow, The Conservative Ascendancy: How the GOP Right Made Political History (Cambridge: Harvard University Press, 2007 ), chs 1 and 2.

${ }^{10}$ Jason Scott Smith makes this point but focuses primarily on national policymakers. Smith, Building New Deal Liberalism.
} 
Cebul

development policies and to block interest group challengers. ${ }^{11}$ While they acknowledge broader structures such as federalism or the international political economy, methodologically, their field of inquiry has been overwhelmingly local. ${ }^{12}$ In contrast, this chapter frames big city businesses' stewardship of urban development policies within the context of the cooperative federalism of the New Deal. Such an approach casts business involvement in local politics in far more nuanced light by illuminating the degree to which federal prerogatives and policy instruments spurred the creation of local public-private governmental arrangements long before the "growth machine" literature pegs their genesis. This prehistory suggests policy and institutional precedents and arrangements that shaped downstream developments in the "growth machine" era. ${ }^{13}$ It also reveals the degree to which business' antigovernment rhetoric was part and parcel of its involvement in government, rather than the expression of a static, limited government ideology.

Local politics also factored greatly in business leaders' embrace of federal programs. The stock market crash and unemployment emergency were political and social crises as much as

\footnotetext{
${ }^{11}$ For an overview of the strengths and weaknesses of the "growth machine" literature, see Clarence N. Stone and Robert K. Whelan, “Through a Glass Darkly: The Once and Future Study of Urban Politics,” in Richardson Dilworth, ed., The City in American Political Development (New York, 2009).

${ }^{12}$ As the European urbanist Alan Harding has written, the dominant paradigms of urban analysis have been "essentially localist" in that they "often underplay the importance of externally imposed structures that predispose local actors to particular forms of behavior." Harding, "Urban Regimes in a Europe of the Cities?," European Urban and Regional Studies 4, no. 4 (1997), 294, quoted in Brenner, “Is There a Politics of 'Urban' Development?” Ibid.

${ }^{13}$ Here I take a cue from Neil Brenner who argues, "growth machines, both in the US and elsewhere, must be investigated and explained, rather than being presupposed." Brenner, "Is There a Politics of 'Urban' Development?" in Dilworth, ed., The City in American Political Development, 122.
} 
Cebul

economic crises. As a class, Cleveland's elites quickly feared that threats from below, from the unemployed multitude, and from above, from the federal government, might eclipse their autonomy and legitimacy as community leaders. Cleveland's unemployed included a variety of recent immigrants and their first generation children. As these working class ethnics joined the growing labor movement and Democratic voting blocs, they posed an increasingly material threat to the political and class hierarchy of Cleveland's elite.

Thanks to the New Deal's model of cooperative federalism, however, which blurred the boundaries between the public and private spheres, an unemployed man's relief program could do double duty as a businessman's economic development initiative. ${ }^{14}$ But, in the return to prosperity that came with war, these increasingly blurred lines between public and private underwrote elites' efforts to reassert their legitimacy and enabled them to plausibly write federal aid and wartime spending out of the history of Cleveland's New Deal and recovery.

\section{The Strains of Voluntarism}

In the first years of the Depression, despite the rapidly deteriorating situation in Cleveland's neighborhoods and factories, the city's political and civic leaders resisted the

\footnotetext{
${ }^{14}$ Elisabeth Clemens, "Lineages of the Rube Goldberg State: Building and Blurring Public Programs, 1900-1940," in Rethinking Political Institutions: The Art of the State, eds. Ian Shapiro, Stephen Skowronek, and Daniel Galvin.
} (New York: New York University Press, 2006), 380-443. 
Cebul

creation of new public institutions to provide relief for the city's poor and unemployed. Chamber

of Commerce President R.B. Robinette argued that the voluntary Associated Charities was the "proper agency" for relief since new public services "would incur considerable cost and could not possibly be as efficient as the leading relief agencies now in the field." ${ }^{\prime \prime}$ Indeed, Robinette had long taken an interest in voluntary civic improvement, having chaired the "Community Betterment Council of Cleveland," which carried out periodic "Clean Up" painting and trash removal campaigns. ${ }^{16}$ In the face of unprecedented misfortune, Chamber members stuck to their voluntary regime, which, as they put it at one meeting, primarily consisted of a "campaign locally to bring money out of hiding." ${ }^{\prime 17}$ The Chamber passed resolutions in December 1931 calling for handling unemployment "on an individual basis, locally, through organization [sic] to that end" and specifying that relief be "provided through private contributions supplemented by state and local governments, and without any federal appropriations for such purpose."18 They were confident their resources were up to the challenge. Said one Chamber member, "We have only to glance at the columns of the daily newspapers to convince ourselves that the citizens of

\footnotetext{
${ }^{15}$ Quoted in Daniel Kerr, Derelict Paradise: Homelessness and Urban Development in Cleveland, Ohio (Amherst, MA., 2011), 80 .

${ }^{16}$ Julius King, "Developments in Cleveland Clean Up,” Paint, Oil and Chemical Review, Vol. 67, 1919, Google eBook.

17 “Money Mobilization,” Annual Report 1931-1932, Volume: Cleveland Chamber of Commerce Annual Reports, 1926 - 1937, Container 75, Greater Cleveland Growth Association Papers, Western Reserve Historical Society, Cleveland, Ohio (hereafter GCGA].

${ }^{18}$ Executive Committee Minutes, December 11, 1931, container 44, GCGA.
} 
Cebul

every community in this country are meeting the responsibilities of the present and measuring up to that high standard we have set for ourselves in this Republic."19 Likewise, Cleveland's Mayor Harold Burton was sure that city bonds and private philanthropy directed to Associated Charities would deliver the necessary relief. As he wrote Wisconsin Senator Robert Lafollette Jr. in December 1931, “Cleveland's feeling and slogan has always been 'Cleveland will take care of her own.' We are certain this attitude will continue and feel that the ability to do so will continue to exist." $" 20$ The roughly $\$ 50,000$ per month Associated Charities spent on relief, however, was hardly up to the task and paled in comparison to future relief needs and efforts. ${ }^{21}$

Cleveland's working class and ethnic residents grew increasingly frustrated with the city and charity's meager relief efforts. Mrs. E. Schaufele wrote an emblematic letter to the mayor, highlighting the inadequacies of the city's charitable organizations. "We have explained our situation to the charities," she wrote, "but they have done nothing and the only thing we can do is starve. We only ask for food. All we ate last winter is bread and potatoes. Now we don't even have that." Like Schaufele, many Clevelanders were denied assistance from the city's Associated Charities. Some were denied service because they could not prove residence in the city; others were denied because of past moral failings. John Pavlik was refused clothing in the 1930s

\footnotetext{
19 “Money Mobilization,” p. 7., GCGA.

${ }^{20}$ Quoted in Kerr, 80.

21 “Spent \$51,000 for Needy in January,” Plain Dealer [PD], February 20, 1930.
} 
Cebul

because, according to the Charities' investigators, he had abandoned his family for a time in

1921, and, upon returning, was "not careful with language he uses to children." Other destitute

Clevelanders wondered what more they could do. "Dear Mayor," a nineteen year old wrote, "I

can't go out and rob a bank because my face don't show guiltness and I may be killed. I want to

be an honest man all my life." His desperation was echoed by a man who asked the Mayor to

"Kindly advise ... what more should I take" before becoming a "gangster or Communist." 22

Along with business leaders' resistance to strong public action, longstanding structural

and political-cultural trends help explain Cleveland's miserly relief efforts. In the decades

leading up to the Depression, Ohio voters repeatedly restricted local governments' ability to raise

new forms of tax revenue. As a result, the state bucked the national trend in the 1910s and 1920s

of increased local and state tax expenditures. That did not mean Ohio's local governments did

not pursue improvements. It meant they did so instead through the municipal bond market. As a

result, as the Depression hit, the state suffered record-breaking local debt, $\$ 100$ million of which

contemporary fiscal experts attributed to the politics of tax limitation. ${ }^{23}$ Servicing that debt

consumed a good deal of local government revenue. Making matters more difficult, in Cuyahoga

County the passage of special levies required support from 65 percent of the electorate. Lower

\footnotetext{
${ }^{22}$ Kerr, $73-4$.

${ }^{23}$ Warren Roberts, "Behind the Cleveland Relief Problem," The Bulletin of the National Tax Association, March, 1940, Vol. XXV, No. 6, in folder 5, container 2, Harold Hitz Burton Papers, Western Reserve Historical Society, Cleveland, Ohio (hereafter HHB].
} 
Cebul

tax rates, in turn, threatened a municipality's credit even in good times, and so as the Depression

arrived, the city's debt plus its inflexible tax code hampered its ability to finance works and relief

programs. As one contemporary analyst put it, "Cleveland stands as an illustration of the fact that

without drastic revision of the tax system, the cities themselves are not self-supporting during a

severe depression."24 Later, the National Resources Planning Board was keenly aware of this

kind of predicament, which was faced by hundreds of municipalities across the country. As a

report by the New Deal planning agency put it, "The sources of revenue of local units are

severely limited, and the type of taxes available to them are not merely relatively inelastic but are

also peculiarly susceptible to pressure from organized taxpayers. ${ }^{, 25}$

As federal work relief programs came online, Cleveland and Cuyahoga County struggled

mightily to raise federally mandated matching funds thanks to this fiscal straightjacket. City

officials urged the state to help cover Cleveland's portion of the appropriations. ${ }^{26}$ Making

matters more difficult, the state legislature was dominated by rural counties, which skewed state

tax revenue in their own favor. Indeed, the Cleveland Chamber estimated that between 1928 and

1937, nearly half the taxes paid by Cuyahoga County motorists was spent elsewhere in the state.

\footnotetext{
${ }^{24}$ Ibid.

${ }^{25}$ Security, Work, and Relief Policies: A Report by the National Resources Planning Board, 1942, Part III, Chapter 10, 295, accessed online, http://www.ssa.gov/history/reports/NRPB/NRPBreport.html.

26 “'Davey Urges 'Big County' Relief Bonds,” PD, July 11, 1935, and "Washington to the Rescue,” $P D$, July 25, 1935.
} 
Cebul

Likewise, roughly half of the state taxes county residents paid on cigarettes, liquor, and other items was returned to the County in $1937 .^{27}$ The most important component of relief during the Depression years in Cleveland, then, would have to be the federal government. In a clear sign of rural politicians' contempt for their urban cousins, however, the Ohio legislature passed the poorly named Ohio Relief Act. The act reigned in relief costs by imposing a mandatory percounty ceiling on administrative overhead. In Cuyahoga County, this mandated a 30 percent cut to the relief and WPA oversight staff, a move that struck directly at the heart of local complaints about relief administration in Cleveland - there was not enough oversight and slipshod interviewing led to workers being mismatched for work or relief assignments. ${ }^{28}$ Even Governor Martin Davey, from rural Kent, Ohio, said the Act was the result of "an unwilling and provincial-minded Legislature." As the Cleveland Plain Dealer put it, as a result of the new law, the Cuyahoga County Relief Agency was forced to wrap "up Cleveland's huge and troublesome relief problem and [toss] it . . to City Hall.” The County relief administration could no longer maintain a large enough staff to oversee the city's portion of the county relief effort. The beleaguered and indebted city was forced to take over its relief program, which accounted for more than 90 percent of the county's total relief load. ${ }^{29}$ Even Governor Davey, who had been

\footnotetext{
27 Ibid.

28 "Social Workers Meet for Fight," PD, February 23, 1936.

29 “Relief Burden is Thrown on City," PD, July 26, 1936.
} 
Cebul

skeptical of urban complaints, joined the call for expanding the federal relief presence in needy

urban areas. "In as much as the federal program is more flexible than the state relief act," he said,

it seems desirable "that counties which will not receive enough for relief needs from the state

might get additional help from the WPA." ${ }^{30}$ As a headline in the Plain Dealer boomed, "RELIEF

ROLL CUT SEEN INEVITABLE."31 By October 1936, thousands of Clevelanders were being cut from relief every month. ${ }^{32}$

In neighborhoods across Cleveland, frustration with the inadequate and erratic relief

efforts spurred the creation of Unemployed Councils, organizations whose sole mission was

pressuring the Associated Charities and its successor organization, the Cuyahoga County Relief

Administration. The Councils demanded not only increased spending for relief but that relief

recipients be brought into the administrative process "without check from the Associated

Charities or any other relief body." 33 As one Czechoslovakian immigrant and Council-member

put it, "The County Relief is starving people. We have to unite and force them into giving us a

living." Likewise, a second-generation Yugoslavian joined his local Council "to fight for relief."

The Councils sprang up first in neighborhoods hardest hit and least served; in Cedar-Central, for

\footnotetext{
30 "Davey Urges WPA and Neediest Area," PD, July 28, 1936.

31 “Relief Roll Cut Seen Inevitable," PD, August 2, 1936.

32 “Expects Cut of 1,000 Relief Cases," PD, October 17, 1936; "Hunt Still on for Relief Purge Cash,” PD, November 15, 1936.

33 “Asks Principals to Seek Hungry,” PD, September 29, 1931.
} 
Cebul

instance, an African American area whose three census tracts endured staggering rates of

unemployment: 91.5 percent, 69.9 percent, and 54.9 percent. On the West Side in Ohio City and

Tremont, areas with heavy ethnic populations of Ukrainians, Poles, Czech, and, further west,

Irish, the unemployment rates were almost as bad, fluctuating between 40 and 45 percent. By

1934, Unemployed Councils had even spread to the city's white Protestant neighborhoods and

were springing up in suburbs as well. In the fall of 1932, the first major relief-related clash

occurred in Collinwood on the city's east side. Some 500 Council members marched to the local

Associated Charities branch and demanded food and clothing. When they were rebuffed, the

crowd swarmed past policemen and Charity workers to seize what food and clothing they could.

The police, however, fired tear gas and beat back the crowd with clubs. ${ }^{34}$

The following summer saw a more significant eruption of working class frustration. On

the morning of July 18, 1933, Cuyahoga County sheriff's deputies arrived just after dawn in a

Hungarian neighborhood on the city's east side. They were there to evict John and Sofie

Sparenga and their four children. Sparenga had been laid off in 1930 and was nearly two years

and $\$ 7,200$ behind on his mortgage and interest payments. ${ }^{35}$ His bank had finally foreclosed. As

the deputies carried the Sparenga's belongings out of their modest home at 11413 Lardet

\footnotetext{
${ }^{34}$ Kerr, $85-91$.

${ }^{35}$ Sparanga paid $\$ 8,800$ for the house in 1928 . In the mortgage crisis of $2008-9$, the same home sold for $\$ 5,000$. See,

"Cleveland eviction riot of 1933 bears similarities to current woes," Cleveland Plain Dealer, March 8, 2009.
} 
Cebul

Avenue, a few onlookers gathered. Word spread through the neighborhood where evictions had become increasingly common - by 1932, some 14,500 families had been evicted across the city. ${ }^{36}$ Four thousand Clevelanders soon converged on the Sparenga's house. Once word reached members of the Small Home and Land Owners' Federation, a grassroots neighborhood "home defense" group organized to protect families from foreclosure, some four to six thousand white ethnic Clevelanders joined the increasingly raucous protest against the Sparenga's - and their own - treatment at the hands of the banks and the government. With the head of the Federation leading the rally from a loudspeaker affixed to the top of a truck, the crowd surged forward in hopes of returning the Sparenga's belongings to their home. More than 160 police officers were soon on the scene, however, and they forestalled increasingly desperate efforts. When the crowd pulled an officer from his car, the police advanced on horseback. Soon, bricks flew. The officers reciprocated, beating back the crowds, first with nightsticks and then with tear gas and fire hoses. Over the ensuing evening, the crowd repeatedly surged forward but was ultimately dispersed some time after midnight. The names of those Clevelanders who were hospitalized or detained for questioning suggests the support the Sparenga's found among their fellow Southern and Eastern European immigrants: Louis Cseh and Joseph Szabo were detained for questioning; Margaret Honrnyak collapsed in the crowd; and Nick Scafilie broke his leg. While the

\footnotetext{
${ }^{36}$ Kerr, 89.
} 
Cebul

Sparaengas lost their home, in writing about Cleveland's most significant but hardly exceptional eviction riot, The Nation reported, "This is a crowd that won't scatter, a crowd that is strangely grim and determined." ${ }^{, 37}$ Over the ensuing decades, these white ethnics would become a potent political force, although when a new generation of city residents expressed a kindred desire to seize the fruits of government support - the city's blacks in the 1960s - Cleveland's ethnics seemed to have amnesia when it came to their period of need and revolt.

\section{White Ethnic Politics}

Cleveland's political and business leadership assumed (and worried) that the Councils were breeding grounds for Communism. While the local Communist Party had initially been involved in their founding, the Party's efforts to generate membership among the ethnic and African American Council members amounted to little. ${ }^{38}$ Many, like Anna Spodnik's Hungarian parents, were among those who came to Cleveland, as she recalled, to "get away from the Bolshevik war." 39 Indeed, for many of the city's ethnics, there was good reason to be skeptical of communist overtures: many had come to the United States to flee communism. Others, having

\footnotetext{
37 “14 Hurt as Crowd Fights 160 Police,” Cleveland Plain Dealer, July 18, 1933.

${ }^{38}$ Kerr, $75-8$.

${ }^{39}$ Anna M. Spodnik Interview, September 24, 1986, Women’s Comprehensive Program Oral History Project, Ethnic Women of Cleveland, October 23, 1986, Cleveland Stand University [hereafter WCPOHP].
} 
Cebul

emigrated prior to communist take over, heard firsthand horror stories from family members

whose property had been seized by communist regimes.

Dmytro Szmagala arrived in Cleveland from Ukraine in 1913. Dmytro was not alone.

The opening decades of the twentieth century witnessed a flood tide of immigration. But, unlike

the mid- $19^{\text {th }}$ century surge of immigrants that was dominated by Irish and Germans, these newly

arrived Americans - some twenty-three million between 1880 and 1919 - were predominantly

southern and eastern Europeans: Italians, Poles, Ukrainians, Slovenians, Czechoslovakians,

Russian Jews, and Hungarians. ${ }^{40}$ These immigrants poured into the industrial North, from

Rochester to Milwaukee, taking jobs in coalmines and shop floors.

The area in Cleveland around $173^{\text {rd }}$ and St. Clair Avenue where Szmagala first

established his family was a Ukrainian pocket tucked among enclaves of Eastern European

immigrants. The east side of Cleveland was fast becoming a mosaic of ethnicities. Slovenes

initially settled "Chicken Village," an area between $60^{\text {th }}$ and $80^{\text {th }}$ Streets along Broadway

Avenue. When Reverend Vitus Hribar was recruited form Slovenia in 1894, the neighborhood

established its Catholic diocese around St. Vitus Church on East $61^{\text {st }}$ St. A new and larger St.

Vitus was completed in 1932 at E. $61^{\text {st }}$ and Glass Ave., built to accommodate the massive influx

\footnotetext{
${ }^{40}$ Edward M. Miggins, "Between Spires and Stacks: The People and Neighborhoods of Cleveland," in W. Dennis Keating, Norman Krumholz, and David C. Perry, eds., Cleveland: A Metropolitan Reader (Kent, Ohio: Kent State University Press, 1995).
} 
Cebul

of Slovenian immigrants to the neighborhood and wider city. ${ }^{41}$ Hungarians settled along the eastern end of Buckeye Road, largely because a wealthy first-wave Hungarian immigrant acquired two thousand lots and sold them to his arriving countrymen. They established St.

Elizabeth's Church on Buckeye in 1893, the first for Hungarian Roman Catholics in the United States. The Czechs built their diocese around St. Wenceslas Church at East $37^{\text {th }}$ and later expanded to Our Lady of Lourdes at East $55^{\text {th }}$ and Broadway. ${ }^{42}$

Unfortunately for Szmagala and his family, Dmytro’s English was not yet strong enough to secure steady work in higher paying manufacturing jobs, so the family left the neighborhood and eventually the city to seek other employment. After searching in vain for work in western Pennsylvania coalmines, Szmagala returned to Cleveland and opened a restaurant, this time settling in the city's near West Side Tremont neighborhood. But his timing was off. With the onset of prohibition, the restaurant's profitability sagged (Dmytro's wife Brunaslava adamantly rejected his proposal that they sell contraband liquor floated over Lake Erie from Canada). Dmytro was forced to sell. Out of work again, he nevertheless landed on his feet, taking a job overseeing a window washing company's charwomen. Szmagala quickly earned a partnership stake in the business and bought a home in Cleveland's suburb within the city, Kamm's Corners.

\footnotetext{
${ }^{41} P D$, November 21, 1932.

${ }^{42}$ Miggins, 186-189. The church was the center of ethnic life. See, especially, Cohen, Making a New Deal, 83-97; and John McGreevey, Parish Boundaries.
} 
Cebul

The variety of Cleveland's ethnic neighborhoods afforded class mobility within one's ethnic

group. Kamm's Corners was no exception - the Szmagalas surrounded themselves with

Ukrainian neighbors. When the weather was good, the Szmagalas headed out to Wallings Grove,

a 30-acre plot of land purchased by their Church in suburban Parma. The Grove was the setting

for demonstrations of ethnic national pride. In 1934, for instance, the Young Ukrainian

Nationalists, No. 8, of Cleveland, pledged their commitment to do their duty for restoring

Ukraine, overcome by the Soviets. Under the watchful eye of Mr. Hrybivsy, a delegate from

Europe, they donned uniforms and performed martial drills. Fathers Merenkiv and Zabava

blessed Ukrainian and American flags, and guests celebrated with food and dancing. ${ }^{43}$ Mary

Fedak fondly recalled these lively Ukrainian church picnics, where she met her husband of 47

years, whom she married in 1940. When asked whether she ever considered marrying a non-

Ukrainian, Fedak exclaimed: "Heaven Forbid!!"44

Long before the vast majority of Americans were concerned by Soviet communism,

Ukrainian-Americans, like the Hungarians who fled the Bolshevik war, highlighted Soviet

brutality. In 1933, Ukrainians in America used their national and international newsletter

Svoboda (Ukrainian for 'freedom') to sound the alarm on a brutal famine in Ukraine, one they

\footnotetext{
${ }^{43}$ Ukrainian Weekly, July 20, 1934, No. 29.

${ }^{44}$ Mary Fedak Interview, WCPOHP. When the same Oral History Project asked a Polish woman a similar question, her response was similar: "I never thought of that. I never thought of that at all.” Helen Karpinski Interview, April 8, 1986, WCPOHP.
} 
Cebul

felt was deliberately exacerbated by Soviet policies. Calls "are being made to the U.S.

Government not to recognize this Communistic dictatorship, as it is founded upon principles that are contrary to all rules of humanity and civilization." The federal government, they argued, must "send a Special Mission to Ukraine in order to study the conditions under which the Ukrainian people are living under the tyrannical and oppressive Bolshevik dictatorship." ${ }^{\text {"45 }}$ These ethnics were not good candidates for the communist cause.

Their homelands were subjugated, and, in America, constant reminders of their place in the social hierarchy only fueled Ukrainians' and other ethnics' sense of outsider status and righteous indignation. ${ }^{46}$ Overt prejudice from elite whites, the nation's 'older stock,' reinforced ethnics' self-perception, often justified, as underdogs. In the teens and twenties, this prejudice was particularly nasty. Older stock Americans seized upon the melting pot mythology to differentiate their own arrival in the United States. A "century ago, Ohio was a melting pot for the best blood," complained one Cleveland writer to the Plain Dealer. ${ }^{47}$ A Cleveland-area judge was quoted in a 1923 article, bemoaning the fallacy of the 'melting pot' ideal when applied to Southern and Eastern Europeans. "You can't make high grade individuals out of low grade

\footnotetext{
${ }^{45} U W$, October 6, 1933, No. 1.

${ }^{46}$ Thomas Guglielmo, for instance, explores the complex insider outsider status of Italians in Chicago, an ethnic group that arrived a generation or more before many eastern and southern Europeans. Thomas Guglielmo, White on Arrival: Italians, Race, Color, and Power in Chicago, 1890-1945 (Chicago: University of Chicago Press, 2003).

${ }^{47}$ PD, March 30, 1924.
} 
Cebul

immigrants," he argued, "simply by letting them bathe in American sunshine, breath American

air, and live on American soil." He summed up his screed: those of "low mentality" were making

America "Europe's dumping ground of late years." 48 The judge would undoubtedly have been a

strong supporter of the following year's federal Immigration Act of 1924, which significantly

curtailed southern and eastern European immigration. ${ }^{49}$

For first generation eastern and southern European immigrants, the 1924 Immigration Act made it all the more crucial for the next generation of ethnic Americans to carry forward their traditions. Many considered themselves refugees, remnants of a nation they hoped someday to recreate. With the interwar turmoil and in many cases outright communist takeover before and after WWII, many first generation ex-pats from Ukraine, Hungary, Czechoslovakia, Yugoslavia, and Poland were ethnic 'nationalists' in the strictest sense of the word: their goal was to foster, in the words of one group, "the Ukrainian national cause of establishing a free and independent Ukraine. ${ }^{, 50}$ From their temporary homes in America, this remnant hoped to keep alive the spirit of nationhood that might one day enable their own repatriation and their homeland's rebirth.

Cleveland's ethnic groups thus identified with a much broader community than their church and neighborhood and viewed their mission in generational terms. The Szmagala family

\footnotetext{
${ }^{48} P D$, September 26, 1923.

${ }^{49}$ On the 1924 Act, see, Gerstle, American Crucible, 103-15.

${ }^{50} U W$, July 20, 1934, No. 29.
} 
Cebul

received the weekly Ukrainian newsletter, Svoboda, which from its base of operations in Jersey

City, New Jersey knitted together a national and international community of Ukrainians. The

Ukrainian National Association (UNA), Svoboda's publisher, was founded in 1894, and, by

1933, it was a three million dollar organization boasting chapters around the country and across

the world. As the younger generation of ethnic Americans began to plug into broader

crosscurrents of American life, their forbears worried their heritage would lose out. In 1933, the

UNA launched a new initiative, Ukrainian Weekly $(U W)$, an English language version of

Svoboda geared specifically to the younger generation of Ukrainian-Americans; both the

Szmagala and Fedak families subscribed. ${ }^{51}$ The first edition of $U W$ took on a clear if slightly

perturbed tone. The buffeting forces of American life, what some called the melting pot, were

taking their toll on intergenerational Ukrainian unity, and Ukrainian-American elders and

Svoboda editors felt it "necessary that the youth read" $U W$. "It is necessary, further, that the

youth become interested in it and give it their support, so that it shall grow and flourish to the

point where it will embrace every phase of life of our American-Ukrainian youth." ${ }^{52}$ Beginning

\footnotetext{
${ }^{51}$ Author interview with Taras Szmagala, December 29, 2010, Cleveland, Ohio; and Mary Fedak Interview, 19, WCPOHP.

${ }^{52} U W$, October 6, 1933, No. 1.
} 
Cebul

in 1933, the UNA hosted a Youth Congress, and the 1934 conference in New York City drew

members from across the country, including Mary Fedak. ${ }^{53}$

While these émigrés and their children organized their spatial and social lives in ways

that confounded easy melting pot assimilation, 'old stock' Americans sought to foster economic

assimilation in order to increase their own wealth and to maintain the social status quo. As

historian Lizabeth Cohen has demonstrated, these efforts were abetted by the rise of a truly

national consumer culture. ${ }^{54}$ In Cleveland, businesses offered financial products that promised to

instill responsible habits of economic citizenship among newly arrived Americans. The Union

Trust Company, for instance, promoted a savings account program that would "build executives"

and competent foremen out of the "rough and tumble in the ... melting pot of Cleveland's shops

and factories." The bank's 1923 "Save at the Shop Plan" offered employers an easy way to help

employees put away portions of their paychecks in mainstream, interest-bearing bank accounts

rather than in economically insulated ethnic mutual aid societies. For company management, the

bank promised to develop "better workmen and better citizens" by encouraging scrupulous

\footnotetext{
${ }^{53}$ The Ukrainian National Association, Fedak said, "has done more for the Ukrainian community than any other. They have helped many people come from Europe after World War II, they have published books." Mary Fedak Interview, p. 13, WCPOHP. The Poles had similar national associations (The Alliance of Poles, the Polish American Congress, and the American Polish Women's Club, for instance, were all still active in the 1980s). See, for instance, Marie Kroll Interview, March 13, 1986, 12-3, WCPOHP. The Lithuanian Catholic Youth organization was called Ateitis, meaning “the future.” Milda Lenkauskas Interview, May 22, 1986, WCPOHP.

${ }^{54}$ Cohen, Making a New Deal, 234-8.
} 
Cebul

saving. ${ }^{55}$ Increased personal equity would ensure a heightened sense of responsibility that would in turn mean lower labor turnover and greater productivity. At home, too, Union Trust promised economically responsible husbands would make happier wives. Several of Cleveland's larger companies signed on, including the welding pioneer Lincoln Electric. Nevertheless, the workers who signed up for such accounts may have lost much of their savings when Union Trust, one of the Van Sweringens' chief lenders, was forced to shutter.

New Deal Works for Business and the Masses

The establishment of the Civil Works Administration in 1933 abated, for a time, some of the relief-related tension among working class, ethnic Clevelanders and city leaders, but its sudden dissolution in March 1934 brought renewed clashes. In July, a group of Council members pushed their way into a relief center. Police arrived to disperse the activists. When they refused, however, the police overreacted and opened fire, killing two Council members, a white man, Salvador Arzentini, and a black man, Vinnie Williams. Several other protestors and a policeman were wounded. Thousands of Clevelanders paraded through the streets in mourning and protest. Proponents of interracial solidarity seized on the twin killings of a white and a black, calling, as one protest sign read, to "Build the Solidarity of Negro and White Against the Bloody CCRA

${ }^{55}$ Union Trust Co. Advertisement, PD, March 19, 1923. 
Cebul

Hunger Program." Relief and eviction riots were not the only forms of unrest gripping the city in the mid-1930s. Cleveland witnessed some of the Depression's most pitched battles between labor and management, particularly following passage of the Wagner Act. The violence and work stoppages in Cleveland gained national news as workers walked off the job. 2,500 struck at White Motor company; Addressograph Multigraph corporation in Euclid had 1,200 striking workers; National Carbon Company, 1,800; the Electric Vacuum Cleaner company in East Cleveland had 1,000; the Industrial Rayon corporation had 1,500 workers walk off the job. ${ }^{56}$ In May, the largest crowd in the history of Cleveland's Public Hall, 24,508, packed in to hear Father Coughlin blast President Roosevelt for nearly 90 minutes. ${ }^{57}$ While an interracial movement on behalf of unemployment rights, labor regulations, and more generous relief was not to be, the political pressure Unemployment Councils, labor, and working class and ethnic masses brought to bear spurred action among the city's business and political leadership. ${ }^{58}$ As early as the summer of 1932, the Cleveland Chamber of Commerce was wrestling with this growing pressure to house unemployed and displaced workers and their families as well as the reality of the dire fiscal crisis facing city government. Prior to the 1930 s, much of the Chambers' relationship with city government had been advisory. They passed resolutions,

\footnotetext{
56 “Mayor Linked with Rioting in Cleveland,” Chicago Daily Tribune, undated, folder 14, container 23, HHB.

57 “Coughlin Hits Roosevelt Bank Bill,” PD, May 9, 1935, folder 12, container 23, HHB.

${ }^{58}$ Kerr, 83-6.
} 
Cebul

offered budget analysis memos, and recommended bonds and taxes. The Depression and New

Deal would change that relationship for good while also introducing a new partnership with the

federal government. A 1932 Chamber report noted, the "only real agreement . . . is that the

objective" of creating housing, and, in turn, construction jobs, "in some form, is not only

desirable, but necessary." Doing nothing "is becoming more expensive than the city can bear."

Over the course of eight pages, the Chamber's City Plan Commission laid out the options as they

saw them concerning "housing, elimination of slums and the improvement of blighted areas.",59

The least desirable option was completely public housing, advocated by "those who look at the

European countries and, seeing the practice of state building and ownership almost universal,

consider that the burden of proof is upon those who take a contrary view." The Chamber rejected

"the unknown dangers" of such a method. Instead, the most desirable solution was for private

enterprise to tackle the problem without public intervention of any kind. Yet, the report found the

"acquisition of land is troublesome; the cost of finance and taxation is high; the cost of building

is lower than it was, but is, nevertheless, high, and rents are low." There was simply too much

risk. Businesses avoided housing especially, instead investing "in things where the profit was

thought to be more sure."

\footnotetext{
${ }^{59}$ Report of the City Plan Commission, Board of Directors Meeting Minutes, July 20, 1932, Volume I, Container 45, GCGA.
} 
Cebul

Increasingly desperate, Chamber members grasped for solutions to the crisis that would maintain a veneer of private leadership and initiative. As far as they saw it, the only other option - "the most popular suggestion, at present" - was a form of public-private partnership, with government insulating private capital from some risk by acquiring blighted land through condemnation or eminent domain and conveying it cheaply to private developers. The Chamber noted matter-of-factly (if not happily) that the Federal Home Loan Bank Act, passed that summer, would set up regional banks to take over bad mortgages from lenders, thus "liquefying frozen assets" and "eventually encourage[ing] individual home building by making home mortgage loans more liquid." The Chamber concluded with pragmatism rather than dogma: "It is ... true that the sickness and consequent weakness in this city due to the widespread blight of improper living conditions may have to be cured by medicines which are afterwards thrown away. ${ }^{, 60}$ By December 1932, the situation had significantly worsened, and the Committee on the City Plan advocated a forceful role for the Chamber. Indeed, the end of October had found " 180,000 of the persons ordinarily gainfully employed were out of work," roughly 46 percent of the city's normal workforce. The unemployment crisis "is so important that any plan which offers such opportunity for the employment of labor as a building plan, should be given every

\footnotetext{
${ }^{60}$ Report of the City Plan Commission, 7, Board of Directors Meeting Minutes, July 20, 1932, Volume I, Container 45, GCGA.
} 
Cebul

encouragement." The Committee argued the Chamber must "encourage and influence the formation of one or more housing companies composed of" interested members. ${ }^{61}$

In order to finance such an undertaking, committee members proposed turning to government to secure a federal Reconstruction Finance Corporation loan, which could cover up to $65 \%$ of the cost of their company's slum clearance projects. In Cleveland, "building and material interests" indicated to the committee "that they would be willing to accept between $25 \%$ and $30 \%$ of the cost of the material ... for the building in securities." ${ }^{\prime 2}$ Though the committee members enthusiastically recommended the proposal to the Chamber's Board of Directors, the Board vacillated. According to meeting minutes, "the directors hesitated to give their 'official sponsorship' to an attempt to form a corporation or corporations of the character described." Their chief concern was that, if the corporation failed, the Chamber's "'sponsorship" of such a company, linked to federal subsidies, would cause undue discomfiture for Board members. Instead, the Directors instructed the committee "to devise a formula that would be satisfactory to the committee and would not embarrass the directors. ${ }^{\circ 63}$ By November 1933, however, as the

\footnotetext{
${ }^{61}$ Report of the City Plan Commission, 6, Board of Directors Meeting Minutes, December 7, 1932, Volume I, Container 45, GCGA.

${ }^{62}$ Ibid, 7.

${ }^{63}$ Ibid.
} 
Cebul

situation continued to deteriorate, the Board blessed the creation of an Industrial Mortgage Loan

Company backed by $\$ 500,000$ in RFC financing. ${ }^{64}$

While federal finance offered a modest inducement for private action, the arrival of

federal works programs instigated a much higher magnitude of relief - as well as economic

opportunities for business. Public works, the Chamber noted, "would provide employment, require raw and finished materials" and "could be made at this time to advantage." But, because the city had such a high level of bonded debt, the Chamber sought other means to meet federal matching requirements - they learned they could do so, in fact, with other federal funds. As one report from the Chamber's Committee on Public Finance and Taxation argued, it "is obvious that no further burden should be placed on the general taxpayer for bond interest and retirement charges at this time." Instead, the Chamber "favors the financing . . of necessary public works" with federal grants offered through the National Industrial Recovery Act. Since the NIRA offered direct grants before local financing had to be established, the Chamber identified a distinct advantage: "prior to [local] financing . . . the direct grant provisions of the [NIRA should] be exhausted." The Committee hoped the NIRA's “direct grants would meet local [matching] needs" without any local expenditure. ${ }^{65}$ If local needs exceeded the direct grant

\footnotetext{
${ }^{64}$ Manufacturers' Committee, Subcommittee on Industrial Mortgage Loan Company Minutes, October 25, 1933 and November 6, 1933, Volume II. Container 46, GCGA.

${ }^{65}$ Report from the Committee on Public Finance and Taxation, Board of Directors Meeting Minutes, June 20, 1933, Vol. I, Container 46, GCGA.
} 
Cebul

provisions of the NIRA, the Committee recommended the city seek to raise its bonded debt ceiling. The Chamber's Board of Directors approved the report with only one dissenting vote.

From practically the very beginning of the New Deal, then, Cleveland's business elite sought to use federal aid for economic development. In one early case, in late 1933, a rayon firm with branches in Cleveland and Covington, Virginia was considering expanding its Cleveland facility, an expansion that would require significant new sewage infrastructure improvements. The city, the Chamber's Industrial Development Committee argued, "can easily decide that this sewer must be built by the Industrial Rayon Company if it is to be built at all. We think that would be a mistake." Yet the rayon company had already offered to cover half the cost of the sewer development. "[A]s a matter of right," one Chamber member contended, "the Industrial Rayon Company should not be called upon for any amount.” After all, "The company has another plant at Covington, Virginia. It can build its expansion there or in many other cities." Instead, the Chamber voted unanimously to "consult with Mr. Hopkins, director of the C.W.A. in Washington, for the purpose of obtaining the necessary consent and necessary appropriations from the CWA to complete this present project." ${ }^{66}$ In another instance, in justifying federal spending that would benefit the Youngstown Sheet and Tube Company, Chamber members emphasized the obvious waste of federal funds were they to be spent elsewhere. As they put it,

\footnotetext{
${ }^{66}$ Industrial Development Committee Meeting Minutes, December 26, 1933, Vol. II, Container 47, GCGA.
} 
Cebul

"this [CWA] fund will be spent for other purposes less permanent, less useful, less worthy and the tax payers will have to pay that money back in any event. It certainly would seem to be sound business if in some way we can induce the Administration to spend this part of the money in a sensible, constructive, permanent improvement. ${ }^{, 67}$ Far from a reckless endangerment of the free market, Chamber members quickly construed federally subsidized inducements for local industrial and economic development in Cleveland and Northeast Ohio as "sensible," "sound business," and a "matter of right."

Nevertheless, along with national elites at the US Chamber of Commerce and the National Association of Manufacturers, business people in Cleveland struggled to reconcile their acceptance of a newly outsized federal role in local developmental affairs with their ideological values of limited government and a free market. In December 1934, a Cleveland Chamber member attended the annual conference of the National Association of Manufacturers in New York. Upon his return, he defended the work done there, saying that "while it may appear from the publicity covering these meetings that considerable concessions have been made to President Roosevelt and the Administration, nevertheless it is a fact that some very forward-looking and helpful resolutions ... were adopted." Among them was the creation of a joint NAM-US Chamber committee, headed by NAM Chairman Robert Lund, of Lambert Pharmaceuticals, and

\footnotetext{
${ }^{67}$ J.C. Argetsinger, General Counsel to Youngstown Sheet and Tube Company to A.Z. Baker, of the CCoC, October 14, 1935, Vol. 1, Container 49, GCGA.
} 
Cebul

Silas H. Strawn, former President of the US Chamber and leading attorney at Chicago's Winston and Strawn. Far from a committee designed to head off future federal incursions, its founding resolution declared it would carry out the current recovery programs "upon which all business elements of the country may unite and cooperate with the Government." ${ }^{68}$ Instead of rolling back aspects of the New Deal - for which the Du Ponts and the nascent Liberty League had begun mobilizing just months prior - two of the most influential business associations were uniting to form a stronger developmental partnership with government. ${ }^{69}$ Another Cleveland Chamber member had attended the meeting, and he was quick to point out, however, that, just to be clear, the delegates also adopted a resolution "against government further encroaching upon the manufacturing business." ${ }^{, 70}$ Indeed, despite the benefits they clearly saw in federal development spending, Cleveland's leading businessmen often turned their meetings into collective grievance sessions over Roosevelt Administration policies. At one 1934 meeting, "Considerable time and thought was given to the entire lack of confidence a good portion of the people of the United States have in the future of our country due to the attitude taken by the Administration at Washington."71 Their incremental slippage, however, became characteristic of Cleveland's

\footnotetext{
${ }^{68}$ Executive Board of the Manufacturers' Committee Minutes, December 10, 1934, Vol. II, Container 48, GCGA.

${ }^{69}$ For an account of anti-New Deal business mobilization, see Phillips Fein, Invisible Hands, esp. chs. 1 and 2.

${ }^{70}$ Executive Board of the Manufacturers' Committee Minutes, December 10, 1934, Vol. II, Container 48, GCGA.

${ }^{71}$ Executive Board of the Manufacturers' Committee Minutes, September 27, 1934, Vol. II, Container 48, GCGA.
} 
Cebul

business leaders. Despite the persistence of ideological rhetoric, strategic accommodation to the

New Deal developmental state was the rule, not the exception.

Business' long-term relationship with the Clevelanders tasked with running federal relief

programs in the city and county was instrumental in their accommodation of the growing federal

presence. Cleveland's business leadership had insiders at the helm of the county's federally

supported relief efforts as well as the WPA. Clark L. Mock was a Western Reserve University

graduate and a Rhodes Scholar who, in the early 1920s, took a job on the professional staff of the

Chamber of Commerce. There, he served as the Chamber's assistant secretary and Labor

Commissioner (essentially an arbitrator representing the Chamber's interests in labor disputes). ${ }^{72}$

In the wake of the 1929 crash, Mock was appointed assistant director of the region's charitable

Welfare Federation where he oversaw welfare planning and coordinated with the public welfare

agencies as well as the voluntary community fund and Associated Charities. With the onset of

the New Deal, Mock was hired away from the private sector to become the county's public relief

director, overseeing federal and state funded relief programs for Cleveland and Cuyahoga

County as director of the Cuyahoga County Relief Agency. Tellingly, one of the first ventures he

\footnotetext{
72 “Federation Names Mock," PD, May 14, 1929, Clark L. Mock to George A. Myers, March 15, 1926, The African American Experience in Ohio, The Ohio Historical Society, accessed online at http://dbs.ohiohistory.org/africanam/page.cfm?ID=13704; and "U.S. Delay Puts Crisis up to CCRA," PD, August 1, 1935.
} 
Cebul

spearheaded was a 2,500 to 3,000-man project of improvements to the county airport, a favored project among businesspeople. $^{73}$

Likewise, the longest tenured administrator of the region's WPA programs was intimately connected to the city's business elite. Joseph H. Alexander had, for decades, been a leader at the Cleveland Railway Company, moving from a position as an engineer to ultimately serving as company president, earning over $\$ 40,000$ a year, a fortune in the late 1920 s (nearly $\$ 700,000$ per year in 2013 dollars). ${ }^{74}$ Alexander was forced out of that position when the Van Sweringen brothers purchased the Railway Company and appointed their own figurehead as president. After a few years consulting for a number of railways, Alexander took the $\$ 6,000$ a year position as a head of the county's WPA program. The "Big Business" Democrat, as he was known, was a close associate and former city employee of Newton D. Baker who, after his term as Cleveland's mayor, went on to found one of the city's most influential law firms, Baker Hostetler, and serve from 1916 to 1921 as U.S. Secretary of War under Woodrow Wilson. ${ }^{75}$ Alexander designed a number of the WPA's initial programs specifically to benefit the white collar unemployed. Indeed, he faced great pressure to do so. The Cleveland Bar Association's executive committee lobbied to have "indigent lawyers" appointed to a special

\footnotetext{
73 “Warn WPA Rebels on Bonfire Ban,” PD, December 6, 1935.

74 “Politics Wins," PD, March 31, 1936; and BLS Inflation Calculator.

75 “Alexander Out As County WPA Chief,” PD, July 23, 1938.
} 
Cebul

committee of WPA workers, which would review municipal laws. The Bar Associations of

Chicago, New York, and Columbus put similar efforts in motion, Cleveland's leading lawyers

noted. $^{76}$ In addition, in an early "planning” program, at a federal cost of nearly $\$ 500,000$,

Alexander hoped to employ out of work draftsmen, planners, engineers, and other white-collar

workers to survey street congestion to determine worthwhile WPA projects. Before a luncheon

of leading businessmen and public officials, Alexander noted that Philadelphia and Columbus

had already carried out similar white-collar WPA programs. ${ }^{77}$ The Plain Dealer editorial board

trumpeted their support: "By employing 400 to 500 'white collar' unemployed in studying the

flow of traffic ... plans can be laid for meeting the increase in traffic which is sure to come in

future years ... [I]f scientifically carried out, [the program] will be of great benefit to the city. It

is an example of foresight in civic affairs which brings rhyme and reason into a situation which

heretofore has been allowed virtually to drift." Alexander, they wrote, "should have little trouble

in persuading Washington officials of the value of the project." It "has every argument in its

favor."78

\footnotetext{
76 “Backs Plan to Put Lawyers on WPA,” PD, December 1, 1936.

77 “Asks Jobs for 500 in Traffic Survey,” PD, May 17, 1936.

78 “Foresight in Traffic," PD, May 18, 1936.
} 
Cebul

A broad swathe of Clevelanders appreciated the incredible array of WPA projects. ${ }^{79}$ With federally funded manpower, one of the city's crown jewels, its “emerald necklace” of parks were improved and expanded. As well, the thousands of dollars and man-hours the WPA spent creating the "monkey island" in the Brookside Park Zoo, for instance, was featured in the Plain Dealer. Its unveiling, helmed by Alexander, was attended by 15,000 Clevelanders who "packed lunches and toted cameras to surround the new ... home of the monkeys. ${ }^{\circ 0}$ Some Clevelanders were outspoken about the many benefits city industry would see thanks to the WPA.

Businessman Jacob Reible, for instance, wrote the Plain Dealer to praise Alexander's "efficient" leadership of the WPA in Cleveland and to emphasize the side benefits of works programs in the city. All "industrialists," he wrote, have found "constructive and beneficent" the "work done here by WPA." Moreover, the "'reliefer' will pay big dividends to private industry by acquiring from WPA experience, efficiency and a well-built morale to carry on when needed by private industry. $" 81$

The WPA was also put to work on projects favored by the city's ethnic communities. The 1940 opening of the Ukrainian Cultural Garden was attended by thousands of Ukrainian

\footnotetext{
${ }^{79}$ Mason Williams has traced the positive impact of works programs on civic engagement in New York City. Williams, City of Ambition.

80 “Doors Open on Their Monkeyshines Today," PD, June 21, 1936; “135 Monkeys Bow to 15,000 Humans," PD, June 22, 1936.

${ }^{81}$ Jacob Reible to Editor, $P D$, December 12, 1937.
} 
Cebul

marchers. The gardens, built with WPA labor, were dedicated to American democracy and freedom and featured a statue of St. Volodimir, the ruler of Kieven Rus and the patron saint of Ukraine. ${ }^{82}$ When the city opened the Yugoslav Cultural Garden on a rainy spring morning, 100,000 people paraded to see WPA Director Joseph Alexander and Mayor Harold Burton christen the space dedicated to the city's Croatians, Serbs, Slovenians, and Yugoslavians. ${ }^{83}$ Most grateful, however, were the workers employed by the WPA. At its peak in October 1938, the federal program employed over a quarter of the city's workers, reaching a total of $78,000{ }^{84}$

Despite the enthusiasm Clevelanders felt for the fruits of Works Progress programs, works in progress were often another matter. WPA-related disturbances became a near-constant theme in local news coverage. One Lorain Avenue physician grumbled that, despite the number of workers he counted on the site each day, improvements were proceeding at "an intolerably slow pace." "I've counted as high as twenty men in the crew and all but two of them seem to be bosses and all the men seem to spend most of their time watching one another." The result of all this oversight was that it "took them four or five days to tear up about 50 square feet of pavement, and they've been replacing it now for three and it isn't finished." ${ }^{\circ 5}$ Residents along E.

\footnotetext{
${ }^{82}$ Rose, 986.

${ }^{83} \mathrm{http}$ //clevelandhistorical.org/items/show/138\#.UrIyW2RK10I

${ }^{84}$ Howard Whipple Green, "Nine Years of Relief in Cleveland, 1928-1937," Cleveland Health Council, 1937, accessed online via HathiTrust.

85 “Complains WPA Paving Crew Seems Nearly All Bosses,” PD, November 29, 1935.
} 
Cebul

$101^{\text {st }}$ Street reported an even more dramatic lag in their street's widening. In July 1936, one

resident complained the "WPA originally started work on the project in October of last year,"

then "laid off for the winter." They began work again in the spring, but "the only sign of activity

has been the presence of two men who have been taking up the paving stones of the sidewalks

and laying them on people's lawns." ${ }^{.86}$

More seriously, by the early summer 1936, concerns spread that WPA wages, which had

been increased to prevailing wages, were so competitive with private rates that men chose to stay

in public employ rather than return to the private sector. Grumbles surfaced, too, that

unemployed veterans were feasting particularly high on the public hog because their "veteran

bonuses" did not disqualify them from WPA work. Even those who'd served their country in war

could be construed as unworthy freeloaders. A Plain Dealer article stoked fears and suspicion by noting that "nothing in the WPA regulations" would "force off the WPA rolls a man who might win a big cut of sweepstakes money, fall heir to a fortune, or get himself a lucrative position which he can fill on days when he is not at work for WPA. In other words," the journalist concluded, "while it was necessary for a man to be 'broke' to remain on relief, it is not necessary for a man to be otherwise penniless to remain on WPA." ${ }^{87}$ This, despite the fact that, just a few weeks later, in a report buried on page 11, the Plain Dealer briefly noted a WPA announcement

\footnotetext{
86 “Demand Speed by WPA on E. 101 Job,” PD, July 13, 1936.

87 “Jobs May Call Men, But WPA Marches On,” PD, May 28, 1936.
} 
Cebul

that some 700 workers were leaving WPA roles each week for private sector jobs ${ }^{88}$ By August, Alexander estimated that nearly 3,000 able-bodied workers were leaving the WPA per month. ${ }^{89}$ Nevertheless, the Plain Dealer sensationalized concerns about "chiselers," describing how the only mechanism Alexander had to "weed out all who no longer need government jobs" was to “depend on anonymous tips.",90

Administering WPA programs could give Cleveland's elites headaches, too. The wives of a number of Cleveland's wealthiest industrialists, for instance, ran the City Garden Center. After pushing for WPA improvements to the city's parks, they were soon up in arms over the course of work. Why, asked Mrs. William G. Mather, the wife of Samuel's younger brother, were "WPA workers ... confining Cleveland park brooks between miles of high stone walls, digging out the homes of little animals and destroying the wild vegetation along the way?" Frustrated, Alexander told the Plain Dealer that it was "all a matter of taste." "Some think a log should be allowed to rot where it is, and others think it ought to be pulled out." Mrs. Mather called in ornithologist S. Prentiss Baldwin to plead her case as well as that of the city's fauna. "It's a terrible thing they are doing, skinning our parks, and making the water inaccessible so that birds ... cannot get a drink ... The dead trees are every one pulled down so woodpeckers can find no holes. Every strip of

\footnotetext{
88 “700 Leave WPA Weekly,” PD, July 30, 1936.

89 “Clash on Method to Cut Dole List,” PD, August 7, 1936.

90 “'Tips Only Check on WPA Chiselers,” PD, November 19, 1936.
} 
Cebul

wood and every log is destroyed so the chipmunks have no place to go. Not even a rabbit can

live." 91 Nevertheless, Mather and her compatriots at the Garden Center were happy to draft the

WPA again when they required a new headquarters, which would later become the Cleveland

Botanical Gardens in University Circle. ${ }^{92}$

The Garden Center women also scored one of the flashiest WPA projects when the agency was contracted to build the Cleveland Horticultural Gardens along the Lake Shore as part of the Great Lakes Exposition. The Exposition was a Worlds Fair-like scheme to help raise the city out of Depression. The Exposition occupied the public mall from St. Clair Avenue north to the Public Auditorium, and along the lakefront from West $3^{\text {rd }}$ Street to East $20^{\text {th }}$ Street - a total area of more than two square miles. ${ }^{93}$ Much of the area had previously been used as a dump. WPA workers filled in portions of the lakefront, completed work on the shoreway freeway, and set to work on the grounds and buildings. Elizabeth Mather chaired the gardens project, and WPA workers cleared the land and planted the gardens that ultimately covered 3.5 acres. Adjacent to the gardens was built a massive horticultural building that hosted rotating flower

\footnotetext{
91 “'Wait and See,' Says WPA, Asked, 'Why Fix Nature?,'” PD, April 21, 1936.

${ }^{92}$ Garden Center, 1939, Cleveland Public Library, accessed online at: http://cplorg.cdmhost.com/cdm/singleitem/collection/p4014coll18/id/1871/rec/46

${ }^{93}$ Rose, Cleveland: The Making of a City, 877.
} 
Cebul

shows, garden club meetings, and a variety of other exhibition spaces. ${ }^{94}$ Three million people

toured the site over the first 80 days of the four-month Exposition (which was extended to a

second year). Most popular was the "Streets of the World" exhibit, comprised of 200 cafes and

shops representing Cleveland's diverse ethnicities. The Exhibition's Aquacade featuring “water

ballet" star Johnny Weismuller was so popular it traveled on to New York. When the

Horticultural Gardens debuted, the WPA workers who'd built the project were given special

tickets to tour the fruits of their labors. As WPA Director Alexander put it, "Such a celebration

has been in mind for weeks because numerous employees," who otherwise couldn't afford

Exposition tickets, "have said they wanted to see the WPA-built gardens . . . one of our first

projects." 95

In a climate characterized in equal parts by approbation and complaints, a Plain Dealer

profile described the key to Alexander's ability to carry out effective developmental work: good

humor. One day over the summer of 1936, for instance, two WPA workers were asleep at the

bottom of a ditch at a worksite along the lakefront (likely the garden project). They awoke to a

tall man looming over them. "Hey, you down there," the figure yelled; "do you know that guy

Joe Alexander?" "Who is he?" one of the rousted workers asked. "He's the big boss," the man

\footnotetext{
94 The Horticultural Building burned in 1941, but the Donald Gray Gardens were kept up until the 1990s when they were torn down for the new Cleveland Browns football stadium.

http://clevelandhistorical.org/items/show/291\#.UqJNxWRK10I

95 “WPA Workers to Be Expo Guests,” PD, September 16, 1936.
} 
Cebul

replied. 'I understand he's on his way over here, and he's a tough hombre. You'd better make believe you're working." The profile described how, as the "dirt began flying," Alexander, the former railway executive, "laughed to himself as he went on to look for more horizontal . . government employees." "The incident ... was characteristic" of Alexander's sense of humor "which is the chief bulwark between a local WPA executive and the insane asylum."

Even more confounding than indolent workers, however, was the maddening relationship Alexander negotiated with federal bureaucrats. Faced with Washington's vacillation and sluggish decision-making, another man "would have been tempted to go on a long drunk," the city's morning paper reported. Instead, Alexander "just laughed and let Washington worry.” The "despair of most local WPA officials is the interminable flow of new regulations and rules of procedure from Washington and regional WPA headquarters.” Many were "completely contradictory, many more of them are absurd." Sensibly, “Alexander's system is to disregard those that no one can understand and follow to the letter those which are just absurd." "When an expert - or a squad of experts - is sent to Cleveland to find out what is the matter Alexander sits back and smiles while they attempt to untangle the results of their own rules and regulations.",96 Nevertheless, Alexander's cavalier attitude toward federal guidelines and regulations also led to his ouster as head of Cuyahoga County's WPA. A “more or less continual undercurrent of

\footnotetext{
96 “WPA Chief Spurs Work With Humor,” PD, January 24, 1937.
} 
Cebul

friction" characterized the former Railroad man's relationship with state WPA officials. The state director, closely allied with the federal administrator, secured Alexander's dismissal.

While Alexander's tenure at the WPA came to a close, his allies and friends at the Chamber of Commerce enjoyed a sustained relationship with federal developmental instruments.

By 1937, Cleveland's business leaders had firmly accommodated themselves to locally administered federal development and infrastructure spending. The Chamber made continual recommendations for city improvement projects to be taken up by the WPA. One was a lakefront boulevard from E. $9^{\text {th }}$ Street to Gordon Park, which used $\$ 4$ million of federal WPA labor to build. ${ }^{97}$ Another report recommended the "WPA be asked to consider setting up a new project which would involve making an inventory of 20,000 sour lots, and selecting those which would make desirable home sites ... This suggestion was adopted unanimously and ordered as a matter of business. ${ }^{.98}$ A $\$ 525,000$ WPA project straightened a narrow bend in the Cuyahoga River and whetted business' appetite for further river improvements. ${ }^{99}$

Indeed, the following year, when A.C. Ernst began his term as Chamber president, he asked members, "What do you want your Chamber of Commerce to do?" The resounding answer was to secure public support for further infrastructure improvements to the Cuyahoga River. As a

\footnotetext{
97 “WPA Begins Work on Lake Drive Bridges," PD, April 6, 1937.

${ }^{98}$ Policy Committee, Construction Industries Meeting Minutes, May 19, 1938, Chamber of Commerce Meeting Minutes, Vol. II, container 52, GCGA.

99 "Start Next Week on Two WPA Jobs," PD, December 19, 1936.
} 
Cebul

later Chamber member put it, infrastructure was "the Number One job in Cleveland."100 The

Cuyahoga River (Iroquoian for "crooked river") was by turns too shallow and too curvy for the increasingly long and deep container ships to safely navigate. Making matters worse, as container ships grew in length, they also grew in height, and Cleveland had a slew of old and low slung bridges that compromised their passage. In 1937, the Chamber formed a River and Harbor Committee whose first successful measure was securing the passage of a $\$ 3$ million River Improvement Bond to widen the Cuyahoga's bends. Construction on the total project - which envisioned the removal of several bridges, a number of widened bends, significant dredging, and a two mile extension of the river itself - was begun in earnest when the Chamber led the city to secure a \$2.6 million federal grant to fund WPA workers to begin the improvements.

With all of these developments, it comes as some surprise to discover the Plain Dealer's astonishment at the massive new federal role in the city. In May 1938, the paper undertook a survey "to gauge the tremendous effect of the federal government on Greater Cleveland's economic life."101 As they concluded, "The more-than-a-quarter-of-a-million persons in Greater Cleveland looking to Uncle Sam for support form only part of the story of dependency on public funds for support." To date, the WPA alone had provided the county and city $\$ 76$ million that

\footnotetext{
${ }^{100}$ Clifford F. Hood, "Building the Port of Cleveland,” A Report to the Board of Directors, December 18, 1945, GCGA Meeting Minutes, volume 1, 1945-1946, container 59, GCGA.

101 “Find City’s 'Big Shot' is Uncle Sam,” PD, May 21, 1938.
} 
Cebul

had been matched by the "so-called sponsors' share," as they put it - a paltry $\$ 5.4$ million. Add

to that financial, mortgage, and old age insurance, not to mention RFC loans to some 1,034 Ohio

companies totaling \$236 million in Cuyahoga County alone, and it was all of a sudden clear that,

as the front page headline boomed: 'FINDS CITY'S 'BIG SHOT' IS UNCLE SAM: Survey

Shows Federal Government Dominates Business Life Here." Interesting, however, was their

choice of the verb "dominates." Indeed, business had, in fact, played an active role in much of

the city's involvement in New Deal programs, especially the program the Plain Dealer

highlighted, the WPA. In sweeping terms, then, the newspaper addressed the policy areas

"dominated" by the federal government:

He inspects [Mr. and Mrs. Cleveland's] foodstuffs; his AAA has a bearing on the price they pay for these foodstuffs; he carries their mail; he insures their bank and savings and loan deposits up to a certain maximum; he regulates transportation fares; he inspects rail, air and marine vehicles of transportation; he steps into labor disputes; he maintains the greatest national police agency; he contributes vast sums, through the bureau of public roads, to the building of highways ... Uncle Sam is shipping in food for relief clients valued at around $\$ 100,000$ a month at retail prices.

All of this on top of the fact that the federal government employed more people than any

other entity in the city. By the end of the summer Cleveland lobbied for and won another $\$ 27$

million in WPA transportation improvement spending alone. ${ }^{102}$ World War II had yet to begin.

102 “Huge WPA Street Grant Approved,” PD, September 16, 1938. 
Cebul

Economic, Industrial, and Urban Planning

A year before the United States' entry into World War II, President Roosevelt instructed

the National Resources Planning Board to study “post-defense planning.” The NRPB's Urban

Section focused first on prospects for the postwar demobilization and reconversion to a

peacetime economy and then on longer term planning for the decade to come. NRPB planners

sought to broaden the planning process from "a one-time undertaking that results in a 'master

plan" to one that viewed planning as "a continuous process." Federal planners hoped to

galvanize local action, particularly between and among local governments, business, and civic

leaders. As Philip Funigiello, a historian of the NRPB put it, this "decision was predicated on the

realistic assumption that private citizens, organizations, and local public officials possessed the

knowledge, good judgment, and experience to manage some segments of the planning better than

outside technicians." Federal agencies and experts would provide data and information, "but the

initiative and . . . the day-to-day planning had to come from the local community." ${ }^{\prime 103}$ The NRPB

focused on a few "demonstration" case studies in medium sized cities that took varying

approaches and saw varying degrees of success, but the spirit of their federally backed, locally

administered planning initiative was being carried out in regions across the country. ${ }^{104}$

\footnotetext{
${ }^{103}$ Philip J. Funigiello, The Challenge to Urban Liberalism, 166.

${ }^{104}$ Ibid., 167-184.
} 
Cebul

Cleveland was no exception. New Deal programs catalyzed a significant broadening in outlook among Cleveland's business leadership that embraced public planning on behalf of the private economy. The decentralization of population that had begun along with the Van Sweringen's Shaker Heights had accelerated, thanks in part to New Deal housing programs, threatening the city's retail and tax bases. Some kind of regional planning - cooperative planning among the city and its suburbs - seemed imperative, but city and business leaders lacked the political will, while suburban municipalities had little legal or economic interest in forging such compacts. ${ }^{105}$ In 1937, Republican city councilman Ernest Bohn organized the Regional Association of Cleveland, a civic organization - indeed, an early public-private partnership - to pursue modern planning for Cleveland. Bohn had been one of the city's most outspoken advocates of slum clearance and public housing. For Bohn, however, those New Dealfunded measures were less about putting Clevelanders to work or constructing more suitable housing. Instead, Bohn framed these efforts as a way to save Cleveland's taxpayer dollars. After commissioning a report on the city's blighted areas, Bohn and his allies charged that social service agencies spent $\$ 1.9$ million to "maintain" the "luxury of a slum." As Bohn put it, "Oh, of course we got the sob sisters, people who wanted to do something for the downtrodden masses.

\footnotetext{
${ }^{105}$ Legal historian Gerald Frug has written about the state and municipal laws that encourage and perpetuate regional fragmentation. Frug, City Making.
} 
Cebul

But I think a public housing program should be based on something sounder than that."106 For Bohn, that "something" was lower taxes and economic growth.

Despite Bohn's rather conservative spin on the value of planning, his Regional Association was fundamentally a creature of the New Deal. Bohn's staff embraced the mandate set by the National Resources Planning Board: planning for the coming war effort with an eye especially toward post-war economic reconversion. Expanding his purview beyond blighted areas, Bohn aimed for the Association to act as a county wide, perhaps multi-county, planning and coordinating body focused primarily on downtown revitalization. On the Association's Board sat Cleveland's civic and business elite, and Bohn kept the Association in close consultation with the Chamber of Commerce. He hired John T. Howard, fresh from MIT's City Planning masters program, as the Association's executive director. Bohn and Howard secured a WPA-funded staff of sixty "white collar" employees who conducted regional research and surveys, performed drafting, and offered other forms of clerical and strategic assistance. With "WPA surveys," one Association report noted, "we have developed a picture of the Cleveland Region as it really is: physical conditions - the land and the structures; social conditions - the people, their distribution and compositions; economic conditions - existing housing, building and other regulations, and the legal basis for planning and carrying out plans." Land use plans

\footnotetext{
${ }^{106}$ Kerr, 95-6.
} 
Cebul

would eventually yield plans for the "orderly guidance of regional development."107 "At that point [in] the Depression," Director Howard later recalled, "there were many qualified people on 'work-relief.,"108 “To prepare base-maps, we had the unemployed chief draftsman of a major steel company ... To manipulate obscure formulas for population forecasts we had a Ph.D. in mathematics." The Depression had put these private sector experts out of business, and New Deal funds put them to work in the city's public-private Regional Association. With this workforce in place, after 1937, urban planning and the city's strategic goals were, to a large degree, a direct product of the New Deal in general and the WPA in particular.

As a 1941 Association report put it, the planners were especially driven by "a growing recognition by business, real estate and public officials of the dangers of the present haphazard decentralization of population and business." ${ }^{109}$ Many among Cleveland's business leadership, too, felt public authorities should be given more power to plan for regional economic growth and to deal with decentralization and the challenges of regional coordination and planning. At one Chamber meeting attended by Bohn and Howard, Chamber members wondered whether "Perhaps a time has come when a change from this limited authority over county planning to a

\footnotetext{
${ }^{107}$ Director's Progress Report, April 1, 1940 to April 1, 1941, folder Regional Association of Cleveland, Public Administration Library, City Hall, Cleveland, Ohio [hereafter PAL].

${ }^{108}$ John T. Howard, "City Planning in Cleveland," 2.

${ }^{109}$ Director's Progress Report, April 1, 1940 to April 1, 1941, folder Regional Association of Cleveland, PAL.
} 
Cebul

broader planning aspect may be strictly in order." ${ }^{, 110}$ As corporate lawyer Walter Flory, a

Chamber leader and Vice Chairman of the City Planning Commission put it, "It would be a great thing, I think, if the county would appropriate more money to the County Planning Commission so that experts could be brought here. The County Planning Commission can do a job that [we] can't do." "The general opinion about the suburbs," according to meeting minutes, "was that they weren't moving very fast in the matter of planning." As Howard put it, "The biggest hole in our picture at present is in the planning being done by the suburbs, rather than planning being done on the city level." By inches, Cleveland's business and planning elite were beginning to see their future in regional terms.

As wartime contracts and New Deal funded planning helped Cleveland's economy begin to roar back, local political developments introduced new actors on the city's developmental scene: white ethnic politicians. A union man and lifelong Democrat, Dmytro Szmagala considered Michael Feighan, their Irish-American, Democratic Congressman, a personal friend. But Feighan was Irish, a different kind of longer settled ethnic. When a politician with Eastern European roots emerged, however, Dmytro felt their connection like family. He swelled with pride when Frank Lausche, a Slovenian, was elected Cleveland's mayor in $1941 .{ }^{111}$ The Irish and

\footnotetext{
${ }^{110}$ Special Meeting on Metropolitan Post War Planning Called by the Chairman of the Lakefront Development and Planning Committee (of the CCC), April 26, 1944, Chamber of Commerce Meeting Minutes, 1944-1945, Vol. II, Container 59, GCGA.

${ }^{111}$ Taras Szmagala interview with author December 29, 2010, Cleveland, Ohio.
} 
Cebul

Italians enjoyed established positions within the hierarchies of organized labor and the city's

Democratic machine, but Lausche's election signaled for Szmagala the emergence into local

politics of people from his neighborhoods. While Cleveland's white working class were bedrock

Roosevelt Democrats, no politician stirred the loyalty of Cleveland's ethnic communities more

strongly than did Lausche (rhymes with "how she") who went on to become Governor of Ohio

and a U.S. Senator. But neither did any politician better symbolize ethnics' fundamental

ambivalence about New Deal liberalism in general and the Democratic Party in particular.

When he won the mayoralty in 1941, Lausche became the city's first fusion candidate,

appealing in different ways to the city's business leadership and its growing base of ethnic

voters. For the former, Lausche was attractive because of his staunch law and order bona fides

and for his willingness to buck Cleveland's labor leaders and Democratic Party bosses. Lausche

made a name for himself as a young judge during Elliot Ness' crusading days as public safety

director in late 1930s Cleveland. ${ }^{12}$ With Judge Lausche's assistance and patronage, Ness (a

Republican) cracked down on the city's rampant racketeering and organized crime. The two

often skirmished with Italian and Irish labor leaders in doing so. Nevertheless, Democratic Party

Boss Miller pledged his support to Lausche in his 1941 run for mayor - some speculated he did so in hopes of coopting the independent politician. Once in office, however, Lausche's poor

\footnotetext{
112 "Elliot Ness," Encyclopedia of Cleveland History, Case Western Reserve University, accessed online, http://ech.case.edu/cgi/article.pl?id=NE.
} 
Cebul

standing with the Democratic Party bosses only worsened. Boss Miller, the story is told, promised labor leaders that Lausche would fire Ness, but Lausche kept Ness, and the two continued their crusading partnership. ${ }^{113}$ For the rest of his career, through his time as U.S.

Senator in the 1960s, Lausche had a standoffish relationship with Democratic Party regulars and organized labor. His law and order values trumped political propriety. Boss Miller had a different take: "The day after [Lausche] was elected, they took him to the Union Club, showed him the promised land and he became as fine a Republican as you could ask for."114

The truth, of course, was somewhere in between. Lausche believed in law and order politics, which rankled union and Democratic Party bosses, but the labor leaders who benefited from insider dealings were not Lausche's kind of ethnics. Irish and Italians dominated labor in Cleveland, and their privileged place within the city's Democratic Party had, until Lausche, left his ethnics outside the city's most important back rooms. Lausche's independence from these elites won the hearts of generations of Cleveland's eastern European ethnics. In a city dominated by one political party, Lausche exposed new political fault lines. His pugnacious individualism resonated with ethnics' own sense of having overcome much to reach the banks of the mainstream of American economic and political life. ${ }^{115}$ The Slovenian was re-elected mayor by a

\footnotetext{
${ }^{113}$ Seltzer, The Years Were Good, 230-1.

${ }^{114} P D$, December 28, 1975.

${ }^{115}$ Author interviews with Andrew Hudak, December 22, 2010, Cleveland, Ohio, Vladimir Rus, January 5, 2011, Woodmere, Ohio, and Taras Szmagala, January 4, 2011, Cleveland, Ohio.
} 
Cebul

landslide in 1943, and in 1944 - a year when President Franklin Roosevelt lost Ohio - the second-generation Slovenian-American Democrat won the governor's office. He did so four more times, a record in Ohio. In a 1956 cover story, Time highlighted Lausche's campaign prowess and his political independence. The Governor, the magazine wrote, "avoids all connection with his state's Democratic organization, offers no help whatever to his running mates on the Democratic ticket, ducks all discussion of campaign issues. He pays his own way into the county fairs, wearing a five-year-old suit and a haircut that looks almost as old." ${ }^{\prime 16}$ In the 1941 and 1943 mayoral races, it didn't hurt that Lausche pledged and then followed through on lowering property tax rates in the city, reducing the average homeowner's rate by 30 percent (based on a 1930 benchmark). ${ }^{117}$

Lausche's appeal to the business community went beyond his sterling law and order credentials. In his campaign, Lausche pledged to build upon Ernest Bohn's federally underwritten public-private planning Association by investing in the city's moribund planning department. ${ }^{118}$ Within a year of taking office, under the moniker "Forward After Victory," Lausche appointed nine members to the Mayor's Advisory Committee on Planning Organization, which he tasked with consulting with other cities, experts, and business leaders to develop a set

\footnotetext{
116 “Ohio: Pursuing the Artful Dodger," Time, October 8, 1956.

${ }^{117}$ Financial Report by the Department of Finance of the City of Cleveland, Ohio, Year Ending December 31, 1943, PAL.

${ }^{118}$ John T. Howard, "City Planning in Cleveland, 4.
} 
Cebul

of recommendations for a new, more vigorous city planning department. Lausche named as

chairman attorney Walter Flory, and he hired John Howard, Bohn's Regional Association

director, to serve as the Committee's "technical assistant." Howard acted as the Committee's

executive director, running the day-to-day work and identifying the outside practitioners and

academics to bring in for consultation. These included planners from Pittsburgh, New York,

Cincinnati, the American Society of Planning Officials, and scholars such as Columbia

University’s Carl Feiss. ${ }^{119}$ “Their advice,” Howard recalled, “was not unanimous, but in general

agreement - and the Committee accepted it."

In July 1942, Flory and Howard's Advisory Committee issued its recommendations.

While Bohn's Association sought a regional approach, that theme dropped out of the document

that became known as the Flory Report. Instead, they called to battle blight through planning and

slum clearance. "Cleveland is in danger in more than one way," the Report began,

The peril of the War ... is urgent and obvious ... There is another peril, less violent, less dramatic, but also urgent - the decay of great areas of our community, and our failure to meet the needs of rapidly-changing conditions of urban life . . This slow insidious rot is evidenced by the decrease in value of taxable property of a billion dollars since 1930 ... It has dragged down the appearance and the livability of residential areas, and encouraged the spread of slums festering with disease and breeding crime ... This is the blight that has driven people out of Cleveland, seeking better living conditions. ${ }^{121}$

\footnotetext{
${ }^{119}$ Born in Cleveland, Feiss was a pioneer of modern urban planning. "Carl Feiss, a Pioneer of Urban Preservation, Dies at 90," New York Times, October 27, 1997.

${ }^{120}$ Ibid.

${ }^{121}$ Report of the Mayor's Advisory Committee on Planning Organization, July 10, 1942, PAL.
} 
Cebul

“There are answers to this problem," Flory's commission assured Lausche. "But the answers can be found only through city planning - the application of intelligent foresight to our problem of urban development." "122 "Much of [planning's] success depends," they concluded, “on voluntary positive action by private individuals and corporations, which cannot be constrained." The solution would be close coordination - but not coercion - between the public and private spheres on behalf of "Urban Redevelopment." Such a program of physical improvement and blight clearance will "give the average family a better place to live . . It can give the property owner and business man security for their investments. It can give industry greater efficiency of operation. It can check decentralization, and make secure the tax values upon which rest all local public services." ${ }^{\prime 23}$ Beyond a strongly worded but vague commitment to the "planning" idea, however, the Commission lacked a concrete program. And without regional commitments, there was little Cleveland could do to stem decentralization The Flory Report recommended amending the city charter to create a City Planning Commission, and, with Lausche's enthusiastic support, in November 1942 voters overwhelmingly passed the measure. The Commission drew directly in spirit from the New Deal. It embraced technocratic, expert-led, ongoing planning inspired by the NRPB and utilized the

\footnotetext{
${ }^{122}$ Ibid.

${ }^{123}$ Ibid.
} 
Cebul

expertise and initial planning supported by the WPA. Howard later put it in terms echoing the

NRPB's planners: "planning in Cleveland, as never before, was to be an active, continuous,

living process, independent of change in the City Administration." ${ }^{124}$ Bohn, the Republican

founder of the Regional Association, was named chairman; Flory, the lawyer, was named vice

chairmen. In a move reflecting the city's growing diversity, Lausche also appointed George B.

Mayer (an architect), Mrs. Malcolm L. McBride (a founder of the Cleveland League of Women

Voters), Norman L. McGhee (an African American attorney and leader of the Urban League),

Peter J. Slach (a leading banker), and Edward L. Pucel, an ethnic city councilman.

Initially, the Commission focused almost entirely on managing the city's colossal war

effort. This included handling housing, zoning, traffic, and other infrastructural logistics related

to the city's surge in production and labor population. One of the biggest developments was a

gargantuan new bomber plant at the airport that, when brought to full scale, would employ

35,000 Clevelanders and would require significant road improvements. ${ }^{125}$ Also near the airport,

the federal government made a $\$ 20$ million investment in an aircraft engine research laboratory,

the National Advisory Committee for Aeronautics, that would occupy a twelve building campus

(the campus would later become a major NASA research center). At the peak of wartime

\footnotetext{
${ }^{124}$ John T. Howard, "City Planning in Cleveland," 9.

${ }^{125}$ Ibid, 10; and Parker James, “This is Cleveland," in "This is Cleveland as others see us," September 1943, folder Cleveland 1940-1949, PAL.
} 
Cebul

production in 1943, Cuyahoga County's 2,500 industrial plants devoted three quarters of their production efforts to the war. From 1940 to 1943 , the city added 15.5 million square feet of manufacturing space through public and private investments totaling \$321.8 million. Between April 1940 and September 1944, manufacturing employment grew from 191,000 to 340,000 (employment in non-manufacturing positions remained steady at around 230,000). The labor market in Cleveland, then, had grown exponentially as a result of the war; indeed, the Bureau of Labor Statistics found that Cleveland's industrial market was among the fastest growing in the nation. ${ }^{126}$ Bertha Modrzynski, whose parents were born in Poland, was one of thousands of Cleveland women who went to work in Cleveland's manufacturing plants, first at Ohio Crankshaft, and then seven nights a week at Cleveland Pneumatic Tool Company. Despite the demands of family, she recalled, "every day I'd stagger to make a different machine . . . And I enjoyed it." ${ }^{127}$ As Cleveland's wartime production reached its full capacity, the value of the products produced by workers like Modryznski, three quarters of which were devoted to the war effort, grew from $\$ 1.1$ billion in 1940 to 2.2 billion in 1942. In 1943, the Cleveland Chamber estimated the value would surpass $\$ 2.4$ billion. From its trough in the early years of the

\footnotetext{
126 "Impact of the War on the Cleveland, Ohio Area," U.S. Department of Labor, Bureau of Labor Statistics, July 1944, PAL.

${ }^{127}$ Bertha Modryznski Interview, April 15, 1986, EWCOHP.
} 
Cebul

Depression when city bank transactions sagged to $\$ 2$ billion, by 1943 they reached new highs of

$\$ 9.4$ billion. $^{128}$

Restored Confidence / Restored Status

Business people's sense of confidence grew along with the city's economy. As the

Chamber and its electric utility ally Cleveland Electric Illuminating (CEI) gleefully declared, the nation's sixth most populous city was back. As one CEI industrial recruitment advertisement crowed, with 75,000,000 American and Canadian customers - 58\% of the nation's total population - residing within 500 miles, Cleveland was, once again, "The Best Location in the Nation." ${ }^{129}$ All of this was possible, the Chamber advertised in 1945, "because industry here was prepared" thanks to "planning and preparation early in the pre-war national emergency program.

The same type of planning and preparation in the latter part of the war period will ensure plenty of peacetime products in a hurry." ${ }^{, 130}$ The Chamber of Commerce sought to capitalize on the "respect of the whole country for [the city's] masterful contribution to war production" by rolling out a new PR campaign. As Chamber leader Walter Beam put it, it "took a couple of years for us

\footnotetext{
${ }^{128}$ Parker James, "This is Cleveland," in "This is Cleveland as others see us," September 1943, folder Cleveland 1940-1949, PAL.

129 "The Best Location in the Nation," folder Cleveland 1940-1949, PAL.

130 "Cleveland: All Geared Up to Serve Industry," Cleveland Chamber of Commerce, April 1945, folder Cleveland 1940-1949, PAL.
} 
Cebul

to correct, or live down the unfavorable and grossly exaggerated national publicity arising out of

our relief problems a few years ago." Wartime production offered a golden opportunity to

"influence the selection of facts about Cleveland which will cause the city to appear to our

country in its best light." ${ }^{" 131}$ The Chamber emphasized private outputs rather than public

stimulus.

Nevertheless, Chamber members continued to work tirelessly to win public support for the infrastructure improvements they felt were essential to sustaining the upswing. Wartime preparedness spending offered new sources of funding as well as martial metaphors to describe their competition in the market of federal aid. The Chamber favored improvements to the river, particularly the "removal of the bottleneck" at Irishtown Bend. ${ }^{132}$ But, with a fiscal conservative ethnic in City Hall and a wary city council, their initial adversary was city government. ${ }^{133}$ In order to win War Department preparedness funding to support their economic development schemes, the city's business people first had to secure matching commitments from the Mayor, who instead was focused on promised tax relief and retiring the city's bonded debt. In his 1941 campaign, Lausche stoked rumors of financial impropriety by his predecessors, charging they had misappropriated some $\$ 3$ million of bonds intended for working class Clevelanders' favorite

\footnotetext{
${ }^{131}$ Walter I. Beam to Members of the Cleveland Chamber of Commerce, in "This is Cleveland as others see us," September 1943, folder Cleveland 1940-1949, PAL.

132 “Postwar Days to See River Improvement Work Pushed," PD, September 24, 1944.

133 “Council Ready to Listen on Main Ave. Bridge Removal," PD, June 12, 1945.
} 
Cebul

agency, the public Municipal Light Company, the city's public electric utility that helped keep

rates low in the neighborhoods. ${ }^{134}$ Lausche linked protecting Muny Light's public subsidies with reducing the city's bonded debt, a political position that played particularly well with working class Clevelanders. ${ }^{135}$ Fueled in large part by wartime growth, by 1943 , the city was on pace to reduce its debt to its lowest level in 20 years. It had done so by retiring issues and greatly reducing the amount of debts that were rolled over or refunded (in 1943 the city eliminated refunding entirely). ${ }^{136}$ Faced with Lausche's thriftiness, the Chamber invited the War Department to hold hearings in Cleveland in order to pressure the Mayor. The Department obliged and issued an order that the city remove a bridge as a first step to federal funding. The Chamber reported their close work with "the Army [Corps] ... enabled us to secure their friendliest cooperation." "I don't know of any project," reported one member "that has required more attention of members of my committee than that spent on the Main Avenue Bridge situation." ${ }^{\prime 137}$ While the federal money was ostensibly for the war effort, the Chamber's aim was clear: "We must do our part . . . unless we want business to go some place else.",138

\footnotetext{
134 “Prove Diversion, Cries Blythin; Lausche Sees Defeat in Foe's 'Eyes,” PD, October 28, 1941.

${ }^{135}$ As Polish-American Clevelander Helen Karpinski recalled in the 1930s, "Democratic women" routinely mobilized "to defeat the sale of the Municipal Light." Helen Karpinski Interview, WCPOHP.

${ }^{136}$ Financial Report by the Department of Finance of the City of Cleveland, Ohio, Year Ending December 31, 1943, PAL.

${ }^{137}$ Board of Directors Meeting Minutes, December 18, 1945, GCGA Meeting Minutes, volume 1, 1945-1946, container 59, GCGA.

138 “Council Ready to Listen on Main Ave. Bridge Removal,” PD, June 12, 1945.
} 
Cebul

Soon, however, their skirmish with the city over a single bridge seemed a minor fracas when compared to war with intransigent federal agencies. The battle over financing bridge and waterway improvements was not unique to Cleveland, and, as a result of a similar contest in Alabama, congress passed the Truman-Hobbs Railroad Bridge Act which, over President Roosevelt's veto, stipulated the War Department foot the bill for bridge removals in situations such as Cleveland's. The Chief of Engineers of the Army, Cleveland's Chamber reported, was "violently opposed" to the "great . . . burden" being placed on the federal purse, but the "powerful lobby" of the American Association of Railways (and a flood tide of letters from local chambers) was sufficient to win passage in Congress. The War Department, however, refused to honor the terms of Truman-Hobbs. The Chamber's River and Harbor Committee members, "therefore, found ourselves in the position of having a Federal Law that should provide us relief, but at the same time an executive department of the government that was opposed to the legislation and would not permit it to go into operation." Their "next offensive in the battle of the bridges" included vigorous lobbying in Washington, contact with the Attorney General, and eventually success in having federal legislation passed stipulating "review reports" for projects under consideration by the War Department.

As part of the preparation for the 1945 report on the Cleveland situation under consideration by the War Department, Brigadier General John J. Kingman visited Cleveland. At 
Cebul

a Chamber luncheon in his honor, Kingman unexpectedly requested to give remarks and then

proceeded to explain why Cleveland would not be receiving War Department funding for bridge

removal. The General, a Chamber member recalled,

stated that his father had served as United States District Engineer at Cleveland some forty years ago ... [The] General [then] read from an address his father made at a Cleveland Chamber of Commerce meeting, in which he recommended that all future industrial development at Cleveland . . be located along the shores of Lake Erie, rather than on the banks of the Cuyahoga River. The General said that inasmuch as his father's advice had not been followed that the Federal government should not bear a large part of the cost for railroad bridge replacement which would not have been necessary had the industries located on the shores of Lake Erie.

"The General," reported the River and Harbor Committee chairman, "had the heaviest artillery ... so we did not discuss the matter further." Months later, the Army Corps of Engineers issued a report again recommending federal support for the bridge removal, and again Kingman's War Department rebuffed the project with a "not convinced" order. Nevertheless, despite their struggles, the Chamber felt "the committee's work on this railroad bridge problem is one of the better illustrations of the place of a Chamber of Commerce in community progress." Indeed, one member of the Board of Directors called their efforts "one of the finest things the Chamber ever did." ${ }^{139}$ Chamber members thus situated themselves as community stewards, in opposition to the public agencies, local and national, upon which their efforts hinged.

\footnotetext{
${ }^{139}$ Board of Directors Meeting Minutes, December 18, 1945, GCGA Meeting Minutes, volume 1, 1945-1946, container 59, GCGA.
} 
Cebul

By 1946, wartime contracting had so galvanized Cleveland's industry that city

employment stood at 613,693 - a figure greater than any reached before or during the war. As

John Grabowski, Cleveland's leading historian has written, with the return of prosperity,

Cleveland "once more seemed in control of its own destiny. The New Deal lived on only in the

murals the WPA artists had painted and in the roads, bridges, and civic improvements it had

helped fund." ${ }^{\prime 40}$ While it was true that fewer and fewer federal agencies were directly employing

hundreds of thousands of Clevelanders, the New Deal's legacy was far greater and was, in fact,

ongoing. With World War II's end in sight, Cleveland's Chamber members turned their attention

to transitioning to a peacetime economy. Despite the considerable New Deal-funded work done

in the city, one Chamber committee reported, “the city's bridges, streets and sewers have been

neglected . . . and other city buildings require reconditioning." ${ }^{141}$ Spurred by the Chamber, Bohn

and Flory’s City Planning Commission generated "a five year plan” for Cleveland's Post War

Public Works Program. While basic infrastructure improvements were heavily represented, the

planners noted that "it will take more than sewer and paving projects to make up a well rounded

program of the kind needed to provide post-war employment for all types of workers and to

\footnotetext{
${ }^{140}$ Grabowski, Introduction, vii.

${ }^{141}$ Report of the Committee on Taxation, April 12, 1944, GCGA Meeting Minutes, volume 1, 1944-1945, container 58, GCGA.
} 
Cebul

provide the community with the public facilities it needs." ${ }^{\prime 12}$ New hospitals, bridges, shore improvements, and significant renovations to the city's public buildings were included as part of the plan. City planners estimated the cost of their proposal for 636 discrete projects would be on a New Deal scale: \$161,856,600, utilizing 10,990 "man months.",143

Reconversion to a peacetime economy was forecast to be a fraught process, and the Labor Department warned that Cleveland, in particular, would likely face "a post-war employment problem of large proportions." ${ }^{144}$ As a result, planners "develop[ed] a backlog of public construction projects to provide employment" during the transition to a peacetime economy. By 1944, the Commission had taken on a regimented structure, with each senior staff member assigned to a major area of "urban function" (e.g., transportation). The planners generated a series of "capital improvement" programs that focused on two areas of the city: lakefront development and urban redevelopment of slum areas. Reflecting their rise in population, Lausche tapped two African Americans to serve on the Commission's professional staff of 25, L.L. Yancey, an attorney, and Roosevelt S. Dickey, a social scientist. Working together, the Chamber and City Planners also focused on industrial recruitment. Almost

\footnotetext{
${ }^{142}$ Report to Mayor Frank Lausche on the Status of Plan Preparation for the 1944-1949 Capital Improvement Budget \& Program, p. 2, April 1, 1944, PAL.

${ }^{143}$ Ibid.

144 "Impact of the War on the Cleveland, Ohio Area," U.S. Department of Labor, Bureau of Labor Statistics, July 1944, PAL.
} 
Cebul

immediately, they landed a "whopper" of a "prize catch," as a 1946 Time profile titled

“Cleveland's Planners" put it: two massive General Motors plants that would employ a minimum

of 10,500. Indeed, Time noted, “All this had not fallen into Cleveland's lap by happenstance.

Before the U.S. was in the war a year, bushy-haired Mayor Frank Lausche . . got industrialists, business leaders, bankers, Chambers of Commerce and city and county officials together for postwar planning." As the city celebrated its $150^{\text {th }}$ birthday, the civic leaders and planners enjoyed a glowing tribute: "Clevelanders dote on Cleveland plans . . . [and] Clevelanders love anything with the word Civic in front of it . . The town is the civic joiner's paradise."

To support these developments, city business leaders consistently called for new bond issues. Immediately following the war, Clevelanders joined voters across the country and embraced the optimistic moment, passing millions in municipal development bonds. ${ }^{146}$ It helped that the City Planning Commission, which had initially proposed their astronomical \$161 million post war public works agenda (just over $\$ 2$ billion in 2013 dollars), eventually cut its proposal to

\footnotetext{
145 “Cleveland's Planners,” Time, July 22, 1946, folder Cleveland 1940-1949, PAL.

${ }^{146}$ Cleveland and Cuyahoga County joined other metropolitan areas across the country in passing a variety of bond issues. In 1944, Cincinnati and its outlying county approved \$41 million of postwar improvement bonds; in a special election in Dallas, voters approved by 2 to 1 all 17 bond issues totaling $\$ 40$ million. "Greater Cleveland," September 27, 1945, p. 69, folder Finance 1940-1949, PAL. See also, John L. O’Donnell, "Public Finance in a Growing Economy: Some Postwar Trends in Municipal Bond Financing," The Journal of Finance, Vol. 17, No. 2 (May, 1962).
} 
Cebul

a more modest $\$ 68.4$ million (\$885 million in 2013 dollars). ${ }^{147}$ In 1947 , projecting for the period

1948 to 1953, the Commission hoped to issue $\$ 94$ million in revenue bonds to pursue

improvements in transit, water and sewage, and for the municipal light plant. ${ }^{148}$ This total would

add to the $\$ 70$ million of outstanding general bonds that had been issued on January 1, 1947. By

1948 , the proposed spending total for all improvements had risen to \$180 million, with $\$ 124$

million in bonds; that year alone would see $\$ 46$ million in new bonds pursued. ${ }^{149}$

But, postwar inflation following the Office of Price Administration's lifting of price

controls led Cleveland voters to reassert their fiscally conservative instincts. By 1948, the City

Planning Commission found prices in Cleveland had risen fifty percent since $1946 .{ }^{150}$ This

frugality clashed with the outsized and expensive vision for postwar planning and development

espoused by business and the city-planning department. For white ethnics, the value of balanced

budgets and low taxes were axiomatic. Lausche strongly supported the planning idea in

principle, but he was not interested in the kind of spending for which his planners called.

Lausche's successor, Thomas Burke, maintained his predecessor's commitment to limiting

municipal debt. In 1930 the city’s bonded debt totaled \$131 million, and, despite the momentary

\footnotetext{
${ }^{147}$ Conversions done with Bureau of Labor Statistics' Inflation Calculator, accessed online, http://www.bls.gov/data/inflation_calculator.htm.

${ }^{148}$ Fifth Annual 6-Year Capital Improvement Program, 1948-1953, June, 1947, City Planning Commission, PAL.

${ }^{149}$ Sixth Annual Capital Improvement Program, 1949-1954, June 1948, City Planning Commission, PAL.

${ }^{150}$ On this trend in Cleveland and its impact of municipal bonds, see Sixth Annual Capital Improvement Program, 1949-1954, June 1948, City Planning Commission, PAL.
} 
Cebul

uptick immediately following the war, between 1941 and 1949, the city’s debt shrunk from $\$ 92.2$ million to $\$ 67.7$ million - nearly halving the 1930 figure. ${ }^{151}$ As prices rose, so did voters’ resistance to new forms of public debt. Voters rejected $54.4 \%$ of the $\$ 46$ million worth of bond proposals in 1948. These trends were reflected nationally, too, when in one election cycle voters rejected $49 \%$ of the $\$ 253.6$ million worth of proposed municipal bonds. ${ }^{152}$

Similar trends played out at the national level, too. Fiscal hawks had long targeted the NRPB, especially following the agency's 1942 report that called for a new slate of "rights and opportunities . . beyond the political forms and freedoms for which our ancestors fought.” The NRPB detailed nine new "personal rights" that included the right to work; fair pay; adequate food, clothing, shelter, and medical care; security, meaning "freedom from fear of old age, want, dependency, sickness, unemployment and accident"; life in a "system of free enterprise, free from compulsory labor, irresponsible private power ... and unregulated monopolies; and equality before the law. National planners also called for rights to freedom from "spying," education, and rest. ${ }^{153}$ When Roosevelt unveiled his "economic bill of rights," he drew directly upon the NRPB's vision of a postwar politics of peace, prosperity, and quality of life. ${ }^{154}$

\footnotetext{
${ }^{151}$ Financial Report by the Department of Finance of the City of Cleveland, Ohio, Year Ending December 31, 1946, PAL, and "0 Debt, Where is Sting, Asks City," PD, July 22, 1949.

152 "Purse Strings Pulled Tighter," PD, December 21, 1948.

153 "Roosevelt Lists Post-War Rights," PD, January 15, 1942.

${ }^{154}$ Brinkley, The End of Reform, 250-3; and Sparrow, Warfare State, 197.
} 
Cebul

Reasserted business leaders and conservatives, however, emboldened by wartime

prosperity were not interested in federal usurpation of their re-secured community stewardship.

Longtime Plain Dealer writer William F. McDermott typified the conservative and localist

stance in an editorial that took on the notion of economic rights. The Report, he wrote, reflects

"excessive expectations of what life below heaven has to offer," and its aims were "basically

paganistic." "Let us pray," he sneered, "the board will manage to give us" these new rights, "For what it envisions is the millennium." The Board's vision was not one for improving quality of

life, argued McDermott. Instead, their recommendations reflect "a completely hedonistic

attitude." McDermott, who spent four decades as the Plain Dealer's theater critic, concluded that there are far "nobler ends than personal happiness ... Any nation nurtured for long on such principles would be softened up enough to be fat and easy prey for an enemy hardened by toil, self-reliance, and sacrifice." economics is of the seventh grade variety and assumes borrowing money in order to have plenty of money to spend is alpha and omega."156

Congressional budget hawks offered similar criticisms. A report issued by the Senate appropriations subcommittee in the summer of 1942 was particularly harsh. Led by Chairman Tydings (D-MD), the report alleged that "certain officials" of the NRPB "have been and are yet

\footnotetext{
155 “McDermott on the Future," PD, January 29, 1942.

156 “An Economist's Point of View,” PD, August 18, 1942.
} 
Cebul

carrying on very discreet but nonetheless pernicious propaganda to the effect that there must

continue after the war even greater mounting deficit spending on the part of the federal

government than was followed during the" 1930s. A Georgia Democrat complained that, if

implemented, the NRPB's program “looks like a $\$ 50,000,000,000$-a-year proposition. I don’t see

where we could get that kind of money." An Ohio Congressman called the NRPB's plans

"nothing less than the absorption of the state of all economic functions and the complete

demolition of free enterprise." The head of the U.S. Chamber of Commerce called the plan a

"totalitarian scheme.",157

While Tydings and his allies succeeded in killing the NRPB in 1943, he and other

Congressmen indicated their openness to planning and development spending - so long as it was

routed through and overseen by Congress. Their major objection, it turned out, was to the

continued agglomeration of power in the executive branch. ${ }^{158}$ Illinois' Republican Congressman

Everett Dirksen explained that he supported planning but he wanted “it done right. I don't want

any more super-boondoggling such as we have had in the past." Tydings warned that postwar

planning could become "a travesty and result in great human suffering." Nevertheless, Tydings,

the NRPB's chief critic, indicated that, if run through Congress rather than the executive branch,

national planning could have a future. Others, too, called for Congress to take over postwar

\footnotetext{
${ }^{157}$ Brinkley, The End of Reform, 254-5.

${ }^{158}$ For a more detailed discussion of these dynamics, see Brinkley, The End of Reform, 255-7.
} 
Cebul

planning. A California Democrat felt the NRPB had done "a worthy job" but that Congress was better suited to "the job of looking ahead." ${ }^{159}$ Meanwhile, Virginia Senator Byrd joined Dirkson in a more purely ideological critique, using the extravagance of the New Deal itself to argue for the demise of the NRPB: "For nearly nine years in our domestic peacetime economy we have indulged in the costly experiment of . . borrowing and spending public money ... We built up a bureaucracy, the like of which the world has never known, and which has centralized the control of nearly all activities and has now become so gigantic and unwieldy as to present a serious obstacle to the full utilization of the man power and resources of this country in winning the war." 160

The Plain Dealer editorial page agreed. Senator "Byrd understand[s] the implications of the planning and spending of the pre-war period for the future of the country ... it would be ruinous ... to proceed as many members of the" NRPB "would, "permanently to maintain the national income at an inflated level, by a new campaign of borrowing and spending."

"Certainly," they concluded, "little has come from the National Resources Planning Board." "161 A subsequent editorial reflected the inflated rhetoric surrounding the Board's recommendations. "If there is a single aspect of the" NRPB's recent report "that is more disturbing than the rest, it is

\footnotetext{
159 “Pennywise, Says FDR of Critics,” PD, February 17, 1943.

160 "Plans for this and that," $P D$, February 23, 1943.

161 "Plans for this and that," $P D$, February 23, 1943.
} 
Cebul

the heavy emphasis the committee places on public investment in private business." This "partnership between public and private enterprise" the Plain Dealer wrote, would result in "an economy that is half free enterprise and half state socialism" that "cannot possibly prosper."162 Beneath such overheated rhetoric, Cleveland's business leaders' support for decentralized, eliteled planning backed by federal spending was there to stay.

In 1946, two members of two of Cleveland's oldest families teamed up to plan the city's Sesquicentennial celebration. William Gwinn Mather, the late Samuel's younger brother and Elizabeth's husband, co-chaired a planning committee with Charles A. Otis, also known by his nickname, "Mr. Cleveland." The Otis family had a variety of interests, from ranching to publishing. To memorialize the major festival honoring Cleveland's history, the men felt a new and sweeping history of the city was in order. The most recently published version had been released in 1933, and its endpoint - in the depths of Depression - was hardly suitable for such a reinvigorated city. Despite its otherwise glowing tone, the 1933 history had gazed ominously toward the city's New Deal future: 'if the 'Technocrats,' with their pitiless charts and graphs, are right in their conclusions, a new generation may find curious reading in this portrayal of a virile

162 "Half Slave, Half Free,” PD, March 20, 1943. 
Cebul

American community in the heydey [sic] of private enterprise." As Otis put it, a new history was required to tell the city's "sound, substantial progress" since the dark days of the Depression. ${ }^{163}$

To write their history, Mather and Otis tapped William Ganson Rose, the founder of an advertising and public relations firm that specialized in large-scale expos and fairs. It took Rose and his team of assistants over four years to complete his volume. A whopping 1,272 pages, upon its publication in April 1950, Cleveland: The Making of a City became a local best seller despite its hefty weight and heftier price of six dollars (the first sentence of the first chapter, titled "Cleveland: Born Great," gives one a sense of its tone: "Under a sheet of ice a mile thick lay the site of the City of Cleveland more than 20,000 years ago."). Part of Rose's tome's appeal was its comprehensiveness. Other booster-induced histories had focused almost solely on the city's leading families. In contrast, the ad-man's volume reflected the city emerging from the war years: one that had elected an ethnic mayor born and raised in the city's neighborhoods; one that had a growing African American community, members of which returned from serving their country in war; and a city with a potent labor movement. Rose covered the quotidian and the popular, including ethnic neighborhood profiles, the city's amusement parks, and its beloved sports franchises. Indeed, for many Clevelanders, this became their book about their city.

\footnotetext{
${ }^{163}$ Grabowski, introduction to William Ganson Rose, Cleveland: The Making of a City, ix.
} 
Cebul

But Rose's volume was also significant for the way it helped curate and refashion

Cleveland's memory of itself. The 1930s received detailed attention over 94 pages, but Rose

expended fewer than five pages on the New Deal. ${ }^{164}$ Reading a bit of what he had to say about

such "socialistic trends in government" suggests why this was the case:

In the middle thirties, government controls and restrictions were shaking the confidence of business and delaying the recovery throughout the nation . . . Emergency alphabetical agencies were identified by a myriad of letter combinations - PWA, WPA, NRA, and hosts of others - of such vast proportions that they threatened to become permanent. Private enterprise felt that the Government had taken from it the opportunity to make reasonable profits, and the public was gradually learning that without profits employment was endangered. Taxes were preventing business institutions from accumulating earnings and planning for the future. ${ }^{165}$

Of Union Trust, the bank whose reckless lending to the Van Sweringens led to its liquidation, Rose wrote: "Drastic treatment of the Union Trust . . . was probably not justified, according to students of finance." Without mentioning the extreme federal lending that underwrote them, the city's other banks, Rose cheerily wrote, "proved their ability to meet the new conditions, carrying on the vast responsibilities demanded by the district's growing business." ${ }^{166}$ Of the decade's vast physical and recreational improvements, he simply noted, despite "complaints . . . registered against pump priming to relieve unemployment, many

\footnotetext{
${ }^{164}$ Grabowski, Introduction, xiii.

${ }^{165}$ William Ganson Rose, Cleveland: The Making of a City, 872.

${ }^{166}$ Ibid., 873.
} 
Cebul

gigantic projects in Cuyahoga County that had long been delayed because of lack of funds were advanced through the emergency-relief program, inefficient as it was." ${ }^{\text {"167 }}$ Despite the WPA's central role, Rose gave it no mention when he described the Great Lakes Exposition as one "of the most constructive enterprises ever undertaken by the people of Cleveland." ${ }^{\prime 68}$ Such an omission is particularly striking given that one of his sponsor's wives, Elizabeth Mather, directly solicited and oversaw a great deal of WPA-related work at the Exposition and in the city's parks. Instead, Rose declared, the "Planned economy and social reconstruction were proving to be gravely expensive":

There was criticism that federal relief pampered the shiftless and weakened the nation's moral structure, and disheartened taxpayers saw little sign of a change in administration policy. Promises of a balanced budget and reduction in the cost of government had long since been forgotten, and the spending program lengthened at an alarming rate. ${ }^{169}$

Perhaps the ultimate irony embedded in Rose's booster history was that, without the WPA's Federal Writers Project, he would never have produced such detailed, data driven work. The Annals of Cleveland series produced by the Federal Writers as well as WPA-supported histories of the city's ethnic communities were almost certainly the principle sources for Rose and his research team, and the ethnic and neighborhood profiles he offered were a major source

\footnotetext{
${ }^{167}$ Ibid., 875.

${ }^{168}$ Ibid., 876.

${ }^{169}$ Ibid., 953.
} 
Cebul

of the book's success. In contrast to his harsh treatment of the WPA and other relief projects in Cleveland, the Federal Writers Project got off easy - he never mentioned it once. ${ }^{170}$

While the two decades following the New Deal and war in the urban North have been characterized as an era of burgeoning "pro-growth coalitions," these partnerships on behalf of publicly induced private development had their start in New Deal works programs. Yet, as postwar prosperity returned Cleveland's elites to a place of relative security, their self-induced amnesia regarding the primary causes of their resurgence - works projects that quieted working class unrest while supporting developmental projects that were extended through wartime contracting - also blinded them to new challenges: decentralization continued apace, working class ethnics sought a surer place in city politics, and African Americans were soon to follow. Managing these interests while pursuing continued growth could necessitate a further involvement in the federal developmental state.

\footnotetext{
${ }^{170}$ John Grabowski makes this point in his Introduction, Ibid., xiv.
} 
Cebul

\title{
Chapter Three
}

\author{
"It Didn't Just Happen" \\ Planning for Growth in Northwest Georgia
}

Not so long ago as time is reckoned a great President of the United States described the South as the nation's 'economic problem number one.' Today, a Quarter century later, this dynamic region might well be called the nation's number one economic opportunity. ${ }^{1}$

- Sen. Richard B. Russell speaking before the 1964 Annual Meeting of the Coosa Valley Area Planning and Development Commission in Rome, Georgia

"Rome is GROWING," exclaimed a 1952 advertisement for the Rome-Floyd County Chamber of Commerce in the News Tribune, Rome's daily newspaper; "GROWING in population - GROWING culturally - GROWING industrially."2 There was more work to be done, though, and the ad announced the Chamber's goal of expanding membership to 1,000 by the end of the year, raising funds for the business association without raising dues. In a corresponding editorial, the papers' editors, Chamber men themselves, reminded readers that, “Rome's present development is not just haphazard; it didn’t 'just happen.' It has been planned, and it is still being planned. The plans are projected far into the future." The paper's editors explained that "with industrial expansion come problems ... There must be new houses, new

\footnotetext{
${ }^{1}$ Richard B. Russell, Remarks Before the Coosa Valley Area Planning and Development Commission, July 15, 1964, box 9, Subseries C, Series III, Richard B. Russell Papers, Richard B. Russell Library for Political Research and Studies. University of Georgia Libraries, Athens, Georgia [hereafter RBRL].

2 Advertisement, “Goal for 1952 - 1000 Members,” Rome News Tribune [hereafter RNT], February $24,1952$.
} 
Cebul

schools. There must be a traffic improvement program. There must be new streets, new bridges.

There must be development of recreation facilities, tourist facilities." "The Chamber," the editors

continued, "is composed of businessmen, industrialists, professional men, retailers, public

officials - its membership is representative of Rome." Therefore, they explained, the

businessmen's association "is the logical leader, the necessary coordinating body, in the

development of the community." "Give your support to the Chamber of Commerce," they

concluded. "It is working for Rome. It is working for you.",

As Americans emerged from World War II, a broad consensus was forming among

business leaders, returning veterans, and middle class Americans concerning the crucial linkages

between a relatively conservative vision of economic citizenship, the value of public service, and

the desirability a positive business climate. ${ }^{4}$ Part and parcel of this postwar ethos, over the 1950 s

and early 1960s, Rome's business leaders joined a broad movement on behalf of regional

\footnotetext{
3 "Rome is Growing," RNT, February 24, 1952.

${ }^{4}$ In addition to exploring the social, cultural, and political effects of foreign and domestic wartime service, James Sparrow suggests the importance of wartime bond purchasing in inculcating a more conservative, middle class version of economic citizenship. Sparrow, Warfare State, 243-7. On the linkages between private interests and public obligation during World War II, see Robert Westbrook, "Fighting for the American Family: Private Interests and Political Obligation in World War II" in Richard Wightman Fox and T.J. Jackson Lears, eds., The Power of Culture. On the effect of wartime service on postwar civic engagement, see Suzanne Mettler, Soldiers to Citizens: The G.I. Bill and the Making of the Greatest Generation (New York, Oxford University Press, 2005). On the postwar politics of consensus and the pressures to forge a positive business climate, see Wendy Wall, Inventing the "American Way."
} 
Cebul

economic planning and development. ${ }^{5}$ In Northwest Georgia, businesspeople developed new

institutional forms - multi-county, regional public-private partnerships - that offered hope for

growth and progress in a region where government and business had long been mired in poverty,

provincialism, and institutional mediocrity. Ironically, however, the institutional mediocrity and

undemocratic practices forged thanks in part to reality and spirit behind Jim Crow Laws subtly

smoothed business leaders' developmental path by enhancing their ability to influence public as

well as private developmental agendas. ${ }^{6}$ Though economic and political historians have joined a

great debate about the role of wartime and postwar spending in jumpstarting the Southern

economy, this chapter focuses on a crucial byproduct of that spending that undeniably shaped

Southern economic capacity: the modernization of Southern political institutions. ${ }^{7}$

By pointing out that regional growth and job creation did not "just happen," Rome's

business leaders aimed to forge a consensus on behalf of their developmental leadership,

\footnotetext{
${ }^{5}$ David E. Wilson, The National Planning Idea in U.S. Public Policy (Boulder, CO: Westview Press, 1980). See also, Gregory S. Wilson, Communities Left Behind: The Area Redevelopment Administration, 1945-1965 (Knoxville: University of Tennessee Press, 2009).

${ }^{6}$ On how relatively few competing interest groups positively affected the economic development of the South, see Mancur Olson, "The Causes and Quality of Southern Growth," in E. Blaine Liner and Lawrence K. Lynch, eds., The Economics of Southern Growth (Durham, NC: Southern Growth Policies Board, 1977). On the ways in which the legacies of interest group formation during the progressive era stymied New Deal development in the urban North, see Margaret Weir, "States, Race, and the Decline of New Deal Liberalism," Studies in American Political Development, September 2005, 19(02): 157-172.

${ }^{7}$ For an overview of the debates about federal spending and industrialization, see Robert Lewis, "World War II Manufacturing and the Postwar Southern Economy," The Journal of Southern History (Vol. 73, No. 4, Nov. 2007).
} 
Cebul

positioning themselves as representative of and thus logical leaders for the broader community.

Their vision of the community, however, which included thriving African American

neighborhoods, was decidedly narrow. Indeed, as political theorist Iris Marin Young has argued,

by invoking "community," business leaders and politicians instead flattened its definition on behalf of conjuring an aura of consensus. ${ }^{8}$ Faced with a politically backsliding state government, business leaders' public partnership was not just with local or state government. During the years of greatest acrimony over federal meddling in local affairs - from the Brown decision through Johnson's Civil Rights and Voting Rights Acts and beyond - Georgia businesspeople sought an outsized role for federal development spending and subsidized technical expertise.

When it comes to perceptions of the federal government, federalism matters greatly. While state and national headlines during these years focused on the white South's strident states' rights ranting's, subtle but significant changes were afoot. As paeans to states' rights flourished, as the Cold War heated up, and as national business and industry campaigned on behalf of an "American Way" against centralization and economic planning, in Georgia, fears of centralized administration were mitigated by localism, unobtrusive federal regulations on development spending, public private partnerships, and the ardent pursuit of economic growth

\footnotetext{
${ }^{8}$ See Iris Marion Young, "The Ideal of Community and the Politics of Difference," in Penny A. Weiss and Marilyn F. Friedman, eds., Feminism and Community (Philadelphia: Temple University Press, 1995).
} 
Cebul

and elite-led economic progress. ${ }^{9}$ In the name of growth, Georgia business leaders thus quietly

embraced key aspects of the cultural milieu of mid-century growth liberalism: a planned

economy, stimulative federal spending, emphasis on job creation and purchasing power,

regionalism, and publicly funded technological expertise. Local business leaders labored on

behalf of federal support they felt was earned, justified, and essential. And, as business leaders

shaped new forms of state capacity, their model of federally backed public-private development

trickled across the state of Georgia, and, by the early 1960s, up to the national level as well.

These local leaders' developmental priorities converged in surprising ways with national

liberals in the Kennedy and Johnson Administrations. At the moment that local business interests

sought federal support for economic development, a range of progressive, antipoverty liberals

were turning their attention to persistent areas of poverty amidst postwar affluence. ${ }^{10}$ One of the

regions that garnered much attention was Appalachia, which stretched into Northwest Georgia.

Reflecting faith in modern managed capitalism, poverty planners did not seek significant

structural reform. ${ }^{11}$ Rather, in a move that jived nicely with Democratic Party electoral strategies,

\footnotetext{
${ }^{9}$ On mid-century suspicion of bureaucratization and planning, see especially, Wilson, The National Planning Idea. For a discussion of localism in twentieth century, see Thomas J. Sugrue, "All Politics is Local."

${ }^{10}$ On the evolution of social scientists' and policymakers' conceptions of solutions to poverty, see Alice O'Connor, Poverty Knowledge.

${ }^{11}$ Wilson, Communities Left Behind. See also Michael Bradshaw, The Appalachian Regional Commission. For a searing critique of liberals' 1960s poverty planning, see Judith Russell, Economics, Bureaucracy, and Race: How Keynesians Misguided the War on Poverty (New York: Columbia University Press, 2004). For a more balanced account of the War of Poverty in the context of the broader Great Society and political context, see Gareth Davies,
} 
Cebul

"growth liberals" explicitly drew upon the regional planning model pioneered in Northwest

Georgia and sought to partner with Southern elites and Governors to grow the regions out of

their social and poverty problems, first through the Area Redevelopment Administration and

then in its successor, the Appalachian Regional Commission. Indeed, while most of the headlines

and historical accounts have focused on national elites' macroeconomic theories and Keynesian

policies, local business leaders were often the micro level engines meant to actually deliver the

growth liberals promised.

But, by emphasizing "free" market means, localist self-help and antipoverty ends, federal bureaucrats reinforced local business and political elites' pious faith that their economic development programs naturally benefitted the broader community. As this chapter suggests, this momentary consensus between Southern businessmen and liberal policymakers depended upon shared and narrow conceptions about who and what comprised the community and upon highly contingent fiscal federal arrangements and regulations - each of which profoundly shaped who had a stake in and thus benefitted from federal aid. In the end, Southern business leaders leveraged the federal purse to revitalize and refashion their region's political economy. The results for poverty alleviation were far more ambiguous.

$* * *$

From Opportunity to Entitlement; and Sidney Milkis and Jerome Mileur, eds., The Great Society an the High Tide of Liberalism. 
Cebul

Over the late 1930s and early 1940s, E.D. Rivers' and Ellis Arnall's 'little New Deal'

administrations offered Georgia businessmen a glimmer of hope for a more proactive and developmentally minded state government. In 1946, Governor Arnall was term-limited out of office, and between 1946 and 1954 Georgia's political system suffered a relapse of provincial and reactionary race-driven Southern politics. Arnall was still quite popular despite his difficulties pursuing a second little New Deal, and in the 1946 gubernatorial primary he supported businessman James V. Carmichael. Carmichael garnered widespread acclaim thanks to his competent leadership of the behemoth Bell bomber plant in Atlanta's suburbanizing hinterland, Cobb County. ${ }^{12}$ Carmichael's candidacy revealed the rising political salience of growth-oriented politics that was gaining traction thanks to the local fruits of New Deal and wartime spending. While Carmichael was confident of a great proportion of the popular vote potentially even a majority - the state's electoral system rendered moot the popular tally. Since Reconstruction, Georgia's state elections had been conducted through evolving versions of the “county unit system," a creative bastardization of the Electoral College meant to keep political power in less populous, rural regions of the state. Each of Georgia's 159 counties were guaranteed one elector, with the most populous counties receiving one or two additional votes.

\footnotetext{
${ }^{12}$ On Carmichael's tenure at Bell and his decision to run for governor, see Thomas A. Scott, "Winning World War II in an Atlanta Suburb: Local Boosters and the Recruitment of Bell Bomber," and Richard S. Combes, "Aircraft Manufacturing in Georgia: A Case Study of Federal Industrial Investment," in Philip Scranton, The Second Wave: Southern Industrialization from the 1940s to the 1970s (Athens, GA: University of Georgia Press, 2001).
} 
Cebul

This resulted in disproportionate representation for sparsely populated, predominantly white, rural counties. Indeed, three tiny counties could counterbalance Atlanta's Fulton County. As one official put it, "Give me five good men in 100 rural counties and I could run the state." Political mainstay and retrograde Eugene Talmadge, 'ole Gene,' a master of the emotional, race-baiting stump speech, openly boasted that he never needed to win a county with a streetcar line. ${ }^{13}$

In 1946, an ailing Talmadge entered his final gubernatorial campaign and forced Carmichael to reorient his appeal to courting the rural, white, county unit vote. Further complicating Carmichael's campaign, former Governor E.D. Rivers, the architect of the first failed little New Deal, entered the race. In a Democratic primary notable for a relatively high turnout, Carmichael won a comfortable plurality of the vote while Talmadge won the county unit tally, taking the election. Talmadge went onto to win the general election, but, his health rapidly failing, 'ole Gene died before what would have been his third inauguration. Pro-Talmadge forces in the legislature preposterously argued that Eugene's son Herman should inherit his father's seat since, they felt sure, Herman had received the lion's share of write in votes (when Gene's health had begun to fail, the Talmadge forces organized a write in campaign to prepare for just such a fight). To their surprise, however, the businessman Carmichael had more general election write in votes, another clear indication of the growing support for a new politics centered on economic

\footnotetext{
${ }^{13}$ Charles S. Bullock III and Mark J. Rozell, The New Politics of the Old South, 50.
} 
Cebul

progress. The Talmadge faction conveniently declared that they had found sufficient misplaced

ballots in Talmadge's home county to deliver Herman the victory. "Do you know," one journalist quipped, "they rose from the dead in Telfair County, marched in alphabetical order to the polls, cast their votes for Herman Talmadge, and went back to their last repose?"14 The legislature quickly voted Herman governor. Soon after, however, the State Supreme Court named as acting Governor M.E. Thompson, Ellis Arnall's lieutenant, until a special election could be arranged. In that 1948 special election, Thompson, not Carmichael, ran against Herman Talmadge - and lost. Talmadge won again in 1950, this time eking out a victory in the popular vote as well.

The forces of economic progress and state-led development had once again been stymied by the anti-democratic county unit system and the racial fear mongering of the Talmadge coalition. As the title of a 1948 feature in Harper's asked, “A Long Dark Night for Georgia?”,15 James Carmichael specifically identified the county unit system as the straitjacket constraining Georgia's progress. "That's the crux of our problem," he said. "Of course, I defended it" during the campaign. "I had to. But it's bad, bad, bad - the worst barrier to good government . . . No legislature is going to vote to abolish it. Hell, few men are going to vote for something that'll abolish their jobs." Until Georgia was rid of the unit system and developed two meaningful

\footnotetext{
${ }^{14}$ Quoted in Numan V. Bartley, The Creation of Modern Georgia, 204.

${ }^{15}$ Calvin Kytle, “A Long Dark Night for Georgia?” Harper's, September 1948.
} 
Cebul

parties, Carmichael argued, the state would continue to languish. ${ }^{16}$ Indeed, a Northwest Georgia ally of Herman Talmadge later wrote to the politician, reminding him that in those years "it was not popular to be a Talmadge-ite on Broad Street, in Rome, Georgia." "Most . . . business leaders were against us," he wrote. "Our white country friends were our salvation at the polls.",17

A handful of Georgia progressives worried that the county unit system, meant to keep power among rural whites, paradoxically enabled a handful of corporations in Atlanta to run the state, most notably Georgia Power. ${ }^{18}$ The system almost certainly endowed a few corporations with disproportionate and corrupting influence on state politics, but their emphasis on Georgia Power's commitment to resisting forms of progress was off the mark. While a nationally salient progressive movement - embracing civil rights, labor rights, or new forms of social provision was hardly in the offing, a developmentally minded vision of proactive state and local government drove Georgia Power's regional and Atlanta-based development experts. Indeed, it was from this branch of the business that the Power Company's new generation of leaders was being plucked: Rome's New Deal era development organizer and federal lobbyist J.J. "Jack" McDonough, for instance, soon became the Company's president. As a result of its emphasis on

\footnotetext{
${ }^{16}$ Calvin Kytle and James A. Mackay, Who Runs Georgia? (Athens, GA: University of Georgia Press, 1948 and 1998), 256.

${ }^{17}$ Robert L. Scoggin to Herman Talmadge, September 12, 1971, folder 20, box 211, series II, Herman Talmadge Papers, RBRL.

${ }^{18}$ Kytle and Mackay, Who Runs Georgia?
} 
Cebul

growth, Georgia Power's developmental influence could have crosscutting effects. By

stimulating regional planning, the utility both broadened and decentralized its influence, increasing its reach while tempering its ability to control the variety of regional agendas. And, while the Company certainly maintained a harsh rhetorical tone concerning certain forms of federal intervention, given the regressive character of state politics, Georgia Power's regional development officers were often at the vanguard of pursuing federal largesse to stimulate economic growth.

\section{Regionalism}

In January 1945, with the end of the Second World War in sight, spurred by fears that federal spending would slow to a trickle, over 60 businessmen from across Northwest Georgia came together to discuss new strategies for regional growth. Across the country, industry and trade development commissions were sprouting up at the state and local levels, but these rural Georgians' emphases on multi-county, regional planning and municipal cooperation was novel. ${ }^{19}$ At the behest of Charles Collier, the Atlanta-based Vice President of Georgia Power, the group gathered in Cartersville's Braban Hotel to explore forming an organization to attract tourism and

\footnotetext{
${ }^{19}$ For an overview of the proliferation of postwar Industrial and Trade development commissions and the degree to which they remained essentially competitive rather than regional or cooperative, see Wilson, Communities Left Behind, 34-47.
} 
Cebul

trade. ${ }^{20}$ Collier commissioned a Georgia Power-funded report on regional tourism opportunities, and three weeks later at a meeting in Rome, the business leaders voted unanimously to create an organization to pursue a "program of development of Northwest Georgia” with Collier's tourism memo as its founding document. ${ }^{21}$ Its first recommendation was that the leaders capitalize on the "golden stream of travel dollars whizzing by Northwest Georgia towns." 22 Second, the report recommended educating voters to support public spending in key areas: "What these people must be taught is that the development of historic and scenic assets . . . is not an object in itself, but a means to an end. History and scenery," the author recommended, "is a background for one of the cleanest, nicest businesses in the world.",23

The tourism and trade group was formed to be a "permanent organization . . . composed of a representative from each county," and Collier was not the only Georgia Power employee involved in the initiative. Among the local business representatives was another Georgia Power employee, Fred F. Starr, a young community development official who also served as Dalton's

\footnotetext{
${ }^{20}$ Handwritten notes, January 19, 1945, Box 2, Rome Chamber of Commerce Papers, Sarah Hightower Special Collections, Rome-Floyd County Library, Rome, Georgia [hereafter RCCP].

${ }^{21}$ A PR and tourism expert at the Virginia Chamber of Commerce wrote the report. Minutes of Meeting with Representatives from Rome, Dalton and Cartersville, January 19, 1945, and Minutes of Meeting of Representatives of Northwest Georgia Counties, February 16, 1945, Box 2, RCCP.

${ }^{22}$ Robert F. Nelson, "Report Dealing with the Potentialities of Northwest Georgia From the Standpoint of the Tourist Trade," undated, Box 2, RCCP.

${ }^{23}$ Robert F. Nelson, "Report Dealing with the Potentialities of Northwest Georgia From the Standpoint of the Tourist Trade," undated, Box 2, RCCP.
} 
Cebul

Chamber of Commerce President. At the conclusion of the Rome meeting, Starr was elected vice-chairman of the newly formed Northwest Georgia Trade Potentialities Committee, the first of what for Starr would be a string of increasingly influential regional planning positions. ${ }^{24}$ Both major papers in Atlanta, the Journal and the Constitution, ran stories about the new organization. Without mentioning his pivotal role, Collier praised the Committee, claiming, "this tourist business in Georgia should develop into a $\$ 100,000,000$ a year industry, and that annual flow of cash into the state would contribute towards the financial betterment of everyone here." As the war wound down, he asserted, "industry alone is not the answer to the problem of furnishing jobs." Indeed, Collier and his local allies embraced the notion that jobs - and the consumer demand they would drive - were the key to broader regional growth. ${ }^{25}$

While Collier presciently warned that service sector jobs would be increasingly important in the postwar economy, Georgia Power was mainly focused on industrial recruitment of manufacturing jobs that would generate increased electrical load. As a result, Company employees became integral players in the quest for publicly funded vocational education, a key weapon in the war for employment, increased purchasing power, and regional development. During World War II, Rome's leaders established the Vocational Education for National Defense program, which provided men and women with crash courses for the region's war production

\footnotetext{
${ }^{24}$ Minutes of Meeting of Representatives of Northwest Georgia Counties, February 16, 1945, Box 2, RCCP.

25 'Entice Tourists' Program Begins for 11 Counties, Atlanta Journal, February 4, 1945, Box 2, RCCP.
} 
Cebul

efforts, predominantly in textile work. After the war, much of the program's equipment was

transferred to Rome High School where, in the evenings, veterans took rudimentary machinist

courses. Following the passage of the GI Bill, by 1947, the rechristened Rome Vocational School

was officially up and running. Over its first few years in operation, some 800 veterans completed

their secondary school coursework or pursued vocational training. ${ }^{26}$ By 1950 , Rome's leaders

partnered with regional interests to reorient RVS's curriculum to attract new industry. As in

Collier and Starr's trade potentialities committee, delegates from five northwest Georgia counties

together lobbied the State Board of Education to fund an expanded area-wide vocational training

school in Rome. ${ }^{27}$ The state delivered modest support for targeted training in 1951.

Private employer's hiring needs shaped the RVS's course offerings. Chamber members

solicited input from existing business and industry and kept an ear out for the kinds of skills

sought by potential industrial recruits. At the top of the list was training in electricity and

electronics, and Georgia Power encouraged its employees to become part time teachers. Rome

native Ken Cormany, a WWII veteran and Georgia Tech trained engineer, was a newly minted

Georgia Power engineer, and he recalled teaching two nights a week to packed classrooms in the

26 “Coosa Valley Tech serves area business, industry,” RNT, February 25, 1969.

27 “Committee to Urge Area Trade School,” RNT, May 15, 1951. 
Cebul

early- and mid-1950s. The vast majority of his students were former servicemen, but his classes

also included a sprinkling of women who had worked in factories during the war. ${ }^{28}$

Romans greatly appreciated these educational opportunities. ${ }^{29}$ One Rome woman testified

before a U.S. Senate committee in hopes of expanding federal aid to include retail and service sector training, areas that had been covered locally by the RVS. "Gentlemen," she testified, "I assure you that not only my progress in the retailing field but my very opportunity to make such progress is due to the distributive [retail] education program within my school." Young people, she said, "especially in our small towns" need federal support for job training. Framing her use of federal support in terms of self-help and citizenship, she concluded, "We want the privilege of becoming self supporting citizens and Americans. ${ }^{, 30}$ Another Roman advocate for federal vocational spending invoked the Cold War, arguing that the Russians were aggressively expanding their own programs "at a tremendous rate with the idea of increasing production through full use of the skills of their people. ${ }^{״ 1}$ For these previously under-skilled white Romans as well as for Georgia Power and local business leaders, federal vocational spending promised to

\footnotetext{
${ }^{28}$ Author interview with Ken Cormany, August 2, 2012, Rome, Georgia.

${ }^{29}$ A veteran named Maurice Culberson was instrumental in persuading the city and county schools to partner with the Chamber. Culberson was a beneficiary of the GI Bill and became a teacher in the Rome School District. He hoped to extend publicly subsidized vocational and higher education to all Northwest Georgians. "Coosa Valley Tech serves area business, industry," RNT, February 25, 1969.

30 "Romans Tell Senators Value of DE Program: Assured Education, Defrayed Expense Rome Graduate Says at Hearing,” RNT, May 15, 1951.

${ }^{31}$ Ibid.
} 
Cebul

support motivated and self-reliant citizens, develop the local and regional economy, and, in so doing, aid the nation's efforts in the Cold War.

Such civic engagement was central to Georgia Power's industrial recruitment efforts, but it was also part of its broader public relations strategy. Scholars have incisively traced "the greatest generation's" civic mindedness to wartime service and the GI Bill, and Georgia Power's PR strategy suggests another source of this generation's public-spiritedness: the links Americans felt between economic citizenship, public service, and the creation of a positive business climate. ${ }^{32}$ Beginning in the 1940 s, the Company paid its employees' dues in associations such as the Jaycees, Kiwanis, and Rotary; for higher ups, it footed the bill for membership in local Chambers of Commerce. Sometimes it matched employees' donations to churches and other community assets. For a utility company, indeed for many larger Atlanta-based businesses hoping to break into rural communities, having a meaningful local presence was crucial to overcoming provincial fears of Atlanta power. Suspicion of Atlanta and big city politics was not merely a county phenomenon. Many Romans, too, looked warily to the growing capital, concerned that state government or big companies overly favored the service and infrastructure

\footnotetext{
${ }^{32}$ See, for instance, Sparrow, Warfare State; Westbrook, "Fighting for the American Family: Private Interests and Political Obligation in World War II;" and Mettler, Soldiers to Citizens.
} 
Cebul

needs of Atlanta. ${ }^{33}$ Over time, by enmeshing its employees in local voluntary associations,

Georgia Power hoped to burnish its reputation as a corporate citizen. ${ }^{34}$

Fred Starr was one of the Company's most engaged citizens. Prior to the war, Starr lived

in Dalton, served on the Dalton Chamber of Commerce, and was the Company's development

specialist, running programs such as the region's Better Home Towns Contests. Starr was an

active participant in the Coosa-Alabama River Improvement Association (CARIA) and had

traveled to Washington on one of their 1941 lobbying junkets. ${ }^{35}$ After the War, Starr was

promoted to the Rome Area Development office. From there, he turned the Northwest Georgia

Trade Potentialities Committee, the postwar group of regional business leaders convened by

Charles Collier, into a multi-state initiative to attract tourism and trade to the broader Coosa and

Tennessee River Valleys. Towns in lower Tennessee, northwest Georgia, and western North

Carolina created shared promotional campaign materials emphasizing their natural recreational

opportunities, Native American heritage sites, and the region's positive business climate. Starr

won state support for the initiative as well, pioneering a set of public-private partnerships

between Georgia’s Highway Department, Parks Commission and the State Chamber of

\footnotetext{
${ }^{33}$ Roger Aycock, All Roads to Rome.

${ }^{34}$ Author interview with Ken Cormany, August 2, 2012, Rome, Georgia.

${ }^{35}$ For these New Deal inspired initiatives, see Chapter 1, "Building the Developmental State in Northwest Georgia."
} 
Cebul

Commerce along with a bevy of local Chambers. ${ }^{36}$ These ventures into public-private

regionalism would neither be his last nor his most significant.

A parallel set of developments in Atlanta's public sector would soon converge with and

empower Northwest Georgia businessmen's still predominantly associational efforts to organize

for regional economic development. Dr. Kenneth Wagner was the entrepreneurial director of

Georgia Tech's Atlanta-based Engineering Experiment Station (EES). As historian Margaret

O'Mara has written, prior to World War II, Atlanta's relatively small population (it had not

reached 500,000 in 1940) and a dearth of state funding hampered Georgia Tech's industrial

development work, the principle goal of Wagner's Engineering Station. After the war, however,

with new federal programs for R\&D, suburban growth, and active lobbying from Atlanta's

"Industrial Development" men, Atlanta gained clout in Washington - so, too, did Georgia Tech.

Over 1943-44, 58 percent of the EES's budget came from federal and industrial contracts (it was

still quite modest: less than \$240,000). By 1951, with the Cold War and the Korean War in full

swing, the EES's budget ballooned to more than $\$ 1.3$ million. Eighty percent of the total came

from federal grants for military-industrial applications. ${ }^{37}$

Military-industrial spending rapidly enhanced the EES's broader capacity and prestige,

and Wagner hoped to harness these assets to focus R\&D efforts on the state's civilian

\footnotetext{
36 "Rome Leaders Awaiting Area Tourist Meet," RNT, August 24, 1955.

${ }^{37}$ O'Mara, Cities of Knowledge, 202.
} 
Cebul

economy. ${ }^{38}$ Diverging from the emphasis of other "cities of knowledge" and reflecting Tech's

responsibility to the state as a whole, Wagner became increasingly concerned with distributing

Tech's influence and expertise across the entire state rather than concentrating it in Atlanta. ${ }^{39}$ In

1955, Wagner secured a \$50,000 grant from Governor Marvin Griffin to develop Georgia Tech's

Industrial Development Branch within the EES in Atlanta. The IDB's mandate was to respond to

the growing demands of Chambers of Commerce from across the state, which were increasingly

turning to Tech to conduct regional economic base analyses to make more sophisticated and

targeted recruitment efforts. As Wagner and his staff conducted these regional analyses, he

recognized the IDB could also help guide the EES's broader research agenda by knitting it more

closely to the needs of the state's diverse and growing industries. Between 1956, the year Griffin

delivered the initial \$50,000 funding, and 1960, Wagner's R\&D team grew from a member

\footnotetext{
${ }^{38}$ There is a rich literature on defense contracting in the South. The case of Georgia Tech offers a very specific instance of defense contracts greatly enhancing an institution's broader capacity to carry out a range of non-defense programs. For the historiographically dominant view of the role of defense spending in the South, see Schulman, From Cotton Belt to Sunbelt. For a skeptical view of defense contracting's role in the so-called "second wave" of southern industrialization, see David L. Carlton, "The American South and the U.S. Defense Economy," in Carlton and Coclanis, eds., The South, the Nation, and the World. For a fine-grained assessment of defense projects in a discrete political-economic region, see James T. Sparrow, “A Nation in Motion: Norfolk, the Pentagon, and the Nationalization of the Metropolitan South, 1941-1953," in Lassiter and Crespino, eds., The Myth of Southern Exceptionalism.

${ }^{39}$ In her incisive study, O’Mara notes that, despite lavish defense spending and other federal contracts, Tech lagged behind Stanford and Penn in transforming their urban environments into a city of knowledge. While her emphasis on Atlanta's unique metropolitan setting is an important factor, another development she overlooks is Tech's statemandated obligation to the entire state of Georgia. Indeed, as the following chapters suggest, if anything, Tech sought to refashion the state of Georgia into an entrepreneurial state of knowledge. O'Mara, 221-2.
} 
Cebul

research faculty to a full-time staff of $33 .{ }^{40}$ Enthused by this growth, Wagner dreamt of

establishing regional branches of his IDB across the state. When, in 1959, Governor Vandiver

commissioned Wagner to write a comprehensive plan for the state's long-term industrial

development, he seized his opportunity. In A Preliminary Blueprint for Industrial Development

in Georgia, Wagner proposed creating "industrial extension” satellite offices through a new

branch at Tech. As he saw it, the service would "supply needed technical assistance to local

development groups, to expedite the collection of resource data, and to provide technical

assistance to established business and industry." ${ }^{41}$ Vandiver used Wagner's Blueprint as the basis

for legislation appropriating funds for Engineering Station field offices.

The proposal's timing and emphasis on "local development groups" was no mere

coincidence. The Rome Chamber of Commerce and Rome-Floyd Planning Commission had

been among Wagner's most frequent correspondents, seeking Tech's support for a variety of

regional analyses. Since at least 1957, Fred Starr and two new allies in Rome had consulted with

Wagner about a new kind of public-private regional development organization. T. Harley Harper

was a Rome furniture storeowner, a leader on the Chamber of Commerce, and had become

chairman of the public Planning Commission. In 1957, one of Harper's first moves as chairman

\footnotetext{
${ }^{40}$ Richard Snyder Combes, “Origins of Industrial Extension: A Historical Case Study in Georgia," Unpublished MA Thesis, June 1992, Georgia Institute of Technology, 44, folder EES-Industrial Extension Division, GTA Subject File, Georgia Institute of Technology Archives, Atlanta, Georgia [hereafter, GTA].

${ }^{41}$ Ibid.
} 
Cebul

was to hire a professional planner, Sidney F. Thomas, a 1956 graduate of Georgia Tech's city planning masters program. ${ }^{42}$ Thomas brought a vigorous, indeed almost "high modernist," vision for the efficacy of planning the region's spatial political economy as suggested by his thesis' title: "The control and elimination of nonconforming uses." 43 Together, the three men would become the animating spirits behind Northwest Georgia's new regional development association. Though Starr and Harper agreed on the promise of regional planning, their partisan leanings and personal backgrounds were quite distinct. Starr was a "yellow dog Democrat" he'd vote for a yellow dog Democrat before a Republican - while Harper quietly, but actively sought to build a Republican Party in Northwest Georgia. ${ }^{44}$ Starr had decades of experience developing data-driven regional development initiatives, and Thomas was trained in the technocratic rationality of the day, but Harley Harper came from a very different background. He grew up one of nine children in tiny Boardtown in the north Georgia Appalachian hills. He may never have ended up in Rome were it not for his mother's "hard shell” Baptism. Strictly opposed to the consumption of alcohol, his mother became persona non grata among the town's bootleg

\footnotetext{
42 “25 Years of Progress: Coosa Valley Area Planning and Development Commission, 1958-1983,”July 21, 1983, 2; in author's possession.

${ }^{43}$ Indeed, Thomas' thesis and emphasis on rational planning calls to mind the era of "high modernist" urbanism. See James C. Scott, Seeing Like a State: How Certain Schemes to Improve the Human Condition Have Failed. New Haven: Yale University Press, 1999. Sidney F. Thomas, “The control and elimination of nonconforming uses," August 1956, Georgia Tech, accessed online at https://smartech.gatech.edu/handle/1853/20933.

${ }^{44}$ Author Interview with Gardner Wright, June 27, 2013, Rome, Georgia.
} 
Cebul

liquor distillers, whose stills she frequently reported to state revenue agents. Social relations

there became sufficiently intolerable that, depending on who tells the story, the family was either run out of town or opted to leave. Thirteen-year-old Harley was sent ahead with supplies, taking the two day, 50 mile trip down from the mountains on dirt roads to Calhoun, spending a memorable night alone in the back of his wagon with the family dog. ${ }^{45}$

Harper aspired to become a professional church singer and enrolled in the New Orleans Seminary, and during the early Depression years he traveled with a preacher, performing in rural revivals across the South. He soon grew frustrated, however because after the preacher took his share of the earnings, there was often little money left over for the singers. Harper turned to the world of business, taking a job with the Baldwin Piano Company in Cincinnati, Ohio where he was trained as a salesman. He soon returned to Georgia and took a position as a salesman for the Rome branch of a regional furniture chain, quickly making a name for himself as an expert salesman. As the depression yielded to increasing wartime prosperity, he and a colleague, Roy Nichols, opened the Harper-Nichols furniture store in 1944 in the middle of Rome's Cotton Block at the bad end of Broad Street, the town's main drag. ${ }^{46}$ Harper shrewdly differentiated his business by offering liberal lines of credit just as the economy was getting rolling again, and, by

\footnotetext{
${ }^{45}$ Author interview with George Harper, August 15, 2012, Rome, Georgia.

46 “New Harper-Nichols Furniture Store Graces Rome Cotton Block,” Rome News Tribune, April 27, 1954, and author interview with George Harper, August 15, 2012, Rome, Georgia.
} 
Cebul

the late 1940s, Harper-Nichols had taken off. Harper became a civic leader in Rome, serving as a head recruiter for the 1952 Chamber membership drive, becoming a Deacon in the First Baptist Church, serving on the city Building Commission, and sitting on the Board of Directors of Rome's Home Federal Savings and Loan. In 1954, Harper celebrated the remodeling and grand reopening of his furniture store with a black tie dinner and beauty contest featuring high school seniors from around the region. After the contest, the girls served as hostesses, and Harry Oldham, chairman of the Rome Chamber of Commerce and an employee of Georgia Power, presented the winner with a 21-inch television and sent her on to Pensacola, Florida to compete in a five state beauty contest. Even in the grand reopening of his furniture store, Harper was thinking in regional terms. ${ }^{47}$

Beginning in 1958, Starr and Harper began meeting with Rome businessmen to conceptualize a new kind of public-private regional development body, what they were calling the Coosa Valley Area Planning and Development Association. Frank Hood, Georgia Power's head of Community Development in Atlanta, Elmer George, executive secretary of the Georgia Municipal Association, and Howard K. Menhinick, the head of Georgia Tech's City Planning department encouraged Starr and assured him of their support. ${ }^{48}$ Sidney Thomas performed

\footnotetext{
47 “25 Years of Progress: Coosa Valley Area Planning and Development Commission, 1958-1983,”July 21, 1983, in author's possession; and "New Harper-Nichols Furniture Store Graces Rome Cotton Block," Rome News Tribune, April 27, 1954.

${ }^{48}$ Ibid.
} 
Cebul

much of the day-to-day groundwork - research, financial planning, and regional base analyses that formed a sturdy empirical foundation for Harper and Starr's nascent Association. The men organized a multi-county regional planning summit in Rome on May 7, 1959, held in Berry College's Ford Auditorium. The summit set the stage for a series of meetings in thirteen Northwest Georgia counties. Over the course of 1959, Harper invited mayors, local planning commissioners, Chambers of Commerce, councilmen, and interested members of the business community to join a multi-county, publicly funded development body comprised of representatives from business and government aimed at strategic planning, land use studies, research and development for business, and modernizing regional infrastructure. Harper spent a great deal of time on the road, and he "spoke, cajoled and convinced" meeting attendees of the value of regional planning. Harper's wife Mary Ruth recalled that, "He talked about it all the time." Even "when we'd go to the market ... he'd see someone and talk planning, planning, planning., ${ }^{49}$ Tech's Kenneth Wagner was an enthusiastic presence at nearly all of the meetings, and he encouraged the men, as he put it at the Calhoun Elks Country Club, to "make a complete audit of resources and assets, locally and on a region-wide basis, and to draft a program for development of these potentials." Deploying his planning argot, Wagner advised the men to "Pin down your local specific problems and assets, analyze and interpret your resources and develop a

\footnotetext{
${ }^{49}$ Ibid.
} 
Cebul

long-range comprehensive program. ${ }^{, 50}$ Wagner, Harper, Thomas, and Starr were creating a

modern, expert, and data-driven public-private organization for regional economic growth.

As a rule, the development leaders' ideas about regionalism, economic growth and

rational, data-driven planning were greeted with enthusiasm, but the men were cognizant of the difficulties they would face if they sought to fund their Association solely through local taxes or state subsidies. ${ }^{51}$ They had a particular federal program in mind to get things moving.

Suburbanization in the immediate postwar years triggered something of a crisis across many

local governments that had once been considered rural but were being pulled into expanding metropolitan areas. Never before faced with such demands for services, infrastructure, or land use planning, these governments struggled with new pressures and complexity. Congress acted to support these units of municipal government through the Housing Act of 1954, which created two-thirds matching grants to fund strategic planning commissions in communities with populations of up to 25,000 residents. In 1957 , the act was amended to include communities of up to 50,000. By 1964, the section 701 Planning Grant Program, as it came to be known, had distributed $\$ 79$ million to 4,462 local governments. ${ }^{52}$ By 1968 , the 701 program had catalyzed

\footnotetext{
50 "Study Committees to Be Named: Area Planning Group Maps Broad Program,” RNT, June 24, 1959.

51 “25 Years of Progress: Coosa Valley Area Planning and Development Commission, 1958-1983,”July 21, 1983, p. 2 ; in author's possession.

${ }^{52}$ Carl Feiss “The Foundations of Federal Planning Assistance: A Personal Account of the 701 Program,” Journal of the American Planning Association, Volume 51, No. 12, 1985.
} 
Cebul

planning agencies of varying effectiveness in 65 percent of the nation's 7,609 units of local

government. ${ }^{53}$ Armed with federal matching funds that covered up to two thirds the cost of local

planning, these commissions and planning agencies, the vast majority of which became branches

of local governments, sought to channel economic growth to encourage efficiency in and rational

development of businesses, industry, and housing and to develop suitable services and

infrastructure. Other federal programs, too, contributed to the widespread use of 701 grants.

Winning Urban Renewal dollars or, later, funds from the Appalachian Regional Commission,

required evidence of a "comprehensive plan" for local development. As two historians of

regional planning have put it, the 701 “program's double barreled combination of requirements

and financial support" led to a golden age of federally funded land use planning across the

country in the late $1950 \mathrm{~s}$ and $1960 \mathrm{~s} .{ }^{54}$ While the 701 program was inspired by the strains of

suburbanization, the inclusion of all communities of up to 50,000 residents meant that rural

regions, too, could benefit from federal planning support.

In order to win 701 funding, however, Harper and Starr had to win changes to state law.

Thanks to the county unit system's effective muzzling of the state's range of progressive interests, home rule, the power to levy local taxes or create local zoning laws, key tools in

\footnotetext{
${ }^{53}$ Cited in Peter Dreier, John Mollenkopf and Todd Swanstrom, Place Matters: Metropolitics for the Twenty-first Century (Lawrence, KS: University Press of Kansas, 2000 \& 2004), 113.

${ }^{54}$ Edward J. Kaiser and David R. Godschalk, “Twentieth Century Land Use Planning," Journal of the American Planning Association, 61, 3, 1995, 127.
} 
Cebul

industrial recruitment, had long been sought by boosters in Georgia's rural towns and cities. Well in to the 1950s, however, the state legislature resisted empowering units of local government. ${ }^{55}$

Under pressure from Northwest Georgia’s boosters, Georgia Power and Georgia Tech’s

Industrial Development chief Kenneth Wagner, Gov. Ernest Vandiver supported an amendment to the 1957 Planning Enabling Act (the Act had prescribed a uniform system of municipal zoning) to enable any adjacent group of counties or cities to create regional Planning and Development Commissions as envisioned in the federal 701 program. ${ }^{56}$ Like 701 grants, the Act mandated a self-help provision before any state aid would be delivered: local seed funds had to be raised in order to win state matching funds. The amendment also stipulated that these Commissions bore no responsibility to State officials, only to their member communities. With the amendment, the state government ceded to local governments and private interests the power to invite a stronger federal presence.

All that remained was raising local seed money. In order to finance the new Association, Harper developed a "grassroots" approach. As implemented across northwest Georgia, Harper's “Quarters for Prosperity” plan led to the passage of a $\$ 0.25$ county assessment for the 249,193

\footnotetext{
${ }^{55}$ Howard, "Home Rule in Georgia: An Analysis of State and Local Power," Georgia Law Review, no. 757, 1975.

${ }^{56}$ Karen Shelley, et al., Spring 2007, “How to Fix Georgia's Planning and Zoning Enabling History," accessed online at: http://georgiaplanning.org/student_reports/2007/14--

New\%20Zoning\%20Enabling\%20Act\%20for\%20GA/New_Zoning_Enabling_Act_report.pdf
} 
Cebul

men, women and children in each of the counties of the Coosa River watershed. ${ }^{57}$ While mobilizing to secure the initial $\$ 61,000$ in local tax effort, Harper and Starr worked closely with the Vandiver Administration, which had promised to deliver $\$ 30,000$ in state funds for the second year budget once the regional Association got off the ground. ${ }^{58}$ The Governor "thought he was safe," Sidney Thomas later recalled. "No one could imagine that many counties working successfully together for the good of everyone." ${ }^{, 59}$ When they defied his expectations, Vandiver delivered the promised sum. Reflecting the terminology of the 1957 state panning law, the nascent Coosa Valley Area and Planning Development Association was rechristened the Coosa Valley Area Planning and Development Commission (CVAPDC). Sidney Thomas moved from the Rome Floyd Planning Commission to become the executive director of the new publicly funded and privately inspired Commission, and the federal government soon awarded the group $\$ 109,000$ in 701 matching funds. As one Georgia official put it enthusiastically, the Commission's model could "lead to the investment of public funds for needed physical developments . . . attract needed private investments, and maintain or achieve viability for each substate district - to the ultimate benefit of the State as a whole." ${ }^{60}$ By 1963, the Coosa

\footnotetext{
57 “25 Years of Progress: Coosa Valley Area Planning and Development Commission, 1958-1983,”July 21, 1983, in author's possession.

${ }^{58}$ Ibid.

${ }^{59}$ Ibid.

${ }^{60}$ Quoted in Bradshaw, The Appalachian Regional Commission: Twenty-Five Years of Government Policy (Lexington, KY, 1992), 27.
} 
Cebul

Commission enjoyed a $\$ 248,998$ annual budget comprised of $\$ 62,005$ of the "quarters for prosperity' tax revenue; another $\$ 102,000$ in federal 701 planning funds; and $\$ 40,000$ in state funding. ${ }^{61}$ The Coosa Commission would soon become a model for the entire state of Georgia.

In an era notable for redbaiting, emphasis on the "American Way," and suspicion of centralized planning, Northwest Georgia's businesses' enthusiastic embrace of federally backed planning and cooperative regionalism is striking. "What affects Cartersville affects the rest of the region," concluded Charles Cowan, the mayor of rural Cartersville, Georgia. The Mayor of Calhoun, (in Gordon County, one County north of Cartersville's Bartow County), echoed Cowan's sentiments: "What is good for Rome is good for Calhoun, and vice versa." As the Atlanta Constitution put it, "This recognition that no man is an island unto himself and no county a peninsula without neighbors made it possible to for the Coosa Valley Planning and Development Commission." On the front page of the News Tribune, editor in chief Bernard Street sang the praises of the Commission's collective vision. "Charter members," he wrote, "made no secret of the fact they aimed for the fullest development of Northwest Georgia business-wise, economically, industrially, culturally and educationally ... What is good for Rome, or Dalton, or Cartersville, Rockmart, Cedartown, Calhoun, Dallas, Summerville,

\footnotetext{
61 “Area Planners Set Budget, Sign New Tech Contract,” RNT, July 19, 1963.

${ }^{62}$ For national business association's campaign against government planning and on behalf of laissez faire values and "Americanism," see Wendy Wall, Inventing the "American Way," 189-93.
} 
Cebul

LaFayette, Ringgold, Chatsworth, Trenton, Buchanan, Bremen, Tallapoosa and other towns is good for the entire area." In short, he wrote, "Selfish motives in seeking industry, in which one town or one county vied with the others, have disappeared.",63

In the 1960s, planners and their plans were nearly ubiquitous features of Northwest Georgia's boosterism. As a later glowing front page Rome News Tribune article noted, “There have been 142 maps, reports, and plans completed; 46 are currently being prepared; and eight are programmed. All this work is scheduled for completion by March, 1967. ${ }^{, 64}$ In these articles, the men on the commission were referred to simply as "The Planners": "the planners will meet regularly with the local Planning Commissions ... The planners will also be working with local officials and agencies on related programs that influence the development of the community. This will involve coordinating the various Federal programs in order to most effectively serve the needs of the Community." "FUTURE PLANNING IS BEING STRESSED," boomed another headline. "A request for Federal funds to assist in the planning projects . . . will be submitted in early September." "The planning staff will be working closely with the State Planning Section . . . and the Local Planning Assistance Section of the Georgia Department of Industry and Trade

\footnotetext{
${ }^{63}$ Bernard Street, "Coosa Planners to Hold Annual Session Thursday,” RNT, July 17, 1960, RFCL / HRA.

64 “Economic Growth, Progress Mark Year in Coosa Valley,” RNT, July 15, 1966.
} 
Cebul

will be gathering information and coordinating our plans and programs with their State planning programs. $" 65$

The planners enjoyed breathless adulation in the pages of the regions' newspapers.

"Progress flags are flying," began one 1961 article. ${ }^{66}$ Another piece highlighted the noble struggle ahead: “There's an old military axiom that no plan is stronger than the men who execute it," and, more than three years before Lyndon Johnson would declare his own war on poverty, Rome's daily paper wrote that the Commission “is carrying on a 'war' - a war against economic blight and economic inertia. Like all wars, it won't be fought in a few weeks - it may take years. The war [is] for [the] improvement of economic, educational, industrial and business improvement in the Coosa Valley ..."67 Despite the long odds, Romans and Northwest Georgians, another piece promised, should take heart, thanks to the Commission members and planners, "headed by T. Harley Harper, with Fred F. Starr as one of its guiding lights.” Their goal, realizable with enough community support, was nothing less than the overall development to make Northwest Georgia, not only the prime center for industrial development in the south, but, at the same time, to achieve a balance of education, vocational training, community planning and research, the proper social and home atmosphere, to make the economic climate of the vast Northwest Georgia area what

\footnotetext{
65 Ibid.

66 “Coosa Valley Program Speeded in 11 Counties,” RNT, September 21, 1961, RFCL / HRA.

67 “Coosa Valley Planning Program Taking Shape,” RNT, September 19, 1961, RFCL / HRA.
} 
Cebul

its actual climate is - a combination of relatively comfortable summer, mild winters, suitable to any type of industrial and agricultural operations. ${ }^{68}$

Planning, regionalism, and cooperative effort were the watchwords, and, as in the 1952

Chamber drive, the businessmen and planners construed themselves as the men best positioned to lead the entire community.

To be sure, while the region's businessmen united in their war for development, they still viewed their mission as inherently competitive and as an effort to win justified public largesse. The northwest region of Georgia had long felt alienated in state politics, outmuscled for resources by Atlanta and rural "rustics" across the state's Southern "black belt." In 1961, as the Commission was swinging into action, the Associated Industries of Georgia released a report on the tax effort and tax returns in the form of services for the Coosa counties. They found that the counties collectively paid more than $\$ 1$ million in taxes than they received back in the form of services (the eleven counties paid $\$ 17,422,062$ in taxes while they received $\$ 16,321,386$ in services). Rome's Floyd County, the report found, had the greatest disparity, contributing $\$ 5.7$ million and receiving only $\$ 3.5$ back in services. In "simple terms," the News Tribune reported, "Floyd County is footing the financial bill for 'debtor' counties" both within the Coosa region and without. ${ }^{69}$ In a state with 159 counties (second only to the much larger Texas), pooling

\footnotetext{
${ }^{68}$ Ibid.

69 “Coosa Valley Group Pays State More Tax Monies Than it Receives,” RNT, July 27, 1961, RFCL / HRA.
} 
Cebul

resources meant pooling clout. The initiative paid almost immediate dividends when the State

Highway department unprecedentedly agreed to conduct a long-term highway needs study for the region rather than on a county-by-county basis, which historically ended up with each county trying to build a road to Atlanta. ${ }^{70}$

The men who comprised the Coosa Commission were dedicated joiners, civic leaders, and embodiments of the mid-century participatory spirit, but their sense that they somehow represented the broad community of interests of Northwest Georgia - working class whites, unionized textile laborers, rural or urban African Americans laborers, and the lower and middle class women who were expected to depend upon male bread winners - relied upon a narrow reading of "the community." vigorous but rather thin engagement these men had with their communities. Col. Douglas E. "Froggy" Morrison, for instance, represented Dade County and was a founding Commission member. Before becoming involved in regional planning, Froggy served thirty years in the US Army, retiring in 1945. A Mason, a Lion, and Past-Commander of Dade County’s Foreign Legion Post, Morrison was also on the Board of Directors of the Bank of Dade and had served as President of both the Dade County Farm Bureau and the Soil and Water Conservation Districts

\footnotetext{
70 “Coosa Valley Plans, Acts As Unit, Finds it Pays Off,” $A C$, September 18, 1961, RFCL / HRA.

${ }^{71}$ Young, "The Ideal of Community and the Politics of Difference."
} 
Cebul

of Georgia. ${ }^{72}$ R.D. Barton, Jr. was, for a time, the Commission's Vice Chairman. Barton owned two businesses, one of which was a furniture store in Bartow County. He was better known for his other business, however, the Barton Funeral Home, which inspired his nickname: "The Friendly Undertaker.” Barton was a Deacon in his Baptist Church, the Vice Moderator of the Middle Cherokee Baptist Associations, a charter member of the Adairsville Lion's Club, and an active Mason and Shriner. ${ }^{73}$ John D. Bankson was the Vice-President and General Manager of the Summerville-Trion Ice and Coal Company and was the main distributor for the Pure Oil Company in Chattooga County. He was a past President of the Southeastern Retail Coal Association, a Director of the National Coal Dealers Association, and past president of the Georgia Ice Manufacturers and Summerville Retail Merchants Associations. Bankson was a charter member of the Commission, serving as chairman from July 1964 to June 1965. Bankson served as the Vice Chairman of the Summerville Housing Authority, overseeing federally funded affordable housing projects, and was the Vice President of the Summerville Industrial Development Corporation. He was a Deacon in his Presbyterian Church and a Lion. ${ }^{74}$ He was unexceptional among his peers at the Commission.

\footnotetext{
${ }^{72}$ CVAPDC Newsletter, May, 1969, RFCL / HRA.

${ }^{73}$ CVAPDC Newsletter, February, 1969, RFCL / HRA.

${ }^{74}$ CVAPDC Newsletter, November, 1969, RFCL / HRA.
} 
Cebul

Like Morrison, Bankson, and Barton, most Commission members moved seamlessly between the public and private sectors, amplifying the developmental capacities of each, albeit along lines approved of by Commission members. J.M. Tutton was a founding member of the Commission, and, at the time of his commissionership in 1969, was also the Mayor of Cartersville and the president of the Cartersville Lions Club. Tutton also served as a Director of the Georgia Municipal Association and was the Finance Chairman for the regional office of Community Action, overseeing the books of the local Office of Economic Opportunity. In addition to these civic commitments, Tutton oversaw a number of private business endeavors, including commercial and residential construction, real estate rentals, and a clothing store. ${ }^{75}$ Indeed, while the Commission was meant to serve a diagnostic and advisory role, the blurring of boundaries between the public, private and voluntary spheres meant the Commission would have a profound influence across a wide range of developments affecting many constituencies. ${ }^{76}$

As a result of their genuine if narrow civic engagement, Commission members felt they represented the best interests of the community as a whole, interests that late 1950s and early 1960s "extremists" threatened to undermine. In an era characterized by challenges to dominant racial, social, and political norms, Rome's business leaders, like many others across the South,

\footnotetext{
${ }^{75}$ CVAPDC Newsletter, January, 1969, RFCL / HRA.

${ }^{76}$ Chapter seven, "Deregulating the War on Poverty in Georgia," focuses closely on the tensions between business leaders' notions of community development and those of the marginalized constituencies targeted by new War on Poverty programs, which arrived with tighter federal regulation and oversight.
} 
Cebul

aimed to chart a middle way. Indeed, a growing literature suggests the ways in which Brown

encouraged segregationist and incrementalist businessmen to tone down racial rhetoric for fear of

losing Northern industrial recruits or federal funding. ${ }^{77}$ A 1957 editorial in the News Tribune

reflected business' self-described 'moderate' position on civil rights. Titled 'A Time for

Moderation," the op-ed described a speech by NAACP director Roy Wilkins in Atlanta as being

“as extreme as anything any of the White Citizens Councils in other states have produced."

Wilkins' words, the paper argued, were as unhelpful as "the mouthings of the most rabid Ku

Klux Klan member." "What the pressure groups - and included are those of both extremes - fail

to realize, or to admit, is that the great majority of Southern people have good will in their hearts, and are anxious to maintain peace and harmony." "The pressure groups and extremists, in seeking to overthrow the will of the majority, are only causing more trouble," the editors concluded. ${ }^{78}$ Likewise, when President Kennedy acceded to Civil Rights plans for a March on Washington, the News Tribune pilloried the President's "shocking display of irresponsibility." "In effect," the editors argued, Kennedy "invites the intimidation of the national assembly" by "an emotion-charged mob" that threatens to "menace . . the very heart of the nation." In considering the Civil Rights legislation, Congress, they concluded, must not be pressured by "an

\footnotetext{
${ }^{77}$ See, especially, Crespino, In Search of Another Country, Kruse, White Flight, and Stone, Regime Politics. See also, Schulman, From Cotton Belt to Sunbelt, 131.

78 “A Time for Moderation,” RNT, January 24, 1957.
} 
Cebul

atmosphere of threatened violence" and instead must deliberate through "logical, temperate

evaluation of the rights of all Americans," the assumption being that certain rights were less

alienable than others. ${ }^{79}$ These men sought maintenance of the status quo and steady progress

guided by their sure hands. And, while Brown threatened to unleash social forces beyond their

control, as of the early 1960s, there was little indication that the federal government was

interested in pursuing major structural change to the institution business leaders cared most about

- the political economy.

Indeed, a brief examination of Civil Rights activism in Rome suggests that so long as

local business leaders were involved and felt in control, moderate integration and reform could

be tolerated, but no more. To a large degree, the reason for Rome's relative calm was a set of

unique relationships between African American ministers and student groups, a leading Jewish

businessman and his wife, and a local branch of a progressive, interracial rights organization.

Rome businessman Jule Levin was a remarkable figure for a number of reasons. Born in

Cincinnati, Ohio, Levin entered the family dress retailing business. On a sales trip through the

South, Levin met Rose Esserman of Rome. They married in November 1940, and in 1942 Levin

purchased a stake in Esserman and Company, a venerable Rome retail store. True racial

progressives, Levin and his wife worked over the 1950s to achieve integration, and Esserman \&

79 “President Shows Irresponsibility,” RNT, July 19, 1963. 
Cebul

Co. became the first retail store in Rome to completely desegregate. This included not just the retail floor, but the fitting rooms, water fountains, and restrooms. Esserman was also the first Rome retailer to employ black sales clerks to wait on whites and blacks alike.

While the Rome Chamber did not allow African American membership, they accepted Jewish members, and Levin became one of the businessmen's association's most active associates. He founded the Rome Jaycees (the junior Chamber of Commerce), served as President of the Merchandise Association, and, in 1962, he was elected President of the Chamber itself. $^{80}$ The timing was auspicious. In the 1950s, Levin's wife Rose had become a close friend of Rome's Shorter College dance instructor, Fransiska Boas (daughter of famed anthropologist Franz Boas). Together they established a Rome branch of the Georgia Council on Human Relations (CHR), an offshoot and affiliate of the Southern Regional Council. The Georgia Council was the fruit of decades of labor by the racial progressive and integration advocate Frances Freeborn Pauley. ${ }^{81}$ Through the Rome branch of the CHR, Rose Levin and Boas organized an interracial discussion group that by 1963 counted 180 Romans, including a number of professionals, business owners, and religious leaders. As B.R. Brazeal, President of

\footnotetext{
${ }^{80}$ Biographical overview of Jule and Rose Esserman Levin, The Ida Pearle and Joseph Cuba Archives of Genealogy Center of the William Bremen Jewish Heritage and Holocaust Museuam, Atlanta, GA. Accessed online at: http://www.thebreman.org/research-n-collections/finding-aids/Jule-and-Rose-Esserman-Levin.pdf

${ }^{81}$ On Pauley's remarkable career as an integrationist, see Kathryn L. Nasstrom, Everybody's Grandmother and Nobody's Fool: Frances Freeborn Pauley and the Struggle for Social Justice (Ithaca: Cornell University Press, 2000).
} 
Cebul

Morehouse College, put it after attending one early meeting, "this meeting together by Negro and

white ministers in Rome, Georgia has created friendships and a reasonable degree of

communication between these groups." ${ }^{" 82}$

In early 1963, African American students from Rome's black high school moved to join the widespread sit-in movement sweeping the South. In February and March, over one hundred students sat in at a number of downtown lunch counters. ${ }^{83}$ While sixty-eight students were arrested and 57 were convicted of disorderly conduct and made to pay a fine or spend a night or two in jail, coordination between student group leaders, the Levins, and Boas helped forestall violence. Indeed, Levin relayed to his wife the daily plans of the Rome police department and the perspectives of local business owners at the Chamber of Commerce, which he led. Rose, in turn, passed the intelligence along to Boas who hosted student activists at her dance studio. In this way, students were able to effectively desegregate Rome's public amenities and many private businesses by the end of the year in a strategic, piecemeal, but peaceful way. ${ }^{84}$ In the wake of

\footnotetext{
${ }^{82}$ Brazeal quoted in Stephen N.G. Tuck, Beyond Atlanta: The Struggle for Racial Equality in Georgia, 1940-1980 (Athens, GA: University of Georgia Press, 2001), 139.

${ }^{83}$ For an oral history account from the perspective of the students including a video dialogue, see "History Remembered, a 1963 Sit-In in Rome for Civil Rights, Highlander, April 19, 2013, accessed online at: http://highlander.highlands.edu/?p=2020

${ }^{84}$ This account is based largely on Tuck, pp. 139-140 and Biographical overview of Jule and Rose Esserman Levin, The Ida Pearle and Joseph Cuba Archives of Genealogy Center of the William Bremen Jewish Heritage and Holocaust Museuam, Atlanta, GA. Accessed online at: http://www.thebreman.org/research-n-collections/findingaids/Jule-and-Rose-Esserman-Levin.pdf
} 
Cebul

these demonstrations, the ministers successfully negotiated the integration of Carnegie Library,

Rome's public library. ${ }^{85}$

The schools, the Chamber, and positions of public authority remained strictly segregated,

but the fragile and deeply contingent partnership between African American students and a

progressive Jewish business leader and his wife had produced moderate change. While the

Levins left Rome for Cincinnati later that year, there does not appear to be any evidence that they

left under duress or pressure from the local Citizens Council or other pro-segregation groups.

Instead, Jules went to partner with his brother in the family business, a lifelong dream. ${ }^{86}$ Indeed,

their warm feelings for their time in Rome remained strong: when their daughter wed in

Cincinnati in 1969, the Levins posted an announcement in the News Tribune. ${ }^{87}$ Yet, while a

moderate degree of closely overseen desegregation was tolerated by the majority of Rome's

white residents and business owners, the arrival of Lyndon Johnson in the White House and the

announcement of his ambitious Civil Rights agenda and goals for minority economic

enfranchisement would rapidly change the tone of local racial politics. For the time being,

\footnotetext{
${ }^{85}$ WSB-TV newsfilm clip of police chief Nelson Camp and downtown Rome, Georgia, 1963 March 28, Walter J. Brown Media Archives \& Peabody Awards Collection, UGA Library, accessed online at: http://crdl.usg.edu/cgi/crdl?action=retrieve;rset=002;recno=3;format=_video

${ }^{86}$ Biographical overview of Jule and Rose Esserman Levin, The Ida Pearle and Joseph Cuba Archives of Genealogy Center of the William Bremen Jewish Heritage and Holocaust Museuam, Atlanta, GA. Accessed online at: http://www.thebreman.org/research-n-collections/finding-aids/Jule-and-Rose-Esserman-Levin.pdf 87 “Miss Ellen Levin married to Mr. Adler in Cincinnati," RNT, August 14, 1969.
} 
Cebul

however, Rome's business leaders still felt they controlled the city's political and economic structures.

Exporting the Coosa Commission Model

In July 1960, the Coosa planners hosted their second annual meeting at Berry College under a massive tent, which the attendees lightheartedly called Starr Hall, a toast to Fred Starr. The event culminated over a decade of hard work. Reflecting the region's enthusiasm for their planners' efforts, the meeting was attended by nearly 1,000 Georgia businessmen and politicians. ${ }^{88}$ The gathering was a boisterous affair and included a variety of industrial and agricultural reports and presentations, including one from Harley Harper. According to the News Tribune, when Kenneth Wagner announced Tech's plans to establish the first state-funded Georgia Tech Industrial Development Branch in Rome the news was "lustily cheered." J.J. “Jack” McDonough, Georgia Power’s President since 1957 and, over two decades earlier, Rome's New Deal-era booster par excellence, hosted a Georgia Power-sponsored barbecue lunch. In his remarks, McDonough hailed the Coosa planners: "Let me assure you that ... the start you have already made ... will in a short time serve other regions as a highly successful example of what area planning can do." McDonough endorsed the local leaders' emphasis on

\footnotetext{
88 "25 Years of Progress: Coosa Valley Area Planning and Development Commission, 1958-1983," July 21, 1983, in author's possession.
} 
Cebul

sound economic planning as the key to economic growth. "High sounding phrases and long lists

of objectives won't do the job. What will do it is down-to-earth, everyday planning and working in the individual cities, towns and communities where our customers live." Georgia Power, he said, believed it would "profit far more in the long run" by "increas[ing] the total number of spendable dollars," indeed, by increasing purchasing power and expanding employment. ${ }^{89}$

On June 15, 1961, Tech's Rome office, the Northwest Georgia Branch (NGB), officially opened, the first in the state. ${ }^{90}$ Reflecting the intertwined interests of the public and private sectors in growth, the Coosa Commission, the Rome-Floyd Planning Commission, and Tech's Branch all shared the second floor of the Chamber of Commerce building rent-free. ${ }^{91}$ The Chamber renovated the space to include three offices, a drafting room, and an open workspace for the three groups and their Chamber allies. ${ }^{92}$ Like the Coosa Commission's members, Tech's engineering staff moved in and out of the public and private sectors. Raymond L. McCrillis, for instance, joined the Branch as a research engineer after five years at General Electric. At GE, McCrillis completed a three-year manufacturing training program and worked in a variety of divisions, including Wire and Cable, Heavy Military and Electronics, and GE's Defense Systems

\footnotetext{
89 "Rome Chosen as Site for Area Engineering Branch,” RNT, July 21, 1960.

90 “Area Planners Set Election,” newspaper clipping, June 8, 1961, R/FCL, HRA.

${ }^{91}$ Rome-Floyd County Chamber of Commerce News-Letter, September 1963, Hargrett Special Collections Library, University of Georgia, Athens, GA [hereafter HSCL].

92 “Renovation of Planning Offices Underway Here,” RNT, Thursday, April 6, 1961, R/FCL, HRA.
} 
Cebul

Department plants. At Tech's Rome outpost, McCrillis used his knowledge of private sector

needs to shape public sector planning.

As Wagner described it in 1962, the Engineering Experiment Station's decentralized

network of development experts and business consultants helped less sophisticated rural

industries and businesses identify weaknesses and capitalize on new opportunities:

The preventative aspects of this program are one of its most important contributions. Assistance with the preparation of adequate cost systems can help keep solvent firms, which would otherwise go bankrupt because they are not aware of critical financial leaks. Others may succumb for lack of guidance with distribution and sales problems. Still others urgently need information on new market opportunities, on machine design problems, and other production difficulties. ${ }^{93}$

Indeed, the Tech-Coosa Commission partnership went far beyond regional economic analyses. During 1962 alone, the development planners undertook 103 separate "technical assistance" programs. Thirty-eight of these were contracted with existing industries in areas such as "product design, product packaging, product line design, office lighting, production contracts, public relations, materials procurement, patent application, export opportunities and many others." Another 51 projects were developed on behalf of local development organizations and Chambers of Commerce and included the publication of prospectuses and glossy materials to

\footnotetext{
${ }^{93}$ Wagner quoted in Richard Snyder Combes, "Origins of Industrial Extension: A Historical Case Study in Georgia," Unpublished MA Thesis, June 1992, Georgia Institute of Technology, p. 47, folder EES-Industrial Extension Division, GTA.
} 
Cebul

send to prospective industries and businesses on issues such as the local labor market, industrial zoning arrangements, opportunities for financing, and data on transportation and infrastructure..$^{94}$

In its first year, Rome's Tech office even conducted targeted mineral resource research. In one case, their discovery of shale deposits led to a new product line for a tile manufacturer. In another instance of "technical assistance," the NGB developed a method for separating feldspar from crushed granite, and, by early 1963, the more efficient process was in use at a Coosa Valley granite quarry. ${ }^{95}$ Across the board, Tech helped business and industry become more productive.

The Commission partnered with Tech's engineers, too, to design "a system of prospect development ... [that included] an industrial 'suspect' file" consisting of over 150 companies. “This file," Tech's staffers reported, "is calculated to receive constant change and experience continued growth." "At the close of 1962," Tech reported, the "staff was maintaining active files for some forty prospects.” In total, in 1962 alone, 25 new manufacturing operations opened in the Coosa Valley area, and 30 existing plants underwent Tech-supported expansions.

Commission member John Bankson recalled a successful recruitment effort. A New Jersey industrialist visited Summerville "seeking a site for a . . plant to manufacture gloves. Ten days was all the time the commission had to provide the necessary and convincing data ... [and] Sid

\footnotetext{
${ }^{94}$ Northwest Georgia Branch, IDD, Georgia Tech to CVAPDC re: Summary of Activities for 1962, January 14, 1963, RFCL / HRA.

${ }^{95}$ Ibid.
} 
Cebul

Thomas ... pulled it all together." The business opened a plant in Summerville, eventually employing 235 Georgians. ${ }^{96}$ As the Rome / Floyd Chamber of Commerce put it in their July 1962 newsletter, the work done by the Commission and Tech scientists was "of much value" in underwriting their own efforts to "locate prospective industries to the Rome-Floyd County area. ${ }^{, 97}$ Federal spending for defense, development, and University led R\&D had moved far beyond Atlanta, the New South Capitol, and was shaping Northwest Georgia's rural political economy as well. And, far from a top down story of Washington pork, the rural businessmen who founded the Coosa Commission had for decades sought such generous but loosely regulated structural intervention. By 1968, the EES model of industrial development and technical assistance was even garnering international attention. That year, Dr. Bernard Wetzel of the Productivity Division of the French Planning Agency visited Rome to view firsthand the workings of the Tech and Commission partnership. ${ }^{98}$

For many businessmen across the state, the Coosa Commission's developmental model was a revelation and many traveled to Northwest Georgia to learn more about forming regional commissions. ${ }^{99}$ Indeed, as Ernest Vandiver enthusiastically put it at the Commission's 1963

\footnotetext{
96 “25 Years of Progress: Coosa Valley Area Planning and Development Commission, 1958-1983,”July 21, 1983, 4, in author's possession.

97 “About Industrial Development,” Rome-Floyd County Chamber of Commerce News-Letter, July 1962, HSCL.

98 “French planner visits Rome,” RNT, June 11, 1968, folder Engineering Experiment Station - Industrial Development Department, GTA.

${ }^{99}$ See, for instance, "Slash Pine Serves Area,” Waycross Journal-Herald, October 21, 1969.
} 
Cebul

annual meeting, "You here in the Coosa Valley have set an example." Your "work has lighted the way along a path of economic darkness and blazed the trail to a bright future." ${ }^{\prime 100}$ To raise awareness about the opportunity to found federally funded Commissions, Georgia's Area Development Division partnered with the Institute of Community and Area Development at the University of Georgia and development experts at Georgia Power to distribute a manual called "Planning for an Area Development Program," which outlined how to set up a regional Commission. $^{101}$

Jimmy Carter was one Georgia businessman who was particularly taken by what he read in the manual, and he traveled to Rome to attend an annual Commission meeting. ${ }^{102}$ As the Coosa Commission was getting off the ground, Carter was headed to serve his first term in the state senate. The first Commission in Northwest Georgia, Carter soon reported to his fellow businessmen in West Central Georgia, had raised a mere $\$ 61,000$ in local funds, and, thanks to state and federal matching provisions, enjoyed a $\$ 225,000$ annual operating budget for planning

\footnotetext{
100 “25 Years of Progress: Coosa Valley Area Planning and Development Commission, 1958-1983,’July 21, 1983, in author's possession.

${ }^{101}$ Howard A. Schretter, “The Area Planning and Development Commission: Its Relationship with Local Planning Programs," Institute of Community and Area Development, The University of Georgia, Athens, Georgia, October 18, 1963, folder Speeches, Draft of Speeches, Notes [2], box 5, Jimmy Carter Papers, Pre-Presidential, 1962-1976, Jimmy Carter Presidential Library, Atlanta, Georgia (hereafter, JCL).

${ }^{102}$ It was at that meeting that Carter first met Bert Lance, a banker from Calhoun, who would become a close political advisor and Carter's director of the Office of Management and Budget. "25 Years of Progress: Coosa Valley Area Planning and Development Commission, 1958-1983,'July 21, 1983, 5, in author's possession.
} 
Cebul

with which they aimed to win even more federal action dollars. ${ }^{103}$ For Carter - who relished his background in Naval scientific expertise; who touted his status as a rural businessman; who shared growth liberalism's faith in social reform through economic growth; and whose instincts engendered a healthy skepticism toward centralization - the Commission model was a wonder. ${ }^{104}$ Decentralized, rooted in expertise, centered on public-private partnerships, and geared toward a localist vision of community and economic development, the Commissions seemed an ideal form of government economic action. In one of his first moves as a state senator, Carter galvanized the creation of a Commission for his home region, spurring local leaders to raise $\$ .08$ per capita in revenue. In 1963, the eight county West Central Georgia APDC (WCAPDC) was born and soon qualified for state and federal 701 matching funds. Carter's West Central Georgia region was not alone. By 1965, 14 multi-county Commissions were established across Georgia, and by 1970 every county in the state had voluntarily joined a federally backed regional planning and development Commission. ${ }^{105}$ Most took fact-finding trips to Northwest Georgia, Sidney

\footnotetext{
103 "West Central Georgia Area Planning and Development Commission: Area Planning and Development Commissions in Georgia," Undated, folder Speeches, Draft of Speeches, Notes [2], box 5, Jimmy Carter Papers, Pre-Presidential, 1962-1976, JCL.

${ }^{104}$ Jimmy Carter's political rise and his formative experiences chairing the WCGAPDC are detailed in the following chapter.

${ }^{105}$ Burton Sparer, “Area Planning and Development Commissions in Georgia Today," February 1975, Prepared by the Legislative Research Division of the Institute of Government, University of Georgia, 7, in author's possession.
} 
Cebul

Thomas recalled. "We were observed by people from everywhere" in the state looking to build

regional Commissions. "Even the folks in Washington came down to see how we were doing."106

The Commission Model Goes National: Growth Liberalism Confronts Depressed Areas

While local business leaders and their political allies pursued regional growth, national political economic developments were leading liberal policymakers in a similar direction along a slightly different track: the pursuit of growth and regional planning as a means to alleviate poverty. From the late 1930s through the 1950s, liberals and their allies in labor forged new forms of worker and consumer protections that aimed to shore up the demand side of the economy by bringing blue-collar workers into the middle class. By the late 1950s and the emergence of a self-consciously "affluent society," liberal economists believed they had solved the problem of boom and bust business cycles through Keynesian macroeconomic policies. "Pockets of poverty" persisted in urban ghettos and isolated rural regions, but liberal policymakers rejected pursuing significant structural changes to the domestic economy. They instead embraced the notion that endemic poverty was exceptional and thus a solvable fluke of

\footnotetext{
106 “25 Years of Progress: Coosa Valley Area Planning and Development Commission, 1958-1983,”July 21, 1983, 3 , in author's possession.
} 
Cebul

modern managed capitalism. ${ }^{107}$ With appropriate fiscal and simulative button pushing, growth

liberals believed consumer-driven economic growth would be extended to all Americans. ${ }^{108}$

In Georgia, little New Dealer Ellis Arnall had long proclaimed the positive social

outcomes that would result from economic growth. "There is no problem in the South that does not have its origin in the poverty and exploitation of this region," he said. "Injustices, instances of racial friction ... and lack of economic advancement are all attributable to the low income of the people of our section." In short, he argued, "Wipe out poverty and the friction will become negligible. ${ }^{\prime 109}$ For Arnall, as for a generation of liberal economic policymakers, the economy was the overriding factor in social and racial relations and was not itself a social construct, beholden to racial or social biases and hierarchies. ${ }^{110}$ Poorly adjusted or isolated individuals simply needed to be plugged into the opportunities of modern capitalism. Among liberal policymakers in the late 1950s and early 1960s, the belief that extending economic opportunity would reconcile racial and social problems would have profound consequences on the scale, substance, and partners in postwar development and antipoverty programs.

In the 1950s, this expanding faith in growth as opposed to stabilizing the business cycle became a dynamic political force in national policy debates, suggesting growth's emerging

\footnotetext{
${ }^{107}$ See generally, O’Connor, Poverty Knowledge.

${ }^{108}$ Brinkley, The End of Reform, Collins, More, 40-68.

${ }^{109}$ Quoted in Schulman, 129.

${ }^{110}$ O'Connor, Poverty Knowledge, Daryl Michael Scott, Contempt and Pity, Wilson, Communities Left Behind.
} 
Cebul

salience beyond local boosters and their political allies. Leon Keyserling, a former student of

New Dealer Rexford Tugwell and chairman of President Harry Truman's Council of Economic

Advisors, boldly proclaimed the new Keynesian consensus regnant among liberal economists

and policymakers: "there is not meaningful stability except a stable rate of constant growth."111

While Keyserling was not the least concerned about inflation, Eisenhower's CEA believed

pursuing price stability rather than economic growth would address their chief concern,

controlling inflation and, perhaps as a side effect, might also offer some growth. When the

economy slowed a bit during his second term, Eisenhower characteristically excused the

downturn as a lesser evil in the service of maintaining stable wages and prices. He explained,

"Some temporary acceleration of growth might have been achieved" if he had allowed

inflationary policies "to persist." But such growth would have been "unsustainable" and would

have caused even worse economic dislocation when the inflationary bubble burst.

The fact that Eisenhower privileged stability over growth even in the face of a slowing economy encouraged the politicization of the issue, and, by the late 1950s Democrats were at work crystalizing a pro-growth political agenda. Following the 1956 elections, the Democratic National Committee formed a policy group, the Democratic Advisory Council, to develop policies and political strategies for upcoming elections. John Kenneth Galbraith chaired the

\footnotetext{
${ }^{111}$ Quoted in Collins, 43.
} 
Cebul

committee, but Keyserling proved to be one of its strongest voices, overcoming Galbraith's

concerns about inflation. Though his influence waned by the 1960 elections, Keyserling led

Democrats to emphasize sustained economic growth as their chief political casus belli. ${ }^{112}$ The

result, historian Robert Collins has argued, was the ascendance of a new paradigm of liberal

politics and policymaking: growth liberalism. ${ }^{113}$ As the Coosa Commission's speedy

mobilization in northwest Georgia suggests, national liberals were hardly the only advocates of

growth-oriented rather than balanced market policies.

Far from the adversarial relationship with business and capital that characterized much of

the early New Deal, growth liberals over the 1950s and early 1960s subtly expanded the target of stimulative policies to include the supply side of the economy (albeit with the ultimate goal of providing jobs and expanding purchasing power), advancing what might be termed "supply side liberalism." The evolution and ultimate passage of liberal Sen. Paul Douglas' 1950s' Depressed Areas Bill reveals the broad ideological and partisan support that was gradually coalescing behind a growth-based federal agenda that aimed to train workers and stimulate business and industries. ${ }^{114}$ Douglas' relatively modest $\$ 251$ million legislation aimed to provide federal loans

\footnotetext{
${ }^{112}$ Collins, More, 44-5.

${ }^{113}$ For Robert Collins' assessment of growth liberalism, see Collins, More, 40-97; and Collins, "Growth Liberalism in the Sixties," in David Farber, ed., The Sixties From Memory to History (Chapel Hill: University of North Carolina Press, 1994).

${ }^{114}$ For the range of area development proposals that came from both sides of the partisan aisle during Eisenhower's years in office, see Wilson, 34-53.
} 
Cebul

to attract or keep industries in impoverished or deindustrializing regions (such as his native southern Illinois) and delivered limited subsidies for public infrastructure improvements, all of which explicitly aimed to benefit the supply side of the economy, which would, to borrow an anachronism, trickle down to the demand side. Douglas' goal in this liberal vision of supply side economics was to use gentle federal stimulus to correct areas of labor market imbalance. A staunch labor liberal, Douglas nevertheless stressed the fact that he did "not support deficit spending, and" was "a strong advocate for economy in Government." 115 Eisenhower, however, twice vetoed the bill, and the National Association of Manufacturers and the national Chamber of Commerce actively sought to undermine the legislation, fearing that it would distort market forces. ${ }^{116}$ Among Democrats siding with Eisenhower were a few Southern Senators, some of whom sought a stronger commitment to rural regions and, from Ohio, Cleveland's white ethnic Senator, Frank Lausche, who opposed more federal spending. The 1960 Democratic presidential hopefuls in the Senate, however - Lyndon Johnson, John F. Kennedy, and Stuart Symington - all voted to override the President. Indeed, after some campaigning in West Virginia had exposed him to particularly abject rural poverty, Kennedy was especially outspoken in promising that economic development as a form of social policy would be a central a campaign issue.

\footnotetext{
${ }^{115}$ Quoted in Wilson, Communities Left Behind, 37.

${ }^{116}$ Ibid., 51-2.
} 
Cebul

Once elected, stimulating growth became President Kennedy's overriding domestic priority, and he extended the kernel of supply side liberalism inherent in Douglas' bill. Kennedy aimed to balance the global demand approach of his Council of Economic Advisers by pursuing what chief economic aide Walter Heller called a "Keynesian-cum-growth" program: CEA advocated tax cuts; wage-price guideposts paired with "jawboning," as Robert Collins terms it, of business and labor to steady inflation as much as possible; and a variety of manpower training, economic development, and education policies to stimulate further demand and job creation.

Soon after the administrative transition, desks in the Commerce Department began sprouting signs asking "What have you done for growth today?” CEA member James Tobin recalled, "Growth was a good word, indeed the good word." In his first State of the Union, Kennedy focused on the dangers of a flagging economy, saying, "The most resourceful industrialized country on earth ranks among the last in the rate of economic growth. Since last spring," he warned, "our economic growth rate has actually receded." Domestically, Kennedy established a Cabinet Committee on Growth comprised of the chairman of the CEA, the budget director, and the leaders of the treasury, commerce and labor departments. ${ }^{117}$ Across a broad spectrum of government activities, the overriding theme was stimulating domestic economic growth principally through structural intervention on the supply rather than demand side.

\footnotetext{
${ }^{117}$ Collins, More, 51-3.
} 
Cebul

Local growth politics advanced by groups like the Coosa Commission and the ascendance of national growth liberalism converged in Kennedy's 1960 campaign and soon became manifest in the policies his administration pursued. Kennedy's political strategists were well aware of the structural and institutional changes afoot across the South and sought to tailor Administration policies to stimulate economic growth and political loyalty. As political scientist Daniel Galvin has suggested, Kennedy’s team explicitly tied federal support for Southern industrial development policies to extrapartisan Democratic Party building. ${ }^{118}$ As one of President Kennedy's advisors wrote ahead of the 1964 elections, "A new South is in the making right now, but [it] is hidden mostly from view [beneath] the surface manifestations of segregation and the pratings about states rights and super-conservatism."119

In Eastern Kentucky, a regional development commission similar to that in Northwest Georgia was mobilizing, and it had an aggressive advocate in Kentucky Governor Bert Combs. As a result of Combs' outreach to Kennedy, John Whisman, the head of Kentucky's first regional commission, was appointed to candidate Kennedy’s “redevelopment taskforce.” At Whisman's urging, the governors of Alabama, Georgia, Kentucky, Maryland, North Carolina, Pennsylvania, Tennessee, Virginia, and West Virginia formed the Conference of Appalachian

\footnotetext{
${ }^{118}$ Daniel Galvin, Presidential Party Building: Dwight Eisenhower to George W. Bush (Princeton: Princeton University Press, 2010), 174-5.

${ }^{119}$ Ibid., 175.
} 
Cebul

Governors. On the campaign trail in May 1960, Kennedy quietly met with the Conference, just after Eisenhower's second veto of Douglas' Distressed Areas Bill. Kennedy heard the Governors emphasize the scope of their developmental problems, and they underscored their inability to develop adequate state or local resources. ${ }^{120}$

While Sen. Douglas had intended the Depressed Areas bill to act primarily as a bulwark against Rust Belt decline, when President Kennedy signed a new version in May 1961, the revised Area Development Act contained changes in emphasis that militated against Douglas' Rust Belt focus. Kennedy's campaign overtures to the Southern and Appalachian Governors meant he had promises to keep, and North Carolinian Luther Hodges was named head of Kennedy's Commerce Department, the executive branch that would oversee the ARA (as opposed to Labor, as Douglas had hoped). ${ }^{121}$ Moreover, in consulting on the ARA legislation, two Appalachian governors, Combs of Kentucky and Vandiver of Georgia (who was simultaneously working to scale up the Coosa Commission model), related to their compatriots and federal policymakers the promise of their states' burgeoning regional commissions. ${ }^{122}$ They

\footnotetext{
${ }^{120}$ Bradshaw, The Appalachian Regional Commission, 28.

${ }^{121}$ For how the ARA spending might have contributed to further rust belt decline, see Wilson, Communities Left Behind.

${ }^{122}$ Georgia's governors and state legislators hosted regular Atlanta breakfast meetings called "Eggs \& Issues" with state business interests, and Rome's Chamber of Commerce members frequently made the trip to take advantage, as one Chamber newsletter put it, of "a wonderful opportunity for fellowship and political skullduggery with our local and state legislators." Forty-three Romans attended the January 1963 Eggs and Issues breakfast, the largest single
} 
Cebul

argued the federal government could use planning grant money and targeted loans to help get similar commissions off the ground in depressed areas across the country. ${ }^{123}$ Indeed, the ARA was based on the principle that local businessmen and politicians would voluntarily come together to partner with federally backed local governments to plan the development of their regions and deliver targeted supply side stimulus. ${ }^{124}$ Echoing the Coosa model, the ARA invited communities, through the creation of regional Preliminary Overall Economic Programs, to bring the federal government into the process of regional development. ${ }^{125}$ Kennedy's ARA hoped to stimulate Coosa Commissions in "depressed areas" across the country.

As the ARA began operation, local governments swung into action. Within its first few months in operation, the ARA received preliminary plans from 334 counties -43 percent of the total designated as depressed areas - and had approved programs covering 194 of those counties in 25 states; by the end of the first year, 500 areas, about 60 percent of those eligible, had

\footnotetext{
out of town contingent at the meeting. Rome-Floyd County Chamber of Commerce News-Letter, February 1963, and April, 1963, HSCL.

${ }^{123}$ On the Coosa Commission as a model for federal and Appalachian policymakers, see Appalachian Regional Commission, The Appalachian Experiment, 1965-1970 (Washington: Appalachian Regional Commission, 1972), 90; Bradshaw, 26-8.

${ }^{124}$ This model of federally funded local or regional public private partnerships would soon proliferate through programs such as President Carter's Urban Development Action Grants.

${ }^{125}$ Peter Eisinger touches very briefly on the role of the ARA as a precursor in his excellent account of the emergence of "the Entrepreneurial State." Peter K. Eisinger, The Rise of the Entrepreneurial State: State and Local Economic Development Policy in the United States (Madison: University of Wisconsin Press, 1988).
} 
Cebul

submitted plans. ${ }^{126}$ The first two action projects to receive approval reflected the kinds of

developmental state initiatives emphasized by Coosa boosters: a $\$ 160,000$ loan and grant for a

new water system in Arkansas, and a $\$ 213,300$ loan and grant for a sewage system in

Cambridge, Maryland. The Kennedy Administration believed the two projects would provide

1,875 permanent new jobs. ${ }^{127}$ The memo described "promising applications" for projects that

would support private developments such as "New local origin plants," "Basic materials

producers," "New plants from out of local area," and "Plant modernization or expansion." The

Administration estimated that its modest initial investment of $\$ 272$ million across these public

and private projects would generate $\$ 138.5$ million of state, local and private investment,

resulting in a (very precise) estimate of 10,942 jobs and, in the short term, "8,000 man years of

construction employment."128 Their optimism went beyond these jobs, though, thanks to the

untold potential of the program's multiplier effect.

ARA staffers, however, sought to emphasize the localism, "self-help," and ostensibly

market-based nature of their program. While they felt their agency represented "A New

\footnotetext{
${ }^{126}$ W.L. Batt to Lee White, October 19, 1961, "New Growth, New Jobs - A Beginning: A Progress Report of the Area Redevelopment Administration, U.S. Department of Commerce,” 2; and Sar A. Levitan and Harold L. Sheppard, "Impact of Technological Change Upon Communities and Public Policy," undated, 16, Area Redevelopment Administration, July 31, 1961 - October 2, 1962, General File, 1954-1964, Series 1, White House Staff Files of Lee C. White, Presidential Papers of John F. Kennedy, digital ID: JFKWHSFLCW-001-011.

127 Ibid., 3 .

${ }^{128}$ Ibid., 4.
} 
Cebul

Partnership" between a variety of federal agencies, state and local government, regional

commissions, and the private sector, all in the pursuit of economic growth and combatting

poverty and unemployment, they nevertheless felt the need to downplay the federal role. They

were quick to emphasize the onus was on local communities, "for unless [they] take the initiative

there is little that State or Federal Governments can do for them. ${ }^{129}$ ARA officials, like other

liberal policymakers during the high tide of liberal state building, strove to frame their program

as in keeping with traditional American values of self-help, local control, and free markets. ${ }^{130}$ As

one administrator put it, "the ARA believes in solving the unemployment problem by the free,

private enterprise system." ${ }^{131}$ Local businesspeople were the agents growth liberals empowered

to grow the nation out of poverty.

In practice, the ARA suffered from a number of difficulties that led to its relatively

speedy demise. The legislation contained no seed funding to stimulate local planning (only funds

once local organizations had mobilized), so the nation's most depressed regions were left to

develop their own leadership, matching funds, and strategic plans in order to win the ARA's

\footnotetext{
${ }^{129}$ Ibid., 9.

${ }^{130}$ Recently, a number of excellent works have suggested the degree to which liberal bureaucrats emphasized American values in order to generate support for new forms of state intervention. See especially, David M.P. Freund, Colored Property: State Policy \& White Racial Politics in Suburban America (Chicago: University of Chicago Press, 2007) and James T. Sparrow, Warfare State. On twentieth century Americanism more generally, see Wall, Inventing the "American Way."

${ }^{131}$ Harold Williamson quoted in Wilson, Communities Left Behind, 88-9.
} 
Cebul

loans and subsidies. This resulted in a handful of well-mobilized counties winning the lion's share of support. ${ }^{132}$ The well-organized northeast Alabama counties that were members of the New Deal-inspired CARIA, for instance, were major beneficiaries of ARA-generated support, receiving millions from the Housing and Home Finance Agency's Community Facilities Administration, Urban Renewal (in Gadsden), 701 Planning grants, and the Dept. of Agriculture's Soil Conservation Service. ${ }^{133}$ In addition, the ARA generally did a poor job of coordinating local plans with the federal agencies that were brought in to provide additional funding for ARA initiated projects. Most vexing, many local businessmen and politicians, those meant to generate OEDPs and ARA projects, often resented their classification as leaders of “depressed areas.” Republican Senator John Tower of Texas complained on behalf of constituencies within the 45 Texas counties targeted by the ARA. "They rightfully resent being held up before the nation as a static underdeveloped area in need of a Federal handout," he grumbled. ${ }^{134}$ A member of the Roanoke, Virginia Chamber of Commerce concurred: "Roanoke

\footnotetext{
${ }^{132}$ Bradshaw, The Appalachian Regional Commission, 29.

133 “An Inventory of Selected Federal Projects and Programs in Appalachia,” November 1962, Dept. of Commerce, ARA, Office of Planning and Research, Area Redevelopment Administration, July 31, 1961 - October 2, 1962 , General File, 1954-1964, Series 1, White House Staff Files of Lee C. White, Presidential Papers of John F. Kennedy, digital ID: JFKWHSFLCW-001-011.

134 “Texans Resent U.S. Listing as Depressed Area,” August 1, 1961, news clipping, Area Redevelopment Administration, July 31, 1961 - October 2, 1962, General File, 1954-1964, Series 1, White House Staff Files of Lee C. White, Presidential Papers of John F. Kennedy, digital ID: JFKWHSFLCW-001-011.
} 
Cebul

businessmen deplore the 'distressed area' tag which has been given national publicity." ${ }^{135}$ Most significantly, though, the ARA was underfunded and slow, prompting President Kennedy himself to pen a perturbed memo to ARA administrators and related federal agencies, demanding that they "process these projects at an even faster rate."136

In Northwest Georgia, the ARA ran into numerous problems. In some cases, existing businesses viewed ARA support for small, new, or expanding industry as direct competition. As one letter to William Batt from a group of textile manufacturers put it, "we regard this contemplated project as competition with private enterprise. Each of the undersigned," they wrote, "have invested substantial capital funds, without any sort of Federal assistance."137 More often, however, the ARA was perceived as slow and unresponsive. One northwest Georgia textile business, Textured Products, presumably not one that had signed the above letter, sought an ARA small business loan. Their Congressman complained that a "bottleneck" resulted from "a difference of opinion between officials of the Small Business Administration and officials of the Area Redevelopment Administration. ${ }^{, 138}$ In this case, the ARA officials objected to a private

\footnotetext{
${ }^{135}$ Quoted in Wilson, Communities Left Behind, 52.

${ }^{136}$ John F. Kennedy to John E. Horne, February 27, 1962, Area Redevelopment Administration, July 31, 1961 October 2, 1962, General File, 1954-1964, Series 1, White House Staff Files of Lee C. White, Presidential Papers of John F. Kennedy, digital ID: JFKWHSFLCW-001-011.

${ }^{137}$ James D. Miller et al to William Batt, September 3, 1965, folder VI B, ARA General 1961-1965, box 69, series VI, James W. Davis Papers, Richard B. Russell Library for Political Research and Studies, University of Georgia Libraries, Athens, Georgia [hereafter JWDP].

${ }^{138}$ James Davis to Gray Burch, September 2, 1965, folder VI B, ARA General 1961-1965, box 69, series VI, JWDP.
} 
Cebul

middleman charging the small Georgia business $8.5 \%$ interest on a 10 year loan delivered by the

SBA at $4 \%$ over 15 years. ${ }^{139}$ As the Paulding County Chamber of Commerce put it in a plaintive letter, "We are embarrassed by the fact that we have told our people that this loan would be forthcoming; and now we feel we are being by-passed and this makes us lose face with our own subscribers. We feel that SBA and EDC have sadly neglected an area for which they were set up to serve and have offered poor excuses for such inaction." ${ }^{\prime 10}$

For all their complaints, however, the ARA was wholly in line with businessmen's belief that local political and business leaders were the best constituencies to lead a struggling community's economic development. A Commerce Department report written with characteristically broad language suggested the narrow boundaries to "community" participation prescribed in ARA planning - echoing the Coosa planners' own narrow vision. The Act, wrote Commerce Department staffers Sar Levitan and Harold Sheppard, "requires that the widest variety of groups in a community - businessmen, labor leaders, public officials, farm group representatives, bankers, and others - participate in a community economic development plan." 141 The ARA's success "depends on the "efforts of such communities to engage their key

\footnotetext{
${ }^{139}$ CE 7 008, 8/31/1965, attached to James Davis to Gray Burch, September 2, 1965, folder VI B, ARA General 1961-1965, box 69, series VI, JWDP.

${ }^{140}$ G.G. Burch to James Davis, August 27, 1965, folder VI B, ARA General 1961-1965, box 69, series VI, JWDP.

${ }^{141}$ Sar A. Levitan and Harold L. Sheppard, "Impact of Technological Change Upon Communities and Public Policy," undated, 15, Area Redevelopment Administration, July 31, 1961 - October 2, 1962, General File, 1954-
} 
Cebul

segments in 'grass roots' research, discussion, analysis and planning process." ${ }^{142}$ Yet, from the start, the NAACP complained to ARA officials that, "Negroes were not being consulted in the drawing up of these programs." As of late 1961, though, Assistant Attorney General Nicholas Katzenbach and the Department of Justice felt that creating a regulation "specifically requiring Negro or minority group representation in these local planning groups would probably do more harm than good," (though they weakly conceded that "a regulation requiring "broad community representation' ... might be effective"). ${ }^{143}$ Liberal administrators and regulators thus contributed to local business' and politicians' sense that their economic development goals benefitted the entire range of local constituencies' economic and social progress. As a result, national growth liberals abetted flattened distinctions about who constituted community stakeholders.

With the limitations of the ARA quickly becoming apparent, the Conference of Appalachian Governors approached the Kennedy White House in 1961 to argue for a substantial new program to fight what they felt was Appalachia's exceptional economic blight. The governors hoped the federal government would develop and fund the program, but William Batt, 1964, Series 1, White House Staff Files of Lee C. White, Presidential Papers of John F. Kennedy, digital ID: JFKWHSFLCW-001-011.

142 Ibid., 16.

${ }^{143}$ Nicholas deB. Katzenbach to Lee C. White, Civil Rights Problems in Programs of the Area Redevelopment Administration, Nov. 9, 1961, Area Redevelopment Administration, July 31, 1961 - October 2, 1962, General File, 1954-1964, Series 1, White House Staff Files of Lee C. White, Presidential Papers of John F. Kennedy, digital ID: JFKWHSFLCW-001-011. 
Cebul

the ARA Director, recommended they develop their own proposal and try to generate some local matching funds. "I never thought the day would come," Batt recalled in 1967, "when I'd be arguing with Southern governors in favor of states' rights, states' responsibilities." "144 Given the anti-federal political economic climate in Southern states, however, the governors failed to raise much local financial support and struggled to even develop workable proposals. By the spring of 1963, with the ARA floundering; a series of disastrous storms in Kentucky raising anew the specter of rural poverty; Appalachia's relatively anemic infrastructure; and the elections of 1964 looming amidst increased pressure from the Civil Rights movement, Kennedy decided that a more vigorous federal "Appalachian program” was necessary.

Again, the Coosa Commission became one of two regional developmental models for what became, after his assassination, Kennedy’s “Appalachian program,” the Appalachian Regional Commission. In April 1963, Kennedy commissioned the President's Appalachian Regional Commission (PARC) to generate "a comprehensive program for the economic development of the Appalachian Region," shifting the rhetorical emphasis from the ARA's “depressed areas" to "economic development," a far more palatable framing for local boosters. In a decision many local leaders hoped heralded a return to New Deal scale spending on public works and infrastructure, Kennedy named Franklin Roosevelt, Jr. chairman of the PARC. Joining

\footnotetext{
${ }^{144}$ William L. Batt, recorded interview by Larry J. Hackman, May 10, 1967, 164, John F. Kennedy Library Oral History Program.
} 
Cebul

Roosevelt, Jr. were representatives from a range of interested federal agencies, delegates from nine Appalachian states, and a professional staff of ten. The two key failings of the ARA, PARC members determined, was the weakness of local or regional planning and shoddy coordination of the wide range of federal programs and agencies the ARA brought to bear on local communities. Representatives from Georgia and Kentucky again offered the example of their states' burgeoning regional planning systems, which, by 1963, were spreading across the states (nine Commissions, including Jimmy Carter's, were established in Georgia by the end of 1963). As

Roosevelt, Jr. put it in Rome at a 1964 campaign event for President Johnson; the Coosa Commission "might very well be our guide in setting up the poverty program for the entire Appalachian area." Rome and Northwest Georgia, he said, are "fortunate in having such a group which I consider a step ahead in solving the many problems that confront us." ${ }^{\prime 45}$ Ultimately, the Coosa Commission did, indeed, become the prototype for Local Development Districts - the multi county units that were the primary building block of the Appalachian Regional Commission's efforts to fight poverty. In contrast to the ARA, which relied on local leaders to organize planning commissions, the ARC instead sent money directly to governors who created a state system of LDDs and coordinated from the governor's office the dispersal of federal aid. ${ }^{146}$

\footnotetext{
145 “Coosa Area Planners Praised by Roosevelt,” RNT, October 4, 1964.

${ }^{146}$ On the Coosa Commission as a model for federal and Appalachian policymakers, see Appalachian Regional Commission, The Appalachian Experiment, 1965-1970, 90; Bradshaw, 26-8.
} 
Cebul

Following Kennedy's assassination, however, the ARC's passage was far from assured, and supporters worried the program would slide down the Johnson Administration's list of legislative priorities as it transitioned to civil rights reform. Roosevelt, Jr. had become a genuine believer in the decentralized model of regional development thanks to his Appalachian travels as PARC director, and he worked hard on the new President. He sought to link delivering aid to Southern states to the political strategy behind advancing civil rights reform, though not at all as part of a broadened civil rights offensive. Instead, William Batt recalled how Roosevelt explained to Johnson that he "was missing a good bet" with the ARC. Here, Roosevelt argued, "was a good way for him to get into the South, a way to find common ground with Southern governors and do something for the South, completely outside the racial issue. Right afterwards," Batt said, "President Johnson exhibited a great interest" in the program, ensuring its ultimate passage in $1965 .{ }^{147}$ Southern Governors, some of the most outspoken opponents of the coming Civil Rights reforms, were thrilled. As an indication of Georgia's prominent role in shaping the legislation, at their first meeting, the Governors elected Georgia's moderate business-progressive Governor Carl Sanders to serve, alongside the federal executive director John L. Sweeney, as cochairman of the Commission.

\footnotetext{
${ }^{147}$ William L. Batt, recorded interview by Larry J. Hackman, May 10, 1967, 180-1, JFKLOHP.
} 
Cebul

The passage of the ARC legislation rode a wave of increased media attention on the individuals who languished in Appalachian poverty, but the program's initial appropriations did not emphasize vocational skills or training and reflected instead liberal policymakers' and local leaders' equation of regional economic development and targeted industrial policy with poverty alleviation. ${ }^{148}$ Indeed, the language Appalachian Commissioners used to describe their program would have been familiar to followers of the Rome News Tribune's coverage of the Coosa Commission: "The [Appalachian] Commission will formulate continuing comprehensive, coordinated plans and programs for the overall development of the region. It will help to provide the basic facilities essential to the region's growth, will help to develop its human resources, [and] will seek to encourage individual initiative and private investments ..."149 The converging priorities of growth-oriented Southern businessmen and national growth liberals was also displayed in the ARC's astronomical budget appropriations. Congress authorized a total of $\$ 1,092,400,00$ of which $\$ 840$ million was set aside for a six-year bonanza of highway construction somehow meant to spur the "individual initiative" to fight poverty. ${ }^{150}$ Appalachian

\footnotetext{
${ }^{148}$ A 1965 New York Times article explored the disjuncture between ARC policy means and ends, suggesting that massive federal economic development spending could actually exacerbate regional inequalities. These tensions and their outcomes are explored in some detail in the next chapter. "Appalachia - Poverty, Beauty and Poverty," NYT, April 25, 1965.

149 Appalachian Regional Commission, Annual report of the Appalachian Regional Commission. Washington: Appalachian Regional Commission, 1965, 4. Accessed online at http://hdl.handle.net/2027/mdp.39015078419804 ${ }^{150}$ Ibid.
} 
Cebul

Governors, boosters, and local planners viewed highways as necessary steps toward economic growth, while federal poverty planners viewed new transportation networks as antipoverty social programming. ${ }^{151}$ As Joe Fleming, formerly John Sweeney's chief policy aid and executive assistant recalled in 1969 from his new post as federal co-chairman of the ARC, the new "regional highway system" would "break down ... the psychological isolation" of Appalachia's poor. "I've always billed this highway system not only in economic terms, but in social terms ... because it provides a way for linking people with contemporary America, quite literally." ${ }^{152}$ In this framing, regional boosters got another massive infusion of federal development spending for which they had systematically worked for decades, and they were again assured that their efforts were for the developmental benefit of the region's poorest and most marginalized.

Not all groups were pleased with the ARC's system of federal development spending. The National Association of Manufacturers and the U.S. Chamber of Commerce, ARA and ARC staffer William Batt recalled, "were passionately opposed" to the programs, and Human Events made the ARA and later the ARC its "whipping boy." Even Readers' Digest, Batt noted, "went

\footnotetext{
${ }^{151}$ For the optimistic economic projections tied to regional highway development, see President's Appalachian Regional Commission, Report of the Subcommittee on Highways of the Transportation Committee, October 25, 1963, Area Redevelopment Administration, 1963:25 October - 19 November and undated, General File, 1954-1964, Series 1, White House Staff Files of Lee C. White, Presidential Papers of John F. Kennedy, digital ID: JFKWHSFLCW-002-002.

152 Joe W. Fleming, II, Oral History Interview, February 19, 1969, p. 13, Lyndon Johnson Oral History Project, Miller Center. Accessed Online, http://web2.millercenter.org/lbj/oralhistory/fleming_joe_1969_0219.pdf.
} 
Cebul

after us." ${ }^{153}$ Batt was quick to point out, though, that despite the fact that the national "Chamber

became more vitriolic in their opposition . . . in depressed areas we worked with local Chambers

hand in glove. They were they moving spirits. But they would never be able to overcome the

numerical majority in the Chamber who were by nature against federal involvement in the

private economy in general." ${ }^{154}$ While national businessmen's associations led the charge against

federal overreach, centralized planning, and wasteful spending, their local affiliates took the lead

in building the decentralized developmental state.

Because the Commission system was maturing just as the ARA and the ARC were

deployed, Georgia's business-led development groups gained a reputation for being particularly

successful at luring federal aid. You "can't drive . . . through rural areas of Georgia," Batt said,

"without seeing results of [federal] programs all through the state. They make very effective use

of it." Federal administrators joked about the effectiveness of Georgia's local leaders in winning

ARC dollars. "Keep your Confederate money," they said, "because the South will rise again.",155

Over 1965-66, for instance, the ARC delivered over \$7 million to Northwest Georgia counties

for new sewage plants, new access roads to industrial sites, and, in Rome, a major expansion of

\footnotetext{
${ }^{153}$ William L. Batt, recorded interview by Larry J. Hackman, May 10, 1967, p. 191, John F. Kennedy Library Oral History Program.

${ }^{154}$ William L. Batt, recorded interview by Larry J. Hackman, May 10, 1967, p. 198, JFKLOHP.

${ }^{155}$ William L. Batt, recorded interview by Larry J. Hackman, May 10, 1967, p. 177, JFKLOHP.
} 
Cebul

Coosa Valley Vocational Technical School, previously the Rome Vocational School. ${ }^{156}$ ARC

funds over the following years supported Central Business District improvements in Cedartown,

a number of regional health clinics and airports, and a housing program in Dalton. ${ }^{157}$

Commissioners happily reported that between 1961-62 and 1971-72, the percentage of local contributions toward the annual budget shrunk from $67 \%$ to just $19 \%$. "This is not to minimize the importance of local financial contribution," they cautioned, "but rather to emphasize the fact that cities and counties in the" Coosa region "have gotten an increase in services at no increase in costs, truly an exception by today's economic standards."

As Georgia's Commissions became better organized and as new sources of federal funding came online, between 1968 and 1973, the percent of total income Commissions received from local v. state v. federal sources shifted considerably. In 1968, just over a quarter (26\%) of Commission funds were sourced locally, with the state pitching in 31 percent and federal programs adding the other 43 percent. Five years later, the local share had dropped to a mere 14.5 percent, the state contribution to 18.8 percent, while the federal total had skyrocketed to 66.7 percent. ${ }^{159}$ A University of Georgia study illuminated the soundness of local investments in

\footnotetext{
${ }^{156}$ CVAPDC Annual Report, June 30, 1966, pp. 15-6, UGA Library, Athens, GA.

${ }^{157}$ CVAPDC Annual Report, June 30, 1968, pp. 5-6, UGA Library, Athens, GA.

${ }^{158}$ CVAPDC Annual Report, 1971, UGA Library, Athens, GA.

${ }^{159}$ Burton Sparer, “Area Planning and Development Commissions in Georgia Today,” February 1975, The Legislative Research Division, Institute of Government, University of Georgia, In Author's Possession, p. 12.
} 
Cebul

federal development dollars: "One APDC estimates that its local dues of $\$ 57,000$ helped the commission acquire $\$ 193,621$ in state and federal planning grants. These planning dollars, in turn, generated $\$ 6,450,000$ in state and federal action grants - grants which provide services or facilities to implement a plan." As the U.Ga. analyst concluded, "for each local dollar invested in the APDC program, $\$ 113$ was returned to the members of this APDC. While this 1 to 113 ratio is by no means typical of all APDCs, this example does demonstrate the importance of local dues in the APDC budget." ${ }^{160}$ It also demonstrated the generosity of developmental state spending at the high tide of growth liberalism and the degree to which Southern businessmen and politicians had become part and parcel of the liberal state's efforts to grow the nation out of poverty. Liberals in Washington were eager to demonstrate the returns on "antipoverty" spending and zeroed in on the Coosa region as a showpiece. In 1966 at the behest of ARC co-director John Sweeney, an official with the Georgia Department of Industry and Trade brought representatives from four developing nations to visit with the Coosa Commission. In the junket were members of the Turkish Promotion and Information Center and the Nepal Industrial Development Corporation. Following their visit with Coosa planners, the group toured the Georgia Kraft Plant, a recent arrival in Northwest Georgia thanks to local planning and development work. A few weeks after this visit, Sweeney steered Virgillio Hilario, an adviser for community development

\footnotetext{
${ }^{160}$ Burton Sparer, “Area Planning and Development Commissions in Georgia Today,” February 1975, The Legislative Research Division, Institute of Government, University of Georgia, In Author's Possession, 11.
} 
Cebul

in the Philippines, to northwest Georgia to visit with Commissions officials. ${ }^{161}$ The News

Tribune reported that Hilario "said the primary reason for his trip to the United States was to see

how the U.S. is tackling some of the problems of poverty and raising the standard of living for

those who need it." Hilario was an official adviser to the president of the Philippines and his

wife, 1951's Miss Universe, joined Hilario for the trip. For federal policymakers, the Coosa

Commission represented federal development and antipoverty efforts put to their best use. ${ }^{162}$

And the Commission had, indeed, accomplished a great deal, although, as the following

chapters suggests, poverty alleviation was not near the top of the list. By 1970, the Coosa

Commission boasted that it had teamed with Georgia Tech's engineers to complete over 300

studies and had worked with more than 220 new industries, which, during the 1960s, brought

roughly 11,000 manufacturing jobs to the region. The Commission's work underwrote a

remarkable inventory of public-sector projects on behalf of cultivating a positive business

climate: 37 new water and sewer projects, 17 public housing projects, 6 regional airports, 8

public golf courses, 8 hospitals, 11 nursing homes, 10 public health centers, 10 vocational

schools, 2 technical schools, 2 junior colleges, 16 recreational centers, 5 libraries, 13 watershed

“improvements," 26 post offices, 19 local planning commissions, and 36 new development

\footnotetext{
161 “Coosa Valley Planners Win Worldwide Fame,” RNT, July 15, 1966.

162 “Coosa Unit Visit Slated By Filipino,” Atlanta Constitution, June 1966, Planning Commission, RFCL / HRA.
} 
Cebul

groups. ${ }^{163}$ All of this development in just 12 relatively small counties over a single decade. These developments augured improved fortunes for the regions' skilled workers, too. Between 1960 and 1967 the state of Georgia saw a slight one percent uptick in manufacturing as a percentage of its total employment; by contrast, in most of the Commission counties the percentage leapt upward. Bartow County saw a 9.4 percent increase; Dade 7.7 percent, and Gordon 8.1. (Floyd, with a higher population and growth in the service sector, declined a bit, by one percent, though its total number of manufacturing jobs increased by 6.7\%). ${ }^{164}$ As a result, between 1960 and 1967, the per family income in the Commission's twelve counties experienced astonishing growth. While the state of Georgia as a whole ( $48 \%$ growth in family income) reflected the national trends toward greater income (in part driven by inflation), the Coosa region enjoyed an average increase of $58.75 \%$. Whitfield County, home to Dalton's unionized textile hub led the way, enjoying 67\% per family income growth; Floyd's family income expanded by 56 percent. ${ }^{165}$ Likewise, the per capita income increase in the Coosa region as a whole outpaced that of the state: the State of Georgia enjoyed a 53.2\% increase while the Coosa counties' per capita income grew by 75.7 percent. ${ }^{166}$

\footnotetext{
${ }^{163}$ CVAPDC Newsletter, August, 1970, RFCL / HRA.

${ }^{164}$ CVAPDC Newsletter, November, 1969, Rome / Floyd County Library HRA and CVAPDC Newsletter, August, 1969, RFCL / HRA.

${ }^{165}$ Percentages compiled by author from figures reported in CVAPDC Newsletter, March, 1969, RFCL / HRA.

${ }^{166}$ Percentages compiled by author from figures in CVAPDC Newsletter, June, 1969, RFC: / HRA.
} 
Cebul

In late 1961, as the Coosa Commission's model was expanding across the state, Arizona

Senator Barry Goldwater visited Northwest Georgia to speak to students at Berry College, blasting President Kennedy's financial "irresponsibility." The "scouts of the 'New Frontier," he said, "have lost their way." 167 Prior to his remarks, Goldwater met with Harley Harper, an early New South Republican, and the Senator came away quite impressed. "The Coosa Valley Commission," Goldwater told reporters, "is becoming nationally known because here in the Northwest Georgia area you have provided your own brains, money and technical know-how to develop the economic and development potentials of this great area." Goldwater praised the localism, self-help, and boots-straps spirit of the commissioners' work. "These dedicated men saw they had a job to do. So they got together on the regional level, raised the necessary money, and they are getting the job done. They didn't come hollering to Washington asking that some federal bureaucrat give them a blue print." The Senator continued,

They know their own problems best and they best know how to solve them. That's what I've been preaching all over the country - fill the vacuums at home and the federal government won't move in. Throw up your hands in defeat and our centralized government will get bigger and your tax payments will get bigger. The Coosa Valley program is a wonderful undertaking and I salute all who play a part in this remarkable

167 “'Goldwater Attacks 'Indecision’ of JFK,” RNT, November 19, 1961. 
Cebul

effort to improve your area economically and industrially. I am certain success will crown your efforts. ${ }^{168}$

The News Tribune summed up the Senator's glowing tribute: "Barry Goldwater has cited the Coosa Valley Planning and Development Commission as a perfect example of the free enterprise system functioning at the local level to solve local and state problems at home - and not looking to Washington to provide the answer."169 Goldwater identified self help and localism as the antidotes to federal invasion, but, the rise of the Coosa Commission suggested the crucial role the federal government could play in generating fruitful results from such bootstraps forms of self help and localism. Instead, Goldwater's remarks and the News Tribune's reporting reflected the ways in which businessmen and local elites around the country had come to consider loosely regulated federal development support to be a natural piece of healthy, growing, and "free" local and regional markets. As long as that aid was directed to and by local elites, the federal role was justified and natural.

Boundaries existed, however, between those elites who pursued a partnership with Washington as a form of self-help, and those whose development would drain the public trust. As a young Georgia Democrat named Zell Miller said in a 1964 campaign, federal War on Poverty planners had been "educated beyond their intelligence," and Americans' "individual

\footnotetext{
168 "Sen. Goldwater Lauds Coosa Valley Planning," RNT, November 20, 1961, RFCL / HRA.

169 “Sen. Goldwater Lauds Coosa Valley Planning," RNT, November 20, 1961, RFCL / HRA.
} 
Cebul

freedoms are being sacrificed away bit by bit." ${ }^{170}$ Two years later, Senator Herman Talmadge

delivered similar remarks at the 1966 Coosa Commission Annual Meeting. The "community

development" programs offered in the War on Poverty were heightening tensions between

worthy and unworthy community development programs and constituencies. "[E]ducating and

training people to earn a living is good business for the economy of the country and can do much

to alleviate dependency and unemployment," he said. But, "if the program is subverted, as it has

been in many instances, to a mere handout and perpetuation of the dole, it will not produce the

desired results ... Organizations such as this commission, which concentrates on hard work,

planning and development of human and natural resources are the key to economic progress,

both for the individual and the community." He continued,

Local, state, and federal efforts, when properly directed, can offer people an opportunity to learn new skills and provide them with economic advantages which otherwise would not be available. And if the people avail themselves of these opportunities, they can improve their standard of living and be made useful and productive citizens . . . Emphasis must be placed, however, on self-help. Handouts in the long run do not help anyone. ${ }^{171}$

\footnotetext{
${ }^{170}$ From the North Georgia Tribune, "Landrum Linked to LBJ," People's Choice, News of the $9^{\text {th }}$ District, September 1966, folder 15, box 1, series II, Zell Miller Papers, p. 5, RBRL.

${ }^{171}$ Press Release from the Office of US Senator Herman E. Talmadge, July 15, 1966, folder 7, box 276, series II, Herman E. Talmadge Collection, RBRL.
} 
Cebul

Individuals, ole Gene's son concluded, must “ help themselves;” indeed, only through individual motivation would the poor be "made useful and productive citizens."172

Highly racialized debates about the federal government's proper role in supporting new forms of "properly directed" community or individual economic development ensued. Contestation over the system of federalism itself would have profound consequences not only for the full spectrum of citizens within rural communities, but also for the kinds of appropriate "self help" programs Talmadge and the Coosa Commission supported.

172 “Talmadge Hails Area Progress, Industrial Gains,” Rome News Tribune, July 15, 1966, Planning Commission, RFCL / HRA. 
Cebul

\section{Chapter Four}

\section{Renewal and Revolt:}

The Boundaries of the Developmental State

"We have, in Cleveland, developed the art of accenting the positive to the exclusion of remedying the negative. How difficult it is, but necessary, to advocate as a remedy the accenting of the negative. How else to strike at and endeavor to dispel the deep, almost indigenous false sense of security and accomplishment that pervades this city?"

- Rep. Carl B. Stokes, 1966 U.S. Civil Rights Commission Hearings, Cleveland, Ohio

"Never in the history of the city has there been a period of greater industrial growth than

that shown for the ten years ended December 31, 1955," began Cleveland's Chamber of

Commerce Annual Report for 1955-56. "During that decade 1,207 new manufacturing

companies added more than 16,000,000 square feet of . . f facilities, provided initial employment

to more than 43,000 workers, with . . annual payrolls aggregating $\$ 125,000,000$. During that

same period," they exclaimed, "existing industries reported 6,477 expansions, adding more than

46 million square feet of production to our industrial empire. In so doing they spent

$\$ 1,673,547,529$ for buildings and equipment." Cleveland Electric Illuminating, the city's private

electric utility, along with the Chamber's Industrial Development promotion, they wrote, had

\footnotetext{
${ }^{1}$ Cleveland Chamber of Commerce Annual Report for 1955-56, folder Annual Reports - Industrial Development Committee, Container 153, Greater Cleveland Growth Association Papers, Western Reserve Historical Society, Cleveland, Ohio [hereafter GCGA].
} 
Cebul

catalyzed this remarkable period. The "Cleveland Electric Illuminating Company is outstanding

in its promotion of Cleveland through national advertising and excellent cooperation in power

negotiations." "2 The city had never been better. The Cleveland Indians won the World Series in

1948, and the Browns won the NFL championship in 1950, their first of three that decade.

Yet, while Chamber members credited themselves and CEI with driving the city's golden

decade, deeper structural, governmental, and international political economic trends were largely

to thank. ${ }^{3}$ Over the ensuing decades, those trends would be dramatically reversed. ${ }^{4}$ The "Best

Location in the Nation" would be redubbed "The Mistake by the Lake." While Cleveland's

Chamber of Commerce was presented with potential remedies - from periodic calls to create a

stronger political and economic regionalism to applied University-based expertise to help

\footnotetext{
${ }^{2}$ Extract from Cleveland Chamber of Commerce Annual Report for 1949-1950, folder Annual Reports - Industrial Development Committee, Container 153, GCGA.

${ }^{3}$ On the postwar political economy in general, see Collins, More. On postwar prosperity and the rise of consumer politics, see Lizabeth Cohen, A Consumers' Republic: The Politics of Mass Consumption in Postwar America (New York: Vintage, 2003).

${ }^{4}$ On the causes of the national and international economic shift, see, for instance, Immanuel Wallerstein, WorldSystems Analysis: An Introduction (Durham, NC: Duke University Press, 2004), and Jefferson Cowie, Capital Moves: RCA's Seventy-Year Quest for Cheap Labor (New York: The New Press, 1999). For an overview of these trends in American cities, see Roger Biles, The Fate of Cities: Urban America and the Federal Government, 1945 2000 (Lawrence, KS: University Press of Kansas, 2011, esp. chs 2 and 3. For an account that emphasizes domestic political choices, see Judith Stein, Pivotal Decade: How the United States Traded Factories for Finance in the Seventies (New Haven: Yale University Press, 2010). On the social, political, and cultural aftermath of deindustrialization, see Jefferson Cowie and Joseph Heathcott, eds., Beyond the Ruins: The Meanings of Deindustrialization (Ithaca, NY: Cornell University Press, 2001).
} 
Cebul

modernize manufacturing and productivity - they instead emphasized physical revitalization of

the city itself.

Over these years, outmigration and creeping deindustrialization left behind a city made

up of poor and middle class blacks and working class white ethnics who competed with suburban

business interests for power in city politics. The 1950s and 1960s were dominated by ethnic

politicians inclined toward "allocational" rather than developmental politics - meting out

services and favors to their constituencies. ${ }^{5}$ From Truman to Kennedy, however, the federal

government sought to extend the New Deal's model of cooperative federalism, sending loosely

regulated federal aid to local governments to be administered in association with local elites.

When these new forms of federal developmental state provision came online - such as Urban

Renewal or the Area Redevelopment Administration - the Chamber of Commerce, rather than

the mayor's office, spurred the city's efforts to win federal funding.

The War on Poverty and a groundswell of African American political mobilization,

however, threatened business' assumptions about their privileged relationship with government.

Local political elites and businesspeople recoiled at the expansion of developmental state

programming that they perceived as threatening to the political and economic status quo. Indeed,

the War on Poverty advanced a more targeted or "categorical" form of federalism, which, when

\footnotetext{
${ }^{5}$ On allocational versus developmental or redistributive urban policies, see Paul Peterson, City Limits (Chicago: The University of Chicago Press, 1981), esp., 41-65.
} 
Cebul

partnered with mobilized African Americans, threated to bypass local elites entirely - ethnic politicians and businesspeople alike. As the March 1966 cover of Nation's Business, the publication of the U.S. Chamber of Commerce asked, "Is [the] War on Poverty Becoming [a] War on Business?" The article explored a litany of complaints about federally funded Community Action Program activists, such as those who pursued "consumer education" programs and boycotts in Washington D.C. or "consumer advisers" in San Francisco. As the Chamber's magazine put it, some businesspeople "admit to a feeling of 'sheer fright' over the influences which people lacking a business grounding can bring to these" tax payer-supported programs. ${ }^{6}$

When the decade's racial violence struck Cleveland, too, business leaders and ethnics looked warily at a city that seemed to be slipping from their grasp. Frustrated by the nation's most ambitious urban renewal program that had run aground; exasperated by the homespun and ineffectual ethnic mayor; and seemingly under siege by African Americans and local militant groups, Cleveland's business leaders would pursue their own more vigorous mobilization.

\section{Renewal}

\footnotetext{
6 "War on Poverty Becoming War on Business?” Nation's Business, March 1966, accessed online at the Hagley Library’s Digital Collections, http://cdm16038.contentdm.oclc.org/cdm/landingpage/collection/p16038coll3.
} 
Cebul

With the withdrawal of New Deal and wartime works spending, Cleveland's business

leadership retired for a time to a primarily advisory relationship with city government. The

Chamber continued to advocate municipal improvements and bond issues, but did so mainly

through internal reports shared with the city's planning department. Very often, these reports

reflected business leaders' suburban outlook, advocating improved highways and light rail lines

linking the suburbs to the city and the airport. Indeed, since World War I, there had been almost

no middle or upper class housing constructed in the city, while suburbs such as Lakewood,

Cleveland Heights, and Shaker Heights flourished. ${ }^{7}$ Occasionally, the mayor appeared at

Chamber Board meetings, but, for the most part, business leaders focused on business, noting

with periodic displeasure the growth in retail sales outside the city or the need for some kind of

downtown redevelopment. ${ }^{8}$ With restored capital liquidity, and with Cleveland's manufacturing

base reaching new heights, the city's business leaders in the late 1940s and the early 1950s were

largely content.

While the city planning commission and Ernest Bohn's voluntary Regional Association

had since the late 1930s identified decentralization as a critical problem, without significant bond

\footnotetext{
${ }^{7}$ And the disparity between Cleveland and its suburbs grew rapidly. Jon C. Teaford found that the average rent in the suburbs was 78 percent higher than that of the city. Teaford, The Rough Road to Renaissance: Urban Revitalization in America, 1940-1985 (Baltimore: Johns Hopkins University Press), 13.

${ }^{8}$ Between 1935 and 1939, retail sales in Cleveland grew by 18.9 percent. In its suburbs, that figure grew by 42 percent. Teaford, Rough Road, 23.
} 
Cebul

revenue, the city lacked tools for clearing land for new, more modern and productive industrial physical plants. And without a system for cooperative regionalism in place, the city lacked the political infrastructure to blunt some of the pull factors favoring the suburbs. Mayor Burke and city planner Bohn made a number of entreaties to city business leaders to find private sources of financial support for slum clearance in order to open new industrial land in the city, but business leaders resisted. ${ }^{9}$

Professional planners also hoped to develop new forms of regional planning to more closely coordinate city and suburban land use and business incentives. Cuyahoga County, for instance, employed a planning director, and at one Chamber meeting he "spoke of the fact that the law gives" his planning "Commission very little power. This fact was brought out again and again." "Perhaps," the county planner proposed, "a time has come when a change from this limited authority over county planning to a broader planning aspect may be strictly in order." While city business leaders were interested in the health of the city, many companies benefited from suburban tax and infrastructure investments and had little material interest in evening the

\footnotetext{
${ }^{9}$ William D. Jenkins, “Before Downtown: Cleveland, Ohio and Urban Renewal, 1949-1958," Journal of Urban History, 2001, 27:41, 483-4.
} 
Cebul

regional playing field. While they heard frequently from Bohn and the County planners, the Chamber passed on endorsing vigorous regional planning and coordination. ${ }^{10}$

Indeed, for Chamber members there was also no sense in expanding the County's

planning authority unless public funds were generated for infrastructure and land clearance to underwrite new private investments in the city. "What's the use of our making plans for construction unless money is contemporaneously being gotten for carrying out of plans," said Walter Flory, the corporate lawyer and Vice Chairman of the City Planning Commission. "It would be a great thing, I think, if the county would appropriate more money to the County Planning Commission so that experts could be brought here." ${ }^{, 11}$ But without the means to carry out the significant work recommended by the planners, why should private firms take the initiative? Another member revealed the other side of the businessmen's politics, fiscal conservatism: "We all know that there will be a limited amount of finances to cover public works, and this is as it should be. We do not want to attempt to sell bonds for millions of dollars to cover public works that could just as well be built many many years in the future." "Our goal for Cuyahoga County and the city of Cleveland," he argued,

\footnotetext{
${ }^{10}$ Special Meeting on Metropolitan Post War Planning Called by the Chairman of the Lakefront Development and Planning Committee (of the CCC), April 26, 1944, Chamber of Commerce Meeting Minutes, 1944-1945, Vol. II, Container 59, GCGA.

${ }^{11}$ Ibid.
} 
Cebul

should be sound planning ... on the level that fits in with the views of the tax payers of the county and the city. We must plan the kind of community that its people will be glad to pay the taxes to build. Therefore, we must not propose ideas that are so far out of the reach of the tax payers that the plans are lost in the clouds. ${ }^{12}$

Fiscal conservatism, material interests, and the complacency that came with restored growth all blunted business leaders' awareness of subtle but accelerating structural shifts in the city and regional economy.

Instead, reflecting their sense of place among the nation's elite businesses and industries, Chamber members adopted a national rather than local outlook, largely focusing on federal issues such as taxation and the budget. The Chamber Committee on Federal Taxation, for instance, actively worked for a "constitutional amendment limiting the power of the Federal government to levy income, estate and gift taxes." As they put it, politicians must be "force[d]" to "recognize the terrific harm being done to the American free enterprise system by the present overwhelming burden of taxation on income and estates."13 The Industrial Development Committee, which had once been deeply involved in lobbying for federal infrastructure spending, returned to a position of elite business orthodoxy, reporting that "taxes have now reached a point of danger and ... the credit of the federal government has been stretched too

\footnotetext{
${ }^{12}$ Statement made by Mr. A.S. Andrews, Chairman, Lakefront Development and Planning Committee at Meeting, April 26, Regarding Metropolitan Post War Planning for Cleveland, Chamber of Commerce Meeting Minutes, 19441945, Vol. II, Container 59, GCGA.

${ }^{13}$ Committee on Federal Taxation Report to the Board of Directors, January 29, 1952, Chamber of Commerce Minutes, 1952-1953, Vol. I, Container 64, GCGA.
} 
Cebul

far. ${ }^{" 14}$ Like the U.S. Chamber, Cleveland's business leaders even generated their own plans for balancing the federal budget. ${ }^{15}$ Postwar prosperity had underwritten Chamber members' return to a more conventional elite business conservatism. ${ }^{16}$

But, passage of the Housing Act of 1949 presented interested businesspeople with a federal spending program they could support. Indeed, at the same moment in 1953 when the Chamber issued its call for a balanced federal budget, another sub-committee was working to secure renewal funds for Cleveland. Passed with business and industrial interests' support in mind, Title I of the Housing Act provided federal funding for slum clearance and urban redevelopment in run down, residential sections of cities. Cities could use federal funding to raze these neighborhoods and build new commercial or industrial projects - just the sort of endeavors the Chamber and City Planners had batted about immediately following the war. The wording, however, was left intentionally vague. As urban planner Catherine Bauer put it, the Act made it through Congress "because different groups of people, like the blind men feeling the elephant, made entirely different assumptions as to the essential nature and purpose of this legislation."

Nothing in the Act restricted the kinds of structures private developers could build on the razed

\footnotetext{
${ }^{14}$ Industrial Development Committee Meeting, November 18, 1952, Chamber of Commerce Minutes, 1952-1953, Vol. II, Container 64, GCGA.

15 "Cleveland Chamber of Commerce Plan to Help Balance the Federal Budget," Report of the Committee on Federal Budget, June 1953, Chamber of Commerce Minutes, 1953-1954, Vol. II, Container 65, GCGA.

${ }^{16}$ On postwar elite business political orthodoxy, see Phillips Fein, Invisible Hands, chs. 2 and 3.

${ }^{17}$ Quoted in Teaford, "Urban Renewal and Its Aftermath," Housing Policy Debate, Vol. 11, No. 2, $2000,444$.
} 
Cebul

land. Thus, while improved housing was ostensibly the Act's goal, and while the Act targeted

low-income neighborhoods, like New Deal works programs there were few federal restrictions

and regulations mandating the ultimate outcomes of redevelopment projects. As Historian Jon C.

Teaford has put it, federal funds "could then serve various purposes, depending on who sought to exploit its provisions." 18

Passed less than a half decade following the close of hostilities and less than a decade from the high tide of federal programs like the WPA, the federal government had once again created a generous developmental subsidy that relied on cooperative federalism and local public private partnerships. The result was a period of heightened expectations in city halls, planning departments, and Chambers of Commerce. Ernest Bohn, who had manned a WPA planning staff of 60 , had a longstanding interest in slum clearance and, to a lesser degree, public housing. ${ }^{19}$ With the new cache of federal program dollars, Bohn hoped to clear downtown slums where, he reported, "there is no vacant land for [industrial] construction. ${ }^{20}$ Bohn explained at a meeting

\footnotetext{
${ }^{18}$ Ibid.

${ }^{19}$ In his article on Urban Renewal in Cleveland, William D. Jenkins mistakenly salutes one private developers' concern that "most developers built decent homes only for upper-income buyers," and so he "enabled black families to own their own apartments for $\$ 500$ down and $\$ 81.50$ per month.” According to figures cited by Jon Teaford, these prices would have been usurious. Indeed, the average rent in the city in 1940 was \$28.93. Jenkins, "Before Downtown: Cleveland, Ohio and Urban Renewal, 1949-1958;” Teaford, 4. For a similar critique of Jenkins' interpretation of Ernest Bohn's motivations, see Kerr, Derelict Paradise, 264, n.77. On profiteering and public housing more broadly, see Nathan D.B. Connolly, A World More Concrete: Real Estate and the Remaking of Jim Crow South Florida (Chicago: University of Chicago Press, forthcoming 2014).

${ }^{20}$ Urban Redevelopment Conference Minutes, May 7, 1952, Vol. II, 1952-53, Container 64, GCGA.
} 
Cebul

with Chamber members that those affected were "primarily . . . the colored population." ${ }^{21}$ The

Mayor hoped business leaders would pool resources to create a "limited profit" housing

corporation to develop new rental housing for those displaced. Bohn pointed out that though

many slated to be displaced owned their current homes, most would "not have a down payment"

- the city would actively turn homeowners into renters. Following the Mayor's presentation, the

businessmen and city officials discussed the issue for over two hours, touching on other cities'

experiences and debating the amount of private involvement and expenditure. ${ }^{22}$

City involvement in shaping the African American community's housing stock had roots

in federal World War II housing programs. With the war's boom in manufacturing, Cleveland

faced a significant housing shortage. By late 1942, the city's War Housing Service estimated that

affordable housing had a vacancy rate of just 0.3 percent. ${ }^{23}$ For city leaders, not surprisingly,

economic development tied to the industrial boom trumped concerns about social conditions, and

they focused on maximizing land use for industrial expansion. Frustrated and overcrowded,

\footnotetext{
${ }^{21}$ Indeed, Cleveland's decision to target an African American neighborhood for renewal may have been a critical strategic error because it eventually triggered significant backlash. Pittsburgh, by contrast, saw far less resistance to its urban renewal efforts in large degree because it focused on decommissioned rail yards rather than residential neighborhoods. See, for instance, See Guian A. McKee, "Blue Sky Boys, Professional Citizens, and Knights-inShining Money: Philadelphia’s Penn Center Project and the Constraints of Private Development," Journal of Planning History, 2007 6: 48.

${ }^{22}$ Urban Redevelopment Conference Minutes, May 7, 1952, Vol. II, 1952-53, Container 64, GCGA.

${ }^{23}$ Todd Michney, "Constrained Communities: Black Cleveland's Experience with World War II Public Housing," Journal of Social History, Vol. 40, No. 4 (Summer, 2007), 936.
} 
Cebul

African Americans wrote plaintive letters to the White House asking for help, but officials in

Washington returned the letters with a form response and a carbon copy to the city's War

Housing Service. The city's Housing Service director wrote to Washington repeatedly "asking you again please to change the wording you use in this letter." "There is nothing we can do for most of these Negro families, and they interpret this phrase to mean that you know we could help them and tell us to do so... They are mad and disappointed enough anyway when their letter to the President gets right back to us!" ${ }^{24}$ In 1943, the Cleveland Press reported on the housing shortage among Cleveland's African American residents. "Cleveland" they contended, "is growing its own "'Grapes of Wrath.'” In Cedar-Central,

nearly 80,000 Negroes are housed in homes for $30,000 \ldots$. It is not a story of poverty, nor of inability to pay ... Many of the Negroes today are making top wages in war industries ... They have no place else to go, and because of that, most of them are paying rents far beyond the value of the homes they must occupy. ${ }^{25}$

The federal government's Emergency Defense Housing program was created to deal with this dire housing situation in Cleveland and many others like it across the country. But, considerable lobbying by the real estate and construction industries successfully opposed the creation of viable, long-term public housing developments. Instead, designers built temporary structures' and planned for their obsolescence.

\footnotetext{
${ }^{24}$ Ibid., 933-4.

${ }^{25}$ Ibid, 938.
} 
Cebul

This pattern of elite led slum clearance and housing programming with little to no regard for the actual residents accelerated in Cleveland's Urban Renewal. In 1950, the Chamber of Commerce created its Better Housing Program and the nonprofit Cleveland Development Foundation (CDF) to help acquire and clear land in the targeted renewal area. The CDF would also coordinate contracting for the city's Urban Renewal efforts. Though they had resisted contributing private funds to public redevelopment schemes, with the potential for tens of millions of federal aid on the line, Cleveland's business leaders pooled a \$2 million seed fund. ${ }^{26}$

In the 1930s, proponents of slum clearance had imagined moving poor African Americans to Civilian Conservation Corps-style farms outside the city. But, by the early 1950s, the city's suburban growth precluded such forced relocation. Indeed, between 1945 and 1952, 69,000 new housing units were constructed throughout Cuyahoga County, and an early community organization found that only 200 were in areas available to black customers. ${ }^{27}$ By the mid-1950s, builders were annually converting over 3,000 acres of Cleveland's rural hinterlands and farms into suburban spaces. ${ }^{28}$ As the Cleveland Press put it in 1953, "The problem of getting new housing for families who will be displaced by the [renewal] programs is as tough as any the city has ever faced." 29 Cleveland Development Foundation director Upshur Evans, an executive

\footnotetext{
${ }^{26}$ Jenkins, 484.

${ }^{27}$ Kerr, 124-5.

${ }^{28}$ Ibid, 136.

${ }^{29}$ Quoted in Kerr, 130.
} 
Cebul

at Standard Oil of Ohio, described in clear terms the rationale behind winning federal support for slum clearance and renewal: "It isn't a matter of social consciousness - it is a matter of plain, ordinary, practical common business sense. In short, we believe it will pay out. It means 'pay dirt' for Cleveland, Cuyahoga County, and northeastern Ohio."30

As the Urban Renewal plans were being drawn up, in 1952, the Mayor and the Chamber also formed a joint Committee on Urban Redevelopment that was comprised of representatives from the city's leading companies (Cleveland Electric Illuminating, American Steel \& Wire, and the major banks) and which would plan parallel developments. The Van Sweringen's train line to Shaker Heights had been one of the first inducements for middle and upper class Clevelanders to move to the suburbs, and business leaders hoped to extend a new line into middle class Cleveland Heights and another to the airport on the west side. The Chamber secured $\$ 29.5$ million from the federal Reconstruction Finance Corporation to extend the city's rapid transit to west side suburbs and the airport, but that total was not quite enough to complete the east side project. $^{31}$ While businessmen cited the rapid train line as a way to "eliminate the need for driving into the city," the next item on their agenda was obtaining federal support for a significant new Inner Belt highway. "To secure these results," meeting minutes noted, "will require intensive

\footnotetext{
${ }^{30}$ Ibid., 131.

${ }^{31}$ Urban Redevelopment Committee Minutes, June 30, 1953, Vol. II, 1953-54, continuer 65, and Cleveland Transit System - RFC Loan, attached to D.C. Hyde to John C. Virden, September 16, 1953, Vol. II, 1953-54, container 65, GCGA.
} 
Cebul

effort on the part of the committee in both Washington and Columbus." 32 There was

considerable grousing about their federal and state partners, however, because "there has been no end to the delays because the [state] Highway Commission has requested additional studies in connection with various engineering plans." The businessmen agreed that, "unless work is gotten underway in the near future, there may be keen competition among metropolitan centers in Ohio for funds for federal-state projects. ${ }^{33}$ Their frustration with government emanated from their desire to be in a closer partnership. Cleveland's businesses' retirement from active association with their local, state, and federal governments hadn't lasted longer than a half decade.

Business leaders were enthusiastic supplicants for federal aid, but they nevertheless made efforts to square their pursuit of government programs with limited government values. Because there were so many interested parties across Cleveland's diverse business community, the Chamber appointed 100 members to the public-private Committee on Urban Redevelopment, which was led by an executive committee of ten. ${ }^{34}$ Reflecting their ideological predispositions, however, Redevelopment Committee members spent a good deal of energy anticipating criticisms of their involvement in the massive federal Urban Renewal program. One executive committee meeting rehearsed and rejected popular business concerns about the program. How,

\footnotetext{
${ }^{32}$ Urban Redevelopment Committee Minutes, May 19, 1953, Vol. II, 1953-54, container 65, GCGA.

${ }^{33}$ Ibid.

${ }^{34}$ Ibid.
} 
Cebul

for instance, should businesspeople respond when someone says, "'My family made its own way in life. Why should we help other people?' That's what you hear, but it is self praise and a smug point of view." Or: “'There always have been slums and there always will be.' But there don't have to be slums if we clear out what we have ..." To those that worried the program was too expensive, the Chamber's suggested response was, "the Federal Government will pay \$2.00 for every $\$ 3.00$ of the loss. The City will get its loss back in less than 20 years because of the five times increased tax return on the improved land." ${ }^{35}$ Business leaders thus sought to reframe Urban Renewal and other federally backed redevelopment efforts as sound business sense that would even "help other people."

In part because business appointed 110 persons to the public-private steering committee, but also because of resident and city council members' concerns about how new highways and slum clearance would influence property values, it took five years for the Cleveland Development Foundation and city planning commission to come up with a location for housing displaced residents. The Kingsbury Run section of Cleveland, stretching south and east along the Cuyahoga River, had been home to a shantytown during the 1930s. The river valley and train path had gained national notoriety over the second half of the 30 s thanks to a series of grisly murders perpetrated by the "Torso Murderer." The serial killer - still unidentified - preyed upon

\footnotetext{
${ }^{35}$ Board of Directors Meeting, October 2, 1952, Chamber of Commerce Minutes, 1952-1953, Vol. I, Container 64, GCGA.
} 
Cebul

drifters in the Run. Experts at the time speculated that the killer was a large man who knew a great deal about human anatomy, a doctor perhaps, because he decapitated his victims and, in some cases, expertly split their torsos in half. By August 1938, when at least 12 victims had been discovered, City Safety Director Elliot Ness opted to flush vagrants - potential victims - from the Run, burning 100 shanties and dispersing at least 300 of the Run's residents. In the decade and a half following the Torso Murders and the evacuation of shanty dwellers, Kingsbury Run was used as a city dumping ground. It was there that the city's business leadership envisioned relocating displaced African American residents.

The Chamber's Development Foundation struck an arrangement with Republic Steel to buy its slag, the leftover stony waste from smelting ore, to fill in the Run. Standard Oil's Upshur Evans spoke in glowing terms about Kingsbury Run's potential: "This forlorn valley ... is going to pay off to the Cleveland community ... when it's potentialities are mined and exploited by the Cleveland Development Foundation.” Redubbed "Garden Valley,” Kingsbury Run was the key to winning further federal support. Mayor Anthony Celebrezze matched Evans' enthusiasm: "If the Cleveland Development Foundation's plan to build a Garden Valley development for slum families on filled land in Kingsbury Run is completed successfully, it will be the greatest accomplishment in Cleveland's history." Emphasizing the opportunity to use the private profit motive to solve social problems, the CDF warned that the federal government "must not fail in 
Cebul

its private enterprise solution to America's slum problem. ${ }^{, 36}$ Cleveland's business people

cloaked their courting of federal aid in the garb of the common good and the rhetoric of private

enterprise.

As an historian of Cleveland's urban renewal put it, the first apartments at Kingsbury Run opened in 1957 "with an attractive dump to the north and a field of industrial slag to the south. ${ }^{, 37}$ Not surprisingly, "Garden Valley" failed to attract a critical mass of long-term residents, and the city Housing Authority's increasing disregard led to resident protests. Within a few years, the civil rights group Congress of Racial Equality (CORE) was at work with residents, as CORE leader Ruth Turner put it, picketing the Housing Authority director's “unjust and unequal handling of tenant problems. ${ }^{\text {"38 }}$ The inadequacies of Cleveland's public housing - both in scale and substance - were echoed nationally. By 1955, only 200,000 of Urban Renewal's targeted 810,000 public housing units had been built; by 1965 , the total had inched to only $325,203 .{ }^{39}$

Despite the developments' obvious and glaring deficiencies - substandard contracting, an almost total lack of recreational space, relative isolation, and proximity to a major dump Cleveland Development Foundation members blamed the victims of urban renewal for its

\footnotetext{
${ }^{36}$ Kerr, 131.

${ }^{37}$ Ibid., 132.

38 "Garden Valley Protests Today," PD, December 2, 1964.

${ }^{39}$ James Patterson, Grand Expectations: The United States, 1945-1974 (New York: Oxford, 1996), 336.
} 
Cebul

failure. "Our experience has established one harsh fact," a CDF report concluded; "a slum area

does not lose its characteristics and reputation as rapidly as the physical improvements within the

area are completed." "It has become abundantly clear that a slum clearance program requires an

incubation period during which the reputation of the area may change and catch up to the

physical improvements." One private developer who had invested in the housing project instead

blamed city government: "I have an impression of an attitude at city hall that they have bigger

and better things than housing to promote and are pushing the dust under the rug so they can get

on with something more pleasant." ${ }^{, 40}$

The nation's mayors, meanwhile, hoped for more federal funding. Indeed, the U.S.

Chamber of Commerce sent an observer to an international gathering of mayors held in Chicago in the spring of 1960. Around 500 American cities were represented among a broader assembly of 1,000 mayors from cities as far flung as Auckland and Delhi. At the gathering, presided over by Mayor Richard Daley, the American delegation passed a series of resolutions, shepherded by the eight mayor Resolutions Committee that included chairman Louis C. Miriani (Detroit), Anthony J. Celebrezze (Cleveland), William B. Hartsfield (Atlanta) and James S. Smith (Charlotte). First, they called for the federal government to revise "the administration of Federal grant programs to encourage maximum state and local control." They called for tax immunity for

\footnotetext{
${ }^{40}$ Kerr, 135
} 
Cebul

municipal bond issues and pressed for expanded urban renewal and housing spending and

heartily endorsed the Area Redevelopment Bill, then working its way through Congress. As the

Chamber's observer warily concluded, "many of the pressures building up for the expansion of

old Federal grants-in-aid programs, and the creation of new ones, trace their origin to this group.

Very few mayors ... support the thesis of limited government.” This fact, he warned, "will

continue to encourage municipal governments to by-pass State governments and to enter into

more direct relationships with the Federal government." ${ }^{41}$ Missing from his otherwise accurate

assessment of the mayors' political mobilization was the foundational role played by the U.S.

Chamber's local affiliates in partnering with local government to win greater federal aid.

In fact, at the same time the Cleveland Chamber was collaborating with city government

on slum removal, its members worked to secure federal funding under Kennedy's Area

Redevelopment Administration. ${ }^{42}$ Working with private consulting firm Ernst and Ernst, the

Chamber drew up plans for a "Forum" of concerned citizens, which, in partnership with the city

planning department, would reframe the 1959 Cleveland Plan as the city's Overall Economic

Development Plan, the federally-mandated regional plan for using redevelopment aid. With the

exception of a representative from the Cleveland Welfare Foundation, the Forum was comprised

\footnotetext{
${ }^{41}$ George Mascott, 1960 International Municipal Assembly, May 20, 1960, folder Report, International Municipal Assembly of Mayors, 1960, box 5, series III, U. S. Chamber of Commerce Papers, Hagley Museum and Library, Wilmington, Delaware [hereafter CCUS].

${ }^{42}$ See "Developmental State," Chapter 3, for its origins and passage.
} 
Cebul

entirely of business elites such as Seth Taft (Senator Robert Taft's nephew and an attorney with the law firm Jones Day), George Herzog (chairman of Union Commerce Bank), and former mayor Thomas Burke, then employed as a corporate attorney. ${ }^{43}$ Their 1964 campaign, however, was a step too slow - the federal government was souring on the Area Redevelopment Administration, which was soon to be replaced by the Appalachian Regional Commission.

The Chamber's ARA lobbying was part of a broader recognition of the mounting exodus of manufacturing and retail firms as well as residents from the city. Between 1950 and 1965, Cleveland's population began the rapid contraction of its white middle and upper middle class, shrinking from 914,808 to 810,858, while African Americans, predominantly poor and working class, increased their ranks from 147,847 to 279,352 - moving from 16 to over 30 percent of the city's population. ${ }^{44}$ Between 1965 and 1970 alone, Cleveland bled more than 60,000 white residents. In the decade following the high-water mark of 1955, Cleveland's economy began its slide. Indeed, the Chamber developed a series of reports on the "movement of industry" and its "profound effect upon the downtown." As one member put it, they "were shocked at the material." ${ }^{45}$ From a peak of some 340,000 manufacturing employees within city limits,

\footnotetext{
${ }^{43}$ Minutes, GCGB Executive Committee Meeting, April 16, 1964, volume same. Container 133, GCGA.

${ }^{44}$ See Moore, 19-21.

${ }^{45}$ Minutes, Joint Meeting, Executive Committee of the Greater Cleveland Growth Board, Board of Directors of the Cleveland Chamber of Commerce, Executive Committee of the Cleveland Development Foundation, November 24, 1964, volume Executive Committee Meeting GCGB, November 24, 1964, container 133, GCGA.
} 
Cebul

Cleveland rapidly slid to 171,300 in 1967 , halving the postwar peak. ${ }^{46}$ Manufacturing

employment totals for the metropolitan area, however, were still strong, 306,700 in 1967,

suggesting that the region's industry hadn't all fled south. They had instead headed to the

suburbs where they could build new, more modern plants and enjoy suburban tax rates and closer

proximity to workers' homes. ${ }^{47}$

While groups like the Coosa Commission in Georgia were developing vigorous public-

private University driven technical assistance programs for plant modernization and recruitment

on a regional basis, the Cleveland Chamber's efforts to save the city remained largely

promotional. They were aware of the decentralizing trend but were confident that its roots were

perceptual rather than structural. If they could change peoples' opinions of Cleveland, they

could change its material fortunes. To do so, they established the Greater Cleveland Growth

Board to attract new industries and investment to the region. ${ }^{48}$ "These efforts," one report urged,

"are imperative if we are to successfully compete with the more than 16,000 other development

groups in the country." ${ }^{49}$ As one advertisement in the Wall Street Journal, put it, " $53 \%$ of the

people in the U.S. are an overnight haul from the Greater Cleveland Growthland." "The Greater

\footnotetext{
${ }^{46}$ Teaford, Rough Road, 213.

${ }^{47}$ Warf and Holly, "The Rise and Fall and Rise of Cleveland," 211.

${ }^{48}$ Recommendations for Greater Cleveland Growthland 1964 Advertising, volume GCGB Special Meeting of Executive Committee, January 15, 1964, container 132, GCGA.

${ }^{49} 1962$ Annual Report, First Year Activities and Progress, Greater Cleveland Growth Board, February 11, 1963, 1, volume GCGB Executive Committee Meeting Minutes Feb. 23, 1963, container 132, GCGA.
} 
Cebul

Cleveland Growthland: One of the World's Greatest Opportunities for Business Growth." ${ }^{„ 50}$ In

1963 , the Growth Board spent $\$ 80,000$ on advertisements in the Wall Street Journal alone, easily

topping the list of Journal advertisers in its vital Midwest and Eastern editions. ${ }^{51}$ For a moment,

the Growth Board's polling of Journal subscribers indicated that opinions about Cleveland "as a

good area for industry and commerce" were improving. ${ }^{52}$ Despite this optimism, however, the

reality of the dire situation was becoming increasingly manifest in the city. It was also physically

manifest in a later Growth Board report. In its appendix, the Board listed in separate sections

"Closed Business," "Principle Key Prospects," and "Retention of Growthland Industry." The

first category comprised 10 pages; the others just four each. ${ }^{53}$

Simultaneously, Chamber leaders believed emphasizing service-sector businesses in its

recruitment and retention efforts might create a more diverse local economy, one that could

weather the loss of industrial firms. While the initial urban renewal plans had focused on clearing

slum housing and opening acreage for industrial development, Cleveland's "Erieview" urban

\footnotetext{
${ }^{50}$ Greater Cleveland Growth Board Advertisement, October 23, 1962, WSJ, volume January 10, 1963 GCGB

Executive Committee Meeting Minutes, January 10, 1963, container 132, GCGA.

${ }^{51}$ Recommendations for Greater Cleveland Growthland 1964 Advertising, volume GCGB Special Meeting of Executive Committee, January 15, 1964, container 132, GCGA.

${ }^{52}$ Ibid.

${ }^{53} 1962$ Annual Report, First Year Activities and Progress, Greater Cleveland Growth Board, February 11, 1963, 1, volume GCGB Executive Committee Meeting Minutes Feb. 23, 1963, container 132, GCGA.
} 
Cebul

renewal project aimed to retain and recruit legal and financial services firms. ${ }^{54}$ Proposed in the

1959 Downtown Plan and adopted just three months later by the City Planning Commission,

Erieview targeted for renewal an area of 194 acres just east of downtown between East $9^{\text {th }}$ Street

and the new Inner Belt expressway, a working class community comprised mainly of run down

homes and "marginal small businesses and parking lots.",55 The project, planners argued, would

revitalize the old Euclid avenue corridor, which had been the heart of Cleveland's business

district until the Van Sweringens built their Terminal Tower and shifted the commercial center of

gravity to Public Square. Erieview would also offer more direct freeway and road access,

generate huge amounts of construction and permanent jobs, all while eradicating slums and

lowering crime.

As of 1960, in terms of acreage and proposed cost, Erieview was the single largest Urban

Renewal project anywhere in the nation. With an initial infusion of $\$ 10$ million in federal Urban

Renewal funds, the city hired I.M. Pei \& Associates to design the massive campus that would

feature four stark new bank buildings that would loom over open lawns overlooking the

lakefront. The Cleveland Press glowingly described the project as "Cleveland's chance to wipe

\footnotetext{
${ }^{54}$ Other Northern cities, too, were transitioning from industrially driven renewal to service sector renewal projects. On Boston and Chicago's efforts to woo the insurance sector through urban renewal, see Elihu Rubin, Insuring the City: The Prudential Center and the Postwar Urban Landscape (New Haven: Yale University Press, 2012).

${ }^{55}$ Theodore Hall, "Planning in Cleveland, 1903-1968," in "A History of Planning in Cleveland, 1903-2000," 27, Public Administration Library, City Hall, Cleveland, OH [hereafter PAL].
} 
Cebul

away the wrinkles of old age." For Cleveland's businesspeople, Erieview was the silver bullet

with which they would slay economic difficulties. ${ }^{56}$ The Chamber exhorted businesspeople to

support Erieview and reassured them that the Chamber was at the helm:

Every effort has been made and will be made ... by the Chamber of Commerce in its general policy to weld the many organizations concerned with the economic growth of Greater Cleveland and most of Northeastern Ohio into one cooperative and harmonious body. It is becoming increasingly apparent to planners and developers that there is a definite need and requirement for unity of effort and thought in the industrial development field. ${ }^{57}$

Nevertheless, difficulties arose almost right from the start. What few Urban Renewal regulations there were stipulated that any federal support for demolition could be applied only to structures found uninhabitable or unsound. City inspectors had very recently deemed sound the majority of the 118 buildings on the Erieview 1 site - some were just a few years old. With $\$ 33$ million in federal aid on the line, city officials arbitrarily reclassified 84 of the 118 buildings as "substandard." In a particularly egregious case, a fairly new eight-story building was cited as substandard simply for having a messy basement and doors that lacked self-closing hasps. ${ }^{58}$ Building owners were outraged and appealed to the regional Urban Renewal office in Chicago to do a review inspection. But, when officials at last came to Cleveland, they made a cursory drive

\footnotetext{
${ }^{56} 1960$ Annual Report, folder Annual Reports - Industrial Development Committee, Container 153, GCGA.

57 Ibid.

${ }^{58}$ Federal Urban Renewal Program: Special Report, undated, 22, folder PUBLICATIONS - not contained in the bound volumes for Chamber Publications, box 5, series III, CCUS.
} 
Cebul

through the area, inspecting no interiors, whereupon they ratified the city inspectors'

determination. Not all business interests were interested in Erieview.

By 1964, developers had completed the central Erieview tower along with two other

smaller buildings, but opposition from small landowners, in particular, and administrative

difficulties in general stymied much of the rest of the program. An air of frustration and

acrimony hung over the project, which, by then, consisted of three office towers looming over

vast acreage of dirt fields between the heart of downtown and the lakefront. ${ }^{59}$ Chamber members

blamed city government for both the sluggish pace of Renewal and the failure to recruit new

businesses to the site. Said one member, "it [is] apparent that most public officials do not realize

the importance of the economic base to the area." ${ }^{60}$ In a decade's worth of investments, Federal

Urban Renewal in Cleveland had spent \$40 million and razed six thousand acres. The city’s

developmental leadership had not completed any of its projects. Displaced African Americans;

disgruntled business leaders and small businesspeople; and restive ethnics would soon do battle

to define the city's developmental future.

Revolt

\footnotetext{
${ }^{59} P D$, March 17, 1964, March 31, 1964.

${ }^{60}$ Minutes, Joint Meeting, Executive Committee of the Greater Cleveland Growth Board, Board of Directors of the Cleveland Chamber of Commerce, Executive Committee of the Cleveland Development Foundation, November 24, 1964, volume Executive Committee Meeting GCGB, November 24, 1964, container 133, GCGA.
} 
Cebul

In 1966 white ethnic Democratic Mayor Ralph Locher blamed Cleveland's impoverished African Americans for the city's worsening urban crisis. Testifying before a weeklong Civil Rights Commission hearing in April, Locher invoked blacks' Southern roots for their inability to acculturate. "[L]ife in a shack," testified the Mayor, "harsh surroundings and an inferior education often make it difficult for the newcomer to conform to the rules and customs of city living." After beginning his testimony by quoting the opening passage of $A$ Tale of Two Cities, Locher suggested the federal government should develop programs for "acculturizing newcomers" to Northern urban life. ${ }^{61}$ During the proceedings, the federal commission heard from frustrated residents, civil rights leaders, and a parade of local and state politicians. Hough, where 60,000 African-Americans lived on the city's near east side and which had become the neighborhood to which displaced African Americans had fled, dominated the hearings.

Respondents told an unequivocal story of decay, deprivation, and waste. ${ }^{62}$ In contrast, Locher and his supporters among the ethnic Democratic Party bosses, argued causes of and solutions for

\footnotetext{
61 “US Rights Unit Opens Hearings in Cleveland.” WP, April 3, 1966. Locher would later be described as an “amiable and ineffective time server." Saturday Evening Post, July 29, 1967, in Estelle Zannes, Checkmate in Cleveland (Cleveland, OH: The Press of Case Western Reserve University, 1972), 28.

${ }^{62}$ Robert E. Baker. "US Rights Unit Opens Hearings in Cleveland,” Washington Post, April 3, 1966; "Hearing Before the United States Commission on Civil Rights,” 1966, Transcript, April 1-7, 1966, Cleveland, Ohio. U.S. Government Printing Office.
} 
Cebul

the worsening urban crisis did not rest with city hall or the business community. Black cultural failures to adjust to city living were federal responsibilities, not local. ${ }^{63}$

The Commission, however, concluded that ineffective and likely corrupt stewardship of urban renewal was to blame for the city's worsening conditions. ${ }^{64}$ City officials had systematically allowed properties to fall into further disrepair in order to secure a lower purchase price prior to demolition. Thousands of residents and businesses were displaced, most without federally mandated relocation assistance. As a New York Times headline put it, "Urban Renewal Plans Scored as Cause of Decay." ${ }^{\prime 65}$ At the end of the Commission's week, attendees heard an impassioned plea to federal officials from a young African-American politician, then serving his third term in the Ohio House of Representatives. Rather than call for more federal oversight or increased expenditures, however, Carl Stokes called for the U.S. Department of Housing and Urban Development to freeze Cleveland's urban renewal funding until local officials could get a handle on the rapidly deteriorating situation. Stokes wanted less federal involvement, even at the

\footnotetext{
${ }^{63}$ There is a rich literature on the creation of the urban crisis and the role of racially biased or overtly racist federal and local policies on the urban core as well as the white migration to the suburbs. For the urban North, see Arnold R. Hirsch, Making the Second Ghetto: Race \& Housing in Chicago 1940-1960 (Chicago: University of Chicago Press, Second Edition, 1998); Thomas J. Sugrue, The Origins of the Urban Crisis: Race and Inequality in Postwar Detroit (Princeton: Princeton University Press, 1998); and Kenneth T. Jackson, Crabgrass Frontier: The Suburbanization of the United States (New York: Oxford University Press, 1985).

64 “Urban Renewal Plans Scored as Cause of Decay,” NYT, April 5, 1966.

${ }^{65}$ Leonard N. Moore, Carl B. Stokes and the Rise of Black Political Power (Urbana, IL: University of Illinois Press, 2002), 45 .
} 
Cebul

cost of valuable subsidies, until Clevelanders addressed the situation themselves. ${ }^{66}$ HUD agreed and halted the city's urban renewal program.

Two months later, on a hot July evening, a white bar owner in overcrowded Hough put a sign on the street that read "No Water for Niggers." When two blacks were told they would not be served and were physically removed, an angry crowd formed. The arrival of over 300 aggressive police officers accelerated the situation and soon bottles and rocks were flying. When Joyce Arnett, a 26 year old mother of three, called from a window to get permission to go home to her children, she was shot dead - it remains unclear by whom. Over the next eight days of arson, sniper fire, and National Guard tank patrols, three more Clevelanders lost their lives, 30 were seriously injured, and over 300 were arrested. The city estimated that during the Hough Riot some 240 fires burned huge swathes on the city's east side. In the aftermath, Frank Lausche, Cleveland's trailblazing ethnic Democrat, then a U.S. Senator, proposed with South Carolina's Strom Thurmond a harsh anti-riot amendment to the Civil Rights Act. ${ }^{67}$ Mayor Locher again deflected responsibility, suggesting instead that communists had infiltrated black neighborhoods. ${ }^{68}$ So demoralized was Ralph Locher's 13 -year veteran planning

\footnotetext{
${ }^{66}$ Moore, 45; "Hearing Before the United States Commission on Civil Rights," Government Printing Office, 1966.

${ }^{67}$ On Lausche and Thurmond's proposed amendment, see Joseph Crespino, Strom Thurmond's America (New York: Hill and Wang, 2012), 104-5.

${ }^{68}$ Locher openly speculated about the role of Communist agitators. See "Rioting in Cleveland Followed Watts Script,” LAT, July 31, 1966, and “Civil Rights: Extremists Breed Extremism,” WP, September 10, 1966.
} 
Cebul

director Eric Grubb, that he failed to report to work for three months after the riot. With no explanation or contact of any kind from Grubb, the Planning Commission voted to accept his resignation in absentia in October. ${ }^{69}$ Instead of pushing back, many black ward and city council members toed the party line, fearful of being replaced by their Democratic Party bosses. ${ }^{70}$ The city's business leadership, however, had had enough of the rapidly destabilizing situation and saw that frustrated blacks and combative white ethnics threatened far more than the safety of their own neighborhoods. The economic health of the city hung in the balance. They sought new solutions and ousting Locher and the ethnics was the first step. As Cleveland Bar Association president James C. Davis put it in a speech called "Cleveland's White Problem," businesspeople were "disturbed about the future climate of Cleveland as a place in which to" do business. Davis placed the blame squarely on the white ethnic "nationality groups" and their mayor. ${ }^{71}$

Merely replacing the mayor, however, would do little to address the structural inequalities and trends that gnawed away at the city's social and economic health. The flight of the white middle-class from the city limits - and tax rolls - meant Cleveland had rapidly become a city of working class white-ethnics and impoverished blacks. Indeed, thanks in part to its early suburbanization, of the nation's 21 most populous cities, Cleveland by the mid-1960s had the

\footnotetext{
${ }^{69}$ A History of City Planning in Cleveland, 1903-2000, 107, PAL.

${ }^{70}$ Lackritz, 20.

${ }^{71}$ Bartimole, "Who Governs: The Corporate Hand," in Keating, et. al., Cleveland: A Metropolitan Reader, 165.
} 
Cebul

smallest percentage of resident white-collar workers. The city's races inhabited vastly different

and strictly segregated worlds, with city services and construction projects overwhelmingly

benefiting white neighborhoods. ${ }^{72}$ In 1965,91 percent of Cleveland's elementary students

attended 95 to 100 percent white or black schools. ${ }^{73}$ Under increased population pressure,

schools in black communities were overcrowded and substandard. In 1964, when the city finally

responded to pressure from black families and community groups by temporarily busing their

children to white schools, whites responded by hurling rocks at the school buses, and ethnic

gangs attacked blacks who entered Little Italy. ${ }^{74}$ A Cleveland welfare expert described the

situation by the mid-1960s: "the city has become three clenched fists ready to strike at Negroes -

one Hungarian, one Polish, one Italian."75

\footnotetext{
${ }^{72}$ See E. Nelson, Jr. and Philip J. Meranto, Electing Black Mayors: Political Action in the Black Community (Columbus: Ohio State University Press, 1977), 78-9. Between 1965 and 1970, Cleveland bled over 60,000 whites, creating a city whose majority population was made up of impoverished and overcrowded blacks and blue-collar, white-ethnics. See Moore, 20; Yong Hyo Cho, "City Politics and Radical Polarization: Bloc Voting in Cleveland Elections," Journal of Black Studies 4.4 (Jun., 1974): 396-417. Cleveland ranked among the highest cities for blocklevel indices of nonwhite-white segregation and black isolation within neighborhoods between 1930 and 1970. In the North, only Chicago showed more isolation, while Atlanta and Washington, DC were the only Southern cities with higher indices. Douglas S. Massey and Nancy A. Denton, American Apartheid: Segregation and the Making of the Underclass. (Cambridge: Harvard University Press, 1993), 47-8.

${ }^{73}$ Nelson and Meranto, 81 . The situation would only become more extreme: by 1986, blacks represented 0.9 percent of the population of white majority schools, while whites represented 5.2 percent of black majority schools. Cited in Matthew Lassiter, The Silent Majority: Suburban Politics in the Sunbelt South (Princeton: Princeton University Press, 2006), 317.

${ }^{74}$ Moore, 34-38.

${ }^{75}$ John T. McGreevy, Parish Boundaries, 228. McGreevy cites racial clashes in Cleveland back to 1953, 88.
} 
Cebul

Indeed, ethnics had come to dominate city politics and the city's Democratic Party. With the exception of a Czech county auditor named Ralph Perk, not one Republican candidate local, state, or national - had won a majority of votes in Cleveland since $1941 .^{76}$ Though business leaders, many of whom resided in the suburbs, possessed great backroom influence, ethnic mayors were most concerned with patronage and allocating services and favors to their constituencies. Moreover, black councilmen, beholden to the county Democratic machine for financial support, ignored constituent complaints and tended to their narrow self-interests. ${ }^{77} \mathrm{~A}$ columnist in the city's black weekly described Leo Jackson, a notorious black councilman:

"Ducking hot issues where Negro interest is concerned is one of Leo's favorite pastimes.",78

Following a visit to Cleveland, the neighborhood organizer Saul Alinsky said Cleveland's black leadership had the reputation as the most "bought out" in the country. ${ }^{79}$

The national media described the situation in 1967 in Cleveland as inevitably hurtling toward an even more violent summer than the previous. "Not If - When," declared a front-page

\footnotetext{
${ }^{76}$ That one Republican was Ralph Perk who later capitalized on white ethnic flight form the Democratic Party and become mayor for much of the 1970s. Kenneth G. Weinberg, Black Victory: Carl Stokes and the Winning of Cleveland (Chicago: Quadrangle Books, 1968), 145.

${ }^{77}$ Nelson and Meranto, 83-4.

78 "Leo Jackson to Ride the Fence Again," Call and Post, July 22, 1967 [hereafter CP].

${ }^{79}$ Roldo Bartimole, point of view, vol. 12, no. 2, August 18, 1979, available online at Cleveland Memory Project, http://images.ulib.csuohio.edu/cdm/singleitem/collection/roldo/id/213/rec/2
} 
Cebul

article in the Wall Street Journal under the headline "Racial Powder Keg." ${ }^{\circ 0}$ Even Mayor Locher

was resigned to the inevitability of future violence: "no Mayor," he hedged, "can guarantee

peace. ${ }^{81}$ The Cleveland Chamber, too, was sent an FBI report on rioting. ${ }^{82}$ Written under the

signature of J. Edgar Hoover, federal investigators speculated that the Progressive Labor

Movement and the Communist Party USA had been active in organizing riots. One member of

the Cleveland Chamber penned a note to his compatriots and attached a pamphlet that "gives you

the true facts of the colored upheaval we are experiencing in all parts of the country ... I hope

you will find ... facts that might be helpful in assisting the colored people to understand that if

they want to improve their situation it has to be done by their own boot-straps." The "Civil

Rights Bill," he wrote, "is not the answer." 83

Business' opposition to federal aid and empowerment for minority groups revealed the

racial and normative boundaries to the developmental state. While Chamber members were

active supplicants for federal aid that would benefit their causes - EDA funding, HUD grants,

Urban Renewal - they drew the line at what they considered unnecessary federal oversight of

\footnotetext{
80 “Racial Powder Keg," WSJ, March 14, 1967. "There are few in Cleveland,” noted the Los Angeles Times, "who do not expect more violence." "Rioting in Cleveland Followed Watts Script." LAT, July 31, 1966.

${ }^{81}$ WSJ, March 14, 1967.

${ }^{82}$ J. Edgar Hoover, Report, U.S. Department of Justice, F.B.I., attached to John J. Gunther, Executive Director of the US Conference of Mayors, "Federal-City Reporter,” Memorandum, September 30, 1964, folder NegroMiscellaneous Info., container 102, GCGA.

${ }^{83}$ Stanley J. Olstyn to Chamber of Commerce, March 24, 1964, folder Negro- Miscellaneous Info., Container 102, GCGA.
} 
Cebul

local affairs and the "hand out" programs of the War on Poverty. "Although business and industry are most sympathetic with efforts of the administration to eradicate poverty from the American scene," one Chamber report noted, "such a hodge-podge of ephemeral hand out schemes must be viewed with a degree of skepticism." While they had actively pursued funds from the ARA, Cleveland's business leaders also singled out its successor, the Appalachian Regional Commission, as an especially wasteful and dangerous program because, they argued, it favored one region above others. The program of rural economic development, they concluded, contained much that was "highly objectionable" and risked "federal domination" of the market and local government. ${ }^{84}$ One imagines they would not have objected to a program of urban economic development.

From Protest to Politics: Black Mobilization for Carl Stokes

What most galled businesspeople, however, was the War on Poverty's attempt to create new federal developmental partnerships with the poor themselves, bypassing city leaders and elites entirely. Over the late 1950s and early 1960s, researchers at the Ford Foundation had to a large degree developed the philosophy behind the first generation of urban poverty programs. As one Foundation official put it, their "Gray Areas" program sought to develop the "latent potential

\footnotetext{
${ }^{84}$ Gordon C. Nichols submitted to the Board of Directors, July 30, 1964, folder Board of Directors Meeting, July 30, 1964, container 140, GCGA.
} 
Cebul

of the human beings now crowded and often crushed at the bottom of the community's totem

pole. ${ }^{, 85}$ Ford hoped to empower marginalized Americans to work within and reform existing

political and social structures. ${ }^{86}$ In these initial programs, Ford perpetuated paternalistic notions

of expert superiority, and its social scientists and advisers were often mired in the racially liberal

"therapeutic ethos" which stifled meaningful understanding of impoverished and working class

blacks' perspectives. ${ }^{87}$ The Foundation's initial unwillingness to face structural and racial

realities was a function of its experts' commitment to consensus, "color-blind" liberalism.

Indeed, Paul Ylvisaker, Ford's public affairs director, had hoped to avoid issues of race

altogether. ${ }^{88}$ As one particularly harsh critic put it, "the people being planned for in a $\$ 1.7$

million Ford Foundation project are hardly even mentioned, let alone represented . . The notion

that citizens conceivably might want to speak for themselves obviously never occurred to the

academicians, government officials, and 'civic leaders' . . . as if the residents of a Negro slum

\footnotetext{
${ }^{85}$ Paul N. Ylvisaker quoted in Daniel P. Moynihan. Maximum Feasible Misunderstanding: Community Action in the War on Poverty (New York: The Free Press, 1970), 36.

${ }^{86}$ Between 1960 and 1966, Ford invested in \$30.9 million in Gray Areas grants. For more on the Gray Areas program, see Alice O'Connor, "The Ford Foundation and Philanthropic Activism in the 1960s" in Lagemann, Ellen Condliffe ed. Philanthropic Foundations: New Scholarship, New Possibilities (Bloomington: Indiana University Press, 1999), 169-194; and O’Connor, "Community Action."

${ }^{87}$ As Daryl Michael Scott argues, this ethos served also to perpetuate racial conservative's contempt for black poverty, especially in the wake of urban unrest and the flowering of black power. See Scott, Contempt and Pity, 7174, and, generally, 137-183.

${ }^{88}$ For a broader discussion of these underlying assumptions among members of philanthropic civil society, see Alice O’Connor, Poverty Knowledge. For a discussion of the liberal consensus, and "color-blind," "opportunity" liberalism, see Gareth Davies, From Opportunity to Entitlement.
} 
Cebul

needed to be told what their problems are. ${ }^{89}$ Learning from Ford's troubles, Lyndon Johnson's

poverty programmers built upon Gray Areas when they established the War on Poverty's

Community Action Programs. ${ }^{90}$ These would seek "maximum feasible participation" of the poor

in the administration and design of local poverty programs.

Speaking on May 22, 1964 before that year's graduates of the University of Michigan,

Johnson invoked a soaring future of "abundance and liberty for all." He called for "an end to

poverty and racial injustice" and challenged the graduates - and through them the American

people - to "enrich and elevate our national life, and to advance the quality of our American

civilization" by meeting the nation's "challeng[es] constantly renewed." 91 At its heart, he

promised, his Great Society would uplift racially and economically disfranchised Americans, too

long denied access to federal guarantees of equal democratic and economic opportunity, while

simultaneously raising all Americans' standard and quality of life.

The national conversation surrounding Johnson's domestic agenda largely focused on the

\$3 billion worth of War on Poverty programming within the Great Society’s Economic

Opportunity Act of 1964. No program was more controversial than the Community Action

\footnotetext{
${ }^{89}$ Charles Silberman quoted in O'Connor, "The Ford Foundation and Philanthropic Activism in the $1960 \mathrm{~s}$," 180.

${ }^{90}$ For a more detailed discussion of the close relationship between Ford and the development of the War on Poverty as well as other aspects of Ford's impact on the Economic Opportunity Act see O'Connor, “The Ford Foundation and Philanthropic Activism in the 1960s," O’Connor, “Community Action,” and O’Connor, Poverty Knowledge.

91 Johnson's speech is available online, http://www.h-net.org/ hst306/documents/great.html
} 
Cebul

Program (title II of the 1964 Act). Johnson's antipoverty planners believed the key to uplifting disfranchised and impoverished Americans was involving poor and marginalized citizens in the actual administration of poverty programs, what they called "maximum feasible participation." Community Action Programs would give disfranchised Americans a seat at the table in planning and executing federally funded social and economic development programs, for which they were meant to primarily benefit. The program deployed $\$ 350$ million in 1965 , a figure that skyrocketed to $\$ 1.1$ billion by 1969 . The "target areas" that received and administered these funds were 55 percent African American, and the program created more than one thousand Community Action Agencies. In 1969, the average Agency enjoyed a budget of $\$ 5.2$ million and employed 230 residents and staffers. ${ }^{92}$ These programs constituted a significant sea change in the nation's efforts to confront poverty and advanced a much more invasive - and visible - model of federalism in which federal regulations guaranteed minority access to poverty funding.

Lyndon Johnson, however, had in fact never conceived of impoverished Americans running their own poverty programs. While the President's rhetoric offered a stirring vision of the future, he had singularly old school notions for how his poverty policies would work. In contrast to "maximum feasible participation," the President imagined a second slate of New Deal works programs: local elite-run public works camps that would instill masculine virtues in

\footnotetext{
${ }^{92}$ Figures cited in Mollenkopf, The Contested City, 91.
} 
Cebul

unemployed young men. 'I'm going to put 150,000" idle young men "to work in ninety days'

time on useful hardworking projects," he explained on one occasion. "Teach them some

discipline and when to get up, and how to work all day ... I'll have them trained where they can

at least drive a truck instead of sit around a pool room." In an often-used refrain, Johnson liked to

quip, "I'm going to take tax-eaters and make taxpayers out of them." 93 Johnson's was hardly a

revolutionary vision of structural reform and racial inclusion.

Instead, Community Action almost entirely bypassed local administrations and sought to

build grassroots civil rights and community advocacy organizations, many of which had gotten

started thanks to the broader civil rights movement. ${ }^{94}$ Mayors like Chicago's Democrat Richard

Daley, key allies of the President, were furious. Daley phoned Johnson to complain that

Community Action participants were "trying to snatch . . . control of this country, control of

everything, just under this program. And the fact is and the truth of the matter is that they've

never had such a fine program in the history of our country." The idea that "only the poor can

control these programs,” Daley protested, “doesn't bear the right of logic.” As Johnson explained

to chief poverty aide Bill Moyers, he had envisioned recapitulating the New Deal's model of

cooperative federalism: local elites managing federal aid. Said Johnson, "I thought we were

\footnotetext{
${ }^{93}$ Quoted in Guian A. McKee, “The Government is With Us”: Lyndon Johnson and the Grassroots War on Poverty," in Orleck and Hazirjian, eds., The War on Poverty.

${ }^{94}$ For an overview of this relationship in the urban North, see Thomas J. Sugrue, Sweet Land of Liberty, 367-90.
} 
Cebul

going to have CCC camps ... I thought we were going to have community action [programs]

where a city or county ... could sponsor a project ... and we'd pay the labor and a very limited

amount of materials on it." 95 Rather than a New Deal model of federal partnership with local

elites that would advance a locally driven developmental agenda and put unemployed Americans

to work, Community Action seemed instead a frontal assault on New Deal federalism. Though

the Great Society in total, which comprised far more than its War on Poverty, spent around half

in real terms what the New Deal spent, its model of fiscal federalism was far more visible and

disruptive to local governing coalitions. While Johnson's policymakers hoped to inculcate new

voting habits and thus constituencies - the urban poor - for the broader Democratic coalition, by

creating alternative institutions, they instead sped fragmentation, both within the Democratic

Party and, in some cases, within marginalized groups themselves. ${ }^{96}$

Johnson and the mayors weren't the only Americans frustrated with community action

programs. While historians have identified how the War on Poverty's more tightly regulated

model of fiscal federalism challenged local political and social hierarchies, the programs also had

an important if unintended effect on civil rights organizations. ${ }^{97}$ Moderate members of the

Congress of Racial Equality, for instance, often became involved in the formation and leadership

\footnotetext{
${ }^{95}$ McKee, "The Government is With Us," in Orleck and Hazirjian, eds., The War on Poverty.

${ }^{96}$ Mollenkopf, The Contested City, 93-4.

${ }^{97}$ On the local use and controversies surrounding Community Action Programs, see Sugrue, Sweet Land of Liberty, $370-8$.
} 
Cebul

of federally funded Action Programs. For CORE chapters, which very often struggled to make

ends meet, these federally backed programs represented a golden opportunity to use outside

funding to advance their agendas. As a result, activists spent less time and energy organizing and

mobilizing for CORE. CORE was not the only group to experience this drain. CAPs often

generated contestation between local civil rights groups. In Cleveland, CORE officials felt it was

their duty "to 'watch dog' [the] federal program . . . so the money . . . is controlled in the right

ways," and they often bickered with the local NAACP over how best to represent the interests of

Cleveland's poor. A Columbus, Ohio CORE leader complained the War on Poverty "blew the

whole thing on CORE, which lost its identity" as an independent group. ${ }^{98}$

Indeed, Cleveland CORE was in dire financial straits, and so too was national CORE,

which faced a mounting debt that in February 1965 had reached $\$ 200,000$. This debt threatened

to fragment the national civil rights organization. CORE's associate national director complained

that it was "practically impossible to do anything beyond caretaker activities," and, in the fraught

political climate of the mid-1960s, "caretaker" efforts would not be enough to maintain unity. ${ }^{99}$

Over the winter of 1966-67, with the counsel of Clevelanders Ruth Turner (who had become

active protesting the failures of urban renewal housing) and Antoine Perot, national CORE leader

\footnotetext{
${ }^{98}$ August Meier and Elliott Rudwick, CORE: A Study in the Civil Rights Movement (Urbana, IL: University of Illinois Press, 1975), 364.

${ }^{99}$ Ibid., 334.
} 
Cebul

Floyd McKissick chose Cleveland as the city where they would try to breathe new life into a struggling CORE project called Target City. The project aimed to build black mainstream economic and political strength by generating cultural awareness and unity, and McKissick hoped eventually to export the model to chapters around the country. Following an April 1966 visit to Cleveland, the Call and Post, the city's African American weekly newspaper, summarized the thrust of McKissick's remarks: "during phase I [of the civil rights movement] CORE consistently pointed out the different problems and now through phase II they plan to formulate programs to solve the problems." ${ }^{100}$ Political power was at the top of the agenda. As McKissick explained it, he took aim at groups like the Chamber of Commerce: "although whites have, in many cases, moved to the suburbs from the cities they have not given up control of the economics and the politics of these cities."101 As Ruth Turner put it, since both white and black political leaders neglected the black community, black power meant "organizing ... the black community for the purpose of promoting the interests and concerns of black people." CORE's black power, she said, would generate black cultural cohesion in order to eventually realize political and economic power. ${ }^{102}$ Only then, when blacks could negotiate from strength and unity, would integration and meaningful economic progress be possible.

\footnotetext{
100 “CORE Leader Sparks New Civil Rights Coalition,” CP, April 23, 1966.

101 “CORE Leader McKissick Takes Leave of Absence,” CP, October 14, 1967

${ }^{102}$ Meier and Rudwick, 416.
} 
Cebul

Like CORE, the Ford Foundation was looking for new initiatives. In 1966, McGeorge

Bundy, national security advisor to Presidents Kennedy and Johnson, left government service to

head the Ford Foundation. In an effort to remake his legacy - tarnished by his involvement in

planning the Vietnam War - Bundy pushed the Foundation to develop new programs that overtly targeted marginalized minority groups, moving away from the colorblind ethos that had once dominated. As Historian Alice O'Connor has argued, Under Bundy, Ford aimed to "carry out" for government "the very functions it could not carry out on its own" - directly addressing structural and political disfranchisement. Staffers hoped, in fact, that these groups would offer the Foundation a chance to develop a truly robust version of "maximum feasible participation," the gold standard by which they measured community organizing. The Foundation solicited proposals for programs focused on "economic and educational advancement of disadvantaged minority groups."103

As always, for CORE, securing funding was crucial. As a Boston CORE leader put it, members, however, feared being forced to turn to "the much and properly maligned but

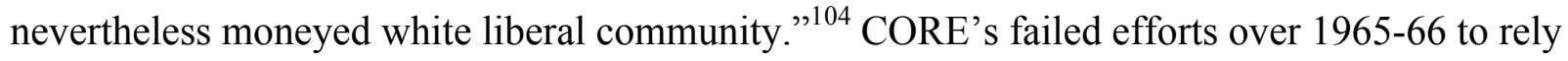

\footnotetext{
103 "Summary of December $23^{\text {rd }}$ [1965] Meeting of Domestic Program Directors." Attachment to Clarence Faust to McGeorge Bundy, March 17, 1966, Office of the President, Records of McGeorge Bundy, Series 2, Box 17, Ford Foundation Archives, New York, NY [hereafter FFA]. The Ford Foundation Archival Records are now held at the Rockefeller Foundation Archive Center in Sleepy Hollow, NY.

${ }^{104}$ Alan Gartner, chair of Boston CORE, quoted in Ibid., 336.
} 
Cebul

on the black community for donations had left the organization deep in debt and local chapters

were withering away. Desperate, McKissick turned to the Ford Foundation. ${ }^{105}$ Though they

rejected his first proposal, the Foundation encouraged him to develop a project aimed more

explicitly at community organization that might give African Americans a seat at the political

bargaining table commensurate to their numbers. In order to ensure CORE developed a fundable

program, the Foundation referred McKissick to the Metropolitan Applied Research Center

(MARC), a think tank geared toward strategic planning for civil rights initiatives. Founded by

Dr. Kenneth Clark with considerable financial support from the Foundation, MARC aimed to

unify civil rights groups through a sharp focus on economic justice. ${ }^{106}$ In June 1967, MARC held

a meeting outside New York City at which Martin Luther King, Jr., McKissick, Whitney Young,

Roy Wilkins, Bayard Rustin, and H. Rap Brown discussed ways to overcome their rivalries and

\footnotetext{
${ }^{105}$ Initially CORE sought money for marches and demonstrations to draw national media attention and perhaps garner indigenous black financial support for more ambitious Target City-styled projects. Under the counsel of its legal department, however, Ford denied McKissick's request. Understandably, the Foundation wanted no part of funding a series of demonstrations that might later be construed as a causal factor in riots most felt were all but inevitable. Cleveland CORE: Target City Assessment, August 1969, FFA, 6.

${ }^{106}$ Clark gained notoriety as the psychologist who attempted to prove the deleterious psychological effects of segregation for black schoolchildren in Brown v. Board of Education. As Daryl Michael Scott argues, Clark played an important role in advancing the "therapeutic ethos" among racial liberals who increasingly subscribed to notions of black pathology. See Scott, 122-25 and 137-38. Between March 20, 1967, the date of the first Ford grant to MARC, and April 30, 1972, the Ford Foundation provided \$1,147,790 in funding for MARC. Funded projects included support for conferences for black elected officials, fellowships and internships for Civil Rights leaders and students, "extensive pre-test coaching session[s] for Negro students taking foreign service examination," and a wide range of other programs and projects on equal opportunity for economics, housing, education, etc. FFA.
} 
Cebul

develop a shared plan of action. ${ }^{107}$ The civil rights elites announced they too would focus on

Cleveland and specifically target "voter registration ... [and] political action" in hopes of

electing an African American mayor. ${ }^{108}$ King planned to spend the summer in Cleveland

registering voters. ${ }^{109}$ As Bayard Rustin had hoped, the civil rights movement was moving from

protest to politics and eventually to economic opportunity. ${ }^{110}$

In granting $\$ 225,000$ for McKissick’s second Target City proposal, Ford hoped to foster "a reliable relationship" between CORE and the city's business and civic leaders. Indeed, Ford also delivered a $\$ 127,500$ grant to attorney Jack Reavis, of Jones Day Reavis and Pogue, to fund his Businessmen's Inter-Racial Committee, a program meant to foster interracial dialogue between business and black community leaders such as ministers and black business owners. Cleveland was especially attractive to the Foundation because, as Jim Cunningham, a Ford consultant in Cleveland put it, the "time is ripe for the political turmoil out of which can come favorable change." ${ }^{111}$ After spending time with leading Cleveland business people like Seth Taft,

\footnotetext{
${ }^{107}$ In addition, MARC used Ford Foundation funding to support Roy Innis' fellowship at the think-tank. Innis, an outspoken proponent of black power, would take over as director of CORE following McKissick's departure in the fall of 1967. Ford granted MARC $\$ 500,000$ for the fellowships; other grantees included Martin Luther King, Jr. and the Rev. Andrew Young. "Harlem CORE Leader Gets Research Fellowship,” NYT, May 12, 1967.

108 "Civil Rights Drive Planned in Cleveland" Chicago Tribune, June 15, 1967.

109 “Rights Leaders Hold Unity Talks; Map Effort to Ease Tension in Cleveland,” NYT, June 15, 1967.

${ }^{110}$ Bayard Rustin, "From Protest to Politics: The Future of the Civil Rights Movement," February 1965, accessed online, http://digital.library.pitt.edu/u/ulsmanuscripts/pdf/31735066227830.pdf.

${ }^{111}$ Cunningham Memo, March 14, 1967, 2 and 12, FFA.
} 
Cebul

Cunningham believed the "white power people of Cleveland['s] . . 'grand design' is to elect a competent Mayor, and back him up with business-supported community development." 112

CORE's "Target City" project, he wrote, "would not prevent riots in Cleveland ... They are coming anyway ... It would not end Negro poverty, or elect a Negro mayor. But it could help get the present Cleveland poverty program moving, and could help defeat the present hopeless Mayor." ${ }^{113}$ Ford's goal, then, was to make "it possible for CORE to operate within the system rather than become another SNCC," and to help deliver a mayor responsive to both neighborhood needs and business' development goals. ${ }^{114}$

Given the national civil rights leaders' and the Ford Foundation's considerable interest in voter education and registration in Cleveland, one might presume that Cleveland's black communities lacked political organization. Such was not the case. Carl Stokes, the three-term state House Representative who had called successfully for HUD to freeze Cleveland's Urban Renewal program, was a savvy and experienced politician who had nearly won the mayoral election in 1965 running as an Independent. He set his sights on another run in 1967, the summer Ford and CORE would roll out their Target City program.

\footnotetext{
${ }^{112}$ Ibid., 5.

${ }^{113}$ Ibid. 12-13.

${ }^{114}$ Cleveland CORE: Target City Assessment, August 1969, 17, FFA.
} 
Cebul

While Stokes planned to again run as an Independent (he knew the Democratic Party machine would not support a black candidate), the city's business leadership had their own plan.

With their help and funding, Stokes could win the Democratic primary and oust Locher. Then, in the general election the Chamber would switch their support to a Republican candidate in order to prevent the election of a black mayor. Their candidate would have a good shot at victory since they presumed many white ethnics would cross party lines rather than elect a black mayor. Longtime Chamber member Seth Taft moved into the city from suburban Pepper Pike to run on the Republican ticket. He assured Stokes he would not run if Stokes ran as an Independent. Stokes' hand was forced, and he entered the Democratic primary. ${ }^{115}$

Stokes made the almost total failure of Urban Renewal the centerpiece of his campaign, and he touted a color-blind, pro-growth agenda as the city's way forward, emphasizing the economic benefits of public investments in air and highway transportation infrastructure, in particular. ${ }^{116}$ Despite this moderate, no-nonsense stance, Stokes faced serious obstacles from within the Democratic Party. For decades white ethnic Party leaders had countenanced only token black participation. With the prospect of a black candidate at the head of the ticket and the potential emergence of serious black political influence, Democratic Party chairman Albert

\footnotetext{
${ }^{115}$ Nelson and Meranto, 114-5. See also Roldo Bartimoli, point of view, vol. 28, no. 13, 1996, available online, http://www.clevelandmemory.org/roldo/pdf/wheeib.pdf.

${ }^{116}$ Moore, 53-60; A key aspect of Stokes' pro-growth campaign was taking the initiative on air travel. "At Burke Lakefront Stokes Hits Failure To Develop Air Port,” CP, September 23, 1967.
} 
Cebul

Porter actively worked to undermine Stokes' campaign. Porter threw the Party's endorsement to

Mayor Locher, and, over the cries of the black community, he refused to hold an open

Democratic primary. As a result, Stokes was barred from appearing at any official Democratic

Party events. The strength of the city's Democratic machine was confirmed by the number of

black councilmen and ward leaders who, over the complaints of their constituents, refused to

buck the party line and host Stokes. William O. Walker, editor of the Call and Post, the

mouthpiece for middle class blacks, blasted one such councilman, George White, in an article

titled "Bought And Paid For Or Just Plain Stupid?" Walker pilloried White for admitting he

would "give Stokes token support because the people in my ward are going to vote for him, but

the Locher administration has been good to me, and I'm not about to bite the hand that feeds

me." ${ }^{117}$ Like White, black representatives across the city refused to invite Stokes to ward

meetings and debates, despite a groundswell of constituent support. ${ }^{118}$

Rather than abide this power broker, "custodial” behavior, as political scientist Adolph

Reed has called it, Cleveland's blacks made fighting for their fair share of the county Democratic

Party a central piece of a grassroots campaign. ${ }^{119}$ Voting for Carl Stokes would send a clear

message to "Boss" Porter that blacks had arrived as a potent political force. The Call and Post

\footnotetext{
117 “Bought And Paid For Or Just Plain Stupid?” CP, July 8, 1967.

118 “Dems Courage Falters, in Denying Stokes OK," CP, August 12, 1967.

${ }^{119}$ See, for instance, Adolph Reed, Jr., Stirrings in the Jug: Black Politics in the Post-Segregation Era (Minneapolis: University of Minnesota Press, 1999).
} 
Cebul

became a platform from which middle class blacks voiced discontent with their hollow

representation. As one op-ed title read, "That Did It Mr. Porter."120 The paper's columnists

described how the party machine subverted black interests, revealing how, even when a black

candidate was endorsed, it "was generally ignored by party functionaries in the cosmopolitan

wards through a loose form of gentleman's agreement." ${ }^{121}$ Throughout the summer, the Call and

Post advocated for and reported on "Rebel Democrats." One rebel, Naomi Wilcox, led a march

of Ward 10 Democrats and declared, "We feel Mr. Porter has made a racial issue out of this matter." ${ }^{122}$ Along with Wilcox, Mrs. Rosalee Benton, a Ward 13 Democrat, complained, "they

put the party ahead of the people ... and the voice of the people should be honored." Harold

Saxon, a candidate for city council, agreed, declaring at a rally that "the controls are outside the ward, rather than with the people, and this is outrageous - it's repulsive .... this power should rest with the people. ${ }^{\prime 123}$ Across the city, blacks demanded fair representation in the Democratic Party and, by extension, the city itself. ${ }^{124}$

In addition to fears that his candidacy would drive whites from the Democrats, Stokes worried that the "so-called Big Six" civil rights figures who had settled on Cleveland at the

\footnotetext{
120 “That Did It Mr. Porter,” CP, August 12, 1967.

121 “The Party Machine - How It Works," CP. August 12, 1967.

122 “In Protest Rally Ministers For Stokes Night For Ward 10 Dems, Sept. 1,” CP, August 27, 1967.

123 “Hit Porters Orders, Ward 13 Dems Revolt, Demand Stokes Speak,” CP, August 26, 1967.

124 “A Modest Proposal,” CP, September 2, 1967.
} 
Cebul

spring MARC conference would generate deeper opposition from white ethnics. ${ }^{125}$ Stokes had flown to New York in the spring to explain why "they could only bring problems for us." He beseeched King, "Martin . . . if you come in here with these marches and what not, you can just see what the reaction will be ... you're going to upset the balance we've created." ${ }^{126}$ Despite Kenneth Clark's assurances that "anything the organizations did would be in cooperation with local groups in Cleveland," the civil rights elites plunged ahead with their plans, brushing aside Stokes' fears. $^{127}$

Stokes' concerns were justified. Ford's grant to CORE and Stokes' national support became a highly salient campaign issue for Ralph Locher in the primary, just as they would for Republican Seth Taft in the general election (this despite Taft's behind the scenes support of Ford's grant to CORE). Both of Stokes' opponents highlighted the external financial assistance as well as the fact that Stokes had become the latest darling of the progressive left. ${ }^{128}$ Locher ranted, appealing to his base's localist and often-racist instincts. "New York City will never win an election [in Cleveland] as long as you support Ralph Locher," he cried, reminding white

\footnotetext{
${ }^{125}$ Carl B. Stokes, Promises of Power: A Political Autobiography (New York: Simon and Schuster, 1973), 100.

${ }^{126}$ Ibid., 101-2.

127 "Rights Leaders Hold Unity Talks; Map Effort to Ease Tension in Cleveland," NYT, June 15, 1967. Indeed, nowhere in Ford's and CORE's communications was the possibility of white backlash considered.

${ }^{128}$ Stokes received donations and well wishes from a wide range of prominent national figures including John Kenneth Galbraith, Quincy Jones, Jim, Brown, Bill Cosby, George Steinbrenner, and Clarence Avant. Galbraith apologized for his "rather academic-sized" contribution. See generally, folder 44, container 3, Carl B. Stokes Papers, Western Reserve Historical Society, Cleveland, Ohio [hereafter CBSP].
} 
Cebul

voters of "that wagonload of gold [that] has come ... from the Ford Foundation for the aid of

CORE and for the aid of having voters register. Not one nickel came to the [white ethnic] Fourth

Ward. Not one nickel came to most wards. But many, many thousands of dollars went to certain wards on a restricted, limited basis in this city." ${ }^{\prime 29}$ In Little Italy, the scene of violence in 1964 and 1965, Locher garnered "eighteen separate rounds of roof-raising cheers during a five-minute speech." ${ }^{\prime 30}$ Locher and Porter used the official Democratic Party newsletter for racial fear mongering. One headline read: "DICTATORSHIP IN CLEVELAND: PREVIEW OF STOKES AND MLK AS MAYOR. DO YOU WANT MLK AND HIS DISCIPLES RUNNING YOUR CITY?" 131 Ford's grant to CORE and the presence of civil rights elites had become a crucial factor in the mayoral campaign, but it was operating on behalf of the wrong candidate. Indeed, one angry white voter linked Stokes' primary victory to Ford's grant to CORE, saying, 'I'll never buy another Ford.",132

In his campaign, Stokes emphasized the staggering cost of Urban Renewal for his African American voting base, and he also hoped to generate support from white ethnics, too, who felt urban renewal and other federal programs disproportionately burdened their communities. In

\footnotetext{
${ }^{129}$ Quoted in Zannes, Checkmate in Cleveland, 57.

${ }^{130}$ Ibid., 58.

${ }^{131}$ White anti-Stokes groups sprang up on the South and West sides of the city. One group, calling itself the Save Our Homes Committee warned that "City Hall will be 'open to 'Civil Rights' leaders Mr. King, Stokely Carmichael \& Rap Brown and revolutionaries in the event of Mr. Stokes' election . . ." Moore, 57.

132 “The Making of a Mayor,” PD, December 10, 1967.
} 
Cebul

order to better connect the downtown with the city's growing suburbs, in the late 1950s and early 1960s Cleveland built the Willow Freeway - an extension of Interstate 77 - through the western portion of the Broadway neighborhood. Funded predominantly with federal transportation funds, the freeway construction razed 350 homes and many small businesses. Rose Stepanek owned Stepanek's Grocery. She mourned the loss of the neighborhood's ethnic character. Years earlier, she recalled, "that's all you heard in the store. Czech and Slovak and Polish. Now it's an occasion if you do ... I've lost business, you see."133 Yet, the white homeowners who stayed behind were more concerned about protecting their home values, and the prospect of a black mayor seemed to auger new threats to their bottom line. Indeed, thanks to decades of discriminatory federal housing policy, whites perceived a link between their homes' value and the racial homogeneity of their neighborhoods, homogeneity that was now under attack by federal fair housing laws and public housing developments. ${ }^{134}$ This highly visible development in federal housing policy seemed to threaten the 'natural' or market-won results decades of federally structured mortgage markets, especially mortgage-based retirement nest eggs and inheritances. $^{135}$

\footnotetext{
133 "Progress Wounds ... But it Also Heals: Old Broadway Is Fading for Willow Freeway,” PD, June 5, 1965.

${ }^{134}$ On racial segmentation of mortgage markets, see Thomas J. Sugrue, The Origins of the Urban Crisis and David. M.P. Freund, Colored Property.

${ }^{135}$ On housing policy and racial innocence, see Matthew Lassiter, The Silent Majority.
} 
Cebul

A young ethnic politician made opposition to federal fair housing programs the centerpiece of his successful campaign for Ohio congress. George Voinovich, a Republican and the son of a Slovenian and a Croat-Serb, was elected to the Ohio state house in 1966 carrying an urban district in Cleveland that over the previous decades had turned out 2-1 for the Democrats. The Plain Dealer reported that “the 'white backlash' chewed up Democratic liberals," and, indeed, Voinovich rode a wave of angry homeowners' activism. ${ }^{136}$ Voinovich's election, the newspaper concluded, was "perhaps the outstanding case of an issue holding sway." ${ }^{137}$ In Voinovich's district, which included working class neighborhoods on the northeast side of the city and the blue-collar suburb of Euclid, ethnic homeowners were organizing to protect their home values by guarding the neighborhood's class-based and racial homogeneity.

Voinovich worked to link his supporters to the Republican nominee for Mayor in 1967, the lawyer Seth Taft. Voinovich supporters Frank and Molly Kochevar organized residents in Cleveland's heavily Slovenian Collinwood neighborhood. Their Waterloo Beach Homeowners Association (WBHA) was one of the first of its kind in the city, and the group reflected the growing sentiment - and political clout - among the city's increasingly frustrated white middle and working class homeowners. By the fall of 1967, 2,700 families in Ward 32 had joined the

\footnotetext{
${ }^{136} P D$, November $10,1966$.

${ }^{137}$ The city of Euclid, of course, was no stranger to land use controversies. For a comprehensive discussion of Euclid v. Ambler, see Michael Allan Wolf, The Zoning of America: Euclid v. Ambler (Lawrence: University of
} Kansas Press, 2008). 
Cebul

Kochevar's Association. Politicians frequently spoke before the WBHA, covering issues from law and order to homeowner rights to the outrages of the Supreme Court's liberal judicial activism. As long-serving Ohio Republican Congresswomen Frances Bolton put it to the group, the bench had become "far from nonpolitical and far from weak." She called for restoring "the balance of our federal system.."138 During the 1967 mayoral campaign, the Association garnered appearances by Republican Seth Taft, too. Two weeks before the election, Taft solicited the Association's endorsement at a gathering at the city's Slovenian Home on E. $156^{\text {th }}$ St. in Collinwood. Voinovich helped deliver their support. Taft responded to residents' concerns about safety and promised neighborhood police patrols every fifteen minutes and five-minute response times for emergency calls. He pledged as well that his City Hall would strictly enforce housing codes, a signal that he would strive to keep poor and minority citizens out. ${ }^{139}$

In Cleveland's black communities, Stokes' staffers emphasized one self-evident campaign tactic: "Keep it cool for Carl." They knew that massive demonstrations or violence would all but kill Stokes' chances. At one gathering, Rev. Alfred Walker exhorted thousands not to "get mad, [but to] get smart, and ... prevent riots." At the same rally the Reverend. E.T. Caviness appealed to militant nationalists, saying, "Certainly, we've pushed the soul brother concept too far, for nobody is our brother who wants to burn down our homes, our schools, and

\footnotetext{
${ }^{138} P D$, October 9, 1968.

${ }^{139} P D$, October 11, 1967, and PD, October 15, 1967.
} 
Cebul

our churches ... and when we chase the white man out today, simply because he is white,

tomorrow I know you may chase me out simply because I may not agree with you." ${ }^{140}$ Even

Ahmed Evans, a prominent Nationalist leader and separatist, became a registered voter on behalf

of Stokes (though rumors swirled that Stokes and, during the primary, the city's business

leadership paid Evans and other radicals to keep quiet). ${ }^{141}$ The Stokes campaign developed an

organizational structure that eventually deployed 4,000 campaigners. ${ }^{142}$ As opposed to CORE's

fruitless efforts at fundraising within the African-American community, Stokes received

considerable financial support from Cleveland's working and middle class blacks. A group of

dentists, "Dents for Stokes," held a series of fund-raising dinners and dances. In chain-letter

fashion, women enlisted community members to donate just one dollar each - one group called

themselves "Thins for Stokes" and another "The Feminine Touch." In two weeks Thins raised

$\$ 24,000$, while The Feminine Touch aimed for $\$ 46,000$ by the campaign's end. ${ }^{143}$ Cleveland's

black community was organizing in ways unimagined by the Ford Foundation and CORE.

\footnotetext{
140 "Mass Rally Calls For Positive Action.” CP, August 5, 1967.

${ }^{141}$ Roldo Bartimoli, point of view, vol. 28, no. 13, 1996, available online, http://www.clevelandmemory.org/roldo/pdf/wheeib.pdf.

142 The campaign appointed block supervisors, perhaps thirty or forty per city ward, who reported to one of three or four ward supervisors, who received directives from the ward captain who, in turn, kept in close contact with Stokes' campaign leaders. Nelson and Meranto, 125.

${ }^{143}$ Laurette White, “Dents For Stokes Is Elegant Fare,” CP, September 16, 1967; Nelson and Meranto, 127, and ‘The Feminine Touch’ In Dollars For Stokes Drive,” CP, September 16, 1967.
} 
Cebul

Instead of deliberate and careful planning, community research, and neighborhood

outreach, at local CORE "the main objective was to hit the ground running" on behalf of

Stokes. ${ }^{144}$ National CORE, however, sent Wilfred Ussery, a young San Francisco activist with no experience in Cleveland and not much more in organizing, to run the program. ${ }^{145}$ As a later assessment explained, “it was all but impossible for anyone to have given careful attention to issues of organization and administration because . . of the Stokes mayoralty campaign." Two weeks after Target City began operations - in the middle of the primary campaign - CORE simply did not have the personnel or infrastructure in place to deliver on their hopes for the voter drive. ${ }^{146}$ Faced with such robust indigenous political action, CORE later admitted that it was mired in confusion and frustration from the start. ${ }^{147}$ Just days before the close of voter registration, Thornton Weber, a local CORE member, gave a sober appraisal of the group's registration results: "It's a very small number, not more than two dozen . . . and we're just getting our car pool started." ${ }^{, 48}$ CORE designated $\$ 25,484$ of its grant money for the voter

\footnotetext{
${ }^{144}$ Cleveland Target City Project Evaluation, August 1969, 33, FFA.

145 One consultant worried Ford missed its chance to "head off" the misguided appointment of Ussery. Memo to McGeorge Bundy, David Bell, and “TES” from John R. Coleman, July 20, 1967, FFA.

${ }^{146}$ Ibid.

${ }^{147}$ CORE Target City Cleveland Project Funding Proposal, April 10, 1968, 16, FFA.

148 “Car Pools Take Thousands to Register for Primaries,” CP, August 12, 1967.
} 
Cebul

projects, while the Stokes campaign spent $\$ 240,000$ - ten times CORE's total election budget on advertising and media appearances alone. ${ }^{149}$

In the general election, Stokes figured to receive an electoral boost within the white community simply because of his Republican opponent's last name. Seth Taft, a leader at the Chamber of Commerce, was the grandson of President William Howard Taft and the nephew of “Mr. Republican” Senator Robert Taft, co-sponsor of the anti-labor 1947 Taft-Hartley Labor Act. In such a blue-collar labor-oriented city as Cleveland, voters were initially suspicious of the big business lawyer who had moved back to the city to run for Mayor. Indeed, Stokes enjoyed an initial eighteen percent lead, buoyed by primary endorsements from the city's major newspapers. As the campaign wore on, however, race emerged as the central theme and the mild-mannered Taft learned to adopt the "white ethnic" strategy employed by Locher. Taft staffers sent flyers to the city's ethnic constituents encouraging them to "protect our way of life and to protect Cleveland, the citadel of nationalities in America ... Taft and Taft alone can give Cleveland back to the law-abiding citizenry." ${ }^{, 150}$ These divisive appeals worked. Working class white ethnics embraced racial fears over class animosity or partisan loyalty. Taft trailed Stokes by a distant margin at the outset, but five days before the election, a Plain Dealer poll reported a

\footnotetext{
${ }^{149}$ Cleveland Target City Project Evaluation, August, 1969, FFA, 23; Financial Materials, 1967-69, Series II, folder 78, container 5, CBSP; Weinberg, 82.

${ }^{150}$ Nelson and Meranto, 158.
} 
Cebul

virtual dead heat: Stokes at 50.1 percent, Taft with 49.9 percent. $^{151}$ In an agonizingly close

election - one that went to a recount and only became closer - Stokes won by a margin of 1,679

votes, 129,396 to 127,717 . Blacks formed a solid block and voted for Stokes, but seventy percent

of the city's white Democrats crossed party lines to vote for the Republican candidate. This was

an unprecedented and portentous defection in Cleveland electoral history. ${ }^{152}$

\section{CLEVELAND:NOW!}

Despite having run a candidate against him, in the spring of 1968, Stokes won the

cautious support of the city's business leaders when he helped keep African American wards

peaceful the night of Martin Luther King, Jr.'s assassination. During his campaign, Stokes had

maintained a close relationship with the city's leading proponents of Black Nationalism. His

campaign made "contributions" to their causes, which in turn secured their support of the "Keep

it Cool for Carl" message. Following his election, Stokes continued this relationship through

limited public support for the leaders' projects such as black cultural centers. As a result,

nationalists like Baxter Hill and Harlell Jones joined Stokes in peacefully walking the

\footnotetext{
${ }^{151} P D$, November 2, 1967.

${ }^{152}$ Cho, 414. The controversy over Ford's funding of CORE led to the 1969 Tax Reform Act. Conservatives and others across the country worried that McGeorge Bundy and the Ford Foundation had bought Stokes' election, and the Act significantly restricted foundations' political activities. While historians have largely credited Ford and CORE with pushing Stokes over the top, the opposite was true. Instead of merely underwriting black political organization, Ford and CORE contributed to and accelerated potent and lasting white electoral backlash that would constrain and ultimately defeat Stokes' mayoralty and stymie business' developmental agenda.
} 
Cebul

neighborhoods following the devastating news from Memphis. Stokes also made the canny decision to remove white police officers from beats in black neighborhoods.

Stokes parleyed the good will of the city's business leaders into a massive city revitalization plan called Cleveland:Now! As Leonard Moore, Stokes’ biographer, put it, the Mayor's "versatility puzzled some, as they marveled at how he was able to speak the language of both the boardroom and the poolroom." ${ }^{\prime 153}$ At his initial meeting with the head of Republic Steel, the owner of the Cleveland Indians, and the president of May Company (one of the city's major department stores), Stokes secured their commitment to spur private sector employment for thousands of hardcore unemployed as well as a $\$ 10$ million commitment of development seed funding. With these initial funds, Stokes hoped to advance an agenda that might include both downtown business leaders and his African American base through a mix of spending programs that could offer something from everyone. Stokes also kept the business community motivated by exploiting their fears of black violence. ${ }^{154}$

On May 1, 1968, Mayor Stokes detailed the plans for Cleveland:Now!, a vigorous new public-private partnership. The city would offer generous tax subsidies and abatements for downtown business development, seek to restore federal urban renewal funding for Erieview, and deliver massive new funding for public housing, social services, and education. Along with a

\footnotetext{
${ }^{153}$ Moore, 72.

${ }^{154}$ Moore, 75.
} 
Cebul

new convention-oriented luxury hotel and improvements to the lakefront, Chamber members

were particularly interested in developing commercial ventures in a run down industrial area near

the mouth of the Cuyahoga River known as the Flats. All told, Stokes' plan aimed to create

16,000 new jobs and offer initial subsidies for business development for the Flats and the stalled

Urban Renewal project. ${ }^{155}$ From the get-go, Stokes worked closely with the Chamber of

Commerce to find tenants for Erieview and for the project's other planned buildings. ${ }^{156}$ Business

leaders took out a full-page ad in the Wall Street Journal trumpeting the new leadership in the

nation's eighth largest city. ${ }^{157}$ In total, Stokes envisioned $\$ 1.5$ billion of public and private

contributions over ten years, with $\$ 177$ million earmarked for the first two. Of the total, Stokes

had secured $\$ 143$ million in federal commitments. He even convinced the city council to raise

the city income tax, and voters approved a new $\$ 100$ million bond issue to improve city

infrastructure, for which the Mayor secured the Chamber's endorsement as well. Longtime

Chamber stalwarts George Dively and John Sherwin headed up the effort to raise \$10 million in

business contributions. At that first press conference, Stokes announced the city had already

\footnotetext{
${ }^{155}$ Moore, 72-4.

${ }^{156}$ Board of Directors Meeting Minutes, November 29, 1967, Volume 1967-1968, Container 165, GCGA.

${ }^{157}$ Roldo Bartimole, "Who Governs? The Corporate Hand," in Keating, et al, eds, Cleveland: A Metropolitan Reader, 165.
} 
Cebul

secured \$5 million in private commitments. Things seemed to be looking up for Cleveland. "This time things are different," the Cleveland Press exclaimed. ${ }^{158}$

The opening days were, indeed, auspicious. In Cleveland's black community especially, spirits were high. "He’s the best damn mayor Cleveland ever had," one resident declared. Cleveland:Now! another resident said, was a "wonderful program . . . we should have had someone like Mayor Stokes years ago.” Indeed, as summer approached, Stokes was especially pleased that his Summer Youth program would be fully funded, offering otherwise idle black teens employment. With the one percent income tax issue approved by voters, Stokes hoped to raise city workers' pay, engendering good will among the city's predominantly white bureaucracy and police force. By July of 1968 , Stokes had become a national media darling. ${ }^{159}$ The honeymoon ended abruptly. Once Cleveland:Now! was underway, Stokes again spread funds throughout the community. Groups like Baxter Hill's Pride, Inc. and Ahmed Evans' Black Nationalists of New Libya received grants for African cultural centers. In addition to his cultural programming, however, Evans used some of his $\$ 10,300$ grant to rent an apartment in Glenville where he and his compatriots began stockpiling weapons. The building owner discovered their growing cache and notified the police, who had a long history with Evans. On July 23, after Evans threatened police inspectors at the apartment, the Mayor's office had

\footnotetext{
${ }^{158}$ Moore, 74.

${ }^{159}$ Ibid., 76-7.
} 
Cebul

Glenville's City Councilman George Forbes confer with Evans. Evans promised to keep the peace. Some hours later, however, Evans and his associates mistook two white tow truck drivers for police and opened fire, inviting returned fire from police who descended upon the area. With their heavy artillery, the New Libya members killed three police officers, even managing to detonate a patrol car.

In the Glenville shootout, seven Clevelanders - three police officers, three New Libyans, and one bystander - lost their lives. In response to a harsh police crackdown across Glenville, black youths looted white properties, moving east along Superior Avenue and west toward Rockefeller Park. The epicenter of the looting and burning was along East $105^{\text {th }}$ Street, but it stretched a mile north of Superior and as far west as East $55^{\text {th }}$ Street. The following day, Stokes again moved to keep white officers from patrolling the black neighborhoods, but the response this time from the majority of the force was violently opposed. "Fuck that nigger mayor," said one officer. "Tell Stokes to go piss on it," said another. Despite this response, the all-black peace keeping effort ultimately held. ${ }^{160}$

What did not hold together, however, was Cleveland: Now! In the aftermath of the shooting, it was quickly revealed that Stokes' grants to Evans been used to purchase the weapons and artillery used to kill city cops. ${ }^{161}$ A Stokes ally later explained, "The funds allocated to

\footnotetext{
${ }^{160}$ Moore, 88.

${ }^{161}$ Moore, 80-5.
} 
Cebul

Ahmed were a sincere effort by those involved to give him and his associates the opportunity to work in a positive way in the community." ${ }^{\prime 162}$ All the sincerity in the world would not win back the support of Cleveland's business community, however, convinced now that not even an African American mayor could keep black neighborhoods quiet. ${ }^{163}$

Stokes barely won reelection in 1969 , but morale was so low and the city so fractured that his relationship with the ethnic-dominated city council ground to a halt. Stokes simply stopped going to council meetings, and rumors circulated the Mayor had developed a serious martini habit that began over lunch each day at the New York Spaghetti House and extended well into the evenings. Stokes had run up against the limits of the white majority's willingness to support a developmental agenda that empowered African Americans. With a lame duck and increasingly ineffectual mayor in office, both groups, ethnics and business, strategized paths to power. As the city's dominant groups - white ethnics, African Americans, and business

\footnotetext{
162 Kerr, 174.

${ }^{163}$ Yet, if the rumors within the black community were true, business leaders were hardly blameless. During Stokes' 1967 primary campaign against Locher, city business interests including Ralph Besse, head of CEI had quietly bribed leading nationalist organizations such as Ahmed Evans, running funds through the offices of the Call and Post. Meanwhile Besse's compatriot Jack Reavis, managing partner of Jones, Day, Cockley, and Reavis, financially supported a third candidate in the Democratic primary, Frank Celeste, in hopes that his candidacy would help split the white vote, ensuring Stokes' victory. After Stokes won the primary, Besse and Reavis abruptly stopped payments and focused on getting Taft elected. Their withdrawal of the bribes may not have signaled their interest in renewed violence, but, if there had been riots, Taft's election would have been all but assured. Roldo Bartimole, “Keeping the Lid On: Corporate Responsibility in Cleveland,” Business and Society, February 27, 1966.
} 
Cebul

leadership - continued sparring into the 1970s, it had been nearly a decade since Cleveland had a dominant developmental vision in place.

In 1971, Cleveland elected a white ethnic Republican mayor. Ralph Perk brought conservative ethnic values first espoused by Democrat Frank Lausche into the Republican Party: fiscal conservatism (low taxes paired with a critique of Stokes' pursuit of corporate tax abatements) and law and order values (Lausche targeted union corruption; Perk highlighted racialized concerns about crime). Perhaps most distinctive, however, was Perk's updated version of ethnic nationalism. While an earlier generation of ethnics had emphasized nationalism in terms of restoring their Soviet-dominated birth countries, Perk redeployed ethnic nationalism in the fraught late 1960s to emphasize the ways ethnic immigrants and their values offered the best path for American salvation. The Americans of "nationality descent" who arrived in the United States after World War II, Perk argued, possess "governmental philosophies and ideals ... compatible to the principles of the Republican Party ... Because of their painful experience with totalitarian systems, they do not take freedom for granted. They stand for free enterprise and against federal controls, because, in the old country they learned that without economic freedom there is no political freedom." "Nationalities," Perk explained to audiences across the country, "are the heart and core of our history. They have laid the foundation of our future and have 
Cebul

become the cornerstone for [our] culture."164 Perk situated his brand of political ethnic

nationalism not as a side project to American nationalism, but as its very essence and salvation.

While the city's business leaders had awoken to the structural economic crisis facing the city,

their unwillingness to continue their partnership with Stokes doomed Cleveland:Now! With a

populist, small government, fiscal conservative ethnic in the Mayor's office, the Chamber of

Commerce faced further obstacles to implementing their developmental vision. Structural

decline continued apace.

${ }^{164}$ Speech by Ralph J. Perk at Woodrow Wilson School - Princeton University, May 3, 1968, Folder 2, Container 1, Ralph J. Perk Papers, Western Reserve Historical Society, Cleveland, Ohio. 
Cebul

\section{Section II}

\section{Deregulating the War on Poverty}

"People on the [nearly all white] west side don't want Model Cities anyhow. I can always get some other program.”

- Cleveland Mayor Ralph Perk, 1972

"You know firsthand the frustrations of dealing with a bureaucracy too often concentrating on the more vocal complaints of urban and industrial areas."

- Georgia Governor Jimmy Carter, 1971

"The idea that a bureaucratic elite in Washington knows best what is best for people everywhere and that you cannot trust local governments is really a contention that you cannot trust people to govern themselves. This notion is completely foreign to the American experience. Local government is the government closest to the people, it is most responsive to the individual person. It is people's government in a far more intimate way than the Government in Washington can ever be."

- President Richard Nixon, State of the Union, January 22, 1971 
Cebul

\section{Chapter Five}

Deregulating the War on Poverty in Cleveland

"I believe there is a great potential of strength among the nationality groups," declared

Ralph J. Perk in 1965, "a strength which if unified can exert great force locally and nationally."1

Speaking to a packed audience of white ethnics at Cleveland's Bohemian National Hall, Perk set

his sights high: "We must never be tagged against something, but always for things like freedom

... We will see ... unity [among] nationality people. It will start here in Cleveland and will

spread throughout the country."2 In 1965, with Cleveland's manufacturing base drying up and its

African Americans mobilizing within the Democratic Party, Perk, a Czech-American and, since

1961, the County Auditor, sought to move the city's ethnic constituencies into the essentially

dormant local Republican Party through his organization, the Nationalities Movement of

Cuyahoga County. ${ }^{3}$ After another meeting of over a thousand ethnics at the Sheraton Hotel, the

\footnotetext{
${ }^{1}$ Perk quoted in History: “The Nationality Movement of Cuyahoga County,” undated, folder 2, Container 1, Ralph J. Perk Papers, Western Reserve Historical Society, Cleveland, Ohio [hereafter RPP].

${ }^{2}$ History: The Nationality Movement of Cuyahoga County, undated, folder 2, Container 1, RPP.

${ }^{3}$ Self styled "moderate" business people in the South pursued a similar tactic, taking over inactive Republican Party apparatuses, in the face of increasingly hostile, segregationist actions by Democratic Party leaders. See Joseph Crespino, In Search of Another Country.
} 
Cebul

Rev. Leon Telesz ordained Perk the leader of a movement: "we are developing a new man for the future leadership in the City of Cleveland."4

Between 1965 and 1971, ethnics' and business leaders' response to the War on Poverty and Carl Stokes' mayoralty rapidly changed the tenor and stakes of Cleveland politics. Whereas once “caretaker” Democratic mayors such as Anthony Celebrezze or Ralph Locher had pursued unremarkable allocational politics, shunting benefits to their core constituencies and working constructively if unsophisticatedly with the city's business leadership, mobilized African Americans and federal policies that seemed to stack the decks in their favor altered each group's calculus. ${ }^{5}$ Indeed, while working class ethnics had been at the heart of relief unrest and home foreclosure riots during the Depression, they now invoked individualism and self help to reject forms of public support and political empowerment for the city's impoverished African Americans. And, in the context of mounting inflation, industrial and residential outmigration, and the corollary dwindling of city tax revenues, businesspeople and ethnics increasingly construed city services and developmental programming in zero sum terms. ${ }^{6}$

\footnotetext{
${ }^{4}$ History: The Nationality Movement of Cuyahoga County, undated, folder 2, Container 1, RPP. On white ethnic political and cultural reassertion more broadly during the 1960s and 1970s, see Matthew Frye Jacobson, Roots Too: White Ethnic Revival in Post-Civil Rights America Cambridge: Harvard University Press, 2006).

${ }^{5}$ On "allocational" politics, see Paul Peterson, City Limits.

${ }^{6}$ On the impact of inflation on popular politics in the 1970s, see Bruce J. Schulman, The Seventies, 129-43. On its impact on national policymaking, see "Exorcising Inflation-Mindedness: The Transformation of Economic Management in the 1970s," in David Brian Robertson, ed., Loss of Confidence: Politics and Policy in the 1970s. See also Jefferson Cowie, Stayin’ Alive, 222-7.
} 
Cebul

At the national level, a similar contestation played out, as Richard Nixon invoked the “silent majority," implicitly running against noisy minorities. This political appeal shaped

Nixon's policymaking, too. His New Federalism explicitly aimed to deregulate the War on

Poverty and, under the guise of continuing to fight poverty and blight, to move control of these federal revenues away from minority groups and toward a much broader base of voters, government officials, and private interests. By creating Community Development Block Grants, which bundled together a range of development programs such as Urban Renewal and the War on Poverty's Community Action and Model Cities, Nixon re-framed the New Deal's model of developmental state fiscal federalism - loosely regulated federal funds controlled locally by elected officials and their allies in the business sector - as a conservative innovation. ${ }^{7}$ Such an approach had broad appeal, among suburbanites, ethnics frustrated with government's seemingly unfair minority support, and business interests, with whom the Administration explicitly consulted in its reforms. ${ }^{8}$

Exploring these developments on the ground in Cleveland reveals the consequences for fighting poverty and blight at precisely the moment when neighborhood groups had mobilized to

\footnotetext{
${ }^{7}$ On Nixon's efforts to use fiscal federalism to create a new political majority, see John Mollenkopf, The Contested City,123-34; and, generally, Timothy Conlan, From to Devolution.

${ }^{8}$ The best work on Nixon's "Silent Majority" appeal places its effectiveness among suburbanites especially. See Matthew Lassiter, The Silent Majority, introduction and 221-9.
} 
Cebul

claim their rightful place within the developmental state. ${ }^{9}$ Indeed, at the same time that local

officials and national policymakers deregulated and rerouted poverty funding, Nixon's “New

Federalism" maintained a rhetorical commitment to fighting poverty. In so doing, New

Federalism inaugurated a process in which local parties, public or private, interested in federal aid learned to frame their appeal not in terms of economic development but in fighting poverty.

\section{White Ethnic Mobilization}

Though it was decidedly not family or holiday fare, Dirty Harry made its national debut

three days before Christmas, December 22, 1971. That winter, the Clint Eastwood cop-shoot-emup jump-started a whole new Hollywood genre. Americans flocked to theaters to watch Harry Callahan deal out street justice with his trademark Smith and Wesson .44 Magnum. That particularly nasty gun in the hands of a classic American character - a Shane for the 1970s seemed tailor made for a society on the brink. Called Dirty Harry for his ability to handle any job no matter how murky, Callahan was the ultimate working class hero for a working class that gazed uneasily upon insurgent groups and institutions that seemed about to shred the social, moral, and economic fabric. Faced with an American melting pot that seemed boiling out of

\footnotetext{
${ }^{9}$ On neighborhood organizing more broadly, see Suleiman Osman "The Decade of the Neighborhood" in Schulman and Zelizer, eds., Rightward Bound. There is a growing literature on efforts to roll back the welfare state. See, for example, Marissa Chappell, The War on Welfare.
} 
Cebul

control, Harry Callahan - of Irish decent himself - hated them all. Says one cop, "that's one thing about our Harry, he doesn't play any favorites. Harry hates everybody. Limeys, Micks, Hebes, Fat Dagos, Niggers, Honkies, Chinks, you name it.” When Gonzalez, Harry’s new MexicanAmerican partner, asks him whether he hates Mexicans, too, Harry is unequivocal: "Especially Spics." Harry's hate, however, would have been seen by Cleveland's ethnics as curmudgeonly and fraternal, akin to their shop floor-ese - racism with a smile.

Harry's personal code underscored the growing clash of values that characterized the decades to come and which increasingly pivoted on who deserved to benefit from government policies and protections. Indeed, Dirty Harry was one of the first pop-cultural expressions of populist anger at liberal judicial and legislative decisions and played an important role in popularizing more conservative views. When Harry finally nabs the preposterously evil Scorpio (who might have been a suburban kid turned deranged hippy turned serial killer), the District Attorney (who seemed plucked from central casting's 'elitist liberal professor' bin) scornfully rebukes Harry for his illegal search and seizures that led to Scorpio's apprehension. "Where have you been?" he asks Harry. "Does Escobedo ring a bell? Miranda? I mean, you must have heard of the Fourth Amendment. What I'm saying is that man had rights." And those rights and Harry's wrongs conspire to set Scorpio free. As Harry's eyes harden, the audience must have shared his disbelief that American laws had swung so far to protect the unworthy at the expense of the 
Cebul

innocent, the just, and the hardworking. A little vigilante justice from Harry was in the offing.

Dirty Harry and the Hollywood genre it spawned were fictionalized reminders of just how off-

kilter American institutions increasingly seemed. In Cleveland, Dirty Harry stayed on cinema

screens for a full year, throughout 1972 .

Hungarian American Clevelanders, the majority of whom lived along Buckeye Road on

the city's east side, were literally up in arms over their neighborhood's deterioration and many

surely identified with Harry. "Have you heard?" went a joke making the rounds. "There are more

German shepherds here now than Hungarians." The police - and their dogs - had frequently

been called in to settle outbursts of racial violence, and Buckeye's white residents were incensed

about rising crime and the neighborhood's growing African American population. Despite the

police presence, the situation was only growing worse. Deeply unnerved by the changes but

unable or unwilling to move out, as had so many other whites, many neighborhood stalwarts

began carrying weapons.

Stokes' election in 1967 only deepened Buckeye's Hungarians' feeling of abandonment

and isolation; they were alienated from the city's new mayor and felt exposed by the city's

impotent police force that seemed always to be reacting to rather than preventing crime. As an

older resident put it, "If we'd have a Hungarian mayor, he'd take care of us. The black mayor 
Cebul

takes care of them." ${ }^{10}$ Despite having moved to the city's almost entirely white west side,

manufacturing plant inspector Michael Zan organized a citizen patrol effort for his old

neighborhood. Zan claimed he was forced to move out after blacks had burned down his house

and assaulted his wife on four occasions. Some, the city's police chief among them, accused him

of vigilante tactics and targeting black residents. But Zan objected. He had come to the United

States after the 1956 Hungarian revolution. Hungarians, he said, "are not racists. I grew up in

Hungary. I wasn't indoctrinated with the feelings Americans grow up with. How could I be racist

when I didn't see any Negroes in Hungary?"11

Not all Hungarians denied having racial motivations. A group of thirty or so young

Hungarian Americans calling themselves the Buckeye Boys terrorized the neighborhood's black

homes and businesses, crossing the line from Dirty Harry-style vigilante justice to outright

criminality. They repeatedly smashed the front window of a black realty company, Sir Rah's,

whose owner also received frequent threatening phone calls. Other black-owned businesses had

paint splashed on their storefronts, and African Americans' homes were targeted in the night

with potshots, bb guns, and bricks. Nazi swastikas and spray paint scrawls of "White Power"

were not rare sights on the street signs along Buckeye Road. A "sense of communist infiltration

into the civil rights movement," pointed out Sister Loretta Ann Madden, “ is . . . deeply ingrained

\footnotetext{
10 “Buckeye Road, Neighborhood of Fear,” PD, January 18, 1971.

${ }^{11}$ Ibid.
} 
Cebul

into the nationality groups." The Buckeye neighborhood was typical, and Sister Roberta

Steinbacher lamented that it "was just impenetrable" because its residents refused to cooperate with blacks to solve the community's problems. As historian John McGreevy has argued, church and foundation efforts to bridge the racial divide merely exposed a crisis of local authority and the futility of interracialism that characterized the late 1960s in urban parishes across the industrial North. ${ }^{12}$

The emerging consensus among the city's working class whites was against liberal elites' - suburban and national - meddling in local affairs. In the pages of the city's Catholic Universe Bulletin, Cleveland's Bishop William Cosgrove blamed liberal suburbanites for "parasitically" abandoning the city, gutting its tax base, and pitting the city's whites and blacks "against each other to avoid facing responsibilities." ${ }^{, 13}$ Father Andrew Greeley, the nationally syndicated columnist and sociologist, wrote frequently on the topic of ethnics' resentment of liberal elites who claimed political unrest was simply the result of ethnics' racism. In one column entitled "Nonsense about 'white ethnics," Greeley savaged the Democratic liberal elite with his trademark sarcasm: "the Poles and Italians and Irish were the ones who brought slaves to the New World, treated them as three-fifths of a human being in the U.S. Constitution, agreed to the Jim Crow national compromise of the 1880 's, and have grown wealthy and powerful by keeping

\footnotetext{
${ }^{12}$ McGreevy, Parish Boundaries, ch. 9.

${ }^{13}$ Cleveland Catholic Universe Bulletin, May 29, 1970.
} 
Cebul

blacks in their place! ... Never mind," Greeley wrote, "the fact that even though it is the ethnic schools, jobs, neighborhoods and churches which the liberal elites have decreed must be surrendered, the reaction of ethnics has been astonishingly mild ... You," liberals, "can have a Panther to supper and persuade yourself that you're not a racist. But those Poles, they certainly are. ${ }^{14}$ Like their working class and poor white counterparts in the South, whites left behind in the deindustrializing Rust Belt felt the burdens of integration disproportionately rested on their shoulders, having to "surrender" their neighborhoods, while wealthy liberals fostered change and cast aspersions from the suburbs. ${ }^{15}$

Ralph Perk embraced many of these themes in his campaign for mayor, but it was his deep roots in the city's ethnic neighborhoods that endowed his Republican candidacy with legitimacy. Born in 1914, Perk was raised in the Czech neighborhood on Cleveland's near southeast side along Broadway Avenue. His parents bought their home at East $50^{\text {th }}$ and Broadway in 1917 and lived there the rest of their lives, fifty more years. Though Perk's father Joseph made a living as an ice salesman, most of his neighbors worked at the nearby Republic Steel plant. Their stretch of Broadway ascended up and out of the city's booming industrial Flats. When young Ralph looked just a half-mile to the north, the smokestacks and steel mills that rose up from the winding banks of the Cuyahoga River partially blocked his view of the Van

\footnotetext{
${ }^{14}$ Catholic Universe Bulletin, January 29, 1971.

${ }^{15}$ On working class whites class grievances in the South, see especially Kevin Kruse, White Flight, ch. 4.
} 
Cebul

Sweringen's Terminal Tower. Perk's parents were fixtures of their Czech and Polish

neighborhood. His mother was an active member of the Altar and Rosary Society at Our Lady of

Lourdes, and until her death in 1964, she was a mainstay at meetings of the Czech Catholic

Union. For much of the twentieth century, Cleveland's branch of this national mutual aid society

was the largest and most vibrant in the nation. Ralph Perk's father, like Dmytro Szmagala,

struggled to find work in the city's manufacturing plants, which were booming thanks to their

close ties to Detroit's automobile industry. Though workers were needed, Perk's and Szmagala's

English simply wasn't strong enough.

Perk did not graduate from high school. He did, however, become a ubiquitous presence in his community. He was a member of just about every fraternal, ethnic, or Catholic organization and mutual aid society. Like Taras Szmagala, Perk had from an early age decided the Republican Party was a better fit for his and other ethnics' inherent values: individual liberty, anticommunist, limited government, and ethnic traditionalism. Perk's political stance, of course, made him something of an oddity in Cleveland's ethnic community. Nevertheless, his dogged participation in the civic life of the nationalities neighborhoods won him their respect and admiration. ${ }^{16}$ While Time magazine described Perk's “purposeful ethnic Bunkerism” (referring to curmudgeonly TV character Archie Bunker), Perk was as genuine as could be.

\footnotetext{
${ }^{16}$ Cleveland's Polish Veterans made Perk the first non-Polish member of the Cleveland Post of the Polish Veterans in Exile Association, and he was Republican Man of the Year in 1953. He was the Czech Man of the Year in 1954
} 
Cebul

By age 35, Perk had already served six terms on the Ohio Young Republican League's executive committee and had twice chaired its 'nationalities' committee, which he had founded. A card-carrying member of the moderately conservative Ripon Society, Perk was enlisted as campaign manager for Franklin A. Polk's quixotic run for mayor in 1949. The central theme of the Polk mayoral campaign was opposition to a city council issue that would have enabled Cleveland to borrow \$22 million from the Reconstruction Finance Corporation for investments in rapid transit and major transportation infrastructure - a program led by the Chamber of Commerce. Perk's limited government commitments were in place from a young age. In 1950, he ran the Cosmopolitan (another word for ethnic) Committee for Senator Robert Taft's reelection campaign, and in 1962 he was elected city councilman for his beloved $13^{\text {th }}$ Ward. Democratic Senator Frank Lausche, notoriously fickle when it came to supporting other candidates, appeared with Perk during his campaign, and they spoke together at the dedication of a Czech Cultural Garden. Lausche hailed Perk's parents' homeland: "The love of liberty lives strong in the hearts of the Czechoslovak people in America . . Freedom will be theirs."17 By 1965, as Cleveland's African Americans made increasing inroads in the local Democratic Party, Perk sensed the opportunity to formalize a movement of ethnics into the city's and Catholic Man of the Year in 1955. In 1957, the Veterans of Foreign Wars selected Perk for the Outstanding Citizenship Award for 1957. Not to be outdone, Perk's wife Lucille was named "Italian Mother of the Year" by the Italian-American Civic Club.

${ }^{17} P D$, June 4, 1962 
Cebul

functionally obsolete Republican Party. In March, Perk called a meeting in his basement

recreation room where he laid out his plans for what he called the Nationalities Movement of

Cuyahoga County. That night and in the following days, he secured the support of key leaders of

ethnic Cleveland: Gustav Kurdziel, publisher and editor of the Polish Daily News; Carl Ernst, the

German publisher and editor of Vereins Nachrichten, Jonas Ciuberkis, chief editor of the

Lithuanian Dirva; Mrs. Miloslava Hyvnar, editor of the Czechoslovakian daily Novy Svet; Tony

Kulaszewski, a leader of the Polish fraternal organization "Kurier;" James Psenicka, publisher of

the Neighborhood News; Frank Dolence publisher of the St. Clair and Superior News; and

Albert B. Hunt, the city editor of the Hungarian newspaper Szabadsag. Soon, Taras Szmagala

(who had been very active in the previous year's Goldwater campaign) signed on. With the broad

backing of these ethnic leaders, Perk began his "Nationality Unity Drive," appearing at every

ethnic event he could find. ${ }^{18}$ In 1967, 25,000 Clevelanders packed Public Square to hear Perk

deliver the keynote during that year's "Captive Nation's Week” commemorations for eastern

European nations imprisoned behind the iron curtain. ${ }^{19}$

\footnotetext{
${ }^{18}$ Neighborhood News, April 15, 1965; Taras Szmagala, interview with author, December 21, 2010.

${ }^{19}$ In the mid-1950s, Lev Dobriansky, a professor of Economics at Georgetown University, began what he called the Captive Nations Campaign. Dobriansky was a Ukrainian-American born in 1918 New York City. Active in the Ukrainian National Association, Dobriansky became chairman of the National Captive Nations Committee, the anticommunism group catalyzed by the 1959 Captive Nations proclamation. When President Eisenhower signed Congress' first Captive Nations resolution, he signed a document Dobriansky had written.
} 
Cebul

Perk became increasingly well known as he honed his appeal to the city's - and nation's

- ethnics, and in 1968 he was invited to speak at Princeton University’s Woodrow Wilson

School. He delivered a passionate jeremiad that would have been quite familiar to his neighbors

in Cleveland. Recent immigrants, Perk argued, "have not been brain-washed by the Roosevelt

era ... They are a humble, but honorable fragment of the record of forgotten thousands who are

trying to preserve this nation." Perk linked the plain and honest values of immigrant peoples with

the salvation of the fractured nation. Members of the ethnic working class were the true

Americans, he contended, because it was their hard work and production that made America:

"their remarkable stamina - sometimes working two jobs and giving the full measure of their

ability to both - [has] brought them a small measure of success, enabling them in many cases to

provide educational opportunities for their children." Whitewashing their experience in the New

Deal, Perk said, they pulled themselves up by their bootstraps not for themselves, but for the next

generation, and the entire country benefited from their gumption. The redistributive, overly

invasive, and independence-crushing policies of the War on Poverty seemed to have changed the

rules of America's meritocratic game. Making explicit a comparison to undeserving beneficiaries

of government largess, Perk concluded: Ethnics "seek not something for which they cannot pay

through hard and honest labor." "Nationalities," Perk soared, "are the heart and core of our

history. They have laid the foundation of our future and have become the cornerstone for [our] 
Cebul

culture." Perk situated his brand of political ethnic nationalism not as a side project to American

nationalism, but as its very essence and salvation. ${ }^{20}$

In his 1971 campaign, months before Dirty Harry hit theaters, Perk did not shy away

from racialized notions of crime. He pledged to "take the "hand-cuffs off" the city's police

department. His supporters in ethnic wards wore star shaped sheriff badge buttons. ${ }^{21}$ Perk

painted growing government under Stokes as a threat to the hard won if modest prosperity

earned by his working class supporters, arguing that he could deliver the same level of services

at much lower cost. While big government had long been at the core of his political values,

Perk's message had finally found its moment. City government had grown under Carl Stokes,

who added over 3,000 workers to the city's payrolls, through which the city's employment

practices had begun to better reflect the diversity of its residents. The Democrats, Perk argued,

were the root cause of out of control government, which was rotten, inequitable, elitist, and

unjustifiably favorable to minorities at the expense of the majority. Though Stokes had opted

against a third term, two weeks before the election Perk made these connections plain: "It is time

for the people of Cleveland to elect their own mayor, not a mayor picked by the newspapers, not

a mayor picked by the establishment, not a mayor picked by political bosses, and most of all, not

\footnotetext{
20 “Speech Delivered by Ralph J. Perk at Woodrow Wilson School - Princeton University," May 3, 1968, folder 2, Container 1, RPP.

${ }^{21}$ WP, October 31, 1971; Call and Post, October 30, 1971.
} 
Cebul

a mayor picked by Mayor Carl B. Stokes."22 Perk capitalized on white working class voters’

anger that the growth of city government was aimed disproportionately at black employment and services. At the top of his agenda was slashing the city payroll of the "drones" hired by the

Stokes administration. $^{23}$

Perk also linked his anticommunist, individual liberty values to a strong critique of Stokes' tax abatements for corporations. The Democrats, he charged, talk "about tax incentives to attract industry, a tax bonanza for big business at the expense of the small taxpayer."24 Taxes were too high, Perk argued, because corporations were getting a break at the expense of the working man. To emphasize his revulsion for taxation and abatements, Perk organized the Ohio Homeowners and Taxpayers Revolt, which distributed leaflets arguing for the tax burden to be placed on industry and corporations. ${ }^{25}$ Perk determined to reform city government without increasing taxes or pandering to business interests. But, he also held up business methods as a model for good governance. "In times of economic stress," he said, "business and industry retrench. They cut out waste and they tighten their belts. If government would do the same, it could slow down or stop continuing inflation or taxes." ${ }^{26}$ Common sense measures appealed to

\footnotetext{
${ }^{22}$ Deborah Atwater Hunter, "The Aftermath of Carl Stokes: An Analysis of Political Drama in the 1971 Cleveland Mayoral Campaign,” Journal of Black Studies, Vol. 8, No. 3 (Mar., 1978), 337-354.

23 “Perk Men Quietly Studying Ways to Cut City Workers,” Plain Dealer, November 5, 1971.

${ }^{24}$ Dennis Kucinich authored this speech. City Club Speech, 1971, folder 1376, container 88, RPP.

${ }^{25}$ The Cleveland Press, April 6, 1971.

${ }^{26}$ Ralph J. Perk Press Release, November 30, 1971, folder 831, container 54, RPP.
} 
Cebul

ethnics' thrifty instincts. As he had put it so many times before, only the wisdom of the ethnics

could save the nation "from the tempest and chaos of America today.",27

In 1971, despite what the New York Times called a "weak and impoverished campaign,"

Perk won the mayoralty with almost no black votes, dominating the city's once-Democratic

white ethnic wards. ${ }^{28}$ Indeed, the national Republican Party offered Perk practically no financial

or organizational assistance in his campaign: a Republican winning in Cleveland - something

that hadn't happened in four decades - was simply too improbable. ${ }^{29}$ Perk's inauguration brought

together and into the open the range of erstwhile Democrats who had secured his victory. Robert

Weismann, Cleveland representative for the United Auto Workers, gave a fiery speech, blasting

“corporate liberalism" and "downtown political power brokers." With the election of a

Republican, the UAW representative chided the city's business elites: "your time has passed.",30

When Perk took the stage, he singled out for praise a fierce young Democratic councilman who

had been instrumental in his election. The councilman, Dennis Kucinich, had organized

“Democrats for Perk” and often served as Perk’s opening act on the stump, blasting Stokes

Democrats and their ties to big business tax abatements and wasteful spending. He even wrote

\footnotetext{
${ }^{27}$ Perk speech notes for the Italian Sons and Daughters of American Convention in Miami Beach, Florida, August 15-22, 1970, folder 18, container 2, RPP.

${ }^{28}$ New York Times, November 3, 1971.

${ }^{29}$ New York Times, November 4, 1971.

${ }^{30}$ Robert Wiesman quoted in Call and Post, November 13, 1971.
} 
Cebul

Perk's speech for one of the campaign's biggest events, the City Club debate. ${ }^{31}$ With Perk's

victory, Kucinich made clear just how racially fragmented the city had become: “There's only

two parties in Cleveland" Kucinich said, "white and black."32 Having helped Perk capitalize on

the city's deep racial polarization, Kucinich celebrated. "The power is with the people," he cried.

Kucinich and Perk had a clear sense of who those people were. ${ }^{33}$

Deregulating the War on Poverty in Cleveland

Between 1960 and 1970, Cleveland's manufacturing employment declined by 34

percent. ${ }^{34}$ During the 1960 s, however, the suburban labor force grew by 35 percent, revealing the degree to which the workforce had suburbanized rather than simply southern zed. Between 1960 and 1975 , the city's population declined from nearly 900,000 to just above 600,000 , while the suburban regions experienced growth that exceeded the population loss of the city itself. Indeed, by the late 1970s, only Newark, New Jersey ranked higher in wealth disparity between city and suburb. ${ }^{35}$ These developments had a dramatic impact on the city's tax revenue, and the city's

\footnotetext{
${ }^{31}$ Todd Swanstrom, The Crisis of Growth Politics: Cleveland, Kucinich, and the Challenge of Urban Populism (Philadelphia: Temple University Press, 1985), 108.

${ }^{32}$ Washington Post, October 31, 1971. See also, Swanstrom, 108.

${ }^{33}$ Kucinich quoted in Swanstrom, 108.

${ }^{34}$ Richard F. Tompkins, “'All the Necessary Services the People Need and Deserve': Federal Grants in Cleveland During 1978," (Washington, DC: Brookings Institution and Cleveland Foundation, 1979), 1.

35 Tompkins, 13.
} 
Cebul

ability to cope with this income gap between city and suburb took a significant hit in 1970 thanks to a significant political miscalculation by Mayor Carl Stokes. In an effort to encourage voters to approve an income tax increase from $1 \%$ to $1.8 \%$ (which would have brought more tax revenue from suburban commuters), Stokes committed to allowing the city's property tax levy to expire. Instead, opposition emerged from suspicious labor leaders who worried the property tax drop was a pander to big business. Left unsupported by his political party and its most crucial interest group, Stokes' income tax increase was defeated by a wide margin. And when the property tax levy expired as planned, city revenue decreased by almost 25 percent, creating a $\$ 27$ million budget shortfall. Stokes was forced to lay off 1,725 city employees including 193 police officers and 146 public health workers (he closed three of seven city health centers). ${ }^{36}$

Making matters worse, the city faced mounting costs associated with what it termed "enterprise" funds. Meant to generate revenue for the city, several enterprise operations were serious drains on the budget. These included Muny Light, the city's municipally owned public light and power utility, which enjoyed wide support thanks to its publicly-subsidized low rates, the city's public auditorium, and the lakefront stadium home to the Cleveland Browns and Indians. The countywide sewer system, too, was operated by a public special purpose agency, which, thanks to rising water pollution control costs following the Clean Water Act, began

\footnotetext{
${ }^{36}$ Ibid., 168.
} 
Cebul

operating under a deficit. ${ }^{37}$ Perhaps most insidious, however, was how the nation's exploding inflation over the 1970s slowly bled the purchasing power of the city's tax revenue. Thanks to inflation, Cleveland's budget crisis became more and more pronounced as the decade wore on. ${ }^{38}$

Nevertheless, Perk was adamant: "To talk of increasing taxes now," he argued, "is . . . without justification or logic. To raise taxes now would be to take the pressure off this administration to modernize and streamline city government." ${ }^{, 39}$ Just a week into his first term, having taken stock of a \$27 million deficit, Perk announced a twenty percent slash of the entire city payroll. Perk's team explained that a "majority of these cuts would be accomplished through layoffs in the middle-management area" of city government. "For example," they reasoned, "laying off administrative assistants, administrative officers and supervisory personnel, who because of previous layoffs have very little to supervise." ${ }^{40}$ Perk envisioned taking city

\footnotetext{
${ }^{37}$ Tompkins, 7.

38 City of Cleveland revenues, $1970-1978$, in Tompkins, 6.
}

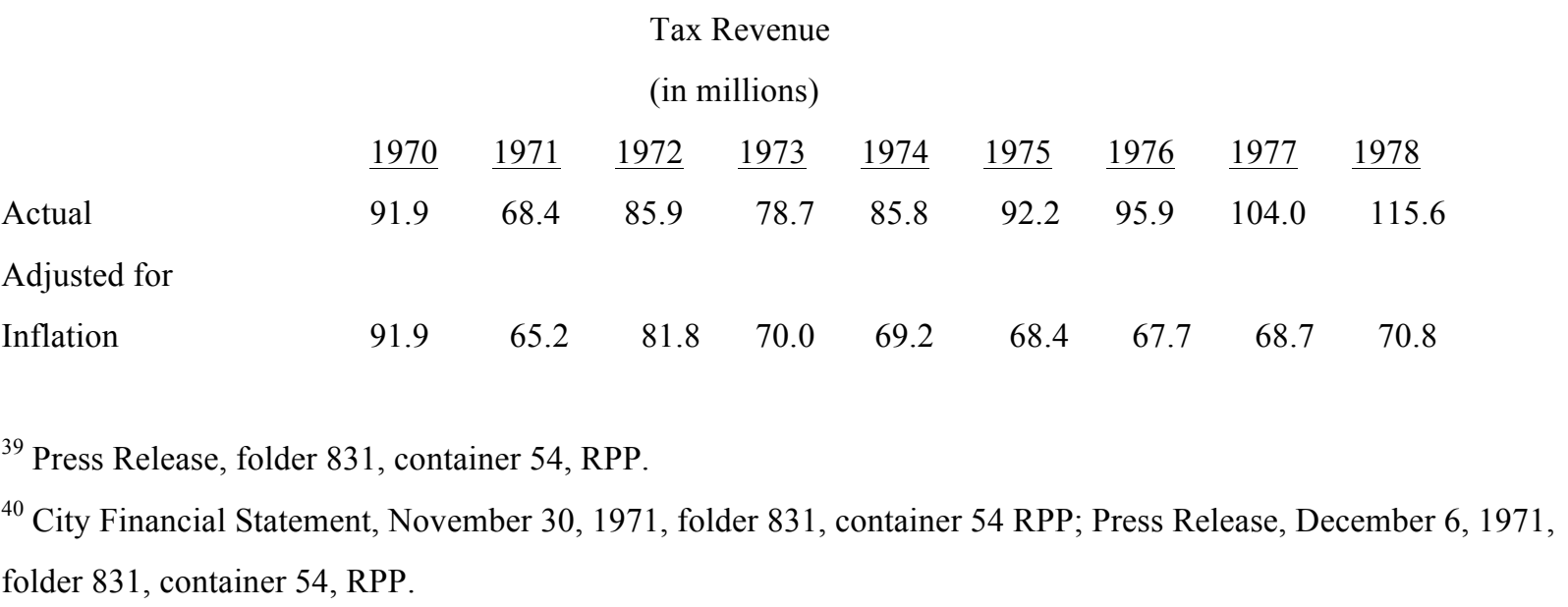


Cebul

government from its peak of 10,000 down to 7,000 employees. As Vladimir Rus, Perk's Director

of Human Resources and Economic Development (and a Slovenian) later put it, "These are times

for austerity and retrenchment." ${ }^{41}$ Perk's small government conservatism had seemingly met its

moment. But angry city employees resorted to strikes and legal action during 1972, Perk's first

full year in office. Overworked, underpaid, and with a dwindling sense of job security, the city's

employees morale sagged. ${ }^{42}$ Clevelanders watched as their government sputtered along,

periodically grinding to a halt during spasms of striking city workers.

Cuts alone wouldn't shrink the budget gap, and Perk had to find ways to raise new

sources of revenue. To generate these operating expenses, Perk first looked to sell city assets. He sold the city's sewers to a regional authority, which generated a one-time sum of $\$ 32$ million. He also developed a plan to sell city land near an east-side suburb on which the Stokes

administration had hoped to build 8,000 badly needed public housing units. Instead, Perk sold parcels to private developers and leased the rest. He reasoned the city might generate an immediate return on the land itself while preventing some tax flight to the suburbs. Perk did not, however, offer an alternative housing plan for the predominantly black population who planned

\footnotetext{
${ }^{41}$ Vladimir J. Rus to Ralph J. Perk, “Austerity Program Suggestions,” November 14, 1974, folder 1431, container 91, RPP.

${ }^{42}$ Jack Cross, III to Ralph Perk, December 28, 1971, folder 596, container 41, RPP; Helen J. Lyons to Vincent C. Campanella, February 10, 1972, folder 587, container 41, RPP.
} 
Cebul

to call these developments home. ${ }^{43}$ While the one-time infusion that resulted from the sale of the city sewers was significant, on the whole, Perk's attempts to sell the city out of debt was unsustainable and actually threatened future public revenues. ${ }^{44}$

Most significantly, Perk relied heavily on short term loans from city banks, loans that, according to law, had to be converted within five years into long-term bonds to be paid down with city tax revenue. The Perk Administration began the process of using bonded debt in 1972 and 1973, and by 1975 one third of the city's debt was in high interest short-term notes. In the short term this provided Perk with valuable operating subsidies, but, in the long term, the debts would have to be renegotiated and paid off with interest. By 1976, the city held $\$ 143$ million in short-term debt. As the city's finance director put it, the city would have to either raise taxes or pass new bonds to pay off or convert the old bonds. ${ }^{45}$ Cleveland was not alone in seeking shortterm debt to cover capital improvements and budgets commitments: by the late 1970s commercial banks held nearly half of the nation's municipal debt. ${ }^{46}$

\footnotetext{
43 "Ralph Perk wants to re-develop the inner city instead of rebuilding in Warrensville Township," Commentary, Dorothy Fuldheim, Memo from Television Station WEWS, November 17, 1971, older 831 container 54, RPP.

${ }^{44}$ Edward P. Whelan, "Mayor Ralph J. Perk and the Politics of Decay,” Cleveland Magazine, September 1975 in Dan Marschall, ed., The Battle of Cleveland: Public Interest Challenges Corporate Power (Washington, DC: Ohio Public Interest Campaign, Conference on Alternative State and Local Politics, 1979).

45 "Will explode into new taxes?" PD, April 18, 1976.

${ }^{46}$ The Role of Commercial Banks in the Finances of the City of Cleveland, Staff Study by the Subcommittee on Financial Institutions Supervision, Regulation, and Insurance of the House Committee on Banking, Finance and Urban Affairs, June 1979, p. 1, PAL.
} 
Cebul

Privatization and loans were not the only options open to the Mayor. He also reached out to the Nixon administration. When he came into office around 40 percent of the city's budget was subsidized by State or federal funds. ${ }^{47}$ Under the guise of small government, localist rhetoric, Perk would dramatically inflate that figure. In his second month in office, Perk headed to Washington during which he enjoyed a personal meeting with Vice President Spiro Agnew and White House aide Harry Dent. Perk revealed the city's economic plight, underscoring the fact that Cleveland was the largest city in the nation with a Republican mayor. Upon returning home, he triumphantly reported that Dent and Agnew were "shocked" at the financial crisis facing the city. The Mayor brought to Washington a \$200 million shopping list of new funding requests, and he secured from the White House team assurances they would expedite aid to the city. But Perk was careful not to let federal largess be construed as a handout. As he framed it, he was speeding the return of Clevelanders' federal tax dollars. Wealth repatriation, not redistribution, was the name of the game. ${ }^{48}$

Perk took great pride in the relationship he was cultivating with the President. "Both of us born under the sign of Capricorn have been assured astrologically one of the best years of our lives," he wrote Nixon in a birthday message. "I know that one of your goals is to use your good offices to help the financially stricken city of Cleveland become economically healthy and give

\footnotetext{
${ }^{47}$ Summary of Federal Grants Awarded Since November, 1971, Undated, folder 996, container 65, RPP.

48 “Perk is Hopeful of Major U.S. Funds for City," PD, November 22, 1971.
} 
Cebul

to Cleveland your help in the rebirth that it is now experiencing. Best wishes for a happy and healthy new year and acourse $[$ sic $]$ again a very happy birthday." ${ }^{49}$ At ethnic events around the city, Perk highlighted Nixon's nationalization of a project Myron Kuropas started in Chicago called Project Senior Ethnic Find (PSEF) ${ }^{50}$ Kuropas, Taras Szmagala's old Ukrainian camp friend, worked in the Chicago office of Action, the national volunteer program, and Ethnic Find connected worthy elderly ethnic Americans with social welfare programs they might not otherwise have known about. As Kuropas put it, the program helped deserving older Americans who, "after a lifetime of service to their communities, find themselves isolated from the mainstream of American life. ${ }^{51}$ The Nixon Administration reciprocated. When planning a trip to Cleveland, one Nixon staffer wrote, "we should let Mayor Perk bring a whole bunch of ethnics to the airport. They can come in their natural costumes and so forth. In other words, we can turn the Cleveland airport event into a Perk ethnic type event. ${ }^{, 52}$

Indeed, while Perk learned quickly that he needed the White House, the White House was developing a political strategy for its 1972 reelection that sought the support of men like Perk

\footnotetext{
${ }^{49}$ Ralph J. Perk to Richard M. Nixon, January 6, 1972. Folder EX FA Federal Aid, 01-1-72 - 2-29-72, Box 3, WHCF, Subject Files, FA, Richard Nixon Presidential Library, Yorba Linda, CA [hereafter RNL].

50 "Department of Human Resources and Economic Development Departmental Progress Notes for Mayor's State of the City Speech - City Club," undated, 1974, folder 587, container 41 RPP.

${ }^{51}$ Project FIND Fact Sheet, Undated, folder Announcement of Project FIND, 8/2/72, box 11, MBKP, Gerald R. Ford Presidential Library, Ann Arbor, Michigan [hereafter GRFL].

${ }^{52}$ Dwight L. Chapin to Ronald H. Walker, October 17, 1972, box 10, WHCF, Local Governments, RNL.
} 
Cebul

and the working class ethnic constituencies they represented. It took a while to develop, though, because some of Nixon's chief political advisers and pollsters - Pat Buchanan and Robert Teeter among them - worried that going too hard for the Catholic working class vote might alienate Republican's blue blooded base; as one memo put it, Protestants represented "two out of every three voters." 53 One memo reflected the changing perspective in the administration: while Republicans had struggled with ethnics in the past, "there is a changing of attitudes on the part of the ethnic population, prompted by the pressure from the Blacks and their own increasing standards of living." ${ }^{, 54}$ As a result, the Nixon camp developed relationships with ethnic elected officials across the country. ${ }^{55}$ Perk became swept up in the President's reelection campaign and consulted with the newly formed National Republican Party Heritage Groups Council, the outreach vehicle at the heart of Nixon's "white ethnic strategy." 56 In advance of a lunch between

\footnotetext{
${ }^{53}$ Roy Morley to Ken Cole and Ed Harper, Confidential Memorandum Re: The Catholic Vote and 1972, September 16, 1971. RN Library, Committee for the Re-Election of the President Collection (CRP): Frederick Malek Papers, Box 27, Citizen Groups Folder; Robert M. Teeter to H.R. Haldeman, Confidential Memorandum Re: Catholic Vote, January 6, 1972, folder Citizens Group, box 27, Committee for the Re-Election of the President Collection (CRP), Frederick Malek Papers, RNL.

${ }^{54}$ Bob Marik and Jeb Magruder to Ken Cole and Ed Harper, Confidential Memorandum Re: Strategic Considerations for the 1972 Campaign, October 21, 1971, folder Campaign Administrative Files, box 9, Frederick Malek Papers, RNL.

55 "City taxes couldn't support safety forces; aid pays bills," $P D$, January 17, 1975.

${ }^{56}$ RPP F779. Nixon telegrammed Perk with thanks on election night: "Your efforts helped make tonight's victory possible." Richard Nixon to Ralph Perk, folder 779, container 52, RPP. For Nixon's white ethnic strategy more broadly, see Thomas J. Sugrue and John Skerenty, "Nixon's White Ethnic Strategy," in Bruce J. Schulman and Julian Zelizer, eds., Rightward Bound: Making America Conservative in the 1970s. Cambridge: Harvard University Press, 2009.
} 
Cebul

Perk and Nixon aide Ken Cole, a White House staffer prepared a memo outlining Perk's

relationship with the administration. "The Mayor has been a staunch Administration supporter,

and we have been able to assist him in arranging considerable Federal assistance for

Cleveland. ${ }^{, 57}$

Nixon selected, at Perk's recommendation, Nicholas Bucur, Perk's campaign director and chairman of the Cleveland Transit Board, to be the ethnic coordinator of his 1972 campaign. $^{58}$

Taras Szmagala, who had served as campaign director for Sen. Robert Taft, Jr., was appointed the Midwestern director of Nixon's ethnic campaign. Nixon's ethnic surrogates highlighted positive policy steps his administration had taken on behalf of working class whites, such as safeguarding pension funds, the creation of revenue sharing, and the increased minimum wage. ${ }^{59}$ But CREEP did not just cultivate Republicans. Chuck Colson, Harry Dent, and John Ehrlichman were in close contact with Philadelphia's ethnic Democratic Mayor Frank Rizzo throughout much of 1971 and 1972. Rizzo was adamantly opposed to George McGovern, and he publicly praised Nixon and his Revenue Sharing proposals. ${ }^{60}$

\footnotetext{
${ }^{57}$ J. Marsh Thompson to Ken Cole, re Lunch Today with Mayor Ralph Perk, January 5, 1973, box 10, WHCF, Local Governments, RNL.

58 "Perk Picks Bucur for Nixon Post," Plain Dealer, February 15, 1972.

${ }^{59}$ Myron B. Kuropas, “Addressing the Needs of Ethnic America: A Proposal,” December 8, 1975, folder Special Assistant for Ethnic Affairs, box 11, Myron Kuropas Papers, GRFL

${ }^{60}$ See generally, folder Michael P. Balzano: (Ethnic Leaders) Rizzo, box 35, Michael P. Balzano Papers, White House Central Files, RNL.
} 
Cebul

Prior to the passage of General Revenue Sharing and Community Development Block

Grants, one program in particular promised to offer the Perk Administration critical federal

support. As envisioned by its federal planners in 1966, Model Cities aimed to coordinate various

War on Poverty programs and fund a broad range of improvements to narrowly demarcated and

struggling minority neighborhoods. But, as historian Alice O’Connor writes, it was also the

Johnson Administration's first attempt to “make up for the failures of federal antipoverty

initiatives" by returning to city officials some measure of control over planning and coordination

of federal program dollars. ${ }^{61}$ Rather than go directly to community groups as it had in several

other Great Society programs, federal money would be channeled through a local Model Cities

administration appointed and overseen by the mayor and city council. Final veto power over

other War on Poverty programs undertaken in the Model Cities neighborhood would also be

restored to elected officials. ${ }^{62}$ In regions that had established Community Action Agencies, for

example, mayors often hoped to use Model Cities to regain control over groups they feared

challenged their dominance. ${ }^{63}$ Indeed, thanks to the overwhelming discontent of the nation's

\footnotetext{
${ }^{61}$ Alice O'Connor, "Swimming Against the Tide: A Brief History of Federal Policy in Poor Communities," in Ronald F. Ferguson and William T. Dickens, eds., Urban Problems and Community Development (Washington, D.C.: Brookings Institution Press, 1999), 104.

${ }^{62}$ Robert A. Aleshire, “The Community Performance Standard: An Incentive Approach to Intergovernmental Program Relations," November 1968, 2, folder Model Cities \& CAP info., Box 11, Richard P. Nathan Papers, Hoover Institution, Stanford University, Stanford, CA [hereafter RPN].

${ }^{63}$ In Philadelphia, for instance, the inauguration of the Nixon Administration and its deregulation of Model Cities thwarted a more vigorous approach to structural poverty. See Guian A. McKee, The Problem of Jobs, 255-70. See
} 
Cebul

mayors at the War on Poverty's more categorical and tightly regulated version of fiscal

federalism, the deregulation of the War on Poverty began in the Johnson Administration. ${ }^{64}$

HUD, however, continued to stipulate community participation be a part of the program.

The federal agency required that "citizens have clear and direct access to the decision-making

process," a watered down revision of "maximum feasible participation." Each constituency,

mayors and council members on the one hand, and recently empowered community groups on

the other, read these new mandates in very different ways. Nevertheless, the program perpetuated

the rhetoric of fighting poverty and so speeded a process whereby mayors, council members, and

other parties interested in federal aid learned to couch their requests in terms of the ostensible

good such aid would deliver the poor.

Like many others across the country, Model Cities Cleveland was ambitious. The Model

City area -locals called it the "model neighborhood" - covered twenty-five square blocks, the

majority of which were located in Hough, the site of both deadly unrest and hopeful organizing

in the 1960s. Most of the neighborhood's 45,000 residents were African American. As originally

conceived under the Stokes administration, the program's goal was comprehensive

redevelopment of the social, economic, and educational services offered to residents: jobs and

also, Margaret Weir, "Power, Money, and Politics in Community Development," in Ferguson and Dickens, ed., Urban Problems and Community Development, 145.

${ }^{64}$ The Johnson Administration passed that first piece of legislation considered a "block grant," Partnerships for Health. The 1966 legislation bundled nine public health formula grants into one program to be administered locally. 
Cebul

jobs training, health services, improved education, new and repaired housing, local business

stimulus, and infrastructure were all to be addressed. ${ }^{65}$ With such an extensive slate of

interventions planned for a single neighborhood, citizen participation and coordination would be

crucial for ensuring smooth implementation. To this end, Stokes established a Citizens

Participation Association (CPA). The CPA, along with a neighborhood-elected Resident Board

of Trustees, was meant to amplify residents' voices in conversations with the mayor's Model

Cities administrator, the city's Economic Development office, and the City Council, which

together had the final say on programs. The CPA's professional staff was funded by federal

money, but the responsibility for dispersing funds was left to the city's Economic Development

office, which reported to the mayor.

While residents looked optimistically to the program, local and national developments

stymied their efforts. Some Model Cities programs across the country hit the ground running, but

\footnotetext{
${ }^{65}$ Backed by a Model Cities-funded Homeowners Assistance Fund, mortgage and home rehabilitation loans were to be made available to area residents. A manpower training system would provide area residents with jobs through the creation of a concentrated labor pool to respond to the new home rehab projects made possible by the Homeowners Assistance Fund. More jobs were to be provided through area renewal efforts - landscaping, infrastructure development, and home inspections. Model Cities sought as well to address abstract issues of quality of life by creating an experimental school for the special needs of inner city children. Funds were set aside for a Mental Health Planning Unit that would eventually use established spaces - schools, hospitals, and community centers - as mental health outreach facilities. In addition, the program aimed to develop school lunch programs, a Nutrition Information Center, a 24-hour Child Care Center, and a Mini-Bus Service for the disabled and elderly. Finally, the program included jobs counseling and employment programs for parolees as well as legal counseling and referrals for neighborhood residents. Fact Sheet, Cleveland Model Cities, First Year Program, folder 793, container 53, RPP.
} 
Cebul

rancor between Mayor Stokes and the City Council ensured Cleveland struggled, as a subsequent report put it, "even to agree upon a single program." ${ }^{, 66}$ Perk inherited an already fraught situation, and, with the Nixon Administration's explicit support, he quickly made it all the more so. Perk met with HUD's regional director who assured the mayor he had the authority to determine the structure, type, and procedures for the citizen participation component of the program. ${ }^{67}$ As a result, Perk allowed the original Residents Board of Trustees' mandate to expire in order to populate his own board. The previous board and its supporters were outraged. Wilbur Warren, a neighborhood resident, wrote Perk excoriating him for his "act of maximum feasible manipulation to disenfranchise and shortchange widespread citizen participation." ${ }^{68}$ In language reflecting previous federal participation mandates, model neighborhood residents were beginning to understand that, while their patrons had, for a fleeting moment, been federal agencies, they would now be forced more than ever to deal with the local administration.

Even County GOP leader Saul Stillman worried that Perk’s tin ear for African American neighborhood concerns would lead to costly confrontations. Stillman recommended the Mayor attend to "what [model neighborhood residents] consider to be the erosion of their responsibilities and duties." The GOP chair "respectfully suggest[ed] that a new meeting might

\footnotetext{
${ }^{66}$ Report of the Model Cities Investigating Committee, prepared by Peat, Marwick, Mitchell and Company, September 25, 1973, folder 793, container 53, RPP.

${ }^{67}$ Ibid.

${ }^{68}$ Wilbur C. Warren to Ralph Perk, December 7, 1971, folder 789, container 52, RPP.
} 
Cebul

be a fruitful area to explore what can be done." ${ }^{69}$ Stillman understood that far from being merely

a handout to impoverished residents, the Model Cities program demanded and was fostering hard work from area residents, efforts the residents had come to view as "responsibilities and duties."

Indeed, model neighborhood residents regrouped and prepared for elections to the new board.

Many citizens - the vast majority of whom were women - competed to serve on the board, and

the number and range of community organizations with which candidates were affiliated

demonstrated the neighborhood's social capital and institutional vitality. ${ }^{70}$ Despite the setbacks

and stalling they had endured, residents were still hopeful of getting their program moving. The

Perk administration's primary goal, however, was to get federal money flowing into the city with fewer and fewer strings attached, not to respond to residents in whom he had no political stake. ${ }^{71}$

The Nixon Administration and HUD aided the mayor's efforts. As the federal

government prepared in 1972-73 to transition from Great Society-style targeted grants to its various Revenue Sharing plans (described below), HUD officials worked with local

\footnotetext{
${ }^{69}$ Saul G. Stillman to Ralph Perk, February 24, 1972, folder 715, container 48, RPP.

${ }^{70}$ Included among the many civic organizations involved in the election efforts were the local NAACP, the Universal Negro Improvement Union, the Hough Community Council, the National Senior Consumer Organization, the Rosicrucian Fraternal Society, the Salvation Army Women's Auxiliary, the Civil Service Employees Association, the Phyllis Wheatley Association, the Whittier Avenue Neighborhood Club, and a broad spectrum of churches and street associations. See Model Cities election, folder 799, container 53, RPP.

${ }^{71}$ A similar situation was developing in other Model Cities projects. See, for example, the case of Democratic Mayor Richard Daley in Chicago. "City Hall Muffles Voice of Model Cities Poor,” Chicago Tribune, February 22, 1972.
} 
Cebul

administrations to develop transition strategies. ${ }^{72}$ HUD's acting director for Cleveland's segment

of the Midwest emphasized the new flexibility in a letter to Perk. The mayor, he wrote, could

develop and implement "locally established procedures" for Model Cities. ${ }^{73}$ With HUD's

blessing Perk redesigned the program in ways that provided budgetary relief to the city. ${ }^{74} \mathrm{New}$

points of emphasis in Model Cities included contracting housing projects with favored

community development corporations and using the city's own health and welfare departments

to administer social service programs in the neighborhoods - this way federal funds could offset

costs of services the city already rendered. This enabled the Mayor to keep federal money in city

agencies rather than dispensing it to new programs in the neighborhood. Nixon further loosened

regulations to emphasize "local discretion," "additional authority to local chief executives," and

expanding "the program beyond model neighborhoods to include entire cities.",75

With the new Resident Board in place, bickering only worsened, spurring Perk to lash out

and highlight the highly racialized view ethnics had of Model Cities in particular and the waning

War on Poverty in general. Spurred by the Nixon Administration, the mayor argued he no longer

\footnotetext{
72 “2 Model Cities Planners Hired,” PD, April 12, 1973.

${ }^{73}$ Elmer C. Binford to Ralph J. Perk, March 5, 1973, folder 793, container 53, RPP. Nevertheless, Binford emphasized "the delegation of responsibility to local officials . . includes the continued involvement of . . citizen participation organizations."

74 “Model Cities’ Impact Doubted,” PD, April 13, 1973; “Plan Offered to Break Model Cities Logjam,” PD, March $28,1972$.

${ }^{75}$ Conlan, From New Federalism to Devolution, 48.
} 
Cebul

needed the board's consultation for any plans. In a caustic response to the Mayor, one Board member threatened a lawsuit. ${ }^{76}$ Other Model Cities leaders issued a statement decrying moves that undermined community prerogatives, saying they compromised a "moral and legal commitment between the City of Cleveland and the residents of the Cleveland Model Cities Neighborhoods ... We do not believe any public monies should be spent to operate a Cleveland Model Cities Program which dilutes the role of responsible and effective citizen participation in its projects. ${ }^{, 77}$ Perk hit back, highlighting the racial tensions that were crystallized in white neighborhood's perception of the Model Cities program in particular and the War on Poverty in general. "I am going to present my program to this board in three weeks," he said. "If you do not wish to accept it, I will cut the program off." Then, he pointed out the spatial and social divisions that existed between the city's races: "People on the [nearly all white] west side don't want Model Cities anyhow. I can always get some other program."78 The Mayor submitted his updated funding application and in July 1973 received a $\$ 9.3$ million Model Cities grant. ${ }^{79}$

Fannie Lewis was a single mother of three and poverty activist who had plunged into community organizing after the Hough Riots. Lewis directed the Model Cities Citizens

\footnotetext{
${ }^{76}$ C. Lyonel Jones to Robert Doggett, City Demonstration Agency, April 24, 1973, folder 792, container 53, RPP.

${ }^{77}$ Statement of Mrs. Fannie Lewis and Mr. Willie Tufts, August 1, 1971, folder 1 container 1, Fannie M. Lewis Papers, Western Reserve Historical Society, Cleveland, Ohio [hereafter FMLP].

${ }^{78}$ Call and Post, April 14, 1973.

${ }^{79}$ HUD Regional Administrator George J. Vavoulis, "Position Statement Regarding the Status of Cleveland's Model Cities Program," Undated, likely late July or early August 1973, folder 792, container 53, RPP.
} 
Cebul

Participation Association that operated citizens' outreach centers at three Citizens Participation

Offices. She got her start in community organizing during the initial wave of War on Poverty

programs, working as an Intake Counselor at the Hough Opportunity Center's Neighborhood

Youth Corps office. Lewis felt deeply empowered by her involvement in the War on Poverty,

and those experiences shaped what would become a nearly three-decade career in community

organizing. In a statement about her experiences in the War on Poverty, Lewis wrote,

it has been a pleasure for me to serve these young persons amid all the heartaches and opposition that I have encountered since working for neighborhood youth corp. ... I have been in touch with some one's life to the extent that, what I have said and done has made a change for the better in them. I have caused them (in my unskilled an untrained way in the area of professional counseling but richly and fervently, an most decidingly) to make a start upward by believing in them an respecting them as the important person when and where ever we Meet. ${ }^{80}$

While she worked for Model Cities, Lewis also struggled to keep food on her family's table. $^{81}$

Lewis fiercely watchdogged the program she saw slipping away. After rumors circulated that the city planned to avoid paying full wages to young people hired as part of the Model

\footnotetext{
${ }^{80}$ Fannie Lewis, What My Job Means to Me, April 11, 1968, folder 283, container 13, FMLP.

${ }^{81}$ Troy Lee James, for instance, Lewis' State House District Representative, appealed to the Ohio Bureau of Unemployment for aid. "Mrs. Lewis is in desperate need of money as she has two children with one in college. It would be of great importance to me if in any way possible you could get Mrs. Lewis an early hearing. She needs financial help now.” Troy Lee James to Ohio Bureau of Unemployment, October 4, 1971, folder 1, container 1, FMLP.
} 
Cebul

Cities' summer youth employment program, Lewis sent caustic letters to the Mayor's office and to Council President George Forbes. ${ }^{82}$ She also wrote (to no avail) for support from regional HUD officials: "CLEVELAND'S MODEL CITIES PROGRAM IS AGAIN IN JEOPARDY."83

The city's Model Cities supervisor, one of Lewis' allies complained, "has the prerogative of making decisions to cripple and deny the Citizens who work in this office the right to have their checks." Residents frequently complained that Perk's administrator skipped scheduled meetings and ignored requests for other consultations. ${ }^{84}$

Nearly two years after Perk's inauguration, the program had lost almost all contact with the people it was originally meant to serve. In one of its few actual community outreach efforts, the Perk administration hired an independent consultant to act as a neighborhood liaison. Alice Ashford, too, felt all but abandoned by Perk's team. Ashford worried about the effect of dashed expectations among community leaders with whom she worked. In a ten-page letter to Perk's Economic Development director Michael Pap, she complained that her efforts had been "obscured and confused" by the administration. She worried that "no one has tackled ... communicating with the ministers of the Black Community, who I know are anxiously waiting to

\footnotetext{
${ }^{82}$ Fannie Lewis to Tom Brown, August 9, 1973; Fannie Lewis to George Forbes, August 14, 1973; and Tom Brown to George Forbes, August 14, 1973, folder 792, container 53, RPP.

${ }^{83}$ Fannie Lewis telegram to Susan Schick, April 6, 1973, RPP F793, Fannie M. Lewis to Ralph Perk, April 26, 1973, folder 792, container 53, RPP.

${ }^{84}$ Alice Ashford to Robert Doggett, April 12, 1973, folder 793, container 53, RPP.
} 
Cebul

hear something of the plans ... they" had developed and proposed ${ }^{85}$ Ashford described how

black community leaders viewed successful implementation of Model Cities as a responsibility

on which they hoped to deliver. Indeed, as Perk's first re-election campaign got underway in the

summer of 1973, the city's black communities were still reeling from the loss of Carl Stokes and

were struggling to assert their voices. The new African American city council president, George

Forbes, had so far been a disappointment, despite his rather militant origins, and any non-City

Council mode of citizen participation mechanism was rapidly drying up. In a front-page editorial

in the city's weekly black newspaper, a writer lamented the situation facing black Clevelanders

just two years after Stokes' departure: "Isn't it strange indeed that Cleveland is the only city

where Negroes are retreating politically rather than advancing?" ${ }^{\prime 86}$

In September 1973, as rumors of corruption and fiscal impropriety at last reached

mainstream news outlets, the Perk Administration acceded to an independent report on the

program. "The dismal record of Model Cities programs across the nation has been one of failure

to the point of disaster and disappointment beyond belief," investigators began. "Cleveland has

been no exception." What made Cleveland unique, though, was the extent of its failures.

Residents, "the almost forgotten people whom the program was intended to benefit," were

${ }^{85}$ Letter to Ralph Perk, folder 792, container 53, RPP.

${ }^{86}$ Call and Post, June 30, 1973. 
Cebul

ignored by City Hall despite their activity and optimism. ${ }^{87}$ In fact, a contemporary Rand study

found that, in programs across the country, with the quiet support of HUD, local politicians had

been "determined to return the genie of citizen power to the bottle from which it had escaped." 88

Moreover, with the prospect of Nixon's ultimate deregulation of the funding, city administrations

opted to sit on the grants rather than deliver funds to neighborhoods. If they waited long enough,

they could use the funds wherever they chose. Cleveland's abysmal rate of spending was an

extreme example of a much broader national trend: expenditures of federal funds across all

Model Cities programs was only 54 percent of the total allocated in $1972 .{ }^{89}$

Nevertheless, the publicity generated by Model Cities' failures in Cleveland often

centered on the $\$ 9.3$ million "wasted" by the federal government on the city's poor and black

neighborhoods. ${ }^{90}$ Overlooked entirely was the fact that almost none of the money was ever spent

in the neighborhood for which it was intended. When the national Model Cities program was

ended on June 30, 1974, Cleveland's $\$ 9.3$ million grant was rolled into the city’s Community

Development Block Grant funds, spending which was entirely at the mayor's and city council's

\footnotetext{
${ }^{87}$ Donald G. Jacobs and Herbert R. Whiting, Report of the Model Cities Investigative Committee, September 25, 1973, folder 747, container 50, RPP.

${ }^{88}$ Robert K. Yin, ed., The City in the Seventies (Itasca, IL: F.E. Peacock Publishers, Inc., 1972), 116.

${ }^{89}$ Bernard J. Frieden and Marshall Kaplan, The Politics of Neglect: Urban Aid from Model Cities to Revenue Sharing (Cambridge: MIT Press, 1975).

90 “Cleveland's Model Cities Program: Why, When, What, Where, How Much, and Why it Has Failed So Far,” $P D$, January 13, 1974.
} 
Cebul

discretion. One analyst called Model Cities "the most unequivocal failure of all the 'Great

Society' programs" Flawed though Model Cities was, local politics and the progress toward

Nixon's New Federalism played a critical role in undermining the program. ${ }^{91}$ In Cleveland, if

Model Cities benefited anyone, it was the Mayor, who used unspent federal funds to fill in the city's growing budget deficit and maintain services for his white ethnic constituency.

Fannie Lewis well understood the importance of maintaining community organization in the face of Nixon's looming reforms. With the arrival of Nixon's New Federalism, she wrote, and "because Model Cities will possibly be moving into a City Wide Program under Community Development" Block Grants, Lewis encouraged community groups "to form a Coalition to address themselves / ourselves to funding under Revenue Sharing ... We do hope that you see the need for such a Coalition, for we need to immediately become organized, chartered, start to provide workshops and orientation to the Community." 92

Nixon's New Federalism: Federal Deregulation of the War on Poverty

In this fracturing political climate, Richard Nixon sought to forge a new electoral majority through a slate of intergovernmental reforms he called New Federalism. As he took

\footnotetext{
${ }^{91}$ Donald F. Kettl, Managing Community Development in the New Federalism (New York: Praeger Special Studies, 1980), 5 .

${ }^{92}$ Fannie M. Lewis to various community organizations, August 16, 1974, folder 35, container 2, FMLP.
} 
Cebul

office in 1969, the federal system seemed to be in crisis. The nonpartisan Advisory Commission

on Intergovernmental Relations (ACIR) reported that local governments were suffering growing operating deficits tied to increased programmatic commitments (sometimes thanks to unfunded federal mandates) and worsening inflation, which drove up the cost of delivering services. ${ }^{93}$

Worsened by a slowing economy, state and local revenue sources experienced increasing volatility. This was so especially in comparison to the national government's main source of revenues, the income tax, which remained a relatively stable source of funds even in tough economic times. State and local governments derived their revenue predominantly from property and sales taxes, sources of revenue that more closely tracked market fluctuations. Sales taxes were particularly volatile since inflation drove up receipts in some years and then could crash the next if consumer spending responded by drying up. And, in 1972, the ACIR found that Americans felt the property tax was the most regressive and "the least fair of the major tax sources." 94 To a large degree, state and local governments, whose services were most visible to constituencies, also had the most visible tax receipts. Raising new sources of local revenue in a period of inflation would be a singular challenge. ${ }^{95}$

\footnotetext{
${ }^{93}$ Advisory Commission on Intergovernmental Relations (ACIR), Federalism in 1973: The System Under Stress, (Washington, January 1974).

${ }^{94}$ ACIR, Public Opinion and Taxes, May, 1972, 1-4.

${ }^{95}$ On the modern history of state and local taxation, see David Brumori, State Tax Policy; and Brumori, Local Tax Policy.
} 
Cebul

With rising costs and obligations to service bonded debt, more and more units of government felt pressure to raise taxes. As another ACIR report found, in 1960, only 19 states imposed general sales and personal income taxes. By 1970 that number had grown to 33. Over the same period, increased state and local tax collection actually outpaced economic growth. ${ }^{96}$ Making matters worse, as municipal governments modernized their property tax assessment systems, the average property tax bite increased. ${ }^{97}$ In San Francisco, for instance, homeowners were historically assessed at 9 percent of market value, "an absurdly low" figure, as historian Bruce Schulman has put it. ${ }^{98}$ But, as computerization ended this informal practice of "fractional assessments," Americans' assessed home values started to more accurately reflect market values. So did their property tax rates. The Nixon Administration was keenly aware of growing unrest over creeping property taxes, and the President argued his New Federalism program would help "stabilize" or perhaps even reduce local property taxes. ${ }^{99}$

The Administration wisely chose to pursue Revenue Sharing as its opening salvo in the New Federalism reforms. Nixon first used the phrase "New Federalism" in August 1969 in a

\footnotetext{
${ }^{96}$ ACIR, Revenue Sharing - An Idea Whose Time has Come, December, 4., 1970.

${ }^{97}$ Isaac Martin, The Permanent Tax Revolt (Stanford: Stanford University Press, 2008); and Bruce J. Schulman, The Seventies, 205-7.

${ }^{98}$ Ibid., 206.

${ }^{99}$ Raymond Waldmann to Ed Harper, February 23, 1971, folder Revenue Sharing, box 32, White House Central Files: Federal Aid, RNL; John C. Murphy, “General Revenue Sharing's Impact on County Government,” Public Administration Review (Vol. 35, No. 2, March - April, 1975), 134.
} 
Cebul

primetime television address (speechwriter Pat Buchanan coined it) in which he laid out his domestic policy agenda. The President outlined plans for tax and welfare reform (his failed Family Assistance Plan), jobs training (Comprehensive Employment Training Act, which passed), Revenue Sharing, and Block Grants. By sharing string-free federal tax receipts, Nixon framed Revenue Sharing, his top legislative agenda, as “a gesture of faith in America's State and local governments and in the principle of democratic self-government." ${ }^{\prime 100}$ In his 1971 State of the Union, Nixon more forcefully framed the majoritarian, "Silent Majority," spirit behind his New Federalism proposals, which had, by then, begun to take shape in the White House and Congress: "The further government is from the people, the stronger government becomes and the weaker people become." "Local government," he said, "is the government closest to the people, it is most responsive to the individual person." New Federalism would constitute a "new American revolution" in which the federal purse would be deployed to enhance the effectiveness and lower the cost of state and local government. ${ }^{101}$ As an added benefit, Nixon promised, New Federalism "can provide desperately needed tax relief for millions of Americans.", 102

\footnotetext{
${ }^{100}$ Richard Nixon, Address to the Nation on Domestic Programs, The American Presidency Project, UCSB, http://www.presidency.ucsb.edu/ws/index.php?pid=2191\#ixzz1tqRLnoIG

${ }^{101}$ Richard Nixon, "State of the Union Address," January 22, 1971, the American Presidency Project, UCSB.

102 Richard Nixon: "Statement About the General Revenue Sharing Bill," October 20, 1972. The American Presidency Project, UCSB,. http://www.presidency.ucsb.edu/ws/?pid=3636.
} 
Cebul

Members of the Office of Management and Budget (OMB) and John Ehrlichman's

Domestic Policy Staff designed the programs, and Ehrlichman in particular believed in the

program's promise for forging a new Republican majority. ${ }^{103}$ Ehrlichman's staff relished the

process of developing the political and philosophical rationale behind the slate of reforms. In

glaring contrast to the grim realities of local internecine battles over federal poverty and

development spending, Nixon's staffers deployed high minded and abstract political theory.

Invoking the authors of the original Federalist Papers and classical Western political thinkers, the

staffers created pen names for themselves - Althusias (Richard Nathan, assistant director of

OMB), Publius (William Safire, a speechwriter) and Cato (Tom Charles, a conservative attorney)

- and engaged in philosophical tête-à-têtes on the merits of American federalism. ${ }^{104}$ Their central

goal, Althusias (Nathan) wrote in "Federalist No. 3," was to "invigorate American" federalism

"at a time when the anonymity and frustrations of modern life require that we build a stronger

sense of community and make our public institutions more adaptable to the needs and wishes of

our citizenry." They sought "the re-establishment of the political ideas of American federalism

\footnotetext{
${ }^{103}$ David A. Caputo, "Richard M. Nixon, Revenue Sharing, and Federalism,” in Friedman and Levantrosser, eds., Richard M. Nixon: Politician, President, Administrator (New York: Greenwood Press, 1991), 62.

${ }^{104}$ Althusias (Nathan) had been a chief domestic policy aid in Nelson Rockefeller's 1968 campaign for the presidential nomination, and Rockefeller had long been a staunch advocate for revenue sharing and the ideas bound up in New Federalism. For Rockefller's influence, see Edward L. Morgan to John Ehrlichman, March 5, 1971, box 33, folder Revenue Sharing, FA7, RNL; Jamie McLane to John Ehrlichman, December 9, 1971, folder Federal Aid, box 34, RNL; and “Federal Revenue Sharing: Born 1972. Died 1986. R.I.P.,” New York Times, October 10, 1986.
} 
Cebul

plowed under by the Great Society," the legacies of which "make it extremely difficult for chief executives at the State and local levels to set and implement their own priorities."105

While Nixon's staffers planned and strategized in high-minded terms, the President had a more partisan agenda. He aimed to undercut an unwieldy and politically adversarial bureaucracy by removing its central purpose: overseeing and administering federal programs and expenditures. ${ }^{106}$ As Nathan later put it, "federal grant programs are more than fund transfers. They are, in varying degrees, transfers of power." Nixon's unstated goal was "deliberately . . . to bring about certain political consequences." ${ }^{107}$ Said Nixon, "A third of a century of centralizing power and responsibility in Washington has produced a bureaucratic monstrosity, cumbersome, unresponsive ... a colossal failure." ${ }^{108}$ Such an appeal was one with which the nation's suburban

\footnotetext{
105 Althusias, “Federalist No. 3,” June 29, 1970, pp. 1-21, folder New Federalism, 1969-72, box 1, RPN.

${ }^{106} \mathrm{He}$ had good reason to be suspicious of liberal bureaucrats' opposition to his agenda. Racially liberal HUD staffers deeply resented the direction the Administration was taking their organization. See, for instance, the newsletter "Quest," in which bureaucrats wrote satirical articles. "The Majority Is Not Silent The Administration is Deaf," proclaimed one headline in June 1971. Quest writers skewered HUD director George Romney after he'd given out that year's HUD Awards. In their "Quest Awards," the bureaucrats gave their Quest Urban Crisis award to OMB for its "actions with regard to HUD appropriations." Richard Nixon, John Mitchell and George Romney received the Quest Anti-Obfuscation Award for "outstanding achievement in furthering the clarity of public information" for "their contributions to the public discussions of forced integration of the suburbs." Quest, Vol. 1, No. 3, June 1971, 3., Reel 202, Southern Regional Council Papers, Alderman Library, University of Virginia, Charlottesville, Virginia.

${ }^{107}$ Richard P. Nathan, et. al., Block Grants for Community Development, 1977, 363.

${ }^{108}$ Richard Nixon, “Address to the Nation on Domestic Programs,” August 8, 1969, American Presidency Project, UCSB.
} 
Cebul

residents, working class whites and ethnics, and businesspeople could all agree. In a letter to

hundreds of prominent businesspeople, the President wrote,

you know the value of sound fiscal management and are doubtless aware of the bankruptcy which threatens local and state government. By collecting funds in an orderly manner and then distributing them fairly to these governments, and by giving these governments flexibility in adapting expenditures to local needs, we have the opportunity to enhance both efficiency and accountability. ${ }^{109}$

Nixon thus aimed to simultaneously undercut the bureaucracy and thread the needle of

American political culture by using relatively inconspicuous federal income tax revenue to assist state and local governments in delivering valued services for local electoral majorities without having to raise the more visible revenue sources upon which they relied. ${ }^{110}$

Critics warned the Administration that sending loosely regulated aid to state and local government, particularly if they deregulated War on Poverty and other categorical programs, would result in a loss of public resources for poverty groups, electoral minorities, and marginalized Americans. ${ }^{111}$ Nixon's staffers, however, operated under the myopic assumption

\footnotetext{
${ }^{109}$ Richard M. Nixon to Business Leaders, March 1, 1971, folders 3-1-71 3 of 4 and 4 of 4, box 37, Federal Aid: Revenue Sharing, RMNL.

${ }^{110}$ The classical formulation of this seeming paradox of American political culture - high expectations for government and an unwillingness to pay for it - is Hadley Cantril and Lloyd Free, of whose scholarship Nixon was keenly aware. See Lloyd A. Free and Hadley Cantril, The Political Beliefs of Americans: A Study of Public Opinion (New Brunswick, NJ: Rutgers University Press, 1967).

${ }^{111}$ See, for example, "Hatcher Sees Revenue Sharing As a Threat to Blacks in Cities," New York Times, February 23, 1971, folder Revenue Sharing, box 33, FA7, RNL.
} 
Cebul

that the federal government had little role left to play in redressing structural racial

discrimination and that, in the aftermath of the 1960s Civil Rights and Voting Rights Acts, local governments - the bête noire of racial progressives - could be trusted to protect minority rights and access to federal aid. Nixon advisor Daniel Patrick Moynihan was particularly critical. When it came to such concerns, "Mostly," Moynihan said, the domestic policy team "doesn't think at all" about race or poverty. ${ }^{112}$

In addition to analysts at the ACIR, a growing coalition of interests - from businesspeople to state and local officials - supported the Administration's conception of New Federalism. ${ }^{113}$ Staunch liberal Walter Heller was the godfather of the revenue sharing idea, and he had envisioned creating a program, an Area Redevelopment Administration on steroids, that would target depressed regions with significantly more funding than had the ARA. Thanks to Congressional horse-trading, however, the Revenue Sharing bill Nixon signed included vastly more recipient governments than its original proponents had ever imagined. ${ }^{114}$ Instead of shoring up governments that needed help delivering social services or stimulating growth, the final bill

\footnotetext{
${ }^{112}$ William Safire, Before the Fall: An Inside View of the Pre-Watergate White House (New York: Transaction Publishers, 2005), 224.

113 ACIR, Revenue Sharing - An Idea Whose Time has Come, (Washington, December, 1970), 3.

${ }^{114}$ On the history of the idea of revenue sharing, see, for instance, Caputo, "Richard M. Nixon, Revenue Sharing, and Federalism," in Friedman and Levantrosser, eds. Richard M. Nixon.
} 
Cebul

included the vast majority of state and local governments. ${ }^{115}$ As a result, practically every unit of government soon began receiving direct, string-free checks from the federal purse. By 1976, half of the 37,000 units that received checks had fewer than 1,000 inhabitants, and eighty percent had fewer than 5,000. ${ }^{116}$ At the signing ceremony, which the Administration symbolically held in Philadelphia, Nixon invoked first principles, deploying overheated language well honed in Cato, Publius, and Althusias' new Federalist Papers. Nixon framed as revolutionary a program that was anything but. The "Founders," Nixon said, came to Philadelphia,

in the $18^{\text {th }}$ century to establish the federal system. We return here in the $20^{\text {th }}$ century to renew the federal system. They came here to create a balance between the various levels of government. We come here to restore that balance . . After many years in which power has been flowing away from those levels of government which are closest to the people, power will now begin to flow back to the people again. ${ }^{117}$

The key to Nixon's restored balance was massive new federal expenditures. By the end

of 1976, the program had pumped more than $\$ 30$ billion of federal tax revenue to state and local

\footnotetext{
${ }^{115}$ Rural and Western representatives altered funding formulas to increase their own allocations, and the Democratdominated Ways and Means Committee proposed byzantine funding formulas tailored to benefit urbanized states with relatively high income tax efforts. Though these amendments passed the House, the Senate version favored rural, low income states, heavily populated cities, and had a three-part formula based on population, income levels, and the tax effort of state and local governments. Frustrations abounded as the House-Senate conference committee attempted to iron out the differences. Up against the end of the legislative term, Wilbur Mills ultimately led the decision for a dual formula: each Revenue Sharing recipient-government would choose the formula they preferred. For especially thorough discussions of the Congressional process that led to the final version of GRS, see Conlan, 65-76 and Wallin, 34-52.

116 “Revenue Sharing Five Years Later,” Washington Post, April 4, 1976.

${ }^{117}$ Richard Nixon: "Statement About the General Revenue Sharing Bill," The American Presidency Project, UCSB.
} 
Cebul

government. Framed as dialing back the overbearing power of the federal government, state and local governments instead learned to became more dependent than ever on federal funds.

As the Administration had intended, Revenue Sharing's popularity cleared a legislative path for the President's Block Grant program by demonstrating anew to state and local leaders the benefits of cooperative rather than categorical federalism. ${ }^{118}$ While his initial proposal for a “mega grant” fell flat in 1970, his plan for Community Development Block Grants gained traction over 1972 and 1973. Empowered by his electoral landslide in 1972 and with support from state and local officials who were beginning to enjoy the spoils of revenue sharing, Nixon's team pivoted to deregulating key programs of the War on Poverty. The federal programs they targeted for bundling and deregulating included Model Cities, Urban Renewal, and Community Action, some of the most controversial programs of the previous decade.

As they did so, Nixon's staffers seized upon the notion of public private partnerships as way to advance local developmental agendas. In one report concerning the Administration's "New Communities Act” (which would set aside funds to create entirely new, planned communities), HUD staffers explained how cooperative federalism would underwrite local development and foster private sector cooperation. "Perhaps the most fascinating issue concerns

\footnotetext{
${ }^{118}$ On the process of passing CDBGs, see, Conlan, From New Federalism to Devolution, 56.
} 
Cebul

the mix of public and private in the complex process of [developing] communities." As they put

it,

Cooperation with the private sector may be a means of realizing the goals of 'local autonomy' ... on matters of immediate significance (e.g., housing and community facilities) than would otherwise be possible ... Such an approach, of course, arises from the realization that local autonomy without [public] financial resources may be a meaningless concept ... [This] will depend in large measure upon the nature and extent of government participation. ${ }^{119}$

Nixon's staffers well understood that public private partnerships very often rested on the public's ability to deliver necessary stimulus. Block Grants could offer such federally delivered local capital.

In order to ensure as much administrative autonomy for local leaders while paying lip service to the original intent of antipoverty development programs like Model Cities, Nixon's team crafted vague language that could be read as a ratification of War on Poverty goals on the one hand, or, on the other, as a massive federal loophole through which any development could be pulled. Community Development Block Grant money, the Administration mandated, had to be used in one of three areas: 1) to benefit low and moderate income persons; 2) to clear slums and blight; or 3) or to "meet an urgent local need." Just about anything, it would turn out, could be fit into one of those three categories.

\footnotetext{
119 "Financing New Communities: Government and Private Experience in Europe and the United States," A report prepared by the U.S. Department of Housing and Urban Development, Office of International Affairs, May 1973, p. 8-9, Government Documents, Alderman Library, University of Virginia, Charlottesville, Virginia.
} 
Cebul

The Administration reached out to leading business groups to explain the benefits of

Block grants. In 1973, a year before their passage, James T. Lynn, Nixon's HUD Secretary, and

Floyd Hyde, HUD Undersecretary, partnered with the US Chamber of Commerce to create a

video series for local Chambers of Commerce. Joining the Nixon officials were US Chamber

President Arch Booth and a number of big city mayors, including one of Nixon's chief

Republican allies, Richard Lugar of Indianapolis. The tapes, the Chamber advertised to its

affiliates, contain "the complete story of the Better Communities Act" and were a "must for all

community planners, chambers of commerce, city officials and local businessmen." ${ }^{120}$

In addition to explicitly working to partner with business, in its ongoing negotiations with

Congress, the Administration and its Congressional allies steadfastly defeated amendments in

favor of more muscular community participation mandates. ${ }^{121}$ Indeed, an early Senate offering

included a regulation that communities spend $80 \%$ of their grants to help the poor or eliminate

blight and included stiff participation requirements. In the final bill, this language was amended

to require "maximum feasible priority" to these ends, a mandate wide open to interpretation. The

Administration also haggled with Congress over how to allay fears that beneficiaries of block-

\footnotetext{
${ }^{120}$ The Better Communities Act, Chamber of Commerce Newsletter, August 1973, box 5, series II, US Chamber of Commerce Papers, Hagley Museum and Library, Wilmington, Delaware [hereafter CCUS].

${ }^{121}$ Internal Memo re: Community Development Legislation: Major Differences Between Administration's Urban Community Development Special Revenue Sharing Proposal and Community Development Grant Program Proposed by Housing Subcommittee's Study Panel III, June 25, 1971, folder Revenue Sharing, 7-1-71 - 7-31-71, box 34, FA7, RNL.
} 
Cebul

granted categorical programs would not lose out in the new formulas. The Administration

negotiated a series of "hold harmless" provisions that would guarantee a period during which

funding levels would be locked in at a minimum of past levels. ${ }^{122}$ Once these issues were ironed out, the Housing and Community Development Act sailed through both houses of Congress, 76 to 11 in the Senate and 351 to 25 in the House. These returns suggest the Democratic Congress' low level of concern with maintaining robust "maximum feasible participation" regulations. Though Nixon resigned in shame just a month prior to the August 1974 vote, a broad consensus had formed once again on behalf of the notion of cooperative federalism. Community Development Block Grants consolidated urban renewal, Model Cities, water and sewer grants, and other smaller development instruments into a single program distributed by formula. The formula favored population growth, poverty rates, and levels of crowded housing (which, in time, was found to favor fast growing, low wage Sunbelt cities, part of Nixon's Sunbelt strategy, Democrats later alleged). ${ }^{123}$ In effect, President Ford signed a bill that relied on a pre-Great Society model of developmental federalism and demanded little more than lip service for community participation and fighting poverty. Yet, while conservatives had steadfastly headed

\footnotetext{
${ }^{122}$ On these negotiations, See Tab A, Dana Mead to Ken Cole re: Urban Community Development Revenue Sharing, February 8, 1972, folder Revenue Sharing, 01-01-72 - 12-31-72 [1 of 4], Box 34, Subject Files, FA, RNL.

${ }^{123}$ As Robert E. Malakoff, staff director of the Senate Banking, Housing and Urban Affairs Subcommittee on Housing and Urban Affairs later put it, "the real agenda was to get money to the suburban communities - to spread the money around . . It was a fixed political judgment," he contended, "to serve their clientele." "Government Seeks the Right Formula for Community Development Funds," National Journal, February 12, 1977.
} 
Cebul

off liberal support for participation mandates, the loosely regulated nature of the new programs which ballooned federal spending far faster than had the Great Society - encouraged the reinvigoration of urban growth-oriented public private partnerships, increasingly advanced in the name of poverty alleviation not merely growth or clearing blight.

\section{Rustbelt Welfare}

Perk was confident in his relationship with the Nixon and Ford White Houses, and he felt sure Cleveland would receive a great deal of Revenue Sharing and Block Grant funding. The Growth Association, however, was justifiably concerned that once funding arrived it would be put to poor and inefficient use. What the city needed, they argued, was a comprehensive plan aimed at investments in infrastructure, renewal, and corporate and service sector growth downtown, the benefits of which, they contended, would trickle down to the city's neighborhoods. And they had just the plan. ${ }^{124}$ That year, 1975, marked the arrival of Community Development Block Grant money.

Perhaps the clearest sign that HUD was significantly relaxing federal controls was the dramatic drop in the amount of paperwork and oversight required to trigger the dispersal of federal aid. There was no book of rules sent to local administrators. The guidelines issued in the

\footnotetext{
124 “City may run \$18 million in the red by '75," PD, July 10, 1974.
} 
Cebul

Federal Register, too, went little beyond the vague language of the bill itself. Periodically, HUD's David Meeker sent memos of clarification, but these missives - dubbed "Meeker Memos" - were regarded not as the law of the land but as helpful rules of thumb. Rather than audit or closely review programs, HUD simply asked cities to sign "assurances" that their proposals met the spirit of the law. As Floyd Hyde, who had appeared in the US Chamber video put it, when HUD staff members met with local officials to brief them on the new program, they simply stressed local autonomy: "This is your program. We are not going to second-guess you, nor look beyond your certifications and if we get citizen complaints about your performance, we will simply refer them to you." $" 125$

The city of Cleveland's byzantine political system was a direct challenge to the notion that local government was intrinsically more effective than the national at identifying and solving social problems. Each of the city's 33 ethnically and racially balkanized wards elected its own councilperson to a two-year term. The result was a near constant state of campaigning punctuated by volatile factions, backroom deals, and a steady flow of petty scandals and generally embarrassing behavior. The Mayor, who was also elected to two-year terms, was supposed to herd the city council, and, as Carl Stokes' demise revealed, this was no easy task. Over the previous two decades, most of Cleveland's mayors left office in anguish or stalemate.

\footnotetext{
${ }^{125}$ Quoted in Kettl, 22.
} 
Cebul

As Stokes bitterly put it, "No other major city in the country has such an unwieldy legislative body. Unwieldy is not the word; it is corruptive, it is crippling." 126

The corrosive political situation in Cleveland only grew worse with the arrival of millions of dollars of unregulated Revenue Sharing and Block Grants. One of the few federal mandates demanded that both the mayor and the city council approve funds dispersal. Rather than sign off on unified spending packages, however, Cleveland's acrimonious city council demanded the prerogative to vet each title. For any single year of Block Grant appropriations, this could mean over 100 individual instances of council-approved legislation, a boondoggle of politicking and grandstanding. ${ }^{127}$

The implementation of the city's Block Grant program - particularly the meager citizen participation aspects - was critically and perhaps intentionally flawed from the start. The city's Block Grant planners rarely announced hearings with enough lead-time to generate public interest. A Brookings Institution assessment of the program described its citizen participation system: "The public hearings were not well attended. Few substantive comments were made, and," according to a local foundation representative, "those groups that participated were only marginally influential." In the end, "Few changes were made in the city's application as a result

\footnotetext{
${ }^{126}$ Quoted in Tompkins, 12.

${ }^{127}$ CDBG Overview, 7, folder 50, container 3, Buckeye Woodland Community Congress Papers, Western Reserve Historical Society, Cleveland, Ohio [hereafter BWCC].
} 
Cebul

of the post-draft hearings." When neighborhood groups, like the kind Fannie Lewis was

organizing, accused the city of ignoring neighborhood needs, officials "asserted that "priority

areas for receiving low-interest loans for new construction or housing rehabilitation were those

where it was deemed that the money would go the farthest." ${ }^{\prime 28}$ In fighting poverty and blight,

poor areas were becoming construed as bad investments.

From her post at the Citizens Participation Association of Cleveland, Inc. of Model Cities

Residents, Lewis continued to mobilize community residents and groups. The arrival of Block

Grants she wrote her allies, inaugurated an "era of fast changing federal, state and local

programs." Citizens "must have instantaneous communication resources on the broad issue of

social policy." Community groups must "provide the needed source for citizens to get

instantaneous information, interpretation of policies, and Technical Assistance." ${ }^{129}$ By the next

month, she had established the City of Cleveland Citizens Participation Association. They wrote

to the Mayor, "There is fear in the community that documents presented as explanation and

clarification may be part of a plan the community will ultimately be forced to accept or reject"

rather than consider and modify. "Fears are founded upon the fact that the citizens do not have

enough information to make sufficient, knowledgeable recommendations and responses to the

\footnotetext{
${ }^{128}$ Nathan, "Block Grants for Community Development,” Brookings Report, 1977.

${ }^{129}$ Fannie M. Lewis to Community Agencies, Groups and Organizations, October 8, 1974, folder 36, container 2, FMLP.
} 
Cebul

presentation, of those who may stand to gain large economic or political profits as well as prestige. ${ }^{130}$ By March 26, 1975, Lewis' group reached out to David Meeker and others at HUD. ${ }^{131}$ "There was a brief discussion on a group of dedicated people to go to Washington to meet with the Secretary of HUD," meeting minutes noted. "There was a great deal of volunteering of people to go."132 Lewis' group even appropriated the rhetoric of New Federalism to argue for their legitimate roll in city development planning. "New Federalism," they argued, "means we as Citizens have to demand from City Hall what is rightfully ours. Our City is NO better than we demand it to be through our vote ... Allow the citizens to make recommendations for approval of programs that can be beneficial to us ... This can be the end of Federal Grant Rip Off."133

Lewis also kept her Congressman, Louis Stokes, Carl's brother, informed and lobbied for assistance in restoring meaningful citizen participation. As Stokes wrote to Meeker, "I am writing because of my continued concern over the way in which the regulations governing the block grant applications have or have not been complied with by the City of Cleveland.” He enclosed a letter from Lewis' group,

\footnotetext{
${ }^{130}$ Fannie M. Lewis and Joseph Hagerty to Ralph Perk, November 15, 1974, folder 36, container 2, FMLP.

${ }^{131}$ CCPA Meeting Minutes, March 26, 1975, folder 36, container 2, FMLP.

${ }^{132}$ CCPA Meeting Minutes, March 26, 1975, folder 36, container 2, FMLP.

${ }^{133}$ CCPA Statement Prepared for the Community Development Block Grant Hearing, April 26, 1975, folder 52, container 3, FMLP.
} 
Cebul

which specifies in some detail the ineffective and less than thorough compliance with the citizens participation requirements ... [I]t appears that there are a great number of questions which need specific answers ... such a review, to be thorough, should make reasonable efforts to contact representatives of active citizen groups who are those most likely to benefit or to suffer by the proper or improper participation plans of the City.

"In this regard," Stokes wrote, "I would hope that Ms. Fannie Lewis would be contacted and that her in depth awareness of what is actually transpiring be taken into careful account. I find it unacceptable to analyze the effectiveness of such a program merely by asking those charged with improper conduct to explain their behavior."134 There is no indication that Meeker or anyone else at HUD reached out or responded to Lewis.

Despite stipulations that Block Grant funds were to be used for new or refurbished housing, infrastructure projects, or areas of pressing need, the Perk administration developed a plan to use the funds to pay the salaries of nearly 200 police officers who were already on the city's payroll. In order to meet the citizen participation stipulations but fearing the overwhelmingly negative reaction, Perk's team held two rushed hearings on the day it rolled out the program. While HUD initially refused to fund the project, the Perk administration won an exception from Meeker, who ruled "Concentrated Crime Patrol" was a "supportive service" and

\footnotetext{
${ }^{134}$ Louis Stokes to David O. Meeker, April 22, 1975, folder 36, container 2, FMLP.
} 
Cebul

therefore fundable under CDBG. ${ }^{135}$ Neighborhood groups cried foul, but, as a Brookings report

on Block Grants in Cleveland concluded, "Their protests were largely ignored by the city.",136

The Perk Administration's actions, quickly drew the ire and activism of a number of

neighborhood groups that had mobilized through the War on Poverty, Model Cities, and to

watchdog the Block Grant program. The Buckeye Woodland Community Congress (BWCC), for

instance, had roots in 1960s Ford Foundation programming meant to foster interracial

dialogue. ${ }^{137}$ Given the pitched state of affairs in the Buckeye neighborhood, however, the early

efforts to organize had largely fizzled. To the more abstract (and older) goals of racial

reconciliation, interfaith understanding, and class and neighborhood-based solidarity, the

Congress attached economic and physical improvement of the neighborhood and residents'

homes - a crucial innovation. At the top of their list when they first organized was the demolition

of abandoned structures that were quick tinder for fires and safe havens for criminals. The

Congress hoped to use shared economic and material concerns to defuse the tension sewn by the

rising crime rates and the racial scare tactics of groups like the Buckeye Boys.

The Congress was at the leading edge in Cleveland of a national proliferation of

neighborhood associations that actively sought a place within the developmental state. Their

\footnotetext{
${ }^{135}$ Nathan et. al., 1977, 441.

${ }^{136}$ Nathan et. al., 1977, 442.

137 John McGreevy, Parish Boundaries, 227-8.
} 
Cebul

mobilization was part of what historian Suleiman Osman has argued made the 1970s "the decade

of the neighborhood." ${ }^{\prime 38}$ Cleveland in the 1970 s, as one analyst put it, "was undergoing a

veritable revolt of the neighborhoods," and the new round of activism combined older direct

action tactics with a focus on economic conditions brought about by the interactions of public

programs and private market forces. Starting in 1974, the BWCC conducted studies on housing

and economic issues facing the neighborhoods. And the Congress was just that: over 700

Buckeye-Woodland residents and representatives of 105 social, civic, and church groups

attended its opening conference. ${ }^{139}$ Across the city, similar groups, though less well staffed or

funded, sprang up throughout the decade. ${ }^{140}$

The Congress' first president was Kenneth Kovach, a young sociology professor at Notre

Dame College. Georgiana Watts, an African American resident of Buckeye, was the first housing

committee chair, and she, like many others, worried that political pressure from business leaders

would encourage the city to squeeze out the neighborhood's residents in favor of industrial or

downtown development. "We feel we are being pushed out and there is no place else to go," she

said. As Thomas Gannon, Kovach's 26 year old deputy put it, the city's politicians “are far

removed from the problems and respond, it seems, only to pressure, and that pressure has been

\footnotetext{
${ }^{138}$ Osman, "Decade of the Neighborhood."

139 “Buckeye-Woodland group to fight blight,” PD, February 16, 1975.

${ }^{140}$ Examples include Fannie Lewis' group in Hough, the Citizens to Bring Broadway Back, and St. Clair-Superior.
} 
Cebul

coming in the past from well-organized groups like the downtown merchants and owners and managers of industry." ${ }^{141}$ The Congress would unite Buckeye residents to pressure the city to deliver the services they were promised by law. The city administration, it seemed to these residents, could actually be harder to reach than Washington bureaucrats.

While the Nixon and Ford Administrations had successfully fought community participation mandates in passing their Block Grant legislation, the legacy of the War on Poverty's more stringent regulations endowed groups like the Congress with high expectations for democratic access to programs ostensibly meant to benefit their neighborhoods. Indeed, under Title II, the Block Grant legislation specifically stated, "The primary objective of this title is the development of viable urban communities by providing decent housing and a suitable living environment and expanding economic opportunities, principally for persons of low and moderate income." Moreover, in its overall statement of purpose, the Act stipulated, "Priority must be given to activities that benefit families with low or moderate incomes." The Congress sought its fair share of the city’s first \$16 million Block Grant.

As a result, another of the Perk administration's first Block Grant proposals met with stiff resistance. In 1976, businessman Nick Mileti, owner of Cleveland's professional basketball and hockey franchises, moved the teams to a new arena thirty miles south of the city, hoping to

\footnotetext{
141 "Black and white join to fight City Hall,” PD, April 27, 1975.
} 
Cebul

attract more suburbanites as well as residents of Akron. Mileti still owned the old city arena,

however, located on the city's east side at E. $36^{\text {th }}$ St. and Euclid Ave. It was an albatross for him, and, after trying unsuccessfully to sell it to private investors, Mileti turned to the city. ${ }^{142}$ By early

July 1976, news that the Perk administration was interested in purchasing the arena had leaked.

Neighborhood groups were incensed to find out that Perk planned to use \$1 million of Block

Grants (along with another $\$ 1$ million in EDA grants) to purchase the obsolete arena. Perk

argued the \$2 million investment would enable the city to lease the arena to private investors, generating a paltry $\$ 15,000$ to $\$ 25,000$ a year. ${ }^{143}$

Though it had little or no actual connection to revitalizing struggling neighborhoods, HUD assisted Perk in his scheme. The Block Grant legislation did not allow for the purchase of developed property, they explained; it permitted only the purchase of land upon which new housing or other projects would be constructed. HUD helped Perk reconfigure the transaction: if Mileti would donate the arena to the city, Perk could purchase the land with Block Grant

\footnotetext{
142 "Buckeye-Woodland residents meet to rap city plan to buy Arena," PD, July 14, 1976.

143 “200 protest Perk’s plans to buy Arena for investors,” PD July 16, 1976.
} 
Cebul

funds. ${ }^{144}$ "Our houses are falling down and Mayor Perk's city is deteriorating - this is where we need the money," demanded Margaret Foster, a leader of Buckeye's Congress. ${ }^{145}$

Along with Foster, 200 residents attended an emergency meeting to which they invited Perk. The Mayor sent a mid-level staffer who professed no knowledge of the Arena plan. After the Congress threw out the mayor's representative, Barbara Pertz, a Buckeye resident and homeowner, expressed her frustration over the city's bankrupt community participation processes: “I don't want to read in the newspaper that the mayor is going to spend $\$ 1$ million for the Arena ... I want him to come here and suggest it first." ${ }^{146}$ Perk also faced stiff resistance from the majority of City Council, which saw little to gain from the scheme. Council's reticence combined with the Congress' noisy protests scuttled the Mayor's efforts to purchase the arena. It was a rare victory for citizen participation in the Block Grant process, one HUD officials later highlighted when it offered community participation success stories - whitewashing its own role in assisting the city in bypassing residents.

Perhaps more than any other aspect of the legislation, Block Grants brought new hope among neighborhood residents that federal dollars would assist them in revitalizing their own

\footnotetext{
${ }^{144}$ Dean K. Clark to Paul G. Lydens, September 3, 1976, folder City Club of Cleveland, 10/8/76, Box 40, Carla A. Hills Papers, Hoover Institution, Stanford University; Paul G. Lydens to William Slider re: Secretary's Briefing Paper-Cleveland, Ohio, September 21, 1976. City Club of Cleveland, 10/8/76 Folder, Box 40, Carla A. Hills Papers, Hoover Institution, Stanford University [hereafter CAHP].

145 "Neighborhoods first, city told," The Plain Dealer, July 17, 1976.

146 “200 protest Perk’s plans to buy Arena for investors," The Plain Dealer, July 16, 1976.
} 
Cebul

homes. Particularly promising were Titles II and III of the legislation that created financial tools

for home renovation. The titles acknowledged that many homes purchased in blighted areas with

FHA-backed mortgages had been poorly inspected (or not at all) and the costs of maintaining

substandard homes were being unfairly borne by the nation's poorest homeowners. Title III's

$518 \mathrm{~b}$ program authorized the creation of a pool of federal funds to reimburse those owners who

had purchased FHA-backed mortgages between August 1968 and January 1973 for the repair of

major defects that inspectors had missed and which posed "a threat to life or safety." The

legislation also sought to encourage both federal and private lending for home improvements by

relaxing federal regulations on the amount local savings and loans could lend. But thanks in part

to Cleveland's own programmatic failings and also sluggish roll out from Washington, these

aspects of the program were the slowest to develop.

The Buckeye Woodland Community Congress made lending redlining and the failures of the $518 \mathrm{~b}$ program, which they argued perversely benefitted better off homeowners, the central focus of its efforts. Under 518b, local Community Development offices were empowered to offer small low-interest loans: $\$ 200$ for a new furnace, $\$ 750$ for roof work. In investigating this program, the Congress found an even more confounding outcome than simply a private bank's unwillingness to loan money for repairs or mortgages. Cleveland's CDBG-backed program offered direct loans at fixed 3\% interest for 20 years with a maximum loan of $\$ 17,400$. As the 
Cebul

Buckeye's Margaret Foster testified before U.S. Congress, "many homes in our community would not even be appraised at $\$ 17,000$ and it would be foolish to pour that much money into rehabilitation. ${ }^{, 147}$ Foster complained that HUD's “'hands-off" policy ... let city officials use the funds for political projects which bypass the people." ${ }^{.148}$ Indeed, much of the city's home rehabilitation loans were directed to better-off areas already on the upswing, like the white near west side neighborhood of Ohio City, home to members of Perk's ethnic base.

The city's failure to deliver loans in poorer neighborhoods created publicly structured incentive systems that actually reinforced private banks' unwillingness to lend. Foster testified before the Senate Banking Committee on Neighborhood Preservation and described how the process worked. Once a neighborhood like Buckeye had been effectively redlined by private lenders, the only options for potential homebuyers was to purchase FHA or VA-backed mortgages. "FHA/VA is supposed to inspect the house before insuring the mortgage, but in most cases," as the CDBG legislation recognized, "no inspection takes place.... The home buyer, thinking the house has met standards of the federal government, moves in. Then the first time he turns on the furnace he finds it out of order." Had the city's Community Development office been more responsive, perhaps Buckeye's new homeowners might have been able to shoulder

\footnotetext{
${ }^{147}$ Testimony of Margaret Foster before the House Committee on Banking, Currency, and Housing, September 29, 1976, Congressional Record, p. $853-859$.

${ }^{148}$ Testimony of Margaret Foster before the House Committee on Banking, Currency, and Housing, September 29, 1976, Congressional Record, p. $853-859$.
} 
Cebul

the burden of their collapsing homes. Instead, a "tight financial situation makes the homeowner

face a decision to make a major repair or be late on his mortgage payment." A more insidious

process ensnared them. Financially strained by the costs of their disastrous mortgages and unable

to secure a loan from the city's unresponsive development office, Buckeye's new homeowners

began to fall behind on their mortgage payments. Rather than work with the homeowners, local

mortgage banks instead invalidated late payments and demanded late fees. After just two or three

late payments, mortgage companies foreclosed. Soon, many homeowners found themselves

trapped by what the Buckeye activists called "fast foreclosure." The process, Margaret Foster

testified, had reached "systemic" status. By backing the mortgage and not the homebuyer or the

actual home, the FHA and VA had incentivized the fast foreclosure process. Mortgage

companies foreclosed, owners were evicted, the house was abandoned, and the mortgage

company received the full value of the home from the federal government. Foster provided to

Congress information on 300 such foreclosures in Buckeye-Woodland alone. ${ }^{149}$ Funds that had

originally been created for a War on Poverty were speeding the eviction of aspiring homeowners.

Faced with these circumstances, Sarah Turner, a member of the Congress, brought pieces

of her home's broken banister with her to Washington, DC. She and 100 others - every one of

them carrying pieces of their deteriorating homes - barricaded themselves in the lobby of HUD's

\footnotetext{
${ }^{149}$ Margaret Foster, Testimony before the Senate Banking Committee on Neighborhood Preservation, June 1976 , Congressional Record. See also, PD, June 15, 1976.
} 
Cebul

headquarters. The protesting homeowners were in Washington as part of a series of

demonstrations and public hearings organized by National Peoples Platform, a Chicago based

neighborhood movement. They used the fragments of their homes to erect a shack in the federal

building's lobby. The Rev. William Tanguay of Providence, R.I. spoke for the group: "We got

community development money in our cities and all we really got was political patronage ... We

know where the [HUD] money is going ... while our houses are going down the drain." ${ }^{150}$ Block

Grants, the protestors argued, helped develop political patronage, not homes and communities. ${ }^{151}$

When 200 more demonstrators gathered outside the lobby, HUD administrators set up a platform

with a PA-system from which they promised investigations. As protestors inside and out sang

“America the Beautiful” and "We Shall Overcome," David Meeker signed an agreement

pledging his administration would identify 20 cities to consider enhanced citizen participation,

lower administration costs, and to ensure proper use of funds. "We don't want any more big

government programs," Gail Cincotta, a national neighborhood advocate, said. As she put it, "It

was big government programs that destroyed our cities." ${ }^{\text {"152 }}$ Conservatives weren't the only ones

leveling criticism at big government.

\footnotetext{
150 "Neighborhood chiefs force HUD to action," PD June 15, 1976.

${ }^{151}$ This is a great opportunity to highlight the liberal critique of big government waste ...

152 Quoted in Osman, "The Decade of the Neighborhood," 119.
} 
Cebul

Neighborhood groups and progressive policy analysts called upon the Ford White House

to mandate or earmark a clearer portion of funds specifically for neighborhood development.

"Sympathetic as I am to those needs," Ford said,

I have concluded that it would be a mistake for the Federal government to attempt to impose allocation requirements on the block grant program. This would certainly begin to lead us back to the categorical grant era, with its ponderous federal red tape, bureaucracy, and lack of flexibility and accountability.

Instead, the President restated the law's proven-toothless requirement that "maximum feasible priority" be given "to activities which will benefit low or moderate income families or aid in the prevention or elimination of slums or blight." "I take these requirements of the law seriously," Ford said, and it "should be the business of the citizens to determine the use of CD funds at the local level."153 Thus, President Ford essentially told citizens frustrated at local uses of Block Grants that it was their responsibility to steer block grant funds to the kinds of projects they desired. The Buckeye Woodland Community Congress must have been astonished when the Ford Administration tapped Ralph Perk to represent the United States and to tell of Cleveland's success in fighting poverty at a United Nations conference on sustainable neighborhoods.

${ }^{153}$ President Ford's Neighborhood Policy Address, Draft, October 19, 1976, folder Urban Development and Neighborhood Revitalization Committee, box 11,Myron B. Kuropas Papers, GRFL. 
Cebul

During the 1976 presidential campaign, Ford's team and HUD staffers traveled the country offering a very different vision for the use of Block Grant funds. A particularly fraught visit to Cleveland by Ford's Director of Housing and Urban Development, Carla A. Hills, provided a good example. After the summer demonstrations in Washington, the Buckeye Woodland Community Congress reached out to Hills to arrange a meeting to discuss the situation in Cleveland. Hills agreed, but they were disappointed to learn upon their arrival to the meeting that they only had 40 minutes and that 20 other people - many of whom worked for the city - were in attendance, too. "For these reasons," Ken Kovach later angrily wrote to her, "this was a bogus meeting and phony attempt to discuss new ways to revitalize neighborhoods."154

In contrast, Hills spent an hour with the city’s business community. In her remarks, she underscored the constituencies with whom she and Ford envisioned HUD partnering: "The presence today of Cleveland's business community - listening to, and questioning a representative of the Administration - is proof, if any were needed, that this nation's private sector and this nation's government constitute an insoluble partnership - and verifies the proposition basic to my area of concern that the Federal government, working through the

\footnotetext{
${ }^{154}$ Secretary Carla A. Hills, Itinerary, City Club of Cleveland, October 8, 1976, folder City Club of Cleveland, 10/8/76, Box 40; Kenneth J. Kovach, Diann Yambor, Pat, West, Sarah Turner, and Rufus Banks to Carla Hills, October 22, 1976, folder City Club of Cleveland, 10/8/76, Box 40, CAHP.
} 
Cebul

private sector, can have a vital role in both housing and the economy." $" 155$ She flew back to

Washington that night on Eaton Corp.'s private jet. ${ }^{156}$

The Nixon and Ford Administrations had effectively laid down the nation's arms in the

War on Poverty, but the massive federal subsidies set aside to fight the war lived on in

Community Development Block Grants. While the Perk Administration had initially kept

business interests at a distance, even campaigning against their involvement in city politics, the

Nixon and Ford Administrations had explicitly created Block Grants with business involvement

in mind. The second half of the 1970s would see Cleveland's business people's more vigorous

efforts to seize the fruits of these public subsidies.

${ }^{155}$ Carla A. Hills Speech, City Club of Cleveland, October 8, 1976, folder City Club of Cleveland, 10/8/76, Box 40, CAHP.

${ }^{156}$ Asst. Sec. for Legislative Affairs re: Secretary’s Trip to Cleveland - October 8, 1976, Ibid. 
Cebul

\section{Chapter Six}

Deregulating the War on Poverty in Georgia

Though one rarely read about it in the News Tribune, Rome, Georgia was home to a vibrant and, in many ways, thriving African American community. The Five Points neighborhood just north of Rome's downtown stretched up along Broad Street and out East First street and comprised the heart of the black community. Between 1940 and 1950, the black population in Floyd County, mainly based in Rome, grew from 8,637 residents (out of 56,141 total) to 9,273 (of 62,899 ). Though their relative share of the population shrunk as whites moved in from the county to take new manufacturing jobs, for the most part, Rome's African American population during and after the war stayed put rather migrate northward. ${ }^{1}$ Between 1950 and 1960 , the community continued its steady growth. ${ }^{2}$

While the East First Street and Five Points neighborhoods contained some pockets of grim poverty - decrepit shacks with no plumbing or heat, for instance - there was also a sturdy middle class and thriving business district. In the 1940s and 1950s, walking along Broad Street, one passed George Smith's Barber Shop near “Bubber” Duke's grocery store. Gertie Duke's

\footnotetext{
${ }^{1}$ Between 1940 and 1970, some five million African Americans, overwhelmingly from rural parts of the South, migrated to the North. For narrative accounts of the great migration, see Isabel Wilkerson, The Warmth of Other Suns: The Epic Story of America's Great Migration (New York: Random House, 2010), and Ncholas Lemann, The Promised Land: The Great Black Migration and how it Changed America (New York: Vintage, 1992).

${ }^{2}$ Population figures in Historical Census Database Browser, UVA Library.
} 
Cebul

Café was next door, where diners chose from three daily specials. The next building housed

Graham Robinson's Drug Store, which was originally built for Dr. Robert N. Brooks’ Brook

Haven hospital. A native of Trinidad, Brooks studied medicine at Shaw University before

becoming the first intern at Tuskegee Institute Hospital. When he arrived in Rome, blacks were

not allowed in the local hospital, so he performed surgery in patients' homes, often on their

kitchen table. In 1912, he built Brook Haven, where he practiced until his death in 1930. The

larger and more modern Samaritan Hospital was subsequently opened in the neighborhood.

Hubert Holland's six-chair barbershop was next door to the drug store, and his customers often

got a trim before heading to Eli McConnell's Billiard Room. Perhaps the best-known fixture of

Five Points, however, was Webb's Café, run by Carrie Webb, the wife of the Café's owner,

Gene Webb. Travelers to and from Atlanta, Birmingham, Chattanooga often stopped in for some

of the region's best home-style cooking. Five Points was also home to black owned insurance

companies, cleaners, beauty shops, a photo studio, and several churches. During the first half of

the twentieth century, the goings-on of the community were covered by Rome's weekly African

American newspaper, The Rome Enterprise, a title that betokened the neighborhood's vitality. ${ }^{3}$

By the early 1960s, then, Rome's African American community had, despite Jim Crow,

developed an autonomous and bustling community. Nevertheless, even the "best" blacks were all

\footnotetext{
${ }^{3}$ For this overview, I have relied on the rich collection of biographies and interviews in Morrell Johnson Darko, The Rivers Meet: A History of African-Americans in Rome, Georgia (Kearney, NE: Morris Publishing, 2003).
} 
Cebul

but excluded from Rome's political and civic life and none held public positions, whether elected

or appointed. Despite their enterprises, Rome's Chamber of Commerce had no black members.

Questions of equitable representation, never much considered before, would be thrust to

the fore as Georgia's local white leadership pursued new federal developmental programs. By

the early and mid-1960s, Rome and Northwest Georgia's white civic and business leadership

enjoyed a robust and expanding partnership with growth-oriented instruments of the

developmental state. The twelve county, public-private Coosa Commission had provided the

model for the Appalachian Regional Commission, and Rome's businesspeople and politicians

were drawing up plans for an Urban Renewal program. Likewise, forward looking white

Georgians like small businessman Jimmy Carter and aspiring politician Sam Nunn mobilized to

develop regional planning and development commissions of their own that could secure their

share of developmental state spending. For these Georgians, the New Deal's model of

cooperative federalism - generous federal subsidies administered by local elites - offered an

ideal form of governmental action on behalf of regional economic growth. ${ }^{4}$

Lyndon Johnson's Civil Rights Act and the subsequent War on Poverty, however,

ruptured this longstanding model of growth-oriented cooperative federalism by imposing

minority participation mandates. Having viewed their earlier partnership with government

\footnotetext{
${ }^{4}$ On the New Deal's model of federalism, see chapters 1 and 2. See also, Smith, Building New Deal Liberalism.
} 
Cebul

through the lens of competitive regionalism, which offered evidence of self-help, rugged

individualism, and community stewardship, leading white Georgians contested federal mandates

for minority and poor involvement. They disparaged antipoverty spending as immoral handouts, wasted tax expenditures, and impediments to smooth and effective development policy.

Moreover, the passage of the Civil and Voting Rights Acts offered white Georgians evidence that the racial issues of the past had already been solved and suggested that new programs, which empowered racial and electoral minorities, threatened local democratically elected institutions as well as elites' sense of consensus behind their developmental leadership. As blacks sought to seize their federally guaranteed share of democratic access and economic opportunity, racial unrest exploded in Rome as it had across the country over the 1960s and early 1970s.

These frustrated outbursts, however, only reinforced for white leaders the legitimacy of their position as shepherds of the community and as rightful caretakers of federal development spending. This chapter illuminates these themes by exploring developments in Rome, but it also tracks the political rise of Jimmy Carter through the lens of debates about federalism, localism, and competition over which constituencies deserved to benefit from federal aid. Carter's most significant political education came through his involvement in Georgia's Area Planning and Development Commissions. This formative period revealed to him the power of local and federal public private partnerships for opening new avenues to economic growth. But, in the context of 
Cebul

rural Georgians' frustration with federal involvement in local racial affairs, he also discovered

the Commissions could be framed as a bulwark against federal encroachment. Both of these

lessons profoundly informed his political style and legislative agenda as Governor. Carter

campaigned as a businessman who would at once tame state government to make it more

responsive to "the people" and to pursue more vigorous economic development. His reforms,

running parallel to President Nixon's kindred New Federalism, effectively deregulated Georgia's

War on Poverty on behalf of a New Deal model of elite-led development and cooperative

federalism. These developments had dire consequences for minority enfranchisement such as

those who lived in Rome's Five Points neighborhood.

Businessmen Fight a War on Poverty

Over the 1960s, the Coosa Commission and its allies at the Chamber of Commerce and

City Commission shepherded the region's initial War on Poverty programs. Indeed, city and regional leaders viewed new federal antipoverty programs through the prism of their past involvement in the developmental state. As a result, the public-private Commission initially saw the War on Poverty as a "human resource development" program, listing their stewardship of Community Action, Head Start, and Neighborhood Youth Corps along with other economic development instruments. In their 1966 annual report, for instance, the Commission placed its 
Cebul

description of War on Poverty programs between a report on a Minerals Development Study and an overview of a series of workshops they conducted on state industrial and building codes. ${ }^{5}$

Northwest Georgia's civic and business leaders were enthusiastic administrative gatekeepers for the region's War on Poverty. The Commission named Richard L. McCullough, clerk of the Floyd Board of Roads and Revenue, temporary chairman of the Rome-Floyd County Community Action Committee, the group of citizens who would establish the region's permanent War on Poverty team. Mather Payne, president of the Rome Chamber of Commerce, was named chairman of the Community Action Council nominating committee. The other attendees named to the committee were school superintendents Harold Lindsey and Milton McDonald, Donald Jackson, "representing the Negro community," and a representative each from the Floyd Health Department and the Jaycees, the Junior Chamber of Commerce. W.T. Levins of the Coosa Commission was brought in as a "technical advisor." At an October 1965 meeting, the group determined both the makeup of the Community Action Committee, and, according to the Rome News Tribune, "would [soon] approve the projects [and] apply for and administer the various programs.” In 1965, the Commission received $\$ 18,250$ in poverty

\footnotetext{
${ }^{5}$ CVAPDC Annual Report, June 30, 1966, UGA Library, Athens, GA.
} 
Cebul

planning dollars to assist member counties in setting up the federal programs, ultimately securing

$\$ 2.7$ million in antipoverty funds. ${ }^{6}$

A nearly identical state of affairs played out in West Central Georgia, where Jimmy

Carter led his Planning Commissions' pursuit of War on Poverty funds. Like the Coosa

Commission, Carter's Commission applied to become the sponsoring organization for local OEO

programs. ${ }^{7}$ When the OEO indicated their proposal did not include the necessary provisions for

participation by the poor, Carter urgently telegrammed the OEO requesting they amend the

application. As he put it, "provisions for incorporating the poor in the actual planning of our

program have been made. Poor have been in the actual power structure itself. We plan to use

their talents and suggestions in all plans under the Economic Opportunity Act." ${ }^{8}$ At a subsequent

meeting, Carter emphasized to other Commission members that "the Developers must be able to

explain the program to top officials and also be able to communicate and work with the poverty

\footnotetext{
6 “Floyd Action Unite to Name Officers In 'Poverty' War,” RNT, October 24, 1965. Across Northwest Georgia, a number of Coosa Commission members became intimately involved in various Community Action programs. R.D. Barton, for instance, served as Coosa Commission president but also chaired the Bartow County OEO and served on the Northwest Georgia Community Action Agency. Another CVAPDC'er served as Finance Chairman of Tallatoona, the regional office of Community Action and the OEO. CVAPDC Newsletter, January, 1969, Rome / Floyd County Library Heritage Room Archives.

${ }^{7}$ Economic Opportunity Act of 1964: Programs Available, box 5, Jimmy Carter Papers, Pre-Presidential, $1962-$ 1976, JCL and "WGCAC Approves Charter, Elects Officers At Meet," undated news clipping, box 5, Jimmy Carter Papers, Pre-Presidential, 1962-1976, Jimmy Carter Presidential Library, Atlanta, Georgia (hereafter, JCL).

${ }^{8}$ Jimmy Carter telegram to Mr. Richard Housler, attn. Arleen Mantell, January 11, 1965, box 5, Jimmy Carter Papers, Pre-Presidential, 1962-1976, JCL.
} 
Cebul

stricken." ${ }^{9}$ Beyond this instruction, however, there is little evidence to suggest that Carter's

Commission actually developed any plans for or carried out community participation beyond

community presentations. Nevertheless, their application was accepted, and the Commission was

put in charge of establishing the local Community Action Council.

Once OEO money arrived, the West Central Georgia Community Action Council ran

OEO programs in the area. ${ }^{10}$ In cities across the North, Community Action Councils became

some of the most contested sites in the War on Poverty, as African Americans mobilized to

direct federal programs meant operate on their own behalf. In many cases, these constituencies

used Community Action programs to challenge local political and business hierarchies. ${ }^{11}$ Such

was not the case in West Central Georgia nor, indeed, for much of the rest of the state. Despite

the fact that Americus, one of the leading townships in the Commission's area, had seen vital

civil rights organizing, and despite OEO guidelines mandating "maximum feasible participation"

of the poor, the civil rights activists who had gained such legitimacy among the local African

American community were never consulted for the federally funded Community Action

Council. ${ }^{12}$ Instead, like the Commissioners in Rome, the council sought token racial

\footnotetext{
${ }^{9}$ Meeting Minutes, WCGPDC, January 27, 1965, box 5, Jimmy Carter Papers, Pre-Presidential, 1962-1976, JCL.

${ }^{10}$ WGCAC Approves Charter, Elects Officers At Meet, Undated Article, Americus Times, box 5, Jimmy Carter Papers, Pre-Presidential, 1962-1976, JCL.

${ }^{11}$ See, O'Connor, Poverty Knowledge, McKee, The Problem of Jobs, Sugrue, Sweet Land of Liberty, Milkis \& Mileur, eds., The Great Society and the High Tide of Liberalism.

${ }^{12}$ Stephen Tuck, Beyonod Atlanta, 173-86.
} 
Cebul

representation rather than real participation. African American members served at the pleasure of local white elites.

Like local leaders in Rome and Americus, other business and political elites in rural areas across Georgia looked with great optimism to War on Poverty programs. The Georgia Mountains Planning and Development Commission based in Gainesville, Georgia led the establishment of the City Demonstration Committee, the first step toward winning federal Model Cities' funding. The Gainesville Times reported optimistically about the Demonstration Committee's partnership with the Industrial Development Division at Georgia Tech, writing "the work would emphasize support to existing business, assistance to the neighborhood planning staff in identifying means for maximizing economic growth and coordination of the economic development efforts.",13 Gainesville's application was accepted, and the city's efforts - which included numerous consultations with federal officials, partnership with experts at the University of North Carolina, Georgia Tech, and the University of Georgia - were characteristic of others underway in regions across the state. $^{14}$

\footnotetext{
13 “CDC Suggests City Seek \$40,000 for Model Cities," Gainesville Times, May 23, 1968, folder Engineering Experiment Station - Industrial Development Department, Georgia Institute of Technology Archives, Atlanta, Georgia [hereafter GTA].

14 “Gainesville model cities puts fully allotted staff into motion," Gainesville Times, June 23, 1968, folder Engineering Experiment Station - Industrial Development Department, GTA.
} 
Cebul

The OEO funded another Model Cities program in rural Georgia. "A great event has taken place," Wm. W. Lee, the co-owner of Lee Feston Chevrolet-Olds of Alma, Georgia, wrote to his Congressman, William S. Stuckey. “Alma has been declared a Model City. This single event," the business owner predicted, "will probably push Alma further into the present than any other event in its history ... We now do not have to worry about becoming a ghost town, slowly drying up into nothingness. We now have a future."15 In his own letter to the Congressmen, Alma's Mayor echoed Lee's words. This “prized recognition” would make "Alma's future a promising one instead of a slow ending." This "was the highest honor ever bestowed on the fine people of this community." "16 To Northern observers, the city's political and business leadership's intense interest in and celebration of the arrival of one of the War on Poverty's most controversial programs would have seemed truly remarkable. Yet a perusal of the mayor's and Model Cities Commission's updates to their Congressman suggests a striking counterpoint to the Northern experience with the War on Poverty's community development programs. Indeed, while African American community leader Bennie Moore hoped the program might offer more jobs to the black community "and keep our young people from leaving town," he tempered his expectations. "We need Negro councilmen, firemen, police clerks, cashiers and sales people," he

\footnotetext{
${ }^{15}$ Wm. W. Lee to William S. Stuckey, November 23, 1968, folder 22, box 21, subseries B, series IV, William S. Stuckey Papers, Richard B. Russell Library for Political Research and Science, University of Georgia, Athens, GA (hereafter WSSP).

${ }^{16}$ Henry S. Bishop to William S. Stuckey, November 23, 1968, folder 22, box 21, subseries B, series IV, WSSP.
} 
Cebul

said. But the powers that be "say that they're not qualified for these jobs." Moore himself planned a run for council in hopes of shaping the Model Cities program, but, he lamented, "I don't think I'm going to win . . . but I'm going to try. It's the principle of the thing." ${ }^{\prime 7}$

Instead, despite community participation mandates, Alma's established leadership overwhelmingly determined the uses of the federal program. Over five years of Model Cities funding, Alma and its outlying county, Bacon, received just under \$5 million in federal aid, a significant windfall for the tiny South Georgia community (Alma also received just over \$2 million in Urban Renewal funding). ${ }^{18}$ Local leaders used federal money to make significant improvements to the county's airport and acquired 200 acres adjacent to the landing strip for industrial redevelopment and recruitment. When she wrote to describe a citizen participation hearing concerning the development of a 117-acre rural recreation park, Model Cities Commission Chairman Omi Walden described the feedback from the rural community's citizens. "Naturally there is some skepticism among some people about getting involved in federal programs ... But the Model Cities program is actually the reverse of what they think. It is returning decision making to the local level by making block grants to accomplish objectives we couldn't do otherwise." Walden explained to her constituency that the program was "an

\footnotetext{
${ }^{17}$ Sam Hopkins, "Town Getting Smaller - But Better," Atlanta Constitution, November 15, 1970, attached to above, folder 1, box 39, subseries B, series IV, WSSP.

${ }^{18}$ Department of Housing and Urban Development, Model Cities Grants, $8^{\text {th }}$ Congressional District, undated, and “HUD Notification,” Project Number ME-10-005, undated, folder 14, box 92, series IV, WSSP.
} 
Cebul

experiment to prove that if people and industry had a hospitable model community - from the

political, social, and economic standpoint - they would remain in small towns."19 The

Chairman's remarkable interpretation of the program suggested just how different the Southern

context could be than the Midwest or Northeast, where mobilized African American community

groups sparred with politicians and other interests over the meaning and use of federally backed

community development programs. Thanks to the disempowerment of its African American

residents such as Bennie Moore, the Alma-Bacon County Model Cities program almost wholly

targeted white-oriented economic development. The prestige it gained Omi Walden catapulted

her to state and national positions. ${ }^{20}$ Across the South, business interests and white civic elites

dominated local war on poverty committees and programs. ${ }^{21}$

Rome's Urban Renewal program best illustrates the strains that eventually developed

between African Americans and local elites over issues of representation, development, and purportedly antipoverty or anti-blight programming. During the New Deal, Millard I. "Jack"

\footnotetext{
${ }^{19}$ Omi Walden to W.S. Stuckey, Jr., November 19, 1970, folder 1, box 39, subseries B, series IV, WSSP.

${ }^{20}$ She went on to serve Democratic Governors Jimmy Carter and George Busbee as their Federal / State relations coordinator before establishing and directing the Georgia Office of Energy Resources. In 1978, President Carter appointed Walden Assistant Secretary for the U.S. Department of Energy. Jimmy Carter: "Department of Energy Nomination of Omi G. Walden To Be an Assistant Secretary.” January 25, 1978. Online by Gerhard Peters and John T. Woolley, The American Presidency Project. http://www.presidency.ucsb.edu/ws/?pid=31178.

${ }^{21}$ In Houston, oil industry executive George H.W. Bush was just one of the city's leading businessmen appointed to the antipoverty board. Wesley G. Phelps, "Ideological Diversity and the Implementation of the War on Poverty in Houston," in The War on Poverty, Annelise Orleck and Lisa Gayel Hairjian, eds., 93-4.
} 
Cebul

Frost served as inspector in charge of CCC programs in Atlanta, overseeing the "efficiency and economy of operations" in six southeastern states. ${ }^{22}$ Thirty years later, Frost was again helming developmental state projects, leading Rome's Urban Renewal program, which began to take shape in 1962. Frost headed the Rome Housing Authority, and he worked to generate support for Urban Renewal among the city's business leadership. Frost equated Rome's East First street African American neighborhood with the worsening Northern urban crisis and warned City Commissioners that Rome was not immune from the strains faced by larger, older industrial cities. John Gutermuth of Rome’s Celanese Fibers Company echoed Frost, noting "the ambitious program [is to be] conducted against several of the same problems existent in Rome" that "are normally associated with larger urban centers.",23

At Frost's urging, the Rome City Commission voted 7-2 to apply for federal Urban Renewal funds. ${ }^{24}$ The initial federal outlay sent to Rome in May 1966 was \$1.4 million, and the

\footnotetext{
${ }^{22}$ Directory of Field Activities of the Bureau of Biological Survey. Washington, D.C.: U.S. Department of Agriculture, January 1939, p. 36. Accessed online at: http://books.google.com/books?id=LaooAAAAYAAJ\&pg=PA36\&lpg=PA36\&dq=\%22Millard+I+Frost\%22\&sourc $\mathrm{e}=\mathrm{bl} \&$ ots $=5$ jf2fjfgs\&sig=ETHDXca7wKgAfI3XQSGGIyvaiYY\&hl=en\&sa=X\&ei=yvhvUaDlOrWy4AP4pIDwA Q\&ved $=0$ CDEQ6AEwATgK\# $\mathrm{v}=$ onepage $\& \mathrm{q}=\% 22$ Millard $\% 20 I \% 20$ Frost $\% 22 \& \mathrm{f}=$ false

23 “Area engineers join in week's observance," RNT, February 13, 1969.

${ }^{24}$ One of the nay voters complained that Urban Renewal's supporters' logic seemed to be, "Everybody else is doing it, so why don't we go along?" He reminded his fellow Commissioners of the cooperative nature of this federal program: there was "no federal law which requires a city to participate in federal Urban Renewal. This decision is entirely in the hands of the various city governments." Quoted in "Urban Renewal: Promises or Progress? Federal project described as 'thing to do' in 1962," $R N T$, August 1, 1971.
} 
Cebul

federal government also lent the city's matching funds, just over $\$ 2$ million. ${ }^{25}$ As one HUD

report put it, the funds would be used for "Clearance of the largest concentration of substandard housing in Rome, Georgia, and redevelopment for new medium-priced housing will be planned when the city begins survey and planning activities for its first urban renewal project, the 105acre 'East First Street."' Rome’s Urban Renewal would raze all 285 homes in the city’s predominantly African American East First Street neighborhood. ${ }^{26}$ The Commission established a separate committee, the Urban Development and Housing Committee, to oversee the program and the parallel development of a housing project for displaced East First Street / Five Points residents who were unable to afford other housing options.

Regarding community participation, HUD's guidelines noted that “in most communities business and civic organizations will be prominent in matters affecting the community as a whole ... This representation," HUD hedged, "should not be exclusive of other elements in the community ... Individuals should be selected who are deeply interested in, and who are able and willing to work for, improvement of the community." While Rome's initial committee included one African American representative, no members of the impoverished neighborhoods slated for renewal were included or consulted. As in many renewal programs in the North, the decision

\footnotetext{
${ }^{25}$ HUD News Release, May 18, 1968, folder VI C Floyd County 1968, box 74, series VI, James W. Davis Papers, Richard B. Russell Library, University of Georgia, Athens, Georgia [hereafter JWDP].

${ }^{26}$ Housing and Home Finance Agency, Urban Renewal Administration News Release, November 22, 1963, folder VI C Floyd Co. 1960-1965, box 74, series VI, JWDP.
} 
Cebul

about which neighborhood to "redevelop" was based on determining which city land would be the cheapest to acquire and raze in order to limit the city's matching obligations. Choosing the poorest African American neighborhood had the added benefit that it promised to generate the least consequential political resistance. In order to limit its portion of the federal matching requirements, the city put up five percent of the program cost through "in kind" work done by city employees (demolition, site clearance, etc.), and, in 1965, it struck upon a scheme whereby the State Highway Department (itself heavily subsidized by federal dollars) delivered the other 20 percent by rerouting GA-HWY 20 through the razed area: a win-win for the city's political and business elite who had long coveted a more direct route to Atlanta and Chattanooga.

Hubert Holland's six-chair barbershop was in the renewal zone, and rather than relocate his business, he hoped to purchase a new lot in the redeveloped area. Ousted blacks, however, found it nearly impossible to submit a winning bid for land that had once been their own. Donald Jackson, a leader of Rome's African American community who had also served as the "representative of the Negro community" on the Community Action Council, also had his business dislocated. He penned a frustrated letter to the News Tribune describing the situation. “About dislocated business, M.I. Frost, executive director of the Rome Housing Authority said 'We would love for 'em (this 'em is Frost's way of saying black businessmen) to come back in there." This "statement by Frost," Jackson complained, "is an inside joke for it has been known 
Cebul

for a long time that once blacks were out of the Five Points and East First area that there would

be no way for them to get back." He continued,

We had a preview of things to come when the property at Five Points was auctioned off some time ago. Mack Lyons, a Negro, was one of the high bidders and it was thought he would buy the property, so the rules were changed in the middle of the game to include property at some other location... This is a trick you can expect to be used in the resale of all urban renewal sales if it appears that some blacks will buy. Negroes were told they could buy lots in the East First area, which they could have done if allowed to buy lots but instead of selling single lots, they were sold as a block of lots to a real estate developer. Between the money lenders, developers, and the power of the Housing Authority, including zoning regulations, we can forget Five Points and East First Street. ${ }^{27}$

African American businesspeople who chose to relocate suffered as well. Callie Martin worried that her business would not recover after her move. The owner of North Broad Street's Let's Eat Café, Martin had previously run a grocery store and café on East First before the Renewal project moved her out. At the grocery, she said, "I was able to give work to two people. But now I'm just working by myself and not really making ends meet at that." Urban Renewal "really caused me to lose a decent living." Martin was just one of 16 black-owned businesses that were displaced by the East First Street Urban Renewal Project. By 1971, only four of those

\footnotetext{
${ }^{27}$ Donald Jackson, Letter to the Editor, RNT, August 8, 1971.
} 
Cebul

businesses had successfully reopened. Said Holland, "The way I see it, they destroyed the Negro businesses, what little they had ... They just destroyed it., ${ }^{, 28}$

Urban Renewal, however, not only dislocated Holland's business; it also dried up his client base as neighborhood homes were razed as part of the slum clearance program. Many residents of the East First Street neighborhood were relocated several blocks away to the Housing Project, attractively named "GA 5-6." Holland lamented the absurdity of taking home owners and renters and putting them in public housing, when, in recent years especially, "We've been preachin $[\mathrm{g}]$ this thing about self-help." Many "families," he said, "scuffled and paid for a little ole raggedy house, even though you and I might not have liked it. But it was theirs. And they ... came along and took it and gave [th]em one or two dollars for it, so to speak, and then put [th]em in the projects. ${ }^{29}$ Others, who hoped to rebuild, often faced bureaucratic intransigence and willful obstruction by realtors and banks. One woman whose house was seized through eminent domain hoped to buy another plot of land on which to rebuild. Without the new plot, however, she was forced to pay rent on her own home. "Whenever I called" real estate agents, "I always told them first that I was living in the Urban Renewal area. So, they knew automatically that I was black. They would say 'I'll see if I can find something for you and give

\footnotetext{
${ }^{28}$ Chris Frazier, "Urban Renewal: Promises or Progress? Four of 16 firms reopen after property is taken,” RNT, August 4, 1971.

${ }^{29}$ Chris Frazier, "Urban Renewal: Promises or Progress? Playgrounds and parking lacking in housing unit," RNT, August 3, 1971.
} 
Cebul

you a call.' Of course, I never heard another word from them." "They just don't want to sell houses in white neighborhoods to black people." In the wake of the removal of some 240 black families, "there just aren't very many nice black neighborhoods where any houses are for sale." After months and months and contacting "real estate agents on top of real estate agents," the Housing Authority at last released a cleared lot, and she and her family were able to begin building a new home. An intrepid News Tribune reporter spoke to three other families who experienced nearly identical scenarios. Reid Brookins, a regional HUD official confirmed that numerous African American families in Rome had been forced into renting their own homes. "This is a very undesirable situation," Brookins deadpanned, "when a homeowner has to rent his own house for any period of time at all." ${ }^{30}$ As in Cleveland, urban renewal in Rome turned homeowners into renters.

For Rome's African Americans, however, the issue was far more serious than an "undesirable situation," one that ultimately boiled down to seizing meaningful representation in the program. The Housing Authority, many argued, "ought to have at least one member who knows and understands the problems of poor blacks." ${ }^{31}$ Instead, the five-member East First Street Urban Renewal board was exclusively white and Chamber-dominated: W.T. Maddox, president of National City Bank; A.L. Barron, secretary of the Rome Coca-Cola Bottling Co.

\footnotetext{
${ }^{30}$ Ibid.

${ }^{31}$ Ibid.
} 
Cebul

(and former president of the Rome Chamber, head of the Rotary Club and chairman of the

Georgia Bottlers Association); Charles Hight, Sr., owner of Hight Insurance Co.; John Jervis, president of Citizens Federal Savings and Loan Association (an active Chamber and Kiwanis member); and J. Dan Hanks, director of alumni affairs and development for the elite, independent Darlington Schools. When pressed on the possibility of adding a black resident to the Housing Authority board, one city leader equivocated. "I would suspect that it would be a reasonable area in which we would benefit from another point of view. We certainly have a substantial black population in the public housing projects ... On the other hand, I wouldn't say that a man who might be eligible for reappointment would be automatically removed to be replaced by a black person simply for the sake of putting a black name on the roll., ${ }^{, 32}$

As of June 30, 1971, Urban Renewal in Rome had spent \$2.1 million (the remainder of the total federal appropriation of $\$ 3.2$ million was still available). As an enterprising young News Tribune writer concluded, however, "After nine years of expensive studies, exhaustive planning, 'slum clearance' and uprooting families by the score, Urban Renewal in Rome has little to show for itself but frustrated blacks, disgusted city officials, six private apartment units and a barren strip of red dust and clay." ${ }^{, 33}$ City Manager Bruce Hamler recalled the early days of Urban

\footnotetext{
${ }^{32}$ Chris Frazier, “Urban Rewnewal: Promises or Progress? Many descriptions fit much-changed program,” $R N T$, August 6, 1971.

${ }^{33}$ Chris Frazier, “Urban Rewnewal: Promises or Progress? Federal project described as 'thing to do' in 1962," RNT, August 1, 1971.
} 
Cebul

Renewal in Rome: "It was just the thing to do in those days, just like fighting pollution is the thing to do today. In those days, cities everywhere were building projects. ${ }^{34}$ In the end, a majority of City Commissioners reported that they would choose against another full scale Urban Renewal program. Said one, "they’re just not what they're cracked up to be.” City Manager Bruce Hamler said the new focus would be on "a block or two at [a] time." Individual homeowners, he said, would be encouraged to get federal loans at "extremely low interest rates," and Congress should fund the program in ways that would enable the local government. One white resident of Rome, however, chose to look at the bright side. "I believe UrbanRenewal is the best thing that ever happened to North Rome! Sure," Mrs. W.T. Skelton wrote the News Tribune. Sure, "it's been long going," and there have been "hardships of re-locating families and disturbing businesses." But, "It's easy to get complaints, or 'I can tell you how it ought to be done,' but let someone else do it and, if it doesn't work out, say 'Well I wasn't right for it anyhow." The good news, however, was clear. "We are getting a new drive-in bank, larger and more convenient North Rome Fire Department, New North Rome School ... [and] the Atlanta expressway will be closer to Rome." "So," she concluded, "let's exercise our faith in the future and our government, up-grade our family and brighten the corner where we are and I am sure this time next year if God let's us live, things will look much better." ${ }^{35}$

\footnotetext{
${ }^{34}$ Ibid.

${ }^{35}$ Mrs. W.T. Skelton, Letter to the Editor, RNT, August 8, 1971.
} 
Cebul

A Not So Silent Majority

Despite Mrs. Skelton's rather naïve optimism, by the early 1970s the politics of race and community development had changed dramatically from the optimistic days of 1962 . While most of Rome's business people tolerated a moderate degree of closely overseen desegregation and many played a key role in bringing federal antipoverty dollars to the region, President Johnson's ambitious Civil Rights agenda changed the tone of local racial politics almost overnight. Even before the Civil Rights Bill had become the law of the land on July 2, 1964, the News Tribune's editorial page was emphasizing the downsides of Johnson's ambitious legislative agenda. Next to another editorial titled "Goldwater Stands by Convictions," the paper's editors decried the reckless federal expenditures that were bound up in his agenda. The "most disturbing built-in [spending] increase of all," they noted, was the increasing costs of servicing the nation's "\$315 billion public debt. The debt interest rises relentlessly and will exceed \$11 billion in fiscal 1965." Yet, "President Johnson is pressing for several high cost new programs and is letting nothing expire ..."36 The following day's editorial pages continued the theme of sectional grievances and fiscal conservatism. One piece was titled "Local Autonomy Right at Stake" and described the looming shutdown of the Prince Edward County, VA schools. Another conspiratorially

\footnotetext{
36 “"Beaten path,” RNT, June 22, 1964.
} 
Cebul

alleged "Electoral Vote Rigged Against Conservatives. ${ }^{, 37}$ A letter to the editor that day by

Minister Rev. Thomas Wheelis, pastor of the First Methodist Church of Rome, put a fine point

on the matter: "every person in America has less freedom" as a result of this bill. That day, a

doctor, a restaurateur, a motel owner, and a member of the Rome City Commission expressed

similar sentiments. ${ }^{38}$ Freedom and fiscal responsibility were both at stake.

In the ensuing months and years, the editorial page of the News Tribune took on an

increasingly defensive tone. In February 1964, the News Tribune warned that the new civil rights

legislation augured the encroachment of "all-powerful, centralized government."

also ran screeds, for instance, from the reactionary Mississippian Thurman Sensing. ${ }^{40}$ The long-

time leader of the Southern States Industrial Council, Sensing made a name for himself in the

1930s by staking out a nearly opposite position on the New Deal than that of Northwest

Georgia's and Northeast Alabama's business leaders, calling for zero federal presence. ${ }^{41}$ Over

\footnotetext{
${ }^{37}$ Both in RNT, June 23, 1964.

${ }^{38}$ Cited in Brattain, 231.

${ }^{39}$ Quoted in Brattain, 247.

${ }^{40}$ See, for example, Thurman Sensing, "Lesson Learned from Newark," $R N T$, July 25, 1967, "Climate of Violence Grows," $R N T$, May 16, 1967, and "Evidence alarming that Nixon is neglecting conservatives," $R N T$, March 14, 1969.

${ }^{41}$ On Sensing and the Southern States Industrial Council, see Katherine Rye Jewell, “As Dead as Dixie: The Southern States Industrial Council and the End of the New South, 1933-1954" (Ph.D. diss., Boston University, 2010). On Sensing's place among 1950s conservative activists, see a fascinating report, Ralph E. Ellsworth and Sarah M. Harris, "The American Right Wing: A Report to the Fund for the Republic, Inc.," University of Illinois Graduate School of Science, 1960, accessed online at https://www.ideals.illinois.edu/bitstream/handle/2142/3928/gslisoccasionalpv00000i00059.pdf?sequence=1
} 
Cebul

the 1950s and into the 1960s, Sensing was an outspoken segregationist, too. One particularly nasty 1964 editorial began, "To discuss the so-called 'civil rights' bill and be forced to use the words 'civil rights' is in itself a victory for totalitarians in our midst." ${ }^{, 42}$ Sensing quoted a supporter of the bill who hoped the measure "would encourage the Negro movement to develop sit-ins and other non-violent techniques." In other words, Sensing wrote, "the provisions of the 'civil rights' bill would encourage revolution in the streets of America." ${ }^{43}$ A Rome physician echoed Sensing in a subsequent letter to the editor, comparing the law to the "tyranny and oppression of a strong central power" that had given birth to the nation in the first place. ${ }^{44}$ That November, the News Tribune endorsed Goldwater for President. Goldwater, they wrote, embodied "the belief that the best government is that which governs least." ${ }^{, 45}$ Even Rome's leading union, Local \#689 of the Textile Workers Union of America endorsed Goldwater, arguing in a full page advertisement that Goldwater's election (and that of Davis' opponent in that year's Seventh District Congressional race, Republican Ed Chapin) was essential "to preserve American freedom and to stem the tide of socialism and overpowering centralized government." Davis, the union's leadership wrote, "claims to be a conservative but continues to vote more liberal than any other Georgia congressman." Goldwater's "strong stand

\footnotetext{
${ }^{42}$ Thurman Sensing, "'Civil Rights' and Totalitarianism," RNT, February 10, 1964.

${ }^{43}$ Ibid.

${ }^{44}$ Quoted in Brattain, 247.

${ }^{45}$ Ibid.
} 
Cebul

for state's rights, for integrity, morality, and fiscal sanity in government more truly represents the views of the voters of Floyd County." They assured readers that " $75 \%$ of the Local membership feel the same way."46 "Fiscal sanity," however, did not seem to apply to the millions in federal aid the Coosa Commission was concurrently reeling in to spur regional economic development.

These racially bounded views were widely shared. Julius B. Dodd, President of the Rome Bank and Trust, mailed to Congressman Davis a copy of an article written by Reverend Wheelis for his church's "Roman Herald." The piece, Dodd wrote, "summed up the situation" regarding the concentration of "more and more power in Washington . . the best of anything I have read." "Though Government officials scream to high heaven," wrote the Reverend, "that there is no communism in America, it is not true." "As long as people are independent, earn their own living, and expect to, the Government is helpless to infringe upon the people's rights. But when people cease to be the masters of their fate, and turn to the Government for security," he explained to his parishioners, "they become serfs to do their master's will. And that is what has happened to us."

"The Great Society" would be an insult to the rugged individuals who fought for, worked for, and built this nation. This was a union of states made up of citizens who asked nothing more from the government than that it protect their lives, liberties and happiness

\footnotetext{
${ }^{46}$ Quoted in Brattain, p. 247.
} 
Cebul

while they built their homes, businesses and churches. It is time for this nation to awaken from its slumbers. ${ }^{47}$

Several other members of the First Methodist Church sent that edition of the "Roman Herald" to members of their Washington delegation. ${ }^{48}$

Goldwater's candidacy inspired Georgia Republicans to seek seats on city and county commissions. In February 1964, 300 northeastern Alabama and northwestern Georgia GOP members came together for a barbecue chicken dinner and rally in Rome. Two of the speakers called Lyndon Johnson "the betrayer of his native Southland." Gadsden, Alabama Republican James D. Martin, a regional oil dealer who nearly upset veteran legislator Sen. Lister Hill in 1962, told the assembled Republicans, "we in the South are shaking off the chains of one-party political slavery and we have the power to change the structure of both the national political parties and turn them back into instruments for individual liberty and the restoration of the free enterprise system." The civil rights bill, he said, perpetrated by "Judas Johnson," inflicted "the raw, brutal force of federal power on every man, woman and child in America." Another speaker decried the "Democratic power grab" in Washington. We "have been represented by Democrats in Congress who talk a good Southern line when they are running but vote for the big centralized

\footnotetext{
${ }^{47}$ Thomas Wheelis, "What I see From the Church Window," The Roman Herald, Vol. II, No. 42, August 19, 1965, attached to Julius B. Dodd, Jr. to JWD, August 30, 1965, folder VI A Civil Rights 1965-66, box 53, series VI, JWDP, RBRL.

${ }^{48}$ See generally folder VI A Civil Rights 1965-66, box 53, series VI, JWDP, RBRL.
} 
Cebul

government." Gardner Wright, Jr., a Rome Republican, crowed that, while the "Floyd

Democratic Assn., at its annual meeting here last week, boasted that it was the largest such

organization in the state ... I am happy to be able to tell you tonight that we have a larger crowd

for our meeting than the Democrats had for theirs, indicating the tremendous growth of the

Republican party in Floyd County in the last three years."

Rome, it turned out, was one of the most fertile regions for Republican insurgency. As

the News Tribune editors put it, the impending Goldwater-Johnson contest offered a stark

"choice preferred by many voters across the land who do not relish the 'mainstream' of

government paternalism and dictation represented by the more liberal elements of the GOP and

Democrat parties." ${ }^{\prime 4}$ Two years later, a plurality of Rome and Floyd County voters chose the

Republican candidate for Governor, State Representative Howard "Bo” Callaway. In 1964,

Callaway had become the first Republican state representative in Georgia since Reconstruction,

running as a businessman and self-styled Goldwater Republican. In 1966, Calloway ran for

Governor against Democrats Lester Maddox and the relatively unknown Jimmy Carter. Neither

Calloway nor Maddox secured a majority at the state level, throwing the contest to the

Democrat-controlled state legislature (Carter finished a distant third). In Rome, Callaway

supporters felt strongly that their delegation - despite partisan affiliation - had a duty to choose

49 “It's Our Choice,” RNT, July 14, 1964. 
Cebul

Callaway since Rome had given the Republican a plurality. E.W. Hine of the Hine Cotton

Company was particularly outspoken on the matter. "I feel very violently that the Floyd County

legislators who do not vote the way the county voted are not representing the people. They owe it

to us to vote the way we vote. I believe that being a good citizen comes before being a Democrat

or Republican.." ${ }^{50}$ D.B. Magruder, a Rome lawyer, echoed Hine's sentiments, saying he "would

feel disfranchised if they do not vote for the candidate the county supported."

Ahead of the 1968 elections, the Rome Chamber of Commerce made uncharacteristically

clear calls for political action, reflecting Marguder's sense that business-like views were being

crowded out by a minority of voters. Chamber President Charles Doss invoked language akin to

Nixon's Silent Majority in his column in the organization's monthly newsletter:

These are trying times ... when we need straight-thinking people in public office. We need people who are elected to office by a majority and not by default. If a candidate is elected to office by a handful of people simply because the majority stayed away from the poll ... then he really is elected by default ... If he is the wrong kind of candidate, we cannot excuse our responsibility in the matter by saying 'I didn't vote for him.' . . . [W] simply MUST exercise our rights as citizens of this great country ... to vote ... RIGHTS that we COULD LOSE if we DON'T USE! ${ }^{51}$

\footnotetext{
50 “Voting Sample Backs Callaway for Governor," RNT, December 14, 1964.

${ }^{51}$ Charles E. Doss, "President's Pen," The Forum, May, 1968, Hargrett Special Collections Library, University of Georgia, Athens, GA [hereafter HSCL\}.
} 
Cebul

In a subsequent column, Doss linked majoritarian democratic participation to support for "modern city and county government," emphasizing the importance of "good streets, good roads, a clean, well-kept city and ... good schools and many other things.. ${ }^{.52}$ Noting with disappointment the low voter turnout in a recent primary, Doss warned Chamber readers, "Effectively, then, we have government by the minority ... We are in danger of losing our great American values, even our right to vote, if the great majority of Americans don't start accepting the responsibility of being citizens. The responsibility of citizenship includes voting.",53

In a county where blacks made up less than 15 percent of the population, Doss had little to worry about in terms of local minority electoral insurgencies. Local hierarchies were hardly at stake. Instead, his outspoken call for voting focused on national elections, where federal regulations that came along with new War on Poverty funds threatened to undermine Doss and other elites' longstanding administrative autonomy. As in Atlanta, Rome, and across Georgia, other businesspeople the south were wrestling with newly assertive minority groups. Fred Burtner, the Executive Vice President of the Greater San Antonio Chamber of Commerce, wrote an article for the Chamber of Commerce Newsletter explaining the situation in his Texas city.

"Recently," he wrote, "I discovered a private organization in San Antonio duplicating many of the programs of our Chamber. I was shocked to learn it has nearly twice as many employees and

\footnotetext{
${ }^{52}$ Charles E. Doss, "President's Pen,” The Forum, August, 1968, HSCL.

${ }^{53}$ Charles E. Doss, "President's Pen,” The Forum, September, 1968, HSCL.
} 
Cebul

a larger budget than our Chamber $-80 \%$ of which is federal money." "Both organizations have

the same goals - to create a better and stronger community and to provide more jobs for our

citizens. The difference is the Chamber speaks and acts for the business community in behalf of

the total community while the other organization is minority oriented, seeking jobs only for ethnic group citizens." Burtner confessed the "discovery probably should not have surprised me, since ... such organizations . . . have taken small, but ever-increasing, bites out of what was once the bailiwick of chambers of commerce." He noted that some had done "outstanding" jobs, but others, "unfortunately, have only served to muddy the waters, overlap with other organizations, dilute available resources and perpetuate needless bureaucracies. These are the ones which should concern chamber executives." Burtner put part of the blame for their proliferation on Chambers themselves, writing "too often we have not done our job well, leaving a vacuum which has been filled by some other organization. To put it bluntly, we have failed." Burtner called for responding "courageously to [community] needs" which would require hiring the best and the brightest young people to work for local Chambers. While his identification of the Chamber's role in local affairs, his solution had almost nothing to do with engaging those marginal and mobilizing communities. He titled his piece "A Matter of Survival.",54

\footnotetext{
${ }^{54}$ Fred W. Burtner, “A Matter of Survival,” Chamber of Commerce Newsletter, December 1972, box 5, series II, CCUS.
} 
Cebul

Rome's leadership experienced similar contestation. Intergovernmental regulatory wrangling over Rome's plans to desegregate its public schools, for instance, stymied the city's Headstart program, a federal initiative about which local leaders had originally been quite supportive. After securing initial approval for its desegregation plan from the Department of Health Education and Welfare, the city announced that it would build two new schools, one on each side of town. HEW, however, reported justifiable suspicions that, according to the News Tribune, "each of the two ... schools will become racially identified, reverting to all-Negro or all-white schools." Rome's superintendent admitted as much, saying "You can't keep people from moving if they want to." HEW expressed frustrations that a new round of plans would be necessary for the 1970-71 school year, and that the federal agency would again be forced to send a representative to "outline alternatives" for Rome's leadership. Because Headstart funds were tied to regulatory approval of the desegregation process, the program would be stymied heading into the school year. The News Tribune blamed the federal government: "For the last several years, Rome Headstart has been late in beginning due to delays at the federal level. ${ }^{, 55}$ While Rome's "moderate" business leadership had managed to steer Rome through the 1960s and early civil rights mobilization, by the early 1970s, on the heels of Urban Renewal and flimsy War on Poverty results, a new generation of the city's African American community

\footnotetext{
55 "Rome school leaders look to '70 session," RNT, September 23, 1969.
} 
Cebul

pressed for more meaningful representation. Frustrations mounted among this younger

generation, dislocated by urban renewal and denied federally guaranteed access to Headstart, desegregated schooling, and political representation. The most vocal, wide ranging, and violent expression came toward the end of the summer of 1971. Jimmy Hardy, an organizer of Rome's Black Coordinating Committee, spoke for a younger group of African Americans who pushed for more meaningful representation within city government and for improved job opportunities, education, and housing. Younger black residents were frustrated not only with white civic leaders but also with older African American leadership. "It's to the point now, especially with the young blacks," said Hardy, "that we don't care, really, how you feel about us. But we want to see some effective action taken on what we want." Meaningful integration was at the top of his list. Whites did not understand, he said, "what happens in the black community." "They leave their jobs, and get in their cars, and roll up their windows and turn on their air conditioners and they go back home" to "their side of town." A black activist warned the News Tribune, "You haven't had a demonstration yet . . . you haven't had any real serious vandalism or rioting . . . but you see it's something that can happen.",56

It remains unclear who perpetrated the violence or what sparked it (some said police misconduct following allegations of black on white crime) but, on the night of August 31, 1971,

\footnotetext{
${ }^{56}$ Quoted in Brattain, 273-4.
} 
Cebul

five downtown, white-owned businesses were firebombed. Then, on September 2, a small bomb exploded near the main entrance to a bowling alley. The city hosted a mass meeting of

predominantly black residents, but little progress was made on addressing grievances or identifying the culprits. Two weeks later, an arsonist lit a home on fire, and, when the fire department arrived, black bystanders pelted the men with rocks. The following day, three hundred African American students walked out of Rome's East High School to demand greater representation in student affairs and access to extracurricular activities. ${ }^{57}$ Sixteen students were arrested, and the city commission declared a curfew. The Rome unit of the Georgia National Guard was put on standby alert. ${ }^{58}$

Rome's white leadership responded with a series of interracial meetings. Blacks sought better representation in the police and fire departments, more than a token presence on the city's various commissions and boards, and meaningful access to jobs. The Chamber of Commerce, in particular, met with black leaders. They heard from residents like Jeffrey Jackson who complained that usually "we've been given one clerical job or one job in front of the show window. They [employers] want people to walk by and say 'that place is integrated' but it's not

\footnotetext{
${ }^{57}$ WSB-TV news film clip of a civil rights demonstration as well as a press conference with Ben Lucas, chair of the Board of Commissioners, in Rome, Georgia, 1971 September 15, Walter J. Brown Media Archives \& Peabody Awards Collection, UGA Libraries, accessed online at: http://crdl.usg.edu/cgi/crdl?format=_video\&query=id\%3Augabma_wsbn_64077\&_cc=1

${ }^{58}$ Brattain, 273-4.
} 
Cebul

really integrated because when you go upstairs, you do not see any blacks in any responsible positions." Jackson charged that members of "the white business and industrial world" were guilty of perpetuating the "stereotype ... that blacks, regardless of their education [, were] simply not capable of performing well in anything but menial jobs." White business owners, Jackson pointed out, were "getting rich off the black community. They're taking the money out of the black community and into [the white subdivisions of] Garden Lakes or Horseleg Estates or wherever they live." ${ }^{, 59}$ The passage of the Civil Rights Act, it turned out, had done little to change discriminatory patterns or to create new avenues for economic opportunity. Indeed, the bulk of Rome's urban renewal "slum clearance," which effectively killed the black business district in Rome, occurred after the bill's passage, between 1965 and 1968.

\section{"New” Democrats}

Despite the fact that the War on Poverty in Georgia had, in many cases, been initiated, administered, and blunted by local white elites, its cost and regulations provided easy targets for politicians seeking to politicize still potent racial resentments stirred during the 1950s and 1960s Civil Rights gains. ${ }^{60}$ Compared to George Wallace, Richard Nixon hit the rhetorically more

\footnotetext{
${ }^{59}$ Brattain, 275-6.

${ }^{60}$ On the various ways local elites sought to administer, roll back, or redirect War on Poverty programs, see, especially, Kent Germany, "Poverty Wars in the Louisiana Delta: White Resistance, Black Power, and the Poorest
} 
Cebul

moderate mark with his "Silent Majority" appeal. ${ }^{61}$ Similarly, a number of young Georgia

Democrats, later considered harbingers of another, more progressive "New South," gained

traction throughout the state by legitimizing the newly transfigured racial politics, moving from

overt race baiting to targeted, veiled, policy oriented appeals. Over time, however, the

unintended effect of this new political mode was to discredit the very public institutions these

politicians sought to join.

Zell Miller hailed form the North Georgia mountain town of Young Harris, and he

initially made a name for himself as a pragmatic centrist who represented the turn away from

race baiting rural politics as usual. After serving two terms in the state house, however, Miller

packaged the new politics of race in 1966 in a failed effort to unseat incumbent Democratic U.S.

Representative Phil Landrum. The War on Poverty, Miller claimed, had been "laid by Lyndon

Johnson and hatched by Phil Landrum" and "would go down in history as containing some of the most wasteful uses of the taxpayers' money ever conceived by man." Miller charged that antipoverty funds were being used to rent tuxedos for black high school students to wear to a juniorsenior prom or to fly youngsters to big league baseball games. All of this at a time, he suggested, when funds were being cut for U.S. forces in Vietnam. "I was talking to a man in the Ninth

Place in America;" and Wesley G. Phelps, "Ideological Diversity and the Implementation of the War on Poverty in Houston," in The War on Poverty: A New Grassroots History, eds., Orleck and Hazirjian.

${ }^{61}$ Lassiter, The Silent Majority, 269-70. 
Cebul

district recently," Miller testified on the campaign trail, "who had to send boots to his son in Viet

Nam because he didn't have adequate footwear and yet our money is being spent for tuxedos."

Our "individual freedoms are being sacrificed away bit by bit at the altar of political expediency,

and I firmly believe it is high time that we resort to whatever political influences are available to

us in order to recapture them. ${ }^{, 62}$ Zell's main themes, then, were absenteeism (on the part of

Landrum), waste (in terms of the War on Poverty), and Lyndon Johnson: "The people of the

Ninth District will THINK FOR THEMSELVES, and they will not LET LBJ CHOOSE THEIR

CONGRESSMAN." "63 "I shall work for federal cooperation, rather than federal domination," he

promised. "I shall resist, not endorse, the destruction of state's rights and individual freedoms

along with the further centralization of power in Washington." ${ }^{, 64}$

Like Miller, Jimmy Carter's early political career initially hadn't much to do with the

politics of race, civil rights, or desegregation. Instead, Carter positioned himself in the early

1960s as a 'business progressive' in the mode of Governor Carl Sanders. ${ }^{65}$ It was for that reason,

Carter felt, that he lost his surprisingly strong showing for governor in 1966 to the reactionary

\footnotetext{
${ }^{62}$ From the North Georgia Tribune, "Landrum Linked to LBJ," People's Choice, News of the $9^{\text {th }}$ District, September 1966, folder 15, box 1, series II, Zell Miller Papers, RBRL [hereafter ZMP].

63 “Zell Miller Speaks on Issues," People's Choice, News of the $9^{\text {th }}$ District, September 1966, folder 15, box 1, series II, ZMP.

${ }^{64}$ People's Choice, News of the $9^{\text {th }}$ District, September 1966, folder 15, box 1, series II, ZMP.

${ }^{65}$ On Sanders, see, James F. Cook, Carl Sanders: Spokesman of the New South (Macon, GA: Mercer University Press, 1993).
} 
Cebul

and segregationist Atlanta restaurant owner Lester Maddox. Without an elected position, Carter redoubled his activity on the board of his region's Planning and Development Commission and secured a seat on the State Advisory Committee for Planning and Development, Georgia's APDC oversight committee. Carter was soon named the committee's Vice-Chairman (the Rome Commission director and long time Georgia Power employee, Fred Starr, was the Chairman). ${ }^{66}$ Under Starr's and Carter's stewardship, the Committee resolved to "protect the right of the individual APDC to retain local control" and to "guard against any tendency by this Advisory Committee to exercise control over the individual" Commissions. ${ }^{67}$ It was from this post and among these representatives of local government and private business that Carter developed the themes that would animate his 1970 run for governor and inform his policy goals in Atlanta and, later, in Washington, D.C.

Carter used his positions on the local and state commissions to run a nonstop campaign for governor. He traveled almost constantly, meeting with regional business leaders, evangelizing for his vision of comprehensive planning, public-private partnerships, and locally directed but state and federally funded development projects. He honed his message in the pages of "The Activator," the monthly newsletter of his regional Commission. In one piece titled

\footnotetext{
${ }^{66}$ Meeting Minutes, State Advisory Committee on Planning and Development, January 12, 1968, folder Area Planning and Development Advisory Committee, box 23, Pre-Presidential Materials, JCL.

${ }^{67}$ Ibid., p. 2.
} 
Cebul

"Commission Growing in Usefulness As Channel to State Resources," Carter displayed

sensitivity to mounting concerns over federal intervention. He described the initial "fear ... that

the organization of a multi-county commission might tend to weaken or to interfere with the

autonomy of local government.” Instead, Carter wrote, “just the opposite has taken place.”

Moreover, he singled out the cooperative partnership that was forged between "Georgia Tech,

the University of Georgia, state agencies, Georgia Power Company . . . and other major

organizations interested in the future of Georgia." Carter argued that the "most important factor

in the maintenance of constitutional government in our nation is to nourish strong local

governments." Only if "we fail to meet the needs of our people ... will [we] be faced with the

specter of interference by our state and national governments. ${ }^{\circ 6}$ Carter buried the intrinsic role

federal spending played in the Commission system.

In the context of heightened frustration with federal overreach, Carter was learning that

regional planning could be framed as both a conduit for federal largess and as a bulwark against

federal meddling. Carter often highlighted the ways the Commission model served to protect

local prerogatives. In one speech, the peanut farmer argued that "the major goals of the next

administration in Georgia" must "be to return control of government to the people of our state

\footnotetext{
${ }^{68}$ Jimmy Carter, "Commission Growing in Usefulness As Channel to State Resources," The Activator, May 1966, box 5, Jimmy Carter Papers, Pre-Presidential, 1962-1976, JCL.
} 
Cebul

instead of to a few political big shots. ${ }^{, 69}$ In another speech before municipal officials, Carter

asked a simple question: "How can we retain the community identity which creates citizen

interest and participation and at the same time cooperate with other governments in the area to

provide optimum services to our people?"70 Carter proposed dropping the municipal

consolidation and annexation plans that had caused so much unrest in rural regions (of which he

had been an early proponent) and called instead for focusing on the kind of coordinated and

comprehensive regional planning pioneered in the APDCs. "This approach," he contended,

"relieves the anxiety of local officials concerning the future existence of their city or county and

permits a cooperative and successful approach to the solution of mutual problems." ${ }^{, 71}$

Carter's time traveling the state helped him sharpen his message. By 1969, he had visited, as he put it in a speech before an Atlanta Kiwanis Club, "more than 350 of Georgia's

communities." A brief glance through his personal planner confirms the doggedness with which

he crisscrossed the state, making several appearances a week, either in his capacity on the state

planning commission, as a Lion, or to deliver Sunday morning sermons in his capacity as a

Baptist Deacon and lay leader. These appearances, Carter told Atlanta's Kiwanians, helped him

\footnotetext{
${ }^{69}$ Jimmy Carter, Speech to Association of County Commissioners of Georgia, April 13, 1970, folder Speech Material [1], box 39, Pre-Presidential Materials, JCL.

${ }^{70}$ Jimmy Carter, Handwritten Speech Notes, GMA Convention, 1969, folder Speech Material [1], box 39, PrePresidential Materials, JCL.

${ }^{71}$ Ibid.
} 
Cebul

develop a keen understanding of "a problem which afflicts our state." The broad moderate

middle of the electorate, Carter said,

feel threatened, and often distrust the rich, the poor, students, politicians ... They sometimes forget that their taxes go for education, highways and national defense, but they remember the welfare programs and the pockets of dishonest public officials. Their government seems to have most concern for the 'loafing' class, for unappreciative students, for the rich who somehow avoid taxation, and for the poor who seem to get along pretty well without working. ${ }^{72}$

Carter recognized that many Georgians had come to take for granted aspects of

government from which they benefited and focused almost entirely on government services that went to "unworthy" Georgians.

Rather than remind voters that they, too, benefited from public provision, Carter chose to politicize the divide. ${ }^{73}$ Once the 1970 Democratic Primary campaign was officially under way, Carter had so honed his various talking points that he rarely, if ever, wrote out his speeches.

Instead, he jotted a few key words on $3 \mathrm{X} 5$ cards, noting his talking points. The most frequent included "Control government - individual," "Failures - dissatisfaction," "individual freedom =

\footnotetext{
72 Jimmy Carter, Speech Notes before the Atlanta Kiwanis, August 5, 1969, folder Speech Material [1], box 39, PrePresidential Materials, JCL.

${ }^{73}$ As his Washington, DC based pollster found, 81 percent of the Georgia electorate reported feeling alienated from government. High taxes, welfare, and rising crime were their major concerns, and 54 percent felt integration was moving too fast. Carter's pollster later described the strategy they developed: "More important ... than specific issues was the selling of populist symbols. The common ingredient was voters believing the candidate cared about what they cared about, that he was one of their own and would not forget them.” Bourne, pp. 188-9.
} 
Cebul

freedom of the nation," "heritage," and "conservatism."74 Because very few complete speeches

exist in Carter's archives, the best way to get a feel for how he tailored his message in rural

regions is to explore the archival record of the state's rural newspapers. In Bainbridge, a small

city in Decatur County, Carter spoke at the opening of a campaign office. Referring to his

primary opponent (and former ally) Carl Sanders' refusal while governor to allow George

Wallace to speak in and at the invitation of the Georgia General Assembly, Carter said, "when I

am your Governor, Governor George Wallace of Alabama ... will be welcome to visit the State

Capitol of Georgia, the General Assembly or any public building under my control. . . [S] uch

bad manners [as Sanders'] are not the kind of conduct that Georgia people engage in or

approve." ${ }^{, 75}$ Carter blasted Sanders for trying "to please a group of ultra-liberals, particularly

those in Washington."76 One Carter television spot drew a distinction between Carter's

conservative Southern Democratic traditionalism and Carl Sanders' sympathies with national

liberal Party leaders. The ad featured a Sanders campaign button that, when rubbed with a rag,

turned Sanders' face into Hubert Humphrey’s. ${ }^{77}$ In Brunswick, Carter distanced himself from his

\footnotetext{
${ }^{74}$ See generally, copies of note cards in folder Speech Notes by Community B, box 40, Pre-Presidential Materials, JCL.

${ }^{75}$ Bainbridge Post-Searchlight, July 23, 1970, Georgia Newspaper Project, University of Georgia, Athens, Georgia [hereafter GNP].

${ }^{76}$ Carter quoted in Betty Glad, Jimmy Carter: In Search of the Great White House (New York: W.W. Norton, 1980), p.130.

${ }^{77}$ Steven Brill, “Jimmy Carter's Pathetic Lies,” Harper's, March 1976, p. 79.
} 
Cebul

1966 campaign and the national leaders of his own Party, proclaiming, "I was never a liberal; I

am and have always been a conservative," allowing his rural, working class white supporters to

define these protean political terms for themselves. ${ }^{78}$ The southeastern Laurens County News

endorsed Carter because "[we] are convinced that he is a man susceptible to the will of the

majority of the people." Carter, they argued, "is a conservative . . . [and he] speaks the language

of the people of Georgia."79

As primary day approached, Carter ratcheted up his rhetoric in an attempt to convince

rural white voters' that he was on their side of one particularly racially fraught issue. Officials in the Nixon Administration had unwittingly created a firestorm across the South when they called into question the tax exempt status of "segregation academies": inexpensive private or religious schools that had been established to take advantage of private school tax loopholes in the wake of the Brown decision. ${ }^{80}$ By repudiating such seeming government overreach, Carter could paradoxically stake a claim for white voters' entitlement to the federal subsidy. To underscore his commitment to private education, Carter visited a Swainsboro, Georgia private school's allwhite sixth-grade classroom, drawing applause from students and parents when he praised Lester Maddox as a potential partner in government. Said Carter, “you can rest assured I'll do

\footnotetext{
${ }^{78}$ Quoted in Brill, 84.

${ }^{79}$ Atlanta Constitution, September 5, 1970.

${ }^{80}$ Joseph Crespino, In Search of Another Country.
} 
Cebul

everything I can for private schools. ${ }^{, 81}$ On other occasions, Carter touted private schools as "a healthy development," saying under a Carter Administration there "will [be] a lot of private schools in the state of Georgia." He again spoke warmly of Maddox, saying, "there's no cross between me and Lester." He repeated one of Maddox's witticisms, highlighting the new bond between the peanut farmer and fried chicken restaurateur: "Fried chicken and peanuts sounds like a pretty good deal for Georgians. ${ }^{\prime 82}$

In Carter's home county, Americus' Heritage Academy was founded in the midst of the 1970 campaign with the mission of "organizing a private school where any white person who wanted to attend would be able to do so, whether or not parents had sufficient monies to send their children ... [by offering] family-students grant[s]" for those unable to afford tuition. ${ }^{83}$ For Heritage, the tax exemption was a particularly important source of funding since, without the subsidy, the school's very existence - as well as that of many white flight academies - was in doubt. In a speech at Southland Academy, another of Americus' white flight academies, Carter made his most outspoken defense of private education found on record:

On dozens of occasions in public speeches, I have specifically credited Southland Academy in Americus as an excellent example of what interested parents can do in establishing an educational institution of superior quality and with educational

\footnotetext{
${ }^{81}$ Laurens County News, September 5, 1970.

${ }^{82}$ Decatur-Dekalb News, September 16, 1970, GNP.

${ }^{83}$ Americus Times-Recorder, July 27, 1970, GNP.
} 
Cebul

opportunities for children of widely varying economic resources . . . I am convinced there is a permanent and important place in Georgia Education for Private Schools. Any citizen who can afford it has the right to send his children to a private school. ${ }^{84}$

Carter echoed segregationists' arguments for the essential role such schools played:

"Georgians have reluctantly agreed to obey the Federal Courts, but rulings are still unclear.

During the next few years, the major responsibility of the Governor and our educators will be to guarantee that in spite of court rulings, school integration, or any other obstacle, the quality of education in our state will not suffer. ${ }^{, 85}$ Desegregation was an impediment to quality education.

Georgia's most prominent segregationists celebrated Carter's twenty percentage point victory, a clear indication that they were convinced he would speak for them. ${ }^{86}$ Not everyone was impressed with Carter's tactics. The Macon News decried the Plains Democrat's “bitter campaign," arguing that the candidate was "a classic example of a good man whose high standards have been undermined by political ambition. ${ }^{, 87}$ Nevertheless, by capitalizing on these

\footnotetext{
${ }^{84}$ Americus Times-Recorder, July 30, 1970, GNP.

${ }^{85}$ Americus Times-Recorder, July 30, 1970, GNP.

${ }^{86}$ Carter won the primary run-off with $60 \%$ of the vote and the general election with $59.3 \%$. Carter received the marginal racist Roy Harris' endorsement as well as that of Marvin Griffin, a former governor and avowed segregationist. In the primary, the openly racist Augusta Courier celebrated the primary results, which also saw a Maddox landslide for Lieutenant Governor, with a headline that echoed the two candidates: "It's Peanuts And Fried Chicken For Next Four Years In Georgia."

${ }^{87}$ Quoted in Atlanta Constitution, September 3, 1970.
} 
Cebul

fears, Carter won Americus' Sumter County (which had proved impossible for him in the past)

by a landslide. ${ }^{88}$

"Post Racial” and Antigovernment Developmental Politics

Once in office, Carter immediately pivoted to a "post-racial," colorblind politics. He gained instant national acclaim for a blunt statement in his January 1971 inaugural address: "I say to you quite frankly that the time for racial discrimination is over." The national media, however, did not cover the broader message of which Carter's discrimination line was just a part. "Our people," his next, more defensive sentence began, "have already made this major and difficult decision." "We Georgians are fully capable of making our judgments and managing our own affairs. ${ }^{\prime 89}$ Now that the segregation and civil rights issue was seemingly past, Carter envisioned a post-racial Georgia where local decisions could be made without the interference or regulation of the federal government. Indeed, Carter's governing agenda - like that of President Richard Nixon's New Federalism - bore many of the hallmarks of the "Silent Majority" appeal as well as the localist leanings that had characterized each politicians' campaigns. To his own Silent Majority appeal Carter added his track record as a businessman and touted businesslike

\footnotetext{
${ }^{88}$ Vidalia Advance, September 17, 1970, GNP.

${ }^{89}$ Governor Jimmy Carter's Inaugural Address, January 12, 1971, JCL, accessed online at http://www.jimmycarterlibrary.gov/documents/inaugural_address.pdf.
} 
Cebul

methods to make government more efficient and responsive to the state's voting majority. "Like

thousands of other businessmen in Georgia, I have always attempted to conduct my business in

an honest and efficient manner. Like thousands of other citizens, I expect no less of

government," said Carter. Invoking his Commission experience, Carter pledged that

"Governments closest to the people should be strengthened, and the efforts of our local, state and national governments need to be thoroughly coordinated."

Both Carter and Nixon had campaigned on an antigovernment politics based on

aggrieved whites' racialized and zero sum sense of entitlement to government provision. As a

result, each pursued remarkably kindred reforms based on rationalizing and reforming

government. Nixon's attempt to translate his Silent Majority campaign appeal into substantive

policy became the slate of executive branch and bureaucratic reforms called New Federalism, which deregulated and decentralized key policies of the War on Poverty through the creation of a number of Block Grants. ${ }^{90}$ Like Carter, Nixon promised to make government more responsive to "average" Americans. In doing so, his New Federalism restored a New Deal model of fiscal federalism, sending generous federal funds to be administered by local elites. Like Nixon, Carter's major priority was a significant reorganization and rationalization of government bureaucracy, framing the sprawling state government as a beast only he could tame. Carter

\footnotetext{
${ }^{90}$ See Cleveland Chapter 3 for a detailed examination of these policy developments.
} 
Cebul

castigated expansive government on behalf of the majority of Georgians' right to public services and developmental support. "It's gotten so that every time I open the closet door in my office," Carter quipped in his first State of the State Address, "I fear a new state agency might fall out."91 For the state's minority groups, however, which, by the early 1970s, were at last gaining a modicum of influence within War on Poverty programs, the twin impact of Carter's reorganization and Nixon's deregulation of War on Poverty programs reversed very recently gained but still tenuous access to development aid.

To generate support for his reorganization plan, Carter kept the electorate focused on the inefficiencies of state government. He enlisted the Institute of Government at the University of Georgia to catalog every unit of State government - all agencies, bureaus, boards, authorities and departments. Armed with their report, the Governor began a complex public outreach campaign that drew upon his gubernatorial campaign infrastructure. "Goals for Georgia" would solicit input from average citizens across the state through a series of regional constituency meetings. As Carter put it upon receiving the U.Ga. report, "Of the more than 250 units [of government] . . . only 39 were established by the Constitution. The rest have been the result of a new law or an executive order. In just the past eight years we have added 74 new units and there are bills

\footnotetext{
${ }^{91}$ Quoted in Leslie Wheeler, Jimmy Who?, p. 68.
} 
Cebul

pending to add another 30 this year." 92 Carter framed Goals as a first step to bringing responsive government back to rural areas. "You are working at that level where state government most often fails - providing services to the rural or local citizen. You know firsthand," he said, "the frustrations of dealing with a bureaucracy too often concentrating on the more vocal complaints of urban and industrial areas." 93 The real benefits of all these initiatives, Carter promised, would be a "simple government which our people can understand and control," and more robust "local and state control over the management of federally financed programs in Georgia." 94 After having emphasized the "more vocal" residents of "urban or industrial" areas, Carter did not need to define "our people."

Most essentially, Goals for Georgia was an elaborate PR scheme meant to put pressure on an unwieldy legislature. ${ }^{95}$ Carter tapped Sam Nunn, a 32-year-old Democrat and rising star, to chair Goals. Nunn had succeeded Carter as president of the Georgia Planning Association, the Planning and Development Commission oversight board, and he had also chaired the Houston

\footnotetext{
92 Jimmy Carter, Governor's Reorganization Message, March 1, 1971, DOC-2227, Governor, 1971-1972, GA Archives.

${ }^{93}$ Quoted in Tom Linder, Jr., Article for Georgia Poultry Federation, DOC-2227, Governor, 1971-1972, GA Archives.

94 Jimmy Carter, Budget Address to Joint Session of the General Assembly, January 13, 1972, DOC 6982, GA Archives.

${ }^{95}$ On the "Goals for Georgia program, see Mattie Sayrs Anderson, "Governor Jimmy Carter, Idealist or Realist: A Study of Carter's Commitment to Citizen Participation and Planning the Goals for Georgia Program," Unpublished MA Thesis, Georgia State University, 1979.
} 
Cebul

County branch of Carter's 1970 campaign. Under Nunn, the Goals apparatus created the Citizens

Committee for Reorganization, which posted 50,000 handbills throughout the state on which

Governor Carter was depicted as a sword-wielding St. George, slashing the hydra-headed dragon

opponent of reorganization; the heads were named Waste, Inefficiency, Special Interests, and

Petty Politics. ${ }^{96}$ Carter's public awareness task force also used the state's APDCs to distribute

100,000 brochures through their local mailing lists. Carter's support from business leaders

proved crucial. The leader of the influential Georgia Poultry Federation, Tom Linder, Jr., was a

former director of his South Georgia Planning and Development Commission (it was through the

Commissions that he and Carter became allies), and he was a key spokesman for the

reorganization. In the past forty years, Linder wrote, "the number of state agencies administering

to the needs of ... Georgians has expanded from 17 to nearly 300. But, as Georgia poultry

farmers well know, this hasn't always meant better government. Too often, the result has been

confusion, inefficiency, and duplication." Carter's reorganization plan, Linder argued, would

make government "more responsive to her citizens," more efficient and less costly. ${ }^{97}$

With the endorsements of the APDCs and the State Chamber of Commerce, Carter's plan

received a full hearing from local business leaders and their various voluntary associations:

\footnotetext{
${ }^{96}$ Bill Shipp, “Campaign Team Helps Carter,” Atlanta Constitution, December 28, 1971, RCB-255, Legislature, State Programs Study Commission, Administrative Records, GA Archives.

${ }^{97}$ Tom Linder, Jr., Article for Georgia Poultry Federation, DOC-2227, Governor, 1971-1972, GA Archives.
} 
Cebul

Jaycees, Lion's, Kiwanis, and local chambers. Soon their endorsements rolled in, too. ${ }^{98}$ The Public Awareness campaign inundated newspaper, magazine, radio and television media. ${ }^{99}$

Carter used his second State of the State Address to strike a more aggressive and resonant chord.

How "much have you read about the thousands of Georgians who are not organized to represent a particular interest, but who are merely confused, frustrated, and even alienated from our government because of its complexity, inefficiency, and inability to meet their legitimate demands?" ${ }^{, 100}$ It was on their behalf - Georgia's Silent Majority - that Carter sought reform.

In reality, the state's business leaders were in the driver's seat when it came to steering the actual reorganization proposals. Carter tapped Linder to lead the policy planning team, and the poultry king recommended developing an informal steering committee of professional management consultants, business executives, and key state employees - essentially the kind of matrix of interests Carter and Linder had cultivated in the Commission system, albeit on a grander scale. ${ }^{101}$ The state hired Arthur Anderson and Company, and Linder requested Georgia's major companies loan executives to the state for up to six months to engineer the reforms from positions within state government. Forty-eight businesses loaned the Administration 65

\footnotetext{
${ }^{98}$ Weekly Progress Report - Public Awareness, July 5, 1971, DOC-2227, Governor, 1971-1972, GA Archives, and Public Awareness - Status Summary, September, 1971, DOC-2227, Governor, 1971-1972, GA Archives.

${ }^{99}$ Public Awareness - Status Summary, September, 1971, DOC-2227, Governor, 1971-1972, GA Archives.

${ }^{100}$ Quoted in Wheeler, p. 72.

${ }^{101}$ Meeting Minutes, Reorganization and Management Improvement Study, July 28, 1971, DOC-2225, GA Archives.
} 
Cebul

employees who became privately salaried public employees. They comprised the majority of the

117 individuals who worked full time on the reorganization effort. ${ }^{102}$ As a result, leading

executives at major Georgia companies like Delta Air Lines, Coca Cola, Lockheed, Southern

Railway, and Georgia Power became integral to the reorganization plan. ${ }^{103}$ Over the spring and summer of 1971, the business consultants conducted a remarkably thorough assessment of the institutional lay out, function, and accountability of every unit of state government defined under eight broad categories (e.g., Social Development; Economic Development; Education and Intellectual Development; Transportation and Communication). ${ }^{104}$ Linder's public-private bureaucracy's final recommendations were compiled in a 2,500 page report that contained nearly 300 discrete proposals for reorganizing and consolidating state government. While Carter's personal political style and unwillingness to horse trade or engage in traditional politics had sometimes put the bill at risk, in February 1972, his reorganization package was passed. In total, 198 of Carter's 243 proposals remained intact.

Three significant developments resulted from Carter's reorganization. First, Carter essentially institutionalized a campaign against government and made a name for himself as an “outsider-in-chief," a businessman-turned-politician who would tame and restrain public

\footnotetext{
${ }^{102}$ Bourne, p. 207.

${ }^{103}$ Undated Planning Committee Roster, DOC-2225, GA Archives.

${ }^{104}$ See especially, “Reorganization and Management Improvement Study: Preliminary Review Summary,” RCB 9313, GA Archives.
} 
Cebul

institutions. ${ }^{105}$ In reality, Carter's reorganization had done little to tame the size or reach of

government. Though government reorganization did away with a bevy of agencies and

departments, none of the state's 50,000 employees were laid off. Instead, the governor promised

to retrain or transfer those who chose to stay on the payroll and to gradually cut the workforce

through attrition. ${ }^{106}$ Speaking before public employees associations, in fact, Carter

characteristically changed tack entirely, arguing that "Uncoordinated and unplanned growth" not

"the rank and file employees" or state institutions were to blame for the state's

unresponsiveness. $^{107}$

Second, Carter's reorganization - in tandem with Nixon's New Federalism - created a

number of new hurdles for impoverished and marginalized Georgians' access to federal

antipoverty programs. Carter's reorganization plan, for instance, mandated that the state's multi-

county OEO funded Economic Opportunity Authorities conform their county makeup to that of

the state's regional Planning Commissions. In North Georgia, this led to a year of stalled payouts

for Headstart and other programs when the North Georgia EOA balked at losing two counties

\footnotetext{
${ }^{105}$ I borrow “Outsider-in-Chief” from Grace Elizabeth Hale. See Hale, “Outsider in Chief,” a paper presented at the Recasting the Modern Presidency Conference, Miller Center, University of Virginia, October 26-27, 2012. In author's possession.

106 “Carter: No Power Play,” Atlanta Constitution, November 17, 1971, box 3, RCB-255, Legislature - State Programs Study Commission - Administrative Records, Georgia Archives.

${ }^{107}$ Reorganization and Improvement Study, November 24, 1971, DOC-2225, GA Archives.
} 
Cebul

(and their funding) to the neighboring Northwest Georgia EOA. ${ }^{108}$ As Community Development

Block Grants came online, Carter's reorganization made the APDCs the regional CDBG

administrators. While Block grant legislation included language mandating continued "citizen

participation," local leaders used federal funding to pursue their own developmental agendas. A

1976 Southern Regional Council report on Block Grants found that in 26 Southern cities

“citizens participation was low and the application and administration of grants was dominated

by local political leaders." The report also "found that many projects were not serving the needs

of the poor, but actually benefitted middle- and upper-income areas."

These deregulations and reforms came when local poverty groups had finally begun to

play their federally mandated role in antipoverty programs. When word came the Nixon

Administration was considering shuttering OEO and ending its more tightly regulated categorical

programs in favor of loosely regulated block grants, Georgians who had begun to benefit from

the programs appealed to their Washington delegation. Juanita Johnson of Augusta, Georgia,

described the positive impact of OEO programs in her community. "As a result of the jobs

created by these programs," she argued, "they have instilled within the individuals a feeling of

self-pride and a sense of belonging." Moreover, in Augusta, she felt the programs contributed to

\footnotetext{
${ }^{108}$ See generally, LC Adams to William "Sonny” Walker, February 4, 1974 and attached report, folder 8: OEO 1974, box 12, subseries B, series VI, JWDP.

${ }^{109}$ Legislative Issues Briefing Book, House Republican Conference, August 1976, pp. 16-17, folder Decentralization \#2, box 5, Newt Gingrich Papers, West Georgia University Library, Carrollton, Georgia.
} 
Cebul

breaking down "the barrier that existed between the "haves' and the 'have nots" because "each group now has a better understanding of the other." ${ }^{, 10}$ Miss Pamela Vaughn of Martin, Georgia, a paraplegic after an auto accident when she was 14, described how, for three years after high school, she struggled to find work. Through the OEO's Operation Mainstream, however, she got a "a job doing clerical work for the Franklin County Neighborhood Service Center ... Now that I have this job, I'm off welfare and out of the house, but more important I now can do my part to contribute to society ... If OEO is cut out I will have to go back home and back on welfare as will others." ${ }^{111}$ Like Vaughn, many petitioners emphasized the self-reliance such programs engendered. The principle of Franklin County Junior High School, for instance, pointed out that he "would be the first Georgian to support cutting funds for giveaway programs of the 'Great Society." "However," he wrote, "I do feel that some programs need not be cut simply because it was an outgrowth of President Johnson's Administration." In particular, he found the OEO's Neighborhood Youth Corps and Mainstream Program to be worthwhile because "the people involved ... earn their way. For me, they have been given a dollars work for a dollars pay. That is important to me because I came up hard and I appreciate people who will work." ${ }^{\prime 12}$ These realities, however, were no match for the myths that had sprung up across the country.

\footnotetext{
${ }^{110}$ Juanita Johnson to HET, received March 13, 1973, folder 24, box 147, series XI, HETP, RBRL.

${ }^{111}$ Pamela Vaughn to HET, received February 26, 1973, folder 24, box 148, series XI, HETP, RBRL.

112 Jim Gurley to HET, February 15, 1973, folder 24, box 148, series XI, HETP, RBRL.
} 
Cebul

Finally, while Carter's reorganization blended with Nixon's deregulation to create institutional instability for federal poverty programs, the reorganization had the opposite effect for the state's Department of Industry and Trade. By 1973, the first full year following the reorganization, Industry and Trade, the state's main publicly funded industrial recruitment agency, had established new foreign branches in Europe, Asia, and South America. Despite a growing budget crunch in the recessionary early 1970s, Carter increased spending for these and older offices in Brussels and Tokyo. ${ }^{113}$ It was no accident that the department was regimented, innovative, and aggressive in international recruitment. From 1967 to 1976 its commissioner was Lt. General Louis W. Truman, President Truman's cousin. Truman brought a well-traveled eye for the global possibilities of business development and capital formation in Georgia and had emphasized this crucial public endeavor from his own seat on the reorganization commission. ${ }^{114}$ Under Carter, Truman especially targeted trade with and industrial recruitment from Canada and Latin America, and, in the reorganization, he successfully advocated linking the state's Planning and Development Commission system more directly to his department's international offices. ${ }^{115}$

\footnotetext{
${ }^{113}$ Jimmy Carter, Budget Message, November 17, 1974, Doc-6950, Governors' Messages to General Assembly, 1908 - 1974, GA Archives.

${ }^{114}$ DOC 6823: Governor '71-'72 Reorganization Study, Advisory Commission Correspondence, 1971-1972, - 1971 1972, Georgia Archives.

${ }^{115}$ In April 1973, Truman led a 15 day trade mission to Brazil (he called it "Georgia Trade Trek One”). He also expressed hope that the state could invite to Atlanta promising leads from this first mission, and he envisioned a mid-summer "Pernambuco Week." Planning for Georgia Trade Trek Two was already underway, and that summer mission would see I\&T reps visit Caracas, Bogota and Quito. Louis W. Truman to Jimmy Carter, January 2, 1973,
} 
Cebul

Foreign firms had invested $\$ 5$ billion in the South by the end of 1972, and by the end of

1974 , that figure had grown to almost $\$ 8$ billion. It was during those years that Georgia paced the

South in its foreign recruitment efforts, opening development offices in Brussels, Tokyo, Sao

Paulo, and Toronto. ${ }^{116}$ Indeed, the state's efforts to expand foreign trade for Georgia businesses

paid off. A study by the director of UGa's International Trade Development Center found that

between 1972 and 1976, increasing exports accounted for \$1 out of every \$12 in the state's

production of manufactured products, while for agricultural goods, the proportion was even

higher, accounting for $\$ 1$ out of every $\$ 5$, totaling nearly $\$ 476$ million by $1977 .{ }^{117}$ Most of the

state's exports went to Western Europe and Canada, though the Middle East and South America

were growing partners, too. In Carter's reorganization, business people had made economic

development a central concern of state government.

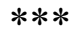

In the aftermath of racialized battles over the fruits of developmental state spending, the

Rome Chamber trumpeted a view of their role in the community that both perpetuated their

longstanding "shepherd" outlook but displayed a new, harder edged, and seemingly race-neutral

RCB-31378, Governor-Executive Dept. - Governor's Subject Files - 1971-1974 -Agency Files - Community Development, GA Archives, Morrow, GA.

${ }^{116}$ Cobb, The Selling of the South, pp. 188-9.

${ }^{117}$ A.G. Kefalas, "International Trade and Small Business," Georgia Business, May-June 1979, vol. 39, no. 3, p. 1, UGa Library, Athens, GA. 
Cebul

vernacular. As a short piece in a 1974 edition of the Rome Chamber newsletter put it, "There are three classes of residents in any community: (1) Those who live off it; (2) Those who live in it, and (3) Those who live for it." ${ }^{, 18}$ While businesspeople in the rural South had always viewed themselves as their community's providers - "Those who live for it" - when pushed by mobilized minority groups, squeezed by inflation, and threatened by new forms of federal regulation, these constituencies joined other businesspeople across the nation in embracing a form of business populism: a refashioned version of producerist politics that positioned businesspeople - not labor or the working class ( "Those who live off it") - as the guarantors of economic opportunity and political freedom.

But, as the next chapters suggest, this new brand of business producerism hinged not on freedom from government action, but on which constituencies most deserved freedom to steer the developmental state. Indeed, while Jimmy Carter sold his reforms in Georgia as a more conservative way to bring responsive government back to the majority - as had Nixon and Fordbusiness interests and local elites were the central beneficiaries. In opposition to the War on Poverty's fleeting attempt to expand the boundaries of the developmental state, they refashioned a venerable model of associational federalism, one built upon federal-local and public-private partnerships. Yet, while the more categorical federalism of Johnson's War on Poverty was

\footnotetext{
${ }^{118}$ W.G. McWilliams, Jr., “President’s Pen,” Forum, October, 1974, HSCLL, UGA.
} 
Cebul

swiftly eclipsed (repudiated even by Johnson himself), the rhetoric and values of fighting poverty

persisted. Attached to a restored model of associational federalism, this rhetoric would create

new opportunities and legitimation for private sector involvement in the developmental state at

the same time that it closed opportunities for antipoverty programs' ostensible beneficiaries. 
Cebul

\section{Section III}

\section{Business Producerism and Embracing "Neoliberalism by Default"}

Americans "seem to be ignorant of the business world and economics . . . They lose track of the fact that business is 'jobs', that it is also the shoes and clothes they wear."

“Americans Do Not Understand Business," Chamber of Commerce Newsletter, 1974

"Leveraging" of private investment "is crucial if you are to really improve conditions in the city." Residents "of the worst-condition area will oppose [such an approach] - naturally . . But you must face up to it if you want funds spent on neighborhoods to have any positive long-run impacts."

Anthony Downs, Carter Administration Urban Policy Advisor

My "dream is that the block grants are only a means to an end. And the end is that the [national] government, which has preempted over the years so much of the tax revenue potential in this country" will devolve as much tax revenue and programmatic authority as possible back to the states.

President Ronald Reagan, Interview on Federalism, November 19, 1981

"The opportunity we have is to give [the poor] the opportunity to help themselves . . Individuals have to save themselves."

Albert Ratner, CEO of Cleveland's Forest City Enterprises 
Cebul

\section{Chapter Seven}

Business Producerism / Urban Populism:

"Neoliberalism by Default" in Cleveland

The Cleveland situation ... is a reminder of the power of commercial banks. The credit powers, alone, can be literally life or death for business enterprises and individuals and, as we have learned in New York and Cleveland, for large municipalities as well. When these credit functions are enhanced by trust investments, linked directorships and other ties, the potential for control and power is awesome.

- U.S. Rep. Fernand J. St. Germain (D-RI)

Scanning the front page of the Plain Dealer on Wednesday, July 10, 1974, Clevelanders

were greeted with news of one crisis after another. All summer, of course, the city's major

newspaper covered the worsening Watergate scandal. But beneath those headlines ("Nixon: 'Get

on with coverup"') was news of ongoing judicial rancor over urban-suburban school busing and

inflating food prices. Ethnic Republican Mayor Ralph Perk brought a folksy, can-do

conservatism to his first years on the job. But, faced with intractable population and industrial

decline and the concomitant shriveling of the city's tax base, the second half of the Perk years

took on an increasingly desperate tenor. Further unsettling the city's political climate, Perk made

a foolhardy and doomed run for U.S. Senate, competing as a Republican against astronaut and

Ohio hero John Glenn during the Watergate summer. While Perk stumped for the Senate, that

same July 10 front page featured a story on a business association's report that Cleveland would 
Cebul

finish 1975 with an $\$ 18$ million budget deficit. Cleveland's local public institutions, like the

federal government, seemed increasingly incapable of meeting the challenges of the modern, globalizing world.

During the 1970s, Cleveland represented an extreme example of the plight facing numerous northern, deindustrializing cities. ${ }^{1}$ Confronted with contracting tax bases, many municipalities used federal funds along with short and long-term credit to paper over yawning budget deficits. By the late 1970s, one U.S. House committee report found that commercial banks held nearly half the municipal debt in the United States. While much of that figure was comprised of long-term notes issued by local governments, private banks increasingly offered short-term credit for local governments squeezed by the inflation, deindustrialization, tax revolts, and outmigration of the turbulent era. ${ }^{2}$ For decades, commercial banks had rolled over municipal debt, an expression of faith in a government's ability to ultimately meet its obligations. But, failing such long-term faith, banks could call the debts, raising the specter of default. As the House report put it, in this new political-fiscal climate, "the decisions of loan officers and the

\footnotetext{
${ }^{1}$ On deindustrialization across the urban North, see especially, Jefferson Cowie and Joseph Heathcott, eds., Beyond the Ruins: The Meanings of Deindustrialization.

${ }^{2}$ There is a growing literature on debt and inflation in the 1970s, but its impact on municipal finance and politics, with the exception of New York City's 1975 fiscal crisis, has largely been overlooked. For excellent examples of this new literature on the political economy of debt and inflation, see Louis Hyman, Debtor Nation: The History of America in Red Ink. On the politics of inflation, see Judith Stein, Pivotal Decade: How the United States Traded Factories for Finance in the Seventies. On inflation and municipal politics, particularly in the New York City fiscal crisis, see Paul Peterson, City Limits, esp. ch. 4.
} 
Cebul

board of directors of financial institutions are critical; at times carrying far more impact than the decisions of thousands of citizens of a municipality." ${ }^{3}$ This chapter illuminates an extreme consequence of these developments through the perspectives of creditors (Cleveland Trust bankers and their allies), and debtors (city government) - each of which felt they best represented the interests of the city of Cleveland. The result was Cleveland's 1978 default and a decisive move toward private-led public-private developmental partnerships.

The chapter also illuminates the emergence of a business brand of "producerist" political culture - nationally and in Cleveland - by explicating the advent of business peoples' self-styled rearguard political mobilization. Historians have explored the political salience of labor and agriculture's “producerist" populism in earlier eras, but, during the 1970s and into the 1980s, businesspeople asserted their producerist role - and privilege. As Michael Kazin has argued, the "producer ethic" legitimizes those who produce tangible wealth as the best protector of the nation's or a community's values and opportunities. ${ }^{4}$ As such, producerist populism also often

\footnotetext{
${ }^{3}$ The Role of Commercial Banks in the Finances of the City of Cleveland, Staff Study by the Subcommittee on Financial Institutions Supervision, Regulation, and Insurance of the House Committee on Banking, Finance and Urban Affairs, June 1979, 1, Public Administration Library, City Hall, Cleveland, Ohio [hereafter PAL]. A subsequent sociological analysis of banks' lending power finds that for corporations and the state, "the process of defining a situation as a crisis sets into motion all the consequences of that definition and can create an actual crisis even where none existed before." See, Davita Silfen Glasberg, The Power of Collective Purse Strings: The Effects of Bank Hegemony on Corporations and the State (Berkeley: University of California Press, 1989), 2. See Davita

${ }^{4}$ Kazin, The Populist Persuasion: An American History (Ithaca: Cornell University Press, 1995).
} 
Cebul

advances a claim for a group or class' more legitimate access to public assistance. ${ }^{5}$ Previously, especially as compared to their Southern brethren, capital-rich Northern business interests stood at a relative remove from the nitty gritty of municipal politics, recommending certain policies, supporting favorable candidates, and advancing targeted developmental partnerships through, for example, urban renewal. Faced first with the Perk Administration's incompetence and resistance to business' developmental agenda, then with Dennis Kucinich and neighborhood groups' insurgent anti-corporate urban populism, a number of Cleveland's business leaders embraced a harder edged version of a business brand of the "producer ethic" then sweeping the nation: businesspeople - not labor, neighborhood groups, or their allies in bloated government - were fiscally responsible job producers. They were thus the best guarantors of growth, opportunity, and sound governance. The city's debt, much of which had accrued thanks to business-backed developmental schemes, gave businesspeople a new form of leverage with which to steer the city's use of developmental state programs.

By focusing on local cases within the context of the 1970s' and 1980s' political economy, this broader section argues that far from embracing an idealized vision of separate public and private spheres, politicians and businesspeople embraced "neoliberalism by default.",

\footnotetext{
${ }^{5}$ See, for instance, Alan Brinkley, Voices of Protest: Huey Long, Father Coughlin and the Great Depression (New York: Vintage, 1982).

${ }^{6}$ Political Scientist Timothy Weaver has deployed this phrase to describe the process by which Philadelphia's politicians, white and black, embraced business friendly policies. See, Timothy Weaver, "Ideas, Coalition Building,
} 
Cebul

Just as capital poor Southern regions had for decades, these constituencies came to view thicker

public and private association as the last best chance to save a struggling community.

Cleveland's politicians, faced with budgetary crises, debt, and fewer paths to their preferred

policies of increased federal aid and local taxation, pragmatically accepted business' alternative

vision of development, based on abatements, subsidies, and land banking - longstanding

developmental state policies, the next chapters argue, repackaged as conservative or neoliberal

through a new vernacular of antigovernment 'market speak.,

But, in Cleveland's case, "neoliberalism by default" had a second meaning, too. The

city’s1978 default enabled business leaders, who were explicitly inspired by a Sunbelt model of

public-private coordination, to more actively shape the city's developmental policies. Indeed, the salience of their antigovernment rhetoric was based on a rearguard, producerist discontent and a

and Political Development in the City: Urban Policy and Politics in the U.S. and the U.K., 1976-2000,” APSA 2011

Annual Meeting Paper, August 15, 2011, accessed online,

http://papers.ssrn.com/sol3/papers.cfm?abstract_id=1903162. See also, Timothy Paul Ryan Weaver, "Neoliberalism in the trenches: Urban policy and politics in the United States and the United Kingdom" (January 1,

2012). Dissertations available from ProQuest. AAI3542903. http://repository.upenn.edu/dissertations/AAI3542903

Other scholars previously used this phrase to describe a pragmatic rather than ideological embrace of business friendly politics. See, for instance, Steffen Ganghof, “The Politics of Tax Structure," in Ian Shapiro, Peter A. Swenson, and Daniela Donno Panayides, eds., Divide and Deal: The Politics of Distribution in Democracies (New York: NYU Press, 2008).

${ }^{7}$ On this "slippage" between language and practice, see Kenneth Lipartitio, "Connecting the Cultural and the Material in Business History," Enterprise and Society, December 2013, Vol. 14, No. 4, 689-90. 
Cebul

pious sense of entitlement to state provision. Yet, the ends of public private coordination they

advanced differed in important ways from their Southern counterparts. ${ }^{8}$

\section{Business Producerism}

In 1967, the Cleveland Chamber of Commerce and a number of industry-specific

associations joined forces, as the Plain Dealer put it, so the "city's future business growth can be planned, programmed, and pinpointed from one dynamic headquarters." Dubbed the Greater Cleveland Growth Association, the new body aimed not only to pursue traditional booster activities, but also to "maintain an active relationship with federal, state, and local government authorities." The Association recruited the executive director of the Seattle Chamber of Commerce as its full time director. They were particularly impressed with his record in securing the passage of municipal bonds for development projects. Indeed, his arrival in Cleveland was delayed because he was committed to seeing through 13 issues totaling $\$ 820$ million. "The city needs all of them," he told the Plain Dealer. "My research on Cleveland shows there are exciting things to be done" there, too. ${ }^{10}$ Clevelanders watched closely as Seattle voters passed the bulk of the measures, which included, after Houston's Astrodome, the nation's second domed stadium.

\footnotetext{
${ }^{8}$ On the importance of waning productivity growth and slowing innovation in speeding deindustrialization, see Barry Bluestone, forward, in Cowie and Heathcott, eds., Beyond the Ruins: The Meanings of Deindustrialization. 
Cebul

A Plain Dealer reporter sent to Seattle noted the measures that failed did so by slim margins, and

Seattle boosters planned to reintroduce them. ${ }^{11}$ Businesspeople in Cleveland's perennial rival,

Pittsburgh, voiced their envy: the "Growth Association is the most perfect vehicle in the nation

to assure a city's welfare and growth . . . Frankly, we Pittsburghers are envious."12 The

Association and its new director augured a bold new course for the city, and its initial reports

suggested 1968 and beyond would be a period of "rosy" economic growth. ${ }^{13}$

Such was not to be the case. By 1971, the Growth Association was "in a leadership

crisis." Their Seattle whiz kid had seemingly spent more time on the road, boasting about his

past success to other Chambers, than in Cleveland developing new projects. This was especially

galling because the Association enjoyed an annual budget of $\$ 1.3$ million, far exceeding the

budget of any other city-based Chamber or Chamber-like organization in the country. Dues

paying members threatened to quit if the leadership situation was not addressed. An insider

complained, because of the absence of leadership, "everyone is building his own empire and

doing what he pleases." The staff of 72 had become a bureaucracy mired by "ineffectiveness,"

trivial "agendas and the complete lack of leadership at all levels." One Association board

\footnotetext{
11 “Seattle's Thrust and Cleveland's," PD, February 15, 1968.

12 “City Awaiting Leadership for Renaissance,” August 20, 1972.

13 “City’s Economic Prospects Rosy,” PD, January 4, 1968.
} 
Cebul

member drew the bottom line: "This organization is supposed to keep companies from moving away and entice new ones here. It has done too little in either direction."14

As the strains of deindustrialization withered Cleveland's industrial base, over the early 1970s its leaders joined other industrialists in expressing mounting frustration, too, with their national lobbying associations' seeming inability - or unwillingness - to help struggling firms and regions. Local industries across the country were leaving the National Association of Manufacturers in droves. "The organization has been in a period of serious membership erosion," a NAM consultant reported. "The NAM has been unable to develop a real, consolidated political action group." NAM hired a pollster to help "redesign its marketing and communications approach to members." "15 The pollster's report was striking - marketing was not the issue. Across the board, firms that were still members felt the conservative lobbying association only looked out for big, healthy business, wasted time on programs such as "Promoting Concepts of Free Enterprise," and would be much more useful if it concerned itself with "the health of the national and local economies." While local businesses toiled in deindustrializing regions, the NAM seemed overly concerned with evangelizing for abstract calls for free markets.

\footnotetext{
14 “Growth Association in Leadership Crisis,” PD, September 25, 1971.

${ }^{15}$ Hugh C. Hoffman to William H. McGaughey, May 17, 1973, folder NAM According to the Field Staff, box 3 , series IV, National Association of Manufacturers Papers, Hagley Museum and Library, Wilmington, DE [hereafter NAMP].
} 
Cebul

"Moreover," the polls found "4 out of 5 members hoped to see NAM get more involved in local politics and in forging local congressional contacts." Members also called for "Aids and courses on practical politics.” Indeed, the polling consultants found that, while NAM scored reasonably well compared to other national business associations, "NAM doesn't do very well compared to state and local business associations." Put most clearly, "All but one on the Field Staff say members think NAM is more allied to the needs of big business than small business" and the concerns of local industry, which depend upon healthy local economies. ${ }^{16}$ In one revealing case, NAM was staunchly opposed to General Revenue Sharing. As they put it, Nixon's program would lead to “increased taxpayer burdens for all and weakening of fiscal responsibility and accountability at state-local levels." ${ }^{17}$ In Cleveland, however, as across the country, business leaders were strong supporters of Revenue Sharing and kept a close and optimistic watch on Nixon's New Federalism reforms. ${ }^{18}$ The NAM, like the U.S. Chamber of Commerce, tended to view its members as its political shock troops, not as constituencies to

\footnotetext{
${ }^{16}$ NAM According to the Field Staff, July, 1973, folder NAM - According to the Field Staff, box 3, Series IV, NAMP.

${ }^{17}$ Guidelines for Action, NAM Government Finances Department, June 16, 1972, folder Field Division Bulletin (1972), box 3, series IV, NAMP.

${ }^{18}$ Greater Cleveland Forward Status Report, January 31, 1973, Folder 997, Ralph J. Perk Papers, Western Reserve Historical Society, Cleveland, Ohio [hereafter RPP].
} 
Cebul

serve. ${ }^{19}$ Poorly represented in national policy debates, squeezed by inflation and flagging

productivity, and faced with new challenges to the legitimacy of their local leadership thanks to

War on Poverty-backed minority and poverty groups, many local businesspeople felt their

influence and prestige slipping away.

Yet, businesspeople across the country soon recognized that involvement in poverty

programming could enhance their reputation as community leaders, perhaps blunt some of the

more radical community development efforts afoot, and simultaneously help to prevent riots

while steering federal developmental funding toward favored projects. Indeed, the pressure from

minority and poor residents' mobilization generated a shift in the way Chambers sought support

and legitimacy from their broader communities. Less than a decade earlier, Chambers of

Commerce construed poor neighborhoods and inhabitants as blighted eyesores to be removed.

The movements of the 1960s, however, expanded the range of constituencies to which Chamber members felt called to appeal, if only symbolically. As one local businessman told Nation's

Business, a publication of the U.S. Chamber of Commerce, in order to maintain business control

of federal subsidies, businesspeople had to recognize that "this war on poverty isn't going to go

away. The poor are on the move. I think we'd better get in there and make sure the job gets done

\footnotetext{
${ }^{19}$ Report to the Board of Directors on Accreditation and Reaccreditation of Local Chambers, February 2, 1977 , folder Board Reports, 1977, box 6, series I, Chamber of Commerce of the United States Records, Hagley Museum and Library, Wilmington, DE (hereafter CCUS).
} 
Cebul

right." ${ }^{20}$ Moreover, creating voluntary, private sector programs for minority business

development or partnering with impoverished neighborhood schools might plausibly deflect

invasive federal policies in the future.

Local Chambers more forcefully attempted to frame their work as on behalf of the entire community. By the early 1970s, the U.S. Chamber's Newsletter described how 26 percent of local chamber dollars went to improve the social conditions of local communities. Nearly 300 chambers reported some kind of "socio-economic program expenditures" totaling $\$ 13.5$ million, $26 \%$ of the $\$ 55$ million of programming over all. Not surprisingly, support for vocational education represented the largest investment. Farther down the list were youth activities $\left(7^{\text {th }}\right)$, while support for minority enterprise development ranked last (though, they pointed out, "this type of activity was virtually non-existent even three years ago"). From internal polling, the Chamber concluded, "Business people are willing to pay their local Chambers to take the lead in organizing effective community improvement programs." ${ }^{21}$ Chamber members were piously learning to construe their organizations as representing the interests of a much broader range of constituencies than ever before.

\footnotetext{
20 “War on Poverty Becoming War on Business?” Nation's Business, March 1966, 61, accessed online at Hagley Museum and Library Digital Collections, http://digital.hagley.org/.

${ }^{21}$ Chamber of Commerce Newsletter, July 1971, box 5, series II, CCUS.
} 
Cebul

Along with emphasizing investments in the community, the U.S. Chamber urged local affiliates to highlight initiatives that reflected racial inclusion. In Cleveland, for instance, a Plain Dealer profile touted the Growth Association's work “to establish and expand minority business." ${ }^{, 22}$ Likewise, the Orlando, Florida Chamber began a program in 1973 that aimed to improve "community communications and understandings." As the Chamber's Newsletter put it, "A subcommittee prepared a description of the problems of the black man in Orlando." Then, "A white member of the committee would introduce a black member who told of some personal examples of discrimination in our own community. In most cases, this was the first time any of our white civic clubs had ever heard the problem from a black man." 23 As a result, most Orlando Chamber committees ended up appointing black members. They even filmed a series of televised public service announcements called "Attitudes Are Changing." Another edition of the Newsletter reported on the Springfield, Massachusetts Chamber's support of a black citizen's Harambee Holiday. Said one Chamber member, "there was never . . . a week that the black population could call its own." 24 Some efforts to appear inclusive, however, recapitulated highly racialized perceptions of labor as well as divisions between deserving and undeserving members

\footnotetext{
22 "New tasks: Growth Association provides service aimed at improving whole community," $P D$, November 25, 1976.

23 “'Understanding' . . A Big Step in Improving Racial Relations," Chamber of Commerce Newsletter, October 1973, box 5, series II, CCUS.

${ }^{24}$ Ibid.
} 
Cebul

of the community. In a piece titled "From 'Wetback' to Chamber President," the U.S. Chamber trumpeted Elias “Chino" Valdes" rise from "agricultural worker picking fruits and vegetables" to small storeowner. The pinnacle was his election as president of the Santa Paula, California Chamber. His "colorful success story" was the toast of the community, where businesspeople celebrated his "rise from 'wetback' to his present civic and business stature in the community." 25

By 1970, the national Chamber was even urging its local affiliates to get involved in the War on Poverty’s Model Cities, a program in which local business had a "vital stake."26 The Chamber emphasized that an "important feature of the supplemental funds is that they can be used in any way a city choses so long as the city gives emphasis to high-priority actions in the model neighborhood area .. . This gives the city great flexibility and strengthens its response to local needs." The Chamber enumerated other federal grants that might cover up to 80 percent of the cost of running the programs. The size of the total investment including state and local matching funds, the Chamber wrote, could hit "\$1.5 billion!” In Seattle, representatives of the local Chamber, Boeing, the American Medical Association, and the Weyerhaeuser Corporation helped develop the city's plan (which included input from 1,700 citizens). Model Cities Seattle created a \$30 million economic development corporation and a \$6 million housing corporation,

\footnotetext{
25 "From 'Wetback' to Chamber President," Chamber of Commerce Newsletter, September 1973, box 5, series II, CCUS.

26 “Model Cities - Outlook for 70s," Chamber of Commerce Newsletter, January 1970, box 5, series II, CCUS.
} 
Cebul

each run by "stockholders from industry, government, and the neighborhood." Similarly, in

Chicago, "private interests will either sponsor projects or take part in carrying them out," including two new hospitals and a moderate-income housing development shepherded by the Chicago Mortgage Bankers Association. In Houston, a "prominent" businessman and Chamber leader led the Model Cities citizen participation and oversight board. ${ }^{27}$ In getting involved in such programs, however, the U.S. Chamber cautioned that business leaders should overcome their discomfort speaking "before vocal minority groups. One unpleasant confrontation," they warned, and businesspeople "often lose enthusiasm for continued involvement." They should stick with it, though, because, "Model Cities offers tremendous potential for revitalizing the social and physical quality of living in slum areas directly." Most notably, however, it "offers a means for decentralizing Federal aid and for sharing Federal revenues." Businesspeople could at once burnish their reputation and direct generous developmental state subsidies.

Another good opportunity for businesses leaders to improve their standing in the community was by assisting local and state government to increase public sector efficiency. Gripped by inflation and increasing resistance to taxation, mayors and governors recognized the need to streamline service delivery. Most "municipalities have failed to keep abreast of new management tools and techniques developed since World War II and now used skillfully by

\footnotetext{
27 "Model Cities - Outlook for 70s," Chamber of Commerce Newsletter, January 1970, box 5, series II, CCUS.
} 
Cebul

corporate management" noted the U.S. Chamber's publication. ${ }^{28}$ As an example of a productive

solution, the Chamber described how, in New York City, "a group of businessmen developed

and helped implement . . . improvements" for the municipal court system that resulted in

"savings of over six million dollars." In Waterbury, Connecticut, city departments used chamber

studies to develop a "program-performance budget" as well as a computer network for the police

department. "The chamber of commerce executive is faced with a [sic] unparalleled opportunity.

The emergence of several factors - citizens fed up with higher taxes, spiraling costs of

governmental activities, and rising demands for more and better services - have forced political

leaders and government administrators to search for better ways to perform their respective

jobs." 29 By touting businesslike methods in government, business could reassert their legitimacy

as community leaders.

Ultimately, the U.S. Chamber led a campaign to help local Chambers reframe business as the forgotten and abused but still-beating heart of their communities. This producerist framing of business' role in society enjoyed broad resonance in disparate regions across the country. One article described the value of private sector employment to a rural Alabama community. The Chamber found that 100 new factory workers in a struggling county meant the community could support at least one more retail establishment; the community would benefit from $\$ 1.04$ million

\footnotetext{
${ }^{28}$ Chamber of Commerce Newsletter, January 1975, box 5, series II, CCUS.

${ }^{29}$ Chamber of Commerce Newsletter, February 1975, box 5, series II, CCUS.
} 
Cebul

in increased personal income; which in turn could support 68 additional nonmanufacturing jobs.

As the piece concluded, "all economic changes" in Cullman County, Alabama were "attributed

to the increase in manufacturing employment." ${ }^{30}$ Another article, titled "A Need to Explain

Business," emphasized business peoples' sense of their underdog status. ${ }^{31}$ "Business has long

been misunderstood," the Chamber publication explained. "It faces growing public hostility. Its

enemies are on the rise." "The declining reputation and image of business needs to be reversed to improve the relation between business and the rest of society so as to maintain and enhance the quality of American life." Most importantly, "Business creates the economy upon which a community is built. It is important to all citizens that we enjoy a healthy, prosperous economic climate so that our job level and tax base meet our needs." "But first, people need to know what business is all about. Its story needs to be told. ${ }^{, 32}$ The U.S. Chamber urged local Chambers to mount a rearguard campaign on behalf of businesses' essential role as the nation's true producers - of jobs, of opportunity, and of vital communities.

Many business groups took action. The Independent Business Association of Wisconsin, for instance, drafted a new bill of rights geared to protecting the rights of small business owners,

\footnotetext{
30 "What 100 Extra Jobs Mean to a Community," Chamber of Commerce Newsletter, April 1973, box 5, series II, CCUS.

${ }^{31}$ For a broader argument about white, middle class Americans' embrace of an outsider cultural perspective, see Grace Elizabeth Hale, A Nation of Outsiders.

32 “A Need to Explain Business,” Chamber of Commerce Newsletter, August 1973, box 5, series II, CCUS.
} 
Cebul

a document that made its way to Professor Newt Gingrich's files at West Georgia College in

Carrolton, Georgia. "The American Dream," they began, "is to be an owner of one's own

business." Under duress from government regulation and tight capital markets that favored big

business, Wisconsin's small businessmen hoped to generate a movement that would lead to the actual passage of their bill of rights. Included were (1) "The right to start, own, and manage a

business without government interference. (2) The right to compete fairly for capital with assurance that capital will be available for private use." Also included were rights to "to be governed by reasonable and understandable laws set forth by elected representatives, not by bureaucratic dictate"; "to be innocent until proven guilty by a jury of our peers; not by administrative edict"; and, last but not least, the right "to equal representation with Big Business, Big Labor, and Government on matters relative to America's economic policies." Small and regional business people felt particularly entitled to these rights since, as they put it, the Small Business Community was comprised of 14 million small businesses that represented 100 million people and $58 \%$ of all private sector jobs. They noted that $97 \%$ of all new jobs in the prior seven years were produced by small and independent businesses. ${ }^{33}$

As a disgruntled member of the Sacramento Chamber of Commerce put it, Americans "seem to be ignorant of the business world and economics ... They lose track of the fact that

\footnotetext{
${ }^{33}$ America's Small \& Independent Business Bill of Rights, folder Small Business, box 287, NGP.
} 
Cebul

business is 'jobs', that it is also the shoes and clothes they wear." ${ }^{\text {34 }}$ Citing a poll of Sacramento high school and college students, teachers, professors, and production workers, the U.S.

Chamber concluded, "Americans do not understand their own economic and business systems."

Most crucially, many of the Sacrementans polled believed business enjoyed outsized profits while consumer prices soared and wages stagnated. As a result of such misunderstanding and frustration, the national Chamber developed a $\$ 500,000$ program, "America Needs to Know ... More About Business," that developed curricula for a broad range of constituencies. A program in Greenville, South Carolina seemed to deliver particularly strong results. Greenville's Chamber partnered with Furman University to teach a summer graduate course for Greenville County teachers called "Teaching Economics." Before the course, 63 percent of the teachers agreed that "American business is overly concerned about profits," and 68 percent felt "Government controls should be used to stimulate private competition." Following the course those figures dropped to 43 and 31 percent, respectively. Moreover, 71 percent (up from 52) agreed that, "Industries should be allowed to make all the profit they can, while 90 percent (up from 74) believed in the "Ability of business to meet needs of the country."

\footnotetext{
34 “Americans Do Not Understand Business," Chamber of Commerce Newsletter, March 1974, box 5, series II, CCUS.

${ }^{35}$ IB / EE Idea of the Month, Chamber of Commerce Newsletter, November 1975, box 5, series II, CCUS.
} 
Cebul

affiliates sought to convince misguided Americans that what was good for business was good for

their local communities.

\section{Business Mobilization in Cleveland}

Cleveland's business leaders certainly felt misunderstood and ignored by the Perk

Administration. A year into Ralph Perk's first term, Growth Association members, the Plain

Dealer reported, were frustrated that Perk "has not yet shown understanding of their problems,

and is in a box of [white] ethnic support." Some Association leaders despaired of ever

"establishing a real rapport" with the mayor. ${ }^{36}$ Indeed, Perk was a tough man for business to pin

down. When he wasn't battling the city's employees over pay cuts and mandatory furloughs, he

was kibitzing with the ethnic community. ${ }^{37}$ In 1972, in the midst of the city's fiscal crisis, Perk

traveled to Eastern Europe and Italy, a publicly funded political tour that was covered daily on

the front page of the Plain Dealer. Emphasizing his populist roots, Perk declared August 16,

1972 "Bowlers' Day" in Cleveland. ${ }^{38}$ Sometimes, though, his homespun nature got the better of

him. Cutting a ribbon to kick off a steel worker's convention, the Mayor chose to use a

blowtorch rather than oversized scissors. His Vitalis-oiled mane went up in flames in front of

\footnotetext{
36 “City Awaiting Leadership Renaissance," PD, August 20, 1972.

${ }^{37}$ His "Ethnics" folders in the archives bulge with certificates, letters, invitations, and commendations from these opening months. See, for instance, folder 744, container 50, RPP.

${ }^{38}$ Sam Levine to Ralph Perk, August 17, 1972, folder 779, container 51, RPP.
} 
Cebul

photographers and TV cameras. ${ }^{39}$ Coming on the heels of the Cuyahoga River fire, Cleveland's national reputation seemed up in flames as well.

Perk's developmental staff wasn't much more sophisticated. It took a great deal of time

for his Economic Development Department to come together, and much of their initial work consisted simply of inventorying the various community development corporations and neighborhood groups that contacted the department for assistance. ${ }^{40}$ A 1975 Cleveland Magazine article neatly summed up the city's strategic planning: “There is absolutely no long-range planning for the use of federal subsidies, or, worse, any check on how they are spent." Between 1974 and 1977, Cleveland was awarded nearly \$50 million in Community Development Block Grants. As a result of its own incompetence and the endemic inefficiencies of the 33-member city council, the Perk administration failed to disperse or contract over \$22 million in Block Grants. Of the \$26 million that was successfully contracted, only \$21 million went to support programs and services. The other $\$ 5$ million was absorbed into the city budget for “administrative" purposes. ${ }^{41}$ Despite having aggressively sought significant federal support, and

\footnotetext{
${ }^{39}$ Perk's obituary in the New York Times describes him as a "hard-luck Mayor of Cleveland" before describing both events. New York Times, April 23, 1999.

${ }^{40}$ Progress Report of the Department of Human Resources and Economic Development, November, 1971 - August, 1973, August 29, 1973, folder 752, container 50, RPP.

41 “Mayor's Economic Coordinating Commission: Agenda for Initial Meeting,” undated 1977, folder 995, container65, RPP; Carla A. Hills, "Federal Fair Housing Policy and Our Ethnic Heritage,” James Cannon Files, folder Community Development, April 27, 1976 - May 10, 1976, box 8, Gerald R. Ford Library [hereafter GRFL]. This habit of shunting Block Grant funds into municipal budgets to cover a much broader and, perhaps,
} 
Cebul

despite the long line of groups seeking funds, the Administration's inefficiency profoundly

blunted the potential developmental impact of federal support whether for neighborhoods or for

business. Finance Director Andrew Putka said he was "somewhat appalled at the Administrative

incompetence." 42

Frustrated with the Growth Association's early drift and Perk's bumbling Administration, the city’s businesspeople elected a new Growth Association chairman. James C. Davis, a brash attorney and partner at Squire Sanders \& Dempsey, made a name for himself in the 1960s when he blamed Mayor Locher and the ethnics for the city's initial decline. Upon his election as Growth Association chairman, Davis "shocked and challenged the business community" by asking for a colossal \$6 million operating budget to implement what he called Greater Cleveland Forward. ${ }^{43}$ Davis explicitly based his program on Sunbelt precedents. Forward Atlanta, a public private partnership designed by Mayor Ivan Allen, focused on building service sector office towers and recreation and entertainment facilities such as the Omni complex that could recapture suburbanizing tax dollars. ${ }^{44}$ Likewise, the Growth Association also consulted with the Houston unauthorized range of activities was a nationwide phenomenon. See Eisinger, The Rise of the Entrepreneurial State, 108-10.

${ }^{42}$ Andrew Putka to Ralph Perk, June 9, 1972, folder 1691, container 105, RPP.

${ }^{43}$ In 1967, then Cleveland Bar Association President, Davis debated Martin Luther King, Jr. in a public forum at Cleveland's Human Rights Institute, on the merits of civil disobedience. "Dr. King Organized E. Side for Vote, Jobs, Rent Unions," PD, April 5, 1968.

${ }^{44}$ On Atlanta Forward, see Numan V. Bartley, The Creation of Modern Georgia (Athens, GA: University of Georgia Press, Second Edition, 1990), 225-6. 
Cebul

Chamber of Commerce. ${ }^{45}$ Growth Association members along with the Cleveland Foundation

(on the board of which sat a number of Association leaders), responded enthusiastically by

raising \$4.8 million to leverage public investments in business, industry, and infrastructure. ${ }^{46}$

Nearly half of the funding would go toward planning and lobbying for an expanded port on Lake

Erie that would feature a fantastical new "jetport."

airport five miles out in Lake Erie - had been underway since 1969. Davis and his predecessors

established contacts with the Federal Aviation Administration, NASA (its Lewis Research

Laboratories were at Cleveland), Ohio’s state house, and the Federal Department of

Transportation. The Association prepared a feasibility study based on "two years of research by

fifty top experts in the fields of ecology, engineering, law and finance." However, they noted,

funding for the project going forward, "must largely come from federal sources." 48 Davis, the

Plain Dealer wrote, was "determined to bridge the gap between the business and political

\footnotetext{
45 "Council on the Future is Organized in Cleveland," Chamber of Commerce Newsletter, April, 1971, box 5, series II, CCUS.

46 “To Those Interested in The Future of Greater Cleveland," Greater Cleveland Forward Status Report, January 31 , 1973, folder 997, container 65, RPP. See also, “Cleveland Awaiting Leadership for Renaissance,” PD, August 20, 1972.

${ }^{47}$ Greater Cleveland Forward Status Report, January 31, 1973, folder 997, container 65, RPP.

${ }^{48}$ James C. Davis to John A. Volpe, Secretary of Transportation, Department of Transportation, December 2, 1971, folder 745, container 50, RPP.
} 
Cebul

communities." 49 Cleveland's business leaders sought institutionalized public private partnerships explicitly based on a Sunbelt model of private sector led developmental state building.

To do so, Davis established the Growth Association's Governmental Affairs Division. In contrast to the Perk Administration, the Growth Association's research and findings benefited from a clarity of purpose: reinvigorating downtown through commercial development, service sector jobs, and stimulating supportive infrastructure and public service improvements. One report, for instance, argued for an expansion of Revenue Sharing to enable local government to cover the costs of infrastructure improvements. The "state and federal governments," Cleveland's businesspeople argued, "simply must return large portions of the taxes collected either in the form of cash grants or assumptions of financial responsibility for services." They advocated transferring costly and, as far as business growth was concerned, immaterial, functions of local government to county, regional, or state authorities. ${ }^{50}$ The Government Affairs branch also studied the intergovernmental transfers of funds, both in terms of tax and welfare payments out of the city and federal grants coming into the community. Based on these figures and the city's financial circumstances, the Association advocated raising the city's income tax. ${ }^{51}$

\footnotetext{
49 “City Awaiting Leadership Renaissance,” PD, August 20, 1972.

${ }^{50}$ Greater Cleveland Growth Association Governmental Affairs Division Taxation Department Policy Statement, February, 1973, folder 752, container 50, RPP.

${ }^{51}$ Greater Cleveland Forward Status Report, January 31, 1973, folder 997, container 66, RPP.
} 
Cebul

Davis doggedly peppered the mayor with correspondence, sometimes with praise, often

with rebukes, but always with clear preferences for policy changes, seeking reassurance that Perk would move in favorable directions. ${ }^{52}$ When it leaked, for instance, that Perk's Planning

Commission was exploring possibilities for expanding the city's publicly-owned electric utility,

Muny Light, to the competitive detriment of its privately held rival, Cleveland Electric

Illuminating, Davis admonished the Mayor. If the city proceeded, it would be "destructive of general business confidence in the administration and [would] tend to make it more difficult to achieve the cooperation between the administration and the business community which you and I both desire." Davis was confident, however, that Perk would "take occasion to make it clear that this was simply a planning exercise by the Commission and does not reflect the official views of the administration." Davis expressed his hope that he would not need to take the issue public. ${ }^{53}$

Perk disavowed the plan. On another occasion, Davis suggested the Mayor work harder "to persuade the business community" that he understands "business problems."

Davis sought to provide the administration with a strategic vision for growth. On top of his list was developing a more favorable funding relationship with the federal government in

\footnotetext{
${ }^{52}$ On inducements to keep specific businesses in Cleveland, see James Davis to Ralph Perk, August 30, 1972; on labor relations, see James Davis to Jackie Presser, cc to Ralph Perk, October 23, 1972; on improving coordination between the city and business, see James Davis to Ralph Perk, November 1, 1972; on city management of ongoing infrastructure improvements, see James Davis to Ralph Perk, February 7, 1973, all in folder 745, container 50, RPP.

53 James Davis to Ralph Perk, May 3, 1972, folder 753, container 50, RPP.

${ }^{54}$ James Davis to Ralph Perk, December 18, 1972, folder 779, container 51, RPP.
} 
Cebul

general and with HUD in particular. ${ }^{55}$ Because some of Perk's key staffers had become members of the Growth Corporation, slowly but surely, the Association's ideas began to trickle over to the Mayor's office. A first sign of improved relations between the public and private sectors came when Perk organized an Economic Development Advisory Committee. Davis, however, was not invited to participate, a sign, perhaps, that Perk resented Davis' aggressive entreaties.

Nevertheless, Perk was beginning to develop a formalized structure that incorporated business interests.

While many of Georgia's business leaders focused on modernizing industrial production methods through technology innovation and partnerships with Universities, Cleveland's developmental emphasis, driven by bankers and lawyers, was geared toward bricks and mortar developments for white-collar business interests. In 1973, the Growth Association funded a visit to Cleveland by high-priced San Francisco architect Lawrence Halprin. A guru of modern planning's new urbanism movement, Halprin was at the vanguard of using recreation and mixeduse public space to lure suburbanites and their tax dollars back into cities. Keying on the city's unique river and lakefront, Halprin was optimistic. "What I'm really good at," he said, "is getting things built." ${ }^{, 56}$ Halprin met with Perk and underscored the Growth Association's efforts to sell the mayor on downtown investment. It worked. In tandem with the Growth Corporation, the

\footnotetext{
55 James Davis to Ralph Perk, November 29, 1972, folder 779, container 51, RPP.

56 “Halprin begins two-day study," PD, February 13, 1973.
} 
Cebul

Growth Association, and the Greater Cleveland Associated Foundation - all of which were

offspring of the original Chamber of Commerce - the city invested several hundred thousand

dollars in Block Grants in Halprin's plan. ${ }^{57}$ The city would bank its future on redeveloping its

downtown to generate new streams of tax revenue. Over the course of 1974, the key advocates of

this plan formed the Downtown Cleveland Corporation. Overseeing its Government and Legal

committee was Jim Davis, who stepped down from his post at the Growth Association to focus

on implementing the new plans. ${ }^{58}$

Like other Chambers across the country, the Growth Association developed its plans in consultation with experts at public institutions of higher education. Following Gerald Ford's failed reelection bid, his Block Grant director moved to Cleveland to assume a new chair in urban planning at Cleveland State University. There, David Meeker, the central villain for the nation's neighborhood groups who mobilized to protest rampant abuse of Block Grant funds, collaborated with Cleveland's philanthropic organizations and business interests on a growth plan. ${ }^{59}$ Meeker more clearly and bluntly articulated the Ford Administration's goals for Block Grants: preserving communities that had not yet fallen prey to the urban crisis. Established neighborhoods and business districts should be "enhanced so that Cleveland will not become a

\footnotetext{
${ }^{57}$ Halprin Plan, Folder 795, container 52, RPP.

${ }^{58}$ Ibid; "Downtown revitalization priorities are established," $P D$, December 11, 1975.

${ }^{59}$ On neighborhood groups' activism against cities' misuse of block grants, see "Developmental State," ch. 5.
} 
Cebul

Black ghetto of lower income classes," Meeker argued. "Each neighborhood," he wrote,

excepting the worst off, "should have an opportunity to develop in a manner which will express

the wishes of the people of the area." "Triage," the term they used for policies that threw good

money after bad on neighborhoods and citizens who were, they believed quite ilterally, beyond

the pale, were poor investments of limited public resources. ${ }^{60}$ Indeed, the City's Planning

Commission agreed, setting a policy in which Block Grant money would "focus primarily upon

those areas which are in the initial, not final stages of deterioration." ${ }^{61}$ Moreover, as Meeker put

it, economic growth centered on downtown revitalization was the only way forward: "the city is

very fortunate to have a new cornerstone in its economic base in the presence of global

management headquarters and related services." Meeker emphasized the "combination of this

potent economic base with Cleveland's cultural assets" could offer the "the city ... the potential

to become a truly major city in the network of international development." ${ }^{62}$ In order to save the

city as a whole, local leaders believed they had to reorient federal antipoverty development

dollars to areas not yet in poverty.

\footnotetext{
${ }^{60}$ Proposed Plan for Neighborhood Revitalization, Recommendations from Workshops on Cleveland Neighborhoods and Housing, Cleveland State University, 1976-77, folder Cleveland State University - Institute of Urban Studies, 1977-1978 (2), box 5, David O. Meeker Papers, GRFL.

61 "A Community Approach to the Development of Cleveland," Institute of Urban Studies, CSU, folder Cleveland State University - Institute of Urban Studies, 1977-1978 (2), box 5, David O. Meeker Papers, GRFL.

62 “A Community Approach to the Development of Cleveland," Institute of Urban Studies, CSU, folder Cleveland State University - Institute of Urban Studies, 1977-1978 (2), box 5, David O. Meeker Papers, GRFL.
} 
Cebul

The city's ongoing financial crisis, too, created opportunities for the Growth Association to press its influence on City Hall. In the early summer of 1974, the businesspeople submitted a report to Perk and the City Council outlining the city's dire financial situation. Unless there was a major federal windfall, the city would be $\$ 18$ million in the red in 1975 , the worst financial year for the city since Carl Stokes' last in office. Perk's gimmicks and short-term measures privatizing the sewer system and 'repurposing' federal grants to cover operating expenses along with General Revenue Sharing only papered over what was fast becoming an intractable budgetary crisis. Making matters more difficult, in 1974, voters emphatically defeated the Growth Association-backed income tax hike. Meanwhile, the depreciation of Cleveland's property values sent city property tax receipts tumbling from $\$ 41.4$ million in 1969 to $\$ 23.2$ million in $1976 .{ }^{63}$ While tax receipts were drying up, city expenses soared as inflation gnawed away at its purchasing power. Perk's economic team refuted the Growth Association's figures, but by 1975 it was apparent that their report had been correct. The city's FY1975 budget was set at $\$ 126$ million, which included $\$ 76.4$ million for the fire and police departments alone; city tax receipts would only bring in $\$ 74.1$ million. As Perk put it, "If I were not able to get continued federal funds, this would be a one-department town." When confronted with the prospect that the

\footnotetext{
63 “U.S. Funds: Catch-22 for city budgets,” PD, April 18, 1976.
} 
Cebul

federal government, too, needed to do some belt-tightening, Perk argued: “Those (federal

dollars) belong to the people." ${ }^{, 4}$

In January 1975, Perk testified before the Congressional Subcommittee on

Intergovernmental Relations and bemoaned the plight of cities like Cleveland. He begged for "immediate federal help to keep our great metropolitan areas alive." As he put it, the people of Cleveland "are demanding a greater share of their state and federal taxes be returned to them.

I am asking ... that the voice of the people be heard - that increased aid to the local governments be the keynote of federal spending so that we as city administrators can provide the basic services to our citizens without further burdening their everdiminishing purchasing power with higher taxes.

Each time he ran for office, Perk was sensitive to the pressures of inflation and pledged to keep taxes low while delivering "all the necessary services the people need and deserve." ${ }^{95}$ The massive redistribution of federal funds to the city had made his high service / low tax conservatism possible, but, as the federal government faced its own mounting fiscal crunch, generous federal aid seemed less and less justifiable to members of Congress - who took the blame for outsized federal expenditures, but, in Revenue Sharing and Block Grants, could reap few of the political rewards that came from administering the programs. Even if federal funding

\footnotetext{
64 "City taxes couldn't support safety forces; aid pays bills," $P D$, January 17, 1975.

${ }^{65}$ Ralph Perk, Testimony before the Subcommittee on Intergovernmental Relations, January 30, 1975, folder 1536, container 96, RPP.
} 
Cebul

levels remained stable, the Growth Association forecast a deficit of $\$ 50$ million by 1980 . But, as inflation reshaped the nation's politics, there was little reason to believe federal aid levels would remain stable. Indeed, Congress sat on revenue sharing's reauthorization package for months over 1975 and early 1976, debating the merits of a program that, in one hotly politicized example, sent $\$ 16$ million to Houston despite the fact that the city was $\$ 16$ million in the black.

Faced with the desperate need to offer a clear developmental path forward, in late 1976, Perk fully acquiesced to Davis and Meeker's plan for downtown, service sector, and entertainment-based development. In adopting this plan, a crestfallen Perk delivered a speech that would make President Carter's 1979 'malaise' speech seem like a pep rally. He painted a dire picture in hopes of justifying to his ethnic base - the group to which he had stoked populist mistrust of big business, calling for business to pay their fair share in taxes - a new partnership between his Administration and Davis' business leaders that advanced an aggressive system of tax abatements. Perk hoped to convince his working class supporters that their fate as well as that of their city was inextricably linked to the fate of the city's businesses. Focusing on the needs of the job producers was the best way forward. Gazing into a television camera, Perk explained, "Cleveland has a disease ... It is mentally crippling, it is spiritually crippling, and it is psychologically crippling ... I do not know its medical terminology, but in every-day language, that disease is better known as an inferiority complex." In order to overcome "our almost 
Cebul

desperate urge to tear our city down" - "this urban masochism" he called it - the Mayor

proposed taking the city's economic development objectives in markedly new directions.

The "Twenty Point Action Program" he laid out had all the hallmarks of Jim Davis' plan,

borrowing a bit from Meeker's model, too. It included creating a land bank (the legislation for

which was written by Davis' firm), the creation of "an equitable tax-abatement formula" (the

legislation for which was being written by Davis' firm), the creation of a "Businessman's

Advisory Council" (to be chaired by the CEO of National City Bank, which would receive one

of the first abatements), and the creation of a city Economic Growth Commission "to pull all

these points together, and to serve as the central force to develop a series of long-range economic

growth plans." 66 When the Growth Commission debuted - under a new moniker, the Mayor's

Economic Coordinating Commission - Jim Davis was appointed head. ${ }^{67}$ Sohio (Standard Oil of

Ohio, now British Petroleum) quickly approached the city about acquiring land on Public Square

across from the Terminal Tower to build a new corporate headquarters. Davis and his law firm

led the negotiations, with Davis advising the city and his firm's lawyers advising Sohio. ${ }^{68}$ Sohio

\footnotetext{
${ }^{66}$ Mayor's Remarks, Land Use Conference, Case Western Reserve University, December 4, 1976, folder 997, container 65, RPP.

${ }^{67}$ News Release Announcing Formation of Mayor's Economic Coordination Commission, July 26, 1977, folder 995, container 65, RPP.

${ }^{68}$ National City Bank also requested and received tax abatements for a new headquarters on Ninth Street. There was outrage among the city's more liberal neighborhood groups including the BWCC who pointed out that For more on this trend in Cleveland and across the nation, see Hearings Before the Senate Committee on Banking, Housing, and Urban Affairs, June 14, 1976.
} 
Cebul

won a \$21 million abatement that would be paired with significant Block Grant-based

commitments for infrastructure and site improvements, too. ${ }^{69}$

Beyond reneging on his fiscally conservative populism, the Perk Administration's legacy

was an economic planning department in shambles and a city budget that was declared

unauditable in 1977 by Price Waterhouse and again in 1978 by Ernst and Ernst. A Brookings

study found that the city's published data for Block Grant expenditures "was greatly at variance

with financial reports filed with the federal government." ${ }^{, 70}$ Brookings found that around one-

third of the city's general operations budgets (not including the 'enterprise' operations) was

dependent upon federal grants. For FY 1978 alone, the federal government contributed $\$ 67.5$

million to the city's operating budget, while local property taxes for homes and businesses

accounted for only $\$ 27.4$ million; wage taxes totaled $\$ 66.8$ million. Of the city’s human

resources and economic development departments, the Brookings report concluded, "Each

department is truly a creature of the federal government." By the end of the decade, Cleveland

was receiving on average 150 percent of its annual local tax effort in intergovernmental

transfers. ${ }^{71}$ And, rather than lay out the facts in an appeal to raise taxes, a subsequent audit

completed by Ernst and Ernst found that Perk misused \$52 million in municipal bonds legally

\footnotetext{
${ }^{69}$ On abatement politics in Ohio, see generally, Alexander P. Lamis, ed., Ohio Politics (Kent, OH: Kent State University Press, 1994), 105-16.

${ }^{70}$ Tompkins, et al., 25.

${ }^{71}$ Tompkins, et al., 27.
} 
Cebul

bound to capital projects (e.g., for making improvements to Muny Light), instead routing the funds into the general budget to pay for basic services. ${ }^{72}$

Making matters worse, a U.S. District Court judge found Muny Light delinquent for past payments to Cleveland Electric Illuminating. The judge required the city to pay CEI $\$ 9.5$ million. Earlier in the decade, Muny invested in badly needed infrastructure improvements that necessitated temporarily closing its external sources of wholesale power, forcing it to buy from CEI. As the Nuclear Regulatory Commission's Atomic Safety and Licensing Board later found, during that time CEI systematically undermined Muny Light by imposing "severe operating problems" that created blackouts in Muny's system. The regulatory commission also found that CEI charged Muny rates three times higher than national wholesale averages. As a result, the public utility ran deeper deficits as the 1970s wore on. The Perk Administration quietly filed an antitrust suit against CEI, but, by the end of his third term, as the city's financial crisis continued to worsen, the Mayor and CEI at last struck a deal to sell Muny and to drop the antitrust suit (a win-win for CEI, which had long coveted Muny's market). For the first time, an ordinance to privatize Muny Light with a real chance at passage was introduced before the city council. The measure called for a $\$ 158$ million sale price with $\$ 38.5$ million paid up front and the balance paid out at $\$ 4$ million per year for 30 years. When an independent appraiser set a much lower

\footnotetext{
${ }^{72}$ Todd Swanstrom, "Urban Populism, Fiscal Crisis, and the New Political Economy" in Keating, et al, eds., 101.
} 
Cebul

value for the public utility, however, the City Council tabled the plan. Muny remained public in early 1977. Without the new infusion of cash, however, the Perk Administration issued over \$25 million in new short-term bonds in its final year alone. ${ }^{73}$

The 1977 mayoral election was a referendum on Perk's efforts to sell the public utility and its use of tax abatements. Democratic Councilman Dennis Kucinich, once a Perk supporter, made opposition to Muny's attempted sale the populist centerpiece of his campaign ${ }^{74} \mathrm{He}$ claimed there was a "shadow government" in Cleveland, led by CEI, its bank Cleveland Trust, major manufacturing interests, and the city's two most important law firms, Jim Davis' Squire Sanders and Jones Day. "They meet every day in the Union Club," Mayor Kucinich told a reporter, pointing out that "they used to meet right here, in [the mayor's] office." ${ }^{, 75}$ Indeed, having flipped on his commitment to attack big business' tax advantages, Perk had lost all legitimacy. In June 1977, Active Clevelanders Together, Kucinich supporters, coordinated a Saul Alinsky-inspired demonstration at National City Bank. Echoing the 1976 National Peoples' Platform action in Washington, they piled debris on the sidewalk in front of the bank's headquarters, calling attention to National City's unwillingness to lend within the city despite the

\footnotetext{
${ }^{73}$ The Role of Commercial Banks in the Finances of the City of Cleveland, Staff Study by the Subcommittee on Financial Institutions Supervision, Regulation, and Insurance of the House Committee on Banking, Finance and Urban Affairs, June 1979, 1, PAL.

${ }^{74}$ For a thorough account of Kucinich's administration and a piercing analysis of the city's "growth politics" and its relationship with private business in the 1970s, see Todd Swanstrom, The Crisis of Growth Politics.

${ }^{75}$ Larry Kramer, ““People Power vs. ‘Shadow Government,” WP, February 13, 1979.
} 
Cebul

massive abatement the Perk Administration had just delivered. Nearly $22 \%$ of National City’s

deposits came from within the city, but the bank only lent 5 percent of its mortgages there. ${ }^{76}$ The perception that city government - black and white officials alike - had sold out to big business opened the door for a new populist candidate. In 1977 Dennis Kucinich focused not on divisive social or racial issues of the past, in which he had played a supporting role, but instead on the common economic issues facing working and poor people across the city's neighborhoods.

\section{The Last Gasp of Urban Populism}

Dennis Kucinich is often thought of today as a political curiosity, but in the late 1970s the nation's retreating left cautiously hailed Kucinich's mayoralty, along with Ralph Nader's consumer movement, as a glimmer of hope. ${ }^{77}$ As The Nation put it in 1979, Kucinich "may well signal a new era in American politics" driven by young people calling for "a program of economic justice and economic democracy."78 Dubbed the "New Urban Populism," the 31 year old Kucinich's brand of politics was fiery, anticorporate, redistributionary, and, thanks to his intemperate, impetuous, and often incoherent style, wholly unsustainable. The issues that

\footnotetext{
76 “2 of city’s top banks lowest in home loans," PD, June 25, 1977.

${ }^{77}$ On Ralph Nader and business politics nationally, see, Benjamin Waterhouse, "The Corporate Mobilization Against Liberal Reform: Big Business Day, 1980," in Julian Zelizer and Kim Phillips-Fein, eds., What's Good for Business: Business and Politics Since World War II (Oxford University Press, 2012)

78 “The Cleveland Story: How the Banks Foreclosed Dennis Kucinich,” The Nation, January 20, 1979.
} 
Cebul

symbolized Ralph Perk's turn away from populist politics - abatements and his proposed sale of

Muny Light -dominated Kucinich's two chaotic years in office. Having won the election

promising to keep Muny Light public and to turn off the abatement system - issues that appealed

to groups like the Buckeye Woodland Community Congress as well as many of Perk's erstwhile

ethnic supporters - Kucinich, dubbed by local media "the boy mayor," generated staunch

resistance from the city's increasingly well organized business interests who had at last gained

Perk's compliance in their developmental vision. In one of his first moves as Mayor, Kucinich

vetoed Standard Oil of Ohio and National City Bank's abatements. Despite the fact that the City

Council overturned his veto, Kucinich repeated his campaign theme: "business must pay its fair

share of taxes." ${ }^{, 79}$ And, by freezing federal funds for corporate projects and halting infrastructure

improvements tied to the developments, Kucinich effectively quashed the Sohio and National

City buildings (they were completed under his successor) ${ }^{80}$ The mayor also blocked public

subsidies for a new ore dock for Republic Steel, arguing the company pay for the development

itself. In this case, at least, he was vindicated.

Kucinich and his city planner, Norman Krumholz, who had also worked for Perk after

having been brought to the city by Stokes, argued that abatements were a political rather than

\footnotetext{
${ }^{79}$ Ibid., 24.

${ }^{80}$ On abatement politics with particular attention to Cleveland, see Scott Cummings, Business Elites and Urban Development: Case Studies and Critical Perspectives (Albany: SUNY Press, 1988).
} 
Cebul

economic tool, robbing the city's neighborhoods of valuable capital while providing nominal

economic support to the city's businesses in return for their political cooperation. Rather than a

useful economic inducement, then, they argued abatements were simply political signals of an

administration's pliability. In planning circles, Krumholz was a well known and leading advocate

for what he called "equity planning," a strategy for long-term development for declining cities

that focused on shoring up services for lower and middle class residents without pandering more

than necessary to business interests or suburban commuters. ${ }^{81}$ As political scientist Todd

Swanstrom describes Krumholz's program, "The solution" to the urban crisis "no longer

centered on enticing investment or the middle class into the city . . but improving the choices of

those who had remained behind." Krumholz and his planning team "did not see equality as a

leveling process; rather," like Ralph Nader and new generation of liberals, "they favored

competition and choice in the marketplace." For instance, though Perk had sold the city transit

system to a regional authority, Krumholz supported the measure as a way to provide urban

residents better access to suburban areas, increasingly where many of the city's jobs were

relocating. ${ }^{82}$ In his campaign, Kucinich cited Krumholz's reports. After his election, however,

\footnotetext{
${ }^{81}$ The foundational document for "equity planning” was Krumholz's paper for the $54^{\text {th }}$ Annual Conference of the American Institute of Planners. Krumholz and Ernest R. Bonner, “Toward a Work Program for an Advocate Planning Agency,” October 25, 1971, City Planning Commission, City of Cleveland, PAL.

${ }^{82}$ Norman Krumholz, "Government, Equity, Redistribution, and the Practice of Urban Planning, in Keating et al, Cleveland: A Metropolitan Reader.
} 
Cebul

his political battles overshadowed judicious planning, and he became a one-note politician, confrontational and bombastic. As Krumholz later ruefully noted, while he and Kucinich were ideologically aligned, he had a more fruitful relationship with the Republican Perk. ${ }^{83}$

Kucinich had been elected as the candidate of the neighborhoods, but his Administration soon ran afoul of his core constituency, members of which were becoming increasingly

frustrated, resorting to excessive measures. Indeed, the Perk years had seen vibrant activism but little policy follow-through, and neighborhood groups in Cleveland, as across the country, were beginning to fragment. ${ }^{84}$ An early and typical confrontation pitted Kucinich and Citizens to Bring Broadway Back (CBBB). The neighborhood group had petitioned the Perk Administration for months to demolish an abandoned home that was frequently the site of small fires. When the Kucinich Administration failed to act on to their request, the Citizens demolished the structure and hauled a truckload of burnt wood to the Community Development department. As one member recalled, "We went into the building carrying all this charred wood . .., we're dropping ashes and junk everywhere, and [the community development director] started screaming, 'Call

\footnotetext{
${ }^{83}$ Author's interview with Krumholz, January 4, 2011, Cleveland, Ohio. Other urban planners were buffeted by the strains of developing political constituencies and political clients. In Philadelphia, for instance, planners' vision for a major urban renewal project was drowned out by various interests political jockeying. See Guian A. McKee, "Blue Sky Boys, Professional Citizens, and Knights-in-Shining Money: Philadelphia's Penn Center Project and the Constraints of Private Development," Journal of Planning History, 2007 6: 48.

${ }^{84}$ Teaford, Rough Road to Renaissance, 244.
} 
Cebul

the police, call the police ... She was literally shoving people out of the office." ${ }^{\circ 5}$ The

neighborhood activists called confrontational actions like these "hits." This hit was just the first

of many they and other groups carried out in the increasingly desperate late 1970s. Some hits

even took place after hours at city officials' homes. ${ }^{86}$

Meanwhile, just four months into his administration, Kucinich triggered a recall election when he impetuously fired the police chief he had hired away from San Francisco. Among other complaints, Chief Richard Hongisto (who had been known in California as the "hippie sheriff") publicly accused Kucinich of political meddling. ${ }^{87}$ Following Hongisto’s accusations and without having a prior conversation with his aides or notifying Hongisto, Kucinich suspended the Chief during a live television news conference - as a shocked Hongisto stood at his side. Kucinich fired him the next day. By the end of the next month, May 1978, the Mayor's opponents had collected the necessary signatures for a recall election. On August 13, 1978, Kucinich survived by a mere 236 votes out of 120,300 cast. Kucinich correctly suspected that the city's business leaders, particularly Brock Weir, the head of Cleveland Trust bank, had played a central role in funding the recall effort. Indeed, the majority of funds supporting the campaign actually came from suburban sources, a subsequent Plain Dealer investigation found. ${ }^{88}$

\footnotetext{
${ }^{85}$ Quoted in Cunningham, 73.

${ }^{86}$ Ibid., 73-7.

87 “Richard Hongisto, 67; Ex-Sheriff in San Francisco Had Turbulent Career,” LAT, November 6, 2004.

88 “Suburbanites top list of donors backing Kucinich recall,” PD, September 28, 1978.
} 
Cebul

Cleveland's businesspeople were mobilizing to take a more aggressive role in city

politics, a stance advocated at an April 1978 Growth Association seminar. Over 300 Association members attended a day of workshops jointly sponsored by the U.S. Chamber of Commerce, the National Association of Manufacturers, and the National Federation of Independent Business. Representatives of the Sunbelt were prominently featured. Speakers from the Center for the Study of Private Enterprise at the University of Southern California worked with businesspeople on "programs by which businessmen could influence the political process and encourage their employees and shareholders to do the same." Virginia Senator Harry F. Byrd keynoted the event, and urged Cleveland's businesspeople to make their voices heard by politicians. Corruption, waste, and mismanagement were rampant in government, he said, because "the commodity in shortest supply" is a business-like "common sense." ${ }^{, 89}$ Shortly after the seminar, Weir informed the city that Cleveland Trust and perhaps other banks would likely not refinance the city's shortterm debt. As the city's finance officer recalled, Weir "declared that 'default might not be bad for the City' because it would, he felt, force the City to address its long term financial problems." 90 Thanks in part to Weir's threat, in June, Moody's downgraded the city's credit rating. It did so again in July.

\footnotetext{
89 “Make views heard Sen. Byrd advises businessmen here," PD, April 15, 1978.

${ }^{90}$ The Role of Commercial Banks in the Finances of the City of Cleveland, Staff Study by the Subcommittee on Financial Institutions Supervision, Regulation, and Insurance of the House Committee on Banking, Finance and Urban Affairs, June 1979., 27, PAL.
} 
Cebul

Undeterred and seemingly emboldened having survived his recall, Kucinich issued an incendiary press release. "The banks," he proclaimed,

represent raw economic power, and some people advise me to cooperate more with them. This might have been good advice decades ago, but today Cleveland's largest banks seem committed to destroying the city. They won't buy Cleveland's bond offerings and they continue their systematic looting of Cleveland's financial resources in the pursuit of maximum profits elsewhere in this country and overseas.

The boy mayor pivoted to an attack on tax abatements and allegations of corporate

collusion:

Bankers are among the strongest supporters of tax abatement. Why? ... the boards of directors of the major banks are dominated by the very same corporate executives who seek the tax breaks from the city. The banks say that the public must pay the price for economic development, take the risks, and so on, to insure the profit margins of the banks and corporations won't be disturbed. It's time to turn the tables on this sort of self-serving logic. Those who are in a position to gain the most, the banks and corporations, should be required to take the risks. ${ }^{91}$

As a U.S. House report on the situation in Cleveland frankly noted, "The press release is illustrative of the depth of the difference between the Mayor and the banks." 92

Meanwhile the deteriorating situation between neighborhood groups and the Kucinich

Administration came to a head at a November 1978 Neighborhoods Conference. Ten

\footnotetext{
${ }^{91}$ Ibid., 31-2.

${ }^{92}$ Ibid.
} 
Cebul

neighborhood groups, comprised of 700 Clevelanders, and representatives of the Kucinich

Administration hoped to put the "hits" of the past behind them and seek compromise and

consensus. The Conference was a disaster from the start. Community Development Director

Betty Grdina said she would not take questions from the neighborhood groups until several other

Administration members, who were not on the announced agenda, were allowed to speak.

Kucinich's chief of staff took the podium and read procedures from a yellow legal pad detailing

"how you're going to have to behave if you want to come down to city hall and see us."

Immediately, the groups started chanting, "You work for us! You work for us!" Diane Yambor

of the Buckeye Woodland Community Congress, a Conference organizer, took the microphone

from Kucinich's aide, and a struggle ensued on stage for control of the mic. Fannie Lewis, the

veteran of neighborhood battles in Model Cities and a Kucinich supporter, mounted the stage,

too. As an attendee recalled, "Lewis walked up and hit Agnes Jackson [of the BWCC] over the

head with the microphone. You heard this big 'bong' go over the PA system. Sarah Turner [also

of BWCC] picked up a chair and was going to hit Fanny (sic) over the head ... at which point

one of the organizers took the chair away, and Sarah grabbed another one, and that's when all

hell broke loose." The Kucinich Administration members fled the hall. The Administration

immediately severed connections with the Buckeye Woodland Community Congress, Citizens to 
Cebul

Bring Broadway Back, and the St. Clair Superior Coalition. ${ }^{93}$ Despite having employed Saul

Alinsky's organizing and confrontational tactics to get elected, as Kucinich put it, "Alinsky was

never on the inside." 94

A month after the disastrous conference, the Congress petitioned the Mayor to send Block Grant funds directly to neighborhood groups, a call groups across the country were making to the Carter Administration as well. In response, Betty Grdina published the Administration's incredulous response in a Plain Dealer op-ed. Without naming specific groups, she first cited certain neighborhood organization's irresponsible confrontational tactics to argue against decentralization of Block Grant funds. Meanwhile, less confrontational groups, she wrote, were at risk of being subverted and coopted (if they hadn't already been) by powerful Cleveland business interests who steered grants from the business-affiliated Cleveland and Gund Foundations. "Republic Steel," she wrote, "is involved in the attempt to subvert a neighborhood group. The Growth Association is now showing interest in neighborhood groups. Believe it or not, Cleveland Trust's Brock Weir has also come out 'in favor' of neighborhood groups."95 These groups, she charged, were unelected representatives of the neighborhood, susceptible to

\footnotetext{
${ }^{93}$ Cunningham, 77.

${ }^{94}$ Swanstrom, 194-5, 122.

${ }^{95}$ Quoted in Randy Cunningham, "Democratizing Cleveland: The Rise and Fall of Community Organizing in Cleveland, Ohio 1975-1985" (2007), 79. Cleveland Memory. Book
}

17. http://engagedscholarship.csuohio.edu/clevmembks/17 
Cebul

coercion by the city's business interests. Block Grants were best left to the Administration.

Indeed, as Kucinich himself told the Plain Dealer early in his administration, "Activist

community groups are unnecessary with a mayor who understands their needs. ${ }^{.96}$ While

Kucinich had campaigned for a stronger citizen role in Block Grants, once in office, the

"populist" Administration moved to tightly control their deployment.

If Kucinich's relationship with the neighborhood groups, his core constituency, was

strained, his relationship with his stated adversary, business, had completely deteriorated. His

confrontational politics were most on display during the crisis that resulted from his battles with

CEI and Cleveland Trust over the fate of Muny Light and his negotiations with the banks over

the city's short term debt obligations racked up by the Perk administration. Perk's willingness to

work with banks and business ensured that Cleveland Trust and the city's other lenders rolled

over short-term debt obligations. Kucinich, however, killed the sale of Muny to CEI, and the

mayor noisily promised to renew the city's antitrust litigation against the private utility.

Simultaneously, despite looming debt obligations, he targeted the banks: "We must bring

democracy to the banks," he liked to say. ${ }^{97}$ On other occasions he alleged, "Corporate Cleveland

is trying to overthrow the local city government. ${ }^{998}$ Most bombastically, Kucinich pilloried the

\footnotetext{
${ }^{96}$ Cunningham, 73.

${ }^{97}$ Swantsom, 123.

${ }^{98} \mathrm{WP}$, February 13, 1979
} 
Cebul

city's "white collar criminals." $"$ As the Washington Post put it, "Since his election in 1977,

Kucinich has made enemies of the newspapers that endorsed him, the city council, the city's

largest bank and most business executives. In a town that boasts 33 national corporate

headquarters and after New York and Chicago, is home to more of the nation's top 1000

corporations than any other metropolitan area, that's a lot of enemies." ${ }^{100}$ By railing against

corporate takeover, however, Kucinich invited just such an outcome.

Energized by these public pronouncements, Kucinich headed into parallel negotiations

with CEI over the antitrust litigation and Cleveland Trust over the city's debt. The companies

shared key board members and legal council, and it would hardly take a conspiracy theorist to

see how working together in negotiations with the Mayor was in the companies' mutual interest.

Indeed, subsequent reporting by the Washington Post and other outlets strongly suggested just

such a situation. ${ }^{101}$ A later House investigation triggered by Kucinich offered a unique glimpse

into just how overlapping were the boards of Cleveland's major businesses:

The six banks have 179 common directorships with 40 Cleveland corporations. During 1978, the banks and CEI shared 8 directors; the banks hold 1,799,445 shares of CEI stock in their trust departments; CEI has $\$ 72$ million in lines of credit from Cleveland banks; both Cleveland Trust Company and National City Bank manage major employee funds of

\footnotetext{
${ }^{99}$ The Nation, January 20, 1979.

${ }^{100}$ Quoted in The Role of Commercial Banks in the Finances of the City of Cleveland, 4, PAL.

101 “Cleveland Default Linked to Effort to Unseat Mayor, WP, July 17, 1979.
} 
Cebul

CEI and those relationships are further enhanced by common club, business association and social contacts. ${ }^{102}$

Lending credence to Kucinich's allegations of collusion, during the fall of 1978, bank

executives and Loan Review Committee members (which included non-baking businesspeople

such as leading Jones Day corporate attorney Richard Pogue) removed decisions about city debt and lending from the commercial banking level at Cleveland Trust to an executive committee at the holding company level. Bank executives and holding company trustees - which included a variety of businessmen and corporate lawyers - rather than professional loan officers would determine the fate of further finance for the city. ${ }^{103}$ Simultaneously, Kucinich announced plans for $\$ 50$ million worth of new bond issues and plans to refinance short term notes ( $\$ 15.5$ million) that were due to be paid or rolled over in December 1978.

The public battle that ensued ultimately hinged on Kucinich's unwillingness to sell Muny Light to Cleveland Electric Illuminating, a move Kucinich claimed the banks required in order to continue lending. Though they publicly denied Kucinich's assertions, the conflict of interest and CEI's longstanding efforts to acquire Muny Light makes Kucinich's claims more than plausible. The public private war attracted national attention with correspondents from major news outlets flocking to Cleveland to watch the drama unfold. Ralph Nader saluted the Mayor for taking steps

\footnotetext{
${ }^{102}$ The Role of Commercial Banks in the Finances of the City of Cleveland, 4-5, PAL.

${ }^{103}$ Ibid., 32-3.
} 
Cebul

New York City's political leadership had avoided in its own crisis. "New York was on the verge of bankruptcy because the corporate government was not challenged by the political government ... Kucinich has challenged the corporate government," Nader said. ${ }^{104}$ The Mayor would not budge on his refusal to sell the public utility, despite a majority of the city council arguing on behalf of privatization (including its African American power broker president George Forbes, whose personal attorney worked at Squires Sanders, the lead counsel for CEI and Cleveland Trust). As Brock Weir, the Bank's chairman, put it, referring to the city's young Mayor, "The only problem" with business' relationship with the city "is the little chancre downtown." "The venom of the business community towards the mayor has foreclosed any chance for a dialogue. We're way beyond the point of trying to recover $\$ 5$ million," said Weir. "[W]e're trying to recover the city." 105

On the day before Weir led the city's banking community in their collective refusal to roll over the city's debt, he penned a letter to a Cleveland resident who had written to express concerns about the bank executive's vituperative rhetoric. Weir vented his discontent,

I personally feel that my [words were] justified in that I have the right, if not an obligation, as both an independent citizen and an officer of a corporate citizen of the community, to rebut ... unfair charges made against me, the company for which I work,

\footnotetext{
104 “Nader cheers Kucinich war” PD, January 19, 1979. See also, "Kucinich Attack on Bank Impresses House Probers," WP, January 23, 1979.

${ }^{105}$ Quoted in Dan Marschall, ed., "The Battle of Cleveland: Public Interest Challenges Corporate Power, Washington, DC: Conference on Alternative State and Local Policies, 1979.
} 
Cebul

and all the banks in this city. Contrary to your observation, I believe the well publicized enmity of the city administration towards Cleveland bank officials has been completely unjustified and is, from my viewpoint, a product of raw political power. I for one do not intend to take these allegations lying down. ${ }^{106}$

Kucinich began December 15, municipal bond D-Day, with an appearance on ABC's

Good Morning America, reiterating his stance against the sale of the city's municipally owned electric utility. As the city inched toward default, the city's evening paper, the Cleveland Press, reported that the other banks holding smaller debts had signaled their willingness to roll over the notes in exchange for a commitment to raise city income taxes. ${ }^{107}$ Weir's Cleveland Trust, however, would not budge. That afternoon, Moody's lowered Cleveland's bond rating to the level New York City reached in the depths of its 1975 crisis. On a live edition of the six o'clock news, Kucinich again rejected a compromise measure or the sale of MUNY light, calling both plans "Baloney!" Sometime that afternoon, Brock Weir left town on a two-week vacation, locked in to his stance. As the clock ticked toward midnight, Kucinich railed against Weir and Cleveland Trust during an emergency city council meeting. When Council President Forbes rapped his gavel at 12:06 AM, the city was in default. ${ }^{108}$ Cleveland became the first major

\footnotetext{
${ }^{106}$ Brock Weir to T.R. Thoren, December 14, 1978, Ibid., 92.

${ }^{107}$ Ibid., 39.

108 Ibid., 42.
} 
Cebul

American city to default on its obligations since the Great Depression. ${ }^{109}$ As Weir later put it,

"We were kicked in the teeth for six months. We got tired - we kicked back.",110

As the bank executive put it in a public letter to bank employees, Cleveland Trust took such a hard line because of "how we view our responsibility to the city and the people of Cleveland." "Your bank," he wrote, "has a commitment to Cleveland that stretches back 85 years." In addition to the $\$ 5$ million note the bank called on December 15 , it held a further $\$ 28$ million "invested . . . in the facilities in the City of Cleveland." As Weir put it, "Presenting our $\$ 5$ million note for payment on December 15 was a very difficult decision, made in the hope that it would help mobilize the city's government to begin to deal realistically with Cleveland's financial problems before the city plunges deeper into financial difficulty." The Wall Street Journal endorsed Weir's producerist vision of the city's financial fathers, its civic patriarchy. “The pressure on Mr. Weir," the Journal opined, "has been all the more intense because no one else has seemed willing to impose fiscal discipline on City Hall." Said Weir, officials throughout the public sector - beyond Cleveland, too - are "not geared up to handle finances ... They don't have the standards of accountability of the private sector." Testifying before Congress, Weir unleashed his producerist indignation at Kucinich's position: "It seems a topsy-turvy world of

\footnotetext{
109 The CBS evening news with Walter Cronkite devoted a three minute segment to the city's default that well captures the acrimony in its aftermath. See: https://www.youtube.com/watch?v=Hz4SwsoW8m0

${ }^{110}$ Marschall, ed., "The Battle of Cleveland."
} 
Cebul

values indeed when by reckless and unsubstantiated charges, a delinquent, deceitful and defiant

debtor can call his all-too-patient creditors to account." ${ }^{111}$ Weir likened his bank to city

government's stern father:

The current barrage of name calling directed against us has not affected our restrained, forceful insistence on financial discipline in the management of the city. On the contrary, our position has generated impressive local and national support for this great company. As the New York Times said, we are 'willing to take the heat ... rather than allowing the city's finances to continue to erode."

A subsequent poll found that Weir edged out Kucinich in terms of favorability among a number of Cleveland's "public figures." Weir continued to pile on the Administration, saying the Mayor's chief financial advisor didn't "know a balance sheet from a slice of bread.",113

The federal government felt the city should take some heat, too. The Carter Administration refused to issue the city's 1979 revenue sharing funds early, and, fearing extensive state controls, the Kucinich Administration resisted reaching out for help from the state of Ohio. ${ }^{114}$ Kucinich complained, "I would feel better having Woody Allen in the White House than Carter." 115

\footnotetext{
111 "Drawing the Line in Cleveland, Wall Street Journal, August 17, 1979.

${ }^{112}$ Marschall, "The Battle of Cleveland," 307.

113 "Drawing the Line in Cleveland, Wall Street Journal, August 17, 1979.

${ }^{114}$ Glasberg, The Power of Collective Purse Strings, 126-7.

115 “Kucinich Says Woody Allen More Capable Than Carter," Pittsburgh Post-Gazette, April 23, 1979.
} 
Cebul

Business' position on the Kucinich Administration and the harm it had done to the

business climate in Cleveland scored a coup de grace when Diamond Shamrock, one of the city's venerable industrial firms, announced in May 1979 that it was moving its headquarters to Dallas.

Despite subsequent analysis that suggested the move had more to do with internal firm dynamics and growing business in the Southwest, William Bricker, its President and CEO, gave the Growth Association and business leaders in Cleveland an assist by citing the city's political climate as the primary reason for moving. According to Bricker, the company was headed to the Sunbelt because of "the political, economic and educational climate in Cleveland and particularly the anti-business attitude on the part of the city administration." ${ }^{116}$ He and the city's business leadership laid the loss of 2,000 jobs at Kucinich's feet. Indeed, rumors circulated that the managing partner of Jones, Day, Reavis and Pogue, Allen C. Holmes, had urged Bricker to make just such a statement. ${ }^{117}$ About Dallas, Bricker said, "It is kind of nice once in a while not to be looked on as a two-headed monster."118 "In recent months," he explained, "several potential employees decided against joining us," because of the city's negative image. The company considered leaving two years earlier, and "It was a bad decision to stay" because they

\footnotetext{
${ }^{116}$ Swanstrom, "Urban Populism," in Cummings, ed., Business Elites and Urban Development, 134.

117 “Principal Guest Conductor,” Plain Dealer, June 18, 1979.

118 “Diamond Shamrock Moving From Cleveland,” Toledo Blade, May 30, 1979.
} 
Cebul

had "to oversubsidize employees to get them to come to" Cleveland. ${ }^{119}$ Bricker predicted other companies would leave, too. ${ }^{120}$ Kucinich thanked him for "the gratuitous kick in the teeth." $* * *$

If the fraught Perk years and the Kucinich fiasco taught business anything, it was that having a sympathetic executive in city hall was essential to advancing their developmental agenda. In 1978, at the peak of the Kucinich crisis, members of the Growth Association and other concerned business leaders traveled to Columbus, Ohio to convince Republican Lieutenant Governor George Voinovich to come home to Cleveland to save his fractured city. As part of his agreement to run for mayor, Voinovich extracted more than mere campaign contributions. He demanded that once he took office, business leaders would lend his administration hundreds of hours of their own time as well as hundreds of private employees to work full time for the city, organizing an overhaul of City Hall operations. Though they were to work for the city, the majority of these loaned executives' salaries would be paid by their private employers. The executives agreed. As Jimmy Carter had done in Georgia in 1970, Voinovich would bring business into government to modernize, streamline, and focus city government on one primary goal: delivering economic growth.

\footnotetext{
119 "Diamond Shamrock Leaving Cleveland for the Southwest," WSJ, May 30, 1979.

120 “Diamond Shamrock Leaving Cleveland,” NYT, May 30, 1979.

121 “Diamond Shamrock Leaving Cleveland for the Southwest," WSJ, May 30, 1979.
} 
Cebul

In his 1979 campaign, Voinovich well understood which way the city's - and the nation's - political winds were blowing. While Kucinich believed he had won office in 1977 thanks to suspicion of corrupt corporate influence on government, the animating force had actually been concerns about ineffectual government. Kucinich rode his antibusiness rhetoric right to default, and, in so doing, in the wake of Watergate, Vietnam, and racialized battles over welfare and affirmative action, he provided further local justification for working class white Clevelanders' precipitously declining faith in public institutions. These public sector failures help explain Americans' search for new institutions and actors to deliver public goods and security. ${ }^{122}$ Indeed, in contrast to the combustible politics of Kucinich and the collapsing ability of the national government to handle inflation, Voinovich joined a new generation of politicians of both parties who promised stability through businesslike moderation and efficiency in public administration. Voinovich promised in his campaign "a very businesslike atmosphere at City Hall." "[W]e'll run the city like the president of a corporation would run a corporation. I look at the taxpayers as shareholders and they have a right to get a return on their tax dollar. That's been my stock and trade." ${ }^{\prime 23}$ While Ralph Perk had campaigned against bloated government and Kucinich had targeted private corruption of government, Voinovich's pivot to venerating a

\footnotetext{
${ }^{122}$ Alan Brinkley has urged scholars to consider the importance of rising inequality and the structural dislocations of the 1970 s as a material impetus in the popular deployment of conservative or free market values. Brinkley, “Conservatism as a Growing Field of Scholarship," Journal of American History (2011) 98 (3): 748-751.

123 "Voinovich: Viewing the front 4," Plain Dealer, September 30, 1979.
} 
Cebul

businesslike solution and his deployment of "market speak" to fix broken government were new.

His contrast with Kucinich was decisive. In a city that had once been a cornerstone of the New

Deal coalition, working class white voters had elected a Democratic mayor only once in over a

decade. In winning the election, Voinovich inherited a city with $\$ 111$ million in debt. ${ }^{124}$

Cleveland's business and political leadership were joining a regional trend that explicitly

took Southern developmentalism and public private cooperation as a model. Indeed, Northern

groups were recognizing that federal funds alone had not been the key to the South's rapid

growth. Instead, cohesive relations between business, government, research universities, and,

where possible, labor had been central to the South's rise. In its 1977 report, "Revitalizing the

Northeastern Economy," the Columbus, Ohio based Academy for Contemporary Problems

focused on local political alliances, not simply fiscal federalism. Prepared in partnership with

Boston's Council for Northeast Economic Action, the report argued that a significant cause of

regional decline was "a set of antagonisms" between the major players in the Northern economy

- business, labor and local government - that had been "destructive to the long-run interests of

all.” The report drew upon interviews with 900 members of these sectors and found that, as

National Journal summarized it, "business has come to feel that government in many parts of the

Northeast is ineffective, fragmented, hostile, and uninterested in the very programs needed to

\footnotetext{
${ }^{124}$ Joseph L. Wagner, “The Man, the Myth, the Mayor: George Voinovich,” Cleveland Magazine, August 1982, PAL.
} 
Cebul

underwrite economic renewal. Business and labor distrust each other and a large and vocal segment of the public distrusts both as well as government." ${ }^{25}$

In the inflationary crisis of the 1970s, Northerners of all stripes had lost faith in two of their most important institutions: government and organized labor. Indeed, Massachusetts Congressman Michael Harrington, who would lead the North in the looming Sunbelt / Frostbelt wars over federal funding formulas, conceded that this "set of antagonisms" was, perhaps, even more determinative of regional decline than was the perceived loss of federal aid to the South.

Said Harrington, "Smug insularity and complacency have held on rather grimly." "We have longer-term wealth and both the benefits that come from it and the drawbacks." Pointing to dynamic, growth-oriented Southern Democrats, Harrington concluded, "We don't have a lot of Bert Lances or John Connallys in our region." ${ }^{.126}$ While Harrington was a Democrat, the incoming Republican Voinovich Administration in Cleveland and its business allies wholeheartedly agreed. Cleveland's troubles were not fundamentally because of too much government. They derived from the absence of vigorous public private partnerships.

\footnotetext{
125 “A 'Hell of an Experiment' in Resolving Economic Growth,” National Journal, January 21, 1978.

126 “Regional Groups Talk About Cooperation, But They Continue to Feud,” National Journal, May 27, 1978.
} 
Cebul

\section{Chapter Eight}

Competitive Federalism:

The Southern Growth Policies Board, the Politics of Inflation, and the Origins of "New" Democrats

In the context of staggering inflation and amidst concerns that the South was repeating developmental missteps of the North, the Southern Growth Policies Board became a petri dish for Southern politicians' efforts to shape a new political economy. The Board became a launching pad for a number of "New” Democrats' political careers, from Jimmy Carter to Bill Clinton. Focused on high tech, research and development, clean industry, and touting their "post racial" future, the governors who sought to build new industrial policy embraced a sunny optimism not seen since the high tide of growth liberalism in the early 1960s. While much of the rhetoric and self-congratulations highlighted what was genuinely new, and much was, an essential thread linked these "New" Democrats' economic efforts with longer standing developmental state building. As before, they sought to use targeted public aid to make structural interventions in Southern markets, creating wholly new sectors and opportunities. Whereas once they had yoked loosely regulated federal spending to chase smokestacks, in the 1970 s, they began to reorient the private sector targets of their public stimulus. In so doing, they forged new public private partnerships and industrial policies along old lines. 
Cebul

But, as inflation withered local governments budgets and challenged their ability to raise local revenue, the glue that bound together these new partnerships and policies continued to be generous federal funding. As racialized views of government waste and inflation spurred voters' rejection of new forms of local taxation and bond revenue, governments became increasingly dependent upon federal aid to meet day-to-day service requirements. In this context, the Southern Growth Policies Board became an active participant in an interregional war for federal aid, "the second war between the states." In the battle to determine worthy beneficiaries of federal aid, development minded politicians in the North and South learned the benefit of touting regional poverty as a way to ensure continued developmental state spending.

\section{Targeting Tech}

In the 1950s, North Carolina's Governor Luther Hodges spurred the creation of the Research Triangle Institute, which officially opened in 1959, the same year Georgia’s Coosa Valley Area Planning and Development Commission began work in earnest. Arguing that research and development packed "tremendous economic wallop," Hodges hoped to use federal contracts to spur indigenous industry, retain and expand local capital, increase productivity and wage rates, and generate a new, high tech innovation economy for the state. ${ }^{1}$

\footnotetext{
${ }^{1}$ Schulman, From Cotton Belt to Sunbelt, 169.
} 
Cebul

But, as urban regions in the North struggled with deindustrialization, pollution, and

unrest, Southern leaders reassessed the "smokestack chasing" model of industrialization they had

long emulated. Recognizing that environmental pollution and an increasingly stagnant

manufacturing sector went hand in hand, Georgia Governor Jimmy Carter joined a group of

'progressive' Southern governors who aimed to change the kind of business and industry

Southern states recruited. In 1971, Duke University president and former North Carolina

Governor Terry Sanford organized a conference in Atlanta, “The Urban South: Northern

Mistakes in a Southern Setting?" Sanford hoped to create an interstate Board of Governors and representatives of Southern business to build upon Hodges' Research Triangle and reorient Southern developmental priorities.

The governors who joined Sanford, including Carter, explicitly considered the era they launched to be "post-racial," a stance that ignored ongoing contestations over equality and representation (1971 was the year of racial violence in Rome). The timing, Sanford felt, was propitious, coming at the end of the South's period of racial exceptionalism. After "a century of being the whipping boy and backward child ... [t]he South can lead the nation, must lead the nation," he said. As Carter had done in the state of Georgia, the region's leaders seized upon the Civil Rights reforms of the 1960s and sought to pivot to a post-racial politics of growth and quality of life. In the context of ongoing racial strife and persistent structural inequality, the 
Cebul

Governors' optimism during the opening years of the 1970s was remarkable. Covering another meeting in Durham, the Washington Post reported the Governors, "by simple fiat, declared an end to racism.” As South Carolina Governor John West put it, attendees must consider the possibilities of "a truly post-racial society." ${ }^{2}$ One attendee of the initial meeting in Atlanta recalled the mood: "For most of us in that ballroom, it was a Southern Epiphany ... No longer would we have to be defensive because we bore the mark of an historic sin." The region was "newly freed, full of energy, confidence, hope and a sense of the possible."3

Four of the "New South" governors all elected in 1970 - Carter of Georgia, Ruben Askew of Florida, Dale Bumpers of Arkansas, and West of South Carolina - sat on the conference's featured panel, and at the meeting's conclusion, Sanford proposed creating a Southern Regional Growth Board. Nine Southern governors signed executive orders committing state funds to the Southern Growth Policies Board, a regional high tech economic development policy think tank. Beneath the headline "Compact Set Up for 'Post-Racial South," the New York Times quoted North Carolina Governor Robert Scott: "We're getting bigger and richer and we just don't want to make the same mistakes we've seen in the North." Said West Virginia Governor Arch Moore, "The Growth Policies Board can save us from the fate of all of the New

\footnotetext{
2 "Another of the "New Souths," WP, October 10, 1971.

${ }^{3}$ Brandt Ayers, "SGPB: An Exciting Beginning," Southern Growth Policies Board $40^{\text {th }}$ Anniversary Commentaries, 7-8.
} 
Cebul

Yorks and the Newarks and the Philadelphias and the Detroits in this country." ${ }^{4}$ In 1973, the

Board received a $\$ 225,000$ challenge grant from the Ford Foundation and established offices in

Research Triangle Park, North Carolina. ${ }^{5}$

For the Southern governors, the problems they saw in Northern Cities weren't primarily

problems of racial turmoil and structural poverty, but rather a failure of regional governments to attend to quality of life issues that could have been mitigated through better planning, research, and growth management. They worried that similar trends were emerging in the South. As

Virginia Gov. Linwood Holton put it at an early Board meeting, "the other day as we were taking off from Chicago the Eastern [Airlines] pilot said look back and look at the haze over Chicago. And he said you think that is clouds. That is pollution. As we approached Richmond he said you see that haze down there. That is the same thing as it was over Chicago. It is just not quite as bad." Though Southern Governors were busy congratulating themselves on the "lead time" they had given themselves to act to avoid Northern problems, Holton warned them that "our lead time is not as much as we have suspected that it is through the years." The other governors agreed,

\footnotetext{
${ }^{4}$ NYT, October 5, 1971.

${ }^{5}$ Cobb, The Selling of the South, p. 201.

${ }^{6}$ Minutes, March 29, 1972, p. 50, folder Executive Committee Meeting, 3/29/72, Richmond Virginia, box 22,

Subseries 1.3, Southern Growth Policies Board Papers, Southern Historical Collection, Wilson Library, University of North Carolina, Chapel Hill, North Carolina [hereafter SGPBP].
} 
Cebul

and they committed to focus on high tech, clean industry that would attract skilled, middle class

workers.

As Holton put it in 1973 during his term as SGPB chairman, the Board was not an

“'Industrial Development Board.' It is hopefully a planning and research agency that will help us study and develop and recommend policies that will enable us to keep a quality of life that we value, while at the same time" ensuring "the benefits of ... desirable economic developments."

As North Carolina Governor and SGPB Chairman James Holshouser put it in 1975, Southern states should be proud that European and other international businessmen considered "the Southeastern part of the United States ... the next growth area of the world." But he cautioned against the "tremendous challenges" that resulted from "unplanned and uncontrolled growth.", As Holton put it, the Board would "help us move to the very desirable goal of being a progressive people living in a land and an environment of infinite beauty and infinite worth."

The Southern Growth Policies Board turned to development consultants who had been influential in earlier industrialization-centered efforts, many of whom emphasized new, cleaner and tech-oriented industrial policies as a way to raise the region's per capita income levels. Two

\footnotetext{
${ }^{7}$ Linwood Holton, "This is the Southern Growth Policies Board," folder Annual Meeting, 3/15-3/17, 1973, subseries 1.3, box 22, SGPBP.

${ }^{8}$ Minutes, Executive Committee Meeting, October 17, 1975, folder Executive Committee Meeting, 10/16 + 10/17, 1975, Atlanta, subseries 1.3, box 22, SGPBP.

${ }^{9}$ Get the specific cite - probably the 3/15-17/73 meeting minutes.
} 
Cebul

speakers at a March 1972 executive committee meeting exemplified these points of emphasis.

Dr. Kenneth Wagner, founder of the Georgia Tech Engineering Experiment Station, spoke about

University led R\&D and high technology transfer to the private sector. ${ }^{10}$ Dolph Norton, Director

of the Cleveland Foundation and a business development activist in Cleveland, Ohio (and

Louisiana native) spoke about that city's recent difficulties and its efforts to develop public

private partnerships for growth. ${ }^{11}$ Georgia Tech's Dr. Ross Hammond, who got his start at the

Rome Industrial Development Branch, was a frequent consultant as well, and he delivered a

featured lecture at the 1973 annual meeting in Montgomery, Alabama. Hammond described how, despite the South's rapidly increasing per capita income, it still considerably lagged the national average, concluding that the "16-state area is essentially a 'have-not' region compared to the nation as a whole." 12 He urged the Board to identify higher wage industries and to push states to pour resources into targeted high tech training for adults and scientific training for younger students. Hammond concluded by calling for "a conscious and coordinated effort to attract

\footnotetext{
${ }^{10}$ The SGPB solicited many reports from Georgia Tech's EES as well as from the region's other research universities. See, for instance, the EES's report on productivity and the role of the "engineering experiment station" concept for "research and extension in business and industrial productivity" in Minutes, Executive Committee Meeting, October 17, 1975, folder Executive Committee Meeting, 10/16 + 10/17, 1975, Atlanta, subseries 1.3, box 22, SGPBP.

${ }^{11}$ Minutes, March 29, 1972, folder Executive Committee Meeting, 3/29/72, Richmond Virginia, box 22, Subseries 1.3, SGPBP.

${ }^{12}$ Ross Hammond, Southern Economic Development Trends and Some Policy Implications,” folder Annual Meeting 3/15-3/17, 1973, Montgomery, box 22, subseries 1.3, SGPBP.
} 
Cebul

highly sophisticated, and hence, higher wage, economic activities to the area." ${ }^{13}$ Hammond, like many other of the Board's consultants, urged state leaders to develop regional industrial policies that would raise the states' per capita income and purchasing power not from the bottom up, by focusing on low skilled workers, but from the middle out, by focusing on high skilled jobs.

Another consultant emphasized the importance of high tech R\&D as a way to survive the 1970s' tectonic shifts in the international political economy. Walt Whitman Rostow, then a professor at the University of Texas and formerly an influential advisor on issues of international security and political economy to Presidents Kennedy and Johnson, similarly pushed the Board to pursue high tech research and development. ${ }^{14}$ In one report, Rostow explained to the Southern governors the implications the emergence of OPEC, rising international grain and food prices, and his (faulty) projection that oil producing nations would begin reaching their limits as soon as 1983. The way forward for the South, Rostow argued, was heavy subsidization of research and development. In "our time," he wrote, "the equivalent of open frontiers is going to be research and development; that is, the creation and application of new technologies" in general, and "energy-related investment" in particular. ${ }^{15}$ Rostow contended that the nation's struggling regions, particularly the Midwest and Northeast, would not "be rejuvenated by acquiring a

\footnotetext{
${ }^{13}$ Ibid.

14 “Busbee Becomes Chairman of Southern Growth Board,” Hendersonville Times-News, October 19, 1977.

${ }^{15}$ W.W. Rostow, "The South and the Future of the American Economy,” February 24, 1978, folder Southern Growth Policies Board, RCB-16535, State of Georgia Archives, Morrow, Georgia [hereafter GAA].
} 
Cebul

margin of extra funds from Washington. But vigorous investment programs could create a

situation where pressures for social services - notably, to the unemployed - would diminish, tax

revenues would enlarge, and one could mount programs to reduce the size of true, hard-core

unemployment." Rostow also emphasized the importance of capital formation for the historically

capital poor region. Regional "development banks," he wrote, "through public-private

collaboration, could increase investment in energy and other resources.” Indeed, in 1974 a mere

$13 \%$ of the nation's R\&D investments had been generated in the South. "In the Southern Growth

Policies Board," Rostow wrote, "an instrument exists which can" spur these developments. In

short, "the key to the resolution of these structural problems lies ... not in federal funds but in

the will and capacity of the peoples in the regions to work together ... This is the hard-earned

lesson of modernization and foreign aid in the developing regions of Latin America, Africa, and

Asia." ${ }^{~} 16$ As Board members would soon learn, however, federal funds were more important than

Rostow suggested.

Governor Jimmy Carter helmed the Board during 1973-74, the first year during which its

staff was fully operational. Under his stewardship, the Board published "The Future of the South:

A Statement of Regional Objectives for the Southern States" which was unveiled at the Annual

Meeting Carter hosted in Atlanta in November 1974. The report was the result of months of

${ }^{16}$ Ibid. 
Cebul

work by 200 consultants, political leaders, and staff members who met every other week in

teams divided into the thematic areas of transportation, land use and natural resources, human

resources, and growth management policies. ${ }^{17}$ As a result of the report's recommendations, the

Board began staffing and developing "technical programs" for each state and sub-region,

researching and recommending specific industries, technologies, and new markets based on the

strength of local human and natural resources. ${ }^{18}$ In his opening remarks, Carter emphasized that,

after leaving the Navy, he "became the chairman and executive director of an area planning and

development commission" and went on to chair the state planning association. These

experiences, he said, taught him the value of countering the "direct adverse impact of unplanned

societal development" that result from "lack of thought in preparing for our future." In addition

to relating his belief in developing regional industrial policy, Carter reemphasized the post-racial

nature of the work they were doing: "I believe the South, for the last 20 years, has been searching

for its soul successfully."19 The Civil Rights Movement, he said, had resulted in the "great

liberation of white people and black people," and its lessons were being "assimilated in our

consciousness and in the decisions of government, business and education." But, while he felt it

\footnotetext{
${ }^{17}$ William L. Bowden to Governors of the Southern States, July 8, 1974, folder Executive Committee May 17, 1974, box 22, subseries 1.3, SGPBP.

${ }^{18}$ William L. Bowden, Purposes of the Southern Growth Policies Board and Review of the Southern Growth Policies Agreement, April 4, 1975, folder Executive Committee, April 4, 1975, box 23, subseries 1.3, SGPBP.

${ }^{19}$ Jimmy Carter, "The Future of the Southern States," Proceedings of the Annual Meeting of the Southern Growth Policies Board, p. 138, November 12-14, 1974, folder 1974, box 22, subseries 1.3, SGPBP.
} 
Cebul

was important that Southern states reassert regional pride, he cautioned, "At the same time, we cannot separate ourselves from government entities in the federal system because of finance, among other things." ${ }^{20}$ Carter specifically detailed the imbalance in tax revenue raising abilities between levels of government, a fact that, as Georgia's governor in a time of increasing inflation, was becoming clear to him.

To pursue high tech, clean industry, the Board identified two mutually dependent essentials: investment capital and financing; and publicly funded research and development. To address the former, the Board spurred the creation of a Southern States Office for Reverse Investment in Western Europe. The Office's goal, the Board's executive director wrote in a 1973 memo, was "to discover, cultivate and focus the interest of European investors upon manufacturing, trade, tourist and related opportunities in the Southern States." While Europe was "being inundated by missions from [all] fifty states," the Board believed that a coordinated "multi-state" initiative would help the region as a whole stand out and so boost any individual state's chances. "Naturally," he wrote, "there will be healthy competition among the Southern States to win a prospective investor." But this "competition will be desirable because it will be

\footnotetext{
${ }^{20}$ Ibid.
} 
Cebul

among people who respect and trust one another." ${ }^{21}$ The Board had essentially internationalized

Georgia’s Commission system's regional recruitment model.

Second, the Board focused on maximizing federal support for Southern R\&D while

pointing to the importance of maintaining regional and local autonomy within federal programs.

Members of the Board criticized the federal government's "failure ... to coordinate their own

programs that have growth impacts on the regions, states and local governments" and called

upon the national government to "encourage the states to" develop "regional agencies" to take

over the planning and coordinating function. ${ }^{22}$ As North Carolina Governor James Holshouser

put it at a 1975 Board meeting, "Frankly, I think the states of this country, working together,

have far better capabilities to manage their growth problems with some help from the federal

government."23 A 1976 Board report on HUD's growth programs, such as Community

Development Block Grants, credited the federal agency for its "reluctance to prescribe federal

solutions" to state and local issues but noted that "certain regional growth trends are beginning to

emerge that transcend state lines ... whose impact appears to be confined to readily identifiable

\footnotetext{
${ }^{21}$ Dr. William L. Bowden to Governors of the Southern States, October 3, 1973, folder Reverse Investment Meeting, June 19-20, 1973, Columbia, SC, SGPB Sponsored, box 22, subseries 1.3, SGPBP.

${ }^{22}$ Minutes, Executive Committee Meeting, October 17, 1975, folder Executive Committee Meeting, 10/16 + 10/17, 1975, Atlanta, box 22, subseries 1.3, SGPBP.

${ }^{23}$ Ibid.
} 
Cebul

multi-state regions. ${ }^{, 24}$ In particular, "capital requirements for financing the South's economic expansion is high on the SGPB agenda." While private and international sources of finance were crucial, the report emphasized the importance of studying "the flow of federal funds into the South and the adequacy of state and local tax bases to support" expansion, social services, and infrastructure. ${ }^{25}$ Developments over the second half of the decade would refocus the Board's attention on the crucial importance of federal aid.

\section{The Intertwining Politics of Race and Inflation}

In the context of worsening inflation, politicians at the local level well understood the value of loosely regulated federal aid offered in federal programs like Block Grants or Revenue Sharing. They made possible the maintenance of services constituencies very often took for granted. Indeed, though Northwest Georgia maintained its peppy growth through the early 1970s, the Coosa region was not immune to the twin ravages of recession and inflation. There, as elsewhere, less generous and reliable services further undermined faith in government, this time at the level closest to the people. A 1975 article in US News cataloged the litany of issues: terrible roads in New York and Boston, unpredictable or shoddy garbage pick up in suburban

Atlanta, rude police officers in rural Arkansas, and impenetrable county offices in Marietta,

\footnotetext{
24 "National Growth Policy Research on the South," attached to Minutes, Executive Committee Meeting, September 24, 1976, folder Executive Committee, Sept. 23-24, 1976, Oklahoma City, box 23, subseries 1.3, SGPBP. ${ }^{25}$ Ibid.
} 
Cebul

Georgia. ${ }^{26}$ In areas hardest hit by inflation, officials felt great political pressure to steer loosely regulated federal tax dollars toward local service delivery, rather than use the funds as intended to generate new projects.

In this context, inflation-fueled frustration with taxation could have the unintended consequence of imperiling local services and thus generating new frustrations with local government, too. As Coosa Commission director John D. Holloway put it, fiscal 1975 was a "particularly difficult" year. Like so many other parts of the country, rising energy costs combined with inflation and recession produced "widespread unemployment and a general economic decline." Many industries were "operating far below capacity" and "local government" faced significant "financial problems," struggling "to provide adequate services and facilities without adding to the citizen's tax burden." Particularly critical, then, was the Commission's efforts to ensure local and county governments applied for and won every possible federal grant - especially since it "saved them thousands of dollars in consultants' fees by assisting them in the preparation of grant applications." Indeed, the Commission served as the clearinghouse for information about the Community Development Act of 1974 and held numerous meetings explaining the benefits of block grants to local officials and members of the private sector. ${ }^{27}$

\footnotetext{
26 “Taxpayers' Lament: Give us Better Services,” US News and World Report, November 17, 1975, folder Decentralization, box 5, Newt Gingrich Papers, Annie Belle Weaver Special Collections, Ingram Library, University of West Georgia [hereafter NGP].

${ }^{27}$ CVAPDC Annual Report, 1975, UGA Library, Athens, GA.
} 
Cebul

Governor Carter's reorganization, however, had significant if unintended consequences for local Georgians' perceptions of their regional Commissions. In 1971, Carter moved oversight of the Commission system into the Governor's office and partnered it with the state budget office. While Carter argued that the "autonomous APDCs are the governmental units of the future," his move to formalize their role within the state's executive branch limited their autonomy and edged them toward the public side of what had been a privately-led public-private partnership. ${ }^{28}$ Coosa Commission director John Holloway noted the new institutional formation had "broadened and strengthened" the Commission's "programs and functions."

But, while the Commission's future was never more secure, its once-laser-like focus on regional economic development was now just one among a number of program areas carried out with state and federal funding. ${ }^{29}$ In 1974 , for instance, the Commission became involved in Child Development programming, and the following year its funding and mandate in that area doubled. With $\$ 687,590$ of state and federal funding (the Commission's largest budget line item that year), the Commission staffed and administered a number of regional childcare and development centers that provided medical, dental, and psychological services as well as early education. ${ }^{30}$ By 1977, the Commission was administering a home-bound and day-care assistance and nutrition

\footnotetext{
${ }^{28}$ Jimmy Carter Memo in CVAPDC Annual Report, 1971, UGA Library, Athens, GA.

${ }^{29}$ CVAPDC Annual Report, 1974, UGA Library, Athens, GA.

${ }^{30}$ Ibid.
} 
Cebul

program for the elderly, an ARC program established in $1975 .{ }^{31}$ Executive Director C.D.

Rampley's introduction to the 1977-78 Commission Annual Report suggested the broadened

points of emphasis that had taken hold over the 1970s, including "community development, child

development, fiscal administration, citizen participation, meeting the needs of the elderly ...

demography, historic preservation, land-use planning, zoning administration, recreation

planning, transportation planning . . a and more." "It is this diversity," Rampley wrote, "that has

brought about the Coosa Valley APDC's success as an agency serving local government.",32

But, that diversity also obscured some of the Commission's prestige in the area of

economic development. While the Commission had become an increasingly professionalized

administrator of state and federal programs meant to assist or offset local government, much

further down the list were programs having to do with industrial recruitment and economic

development. These shifting emphases resulted in a shift in membership, too. By 1980-81, the

vast majority of Commission members were mayors or county commissioners. ${ }^{33}$ That was also

the year that the Commission was moved into its new headquarters, leaving the space it had

shared for two decades with the Rome Chamber of Commerce. As a result, the Commission's

place as a crucial asset of the business community was weakening.

\footnotetext{
31 "Keep the Coosa Valley Planners," RNT, June 12, 1977.

${ }^{32}$ Coosa Valley Area Planning and Development Commission, Annual Report, 1977-78, Hargrett Special Collections Library, University of Georgia, Athens, GA [hereafter HSCLL]

${ }^{33}$ Coosa Valley Area Planning and Development Commission, Annual Report, 1980-81, HSCLL.
} 
Cebul

The accretion of public administrative authority in a public-private agency touched off debates in the Georgia State House when Georgia's Attorney General asserted that state law did not authorize regional Commissions, which were still unelected and public-private in nature, to operate such a broad array of programs. A new bill created a five-year window during which time Commissions would be permitted to continue administering the programs, but, after that time, they would have to subcontract the operations to public agencies. The solution, however, retained for the Commissions administrative and planning oversight of these human service programs. Parallel legislation mandated that the Commissions increase the number of publicly elected officials on their boards to two-thirds of the total membership, in hopes of bringing a bit more democratic legitimacy to the commissions' work. ${ }^{34}$ In doing so, however, the legislature took yet another step in undermining the crucial source of the Commission's longstanding legitimacy, their partnership between the public and private sectors.

Nevertheless, the legislature's decision was in lockstep with voters' concerns about democratic accountability, which were inextricably linked to pocketbook concerns generated by high taxes and creeping inflation. In Rome, the first signs of these developments began simmering in the late 1960s. In 1967, Rome grocery store owner Roy Knowles ran unsuccessfully for the state House of Representatives. The following year, Knowles set his sights

\footnotetext{
34 “”78 big year for Coosa Valley planners,” RNT, ND, 1979, R/FCL, HRA.
} 
Cebul

locally, challenging the incumbent sheriff of nearly two decades, saying, "I see a dire need for honest government." ${ }^{, 35}$ Knowles lost the sheriff's race in a landslide, but he cemented his status as a fixture in local politics. That year, he became the local leader of George Wallace's presidential campaign, and he hosted fund raising dinners and organized trips to hear the candidate speak. Wallace's Northwest Georgia headquarters was in Knowles' grocery, Roy's Little Garden. ${ }^{36}$ Wallace's unique brew of populist grievances - against race mixing, criminality, and taxes - helped Knowles define his own politics. By 1970, Knowles had organized his own political organization, "Concerned Citizens for a Better Government," and he focused its ire on city and county Commissions as well as the Coosa Commission. Knowles ran advertisements in the News Tribune describing wasted tax dollars, pointing to incompetent and, perhaps, corrupt local officials. One ad titled “TELL IT LIKE IT IS” entreated readers, “LOOK AT THIS TAXPAYERS!" The ad charged that the Chairman of the Floyd Hospital Authority was "not a tax payer of Floyd County" but served on "many civic and advisory committees that are forever seeking new ways of spending our tax money.",37

Knowles also convened "Concerned Citizens" "town hall meetings" at which a predominantly rural assembly vented its spleen over a range of issues. "A fired-up, standing

\footnotetext{
35 “Adams, Knowles will seek sheriff’s office,” RNT, March 11, 1968.

36 “George Wallace speaks twice in Atlanta,” RNT June 12, 1968.

${ }^{37} R N T$, June 5, 1972.
} 
Cebul

room only crowd," the News Tribune reported, gathered at the Floyd County courthouse one

Tuesday night. Led by Knowles, the assembled Georgians demanded the resignation of the

County Administrator, Jerry Singer, and the other five members of the Board of Commissioners

(none of whom were in attendance). Rather "than tightening their belts a little bit and cutting

back," Knowles charged, the Board continued its "foolish spending," drawing "the noose of

higher taxes around our necks until we just about can’t breathe anymore." Invoking his business

experience, Knowles said the "inefficiency and poor management of business that they [the

Board] carry on in this county" inspired his call to action. ${ }^{38}$ Attendees complained about the

wasteful spending, singling out the Coosa Commission, and also highlighted rising water rates,

and increased "race mixing." One woman, a meeting promoter, complained that the County

Board had "completely ignored all petitions presented to it by the citizens of this county." "I am

personally overwhelmed," she said, "by the control these men already have over us." Only one

attendee rose to defend the various Commissioners. Rome real estate agent Hugh Keown told the

frustrated attendees “you people don't have any idea how much punishment these boys . . . have

to take while trying to do a very, very hard job." He called on the audience to develop solutions, rather than spend their time "tearing everything and everybody to pieces." 39 The News Tribune,

38 “'Town meeting' group calls for ouster of Commissioners," RNT, December 9, 1970.

${ }^{39}$ Ibid. 
Cebul

which echoed his criticisms, reported that Keown received a chorus of boos. ${ }^{40}$ Knowles

idiosyncratically summed up the situation: “we've had a Boston Tea Party going on in Floyd

County long enough, and it's time to stop this taxation without representation." Among rural

white voters especially, the twin grievances of public sector support for minorities merged with

inflation to create a particularly virulent antigovernment / anti-tax populism.

The increasingly divisive local political climate and creeping concerns about the nation's

economy generated defensive posturing at the Coosa Commission. In 1974, Calhoun civil

engineer Burton J. Bell was installed as the Commission's chairman. At that year's annual

gathering at Berry College, amidst reports of continued growth (44 new industries expanded in

the Coosa counties during the previous year, generating an additional $\$ 14$ million in tax revenue;

“1973," one speaker said, was "the biggest year in the history of the state"), a note of wariness

crept in. In his acceptance speech, Bell took pains to distance the Commission from other forms

of public regulation and federal action. "Let me emphasize," he told the assembled business

people, "that we are not now nor were we when we organized a regulatory agency." Our "aims,

our visions back there 17 years ago have been realized in many facets of development and with

the help of fine, well qualified officers and members, we will . . . become 'more alive in '75.',41

\footnotetext{
40 “'Town hall' meet lacks solutions," RNT, December 9, 1970. Use the cartoon.

41 “Bell installed as chairman,” RNT, July 19, 1974.
} 
Cebul

By 1976, however, frustration with government at all levels was metastasizing, and Floyd County voters rejected a number of bond issues as well as a number of incumbents. One ousted long-standing Floyd County Commissioner lamented, "This is the worst year in history for incumbents." "I think that's basically what they (the voters) were doing - voting against all incumbents." 42 That year, too, Rome's perennial candidate Roy Knowles finally scored his first political victory: a seat on the Floyd County Commission.

Across the state and nation, entrepreneurial politicians sought to better understand the root of Americans' frustration with government. From his post at West Georgia College an hour's drive south of Rome, Professor Newt Gingrich studied the issue intensely. Gingrich's papers from the mid-1970s are crammed with notes, articles, and a bit of scholarship devoted to understanding, as one US News clipping of an interview with political scientist James Q. Wilson put it, "Why People are Mad at Washington." ${ }^{, 43}$ Bob Claxton, an early political ally sent him a clipping from the Wall Street Journal that reported on growing cynicism with regard to government. Claxton suggested it would be good "for our 'Populism' file."44 The article reported on a number of polls indicating the precipitous decline in faith Americans had for government

\footnotetext{
42 “Three incumbent commissioners defeated, two face runoff; Johnson slips past Rolan,” RNT, August 11, 1976.

43 "Why People are Mad at Washington," US News and World Report, June 21, 1976, folder Decentralization, box 5 , NGP.

44 “Does it Matter Who is Elected President? Many People Say No," WSJ, February 2, 1976, attached to Bob Claxton to Newt Gingrich, January 10, 1976, folder Decentralization \#2, box 5, NGP.
} 
Cebul

and politicians: $58 \%$ believed "people with power are out to take advantage of me"; $57 \%$

believed that "both the Democratic and Republican parties are in favor of big business rather

than the average worker"; $68 \%$ felt that "over the last 10 years, this country's leaders have

consistently lied to the American people"; and 69\% of Americans polled "believe that

government spending is a major cause of inflation." A Democratic pollster found that the "words

'program' and 'bureaucracy' are anathema to the American people .. . People see the

government as just being strangled by useless programs. ${ }^{, 45}$ Claxton included another US News

clipping of a series of interviews with academics around the question, "Is Democracy Dying?"

Political Scientist Samuel Huntington called for Americans to once again accept "the need for

authority in various institutions in the society." Friedrich Hayek proposed drastic reforms to

Congress to limit its power. French Sociologist Michel Crozier argued "grass-roots democracy is

declining because of the complexities of bureaucratic decisions making." Economist Robert

Heilbroner put it more simply: "We're up against a crisis of political faith.” A graph generated

by the University of Michigan Center for Political Studies made the point most clearly: trust in government, it illustrated, had fallen from $76 \%$ in 1964 to $33 \%$ in $1976 .{ }^{46}$

\footnotetext{
45 Ibid.

46 “Is Democracy Dying? Verdict of 8 Leading World Scholars," US News and World Report, March 8, 1976, attached to Bob Claxton to Newt Gingrich, January 10, 1976, folder Decentralization \#2, box 5, NGP.
} 
Cebul

President Carter and the Problem of Federalism

In his campaign for the White House, Jimmy Carter aimed to package a Southern Growth

Policies Board-style approach to solving the nation's waning faith in government and its

inflationary economic woes by promising to restore "a true system of federalism." ${ }^{, 47}$ But his

personal career with federal aid - marked in equal parts by criticism and dependence - suggested

just how murky the issue could be. Indeed, testifying before Congress in 1973 on the effect New

Federalism might have on poor and marginalized access to federal aid, Governor Carter

presciently warned that when "these funds are taken away from the poor and put into general

revenue sharing or block grants, even the most enlightened legislature is not going to take these

funds and put them back exclusively into programs that benefit the poor. ${ }^{, 48}$ Coming on the heels

of Nixon's New Federalism and without his own clearly articulated federalism theory, however,

Carter's campaign promises remained abstract. On the one hand Carter tried to appeal to

constituencies frustrated with the federal regulatory system, promising not to ignore the "lessons

of my own personal experience" as governor and regional planner. Yet, key constituencies

within Carter's national Democratic base hoped for more targeted federal spending, since, as

Carter himself put it on other occasions, federal "funds have been channeled, through

administrative negligence or because of political pressures, into providing services for those who

\footnotetext{
47 "Is the Man from Georgia Ready to Help the States and Cities," National Journal, January 22, 1977.

${ }^{48}$ ACIR, General Revenue Sharing: An ACIR Re-Evaluation (Washington, October, 1974), 48.
} 
Cebul

don't need them nearly so much." Carter pointed out that Block Grant funds "designed for the ghetto families have too often been shifted to further benefit affluent families whose political influence can prevail." In that same speech, however, Carter emphasized the need to cultivate a "balanced national partnership" that would "grant to the local governments the administrative freedom needed for innovative, creative programming." 49

While this tension threatened to scuttle coherent policymaking, Carter's Administration, one aide said, hoped to "find innovative ways to bring in the private sector" and to emphasize "longterm economic planning at the local level." $" 50$ To oversee the administration's conceptualization of federalism, Carter tapped James McIntyre who, under Governor Carter, had served as Georgia's director of planning and budgeting - the administrative head of the APDC system - and was a key player in Carter's efforts to reorganize state government. ${ }^{51}$ Most essentially, however, the question for the Administration, as Jack Watson wrote in a memo to Carter, was "whether we are philosophically in favor of more grant consolidation and fewer program requirements, or whether we favor greater targeting and more prescriptive requirements." In short, "questions of categorical versus block grants and targeting versus

\footnotetext{
${ }^{49}$ Carter quoted in Patricia Roberts Harris to Jimmy Carter, June 12, 1978, folder FA 6/1/78-6/15/78, box FA-3, WHCF, Jimmy Carter Presidential Library, Atlanta, Georgia [hereafter JCL].

50 "Is the Man from Georgia Ready to Help the States and Cities,” National Journal, January 22, 1977.

${ }^{51}$ Miller Center. “Interview with James McIntyre.” University of Virginia. October 28-29, 1981. 23 Jul. 2013 $<$ http://millercenter.org/president/carter/oralhistory/james-mcintyre $>$.
} 
Cebul

revenue sharing raise fundamental philosophical questions on which we need to develop

consistent policy soon." ${ }^{52}$ Carter's failure to develop a coherent domestic development policy

was fundamentally based on his failure to reconcile his views on federalism and minority

empowerment.

The Carter Administration was well aware of and sympathetic to complaints about the various regulatory requirements that came along with federal grants. Early in his term, the Advisory Commission on Intergovernmental Relations submitted recommendations to his intergovernmental staff that identified 442 discrete funded categorical grant programs, each of which required recipient governments to develop and report some form of local planning. ${ }^{53}$ As chief intergovernmental advisors Jack Watson and Bert Lance put it in a subsequent memo, the "number of plans which must be prepared by state and local grantees is staggering: At least 80 separate state plans and 32 substate regional plans must be developed." Making matters worse, many "have their own formats, timetables for submission and narrow prescribed purposes, making it almost impossible to coordinate related federal programs, or to integrate them with the jurisdictions' own planning and budgeting processes." As a result of crosscutting requirements, confusion, and inefficiency, Lance and Watson recommended the creation of the President's

\footnotetext{
52 Jack Watson and Larry Gilson to Jimmy Carter, July 18, 1977, folder FA 7/1/77-7/15/77, box FA-1, WHCF, JCL.

${ }^{53}$ Robert E. Merriam to Jimmy Carter, June 28, 1977, folder FA 7/1/77-7/15/77, box FA-1, WHCF, JCL.
} 
Cebul

Reorganization Project in order "to reduce the burden of regulations ..."54 Carter issued an executive order to his Office of Management and Budget instructing that "the number and complexity of planning requirements for federal aid be sharply reduced.",55

Yet the Administration's progress on answering the crucial philosophical question of federalism remained ambivalent and halting. ${ }^{56}$ Carter's Interagency Task Force on Federal Planning Requirements generated numerous memos and reports, but they simply resulted in more weak executive orders that tended to highlight the problems without offering clear solutions. As Carter put it in one statement, the $\$ 72$ billion system of federal grants had "grown increasingly irrational, inefficient, and insensitive to the various local needs and idiosyncrasies it was originally deigned to accommodate ... [T] he cost of administrative inefficiencies and the paperwork itself are staggering." Carter outlined a series of administrative solutions that essentially passed responsibility for actual reform to executive department heads. The President weakly exhorted them to eliminate duplicate reporting requirements and adopt common financial reporting formats - technical rather than philosophical solutions. Rather than offer a clear proposal, Carter called for concerned agencies to study their requirements to "identify

\footnotetext{
${ }^{54}$ Jack Watson and Burt Lance to Jimmy Carter, July 11, 1977, folder FA 7/1/77-7/15/77, box FA-1, WHCF, JCL.

${ }^{55}$ Press Release, July 19, 1977, folder FA 7/16/77-7/20/77, box FA-1, WHCF, JCL.

${ }^{56}$ For instance, in February of the following year, the Comptroller General wrote to Watson decrying the continuing lack of clear information "on the costs and functions of administering assistance programs." See Elmer B. Staats to Jack H. Watson, February 14, 1978 and attached report to Congress, The Federal Government Should But Doesn't Know the Cost of Administering Its Assistance Programs," folder FA 2/1/78-2/28/78, box FA-3, WHCF, JCL.
} 
Cebul

redundancy and gaps in coverage so that we can develop simpler, uniform requirements." ${ }^{, 57} \mathrm{~A}$

year later, when the President issued an executive memorandum on the issue, he again passed the buck to the executive agencies, calling on them to eliminate, correct, or rewrite regulations so the system of intergovernmental aid would become as understandable and equitable "as human beings can make" it. ${ }^{58}$ This was neither particularly inspiring rhetoric nor a clear mandate.

The upshot was that irritated local leaders continued to complain about bureaucratic inefficiencies and red tape that came along with securing the federal aid. The Albany County, New York executive wrote an emblematic letter to Jack Watson, complaining that his "exasperation is eventually going to get the best of me." "It's tough for a Democrat to criticize Washington," he wrote, but he had been unable to receive from HUD "a straight answer on our project, once and for all.” Instead, they suffered “mixups, delays and 'try again next time.",59

Similarly, Governor James Rhodes of Ohio wrote numerous appeals to the White House to speed along support for laid-off B-1 bomber factory employees. "The bureaucratic delay," the Republican Governor wrote, " has caused human suffering which is unnecessary." "The former . . employees have lost faith in not only the state but the federal government as well."60

\footnotetext{
${ }^{57}$ Statement by the President, September 9, 1977, folder FA 9/1/77-9/9/77, box FA-2, WHCF, JCL.

${ }^{58}$ Jimmy Carter, Memorandum for the Heads of Executive Departments and Agencies, June 21, 1978, folder FA 6/1/78-6/15/78, FA-3, WHCF, JCL

${ }^{59}$ James J. Coyne to Jack Watson, October 13, 1978, folder FA 11/20/78-12/31/78, box FA-3, WHCF, JCL.

${ }^{60}$ James A. Rhodes to Jimmy Carter, April 17, 1978, folder FA 8/1/78-9/15/78, box FA-3, WHCF, JCL.
} 
Cebul

Others criticized new regulations attached to older, favored programs. Alabama Governor

George Wallace characterized the 701 planning program as "the cornerstone since the mid-50s

for most long-range general or comprehensive planning for Alabama's towns and cities.” But,

“gradually, specific requirements began to emerge in the '701' program." New regulations issued

in 1968 were particularly onerous, and they marked "the beginning of a period when the entire

planning function became suspect." Worse, more recent regulations concerning land use

reporting arrived at the same time that funding began to decline, further adding to the burdens

creeping into the program. "In Alabama," Wallace wrote, "this has led to concern that the '701'

planning program is producing 'Federal plans' and not state plans." Wallace argued the "need for

Federal support for comprehensive state planning and policy development is most important,"

and he held up the Appalachian Regional Commission (ARC) and the Economic Development

Administration's (EDA) ‘302' state development plans as "reasonable” programs. "The

flexibility permitted here should be acknowledged and encouraged."61

Ann Chrichton, the 27-year-old mayor of rapidly urbanizing Decatur, Georgia, Atlanta's

immediate neighbor to the east, echoed Wallace. She called for maximizing "the options of local

governments," complaining that mandates to target federal aid in the worst-off areas were a

waste of resources. "We need to learn from the impractical mistakes of the past," she wrote,

${ }^{61}$ George Wallace to Jack Watson, September 22, 1977, folder FA 9/10/77-9/30-77, box FA-2, WHCF, JCL. 
Cebul

when we "often wasted money on areas which could not be rehabilitated." Instead, she sought a program that allowed local officials to start in better off neighborhoods. "Cities have found that their greatest successes come when they formulate a strategy of moving from least blighted to most blighted areas. We have certainly found this to be true in Decatur," where, an improved area "provides an anchor, a stable section which can provide a stimulus to a neighboring blighted area." "Please," she concluded, "do not allow HUD to doom the community development program to failure by overzealous regulations which establish arbitrary goals nationwide." "Please," she wrote, "trust us to care about our communities."

Crichton was not alone among politicians who hoped to focus on shoring up stable communities in ways that might ultimately trickle down to those where War on Poverty funding had once been targeted. As a Brookings report on Block Grants usage put it, "the block grant program is a better instrument for aiding transitional neighborhoods and preventing blight than were the folded in (categorical) grants, but ... is more limited as an instrument for redeveloping the most seriously deteriorated urban areas." While Donald Dodge, HUD's head of Community Planning and Development Office of Evaluation said that he "hate[d]" the term "triage," used by Carter advisors such as Anthony Downs, he nevertheless acceded to the same goals: "What these areas really are doing is making a choice to concentrate their efforts on neighborhoods that really

\footnotetext{
${ }^{62}$ Ann A. Chrichton to Bruce Kirschenbaum, September 26, 1977, folder FA 9/10/77-9/30-77, box FA-2, WHCF, JCL. Chrichton went on to become Kentucky's trade representative in Great Britain.
} 
Cebul

can be helped with the resources available." Even Richard Nathan, one of the central architects

of New Federalism and Community Development Block Grants, which had effectively

deregulated the War on Poverty, acknowledged that he didn't "think community development

can deal with the deep, stubborn problems of the most distressed parts of the city." He did feel,

however, that those problems would take care of themselves, as National Journal paraphrased,

"as those sections of the city are abandoned.",63

On the other hand, as the economic and social crisis facing urban areas worsened,

political pressure from more liberal constituencies within the Democratic base also hampered the

Carter Administration's efforts to develop a coherent overarching philosophy regarding

federalism. Hubert Humphrey and William Moorhead, staunch liberal members of Congress,

pushed the President to express "concern for what appears to us to be a diminished emphasis on

the need for a strong and comprehensive urban assistance program" and cited Carter's "failure to recognize the degree of importance many members of Congress assign to this problem." They reminded the President that while liberal Congressmen may differ to some degree on the specific types of assistance they would prescribe, "all recognize the size and complexity of the problems our cities face, and all propose programs of Federal assistance far broader in scope and more

\footnotetext{
63 "Government Seeks the Right Formula for Community Development Funds," National Journal, February 12, 1977.
} 
Cebul

directly targeted than do any existing programs of economic development assistance."64 They

sought significant new federal expenditures targeted to declining urban centers. Richard Hatcher,

the African American mayor of Gary, Indiana, joined with Carl Holman, president of the

National Urban Coalition, and Vernon Jordan, executive director of the National Urban League,

in making a more blunt appeal to the White House. "For more than eight years," they wrote,

we have seen the communities we represent ignored or short-changed by the ineffective ... programs and policies supposedly being designed to benefit them. In too many cases this was possible in large part because the language of legislation or regulations barred the supposed beneficiaries and those who work most closely with them on a day to day basis from any real opportunity to help shape the outcomes of these programs and policies.

They urged the President "to make sure that the authorizing language of" a new urban program (what would become Urban Development Action Grants) “provides for structured citizen participation and for the active involvement of non-governmental organizations with established records of working effectively with low-income and minority communities." ${ }^{\circ 5}$ These varied political pressures, Carter's personal ambivalence, and a second "war between the states," this time over the definition of deserving beneficiaries of federal aid, would overshadow the Administration's anemic quest for a national development policy.

\footnotetext{
${ }^{64}$ Hubert H. Humphrey and William S. Moorhead to Jimmy Carter, August 9, 1977, folder FA 9/1/77-9/9/77, box FA-2, WHCF, JCL.

${ }^{65}$ Richard G. Hatcher to Frank B. Moore, September 25, 1977, folder FA 9/10/77-9/30-77, box FA-2, WHCF, JCL.
} 
Cebul

A Second War Between the States

While popular political sentiment increasingly focused on high taxes, out of control

inflation, and sluggish institutions, pushed by their growth-oriented business constituencies and citizens' continued expectations for government services, state and national politicians came to blows over which regions of the country most deserved federal aid: those with low growth, or those with low wages. Early in the summer of 1976, as the nation geared up to celebrate the Union's $200^{\text {th }}$ birthday and as the Carter-Ford election campaign got into full swing, two articles stirred up the longstanding American bugbear of sectionalism. In May, Business Week published "The Second War Between the States" which focused on the battle for industry that the South appeared to be winning in a landslide. The following month, National Journal published “Federal Spending: The North's Loss is the Sunbelt's Gain,” which poured salt into Northern state's industrial wounds by suggesting that Northern tax dollars had long been redistributed to Southern states to further increase their developmental advantages. For much of 1976 and 1977 the national media covered the issue, so much so the Wall Street Journal editorial board awarded the Sunbelt-Snowbelt controversy the "most overblown political issue of 1976."66

\footnotetext{
${ }^{66}$ WSJ, December 27, 1976.
} 
Cebul

Regardless of whether the issue was overblown or not, the reaction in the North was

swift. Massachusetts Congressman Michael Harrington, who had been focused on the issue since as early as 1972, organized the Northeast-Midwest Congressional Coalition (NMCC) to work from within Congress to revise federal funding formulas, particularly in Community Development Block Grants, which he correctly contended disproportionately benefited the growing cities of the Sunbelt. ${ }^{67}$ Harrington was also a moving spirit behind the creation of the bipartisan Northeast-Midwest Economic Advancement Coalition (NMEAC). Harrington was explicitly inspired by the South's example. "Regionalism, which everyone decries," he said, "has been a Southern specialty for the better part of the post-Civil War period." ${ }^{, 68}$ Indeed, as Harrington wrote in a New York Times op-ed, one of his policy dreams for the North, suffering through inflation and high energy costs, was a TVA for the Northeast and Midwest. ${ }^{69}$ As the Coalition's director John Moriarty, put it, the new Coalition drew on the SGPB's model: "We're tying to learn what you people (Southerners) have known for a long time - how to make the federal government responsive." As Harrington put it, the Southern Growth Policies Board "has taught us some valuable lessons since the 1960s about long-range planning and what a region

\footnotetext{
67 “Mr. Harrington Responds,” WSJ, February 11, 1977.

68 “'Frostbelt' Gains in Fight for U.S.," LAT, November 13, 1977.

69 “Rescuing the Region,” NYT, July 1, 1977.
} 
Cebul

needs to do." ${ }^{, 70}$ The south had enjoyed favorable status ever since FDR declared the region the nation's number one economic problem: "Now it's our turn," Harrington said. ${ }^{71}$

Harrington's Coalition quickly garnered a membership of 204 out of 435 total

Congressmen and set an aggressive agenda of steering increased federal aid toward cities like

Boston, Buffalo, Chicago, Cleveland, Detroit, and Philadelphia. Aiding the effort, Louis Stokes, former Cleveland mayor Carl Stokes' brother, commissioned a Congressional Budget Office study that, when published in 1977, made the case for greater federal spending in struggling urban regions. ${ }^{72}$ As Ohio Representative Thomas L. Ashley put it, Northerners must "demand equity." ${ }^{, 73}$ And, these reports generated mounting publicity across the North detailing just how little "equity" Northern taxpayers were receiving from their federal taxes. In New England, the media highlighted how states paid $\$ 30$ billion more in federal than the government returned in services or contracts. ${ }^{74}$ The Chicago Tribune reported that the Midwest received far less tax to service equity. While the Northeastern states receive 86 cents on the dollar, the Midwest received only 70 cents. $^{75}$ A 1977 New York Times headline read, "New York State is Shortchanged on

\footnotetext{
70 “'It's Frostbelt vs. Sunbelt for U.S. funds,” PD, October 23, 1977.

71 “North-Midwest Coalition Imitates South,” Raleigh News and Observer, May 22, 1977, folder Southern Growth Policies Board, RCB-16535, GAA.

72 “Troubled Local Economies and the Distribution of Federal Dollars,” August 1977, Congressional Budget Office. Accessed online at http://www.cbo.gov/sites/default/files/cbofiles/ftpdocs/113xx/doc11362/1977_08_troubled.pdf

73 “House Group Wants to Stem Sunbelt Flow,” WP, September 2, 1976.

${ }^{74}$ Ibid.

75 “US Aid lopsided: Walker,” CT, December 15, 1976.
} 
Cebul

Federal Aid, New Study Finds. ${ }^{, 76}$ The Cleveland Plain Dealer informed readers that Ohio paid

"Uncle Sam $\$ 4.6$ billion more in taxes than the state gets in return." ${ }^{, 77}$ Cleveland's Growth

Association joined Mayor Perk in decrying the disparities, especially after the Defense

Department announced it would likely move 500 defense-related jobs and the $\$ 8$ million in

payroll to Tennessee. ${ }^{78}$ A Plain Dealer writer called Harrington's Coalition a “welcome

development. ${ }^{, 79}$ Another pointed out that Ohio's tax deficit amounted to $\$ 572$ lost per resident. ${ }^{80}$

The Coalition's efforts paid quick dividends. When President Carter called for doubling

the $\$ 2$ billion antirecessionary local public works program, the Coalition designed and succeeded

in spurring changes in the allocation formula that appreciably favored their states. While North

Carolina’s allotment, for instance, increased from \$28 million to $\$ 43.8$ million, New York’s

share soared from $\$ 232.9$ million to $\$ 488.1$ million; likewise, Pennsylvania’s rose from $\$ 83.3$

million to $\$ 182$ million. ${ }^{81}$ While the federal government had been instrumental in the South's

modernization, as Carter later put it in his 1980 campaign, "Today, there is a different region that

\footnotetext{
76 "New York State is Shortchanged on Federal Aid, New Study Finds," NYT, July 4, 1977.

77 “It's Frostbelt vs. Sunbelt for U.S. Funds," PD, October 23, 1977. See also, "Ohio trails sun belt in getting back U.S. taxes," PD, November 24, 1977.

78 "Efforts to save jobs must await decision of Defense Department," PD, May 27, 1977; "House coalition to appeal Pentagon cuts to Carter," PD, September 22, 1977.

79 "Reviving the frost belt," $P D$, September 12, 1977.

80 "Federal aid formulas unfair to the North," PD, February 3, 1980.

81 "North-Midwest Coalition Imitates South,” Raleigh News and Observer, May 22, 1977, folder Southern Growth Policies Board, RCB-16535, GAA.
} 
Cebul

demands our concern. The potential decline of the Northeast is a major peril" for the entire nation. 'I pledge to follow Franklin Roosevelt's example and rebuild the region that now demands our help." ${ }^{82}$

The real prize, however, would be in reorienting the formulas in Community Development Block Grant funding. Under the original legislation, nearly all units of government were permitted to compete for a small portion of block grants, but a funding formula determined those municipalities that were entitled to the vast majority of funds. Nixon and Ford's formula emphasized population, overcrowded housing, and poverty (which was weighted twice). As a result, the South's lower wages and population growth better positioned the region to win Block Grant entitlement spending. Mobilized Northern Congressmen quickly moved plans through committees to shift CDBG funding formulas from targeting low-income areas with relative growth to areas with pre-1940 housing stock, which favored the industrial North. The powerful House Speaker, Massachusetts’ Tip O’Neill, was particularly active, shaping (some said "packing") the membership of the House Banking and Finance Committee. As one Southern representative said upon beginning the new Congressional session, "I was amazed to discover that the Banking Committee was not smaller, as we had requested, but larger. We saw all these

\footnotetext{
82 "Federal aid formulas unfair to the North," $P D$, February 3, 1980.
} 
Cebul

New Yorkers? Where did they come from?" "The reason for that was made quite clear," he said,

"when we started to consider the housing and community development bill."

Blindsided, Southern governors and the Southern Growth Policies Board initially spun

their wheels for much of 1976, passing a lame resolution urging the White House to "prohibit

economic discrimination against the southern states. ${ }^{\prime 84}$ While the Governors relied upon the

Board for information regarding federal programs, it had never been construed as a lobbying

agency. Initially, as one founding member put it, "lobbying for a particular [piece of] legislation

cannot be done by the Board." Instead, "the Board would arm governors with better information

about what the South really needs," and the governors would take the lead in lobbying the

federal government. ${ }^{85}$ In 1976, Carter's successor as Governor of Georgia, George Busbee, was

elected Board Chairman. He used his keynote address at the 1977 meeting of the Southern

Governors Association in San Antonio to join the fight over federal funding levels:

Since the National Journal printed its now famous 'Sunbelt versus Snowbelt' article on how the South was ripping off federal dollars from the North, it seems that everyone has been hellbent on creating another sectional war between the states ... As a result, while we sit here attending this conference ... Northern and Midwestern Senators and Congressmen are subtly and often submitting bills and making formula changes with the sole purpose of simply pumping more money into the North.

\footnotetext{
83 “'Frostbelt' Gains in Fight for U.S.," LAT, November 13, 1977.

${ }^{84}$ Federal Policy Impacts on Southern Growth, October 19, 1977, attached to Minutes, Executive Committee Meeting, July 29, 1977, folder Executive Committee, July 29, 1977, Atlanta, box 23, subseries 1.3, SGPBP.

${ }^{85}$ Terry Sanford, Remarks, Southern Regional Growth Planning Board Meeting, August 13-14, 1971, folder August 13-14 Meeting Minutes, box 22, Subseries 1.3, SGPBP.
} 
Cebul

Busbee went on to detail the proposed changes to Block Grant funding formulas. Saint Paul, Minnesota, he pointed out, "would receive a 110 per cent increase to $\$ 10.5$ million. New York City would receive a 45 per cent increase to $\$ 258.3$ million. Atlanta and New Orleans, by contrast, would receive increases of only 12 per cent and 14 percent respectively. How can this happen?" "The Northeastern coalitions are known to meet and strategize on a daily basis," Busbee explained. The Board had "just begun to advise our Congressmen of the effect of some of these formula changes." Many Southern papers carried news of Busbee's harsh words. The Huntsville Times, the daily paper serving NASA's Alabama outpost, noted that the Board, with a professional staff of four and a budget of $\$ 258,000$, was “competing against the seven 'Snow Belt' organizations with 24 professional staff members and combined budgets in excess of \$1 million ..."86 Busbee closed with an appeal for the Southern Governors to commit funds to hire Washington lobbyists employed by the Board: "you can pay Southern Growth Policies Board now, or pay the North later.",87

Pressure from Southern and Western Congressmen succeeded in spurring a compromise in the Block Grant funding formula, which was brokered by Brookings Scholar and Block Grant

\footnotetext{
86 “South Said 'Asleep' on Programs, Losing Millions," Huntsville Times, August 31, 1977, folder Southern Growth Policies Board, RCB-16535, GAA.

${ }^{87}$ George Busbee, Remarks on Southern Growth Policies Board, August 30, 1977, folder Southern Growth Policies Board, RCB-16535, GAA.
} 
Cebul

architect Richard Nathan. Nathan's "dual formula" created two different funding formulas and

allowed grantees to choose the formula that would most benefit their region. The original

formula emphasizing population growth and poverty levels remained, but a second formula,

emphasizing pre-1939 housing stock was added, promising to both grow the pool of federal

Block Grant spending and send more funds to the industrial North. ${ }^{88}$ As National Journal put it, the dual formula sought a political-economic balance: "Nobody loses absolutely under either proposal, but the degree of winning varies considerably." ${ }^{89}$ Congress passed the amendments.

Still, the South cried foul. Rather than use the 1939 housing census, the normally mildmannered Busbee quipped, "Let's go back to 1864 and count the number of burned homes we had in the state after Sherman went through Georgia." ${ }^{90}$ A Board report on the new formulas described how "Northern coalitions succeeded in redirecting significant shares of CDBG funds from low-income Southern areas ... to higher income Northern areas . . by [employing] specious but authoritative-sounding analyses supporting the shifting of dollars toward areas with

\footnotetext{
${ }^{88}$ Richard P. Nathan, Paul R. Dommel, Sarah F. Liebschtz, and Milton D. Morris, "Monitoring the Block Grant Program for Community Development," Political Science Quarterly, Vol. 92, No. 2 (Summer, 1977), p. 240.

89 "Government Seeks the Right Formula For Community Development Funds," National Journal, February 12, 1977.

90 “North's Grants Formula Rapes Dixie, Busbee Says," undated Atlanta Constitution clipping, attached to Federal Allocation Formula Changes and their Implications, SGPB, folder Southern Growth Policies Board, RCB-16535,
} GAA. 
Cebul

'growth lag' and 'age of housing' ..."91 Despite the fact that Southern states joined all other

regions of the country in receiving an increase in block grant spending through the dual formula,

the Board looked jealously toward the outsized increase for northern states, which their analysis

suggested received a bump of 40\% in 1978 and $71 \%$ in 1980 (Southern states enjoyed increases

of $7 \%$ and $12 \%$, respectively, while the Midwest's share rose by just $6 \%$ and $11 \%$ ). As they put

it, under the dual formula, "no entitlement city will get fewer dollars," but "a great many

Southern cities will lose in relative terms." The "results of the CDBG formula revision suggest

that its authors were less interested in equity than in increasing the regional advantage of high-

income states." Southern leaders decried the greedy and wasteful spending on the rich North.

The Southern response proceeded along rather contradictory lines. The Board set out to

debunk notions that the rise of the Sunbelt had been dependent upon federal aid or that it had

come at the North's expense. In a carefully worded letter to Hugh Carey, Governor of New York and Chairman of the Coalition of Northeastern Governors, Busbee detailed the Southern position on federal development spending and regional industrial trends. While the national media had popularized the notion that Northern industrial decline was the result of a Southern migration, Busbee cited statistics that suggested only 1.2 percent of Southern employment growth between 1969 and 1972 was the result of Northern firms' relocation. Instead, "expansion of existing firms

\footnotetext{
${ }^{91}$ Federal Allocation Formula Changes and their Implications, SGPB, folder Southern Growth Policies Board, RCB16535, GAA.
} 
Cebul

accounted for 64.3 percent of the employment growth in the South." "In fact," he contended, " many of the operations which have located in the South are marketing and distribution centers which were opened primarily to serve southern market areas, and therefore complement the industrial producers of the North rather than compete with them."92 Willis Whichard, the Board's Vice Chairman and North Carolina State Senator, extended Busbee's argument in a policy memo. "[M]arginal shifts of populations and new jobs Southward," he argued, "are fueling the economic boom in the Sunbelt - not massive flows of federal funds."93

Yet, the Board's researchers also generated reports revealing the extent to which the withdrawal (or relative decline) of federal aid might retard Southern economic growth. The new funding formulas, they contended, "might mean a moratorium on southern growth, at least until these policies are redirected." ${ }^{, 94}$ Nevertheless, on the very next page of this report, researchers offered statistics showing the effects the formula changes would have on Southern Block Grant allocations. While North Carolina, Virginia, Arkansas, and Oklahoma would experience modest decreases (ranging from declines of 1.1 percent to 8.4 percent), the majority of southern states would enjoy increases. Louisiana would receive 48 percent more in FY 1978 than in 1976; Texas

\footnotetext{
92 George Busbee to Hugh Carey, February 21, 1977, attached to Federal Allocation Formula Changes and their Implications, SGPB, folder Southern Growth Policies Board, RCB-16535, GAA.

${ }^{93}$ Southern Policy Statement, folder Southern Growth Policies Board, RCB-16535, GA Archives.

${ }^{94}$ E. Blaine Liner and David Godschalk, report title cut off, folder Southern Growth Policies Board, RCB-16535, GAA.
} 
Cebul

would enjoy a 31.9 percent increase; Alabama, Florida, and West Virginia would receive respective bumps of $23 \%, 34.9 \%$, and $53 \%$. (Georgia would receive a $2.4 \%$ increase). ${ }^{95}$

Regardless of whether aid was the key to Southern industrial growth, Southern leaders

learned that focusing on the region's low wage and high poverty rates offered the most compelling justification for continued federal favoritism. Indeed, for Busbee and his Southern allies, a major feature of the region's "positive business climate" - its low wages - became the core problem that justified ongoing special treatment in federal development aid. At its fall 1977 meeting in Oklahoma City, Busbee took a hard line against federal funding formula changes emphasizing this new argument. "As long as the South has more people in poverty than any other part of the nation," he argued, "and as long as our family income is less than any other part of the nation, then we will work against all forms of domestic colonialism." Georgia's Governor charged that Northern efforts had succeeded thanks to "infuriating myths, false testimony and poor thinking." 96 As Busbee put it, "It is precisely the low average income in too many Sunbelt states that continues to depress prices, and therefore, the cost of living," contributing to the South's persistent poverty. To reduce federal spending in the South, he said, "could result in a wider gap in per capita income levels between the South and the rest of the nation" and would

\footnotetext{
${ }^{95}$ E. Blaine Liner and David Godschalk, report title cut off, folder Southern Growth Policies Board, RCB-16535, GAA.

96 “Parley on US Policy Toward South Asked," NYT, October 20, 1977.
} 
Cebul

mortally injure "the region's growth potential," which could also "devastate the national

economy." 97 The contrast to the confident early days of the SGPB was striking.

Indeed, the threat to federal aid led to a remarkable rhetorical about face at the once

optimistic tone of Growth Policies Board meetings. In order to maintain federal spending that

they channeled toward the development of their new high tech, high skill economy, leaders were learning to emphasize regional poverty and blast Northern and federal discrimination. ${ }^{98}$ Far from leading the nation, as Busbee put it in late 1977, "any notion that we in the South have arrived, that there are no more serious problems to be dealt with, that we can turn the keys to the federal treasury over [to] the other regions because we have no more need of outside help, is nonsense." 99 The Southern Growth Policies Board continued its federally backed high tech R\&D advocacy aimed at generating high paying high skilled jobs. But Busbee and his Southern allies transitioned to a defense of federal dollars that supported such initiatives by switching to a rhetorical emphasis on fighting poverty.

\footnotetext{
${ }^{97}$ George Busbee, Comments about the Sunbelt-Snowbelt Debate, folder Executive Committee, 12/15/77 - Atlanta, box 23, subseries 1.3, SGPBP.

${ }^{98}$ Statement by Incoming Chairman, Governor George D. Busbee, attached to Summary of Minutes, Executive Committee Meeting, July 29, 1977, folder Executive Committee, July 29, 1977, Atlanta, box 23, subseries 1.3, SGPBP.

${ }^{99}$ George Busbee, Comments about the Sunbelt-Snowbelt Debate, folder Executive Committee, 12/15/77 - Atlanta, box 23, subseries 1.3, SGPBP.
} 
Cebul

Though it was not originally organized to engage the Sunbelt-Frostbelt debate, the White House Conference on Balanced National Growth, a "national town meeting" held January 29 to February 2, 1978, became the national venue for airing these grievances. ${ }^{100}$ Authorized in 1976 , the Carter White House hoped to use the Conference to generate policy ideas for a postKeynesian, recessionary world rocked by energy crises and inflating commodity prices. Two years of planning had gone into the event, which hosted 500 representatives of state and local government, business, academia, and concerned citizens' groups. Conference director Michael Koleda described nearly universal frustration with the confused and cumbersome state of intergovernmental relations and hoped the conference would generate a "breakthrough idea," something, National Journal wrote, "as dramatic as the New Deal in the 1930 s . . to make the federal system more responsive to real problems." Many businesspeople were among the delegates, too. As Quintus Anderson, the president of a Jamestown, New York steel company put it, "I'm obviously no economic liberal," but he hoped the White House would develop a vigorous new economic development policy. ${ }^{101}$

For the White House, however, the goal was much simpler: to take some of the pressure for local development issues off the President's shoulders. As Jack Watson put it, the Administration hoped the conference would help state and local officials "pull away from this

\footnotetext{
100 “An Elusive Economic Goal,” NYT, February 3, 1978.

101 "White House Balanced Growth Forum Promises Controversy," WP, January 1, 1978.
} 
Cebul

notion that everything has to fall squarely on the lap of the federal government." Not only, he said, are there "not enough dollars in the federal budget," but state and local decision making "are in many respects more crucial than the federal role. I believe we must start acclimating people's thinking along those lines, and I hope the conference will help us do that."

Massachusetts Governor Michael Dukakis emerged as a forceful voice on the issue of federalism and intergovernmental relations. Despite the Sunbelt-Frostbelt imbroglio, from his post as chairman of the National Governors Association, Dukakis' proposals for refashioning the federal-state relationship earned him the support of key "New Democrat" Sunbelt governors such as Busbee in Georgia and James B. Hunt, Jr. of North Carolina. Dukakis called for increased federal spending paired with increased state discretion in urban and regional development, essentially an expansion of Nixon's cooperative New Federalism. States would take the lead in creating new "investment strategies" concentrating on areas of poverty and unemployment. The White House was well aware that local leaders and their interest groups such as the US Conference of Mayors would vehemently oppose handing to states the leadership role in local development. Nevertheless, at a White House meeting with Dukakis, the President, who had a long career in state supported regional economic development planning, told the Massachusetts Governor, "You're talking my language."102

\footnotetext{
102 “A 'Hell of an Experiment' in Resolving Economic Growth,” National Journal, January 21, 1978.
} 
Cebul

The major themes of the conference then were addressing development and local budget crunches through regionalism, public-private partnerships, and rolling back federal regulation of local developmental decision-making. Dean of the Harvard Graduate School of Education, Paul Ylvisaker, a pioneering Ford Foundation poverty warrior in the 1960s, said the most "striking theme" was "a declaration of independence" issued by state and local interests. ${ }^{103}$ But, as the National Journal noted, conferees' ire focused on federal regulatory mechanisms (“inconstancy, inconsistency and obstinacy"), not the untoward role of federal spending. Indeed, most attendees sought more spending, not less. The Conference's main event, was a panel - what many hoped would become a debate - featuring Georgia Governor and Policies Board chairman George Busbee and New York Senator Daniel Patrick Moynihan. There was no declaration of independence from federal aid in their debate. As Moynihan put it passionately,

What will become of this tradition of national liberalism if the region from whence it emerged should look up two generations later and find that while other regions were willing enough to accept a transfer of resources when they were the beneficiaries in need, that no such reciprocal impulses will appear, now that the Northeast is in need? What if it turns out that the New Deal was a one-way street, that the policies of the New Deal brought about the downfall of the region which nurtured them and gave them to the nation? I will tell you what will happen. There will be a response of bitterness and reaction which will approach in duration if not in intensity the response of the South to defeat in what we now call the War Between the States. ${ }^{104}$

\footnotetext{
103 "Growth Conference Wary of National Plan," National Journal, February 11, 1978.

104 “Moynihan Warns on Aid for New York City," NYT, February 1, 1978.
} 
Cebul

Moynihan perceptively saw that the New Deal's model of cooperative fiscal federalism

had knitted together competing regions. Its withdrawal, either through ideologically motivated

program cuts or interregional squabbling, could lead to moribund political institutions, further

interregional bickering, and sluggish regional economies. Busbee engaged Dukakis not over the

value of federal spending, but over whether areas of slow growth or low wages were more

deserving of federal aid - hardly a "declaration of independence" from the federal purse.

As further evidence of the regions' undeclared dependence, immediately following the

Conference, Busbee spurred the Policies Board's new focus on lobbying, making the Board a

leading organization in the South's competition in the market of federal aid. Busbee secured

significant funding to create and hire a staff for a new Board office in Washington, DC, which

was up and running in the summer of $1978 .{ }^{105}$ While the Northern groups "posed an ominous

threat ... only a year ago," with its new capabilities, Busbee assured the Board's Executive

Committee the "Board is capable of responding to any threat perpetrated by Northern groups."106

Busbee's attention wasn't just on Washington, however. He invited Southern Municipal Leagues

\footnotetext{
${ }^{105}$ E. Blaine Liner to George Busbee, March 30, 1978, folder Executive Committee, 4/14/78 - Atlanta, box 23, subseries 1.3, SGPBP, and 1978-79 Proposed Budget: Project Income and Expenses, folder Executive Committee, 6/21/78, Atlanta, box 23, subseries 1.3, SGPBP; and Opening Remarks of Governor George Busbee, June 21, 1978, attached to George Busbee to Southern Growth Policies Board, May 31, 1978, folder Executive Committee, June 21, 1978, Atlanta, box 23, subseries 1.3, SGPBP.

${ }^{106}$ Opening Remarks of Governor George Busbee, June 21, 1978, attached to George Busbee to Southern Growth Policies Board, May 31, 1978, folder Executive Committee, June 21, 1978, Atlanta, box 23, subseries 1.3, SGPBP.
} 
Cebul

and Councils of Cities to attend Board meetings, and he led the creation of a Local Government

Advisory Council, the goal of which was developing "a closer working relationship between industry, State government, and local government." He would link the Board's research and lobbying to local communities, "the building blocks of commerce and government.",107

In thickening the relationship between local development efforts, Washington lobbying, and federal spending, the Governor also led "teach-ins" for Governors and their Washington delegation. At the April 1978 meeting of the Southern Governors Association in Washington, for instance, in addition to outlining the changes to Block Grants, Busbee explained proposals to end small-issue Industrial Development Bonds, an important fiscal tool in economic development, and described the likely depth of cuts to Carter's countercyclical stimulus. ${ }^{108}$ Busbee reported that the "meeting ended on a vote of strong solidarity behind our work to check the Northern groups, and I believe we have the undivided attention of the Southern political leadership."109 After assigning governors particular action issues, Busbee organized a follow up meeting in Washington with key Southern Committee Chairman. Led by Senators John Stennis and Strom Thurmond, the Southern delegation promised to persuade "newly elected members of Congress

\footnotetext{
${ }^{107}$ A Resolution for the Creation of a Local Govern Advisory Council of the Southern Growth Policies Board, attached to George Busbee to Southern Growth Policies Board, May 31, 1978, folder Executive Committee, June 21, 1978, Atlanta, box 23, subseries 1.3, SGPBP.

${ }^{108}$ Executive Committee Minutes, folder Executive Committee, 4/14/78 - Atlanta, box 23, subseries 1.3, SGPBP.

${ }^{109}$ Executive Committee Minutes, folder Executive Committee, 4/14/78 - Atlanta, box 23, subseries 1.3, SGPBP.
} 
Cebul

to accept appointments to Committees where we are now vastly outnumbered by the North and Midwest." ${ }^{110}$ As he reflected on his term as chairman, Busbee was satisfied that his efforts and the Board's had "saved the South millions of dollars" in federal aid. ${ }^{111}$ As his successor put it, Busbee "has given the Southern Growth Policies Board a bold new purpose." ${ }^{112}$ At the moment when historians have argued for a cresting wave of antigovernment, free market sentiment, the Sunbelt joined its Northern competitors in seeking to strengthen ties to public spending, not to weaken them and free the market. ${ }^{113}$

Increasingly frustrated by their inability to develop a robust federalism and developmental policy and buffeted by tax revolts on the one hand and desperate state and local governments on the other, the Carter Administration reached out to its allies for ideas. Over the winter holidays of 1978-79, Presidential advisors Charles Kirbo and Griffin Bell had a long breakfast meeting with George Busbee. At the time, the Carter Administration was swinging away from emphasizing full employment and countercyclical spending and toward cutting

\footnotetext{
${ }^{110}$ George Busbee to Members of the Southern Growth Policies Board, April 26, 1978, folder Executive Committee, 4/14/78 - Atlanta, box 23, subseries 1.3, SGPBP.

${ }^{111}$ Report of the Chairman, SGPB Annual Report 1978, folder Annual Report - 1978, box 23, subseries 1.3, SGPBP.

${ }^{112}$ Gov. Jim Hunt, The Year Ahead, December 1, 1978, folder Annual Meeting, Nov. 30, 1978, box 23, subseries 1.3, SGPBP.

${ }^{113}$ See, for instance, Burgin, The Great Persuasion, 204-7.
} 
Cebul

spending to drive down inflation. ${ }^{114}$ Busbee laid out a variety of ways the President could

balance the budget and better sort out intergovernmental relations and responsibilities. Kirbo and

Bell were so impressed they requested Busbee draft a memo for the President, which the

Governor delivered January 5, 1979.

Busbee began by offering his impressions, fresh on the heels of Dukakis' defeat in

Massachusetts, of the shifting political winds. "While I am not panicking over Proposition 13"

and the tax revolt in Massachusetts,

there is a new awareness and a growing concern on the part of the American people ... The new priority has taken the form of an out-right demand . . . that we curb both growth and spending. In short, I believe that President Carter has approximately twelve months to produce sufficient results in slowing down government spending, in balancing the budget, and in constraining government growth in order to gain enough of the confidence of the American people to run successfully for reelection. ${ }^{115}$

Many Romans were among the Georgians who impressed upon Busbee the reality of this new political climate. One Rome businessman linked out of control taxation with government's tin ear for "real" citizens and its lack of a businesslike basis. "Believe me," wrote Charles Bailey to the Governor, “we are getting fed up with taxes and if something isn't done soon, I will push for a Georgia proposition 13 for a tax rollback. It seems that government and politicians don't

\footnotetext{
114 On Carter's broader policymaking vacillation, see especially, Bruce J. Schulman, "Slouching toward the Supply Side: Jimmy Carter and the New American Political Economy;" and Thomas J. Sugrue, "Carter's Urban Policy Crisis," in Fink and Graham, eds., The Carter Presidency.

${ }^{115}$ George Busbee to Charles Kirbo and Griffin Bell, January 5, 1978, folder FA 2/1/79-2/15/79, box FA-5, WHCF, JCL.
} 
Cebul

work on the same financial principles as our manufacturing businesses. When the boss says

we're spending too much, we cut expenses and make do with what we have ... My opinion is

that we are overtaxed and like the California's public officials, our public officials are not

listening." $" 116$ Other Romans such as Dr. Gene Davidson echoed Bailey and drafted a petition

calling for state tax revenues to be returned to the people. They argued for "the silent majority to

awaken and become the very loud majority." 117

With these Georgians' concerns in mind and his own experiences with the state budget,

Busbee offered his solution to the President, which would maximize cuts to non-essential federal

spending and develop a sorting out program for federal versus state versus local responsibilities.

What I am suggesting is that the President's policy should be for the Federal government to either fully get in or get out of many of the existing national programs. If there is truly a Federal purpose involved (i.e. which cannot be adequately or effectively addressed by the States) then the Federal government should remain involved. But if there is no Federal role and the financial conditions of the States do not demand assistance from a more powerful Federal government, then I think the Federal government should get out of such programs.

Busbee suggested a few federal block grants could replace the bevy of federal categorical grants in education, social services, vocational training, and nutrition assistance, arguing that federal administration costs would plummet. Community development, however, offered "the

\footnotetext{
${ }^{116}$ Charles N. Bailey to George Busbee, July 7, 1978, RCB - 21816, GAA.

${ }^{117}$ Petitioners to Buddy Childers \& George Busbee, January 19, 1978, RCB - 21816, GAA.
} 
Cebul

most impressive area of consolidation.” In Georgia, Busbee identified a broad range of federal

development grants that could be consolidated, sending federal revenue to state and local

government to administer. ${ }^{118}$ Lumping much of this spending together in a block grant, Busbee

argued, would save administrative costs and help states streamline their own development

programs, thereby saving even more.

To do so, however, would require Carter take on what Busbee called the "Federal

Powers," a "triangle composed of the committee staffs in Congress, mid-level bureaucrats in the

Federal government, and public interest groups." Fortunately, the Democratic Governor noted,

"people power and the public attitudes toward spending and less government have no roots in

party affiliation. In my judgment, the candidate, republican or democrat, who captures these

themes in his or her campaign will be the victor whether the race is a primary or a general

election." Wrote Busbee, the "importance of reducing the number of employees in government

should also not be underestimated. There is no better way for the President to demonstrate that

${ }^{118}$ These included EDA Title I Public works (\$228M); EDA Title III Governor’s Discretion (\$90.8M); EDA Title V Regional Commissions (\$33M); Title IX Special Impact (\$88.5M); UDAG (\$400M); CDBG Entitlements (\$2.733B); CDBG Small Cities (\$814.7M); EDA 301 Technical Assistance (\$5M); EDA 301 Multi-County Planning (\$16.65M); EDA 302 Comprehensive Planning (\$15M); EDA 302 Sub-state Planning \$0.5M); Fm HA 111 Rural Development (\$5M); HUD 701 Planning (\$53M); HUD 107 CDBG Planning (\$5M); Title 5 Regional Commissions $(\$ 5 \mathrm{M})$; for a total of $\$ 4.664$ Billion in project grants and another $\$ 105.15$ million in planning grants. The state also received a total of $\$ 2.557$ billion in federal loans and financing through EDA Title II Business Development (\$182.5M), EDA Title IV Trade Adjustment Loans (\$225M), FmHA Business and Industrial Loans (\$1.1B), FmHA Water and Waste Disposal (\$800M), and Community Facilities (\$250M). 
Cebul

he is constraining the growth of government. I have personally found this approach particularly effective in the State of Georgia." On his copy of the memorandum, President Carter scrawled a note to chief aides Jim McIntyre and Stu Eizentsat: "This is one of the best memoranda I've ever seen from a state or local official. Assess for me how we can proceed."119

When they did so, however, Carter's aides recommended caution and consideration, warning that Busbee's memo contained "highly controversial" questions. Local officials, for instance, "would strongly resist any" initiative "that involved only the Governors . . particularly if such a study was perceived to increase State control over Federal grants-in-aid that currently go directly to local government." Moreover, "Minorities and the disadvantaged are even more skeptical about the responsiveness of State governments to their concerns. Any study, Commission, etc. that seems to increase State responsibilities and reduce Federal responsibilities in these programs would be perceived, perhaps unfairly, as a retreat from our commitment to the poor, the minorities and the disadvantaged." With rural whites and white ethnics fleeing the Democrats, so much of the president's support depended on these constituencies. Pursuing "such a study could be very damaging." In conclusion, they wrote, these "concerns lead us to believe that we should proceed somewhat more cautiously with any major changes in Federal, State and

\footnotetext{
${ }^{119}$ Jimmy Carter handwritten note on Memorandum to Jimmy Carter, January 9, 1979, folder FA 2/1/79-2/15/79, box FA-5, WHCF, JCL.
} 
Cebul

local government responsibilities. We would suggest that we not undertake a comprehensive study of these issues. ${ }^{, 120}$ Carter acquiesced.

By failing to tackle these significant issues head on in some form or other, the Carter Administration opened the door to a challenger who could articulate a clear alternative to the muddling along federalism of the Carter years. The inauguration of the Reagan Administration, noted outgoing Coosa Commission Chairman William R. Tatum, "signaled significant philosophical changes in the roles of local and state governments; and provided challenging opportunities for regionwide planning and development organizations. ${ }^{, 121}$ As incoming director C.D. Rampley put it, "we are apparently entering an era in which" the growth of government "will be curtailed, with the emphasis on planning and development shifted to state and local governments." He predicted the Commission would "narrow its focus, operate in fewer and more defined areas of community and economic development." Though his wariness was apparent, Rampley sought to end on an optimistic note. "The Coosa Valley Area Planning and Development Commission can and will continue to provide services to local governments collectively that they could not provide for themselves." ${ }^{\prime 122}$

\footnotetext{
${ }^{120}$ Stu Eizenstat and Ralph Schlosstein to Jimmy Carter, February 7, 1979, folder FA 2/1/79-2/15/79, box FA-5, WHCF, JCL.

${ }^{121}$ Coosa Valley Area Planning and Development Commission, Annual Report, 1980-81, HSCLL.

${ }^{122}$ Coosa Valley Area Planning and Development Commission, Annual Report, 1980-81, HSCLL
} 
Cebul

When Busbee touted his proposals publicly, the Rome News Tribune was supportive.

"This" sorting out program "is both sound and desirable, and certainly is compatible with

President-elect Ronald Reagan's campaign promises to reduce federal bureaucracy and return

power to the states. Mr. Reagan also vowed to funnel federal funds back to the states." As the editors put it, "You have to cut into the bureaucracy, into the waste, into the needless federal programs and regulations. Busbee has made a good point, and we hope his message is heard in Washington." ${ }^{\prime 23}$ A major question remained: whether the crucial federal spending that underwrote regional industrial policy and a modicum of consensus would still be forthcoming.

123 "Busbee makes a point," RNT, January 14, 1981. 
Cebul

\section{Chapter Nine}

Cleveland's Public-Private Governance in an Era of Market Speak, 1979-1990

"One lesson Americans learned in the 1980s was that they had to take responsibility for their own fates." So began the lead article in the March 29, 1989 edition of Fortune magazine. In "How Business Bosses Saved a Sick City," Myron Magnet, a leading neoconservative urban policy analyst at the Manhattan Institute, described how in the 1980s, "no city has battled more cannily than Cleveland. A microcosm - almost a caricature - of all the recent ills of urban industrial America," Cleveland, Magnet wrote, "achieved a unity almost startling in this everyman-for-himself epoch.” Far from describing the city’s ethnically and racially diverse population, Magnet's “unity" described the city's business and political leadership which, in the face of staggering industrial decline had come together on behalf of forming, as he put it, an “executive cabal," which "Set up a formal conspiracy of CEOs to provide leadership."

The process through which Cleveland became Time magazine's "comeback city" had, by the late 1980 s become a nationally familiar story. ${ }^{1}$ Spurred on by the Reagan administration's budget cuts, ascendant free market values, and an embrace of businesspeople as the community's last best hope, Cleveland's political leaders developed public-private partnerships that

\footnotetext{
${ }^{1}$ For an overview of this national narrative covering Cleveland's resurgence, see "Mistake by the Lake Wakes Up, Roaring," NYT, September 10, 1995.
} 
Cebul

emphasized private initiative backed by the light hand of government. Even George Forbes, the city's once militant, African American power broker and City Council President, had come around to the new way of thinking, deploying his own version of business producerism: "I recognized that we politicians don't provide the jobs," Forbes told Magnet. Business leaders "are the guys that provide jobs, and if we don't make them viable, we don't have jobs for our people." While Richard Nixon had famously proclaimed “we are all Keynesians now,” by the late 1980s, Forbes, the leading Democrat of a near-majority black city, certified the political economic sea change that had taken place in under two decades: we are all supply-siders now, Forbes seemed to say. Business and industry were the nation's true producers, and, in an era of rising neoliberal sentiment, government's proper role was to give businesspeople the support they needed - then get out of the way. ${ }^{2}$ Jobs and an improved community would surely follow.

The fruits of Cleveland's supply side gospel seemed manifest to anyone who visited the city's newly glittering downtown. Skyscrapers climbed higher than ever; glass sheathed gallerias dotted a revitalized business corridor; the city boasted the nation's most concentrated theater

\footnotetext{
${ }^{2}$ Neoliberalism is a contested notion in recent historiography. In using the term, I describe neoliberalism as an unattainable ideal in which government is radically scaled back and market systems generate the economic and social good once promised through government's management of the market. For excellent discussions of the 'neoliberal' turn in politics and policymaking, see especially, Angus Burgin, The Great Persuasion: Reinventing Free Markets Since the Depression (Cambridge, 2012); Jennifer Burns, Goddess of the Market: Ayn Rand and the American Right (New York, 2011); and Daniel Stedman Jones, Masters of the Universe: Hayek, Freidman, and the Birth of Neoliberal Politics (Princeton, 2012).
} 
Cebul

district outside New York; and plans were rapidly moving forward for new stadiums and arenas for the city's beloved sports franchises. "The new downtown," Magnet proclaimed, "is springing up as rapidly, extensively, and glitteringly as if by Prospero's magical conjuration.” The conjurers Magnet described were the city's major firms and development companies: Forest City Enterprises, Society (later Key) Bank, the Jacobs brothers, Eaton Corp, TRW, Standard Oil of Ohio (later British Petroleum) and the Cleveland Clinic. The city's "cabal" had pooled resources to create private venture capital funds, developed a synchronous relationship with the mayor and the city council president, and, with government assuming its proper role, the 'free' market took off. As Magnet concluded, “you can't help thinking that this is what community is all about.

Doubtless," he gushed, "it sounds comic to speak of Clevelanders in the same breath as

Athenians, but isn't this at least a little like what the Greeks meant by the Civic ideal - the public life in which people achieve their fullest humanity?"

Yet, as Cleveland's downtown was redeveloped, its neighborhoods slunk further into decline. The city lost $8.9 \%$ of its population between 1980 and 1990 and, soon after, the Brookings Institution found that Cleveland had the second highest percentage of economically dependent residents among twenty-three of the nation's largest cities. ${ }^{3}$ Indeed, the percentage of city residents living below the poverty line soared during the 1980s, jumping from 28 to 43

\footnotetext{
${ }^{3}$ City Planning Commission of the City of Cleveland, Population Trends, accessed online, http://planning.city.cleveland.oh.us/cwp/pop_trend.php\#11.
} 
Cebul

percent, a rate of increase not simply due to the suburban flight of better-off residents. ${ }^{4} \mathrm{~A}$

longtime resident of Hough, community activist Don Freeman, described what had happened in

predominantly African American neighborhoods like his. "Twenty five years ago," at the time of

the city's deadly 1966 riots, "people were not abandoned” by national policymakers. Indeed, in

1989, Cleveland may have been the comeback city, but after two decades of deregulated federal

development aid, Reagan's austerity, and businesses steering what remained of federal and local

development dollars, the residents of Hough had been "abandoned and relegated to permanent

poverty by this society and its institutions." ${ }^{, 5}$ Despite moments that suggested the efficacy of

progressive community development efforts, paradoxically, the uses of available development

programs had been decidedly narrowed as their regulations has been broadened.

This chapter explores how and why these changes came about. The key tenet of Ronald

Reagan's more ideologically strident version of New Federalism was devolving as many

government services from the federal to state and local governments as possible. As this chapter

and suggests, however, Reagan's logic - that local governments were better suited to serving all

of their constituencies and had the fiscal capacity to do so if they only tried - was based on a

shallow and ideologically-motivated reading of fiscal federalism and the fiscal capabilities of

\footnotetext{
${ }^{4}$ G. Thomas Kingsley and Kathryn L.S. Pettit, "Concentrated Poverty: A Change in Course," in Neighborhood Change in Urban America, The Urban Institute, No. 2, May 2003. Accessed online, http://www.urban.org/UploadedPDF/310790_NCUA2.pdf.

${ }^{5}$ Susan B. Griffith, "Hough: 25 years after the riots," Call and Post, July 4, 1991, 1 A.
} 
Cebul

state and local governments, especially in a period of inflation-induced austerity. ${ }^{6}$ As scholars

such as Paul Peterson have long noted, fiscal capacities and political pressures are unique to each

level of the federal system. ${ }^{7}$ Local governments, dependent upon highly volatile property and

sales tax revenues, are wholly unsuited for redistributional politics, particularly when it comes to

minority constituencies. ${ }^{8}$ While Reagan framed his New Federalism as an effort to empower

local governments, his policies accelerated their reluctance to serve impoverished citizens.

Compounding this trend, in the 1980s, after seemingly ineffectual and corrupt

governments had been so politically battered during the fraught 1970 s, a new political economic

consensus seemed to emerge. Civic leaders learned to speak of public policies not as government

initiatives but as "investments" in areas that promised "high returns" for taxpaying

“shareholders." In using such market speak, they slid toward crowding public initiative out of the

\footnotetext{
${ }^{6}$ For an excellent discussion of the evolution of American federalism, see the collected essays in Martha Derthick, ed., Dilemmas of Scale in America's Federal Democracy (Cambridge, 1999).

${ }^{7}$ Paul Peterson, City Limits (Chicago, 1981). For a more recent discussion of the way federalism and local fiscal pressures affect urban leaders' development choices, see Margaret Weir, "Power, Money, and Politics in Community Development," in Ronald F. Ferguson and William T. Dickens, ed., Urban Problems and Community Development (Washington, D.C., 1999), pp. 139-178. See also, Todd Swanstrom, The Crisis of Growth Politics (Philadelphia, 1985). On cities as "growth machines," a sociological theory that builds upon Peterson's insights, see John Logan and Harvey Molotch, Urban Fortunes: The Political Economy of Place (Berkeley, CA, 1987).

${ }^{8}$ A few progressive cities are exceptions that prove the rule about urban redistributional policies. See Pierre Clavel, Activists in City Hall: The Progressive Response to the Reagan Era in Boston and Chicago (Ithaca, NY, 2010).
} 
Cebul

story entirely. Indeed, beginning in the Carter Administration, market rhetoric and metrics also

shaped how politicians and business leaders diagnosed and proposed solutions for society's ills. ${ }^{9}$

Yet, while Americans deployed new forms of 'market speak' and conservatives

advocated government retrenchment and deregulation to liberate market forces, political rhetoric

failed to reflect local policy reality. Faced with a deteriorating local economy, local business

leaders, in contrast to their national lobbying associations, well understood the crucial

stimulative role government had played and which they believed it must continue to play in order

to generate growth. As the Reagan Administration struggled to translate its insurgent values into

a government agenda, it was confronted by the more pragmatic vision businesspeople held for

government action. ${ }^{10}$ What emerged was less a consensus on free markets, neoliberalism, or

limited government than the normatively and racially bounded persistence of developmental

state growth policies - at the local level.

Rustbelt Triage

In an era when politicians and free market conservatives called for greater separation

between the public and private sectors, Cleveland's business leadership drew on a Sunbelt model

\footnotetext{
${ }^{9}$ Daniel Rodgers illuminates the "rediscovery of the market" in the 1970s and 1980s through this new paradigm of market-based thinking and discourse. This chapter explores the on-the-ground interactions between these ideas, local institutions and public policies across the federal system. See Rodgers, Age of Fracture, esp. Ch. 2.

${ }^{10}$ On the Reagan Administration's struggles implementing a socially conservative agenda and its clashes with movement conservatives, see Robert O. Self, All in the Family: The Realignment of American Democracy Since the 1960s (New York, 2012), esp. pp. 367-426.
} 
Cebul

to more closely integrate the two. In the late 1970s, attorney James Davis partnered with Mandel deWindt, chairman of Eaton Corp, to secure a grant from the George Gund Foundation to study the city's rapidly deteriorating political and economic climate. They hired McKinsey and Company to conduct a nearly $\$ 1$ million survey of business' role in the city. The Growth Association was fragmenting under the weight of too many members and competing perspectives, and business leaders struggled to generate consensus. Most fundamentally, as developer Albert Ratner put it, "None of us understood what was happening to our ... economy." Moreover, as businesses globalized, noted Richard W. Pogue, managing partner of Jones Day Reavis \& Pogue, "These people were not necessarily interested in what was going on in their hometown." McKinsey's consultants recommended the businesspeople create a smaller organization devoted to generating the kinds of programs being employed across the Sunbelt: public private partnerships, high tech coordination with research Universities, and closely linked strategic planning for the economy and city. ${ }^{11}$

In George Voinovich, the business leaders found a staunch ally. Voinovich pledged to bring modern business practices into city administration, and, to do so, as Jimmy Carter had in Georgia in 1970, he brought businessmen into his administration. As the Plain Dealer put it, over Voinovich's first three months in office, “a brigade of missionary businessmen” joined the

\footnotetext{
11 “Group is getting things done,” Plain Dealer, April 7, 1987.
} 
Cebul

Operations Improvement Task Force. Eighty-nine full time executives from 62 city businesses descended on City Hall and pinpointed areas to improve, make more efficient, or excise entirely. ${ }^{12}$ E. Mandell "Del" deWindt, the chairman of Eaton Corp. (a multinational power management company), described his excitement. "This is a whole new era in Cleveland ... The city has gone through embarrassment and humiliation nationally and internationally and everybody now is willing to pitch in and turn it around."13

Cleveland's businesspeople did more than consult. Voinovich hired hundreds of private sector employees to join the administration, and, as requested, their companies and law firms continued to pay their salaries. The city's law director, Thomas Wagner, Voinovich's second in command, was on loan from the Mayor's old law firm, Calfee Halter \& Griswold. Wagner's assistants came from Calfee and two of the city's other major firms, Jones Day Reavis \& Pogue and Baker Hostetler \& Patterson. The Plain Dealer reported that "the several hundred businessmen" brought in to "form his government . . . are largely males and part of the city's white power structure ... Most live in the suburbs and head their own corporations or corporate divisions." "You can’t walk through the corridors of City Hall," one city councilman complained, "without bumping into someone in a three-piece suit."

\footnotetext{
${ }^{12}$ George Voinovich, National League of Cities Remarks, December 1, 1981, PAL.

${ }^{13}$ Joseph L. Wagner, "Businessmen, consulting firm join mayor's battle to save city, PD January 13, 1980.

${ }^{14}$ Chirstine J. Jindra, "Big business regains clout: Mayor's corporate cadre awakens City Hall Critics,” Plain Dealer, January 13, 1980.
} 
Cebul

Kucinich's years was stark. As the Plain Dealer pointed out, Voinovich “did not invite any of

the grass-roots neighborhood people to participate." In total, over its first two years in office, the

Voinovich Administration utilized around 37,000 hours of donated private sector labor. ${ }^{15}$

Over the next twelve months, Voinovich's public-private bureaucracy wrought

breathtaking changes to the institutions and practices of city government. Organizationally, one

of the most significant developments was the creation of a separate department of Economic

Development, which, by 1982 expanded its staff from 18 to $28 .{ }^{16}$ In addition to reorganization

and new emphases for the city bureaucracy, the processes of government - as Voinovich had

promised in his campaign - were modeled on the best business practices of the day. In the first

year alone, the city launched a massive computerization program through the creation of a new

Data Center tailored for the city's once unauditable budget. The city hired forty-four technicians

to work in the Data Center, but the relative novelty of computerization of municipal governance

and the difficulty in hiring experienced programmers at public wages posed significant

challenges. ${ }^{17}$ "By utilizing loaned employees of the corporations as project leaders," one of

Voinovich's advisors wrote, we "can provide the supervision and training necessary to bring the

\footnotetext{
15 “Cleveland's Response to the New Federalism: The Private-Public Partnership,” folder FG $006-07096880$ (2 of 9), box 14, FG 006-OPD, Ronald Reagan Presidential Library, Simi Valley, California [hereafter RRL].

${ }^{16}$ Gary R. Clark, "Voinovich wants city to help businesses grow,” Plain Dealer, January 18, 1982.

${ }^{17}$ Donald G. Kasner to Phillip C. Allen, December 26, 1980, folder 53, container 2, George V. Voinovich Papers, Western Reserve Historical Society, Cleveland, Ohio (hereafter GVV).
} 
Cebul

untrained programmers up to some level of expertise." ${ }^{\prime 18}$ Voinovich's staffers mandated better

office processes, too, such as mandatory weekly reports to the Mayor from each department

head. These basic administrative measures had been all but ignored in the Perk and Kucinich

administrations. Voinovich took an especially active interest in reports from William Reidy, his

finance director (on loan from PricewaterhouseCoopers). Reidy was charged with stabilizing the

city's budget crisis in order to convince Moody's and S\&P's to improve the city's bond rating.

Until they did, the city was effectively barred from selling debt on the municipal bond market. ${ }^{19}$

Indeed, the Administration's first goal over its first year in office was stabilizing the

city's debt and credit crisis. In the late 1970s and early 1980s, as cities across the country

struggled with inflation, declining tax bases and dwindling federal support, New York's Lazard

Freres \& Co. became the go-to consultant for public institutions in crisis. Reidy and Voinovich

invited the firm to Cleveland. Felix Rohaytn, a lead council at Lazard, had chaired the city of

New York's Municipal Assistance Corporation (MAC), the state authorized body charged with

handling the city's debt in the wake of its own fiscal crisis. ${ }^{20}$ By the early 1980 s, Rohaytn

advised officials in Cleveland, Detroit, New York, the State of Illinois, and Washington, D.C on

\footnotetext{
${ }^{18}$ Phillip C. Allen to George Voinovich, January 23, 1981, folder 53, container 2, GVV.

${ }^{19}$ See, for example, George Voinovich to Hunter Morrison, December 3, 1981, folder 55, box 2, GVV Papers, and, generally, Bill Reidy’s weekly Finance Department reports in folder 3, box 5, GVV.

20 “Federal Spending Cuts Could Worsen Older Cities’ Ability to Borrow Money,” National Journal, February 7, 1981.
} 
Cebul

ways to avoid or recover from public insolvency. ${ }^{21}$ Referring to the famous oilrig blowout

fireman, Rohaytn boasted that his firm was becoming "the Red Adair of municipal finance.,"22

With Rohaytn's guidance and the cooperation of the city's business elites, Voinovich

orchestrated a deal with Cleveland's financiers: the city would supplement the local property tax with a $\$ 2.5$ million income tax increase, and the banks would refinance and roll over the city's debt. Facing poor credit ratings, Voinovich noted, "I'm realistic enough to know that our major effort in life is not to try to get back into the bond market.". "Our main job is to convince national investors that we have in place responsible financial and management tools and that those tools are working." ${ }^{23}$ While Voinovich had stanched the wounds, the city still had a long way to go before it could begin to issue low interest debt.

The city's business leaders, however, knew that it would take more than a sound budget and reentry into the bond market to stem the flow of businesses out of the city and, ultimately, to convince new business to set up shop in Cleveland. Leading executive Stanley Pace and lawyer Richard Pogue agreed the city needed a steady, reliable and institutionalized system to foster public-private cooperation, one that would maximize the investment the city's business interests had already made in the Voinovich Administration - and vice versa. ${ }^{24}$ The Growth Association,

\footnotetext{
${ }^{21}$ Ivan Peterson, "Cleveland Testing Advice of Rohaytn,” New York Times, February 15, 1981.

22 Ibid.

23 “Federal Spending Cuts," National Journal, February 7, 1981.

${ }^{24}$ Author Interview with Richard Pogue, December 29, 2010, Cleveland, Ohio.
} 
Cebul

formerly the Chamber of Commerce, had been the most influential business association in the 1970s, but it had become overly politicized and fragmented during the Kucinich wars.

To take its place, Pace, Pogue, and Eaton Corp.'s Del deWindt created the Cleveland Roundtable in April 1981. While in its own lore the Roundtable emerged from a study commissioned by "community leaders ... to determine whether there was a need in Cleveland for a forum of black and white community leaders to discuss problems of the total community," the group was plainly geared toward that most mystical of endeavors - creating a positive business climate. ${ }^{25}$ To this end, its four major committees focused on economic development, housing and neighborhood development (tellingly, this committee was later dropped), education, and race relations. Funded by private contributions and support from the Cleveland Foundation, upon whose board sat a number of Roundtable founders, the group hired a full time staff to support each committee. The staff, in turn, coordinated with the College of Urban Affairs at Cleveland State University, the city's public university.

The Roundtable staff and University experts generated reports on a range of concerns such as federal-local issues including the implications of new federal budgets or how changes to Medicare and Medicaid would affect regional businesses. They also conducted local research geared toward generating strategies for developing the city's commercial and industrial bases.

\footnotetext{
${ }^{25}$ Greater Cleveland Roundtable Communication Piece, Final Draft, November 4, 1986, folder 17, box 13, GVV.
} 
Cebul

Armed with professional support staff, voluntary commitments from the city's most influential

business leaders and CEOs, and blessed with the Voinovich administration's explicit support -

the Mayor was a founding member - the Roundtable was in a unique position to shape city

politics and policy in both the public and private spheres. ${ }^{26}$ As one Roundtable document put it, however, "[A]lthough the founding members were among the most influential leaders in the community, the Roundtable adopted the philosophy of being a low-profile organization." For the first time, Cleveland's business leaders began to enjoy what many Sunbelt local leaders had forged decades earlier: a public-private institution capable of shaping policy, lobbying Washington, and galvanizing private sector activity.

Ostensibly, the Roundtable was meant to be a bridge organization between corporate leaders, labor, elected officials and the various ethnic and minority groups in the city, but its purview was far wider and its impact far greater than that of a mere discussion group. ${ }^{27}$ The Roundtable became the steering committee for nearly every major public or private undertaking in the city by either proposing initiatives or clearing them for takeoff. ${ }^{28}$ With members and staff

\footnotetext{
${ }^{26}$ See Cebul, Chapters 2, 4 and 6.

${ }^{27}$ To be sure, the Roundtable gave substantive attention to issues of minority business opportunities, supported affirmative action measures and was careful to appoint minority members. They even hired noted sociologist Kenneth Clark to conduct a study on the city's racial climate. But, the emphasis was almost always on generating economic solutions for a social crisis. On the Clark project see, for instance, Greater Cleveland Roundtable, Board of Trustees Meeting Minutes, January 19, 1983, folder 17, box 13, GVV.

${ }^{28}$ Author interview with Richard Pogue, December 29, 2010, Cleveland, Ohio.
} 
Cebul

coming from both the public and private sectors, the Roundtable became a hybrid bureaucracy,

on which government and business relied and which coordinated the efforts of the city's major

business associations: the Growth Association (which was too large to generate consensus) and

the newly formed Cleveland Tomorrow (a smaller organization of CEOs geared entirely toward

strategic planning for economic development and business modernization). ${ }^{29}$ At one Roundtable

Board meeting, for instance, the Growth Association submitted for approval its new "Call for

Action" PR program to galvanize taxpayer support for income tax increases to support local

investments in economic growth. Though they supported the tax hike, the Roundtable's Board

rejected the proposal and instructed the Growth Association to spend more time honing its goals

and tactics and only then resubmit the plan.

Like the Southern Growth Policies Board, the Roundtable's purview was national in

scope. Within its first few months, Roundtable members became frequent visitors to

${ }^{29}$ Cleveland Tomorrow is discussed in depth in the epilogue. By October 1982, 38 CEOs signed on as members of Cleveland Tomorrow. They created an industrial competitiveness project to coordinate growth strategies with labor and management; a Center for Integrated Manufacturing Systems Technology designed "to link business, university, and government in technology and business growth efforts"; the Cleveland Business Opportunity fund, a venture capital pool that soon grew to $\$ 30$ million; a Center for Small Business Development to provide technical support to the Growth Association's Council of Small Enterprises (COSE); and the Greater Cleveland Government Relations Consortium "to prepare an action-oriented lobbying agenda for Washington and Columbus and to build" the “appropriate local coalition to support it.” Greater Cleveland Roundtable, Board of Trustees Meeting Minutes, October 25, 1982, folder 17, box 13, GVV Papers, pp. 5-6; and Michael Kelly, "Growth Association sets agenda for next governor," Plain Dealer, September 12, 1982. 
Cebul

Washington, where they lobbied for increased federal aid for their struggling city. ${ }^{30}$ Indeed, compared to the amount of funding the city received in federal aid, the potential revenue from a local income tax hike or reentry to the bond market were pittances. For fiscal year 1978 alone, the year prior to Voinovich's election, the federal government contributed $\$ 67.5$ million to the city's coffers, while local property taxes for homes and businesses accounted for only $\$ 27.4$ million; workers employed within the city contributed $\$ 66.8$ million in wage taxes - a bit less than the federal government. Indeed, by the end of the 1970s, Cleveland received from the federal government on average $150 \%$ of its annual local tax effort. ${ }^{31}$ One of the Administration and Roundtable first joint initiatives was the creation of the Cleveland Government Contracts Procurement Office, which, as Voinovich put it, was responsible for "marrying our Greater Cleveland business sector with the federal procurement office in our region of the country." Defense spending was at the top of the list. ${ }^{32}$

National politics, then, mattered greatly for Cleveland's fiscal health. In 1980, a year into Voinovich's first term, another Republican defeated a moribund Democrat incumbent by pledging to return to small government, market-based and business-like values. And so Voinovich headed to Washington two weeks after Ronald Reagan's election to lobby the

\footnotetext{
${ }^{30}$ Greater Cleveland Roundtable, Board of Trustees Meeting Minutes, October 25, 1982, folder 17, box 13, GVV.

${ }^{31}$ Richard F. Tompkins, “'All the Necessary Services the People Need and Deserve': Federal Grants in Cleveland During 1978,” Brookings Institution and Cleveland Foundation, 1979, 27.

${ }^{32}$ George Voinovich, National League of Cities Remarks, December 1, 1981, PAL.
} 
Cebul

incoming Republican administration for more federal aid. The Cleveland mayor was careful to couch his mission in the terms of the day. Voinovich called for Reagan to create tax credits for business that offered new jobs and which "keep manufacturing in the big cities." Though Voinovich acknowledged that he sought more direct federal aid, he struck the prevailing conservative notes. "We send our money to Washington so it can be redistributed ... but," Ohio only get[s] 71\% of our tax dollars back." Voinovich slyly emphasized to the state's tax return, not the city's, which depended upon significant redistribution. With this sleight of hand, the Mayor argued the city did not seek to be on the dole; he simply wanted Cleveland's taxpayers to enjoy fair returns on their federal tax investments. Through a strong partnership with the Reagan Administration, Voinovich was confident he could "get the private sector to provide more jobs." After meeting with a number of administration officials including Vice President-elect Bush, Voinovich headed back to Cleveland with a prediction: "I think there's a good possibility we might do better with the new administration." ${ }^{33}$ Indeed, Voinovich became Cleveland's first mayor to have a full time Washington representative. Tom Duffy sent frequent reports on his lobbying efforts with government agencies as well his coordination with the city's legislators. The initiative, however, that Voinovich was particularly interested in was Duffy's efforts to

\footnotetext{
33 “Voinovich expects increased aid for Cleveland from Reagan,” Plain Dealer, November 21, 1980.
} 
Cebul

synchronize the city's lobbying with that of its major corporations. Duffy met regularly with the

D.C. lobbyists of the city's biggest firms, including Eaton Corp., Sohio, and Republic Steel. ${ }^{34}$

In February 1981, however, Reagan proposed his first outsized package of tax and

spending cuts, and the reaction in Cleveland (and many other cities) ranged from shock to

outrage. ${ }^{35}$ The proposals (and ultimate legislation) included abolishing the Comprehensive

Employment and Training Act (Nixon's federally-funded jobs-training block grant program);

included significant cuts to AFDC, food stamps and Medicaid; and proposed a dramatic cut to

HUD's housing and section 8 vouchers. In addition, the Reagan Administration targeted for

elimination or dramatic funding reductions Urban Development Action Grants (described below)

and Community Development Block Grants. A front-page article in the Plain Dealer made clear

the stakes for Cleveland. The President's message "has sparked a debate over the moral

responsibilities of a democratic society and whether big cities will suffer or prosper under his

economic philosophy. ${ }^{36}$ Cuyahoga County Democratic Chairman Timothy Hagan said Reagan’s

proposals were "a clear call for retreat on every piece of legislation this country has stood for for

the last 50 years ... It benefits the people who have at the expense of those who don't."

\footnotetext{
${ }^{34}$ Thomas Duffy to George Voinovich, April 18, 1980, folder 1, box 6, GVV Papers.

${ }^{35}$ When they were passed that summer, the package reduced individual tax rates by 25 percent over three years and significantly slashed business taxes as well. The revenue losses would soon be staggering: $\$ 128$ billion disappeared from federal coffers over the first two years, and, by 1987, over $\$ 1$ trillion.

36 “Guns vs. butter debate starts anew," $P D$, February 20, 1981.
} 
Cebul

Meanwhile, the local Republican Party leadership tried to toe the national line. Robert E.

Hughes, the longtime local party chairman, refuted Hagan: "I don't think this is an attack on the poor and the helpless ... It's an effort to cut the budget.” The city's Republican mayoral administration, however, was ambivalent. "Any cuts in dollars," Community Development Director Vince Lombardi said, "will hurt tremendously." Voinovich tried to embrace the general spirit of Reagan's cuts while arguing on behalf of continued aid for Cleveland. Referring to the booming Sunbelt, Voinovich argued that, "Cities that don't really need" federal aid "have been getting the money. If you limit it to cities that really need it, it will be better." In a private report, however, the Roundtable offered the clearest appraisal: "Barring a miraculous economic recovery, bleak times are ahead for those dependent upon federal or state aid to any degree." ${ }^{37}$ Indeed, local business leaders knew that ensuring a peaceful social climate through a baseline of welfare, education and social service spending was crucial for fostering a positive business climate. After the fiscally tumultuous 1970s, in which inflation and a shriveling property tax base had squeezed the city's budget, local leaders felt responsibility for such programs fell on Washington or Columbus. Cleveland's Seth Taft, a leading Republican who had lost a campaign for mayor to Carl Stokes in 1967, leveled a particularly outspoken critique of Reagan's policies and organized local and state opposition to Reagan's budget cuts. As a

\footnotetext{
${ }^{37}$ Greater Cleveland Roundtable, "Block Grant Primer Update,” October 1982, folder 17, box 13, GVV Papers.
} 
Cebul

member of the State Budget Coalition, a watchdog group made up of concerned business leaders and representatives from Ohio's various human services organizations, Taft penned a resolution that described how Cleveland was "about to experience a crisis of enormous proportions in the health, education and human services fields.

The projected decline in Federal support . . . the ravages of inflation, the increased unemployment . . . and the decline of state revenues - all these factors are converging now to place the most needy of our people in a more vulnerable position than ever before ... President Reagan's bloc [sic] grant approach to the states will result in at least a $20 \%$ Federal cutback in dollars in fiscal 1982."

The result would be "terrible devastation." While Taft acknowledged the government needed to streamline and belt-tighten, "the proposed combined federal and state cutbacks will require far more than streamlining current operations to continue serving those in need in our community." ${ }^{38}$ Taft, whose failed 1967 bid for Mayor had been inspired in large part by the 1966 Hough Riots, had an intimate sense of the stakes in a city with long-simmering racial tensions.

A Republican lobbying for federal aid during the Reagan era was in a precarious position, but Voinovich managed the balancing act well. In his public pronouncements, Voinovich was unequivocal in his support of the President's principles: "I am convinced, as are many local officials throughout this country that the long-run economic health and prosperity of our nation is dependent upon a concerted effort to significantly reduce" federal spending. "The growing

\footnotetext{
${ }^{38}$ Seth Taft to George Voinovich, July 28, 1981, folder 53, container 2, GVV Papers.
} 
Cebul

Federal debt," Voinovich said, "has become a national scandal." ${ }^{39}$ In his personal

correspondence with the President, however, Voinovich tempered his big picture enthusiasm for spending cuts with pragmatic calls for more conventional, generally considered liberal, forms of federal support. Voinovich appealed to Reagan to establish "a short term Public Works Program to help American ... cities." The Mayor pragmatically framed his proposition as a holdover measure and praised the political sea change that had swept Reagan into office:

Recently when I spoke to the leading business executives in Cleveland, I pointed out to them that 'much of what is coming out of Washington is a result of a nation that has said it wants to take its own destiny back into its own hands. Now that we are getting what we asked for, we have to accept the responsibility that comes with self reliance and local problem solving. This is our challenge. If we fail, the President's program will fail.' But, as you have said many times it takes time for presidential initiatives to take effect. I know there are no quick fixes to the problems confronting our economy. However, we just do not have the time to wait until these permanent solutions take hold.

Voinovich underscored his point: "Our people are crying for relief." A public works

program, the mayor argued, "will not only put people back to work but will also help rebuild the cities of America." Voinovich carefully struck a balance, though, concluding that Public Works "will get us through the difficult economic period ... until the positive aspects of your economic program take effect. ${ }^{, 40}$ The businesspeople at the Roundtable joined Voinovich in lobbying the

\footnotetext{
${ }^{39}$ George Voinovich, Deloite, Haskins \& Sells Review, March 31, 1986, Deloite, Haskins and Sells folder, box 10, GVV Papers.

${ }^{40}$ George Voinovich to Ronald Reagan, April 22, 1982, and George Voinovich to Ronald Reagan, May 10, 1982, Box 7, Federal Aid: FA WHORM, Ronald Reagan Presidential Library, Simi Valley, California (hereafter RRL).
} 
Cebul

Reagan Administration, too. In 1982, one member happily reported that the Reagan

"Administration is impressed with what the City of Cleveland is doing . . Cleveland has been identified as number one in terms of candidates for an enterprise zone program." ${ }^{41}$ Though

Voinovich failed to convince the Reagan team that Public Works were a good idea, the Mayor's behind-the-scenes lobbying and his steadfast public support of the President would soon win the city an outsized portion of federal funding.

In a subsequent report to the Reagan Administration, Voinovich cannily framed his new public-private partnerships - which had begun before Reagan's election - as the city's “response to the New Federalism." "A combination of private business, non-profit corporations, institutions, academia, foundations and government have joined together to prove that selfreliance can work." Focused on "putting together an economic development strategy for the future," Voinovich's team was confident that, "Assuming that there is no further significant reduction of federal funds to Cleveland, this city will survive and ultimately prosper." A subtle shift in phrasing in the report's title emphasized the degree to which the city was partnering with non-state actors: "Cleveland's Response to New Federalism: The Private-Public Partnership.,"42 The ascendant antigovernment political mode into which George Voinovich tapped in

\footnotetext{
${ }^{41}$ Greater Cleveland Roundtable, Board of Trustees Meeting Minutes, October 25, 1982, folder 17, box 13, GVV Papers, 2-3.

42 "Cleveland's Response to the New Federalism: The Private-Public Partnership," folder FG 006-07 096880 (2 of 9), box 14, FG 006-OPD, RRL.
} 
Cebul

1979 - emphasizing market outcomes rather than public policy inputs and promising to run government like a business - were trends that extended well beyond the city of Cleveland. In 1975, acclaimed economist and frequent HUD consultant Anthony Downs, later one of President Carter's chief policy aides, visited Cleveland to deliver the keynote address at a Land Use Conference at Case Western Reserve University. Downs articulated the vision of urban 'triage' that was gaining national ascendance thanks in part to the inflationary economy, the seemingly inevitable less generous federal funding realities, and a white majority that was growing impatient with seemingly fruitless federal investments in the worsening urban crisis. Spending money to shore up solid neighborhoods or to improve those that were in transition, he argued, "is a far more effective use of resources than the worst-first strategy in terms of attracting private dollars into further investment. And such 'leveraging"' of private investment, Downs explained, "is crucial if you are to really improve conditions in the city." Residents "of the worst-condition area will oppose [such an approach] - naturally ... But you must face up to it if you want funds spent on neighborhoods to have any positive long-run impacts. ${ }^{, 43}$ What Downs articulated was hardly a neoliberal, market based solution. But by using market metrics and prioritizing market outcomes he contributed to a significant shift in policy emphases and lent credence to neoliberal

\footnotetext{
${ }^{43}$ Cleveland Press, January 9, 1976.
} 
Cebul

voices. $^{44}$ Downs' (and, later, President Carter's) development model was based on using public spending for strategic market interventions that promised to deliver a higher return on public investments than would the older model which targeted spending on the poor themselves and their neighborhoods. ${ }^{45}$ This framing encouraged policymakers to focus more intently on using private actors and institutions to amplify public policies.

President Carter's signature urban policy was the Urban Development Action Grant (UDAG) program, and, in the spirit of Anthony Downs' 1975 remarks in Cleveland, it sought to enable local administrations in declining cities to use federal funds to leverage private investment. The Federal Urban Renewal program had operated along similar lines - local administrators helped acquire, clear, and prepare land for private development - but UDAG contained much broader possibilities for intervening in local markets. As a report on the first two years of the program prepared by Princeton's Urban and Regional Research Center suggested, UDAG contained within its mandate a multitude of public-private financing options. The program could be applied to just about any sort of public-private partnership whether related to industry, commerce and retail, or housing. Many times, cities set up their own Economic Development Corporations that offered publicly subsidized, low-interest rate loans to developers,

\footnotetext{
${ }^{44}$ On the emergence of neoliberal policy recommendations in the 1970s, see Daniel Stedman Jones, Masters of the Universe, 317-321.

${ }^{45}$ For a succinct overview of these developments, see Alice O’Connor, "Swimming against the Tide: A Brief History of Federal Policy in Poor Communities," in Ferguson and Dickens, ed., 77-121.
} 
Cebul

which, in an era of out of control inflation, promised to stimulate development. Other times, cities acted as the lending agent, either packaging loans with private lenders, or combining UDAG funds with other federal programs (by using Block Grant funds, for example, to redevelop road, sewage, or other infrastructure adjacent to a UDAG site) in order to maximize the public subsidy. Cities could also stipulate that as a condition of a loan a portion of the eventual profit from the redeveloped property would accrue to the municipality ( 50 percent of the profit in one Newark, New Jersey program went to the city). ${ }^{46}$ Cities could use program funds to create a corporation that purchased and prepared land to be leased or resold to new businesses at dramatically sub-market rates. ${ }^{47}$ In all instances, however, in order to qualify for a federal UDAG, cities and local business had to collaborate on an application that demonstrated the potential employment benefit, a high ratio of private to public investment, and, most importantly, a "but for" statement which claimed that, "but for" the public subsidy, the private entity would not pursue the project. In identifying new market possibilities, teaming with business, and directing federal largess, local and national governments were taking on not just an interventionist role in markets: the state itself was becoming an entrepreneur. ${ }^{48}$

\footnotetext{
${ }^{46}$ Richard P. Nathan and Jerry A. Webman, eds., The Urban Development Action Grant Program: Papers and Conference Proceedings on Its First Two Years of Operation (Princeton: Princeton Urban and Regional Research Center, 1980), 28.

${ }^{47}$ Ibid., 30-33.

${ }^{48}$ Peter Eisinger has developed this notion of the state as entrepreneur most forcefully. See Eisinger, The Rise of the Entrepreneurial State (Madison, 1988). For UDAGs in particular, see especially, 114-22. For more detail on eight
} 
Cebul

In the context of ascendant antigovernment politics especially, by describing the program in terms of private development outcomes rather than the public policy inputs, public political discourse surrounding UDAGs slid toward obscuring the state's role in developing local markets. Despite heavy public subsidies and, in some cases, unprecedented interventions, politicians and policymakers usually framed the program as a 'free market' solution for development problems. As Moon Landrieu, Carter's HUD secretary and former mayor of New Orleans described it, "the private sector ... built this country and ... it was certainly capable of rebuilding it if government could create the atmosphere in which the private sector could move and ... exercise its ingenuity and its capital and its desires." ${ }^{49}$

Though one Reagan Administration policy advisor considered UDAGs "pure Reaganism," other members of the Republican's team advanced a more strident vision of New Federalism - devolving, not merely decentralizing or deregulating federal programs. ${ }^{50}$ Their stance threatened all federal development spending, even UDAG. Indeed, Reagan framed his new version of New Federalism as a means of empowering local governments and freeing case studies, many of which were raised in Nathan and Webman, see Ingrid W. Reed, "The Life and Death of UDAG: An Assessment Based on Eight Projects in Five New Jersey Cities," Publius, (1989) 19 (3): 93-109.

${ }^{49}$ Urban Development Action Grant Program Remarks at a White House Reception Commemorating the Second Anniversary of the Program, October 19, 1979, accessed online at The American Presidency Project, University of California, Santa Barbara.

${ }^{50}$ The Urban Development Action Grant: Pure Reaganism," undated memo, folder Urban Development Assistance Program (2), OA 9460, Box 36, Edwin Meese Files, RRL. 
Cebul

market forces, not as federal retrenchment. Speaking before the National Association of Towns

and Townships, Reagan discordantly invoked Martin Luther King, Jr. on behalf of devolving

social service provisions and cutting the social safety net, saying, "I have a dream that someday

we can provide you with the revenue sources co-opted by the Federal Government so that local

money no longer has to make a round trip through Washington before you can use it in your

local area." ${ }^{51}$ Whereas Nixon had sought to support local governments through generous and

loosely regulated federal aid (through Block Grants or General Revenue Sharing), and Carter

sought to give local governments more funding to stimulate private development, Reagan's New

Federalism would force state and local governments to find their own development revenue.

Many mayors and governors looked optimistically to the program, not fully grasping

Reagan's intention to devolve programs entirely. As Voinovich put it before the National League

of Cities in 1981, winning federal grants required planning and engineering programs "five times

over to satisfy" federal regulators. "We all know how long it takes to build a highway today ...

Then there's the question of whether we'd get a grant at all. No," Voinovich concluded, "I don't

want to do all that." "New Federalism is going to bring about new relationships" between the

various levels of government, and a "good deal of this program consists of things we ourselves

have been pushing for: block grants, local control, reduction of Federal restrictions." Voinovich

\footnotetext{
${ }^{51}$ Ronald Reagan, Speech Before the National Association of Towns and Townships, September 12, 1983, folder Enterprise Zones: Contacts / Lists (1), Box 1, David Wright Files, RRL.
} 
Cebul

counseled the best way to "respond to New Federalism" was through "'Public-Private

Partnership." Government "must work with other institutions if it is to realize its potential, just as other institutions must work with government to achieve their potential."52 But Voinovich's sense that Reagan would generate more block grants was considerably off the mark.

The Reagan Administration's sole urban development policy proposal, Enterprise Zones, extended Reagan's notion of federal retrenchment while simultaneously threatening to increase the federal deficit. ${ }^{53}$ In selling Enterprise Zones, a targeted package of tax and regulatory relief for struggling areas of cities, President Reagan offered a simple proposition: "These . . zones [will] demonstrate that freedom of enterprise can succeed where government has failed - if given the chance." 54 The program was initially construed, like the British model upon which it was based, as a place-based development instrument. ${ }^{55}$ As one early Administration memo put it, "The incentives and natural market forces thus unleashed in central cities would then be relied upon to lead to the economic redevelopment of these areas and to [create] real, private sector

\footnotetext{
${ }^{52}$ George Voinovich, National League of Cities Remarks, December 1, 1981, PAL.

${ }^{53}$ Indeed, it was the deficit creating aspect of Enterprise Zones that House Ways and Means Chairman Dan Rostenkowski (D-IL) invoked most often to justify quashing committee hearings on the Administration's proposal. David Wright to Kenneth Duberstein, March 8, 1983, folder Enterprise Zones: Miscellaneous, Box 1, David Wright Files, RRL.

${ }^{54}$ Ronald Reagan, Talking Points for State and Local Officials Briefing on Enterprise Zone Proposals, March 24, 1982, White House Subject Files, BE (Business - Economics), box 91, Ronald Reagan Library.

${ }^{55}$ Stedman Jones, pp. 317-18.
} 
Cebul

jobs for the disadvantaged individuals in or near these areas."

emphasis was on developing struggling areas, which might, eventually, create jobs for

impoverished residents.

Much of the local and national media tended to characterize the Reagan Administration's

Enterprise Zone legislation as an abdication of national agenda setting for community and

economic development. Indeed, critics considered the Zones a replacement for or withdrawal

from older liberal urban policies. Even a supportive editorial in the Plain Dealer argued the

"Enterprise Zone Act is, of course, a conservative substitute for the liberal government spending

programs of the past. It offers a different trickle down theory relying on the private sector, rather

than government." At their worst, critics called the proposed Zones "a way of buying out from

some really rough problems on the cheap," which "in no way constitutes a national urban

policy. ${ }^{, 57}$ Recognizing, however, the unlikelihood of alternative policies, however, the Plain

Dealer endorsed the approach. ${ }^{58}$

Criticism from within the Administration and from its allies in the business community,

however, posed the most significant and penetrating questions about the efficacy of Enterprise

Zone's "free market" development concept. Dan J. Smith, Senior White House Advisor in the

\footnotetext{
56 “The Administration Plan for Enterprise Zones,” January 6, 1982, folder 24, box 10, GVV Papers.

${ }^{57}$ M. Carl Holdman and George Peterson quoted in Roger Biles, The Fate of Cities, 258.

58 “Try enterprise zones,” Plain Dealer, November 30, 1981.
} 
Cebul

Office of Policy Development and one the legislation's chief architects, was particularly clear in his warnings about popular misconceptions of the proposal. "In Congress, in the media and among state and local government officials," he wrote chief Reagan aides Bob Carleson, Martin Andersen, Ed Gray, and Dennis Kass, there were significant misunderstandings about Enterprise Zones: that they would be active and bear fruit within a year; that they represented a comprehensive and sweeping national plan aimed at all cities; and that the Administration viewed them as an alternative to more traditional forms of development programs. The good news was that these expectations "accorded us a honeymoon on the urban revitalization issue." The bad news, Smith wrote, was that the "earliest we can expect to see visible results" would be in 1984 at best and "perhaps not until well into 1985 - the next Presidential term." Making matters more difficult, the Administration only planned to target zones "in a small fraction of ... distressed inner-city communities," and, even worse, if Congress failed to pass the legislation, the Administration had "no direct alternative to traditional revitalization programs." Even if the legislation were passed, "Our Program for Economic Recovery," Smith warned, "is unlikely to affect in any significant way areas containing chronic unemployment and major infrastructural deficiencies. ${ }^{, 59}$ In short, Smith warned, Enterprise Zones would do practically none of the things the President claimed they would do.

\footnotetext{
${ }^{59}$ Dan J. Smith to Bob Carleson, November 5, 1981, folder HUD Enterprise Zone Panels, 05711, Box 2, Dan Smith Files, RRL.
} 
Cebul

The White House convened a series of Enterprise Zone Panels to solicit the advice and support of a representative slice of the nation's business community. The vast majority agreed with Smith's assessment. Business leaders came from across the country - from downtrodden Northern cities such as Baltimore, Toledo, and Cleveland and booming Sunbelt centers such as San Diego, Dallas, and Atlanta. The assembled business interests represented a wide spectrum of the private sector: they came from the American Bankers Association as well as local banks; pharmaceutical interests such as Pfizer; a variety of local construction and development companies including Cleveland's Forest City; small and large venture capital firms were represented; and large multinational corporations such as General Electric, TRW and Sears all participated in the Administration's Enterprise Zone consultation workshops. The consensus across all of the panels was that the Administration was vastly overselling Enterprise Zones' developmental potential. ${ }^{60}$

In essence, business warned, the program would do very little to stimulate small, laborintensive businesses, Reagan's chief claim on behalf of the policy. They leveled a bevy of criticisms. The Administration's emphasis on tax incentives, the businesspeople reported, was at best redundant since the tax cuts of 1981 had already lowered businesses' tax liabilities. As a result, "the effectiveness of new tax-based incentive programs like enterprise zones had been

\footnotetext{
${ }^{60}$ For detailed notes of these meetings as well as summary reports and rosters, see folder HUD Enterprise Zone Panels, 05711, Box 2, Dan Smith Files, RRL.
} 
Cebul

diminished." In addition, they argued that new "business activity will come from businesses

outside the zone who were deciding to expand into a zone and from fresh business start-ups.

Businesses outside a zone are not likely to close down and relocate in zones to" get a little

additional tax break. Most significantly, however, because the proposals were overwhelmingly

geared toward tax relief, the program would be "most attractive to capital-intensive firms and

those having significant tax liabilities" - meaning big, existing businesses. As a result, "it is not

likely to attract small, labor-intensive businesses who create the bulk of new jobs in America." In

contrast to a bit of tax and regulatory relief, the business people described for the Reagan team

what small and fledgling businesses needed from government: "Access to capital"; improved

"wage rates"; "availability of labor"; "availability of training for unskilled labor"; transpiration

and "proximity to markets"; "local government commitment"; quality infrastructure and social

services (including transit, fire, and police); and "strong, resourceful business and community

leadership dedicated to revitalization." In short, what small businesses sought were the kinds of

stimulative programs that had characterized the broad sweep of twentieth century developmental

sate policies: demand-side jobs and job training programs, federal infrastructure spending, and

direct stimulus for the local public and private sectors. Enterprise Zones offered none of these

inducements. $^{61}$

${ }^{61}$ Dan J. Smith to Dennis Kass and Bob Carleson, re: Enterprise Zone Panel Responses, October 28, 1981, folder HUD Enterprise Zone Panels, Box 05711, Dan Smith Files, RRL. 
Cebul

Following the bill's failure to pass Congress in 1982, rather than respond substantively to its internal and external critics, the Reagan Administration ignored the workshops and sought instead to more forcefully reframe the program's politics, doubling down on the mythic potential of free markets. While the Enterprise Zone concept had first been deployed in Great Britain, and while the Administration tacitly acknowledged its debt to British policymakers, the evolving political context in the United States - and, in comparison to Britain, the country's lack of a sturdier and broader social safety net - led the Reagan Administration to emphasize not just the beneficence of free markets to redevelop downtrodden areas, but their potential to offer social reform on behalf of the nation's worst off. The Administration ramped up its overheated, overly ideological, and baseless assertions. "The British model," said Bob Carleson in 1983, chairman of the White House working group that developed the Administration's Enterprise Zone plan, "is significantly different from ours. They had one goal, revitalization of an economic area." The British, he contended, made no promises about creating opportunity for poor or marginalized citizens. In contrast, "We have two goals, job creation - particularly for the disadvantaged - and also revitalization." 62

Indeed, what was distinctive about the American model - a “'Boy Scout' mission" according to the 1983 edition of Government Executive magazine - was its emphasis on social

\footnotetext{
${ }^{62}$ White House Office of Policy Information News Brief, Enterprise Zones, Number 4, June 3, 1983, folder Enterprise Zones (1), OA 12999, box 3, MB Oglesby Files, RRL.
} 
Cebul

revitalization. Beginning in late 1982, the Administration's political and economic rationale for Enterprise Zones was regularly paired with such social or moral claims. When Reagan again sent Enterprise Zone legislation to Congress in the summer of 1983, the first sentence of his statement reflected the Administration's tendency to dress tax breaks in progressive, antipoverty garb: "I am sending to the Congress today," Reagan said, "legislation that will be of primary benefit to America's disadvantaged citizens in our most depressed areas." Part of his Administration's “comprehensive jobs approach," Enterprise Zones would benefit "the long-term unemployed" through tax credits and job training funds delivered to private employers who hired within target areas. Concluded the President, Enterprise Zones "will spark the latent talents and abilities already in existence in our Nation's most depressed areas." ${ }^{63}$ Less government, not more, was the key to reviving the nation's true producers - businesses - and, in turn, to revitalizing marginalized Americans' industriousness and individualism.

Such neoliberal claims soon gained further legitimacy when, the following year, Charles Murray published Losing Ground, a rational-choice based screed against the social welfare state that generated much media attention. Echoing the Reagan Administration's common sense logic, Murray provided seemingly even handed social scientific evidence in support of a radical

\footnotetext{
${ }^{63}$ Statement by the President, March 7, 1983, folder Enterprise Zones (1), OA 12999, box 3, MB Oglesby Files, RRL.
} 
Cebul

conclusion - eliminating the entirety of the nation's social welfare programs. ${ }^{64}$ While the Reagan

Administration failed to enact its Enterprise Zone legislation (a similar bill was later enacted by

the Clinton Administration), it nevertheless continued to put budgetary pressure on local

governments by slashing federal development spending and persisted in its calls for tax and

regulatory relief. In states across the country (including Ohio and Georgia), local versions of

Enterprise Zones legislation were soon signed into law. They were deployed, however, in the

interregional competition for business recruitment, not as social programs.

Voinovich and Entrenched "Neoliberalism by Default"

Speaking before the National Conference of Black Mayors in April 1984, Reagan

Administration Treasury Secretary Donald Regan articulated a solution for the nation's mayors

"to cope" with hemorrhaging tax bases and the rising costs of the President's New Federalism.

You "know that you have to pursue that economic ideal, the net taxpayer - that man, woman,

family or business that pays more in taxes than he demands in services." In the face of the

Reagan retrenchment, the only way to shore up local tax bases (and political bases), he argued,

was to target services and stimulus toward middle and upper class residents and consumers to, in

\footnotetext{
${ }^{64}$ Charles Murray, Losing Ground: American Social Policy: 1950-1980 (New York: Basic Books, 1984). For a rich discussion of Murray's impact on debates about the urban "underclass" and public policy, see Alice O'Connor, Poverty Knowledge, 247-59.
} 
Cebul

turn, win their tax revenue. "By they way," Regan wryly noted, "when you get back home, I

wouldn't put it exactly that way. Believe me those net taxpayers will unnet themselves pretty

quickly when they find out that's what they are. ${ }^{65}$ In the face of dwindling federal aid and

persistent revolts by local voters on behalf of lower taxes, mayors across the country

pragmatically embraced a supply side or trickle down version of urban planning. ${ }^{66}$

Though Voinovich hoped for a much broader range of federal programs, the tenuous

nature of federal aid encouraged the Mayor to channel federal dollars in the ways Regan

described. The Mayor explained the effects of Reagan's New Federalism in a three-page memo

to his department heads, which, for its keen appreciation for the 1980s political and policy

landscape, is worth exploring at length. "It is perceived by the general public that government

(all levels) has gotten too big," the Mayor wrote. "The pervasive attitude is 'cut back', only do it

in programs not "essential."' As a result, Voinovich wrote, "Programs which will be cut will fall

onto a lower level of government to provide the service if it is to be continued." But, local and

municipal governments were in a uniquely tenuous position: "the lower the governmental units,

the closer it is to the voters and the closer it is to the concerns of the people about taxes. The

lower the level of government, the more likely it will have to request funds from the same voters

\footnotetext{
${ }^{65}$ Donald Regan, Remarks Before the National Conference of Black Mayors, April 19, 1984, folder Enterprise Zones: Enterprise Zones (2), Box 05721, Dan Smith Files, RRL.

${ }^{66}$ On the late 1970s and early 1980s tax revolts, see especially, Self, American Babylon, Isaac Martin, The Permanent Tax Revolt (Stanford, 2008), and Bruce J. Schulman, The Seventies, (New York, 2001).
} 
Cebul

who are fed up with government of any level." As disgruntled voters pulled one strand and

Reagan the other, the tightening knot squeezing city government meant Cleveland's municipal departments would have to do more with much less: "we must be extremely careful with grant funds that we do not commit ourselves and then be faced with the removal of these funds."

Moreover, Voinovich noted, the invisibility of federal aid - voters' inability to understand how local sources were funded with federal dollars - was especially confounding.

"The people presume since the service is provided by the city that we are not affected by reductions in Federal or State budgets." Since Cleveland's voters - and especially Voinovich's ethnic base - missed the federal role in the city's delivery of valued services, Voinovich cautioned against assuming

these grants will continue; therefore, any use of grants must be made with future commitments of local funds held to a minimum ... We can no longer view these grants as free resources but should rather structure the programs to fit the length of grant commitments. Even though Community Development funds can build a new recreation center, it is the city which will have to program, staff, and maintain the facility in the future

Reagan spoke easily in market-based terms, but Voinovich well understood the knotty necessity of raising public revenue to continue valued public services. As he concluded, the "City of Cleveland must be on guard that it does not assume the position of trying to cover the costs of programs which have been deleted by a higher level of government. With the city's recent history of fiscal distress, we must all constantly be on guard that we do not over-commit 
Cebul

ourselves. ${ }^{67}$ Opening community centers or developing local social service or welfare projects

were poor investments since, if federal funding disappeared or local tax revenue further

dwindled, the city would be left on the hook. In times of such fiscal and federal uncertainty,

stimulating short-term private sector building projects - the future costs of which would be born

by private entities - were logical choices for public investments.

In Cleveland, then, the acceleration toward stimulating private development was not

primarily driven by a Republican's ideological faith in markets but instead a pragmatic mayor's

concerns about safeguarding the budget. Instead, Voinovich embraced, as had his forerunner

Ralph Perk, "neoliberalism by default." ${ }^{, 68}$ Indeed, the Republican-dominated Roundtable advised

him that he should not expect private actors to suddenly start delivering social services for the

public good. In one report on Reagan's New Federalism, the group concluded by quoting

Detroit's mayor Coleman Young; the President's assumption that the private sector would fill the

void left by diminished federal aid to urban areas was "simplistic and naïve." 69 Reagan's

austerity measures clinched a pragmatic - even desperate - embrace by the city's Republican

Mayor of stimulating private growth and tax revenue through as much public stimulus as the city

could muster.

\footnotetext{
${ }^{67}$ George Voinovich, "Mayor's Statement of Fiscal Policy,” undated, folder 53, box 2, GVV.

${ }^{68}$ Timothy Weaver, "Ideas, Coalition Building, and Political Development in the City: Urban Policy and Politics in the U.S. and the U.K., 1976-2000.”

${ }^{69}$ Quoted in Greater Cleveland Roundtable, "Block Grant Primer Update,” October 1982, folder 17, box 13, GVV.
} 
Cebul

With the city's financial situation stabilized if not improving, Voinovich and business

leaders set about planning for the city's future. The Mayor consulted regularly with private

leaders like Del deWindt, perhaps the Roundtable's most influential trustee. ${ }^{70}$ Without much

debate, the administration and business leadership turned their attention to a development plan

for the "Dual Hub Corridor." The city of Cleveland's downtown core, resting along the southern

shore of Lake Erie, was one of two major sites the city's business leaders hoped to buttress

against decline. The other was University Circle, a green oasis amidst declining neighborhoods

five miles east of downtown that featured the city's world class museum campus, a well

landscaped park, Case Western Reserve University, and Severance Hall, home to the renowned

Cleveland Orchestra. "Obviously," Voinovich wrote in a memo to key members of his private

bureaucracy, "the agreed corridor from downtown to University Circle seems . . to be the City's

best opportunity for future development because of institutions and stakeholders involved."

Voinovich sent the memo to deWindt, founder of Cleveland Tomorrow, Stanley Pace, Chairman

of the Roundtable, William MacDonald, Vice Chairman of the GCGA, and Homer Wadsworth,

Director of the Cleveland Foundation. "I1 "If you concur with this conclusion" Voinovich wrote,

we should "develop an overall plan and strategy for the area" that "would represent our civic

\footnotetext{
${ }^{70}$ See generally, correspondence between George Voinovich and Del de Windt in folder 29, box 13, GVV.

${ }^{71}$ George Voinovich to Del de Windt, Stanley Pace, William MacDonald, Homer Wadsworth, Ed Richard, and Hunter Morrison, February 23, 1983, folder 1, box 13, GVV, 3.
} 
Cebul

vision . . . and would ultimately be adopted by our City Planning Commission." In essence,

Voinovich invited the heads of Cleveland Tomorrow, the Roundtable, the Growth Association

and the Cleveland Foundation to write the city's strategic plan. Rather than use the GCGA,

Cleveland Tomorrow, and the Roundtable as advisory or consultative committees, Voinovich

explicitly formalized their role in the policymaking process, certifying their status as his private

bureaucracy. He clarified their relationship to each other, as well. The Growth Association would

revert to the booster and business coordination duties of a typical Chamber of Commerce.

Cleveland Tomorrow would continue its research and planning for business modernization and economic development in consultation with local Universities. And the Roundtable would continue to serve as, in essence, the city's executive planning and development committee. ${ }^{72}$

The result of this sorting out and strategic planning was "Civic Vision," a document that detailed a comprehensive set of development objectives - the city's "general plan." Civic Vision was unveiled November 8, 1984 in a special section of the Plain Dealer. Its fundamental assumption was that the city would soon begin growing again. While Cleveland's planning director in the 1970s, Norman Krumholz, was a pioneering urban planner who argued on behalf

\footnotetext{
${ }^{72}$ Voinovich and the Roundtable continued to tweak their responsibilities. In 1986, with the city's Dual Hub corridor off and running, for instance, Voinovich requested "the following priorities for the Roundtable" be adopted: race relations and education. Little substantive action was taken on the race matter, though the Roundtable and the GCGA did attempt to help the city's ailing public schools. See Don Plaskett to George Voinovich, re: Greater Cleveland Roundtable Meeting Notes, February 27, 1986, folder 17, box 13, GVV.
} 
Cebul

of "equity planning," a version of managed decline that emphasized neighborhood-centered development geared toward transportation to jobs, the city went a different direction. ${ }^{73}$ The defining feature of Civic Vision was its faith in renewed growth and attention to downtown development, which, as the City Planning Commission put it, would be directed by "local business and civic leaders on the Downtown Plan Steering Committee." 74

While Civic Vision was not revealed to constituents until November 1984, the Administration had aggressively, if in piecemeal, pursued aspects of the Dual Hub development plan since Voinovich's inauguration. Winning federal aid was the lynchpin for further development. The Kucinich Administration had had an abysmal record of securing federal development grants, but under Voinovich the city's federally backed economic development plans took off. To a large degree, this was thanks to the Mayor's deft political support of the President's urban agenda. In his 1979 campaign for mayor, Voinovich had spoken passionately against the overuse of tax abatements, but - spurred on by members of the Roundtable - he became an aggressive supporter of local, state and national Enterprise Zone legislation. Indeed,

\footnotetext{
${ }^{73}$ See, for instance, Norman Krumholz and Ernest R. Bonner, "Toward a Work Program for an Advocate Planning Agency," Background Paper for $54^{\text {th }}$ Annual Conference of American Institute of Planners, October 25, 1971, accessed online at http://pdx.edu/sites/www.pdx.edu.usp/files/usp_bonner.pdf; Krumholz and Bonner, "The Cleveland Policy Plan," 1975, accessed online at http://pdx.edu/usp/planpdxorg-cleveland-policy-plan; and Portland Oregonian, April 2_, 1974. For an excellent and thorough discussion of equity planning in Cleveland, see Swanstom, The Crisis of Growth Politics.

${ }^{74}$ Keating et al., 127.
} 
Cebul

the city passed its own targeted tax relief program, the Target Area Investment Program (TAIP), and Voinovich used his supply side bona fides to trumpet the President's plan and, behind the scenes, to lobby for increased federal spending in Cleveland.

Over 1982 and 1983, supporters of Enterprise Zones worried that the White House's interest was waning, and Voinovich worked hard to ingratiate himself to the Administration, in part to secure Enterprise Zone legislation, but mainly to ensure direct federal spending. When passage of Reagan's proposal seemed more and more in doubt, Voinovich wrote to Reagan's intergovernmental relations team: "you at the White House have to take some effective action, action that clearly shows purpose and direction... When you have done some of this, we can turn out the troops. ${ }^{, 75}$ When the White House responded, Voinovich teamed with Baltimore Mayor William Donald Schaeffer (D) to chair a committee of mayors who lobbied Congress on behalf of the program. ${ }^{76}$ Speaking at a White House Conference on Enterprise Zones in 1983, Voinovich touted Cleveland's TAIP and supported the President's free market stance, claiming

\footnotetext{
${ }^{75}$ George Voinovich to Lee Verstandig, July 29, 1983, folder 24, box 10, GVV. On Voinovich's plans to resuscitate the national enterprise zone legislation, see George Voinovich to Jim Conrad, February 11, 1983, folder 24, box 10, GVV Papers. For the Roundtable's efforts to lobby Congress, see George V. Voinovich to R.F. Mettler, April 25, 1983, folder 24, box 10, GVV.

${ }^{76}$ See for instance, George Voinovich to Dan Rostenkowski, October 12, 1983, Folder Enterprise Zones (2), Box 1, David Wright Files, RRL.
} 
Cebul

that "places like Cleveland and others have businesses that have already located in what we've referred to as our own enterprise zones." ${ }^{, 77}$

Privately, however, Voinovich and Schaeffer penned an urgent appeal to the nation's mayors that sought to reframe the conversation around Enterprise Zones from a policy replacing government action to one that might complement longer-standing developmental state programs such as Block Grants or Urban Development Action Grants. "There has been a tendency in some quarters to burden the concept with unnecessary ideological baggage," they wrote. "This we reject. Enterprise Zones should not be seen as a substitute for urban policy or for vital existing forms of Federal assistance" such as Block Grants. Instead, the program "offers the opportunity of bringing together for the first time the public and private sector in a unique way" for jobs creation and economic development. ${ }^{78}$ Indeed, as one Voinovich Administration analysis put it, "The importance of the block grant extends far beyond the value of the $\$ 29$ million a year we currently receive." The city reported that it leveraged $\$ 1.50$ in private spending for every $\$ 1.00$ in Block Grant funding. ${ }^{79}$ According to Voinovich, such reductive, overly-ideological criticism assumed the program would operate in a vacuum and that existing, often liberal-instituted

\footnotetext{
${ }^{77}$ Press Briefing by Local Officials on Enterprise Zoning, November 16, 1983, folder Enterprise Zones (1), Box 05721, Dan Smith Files, RRL.

${ }^{78}$ George V. Voinovich and William Donald Schaefer to Thomas Faircloth, October 25, 1983, folder 24, box 10, GVV.

79 "How Reagan budget impacts on City of Cleveland," Nation's Cities Weekly, February 25, 1985, PAL.
} 
Cebul

policies that offered direct stimulus, demand side support or other development incentives were being swept away. Instead, far from substituting, supplanting, or replacing prior liberal growth policies, Voinovich privately urged other mayors to think of Enterprise Zones as a complementary weapon to be used in tandem with other public stimuli. But, in the context of the Reagan Administration's assault on federal spending, such an appeal did not ring true.

At home, however, Voinovich's vocal support for the national Administration soon won the city more than its fair share of federal aid. It was a godsend for Cleveland's businesspeople. As one of Voinovich's private consultants put it, echoing the Reagan Administration's business workshops, "businesses need equity capital to start-up or expand." ${ }^{80}$ By 1985 , Cleveland ranked fourth in UDAG money won, behind only New York, Detroit (both of which had significantly greater populations) and Baltimore (whose Mayor Schaefer had joined Voinovich in lobbying for Reagan's urban policies). Between 1981 and 1988 the city was awarded \$103,308,548 worth of Action Grants, which, the Voinovich Administration claimed, leveraged \$672.9 million of private investment and ensured the creation of 3,973 jobs and the retention of 7,875 more. ${ }^{81}$ In one case, a grateful upscale real estate developer expressed gratitude for Action Grant funding, saying winning private finance had been "a very tough sell." Crain's Cleveland Business

\footnotetext{
${ }^{80}$ Paul Bardack to George Voinovich, May 20, 1982, folder 24, box 10, GVV.

${ }^{81}$ Keating, et al., 130.
} 
Cebul

reported that "federal incentives were valuable in obtaining financing and helped the project

achieve a marketable rent." 82

The distribution of Action Grant projects across the city during the Voinovich years suggests the disproportionate use of federal development dollars for downtown / University Circle and commercial development rather than for spending on declining neighborhoods or housing. The city used 21 UDAGs in the Dual Hub area and only 12 in neighborhoods. The overwhelming majority of the grants were for commercial development (24) while only four UDAGs went to support new housing developments. While these disparities were significant, the dollar amounts committed in each category were even more so. For the commercial projects, the UDAGs totaled $\$ 83,618,988$ to only $\$ 10,106,000$ for housing. By area, too, the contrasts were striking. While $\$ 80,623,245$ went to the Dual Hub area, the other $20 \%$ of the city's UDAG program was spent in the industrial and residential neighborhoods, where the vast majority of the city's residents lived and worked. ${ }^{83}$

Such generous federal subsidies were the essential underpinning of the city's purportedly 'neoliberal' tax and regulatory relief program. Gary Conley, the city’s Director of Economic Development, argued the entire city should be designated an enterprise zone, offering local

\footnotetext{
82 "Playhouse Square Hotel UDAG Faces Cancellation,” Crain's Cleveland Business, July 24, 1989.

${ }^{83}$ Figures in Keating, et al., p. 130. A small portion of the commercial funds went to support several strip mall developments in depressed residential neighborhoods.
} 
Cebul

property tax credits of up to $50 \%$ for new or expanding businesses or those that offered their own

job training programs. While a sizeable chunk of revenue would have come out of the funding

for the city's deteriorating schools (their revenue was based on the property tax), Conley argued

that, "after all, this is for the training of the parents so that they can continue to provide a

livelihood for their children." Voinovich was thrilled. "Gary: This is a fantastic idea. Let's

pursue it now," the Mayor scrawled on the bottom of the memo. ${ }^{84}$

Though the city never carried out this blanket enterprise zone, once the state's more

targeted enterprise zone legislation took effect, Cleveland designated 3.5 square miles of "the

wasteland," as the Mayor put it, of the eastside inner city adjacent to downtown which

strategically included much of the "corridor" part of the Dual Hub plan. "[W]e have talked for

years about attracting industries allied with the medical profession," the Mayor wrote, and the

Mayor worked out an understanding with the Cleveland Clinic to make the private hospital the

first to benefit from the new tax credits. ${ }^{85}$ The Clinic's leadership, though, was concerned about

the "character" of the neighborhood surrounding the Chester Avenue site where it planned to

situate its new campus. The private hospital requested that, in addition to the tax credits, the city

provide a number of "incentives": "Financial assistance to the adjacent local development

\footnotetext{
${ }^{84}$ Gary Conley to George Voinovich, February 17, 1984, folder 24, box 10, GVV.

85 “Enterprise zone test seen here,” Plain Dealer, March 25, 1982; and George Voinovich to Brian Bowser and Russ Geuther, June 4, 1982, folder 24, box 10, GVV.
} 
Cebul

corporations"; "the establishment of a non-profit or a for-profit corporation to provide security

services in the area"; and that publicly employed "consultants . . . develop a physical

redevelopment strategy particularly in the E. $82^{\text {nd }}$ Street, E. $107^{\text {th }}$ Street, Chester Avenue,

Carnegie Avenue area and a business marketing and investment strategy for the larger area

focusing on medically related industries." ${ }^{86}$ Far from simply a tax write off, the Clinic asked the city to create an entirely new neighborhood market geared toward the medical industry.

Direct public subsidies like UDAGs were crucial for spurring private investment, but if one read the business pages of the Plain Dealer it would have been hard to find the government's roll at all. "The corridor's comeback," one article explained, "began when business in the area . . . became sold on its value ... [and] formed Midtown Corridor Inc., a private organization committed to generating jobs by creating a good business climate." The result was that "Fifty-four companies have made major investments, totaling nearly $\$ 60.5$ million.” Referring to residents, industry, and businesses alike, Margaret L. Murphy, the executive director of Midtown Corridor Inc., concurred that "stakeholder commitment to the area' ... made it easy to sell the corridor through peer marketing, word of mouth, [and] using 'the old boy network." She made no mention of public subsidies and only vaguely hinted at the thick network and planning that made up the city's private bureaucracy. Likewise, the title of a

\footnotetext{
${ }^{86}$ Brian Bowser to George Voinovich and Russ Geuther, May 25, 1982, folder 24, box 10, GVV.
} 
Cebul

triumphant report Murphy submitted to the Brookings Institution failed totally to mention the

public side of the partnership: “A Private Sector Model for Rebuilding Inner-City

Competitiveness: Lessons from Midtown Cleveland. ${ }^{87}$

The Mayor, too, perpetuated the illusion that the public sector was withdrawing from

Midtown, perversely downplaying his foundational role in the developments. In one press

conference he failed to mention the $\$ 4.7$ million worth of federal funds committed to the small

piece of the Dual Hub Corridor and instead toasted the area's businesspeople. "This one-square

mile area," the Mayor exclaimed, "has taken its destiny into its own hands." 88 On other

occasions, Mayor Voinovich again demonstrated his preference for highlighting the private side

of his public private partnership. The businessmen rebuilding downtown, he said, were "the new

urban pioneers, rebuilding an old city with vision, courage and commitment." 89 While political

rhetoric focused on the beneficence and efficiency of revitalized markets and the productive

power of motivated private actors, in fact, the Clinic project and the revitalization of the "Mid-

Town Corridor" in Cleveland revealed how tax incentives were merely the visible edge of a deep

and submerged package of public subsidies. Indeed, in cities across the country, a study of state

\footnotetext{
${ }^{87}$ Margaret Murphy, “A Private Sector Model for Rebuilding Inner-City Competitiveness: Lessons from Midtown Cleveland," A Discussion Paper Prepared for The Brookings Institution Center on Urban and Metropolitan Policy, December 1998, PAL.

${ }^{88}$ Angela D. Chatman, “Mid-Town makes comeback,” Plain Dealer, August 13, 1985.

${ }^{89}$ Plain Dealer, January 18, 1981.
} 
Cebul

Enterprise Zone legislation suggested, the real package of inducements descended far beneath

the surface of the era's deregulatory, free market, anti-tax rhetoric and constituted a foundation

of robust local, state and federal investments - interventions in the 'free' market. ${ }^{90}$

Across the board, Roundtable and other members of Voinovich's private bureaucracy

embraced a vigorous role for government in creating a positive business climate - so long as the

costs weren't born by industry. While the Roundtable called for business targeted tax and

regulatory relief, they strongly supported an income tax increase to support local infrastructure

spending: "The consensus of the members of the Roundtable was that the campaign for the tax is

crucial to the future of the city," the minutes for one meeting read. In stark contrast to the anti-

tax sentiment sweeping the nation and the Roundtable's own commitment to staying out of the

headlines, its Trustees pledged to publicly endorse the tax. ${ }^{91}$ Two years later, when Voinovich

sought a similar measure, this time to underwrite one of his development projects, the Growth

Association produced supportive letters that were inserted in workers' pay envelopes at 3,000

city businesses. GCGA President Allen C. Holmes, managing partner of Jones Day, pledged the

"Growth Association is committed to working tirelessly toward the passage of this issue." 92 In

another document cleared through the Roundtable, the Growth Association highlighted some of

\footnotetext{
${ }^{90}$ Karen Mossberger, "State-Federal Diffusion and Policy Learning: From Enterprise Zones to Empowerment Zones," Publius, 29:3, Summer 1999, 32.

${ }^{91}$ Greater Cleveland Roundtable Board of Trustees Meeting, January 19, 1981, folder 17, box 13, GVV.

92 Thomas A. Andrzejewski, “Growth Association chief, mayor applaud each other,” PD, January 18, 1981.
} 
Cebul

the key measures for securing the city's steady development. In addition to attracting funds from the Reagan Administration's defense spending hike, three of the Growth Association's prescriptions for improving the business climate in Cleveland included advocating for government spending to "retrain displaced workers and increase private sector participation in training programs"; developing "an adequate public works infrastructure"; and encouraging "vigorous" opposition to "further reductions in federal offices / facilities here, aggressively working with local leaders, legal community, and congressional delegations to prevent closing of U.S. Antitrust offices" and other local outposts of various federal bureaucracies. Far from stifling the free market or the growth of private enterprise, Cleveland's business leaders understood the opportunities inherent in thinking of government itself as a growth industry. ${ }^{93}$

\section{Zero Sum Development}

While business leaders enjoyed unfettered access to the Administration, rebuffed and ignored for over a decade, community associations suffered a dramatic sag in vitality. Though the city had seen pitched battles between neighborhood groups and City Hall in the 1970s, by the 1980s key neighborhood associations - such as the Buckeye Woodland Community Congress had begun to fade from the scene. Some combusted. In 1982, a caravan of National People’s

93 GCGA, “Greater Cleveland Government Relations Consortium Issues \& Strategies,” 1983-1984, folder 17, box $13, \mathrm{GVV}$. 
Cebul

Action activists - the group that led the DC HUD protests against abuse of Community

Development Block Grants - came to Cleveland to work with what remained of Cleveland's neighborhood action groups. Following a workshop, a few Clevelanders invited the NPA members to participate in a "hit." Voinovich had reversed Kucinich's veto of Standard Oil of Ohio's abatement for a new corporate headquarters in downtown Cleveland. Neighborhood activists decided to confront SOHIO's CEO Alton Whitehouse on his own turf, at his country club in suburban Gates Mills. Several busses of enthusiastic activists headed east to the Hunt Club as NPA leader Gail Cincotta, a hero, led them in songs and chants. ${ }^{94}$ Six hundred neighborhood activists spilled out of their busses and confronted a veranda of lunching Club members, some of whom were clad in jodhpurs and chaps, having enjoyed a morning horse ride. One activist recalled that the "Hunt Club had never before seen so many African-Americans." Gates Mills' tiny police force was soon on the scene, but it was paralyzed by the size of the crowd. Activists drank from members' wine and water glasses, as the leadership demanded to see Whitehouse (he was not there). Some of the neighborhood group members crowed - "You do not embarrass the rich, among their rich peers," one boasted. Another considered it the highlight of his career, "the pinnacle for Cleveland groups," better even than when they had taken over the HUD building in Washington. Most activists, however, agreed with a woman who reported that

\footnotetext{
${ }^{94}$ For more on Cincotta, see Suleiman Osman, "The Decade of the Neighborhood," in Schulman and Zelizer, eds., Rightward Bound.
} 
Cebul

is "was an embarrassing thing, very embarrassing." When the Foundations that supported many

of the groups were successfully pressured by Whitehouse and SOHIO to cut off funding, it was

more than just embarrassing - it was crippling. ${ }^{95}$

Fannie Lewis, a veteran of Model Cities and of the neighborhood wars of the 1970s, had become a city council member representing Hough, and over the 1980s she was the chief advocate of the city's impoverished neighborhoods ${ }^{96}$ When Voinovich appeared before the City Council to lobby for the passage of his first budget, Lewis upstaged the Mayor by demanding his full attention on the problems of her destitute Hough neighborhood. "I hope you're not laughing at what I'm saying Mr. Mayor," the single mother of three boomed. "I see you smiling. But I'm not playing. I mean business." Reluctantly, she pledged to support his budget on the condition that "you deliver" on promises to reform police practices in black neighborhoods and to develop programs that meet "the bare necessities." ${ }^{.97}$ Voinovich instead pursued the development of the Dual Hub Corridor. Programs for the city's desperate neighborhoods would have to wait. Lewis, however, would not be deterred. The Councilwoman led the charge on a lowdensity mixed market rate and subsidized public housing project, the first phase of which was

\footnotetext{
${ }^{95}$ Randy Cunningham, "Democratizing Cleveland,” 136-7.

${ }^{96}$ Lewis' political rise is detailed at length in the previous chapter of the Cleveland case study. Councilwoman Lewis, a single mother of three, got her start in city politics first in the Great Society's Community Action for Youth program and then as a forceful voice on the citizen participation committee of Cleveland's Model Cities.

97 “Councilwoman Fannie Lewis Gives Mayor Voinovich 'A Piece of Her Mind,” Call and Post, March 15, 1980.
} 
Cebul

opened to renters on October 1, 1985. Lewis' Lexington Village included a pool, playground, tennis and basketball courts, and one and two bedroom apartments and larger townhouse style buildings with modern amenities such as patios, garbage disposals and central air conditioning.

Lewis secured as the primary investors the Famicos Foundation and McCormack, Baron and Associates, a St. Louis-based development firm. ${ }^{98}$ Famicos was a non-profit group formed in Hough in 1970 to rehab houses and apartments. By 1985, despite very little city or federal support, Famicos had rehabbed over 350 homes and six apartment buildings and had even built a handful of new homes. In neighborhoods like Hough, such homes were often the first new housing construction in over four decades. "Lexington Village," Lewis declared, "proves that the city bureaucracy can function. A lot of people doubted whether the city could work with the developers and the bank, but the city proved it could deliver." 99 When fully completed, Lexington housed 2,000 Clevelanders and redeveloped 31 acres in one of the city's worst neighborhoods. The city of Cleveland committed $\$ 5.5$ million to the project ( $\$ 2.66$ million of the city's share, however, was covered by a UDAG, $\$ 1$ million from CDBGs, and $\$ 2$ million more came from Urban Renewal Bond Funds - for a total of roughly $\$ 0$ of actual city expenditure).

The project was also underwritten by $\$ 7.5$ million from private businesses and foundations:

McCormack, Baron and Associates received a \$2 million construction loan from AmeriTrust; the

\footnotetext{
98 “Minter Named Foundation Director," Call and Post, December 15, 1983, 4A.

${ }^{99}$ Margaret Williams, “Councilwoman Lewis’ dreamvillage a reality,” Call and Post, October 24, $1985,6 \mathrm{~B}$.
} 
Cebul

Ford Foundation contributed \$1 million; the George Gund Foundation \$333,000; Sohio

$\$ 200,000$; and TRW offered another $\$ 50,000$. While Voinovich played an important role in

linking private funds to the project, Fannie Lewis was responsible for keeping the pressure on the

Mayor. ${ }^{100}$ Indeed, Lewis proved public private partnerships could get major work done in the

neighborhoods, too. Yet, the $\$ 10$ million in subsidies earmarked for Lexington Village was a far

cry from the subsidies used for downtown development, of which $\$ 86$ million would soon be

devoted to a single commercial development. ${ }^{101}$

Fannie Lewis' hard work and hard won success, however, was the exception that proved

the rule. Aside from Hough's energetic Councilwoman, the city's African American

communities suffered a severe crisis of leadership. George Forbes, the President of the City

Council and the African American representative of Glenville, a deteriorated neighborhood

adjacent to Hough, had once been on the militant end of the Civil Rights activist spectrum - too

brash by far for the city's business elites' comfort. ${ }^{102}$ By the 1980 s, however, Forbes was a key

business ally and member of the Roundtable, a power broker more concerned with winning

patronage positions and city contracts to shore up his own political position, rather than that of

his impoverished constituents. Indeed, Forbes was a paradigmatic example of the kind of post-

\footnotetext{
${ }^{100}$ William R. Wood, “Hundreds attend Lexington Village ground breaking,” Call and Post, December 6, 1984.

${ }^{101}$ Keating and Krumholz, 342.

${ }^{102}$ On Forbes' relationship with the city’s blacks and business leadership, see Moore, Carl B. Stokes, ch. 4.
} 
Cebul

Civil Rights African American politician political scientist Adolph Reed, Jr. has called

"Bantustan administrators" - referring to the regime-selected representatives of the hypersegregated South African Apartheid-era districts of the same name. ${ }^{103}$

A sterling example of Forbes' cynical politics emerged during negotiations over city subsidies for the Cleveland Clinic's Midtown Corridor campus. When the Voinovich administration proposed financing a low interest loan program for middle-income homebuyers adjacent to the new Cleveland Clinic development, Forbes recognized immediately the prime motivation. As he put it, the new corridor would act as gentrified "buffer zones between the Clinic and the [impoverished minority] residents of Fairfax." Forbes blasted the proposal, and eviscerated Community Development Director Vince Lombardi at a meeting of the Council's finance committee. "I'm telling you that it's not going to happen," Forbes exclaimed; "if you think you are going to start building rose bushes and trees on Cedar [Road] to buffer white folks from black folks you are out of your damn mind ... It's just plain, down-South segregation."104 In classic Forbes fashion, however, his blustery speech was merely political cover. At that same meeting, he voted to pass the low interest loan program.

Members of the African American community were well aware of Forbes' self-interested politics. Armstrong Grace, a resident of Glenville, put a fine point on the matter in a tragically

\footnotetext{
${ }^{103}$ Adolph Reed, Jr., Stirrings in the Jug, 132.

${ }^{104}$ William R. Wood, “Forbes Speaks Out Against Gentrification Of East Side,” Call and Post, June 9, 1983.
} 
Cebul

derisive letter to the Call and Post: "I am writing this to inform the City of Cleveland, that there are people living in the Glenville area, specifically the area southeast of Superior. I say this because, at this time, I am at the end of my patience with this city. The area I'm referring to is part of our most well-known Council President's district. No one, however, in this entire city, including George Forbes, seems to acknowledge our existence." 105 The Plain Dealer, Grace noted, the city's major daily newspaper, even refused to deliver to his house. And Forbes, his councilman, had just advocated withdrawing all city money from public housing projects. ${ }^{106}$ Without meaningful representation, many in the African American community withdrew from participating in city politics. The result, another writer to the Call and Post complained, was widespread apathy. "Black voters won a resounding victory in the primary election" of 1985, the frustrated citizen wrote. "Their candidate, Black apathy (emphasis in original), defeated every other runner-up by a wide margin. ${ }^{\prime 107}$ While Forbes positioned himself as the voice of the neighborhood, because of his position as president of the City Council and leader of the Council's black caucus, his approval of the city's downtown development plans were crucial.

\footnotetext{
${ }^{105}$ D. Armstrong Grace, "Resident Questions Cleveland's Worth," Call and Post, March 19, 1987, 8A.

${ }^{106}$ Kerr, Derelict Paradise.

${ }^{107}$ Governor Foust, Letter to the Editor, “A resounding victory,” Call and Post, October 31, 1985, 9A.
} 
Cebul

His imprimatur on those plans, as well, legitimized for Voinovich and the Roundtable the turn away from creating a comprehensive development vision for the neighborhoods. ${ }^{108}$

With few exceptions, then, there was little organized resistance to the Dual Hub concept.

In part, this was because, with the major community groups demoralized or defunct, the Voinovich administration was left largely alone with business and Forbes' Council to decide the meaning of federal community participation mandates in its UDAG and CDBG programs. In addition, during its opening year, the administration created a highly regimented and politically orchestrated set of community participation workshops that were designed to favorably channel discussion and give the city as free a hand as possible in designating CDBG projects. Vince Lombardi, the director of Community Development, correctly anticipated that "neighborhood groups" would "see this as an infringement upon their role, responsibility and / or power base," but Voinovich opted to press ahead. ${ }^{109}$ When the city held mandated hearings on proposed UDAG or CDBG projects, it almost always opted for Tuesday mornings at 11:00 AM, a tough time to get away from work. ${ }^{110}$ Sometimes, the hour-long meetings were double booked -

\footnotetext{
${ }^{108}$ Indeed, there were alternative developmental visions in Cleveland, particularly during the 1970s. But, as Forbes moved closer to the city's business leaders and forged a productive relationship with Voinovich, the poorest neighborhoods lost their seat at the bargaining table.

${ }^{109}$ Vincent Lombardi to George Voinovich, June 23, 1980; George Voinovich to Boni, June 27, 1980, folder 1, box 6, GVV.

${ }^{110}$ Phillip C. Allen to George Voinovich, June 20, 1980, folder 53, container 2, GVV.
} 
Cebul

hearings for two multimillion-dollar projects conducted in the same slot. ${ }^{111}$ Some frustrated

citizens wrote to the mayor, complaining the meetings "were not the type of citizen

participation" they hoped for, "and that the meeting[s] skirted around neighborhood people."112

No changes to the structure of community involvement ever materialized.

While average citizens struggled to catch the Mayor's ear, business leaders enjoyed their formalized role in the city's private bureaucracy, where they impressed upon the mayor that UDAG spending alone was often not enough to ensure growth. Contrary to the Reagan era's faith in the free market, infrastructure improvements and reliable city services were crucial for creating a positive business climate, too. Leaders at Forest City Enterprises, who became key members of the Roundtable and Cleveland Tomorrow, reached out to Voinovich to secure federal support for Tower City Center, a redevelopment plan for Oris and Mantis Van Sweringen's skyscraper and regional transit hub. "Al Ratner and Shellie Guren," Voinovich wrote to his development director during their first month in office, "are interested in getting one half million to one million dollars worth of money for their Tower City project." Voinovich ultimately delivered far more than their initial request - Tower City received five UDAGs totaling \$31.5 million. UDAGs were instrumental, but it took Congressional rejection of President Reagan's plans to slash Community Development Block Grants to secure the Tower

\footnotetext{
${ }^{111}$ Public Hearing Notification of The Park and Flats Industrial Park UDAG Applications, $P D$, January 23, 1981.

${ }^{112}$ Ellen Abraham to Diane Downing, April 8, 1982, folder 24, box 10, GVV Papers.
} 
Cebul

City project. Indeed, the Roundtable happily noted that Congressional salvation of Block Grants "paved the way for the realization of the Tower City project in Cleveland by furnishing $\$ 12.5$ million [of block grants] for bridge repairs, a major stumbling block for over six years in plans to develop areas surrounding the Terminal Tower." ${ }^{, 13}$ Ultimately, it took an additional $\$ 54$ million from the Federal Urban Mass Transit Administration, the Ohio Department of Transportation, and several smaller contributions from state and federal sources to ensure the project's groundbreaking in 1988, nearly 15 years after it had first been conceived. Rather than inject needed federal and state funding into neighborhoods where Cleveland's residents lived, the city pumped millions of dollars into ensuring Tower City's developers would even take the UDAG. Forest City had not been waiting all those years for a freer market to break ground.

By 1989, when Voinovich became Governor of Ohio, the City of Cleveland would have been hardly recognizable to a visitor who hadn't been through in a decade. In addition to the worthwhile administrative overhaul of city operations, the city itself seemed entirely new. Forest City's Tower City Center was slated to begin leasing to upscale retail tenants that year. A few blocks away on $9^{\text {th }}$ Street, the city used another $\$ 3.5$ million UDAG to support the Jacobs Brothers' new glass roofed Galleria, another glittering upscale retail center that opened its doors in 1989 and that at last completed the campus begun in the early 1960s Erieview urban renewal

\footnotetext{
${ }^{113}$ Greater Cleveland Roundtable, “Block Grant Primer Update," October 1982, folder 17, box 13, GVV Papers.
} 
Cebul

project. On Public Square, across from Tower City, the Jacobs received another $\$ 10$ million in UDAGs to begin redeveloping a site that would soon be the foundation of the city's tallest building, the Society (later Key) Bank building. The city directed millions in UDAGs to an upscale housing scheme for the city's deindustrialized Flats district along the Cuyahoga River and spent millions more of its own capital improvement funds to attract upper income residents to the Warehouse District on the west side of downtown. In all, in just seven years, the city directed \$72.5 million worth of UDAG to commercial redevelopment of the downtown area and another $\$ 8$ million in University Circle. Together, they represented $80 \%$ of the city's total UDAG spending. All of this development was tailored to attracting middle and upper income residents and shoppers to the city's core - the kind of 'net' taxpayers described by Treasury Secretary Regan.

While the city pursued a comprehensive redevelopment plan in the Dual Hub areas, and as the Reagan Administration cut back on Block Grants, the city's neighborhoods were left to skirmish for crumbs from a smaller and smaller pie. Indeed, the money the city spent in community and neighborhood development was ad hoc, piecemeal, and shrinking. Decisions made by the Voinovich team made it even smaller. Though the Administration's use of CDBGs was more in the spirit of the original law than was the Perk Administration's (in part because the Carter Administration had tightened regulations a bit), Voinovich's Community Development department too used the federal program for 
Cebul

general revenue purposes and, when the Reagan cuts came, left the neighborhoods to deal with the costs.

From the 1985 CDBG program to 1986 , the year in which Reagan again slashed the federal budget, the city lost $\$ 9$ million of federal CDBG aid, shrinking the city’s program from $\$ 28,816,000$ to

$\$ 19,883,000$. The Administration was faced with hard choices, but by far the aspect of city governance that sustained the most drastic cuts was housing. Formerly, the city set aside $\$ 3.315$ million for housing and rehab programs. The lions' share of those program funds went to a rehabilitation program for weatherization of deteriorating structures, but that total had was cut from $\$ 2.82$ to $\$ 1.15$ million. The largest housing department expenditures went to fund the city's code enforcement department $(\$ 2.24$ million), which was actually an increase in expenditures that empowered the city to force residents to use their own capital to make renovations - or face fines and eviction. ${ }^{114}$ The city did, however, offer a $\$ 500,000$ program to Community Development Corporations to stimulate private investment in marketrate housing for new middle class residents, which, the city claimed, would soon result in 800 new housing units; however this funding was more about gentrification than shoring up the neighborhoods and homes of longstanding residents. By far, however, the city's largest CDBG expenditure was the \$3.567 million it set aside for “administration" purposes, funds the city could move through its various

\footnotetext{
114 There were a range of other small grants to neighborhood associations for painting and rehabbing homes, but the largest of these in 1986 was $\$ 300,000$ which was spread among 9 discrete neighborhood groups. Otherwise, the city offered grants generally between $\$ 30,000$ and $\$ 50,000$ for neighborhood corporations to rehab or acquire and board up abandoned homes. Figures compiled from Community Development Block Grant, Year XI Projected Use of Funds and Community Development Block Grant, Year XII Projected Use of Funds, Project Summary, folder 12, box 12, GVV Papers.
} 
Cebul

development departments to support whichever programs it saw fit. As this snapshot suggests, while the city poured resources into commercial development and efforts to attract middle and upper income residents, it all but ignored the needs of its residents.

As Voinovich headed to Columbus to take over the Governor's mansion, he left behind a city and region more economically stratified than ever before. As federal community and economic development policies trickled up to the city's commercial core, the impoverished neighborhoods that ringed the city's south and east sides reached levels of poverty inconceivable in Voinovich's first term. Between 1980 and the end of the Voinovich years, the poverty rate in the city increased by more than one third, and over 65 percent of the population in three predominantly black neighborhoods on the east side - including Hough and Glenville, Council President Forbes' ward - lived below the poverty line. Indeed, in 1988, over half the residents of 40 percent of the city's census tracks lived in poverty; in 1970 that figure had been just 3.5 percent. ${ }^{115}$ Despite sizeable though shrinking federal expenditures through CDBGs and UDAG that could have been used to rehabilitate homes and shore up neighborhoods, nearly 20 percent of the city's housing stock was substandard, and the city still had an exceedingly long wait list to get into public housing. ${ }^{116}$

\footnotetext{
${ }^{115}$ Poverty Indicators, Volume VI, 1988, Council for Economic Opportunities in Greater Cleveland, 15, PAL.

${ }^{116}$ Keating et al., 123-4.
} 
Cebul

Under the guise of maximizing investments in community development, a range of motives, policies and values were brought to bear on revitalizing the city of Cleveland. Though elites sometimes meant no harm and some genuinely felt they were doing good, the discourse of public "investments" and the easy faith in trickle down economics provided useful cover for a process of disinvestment in the city's most marginal communities. As a result, Cleveland's political discourse slid further away from venerating public, collective effort and toward lionizing private action. On the surface, it appeared that neoliberal faith in markets was winning the day. In reality, political and business elites embraced the era's ascendant market speak but pursued a much broader range of simulative public policies that suggest striking continuities with, rather than disjuncture from mid-century, growth liberal policymaking. As Reagan slashed federal spending, the result was narrowed room for political and policy actors to maneuver. In total, this suggests that the 1980 s witnessed not so much a sweeping intellectual or ideological sea change, but instead a tentative, pragmatic acceptance of a new policymaking paradigm, the watchwords of which - embraced heartily by Cleveland's Reagan Democrats - privileged market forces rather than enduring but subtle - and normatively bounded - forms of collective initiative. And still the city's urban crisis raged on. In 1970, the city's population was still over 750,000 . By 1990, it had plunged to 505,616 (today it is around 395,000). Instead of advocating for renewed public investments, however, business leaders called for charity and bootstraps 
Cebul

efforts on the part of impoverished citizens. "The opportunity we have is to give them the opportunity to help themselves," said Albert Ratner, CEO of Forest City, Roundtable member and the lead developer of Tower City and its publicly subsidized Ritz-Carlton Hotel. "Individuals have to save themselves."117 Ratner essentially echoed Myron Magnet's prescriptions for solving social ills: "One lesson Americans learned in the 1980s was that they had to take responsibility for their own fates."

Though business had capitalized on robust public policies, as the 1980 s became the 1990s, the city's business elites once again awakened to the dire circumstances in the city's neighborhoods - a situation which threatened their bottom line. Their Dual Hub concept, built on abatements and a nearly zero sum use of federal subsidies, had failed to generate tax revenue or new growth. Instead, they had further impoverished the city's schools and neighborhoods.

Suburban residents, driving past the continued crisis areas, never much considered moving in and instead enjoyed the downtown before retreating back to their suburbs.

It took the Wall Street Journal's closing of its Cleveland bureau in the late 1980s, for Roundtable members to swing into action. Richard Pogue and other leading business boosters, all veterans of the Roundtable, flew to New York to shop an idea for a magazine article that would describe the unusually good climate Cleveland's businesses has created. When they met

\footnotetext{
117 “Reversal of Fortune,” Newsweek, September 9, 1991.
} 
Cebul

Myron Magnet, the group sat down together and penned the over the top Fortune article, "How

Business Bosses Saved a Sick City." ${ }^{118}$ The article did little to galvanize new investment.

Today, Tower City struggles with dangerously low commercial and retail occupancy, and

the city and Forest City recently struck a buyout agreement on the remainder of the company's

UDAG debt. Rather than pay back the total value of the no- or low-interest UDAG loans, the city

cut one-third to half the debt to receive a one-time payment, a final subsidy for a dying project.

While the city's building boom continued into the 1990s - two new stadiums, the Rock n' Roll

Hall of Fame, and a new lakeside Science Center were all built with generous public subsidies -

the federally backed commercial developments of the 1980s struggled with persistently high

vacancy rates. ${ }^{119}$ The Jacobs Brothers' Galleria mall, another UDAG-backed project, opened

with great fanfare in 1987, but, by 2011, it had been converted into a giant, urban greenhouse for

farming organic produce. As one urban farmer put it, "It's not really a shopping mall

anymore." ${ }^{120}$ Thirty years later, however, Fannie Lewis' Lexington Village is still a viable,

almost always at-capacity community in the heart of what is still one of the nation's poorest

city's poorest neighborhoods.

\footnotetext{
${ }^{118}$ Author interview with Richard Pogue, December 29, 2010, Cleveland, Ohio.

${ }^{119}$ Thomas Ott, "Forest City paying \$10.3 million to close out \$15 million in city loans," Plain Dealer, May 25, 2011.

${ }^{120}$ Sarah Crump, "Galleria mall is giant greenhouse, raising organic crops in Cleveland," Plain Dealer, February 27, 2010.
} 
Cebul

\section{Chapter Ten}

Developmental States:

New Democrats and the New Economy

The Reagan Revolution seemed to cement a reassertion of the primacy of private sector action and the intertwined values of restrained government and individual initiative. Analysts then and since have written a variety of elegies for the Democratic Party and the New Deal Order. ${ }^{1}$ The "New" Democrats who emerged during the 1980s, scholars have argued, represented a turn to the right - a capitulation to the Reagan revolution. ${ }^{2}$ But these interpretations of the "New Democrats" and of the wholesale demise of liberalism, rely on a narrow reading of the history of the Democratic coalition and overstate the degree to which the Reagan years overturned New Deal policies and modes of governance. ${ }^{3}$ Indeed, as this chapter reveals, Reagan faced strong philosophical differences within his own party and from Democrats. Recent narratives, too, also obscure one of the Democrats' longstanding sources of broad political appeal: their producerist emphasis on economic growth. Indeed, rather than steal from the Republicans, the "New" Democrats updated and repackaged New Deal and postwar

\footnotetext{
${ }^{1}$ See, for instance, Steve Fraser and Gary Gerstle, eds., The Rise and Fall of the New Deal Order, 1930-1980 (Princeton: Princeton University Press, 1989), and Jefferson Cowie and Nick Salvatore, “The Long Exception: Ret hinking the Place of the new Deal in American History," International Labor and Working-Class History, 74, 1-32.

${ }^{2}$ See, for instance, Kenneth Baer, Reinventing Democrats.

${ }^{3}$ Judith Stein points out, for instance, that labor had always been a minority stakeholder in the Democratic coalition, and that, the AFL-CIO, for instance, was only active in ten states. See Stein, Pivotal Decade, 181.
} 
Cebul

developmental state liberalism as a high tech, public-private model of growth-oriented

leadership. Democratic Governors such as Bill Clinton in Arkansas, Joe Frank Harris and Zell

Miller in Georgia, and James Hunt in North Carolina created innovative partnerships with

Universities and between the public and private sectors that generated new forms of venture capital, business incubators, and offered new tools for generating productivity and insulating high tech entrepreneurs from risk. ${ }^{4}$ Indeed, these governors greeted the reality of the Reagan years by creating developmental states across the country. ${ }^{5}$

To be sure, their conflation of "economic development" with fighting poverty angered the Democratic left, but conservatives had hardly cornered the market on denying structural poverty or racism. An aversion to outcome-based redistribution had deep roots among many in the Democratic coalition, as well, and reflected a majoritarian and anti-structural strain of liberalism that had held a prominent place in the Party since at least the New Deal. ${ }^{6}$ By Turning

\footnotetext{
${ }^{4}$ As economic historians David Carlton and Peter Coclanis have argued, prior to World War II, the South had generally failed to "develop the sort of institutional 'support network' that could underwrite risk and absorb failure." Without well-developed capital markets or publicly backed research and development, the leaders of southern business and industry had generally "prized stability over risk," which "reinforced the propensity of southern entrepreneurs to go for the tried and true, rather than the risky cutting edge." This chapter explores how New Democrats forged ne public instruments that enabled them to stimulate innovation and entrepreneurship. David Carlton and Peter Coclanis, The South, the Nation and the World, 9.

${ }^{5}$ On Michael Dukakis' efforts to create high tech economy in Massachusetts, for instance, see Lily Geismer, forthcoming book, Princeton University Press.

${ }^{6}$ Astute political commentator E.J. Dionne drew direct parallels between Jimmy Carter and the next New Democrat to vie for the White House, Massachusetts Governor Michael Dukakis. See Dionne, Why Americans Hate Politics. On Democrat's longstanding aversion to fundamental structural reform on behalf of minority members of their
} 
Cebul

to Technology, as a Southern Growth Policies Board publication during Clinton's time as

chairman put it, the new Democrats reawakened a potent strain of majoritarian liberalism that brushed aside concerns about structural discrimination in favor of an optimistic ethos of social reform and individual opportunity promised in a high tech future.

\section{The New Politics of Austerity}

Newt Gingrich spent the second half of the 1970s searching for fresh political ideas and wedge issues. On the campaign trail for U.S. Congress in 1978, the history professor believed he had finally found the one. Georgians' response to the Kemp-Roth tax cut proposals was, for Gingrich, a revelation. After speaking in 1978 before Jaycees, Kiwanians, and Civitans, the Congressional candidate wrote an effusive memo to Georgia Republican Party chairman (and later U.S. Senator) Mack Mattingly. Some members of his audiences expressed some "disbelief on the grounds that" it sounded gimmicky and would "increase the deficit and therefore increase inflation ( . . inflation is the \#1 concern in our district. . . )." Otherwise, Gingrich wrote, the proposal, "is working more effectively than any issue I have discussed in 5 years of campaigning." He closed with trademark gusto: "IN CONCLUSION: THE PROPOSAL EXCEEDS ANYTHING I HAVE SEEN IN 18 YEARS OF POLITICS AND 5 YEARS

coalition, see Stein, Pivotal Decade, McKee, “The Government is with Us," in Orleck and Hazirjian, eds., The War on Poverty, and Katznelson, When Affirmative Action was White. 
Cebul

CAMPAIGNING IN ITS POTENTIAL TO CREATE A CONSERVATIVE MAJORITY IN

THIS COUNTRY."7

Gingrich's papers from these years offer a rich archival snapshot of a nation and an

opportunistic politician wrestling with a new politics of austerity. As prices rose and rose,

Americans of all walks of life questioned their civic (i.e. tax paying) obligations. ${ }^{8}$ Some

wondered whether paying taxes actually contributed to spiraling inflation. As a US News and

World Report poll found, 61\% of Americans by 1978 agreed that government was the major

cause of inflation; $60 \%$ also blamed labor unions. The bottom line was that there was

"Widespread distrust of government in practically all its forms, with a feeling that elected

officials are not up to coping with many national problems." These sentiments were paired with

Americans" "reluctance ... to make financial and other sacrifices required to solve national

problems." "I’m basically down on everything," a small business owner told US News. A

salesman suggested, "We should scrap most welfare programs, provide jobs and make everyone

who gets anything free prove they need it." Particularly visible policies and institutions such as

\footnotetext{
${ }^{7}$ Newt Gingrich to Mack Mattingly, March 1978 memo, folder March 1978 memo, box 37, Newt Gingrich Papers, West Georgia University, Carrolton, Georgia [hereafter NGP].

${ }^{8}$ See, for instance, Molly Michelmore, Tax and Spend: The Welfare State, Tax Politics, and the Limits of American Liberalism (Philadelphia: University of Pennsylvania Press, 2012).

9 “When People Speak Out on Today's Issues," US News and World Report, February 13, 1978, folder Inflation, box 37, NGP.
} 
Cebul

welfare, greedy labor unions, and federal support for minority hiring were most often singled

out. "As for politicians," said one craftsman, "95 per cent belong in cages."

As Gingrich well understood, it would be hard to overstate the impact of inflation on

American politics over the late 1970s. August institutions like the Wall Street Journal wrung

their hands over whether, as one 1978 editorial headline asked, "Has Capitalism a Future?"10 In

Georgia, the Atlanta Constitution editorial page worried "if America ever falls" inflation may

well be "the terminal disease that killed us." As the annual inflation rate hit 10.8 percent - a rate

at which prices would double roughly every nine years - the Constitution reflected the popular

wisdom that spiraling rates were "a plague of our own making."

Government spending billions of dollars in deficit year after year; . . the idea that every person deserves a high standard of living in America whether he works for it or not; the idea that business profits are 'dirty'; the high rate of taxation on personal and business income to finance increasingly wasteful government programs; the idea that government bureaucrats know better how to regulate and run the nation's businesses and industries than the businessmen themselves ... ; the idea that workers deserve more and more pay for less and less work.

As the editors of Atlanta's leading paper bluntly concluded, "Inflation is messing us up.

And it will continue to do, until we learn that we - government, business, labor - are in the same

\footnotetext{
${ }^{10}$ Paul Johnson, “Has Capitalism a Future?” WSJ, September 29, 1978, folder Inflation, box 37 NGP.
} 
Cebul

boat." ${ }^{11}$ Their litany of complaints, tensions, and oppositions, however, belied any sense of

optimism. In the new politics of austerity, most Americans called for others to sacrifice.

Keynoting the Rome Chamber of Commerce's Annual Meeting in 1980, William R.

Bowdoin offered his diagnosis of the nation's ailments. Bowdoin was the retired chairman and director of the Trust Company of Georgia and was an advisory director to the statewide First National Bank and Trust. An Atlanta resident, Bowdoin's rearguard call for businessmen to reclaim their political standing belied his status among the state's elites: he served on the Board of Trustees of Emory University and was the chairman of Emory's Woodruff Medical Center. As he reminded Rome's Chamber members, private enterprise is "the keystone to all we have." As the News Tribune put it, business was "the country's provider." Bowdoin linked the possibilities for renewed business leadership to his concerns about weak voter turnout. As he put it, "it's no longer a democracy when we are governed by minority interests. . When those who pay no tax use their vote to dictate how the taxes are spent ... we're in trouble." In short, "We've got to get back to the values born in hard work." ${ }^{12}$ Bowdoin's perspectives were widely shared among

\footnotetext{
11 "Spolier of the Dream," Atlanta Constitution, August 24, 1978, folder Inflation, box 37, NGP.

${ }^{12} R N T$, January 18, 1980, folder Chamber of Commerce: 1980s, RFL / HRA.
} 
Cebul

many of the nation's businesspeople, from small shop owners to corporate executives. ${ }^{13}$ Indeed, Georgia's businesspeople embraced the business producerism sweeping the country. ${ }^{14}$

The new politics of austerity fostered a period of dramatic ideological transformation among members of the Rome Chamber of Commerce. In contrast, in 1975, the Chamber had pragmatically pointed out the value of public services that failed "to turn a profit." In the Forum, the Chamber's bimonthly publication, Chamber president W.G. McWilliams laid out a nuanced argument for public spending, especially as a counterbalance for sagging markets. But, as gas prices soared that summer, the City Commission voted to end bus services because, "the service has not been profitable." "It seems to me," McWilliams argued, "that this is the wrong course to take at this time." "In every instance, officials of firms considering locating here will ask about public transportation. Our favorable position ... won't be improved when we have to say, 'Well, we just don't have any wheels.' Let's go slow on this recommendation, City Commissioners." 15 McWilliams made a broader appeal: "a lot of other city services are unprofitable too, but we like to hope they will be continued for those who are dependent upon them."

\footnotetext{
${ }^{13}$ On big business' political mobilization, see Benjamin Waterhouse, Lobbying America: The Politics of Business from Nixon to NAFTA (Princeton: Princeton University Press, 2014). See also, Kim Phillips-Fein, Invisible Hands. 
Cebul

Like so many other communities across the country, however, as Rome entered the 1980s, morale was low, particularly among its businesspeople. Battered by the economic distress of the 1970s, between 1979 and 1984, Floyd County lost 1,676 manufacturing jobs as several firms downsized and one closed. ${ }^{16}$ To the north, Dalton, America's "Carpet Capital," fared even worse as international competition withered the American textile industry. ${ }^{17}$ This deteriorating climate was exacerbated by local manifestations of the national trend toward decentralization of business and residences. Romans initially heralded the development in 1975 of a major shopping mall on the outskirts of town as a sign of progress and growth. As the Chamber's Forum put it, "The project assures Rome's dominance as a regional shopping center."18 The mall ultimately lured two anchor department stores away from downtown. By 1980, Rome's downtown occupancy rate had plunged to 25 percent. "The consensus after the mall opened," said one city official, "was that downtown was dead, that all those old buildings ought to be bulldozed into the river." ${ }^{19}$ One Chamber survey of its members found that many "do not feel good about their community, and some have lost confidence in their community's ability to compete. These are

\footnotetext{
${ }^{16}$ Stuart Mieher, "How Diversity Saved North Georgia," Georgia Trend, April 1986, HSCL.

${ }^{17}$ On Dalton's carpet mills struggles with unionization, globalization, and stagflation, see Douglas Flamming, Creating the Modern South: Millhands and Managers in Dalton, Georgia, 1884-1984 (Chapel Hill: University of North Carolina Press, 1992), 309-27. See also, Randall L. Patton with David B. Parker, Carpet Capital: The Rise of a New South Industry (Athens: University of Georgia Press, 1999), 248-85.

${ }^{18}$ Forum, January 1974, HSCL.

${ }^{19}$ Stuart Mieher, "How Diversity Saved North Georgia," Georgia Trend, April 1986, HSCL.
} 
Cebul

strong feelings," the Chamber reported, "which could not be swept under the rug."20 "Rome is just not keeping up with our competitors," warned Chamber president Seth "Pistol" Knight.

Trapped by the new economic climate, Chamber members like Knight hoped for public subsidies for industrial development, calling for infrastructure improvements and public finance for a new 500-acre industrial site. He recognized, though, that "We're going to have to look stronger, harder for diversified growth." ${ }^{21}$ Industrialization seemed less and less sustainable. Upon his retirement after 21 years as the Chamber's executive vice president, Carl Collins agreed, calling for programs to revitalize the downtown service, retailing, and entertainment sectors. "I would like to see the Rome bypass completed, a civic center complex become a reality; the Rivers Beautification Park program, complete with river front shopping mall and modern libraries facilities instituted."22 Still, each of these projects required significant public resources, funds that were hardly in the offing in the early 1980 s.

Dwindling opportunities for publicly financed improvements coincided with changes in the Chamber's professional staff and a shift in the Chamber's ideological outlook. Bruce Schlosberg, a Massachusetts native who had run a rural North Carolina Chamber replaced Collins as executive director. Schlosberg arrived in 1982, and, in addition to diversifying the

\footnotetext{
${ }^{20}$ Forum, August 1983, HSCL.

${ }^{21}$ RNT, January 19, 1981, folder Chamber of Commerce: 1980s, RFL / HRA.

${ }^{22} R N T$, December 30, 1981, folder Chamber of Commerce: 1980s, RFL / HRA.
} 
Cebul

city's economic base, he identified promoting free-enterprise as a major goal, an activity that had not been a significant piece of Chamber programming to that point. "It's not just educating the public," he said. "It's starting in the schools to educate the kids. You'd be surprised how many kids think it's a sin to make a profit." ${ }^{, 23}$ For recruitment, Schlosberg targeted small and medium sized businesses, and, despite his interest in free markets, he secured the Chamber's designation as a federal Small Business Administration Resource Center. The Chamber, rather than the Coosa Commission, would serve as the local clearing house for information about SBA financing, training programs, as well as the federally funded Small Business Development Center at Floyd County Junior College. Said Schlosberg, “The Chamber's willingness to embrace this concept is an excellent example of positive partnership between the public and private sectors. ${ }^{, 24}$

Schlosberg's next move, however, generated grumbles from longer standing Chamber members as well as the broader community. In focusing laser like on industrial and business recruitment, he recommended the Chamber move away from promotional and civic activities. "You have to ask yourself about the Christmas parade's role in economic development," Chamber president John Graham said, echoing his new director. The parade entailed "an awful lot of staff time and other work," and given the Chamber's "limited resources" it made more

${ }^{23} R N T$, January 8, 1982, folder Chamber of Commerce: 1980s, RFL / HRA.

${ }^{24} R N T$, February 23, 1982, folder Chamber of Commerce: 1980s, RFL / HRA. 
Cebul

sense for it to function as "a think tank type place." Schlosberg brushed aside questions about the Chamber's role in the city's civic life: “The public wants a good economy. We're going to be actors, rather than reactors." Wesley Johnson, a decades long veteran of the Rome Chamber and Coosa Commission wasn't so sure. 'I've always been in favor of good economic and industrial development," he said, but "I certainly feel there are other areas our Chamber needs to address besides economic development." Events like the parades and luncheons, he said, were "kind of a rallying point for the community." 25 Despite such misgivings, the Chamber halted sponsorship of its non-recruitment activities. This included the city's Fourth of July celebration, which the businessmen had sponsored since the turn of the century. "We've got to realize we can't do everything for everybody," the Chamber president said. ${ }^{26}$

This turn toward a narrower conception of the Rome Chamber's role in the community reflected an embrace of a harder ideological mode spurred by the politics of austerity. Previously the venue for pragmatic calls for public investments in infrastructure and civic services, under Schlosberg the Forum became a swashbuckling mouthpiece for economy in government and free markets. When the County Commission and the Floyd County Board of Assessors faced massive budget shortfalls, the agencies updated their method of assessing the value of industrial

\footnotetext{
25 “Chamber of Commerce reorganization sparks debate," $R N T$, December 5, 1982, folder Chamber of Commerce: 1980s, RFL / HRA.

${ }^{26} R N T$, December 7, 1982, folder Chamber of Commerce: 1980s, RFL / HRA.
} 
Cebul

machinery in hopes of closing their budget gap. "Trending" assessments incorporated the inflated worth rather than the original purchase price of equipment, pushing up the assessed value. ${ }^{27}$ Whereas once the Chamber might have worked behind the scenes to find alternative revenue sources, their response in 1983 reflected an increasingly extreme market discourse that had arrived with inflation and Schlosberg. "To me," wrote the Chamber president,

COMPETITION is the brightest, shiniest, most magnificent, word in the dictionary, while its nemesis, SECURITY, is a dirty, four-letter word, not fit to be used in the company of good Chamber members. COMPETITION means that there are no favorites - merit determines all reward ... COMPETITION demands innovation, and it demands efficiency; and, thus, it is COMPETITION that reduces costs, creates new products and new jobs, and increases our standard of living ... It should be remembered that the cancer of government inefficiency, waste, and out-of-control growth has, as its major symptoms, the insatiable demand for higher taxation. Taxation is, at best, a necessary evil; but it is foolish when it discourages investments and therefore job expansion...

In decrying government inefficiency and waste, the Rome Chamber invoked a muscular vision of business producerism. "We must remember that all jobs, be they government or private, depend upon the success of private industry operating in this community." Whereas once partnership with government offered fruitful possibilities, in the wake of the 1970s and local policies like trending, the Rome Chamber viewed the public and private sectors in increasingly zero sum terms. "Continued government growth and spending, while the private economic base

\footnotetext{
${ }^{27}$ Forum, November 1982, HSCL.
} 
Cebul

declines, cannot long continue. Our message to government is, "YES, WE KNOW YOU HAVE

A BUDGET PROBLEM ... BUT, SO DO WE. YOU CANNOT SOLVE YOUR BUDGET

PROBLEMS UNTIL WE SOLVE OURS. .28 Business was primary.

As opposed to the Coosa Commission, whose activities went largely unreported in the

Forum during these years, the Chamber viewed Rome's place among the other cities and

counties of the region in partisan terms. Under its new leadership, the Chamber believed that

sound business leadership and private initiative would lead the city back to economic health, but

it would do so in competition with its former regional partners. To attract new industry and

service sector jobs, the Chamber developed a new multiyear program called "Greater Rome: A

Partnership for Growth." "We've seen all sorts of cities getting ahead of us," said Knight.

“There's enormous competition for new business money and we've got to go out and get it."

Targeting one million dollars in private donations, the Chamber planned to build a new Chamber

home "that will more faithfully reflect the image of a community on the move." ${ }^{, 29}$ Their new base

of operations would house a refashioned marketing operation that would target health and

education related service jobs. ${ }^{30}$ Once the Chamber funded its million-dollar pool, Pistol Knight

told the News Tribune: "We're like a panther or a tiger," he said. "We're poised and we're just

\footnotetext{
${ }^{28}$ Forum, February 1983, HSCL.

${ }^{29} R N T$, January 23, 1985, folder Chamber of Commerce: 1980s, RFL / HRA.

${ }^{30} R N T$, clipping 1985, folder Chamber of Commerce: 1980s, RFL / HRA.
} 
Cebul

ready to pounce on somebody." ${ }^{31}$ Rome's businesspeople believed their efforts would be

sufficient to generate economic growth. Rather than engage the Coosa Commission's publicly

funded experts, the Chamber hired its own "economic-development specialist.",32 They viewed

public and private initiative, for the time being at least, as in competition.

Reagan's New New Federalism

This spirit of competitive market individualism and business producerism formed a

crucial piece of Ronald Reagan's electoral appeal. ${ }^{33}$ Often overlooked in accounts of the Reagan

Administration's domestic agenda, however, was the attention the President and his aides

focused on philosophical questions of federalism. ${ }^{34}$ Reagan linked "restoring" a proper model of

federalism to freeing individual, private sector, and local governmental initiative from the

strictures of national regulation and bureaucratic imperatives. If Nixon's New Federalism sought

to rationalize and reform national government, Reagan's New Federalism aimed to decentralize

${ }^{31} R N T$, January 16, 1987, folder Chamber of Commerce: 1980s, RFL / HRA

${ }^{32} R N T$, February 4, 1986, folder Chamber of Commerce: 1980s, RFL / HRA.

${ }^{33}$ There is a rich and growing literature on Ronald Reagan and his electoral appeal. Less attention, however, has been paid to his policies and governing legacy. On the former, see especially, Gil Troy, Morning in America, Sean Wilentz, The Age of Reagan, Daniel T. Rodgers, Age of Fracture. On Reagan's policies and governing agenda, see especially, W. Elliot Brownlee and Hugh Davis Graham, eds., The Reagan Presidency: Pragmatic Conservatism and its Legacies (Lawrence: University Press of Kansas, 2003), Robert O. Self, All in the Family, ch. 13, and Paul Pierson, Dismantling the Welfare State?

${ }^{34}$ In one excellent edited volume, for instance, "New Federalism" receives four mentions. Brownlee and Graham, eds., The Reagan Presidency. 
Cebul

and devolve key programs through a frontal assault on the New Deal and Nixon's New

Federalism model of cooperative federalism. ${ }^{35}$ Much of Reagan's first State of the Union was

devoted to laying out his new vision of intergovernmental relations, and in March 1981 the

President instructed his cabinet to begin working out the details of a federalism reform

program. ${ }^{36}$ As the Administration's subsequent statement, "Reagan Federalism: Restoring the

Balance" put it, "During some 50 years, power and revenue sources have flowed relentlessly

toward Washington. Federal bureaucrats have been treating elected state and local officials as if

they are nothing more than administrative agents for Federal authority." In order to make

government work again, Reagan pledged "to return power and authority and revenue sources

back to state and local governments.",37

Returning power, authority, and revenue sources sounded good to state and local

governments, which had been slammed by inflation and tax revolts. To many, Reagan's words

echoed Nixon's New Federalism, which had created Revenue Sharing and Block Grants,

\footnotetext{
${ }^{35}$ For an incisive if overly sympathetic analysis of conservative efforts to roll back the national government, see Timothy Conlan, From New Federalism to Devolution: Twenty-Five Years of Intergovernmental Reform (Washington, D.C.: Brookings Institution Press, 1998). On the evolution of American federalism in general, see especially, Martha Derthick, Keeping the Compound Republic.

${ }^{36}$ Ronald Reagan, Memorandum for Members of the Cabinet and Agency Heads, March 20, 1981, folder M, RCB19481, State of Georgia Archives, Morrow, GA [hereafter GAA].

37 "Reagan Federalism: Restoring the Balance," folder Federalism Initiative (1), box 13, series II: Subject File I, 1981-1984, WH Staff Member and Office Files: Media Relations, Ronald Reagan Presidential Library, Simi Valley, California [hereafter RRL].
} 
Cebul

mother's milk for local governments' strained budgets in the 1970s. George Busbee's successor

as Governor, Democrat Joe Frank Harris, reflected this hope for another Nixon-style New

Federalism. Like Mayor Voinovich in Cleveland, Harris thought Reagan's New Federalism would mean "Fair Deal Federalism" for Georgia. "Block grants," Harris said, "are a key factor in New Federalism because they represent a combination of budgets of a number of previously separate programs into a lump sum for dispersal by state governments." He pointed to the success of the state's use of Community Development Block Grants: "As other block grants come to Georgia, we will repeat this highly successful approach to their allocation, involving the players in writing the rules of the game. New Federalism," said Harris, "doesn't mean a free ride for Washington at the expense of the state."38

Along with Harris, politicians like Newt Gingrich joined a broad base of local businesspeople who subscribed to Nixonian New Federalism. In 1979, the freshman Congressman commissioned a report on the impact the loss of General Revenue Sharing might have in his district. From tax hikes and new usage fees to reducing services, a post-Revenue Sharing financial situation in small, rural areas looked bleak. The demise of Revenue Sharing would likely result in an $18.8 \%$ property tax hike throughout Gingrich's district at precisely the

\footnotetext{
${ }^{38}$ Joe Frank Harris News Release, July 12, 1982, DOC-3862, GAA.
} 
Cebul

moment when property tax revolts were springing up around the country. ${ }^{39}$ Across the state,

Revenue Sharing funding accounted for 8.5 percent of local government revenue. In an article

strongly echoing his report and another from the Advisory Commission on Intergovernmental

Relations, Gingrich argued that, while "we have to balance the budget, . . . revenue sharing

should be the last program we cut" in order to do so. The "villain," he argued, "is the steadily

increasing number of categorical grant programs with their rules, regulations, and mandates.” He

argued for cutting programs that "accelerate the trend towards centralization of power in the

federal government - programs that put local governments in a straight jacket." ${ }^{40}$

Like Gingrich, businesspeople supported revenue sharing in great numbers. The Chamber

of Commerce of the U.S. was one of the first business organizations to come out in support of

revenue sharing. Prior to its reauthorization in 1975, the Chamber surveyed its local affiliates and

"found overwhelming support for the program." They reissued the survey in 1980, when the

program was again up for reauthorization, and found that "the GRS program is strongly

supported by local chambers of commerce throughout the nation.” Seventy-three percent of local

Chambers said they would actively support reauthorization. Meanwhile, 8 local chambers, or

\footnotetext{
${ }^{39}$ An Analysis of the Impact of General Revenue Sharing on Georgia's Cities, The Georgia Municipal Association, August, 1979, folder Revenue Sharing Article, box 147, NGP.

${ }^{40}$ Article for Urban Georgia, Newt Gingrich, October 31, 1979, folder Revenue Sharing Article, box 147, NGP.
} 
Cebul

$.03 \%$, opposed the program. ${ }^{41}$ Businesspeople joined Gingrich in supporting Nixon's version of cooperative federalism, not Reagan's devolutionary New Federalism.

Indeed, House Republicans were far more pragmatic during these years than their rhetoric suggests. Over 1979 and 1980, the Republican Economic Task Force - whose members included Gingrich, Barber Connable, Jack Kemp, David Stockman, and John Rhodes developed economic policies that were explicitly based on old growth liberal programs but which they sought to reframe as both new and conservative. ${ }^{42}$ Given the history of liberal economic development stimulus for business, these insurgent Republicans worried, as one Gingrich staff memo put it, that most Americans “wouldn’t identify 'supply-side economics' as a Republican approach. They would get a general message of a 'new business program supported by liberals." But, by repackaging longstanding Democrat programs - business investment credits, tax cuts, defense spending - in a new rhetorical frame (Gingrich's aide proposed "growth economics," "incentives economics," or "opportunity economics") they hoped to boldly recast venerable and rather quotidian growth strategies as a genuinely new Republican strategy for

\footnotetext{
${ }^{41}$ Report to the Board of Directors on General Revenue Sharing, February 6, 1980, folder Board Reports $409^{\text {th }}$ Meeting, February 21, 1980, box 6, series I, Papers of the Chamber of Commerce of the United States, Hagley Museum and Library, Wilmington, Delaware [hereafter CCUS].

${ }^{42}$ Meeting Minutes, Republican Economic Task Force, December 18, 1979, folder Economic Task Force, box 293, NGP.
} 
Cebul

growth. ${ }^{43}$ Gingrich's staffer struck a nerve. In the margins Newt wrote, "Bold . . . well thoughtout." Newt suggested the path that House Republicans would ultimately choose: "If supply-side economics will be written about favorably - no matter what the content - we don't need to control that lable $[\mathrm{sic}]$ - we need only surf upon it." Nevertheless, concerns about being associated with past Democrats persisted. When the Republican task force circulated an informal poll to find consensus on a label, "growth economics" was the clear winner. "Supply-side Economics" received zero votes. ${ }^{44}$

Republicans were right to worry that Democrats might seize the tactical higher ground on supply side. Texas Democrat, Senator Lloyd Bentsen, chairman of the Joint Economic Committee, was an outspoken supporter, saying "By force-feeding demand and starving supply over an extended period of time, we've created a situation in which inflation is inevitable.",45 Staunch liberal Massachusetts Senator Edward Kennedy agreed. "The top priority on our economic agenda must be a major new national commitment to the twin goals of productivity and innovation ... That means new incentives for savings and investment, for entrepreneurs and

\footnotetext{
${ }^{43}$ David Warnick, Can We Seize Control of the Supply Side Economic Label? Should We?, folder Economics Information, box 294, NGP.

${ }^{44}$ Poll attached to David Warnick, Can We Seize Control of the Supply Side Economic Label? Should We?, folder Economics Information, box 294, NGP.

45 “Big Push For Business Tax Cuts,” Dun's Review, November 1979, attached to David Warnick, Can We Seize Control of the Supply Side Economic Label? Should We?, folder Economics Information, box 294, NGP.
} 
Cebul

business firms. ${ }^{46}$ That year, 1979, the Joint Economic Committee published its first report in two decades calling for supply-side solutions to the nation's slumping economy. Indeed, their recommendations read like a document from the high tide of late 1950s and early 1960s developmental state building: programs and incentives for investment and savings; funding for research and development; trimming government spending; and easing the regulatory burden on business. Joining Kennedy and Bentsen in signing the recommendations were dyed-in-the-wool liberals such as George McGovern.

Pressured by liberals who were looking for policy inspiration to the early 1960s, conservative politicians sought other ways to draw distinctions. Perhaps no politician's early career best illuminates the disjointed nature of conservative politics in the 1980s - swaggering and combative rhetoric masking more pragmatic policy realities - than Gingrich. In terms of political style, Gingrich explicitly sought to cultivate a harder hitting, more polarizing political discourse. His efforts bordered on the obsessive. The Congressman filled notebook pages with long numbered lists of maxims and strategies. One 85-point list included items such as: "44. Real opposition leads to real victory. 45. Eschew 'consensus' that impedes leadership . . . 48. Use individuals as symbols - examples." Republicans, he noted, must “change governing strategy so

\footnotetext{
${ }^{46}$ Ibid.
} 
Cebul

we fund our friends, not enemies." Another list included the axiom:“64. Have no shame.” The

first item on yet another read, "1. Bomb appropriate persons."47

While Gingrich planned partisan bombing runs, his policy preferences continued to hew

to the middle of the spectrum. Gingrich's support for some of Reagan's policies, in fact, reveals

a politician who well understood how disjunctive LBJ's Great Society / War on Poverty

federalism had been for Americans' perceptions of government. In a 1982 speech defending his

(and Reagan's vision of the "conservative opportunity society"), Gingrich made clear the degree

to which his early career "conservatism" was a repackaged version of pre-Great Society

federalism. "Ronald Reagan uses the term 'social safety net' when he describes those federal

policies the President would continue to defend as he implemented his New Federalism.” But,

said Gingrich, "I'm going to use an older term many of you will recognize: we believe in the

New Deal." "But," he continued, "in the last twenty years we've built on top of the New Deal a

thing called the Great Society, and that is a very different creature indeed." Gingrich continued,

The Great Society didn't help those who temporarily couldn't help themselves. It helped anybody who showed up Monday morning, or, if they didn't show up, it would help them when they called in . . And so now we have an entire machine - the Lyndon Johnson Memorial Welfare Machine - designed to encourage the American taxpayer to grow more desperate and more despondent ... We have to undo the Great Society, which doesn't work and is unfair to those who do, to preserve the New Deal, which does work

\footnotetext{
${ }^{47}$ Handwritten notes, folder Task Force Stuffs, box 147, NGP.
} 
Cebul

and is fair. The country wants the New Deal and would be delighted to give up the Great Society early tomorrow morning. ${ }^{48}$

In selling Reagan's tax cuts, too, Gingrich made yet another parallel to the growth policies of pre-Great Society growth liberals such as John F. Kennedy. To be sure, he noted, "Many dissimilarities can be cited. But, in the area of economic proposals and performance, the similarities are astonishing." Gingrich cited Kennedy's investment tax credit for business, and his income tax cuts. The Georgia Republican argued that the results of Kennedy's cuts were so very near perfect that it is "almost impossible to find anything wrong with the American economy" between 1962 and 1965. "It seems eminently fair," Gingrich argued, "to state flatly that what we've tried since 1965 has failed, and what we tried in the years before 1965 worked magnificently." Indeed, Gingrich explicitly advocated associational state building, calling for "a shift from the centralized bureaucratic state towards the use of the entire society." Republicans' allies would then include "churches, labor union groups, professional associations, private industry, neighborhood associations, and local governments." In contrast, he charged, the Democrats stood "for the centralized bureaucratic state, [and] their major ally is the bureaucracy." This "conservative trend leads to a natural reemergence of non-statist ways of

\footnotetext{
${ }^{48}$ Speech by Rep. Newt Gingrich, March 27, 1982, folder Speeches, box 32, NGP.

${ }^{49}$ Newt Gingrich, “Jack Kennedy's Record and Ronald Reagan's Program: Can Economic History Repeat Itself?" folder Budget fight, box 293, NGP.
} 
Cebul

solving problems. ${ }^{, 50}$ In essence, perceptions of the War on Poverty's invasive federalism had

made it possible for Gingrich to claim that associational governance - public-private partnerships

paired with cooperative federalism - was a conservative alternative to liberals' statism.

Joining with their Congressional delegations in seeking practical reforms, over 1981 and into early 1982, many state and local officials, it seemed, simply did not understand the Reagan Administration's argument that states and local governments would be "empowered" by the new New Federalism. For instance, block grants, the governor's favorite program, were instead for the President a way station on the road to complete devolution of a number of federal programs. In its "Reagan Federalism" statement, the Administration offered a rather circuitous way of explaining why state and local governments would have access to more revenue: "In the area of revenue sources, the very fact that the Federal tax rate would be dramatically cut in the President's proposal will allow more money to be available for state and local governments."51 Reagan invoked Nixonian language about empowering state and local government, but he aimed to do so by radically different means. Whereas Nixon raised federal revenue and dispersed it with few strings to lower levels, Reagan planned to cut programs entirely and to "empower" state and local government to raise revenue - taxes - for programs they hoped to continue.

\footnotetext{
50 “'Speech to Republican Candidates \& Workers, April 18, 1982, folder Speeches, box 32, NGP.

51 “Reagan Federalism: Restoring the Balance,” folder Federalism Initiative (1), box 13, series II: Subject File I, 1981-1984, WH Staff Member and Office Files: Media Relations, RRL.
} 
Cebul

The Administration prioritized budget and tax cuts before pursuing reform to the federal system. Over its first six months in office, Reagan's team pursued and largely succeeded in passing a breathtaking agenda of federal tax and budget cuts. The three year 23 percent reduction in federal income tax was the single largest tax cut in history. The administration also slashed \$35.2 billion from the federal budget, cutting 400,000 Americans' welfare benefits entirely and reducing payments to another 279,000 . Food stamps were cut for one million more. While Democrats may have chafed a bit at targeting programs for the poor (60 percent of the 1981 budget savings came from antipoverty programs which, in total, only amounted to 18 percent of federal income maintenance programs such as Social Security, which went unscathed), there was a broad and largely bipartisan consensus on the need to address federal spending. ${ }^{52}$ As Newsweek put it in an article titled "Rest in Peace, New Deal," Reagan's “opposition lay broken before him, so completely that he had to warn his own people against gloating., ${ }^{, 53}$

Yet, while Reagan had slashed key programs of the New Deal and Great Society regimes, the programs themselves and their model of federalism remained intact. To truly undo the New Deal, Reagan would have to quash its model of fiscal federalism. He would have to unravel the

\footnotetext{
${ }^{52}$ Gareth Davies, "The Welfare State," in Brownlee and Graham, eds., The Reagan Presidency, 211-2. For a detailed account of the Reagan assault on welfare and its social consequences, see especially, Marisa Chappell, The War on Welfare: Family, Poverty, and Politics in Modern America (Philadelphia: University of Pennsylvania Press, 2010), esp. ch. 5. On Reagan's tax policy, see Molly C. Michelmore, Tax and Spend: The Welfare State, Tax Politics, and the Limits of American Liberalism (Philadelphia: University of Pennsylvania Press, 2012), 137-44.

53 “Rest in Peace, New Deal," Newsweek, August 10, 1981.
} 
Cebul

blend of federal taxing responsibility and local administrative authority that had characterized

developmental state federalism from the New Deal through Nixon's New Federalism and

Carter's Urban Development Action Grants. In order to make devolution even remotely

politically palatable to state and local governments, Reagan needed to offer some form of

transitional funding. Their solution was to create a "trust fund" to be phased out by 1991 .

Determining what and how much to cut, however, and how big a trust fund to provide, proved

difficult. In their internal analysis, officials grew frustrated trying to determine the "actual" cost

of cooperative federal programs. As one staffer wrote, "Even setting aside the specter of venal

bureaucrats protecting their jobs at the expense of program beneficiaries, there is the fact that

many overhead costs are fixed in the short term," resulting in "'sticky' overhead charges" that

may or may not have anything to do with the actual service rendered." Determining, then, the

"actual" costs of covering program beneficiaries became very "difficult to measure

empirically." ${ }^{, 54}$ As Bob Carleson wrote, "The answer is block grant everything in sight."55

In his capacity as President of the National Governors Association, Georgia’s Democrat

Governor George Busbee reached out to Reagan, encouraging the President "to make reform of

\footnotetext{
${ }^{54}$ Don Moran to Edwin L. Harper, June 21, 1982, folder ST State Government (047000-072999), box 1, WHORM: Subject File: ST, RRL.

${ }^{55}$ Robert B. Carleson to Edwin L. Harper, July 1, 1982, folder ST State Government (047000-072999), box 1, WHORM: Subject File: ST, RRL.
} 
Cebul

the federal system a principal theme of your administration.. ${ }^{, 56}$ Busbee had urged just such an initiative upon the fatally indecisive Carter Administration. The Governor took a prominent place on Reagan's Federalism Commission, rankling fellow Democrats, none more so than House Speaker Tip O’Neill. Reagan enflamed tensions within the Democratic ranks by touting Busbee's support and circulating a story (which Busbee denied) that Georgia's Governor had told O'Neill, 'he would not be speaker after the next election if he didn't support the President's program." ${ }^{57}$ Busbee, however, penned a supportive op-ed in which he argued that, "Whatever the good intentions involved, the federal government's plethora of programs designed to address scores of problems once the exclusive responsibilities of state and local government have not worked very well., ${ }^{, 58}$ New Federalism could address such failures and waste.

By the summer of 1981, the Administration's indecisiveness about financing the trust fund sped mounting concerns among governors that Reagan's initial budget cuts were meant to preemptively slash programs in order avoid establishing an equitable trust fund. ${ }^{59}$ Numerous Democratic Governors voiced concerns the Administration was playing a "shell game" that

\footnotetext{
${ }^{56}$ George Busbee and Richard Snelling to President Elect Reagan, folder FG006-07 096880 [2 of 9], box 14 WHORM: FG 006-07, RRL.

${ }^{57}$ Recommended Telephone Call, March 3 or 4, 1981, folder PQ007-02 President's Telephone Calls, box 1 WHORM: Subject File: PR, RRL.

${ }^{58}$ Recommended Telephone Call, May 29, 1981, folder PQ007-02 President's Telephone Calls, box 1 WHORM: Subject File: PR, RRL.

${ }^{59}$ Recommended Telephone Call, June 16, 1981, folder PQ007-02 President's Telephone Calls, box 1 WHORM: Subject File: PR, RRL.
} 
Cebul

would ultimately "short change" them. ${ }^{60}$ As North Carolina's James Hunt, a cautious early

supporter of New Federalism, put it, "If we don't look out . . . we're going to snow ourselves.",61

Busbee's successor as chairman of the National Governor's Association, Republican Richard

Snelling of Vermont, touched off a panic within the Administration when he said Reagan's cuts

paired with devolution of program responsibilities constituted "an economic Bay of Pigs ... not

an economic policy." The Administration reached out to Busbee in hopes that he would work to

calm the situation, but he was growing wary, too. ${ }^{62}$

Over the late fall and winter of 1981 and into 1982, the governors increasingly

challenged the Administration. Chiefly, they worried poor states - the states that struggled to

raise revenue even in good economies - would be left behind by the New Federalism. In

contrast, the Administration imagined it could somehow conduct negotiations about the

federalism initiative on a separate track from debates about budget cuts and considerations of the

broader economy. This was a nonstarter for poor state governors. ${ }^{63}$ Having spent the late 1970 s

developing a keen sense of deserving and undeserving states with regard to federal funding

formulas, Busbee was concerned the President simply did not understand the great fiscal and

\footnotetext{
60 “Governors Warn on Welfare Cuts,” NYT, August 12, 1981.

${ }^{61}$ States Offer Reagan a Deal on Aid Cuts," WP, August 12, 1981.

${ }^{62}$ Recommended Telephone Call, December 3, 1981, folder PQ007-02 President's Telephone Calls (844000-

046299), box 1 WHORM: Subject File: PR, RRL.

63 “Governors Insist 'New Federalism’ Must be Tied to Reagan’s Budget,” NYT, February 22, 1982.
} 
Cebul

revenue raising disparities between the various levels of government. ${ }^{64}$ As Busbee asked with mounting frustration, "What is the Reagan Administration's philosophy of federalism? Does federalism just mean that states and localities should absorb all excess federal costs that stand in the way of balancing the federal budget?" ${ }^{65}$ Others who were concerned about federal aid for poor and minorities, even those within Reagan's own party, took a harder edge. Senator David Durenberger (R- MN) called Reagan’s New Federalism “baloney.”66

Faced with dissent, Reagan instead doubled down on hard-edged, ideological rhetoric.

"The built-in guarantee of freedom is our federalism," he said. "That makes us unique. That is, the right of a citizen to vote with his feet. If a State is badly managed, the people will either do one of two things: They will either use their power at the polls to redress that, or they'll go somewhere else." ${ }^{67}$ Americans, Reagan argued, were essentially rational, like a business: “we’ve seen industries driven out of some States by adverse tax policies and so forth.” Inequalities between states should be taken care of, Reagan argued, by “the marketplace.” As the President told reporters in a session devoted entirely to his federalism proposals, "my dream is that the block grants are only a means to an end. And the end is that the [national] government, which

\footnotetext{
64 “Reagan Will Seek Governors’ Views on Transfer Plan,” NYT, February 2, 1982.

65 “One Mayor on 'Fiscal Death Row”” LAT, November 22, 1981.

66 “A Rich Foe and Reagan Vex GOP Incumbent,” NYT, October 12, 1982.

${ }^{67}$ Ronald Reagan, Interview with Reporters on Federalism, November 19, 1981, The American Presidency Project, UCSB.
} 
Cebul

has preempted over the years so much of the tax revenue potential in this country" will devolve as much tax revenue and programmatic authority as possible back to the states. ${ }^{68}$ Neal Pierce, a keen observer of government at National Journal, was well versed on the revenue raising disparities between the various levels of government. He penned a highly critical op-ed for the Los Angeles Times, arguing that Reagan "apparently feels that the federal government has no obligation to people or states or communities dealt crippling blows by the economic vagaries of the times. ${ }^{69}$ On the shoals of such ideological pronunciations, and in the face of bipartisan state and local politicians and members of Congress, all of whom championed cooperative, associational federalism, Reagan's New Federalism ran aground.

By the summer of 1982, the Administration settled on its federalism package. The federal government would devolve AFDC and food stamps to the states, establish a trust fund, and, in return, the national government would take over funding and administration of Medicaid. ${ }^{70} \mathrm{Had}$ it passed, New Federalism's “swap” would have profoundly undermined two key liberal “entitlement" programs by making them state-based rather than federal: the New Deal's welfare provisions (AFDC) and the Great Society's nutrition assistance (food stamps). After the governors' initial flurry of support, in the wake of Reagan's aggressive tax cuts and the

\footnotetext{
${ }^{68}$ Ibid.

69 “The States Can Sink or Swim,” LAT, November 22, 1981.

70 "Background and Status Report on Federalism Initiative” Fact Sheet, July 13, 1982, folder FG (Federal Government - Organizations) (091600-091699), box 6 WHORM: FG, RRL.
} 
Cebul

President's doggedly ideological rather than cooperative view of federalism, Reagan lost the support of his chief constituency. Governors no longer trusted that the "trust fund" Reagan promised would be sufficient. ${ }^{71}$ Members of Congress, concerned with the pace of change, were hesitant, too. Though it had taken serious hits, the New Deal's model of cooperative federalism persisted.

Having failed to overhaul the federal system, the Reagan administration instead pursued a haphazard program of cutting domestic social and development spending wherever possible. Clark Stevens, director of George Busbee's State Planning and Budget Office was outraged over the Administration's cuts to federal community development block grants. Despite all the bluster over New Federalism and local empowerment, "It's ludicrous to even think there's any ... new situation with block grants," Stevens complained. "All we received are the cuts." As Busbee wrote in a letter to the Washington Post, "At this point, governors and state legislators - and the taxpayers - need to ask the administration some very basic questions about the federal-state partnership." ${ }^{72}$ Two years later, when the Administration and its few Congressional allies sought to retroactively cut or defer community development block grant commitments, Georgia's Republican Senator Mack Mattingly wrote (along with 14 colleagues) to President Reagan,

\footnotetext{
${ }^{71}$ For more detail on Reagan's broader social policy agenda and legacy, see Gareth Davies, "The Welfare State," in Brownlee and Graham, eds., The Reagan Presidency.

${ }^{72}$ Linda Parham, "State Officials Decry Block Grant Inflexibility," $A C$, undated, folder 9, box 12, subseries C, series I, Mack F. Mattingly Collection [hereafter MFM], RBRL.
} 
Cebul

protesting the withholding or deferral of $\$ 500$ million of FY1986 appropriations. Mattingly

fumed: "As they should, many local communities across this nation took the 'word' of the

federal government and believed that if an appropriations bill was passed by congress and signed

by the President, then the money could be counted on. They made plans based upon this

commitment and processed with their projects in a business-like manner." "In my state, the

CDBG represents the largest single source of federal assistance for municipalities.

In fiscal year 1985, Georgia received just over \$64 million in CDBG funds . . for many worthwhile projects, such as the installation of water and sewer lines . . I have always supported efforts to reduce federal aid and the federal mandates placed on those in our home states and home towns. But let's be fair $!^{73}$

Throughout the 1980s, key developmental state programs - the Appalachian Regional

Commission, CDBGs, and Revenue Sharing - were consistently rumored to be on the verge of

being cut or killed. But, with the exception of General Revenue Sharing, which Reagan

succeeded in killing in 1986, most programs, though sustaining cuts, persisted thanks to broad, bipartisan support.

As the Rome Chamber dabbled in a more doctrinaire market conservatism, the Coosa

Commission and Floyd County's Industrial Development Committee went on about their usual

business, offering taxpayer subsidized technical assistance, land use planning, and access to

\footnotetext{
${ }^{73}$ Statement of Senator Mack Mattingly, February 19, 1986, folder 8, box 31, subseries C, series III, MFM.
} 
Cebul

federal funding for expanding or recruited businesses. As the national economy began to move out of recession, so too did Rome's. In 1983, Gov. Joe Frank Harris cut the ribbon on the 600acre, \$3.5 million Floyd County Industrial Park, coordinated by the Coosa Commission and jointly funded by the Floyd County Board of Commissioners, the Industrial Development Authority, and the state Industrial Development Commission. Several industries including Integrated Products, Klopman Blended Fabrics, and Florida Tile expanded in or moved to Rome and Floyd County, adding 1,100 new jobs to the region against losses of only 78 . The net gain for the year was only 167 fewer than for the years 1980,1981 , and 1982 combined. $^{74}$

Other aspects of Reagan's domestic policy had actually bolstered the rural planners' access to and flexibility in using developmental state finance. Reagan's tax cut legislation loosened block grant regulations by broadening eligibility for Block Grant-based loan recipients. In effect, the measure ratified the economic development role Block Grants, originally intended to stimulate affordable housing, had always played. Under the new guidelines, communities could "provide assistance to private, for-profit entities, when the assistance is necessary or appropriate to carry out an economic development project." The amendments enabled local governments to use Block Grant funds to make direct loans to business. By 1985, local governments were allotting half of the portion of CDBGs earmarked for economic development

\footnotetext{
${ }^{74}$ Stuart Mieher, "How Diversity Saved North Georgia," Georgia Trend, April 1986.
} 
Cebul

for direct loans to business. ${ }^{75}$ As C.D. Rampley, executive director of the Coosa Commission put it in 1983, "A couple of years ago, there was no money available for much of our work. But now the release of federal money in block grants has awakened cities." In 1982, Rampley noted, the Commission made "23 applications under community development block grants." ${ }^{, 76}$ At precisely the moment when government was supposedly withdrawing from the market, these amendments, like Urban Development Action Grants, expanded the range of governments that could become equity partners with business, supporting the kinds of 'industrial policies' - choosing winners and losers - the conservative turn seemingly repudiated. In one case, Rome used $\$ 200,000$ in block grant subsidies and a $\$ 1$ million Small Business Administration loan to underwrite the renovation of an old warehouse to attract a new manufacturer and 400 jobs. $^{77}$ As Georgia Trend, Georgia's leading business magazine, put it, this "story has a lot in common with business development in parts of North Georgia." 78 In 1985, similar inducements attracted a new metalworking firm, a pair of plastics companies, and a cabinet manufacturer. These new concerns brought 800 new jobs.

Gradually, however, spurred in part by reports from the Southern Growth Policies Board, the Coosa Commission, the Rome Chamber, and other groups were recognizing that

\footnotetext{
${ }^{75}$ Eisinger, The Rise of the Entrepreneurial State, 106-113.

${ }^{76}$ CVAPDC: 25 Years of Progress, 2, in author's possession.

771985 Employment Incentive Program Application for Rome, Georgia, RCB-30184, GAA.

${ }^{78}$ Stuart Mieher, "How Diversity Saved North Georgia," Georgia Trend, April 1986.
} 
Cebul

manufacturing alone no longer promised sustainable growth and development. ${ }^{79}$ As a 1983

Board report on the rural South argued, new strategies were required to ensure new forms of

growth. The positive aspects of the rural South - cheap labor, cooperative government, and

cheap land - "that attracted labor intensive industry initially" had ironically led to the regions'

loss of jobs to "mostly third world countries" that could out-South the South. As the Board put it,

"Just as" rural communities "began to catch up, the ground rules have changed." In the 1980s,

"A skilled work force, strong schools, and expensive communication links have been added to

the list of factors needed to sustain growth." Communities had to focus on education, updated

infrastructure, "access to the risk capital needed to convert new ideas . . . into business

opportunities," and, finally, "obtaining the technical assistance . . . needed to exploit new

opportunities." ${ }^{80}$ The Board pointed specifically to the Appalachian Regional Commission as

useful model for fostering "the kind of economic development most likely to be successful, e.g., small service businesses, specialty manufacturing and crafts, agribusiness and tourism." At that

\footnotetext{
${ }^{79}$ Forum, June 1984, HSCL. They weren't alone in keeping abreast of SGPB reports. The Atlanta Chamber was a dues paying member of the SGPB, and its staff corresponded as well with researchers in the Research Triangle. See, for instance, Thomas K. Hamall to E. Blaine Liner, September 15, 1980, folder Other, box 18, subseries 1.2.3, Southern Growth Policies Board Papers, Southern Historical Collection, Wilson Library, University of North Carolina, Chapel Hill [hereafter SGPB].

${ }^{80}$ Forum, June 1984, HSCL.
} 
Cebul

meeting, Board leaders identified education and capital formation as the two key economic

development issues for the region. ${ }^{81}$

The Rome Chamber of Commerce reported on the Board's finding in the Forum.

Government, they explained to Floyd County's businesspeople would have "to make sure that venture capital is available. Although there seems to be no shortfall in the aggregate amount available, small business and rural entrepreneurs often have trouble securing loans." States, they argued, "can directly assist innovators by helping them test their ideas, and, if promising, turn them into business." ${ }^{82}$ The Rome Chamber of Commerce, despite its ideological spasm, was keeping abreast of the Growth Policies Board's efforts to assist southern states as they turned to new government-led strategies for a new economy.

\section{New Democrats \& Growth Strategies}

Coming on the heels of the recessionary late 1970s and early 1980s, and in the wake of Reagan's budget slashing, states across the country began to generate new and highly

\footnotetext{
${ }^{81}$ Indeed, at their Annual Meeting in 1983, the Board heard from Sar Levitan, who had been influential in establishing both the ARA and the ARC. See folder Annual Meeting 6/3/82 R\&D, box 24, subseries 1.3 Executive Committee, 1971-1989, SGPB. See, also SGPB Subcommittee on Finance, Issue Paper, September 18, 1981, folder Executive Committee and Annual Business Session 9/29/81, and Remarks by Dr. Bernard Weinstein, Task Force on the Southern Economy, "The Southern Economy in the 1980s," folder Annual Meeting 9/28/81, Dorado Beach, PR, box 24, subseries 1.3, SGPB. Indeed, the meeting minutes and agendas contained in this box suggest the Board's intense focus on finance.

${ }^{82}$ Forum, April 1983, HSCL.
} 
Cebul

competitive developmental state programs of their own. Georgia was no exception, and, in some

ways, paced the nation. Indeed, by focusing on Georgia, one can draw a straight line from the

technocratic, industrial developmentalism of the New Deal-inspired regional planners and

industrial engineers in Georgia during the Kennedy and Johnson years and the high tech

developmental outlook of the so-called "New Democrats" who shaped the Southern Growth

Policies Board and the Democratic Leadership Council.

From the mid-1970s through the early 1980s, advocates of high technology innovation as

a form of economic stimulus made halting calls for the federal government to pursue a new,

high-tech industrial policy. What the Morrill Act had done for agriculture in the $19^{\text {th }}$ century,

high tech evangelists believed a new round of federal spending and planning could do for the

digital age. Nevertheless, both the Carter and Reagan Administrations avoided the notion of

national industrial policy, and Congressional efforts were halting. ${ }^{83}$ While these efforts

floundered at the national level, a number of states were embroiled in a high-tech arms race that

amounted to a decentralized system of high tech industrial policies. Indeed, a 1983 study by the

Congressional Office of Technology Assessment found 153 distinct state-supported programs

pursuing everything from conventional industrial recruitment tactics such as site improvements

\footnotetext{
${ }^{83}$ On these trends nationally, see especially, Judith Stein, Pivotal Decade: How the United States Traded Factories for Finance in the Seventies (New Haven, 2012). On Carter's tactical muzzling of the Humphrey-Hawkins Full Employment Act see, Jefferson Cowie, Stayin' Alive: The 1970s and the Last Days of the Working Class (New York, 2010), 270-88.
} 
Cebul

and "technical assistance" to new forms of high tech R\&D transfers and publicly structured

venture capital pools. ${ }^{84}$

On the occasion of its tenth anniversary, the Southern Growth Policies Board convened a special session of its Annual Meeting to focus on "Cooperative Strategies for Growth." Sitting on the panel were leading "New South" Democrats such as Virginia's Charles Robb, North Carolina's James Hunt, and Florida's Bob Graham - all of whom would subsequently help form the Democratic Leadership Council. They believed a state's most important role was fostering strong education "for the jobs of tomorrow" and aiding capital formation. As Governor Robb put it, "It's interesting that we are all competing with each other, yet when we get together we all talk about the same things that our states are doing." Robb suspected, he said, "our priorities are essentially the same. We all have to develop programs and to provide capital, both human capital and investment capital." Echoing his fellow governors, Robb called on the federal government to "guarantee equal access and certainly to provide certain types of research that will have a national impact. Beyond that," though, "we are willing to wrestle with the basics and to provide a more stimulating atmosphere." When pushed by the moderator on whether the states were doing enough to ensure minority access to education and economic opportunity, the governors were of one mind. As Hunt put it, "I believe leadership is more involved in the South than in any

\footnotetext{
${ }^{84}$ Robert C. McMath, Jr., et al, Engineering the New South: Georgia Tech, 1885-1985 (Athens, 1985), 437-8.
} 
Cebul

other region of the country by far ... We've been held back by the fact that we haven't given

them full opportunities in the past." ${ }^{85}$ Though they had been held back in the past, the governors

felt sure that structural impediments to meaningful opportunity were increasingly behind them.

Drawing on Southern Growth Policies Board recommendations, in 1979 Governor

Busbee commissioned Georgia Tech's Engineering Experiment Station researchers to study the

state's scientific and technological assets and their potential for driving new forms of economic growth. ${ }^{86}$ After visiting Silicon Valley and North Carolina's Research Triangle, Tech's experts recommended the state subsidize its own publicly financed high tech research center - Georgia Tech's Advanced Technology Development Center (ATDC). ${ }^{87}$ The Center would serve as an “incubator” for “a community of advanced technology companies in Georgia." The Center's developers consciously thought of their work as a high tech update of the older Engineering Experiment Stations - those founded by early Coosa Commission ally Kenneth Wagner. They would take them one step further, though, by offering entire private companies residency within the publicly subsidized research center. ${ }^{88}$

\footnotetext{
${ }^{85}$ Anniversary Conference Proceedings, "Cooperative Growth Strategies for the 80's," 57-69, folder Annual Meeting, 6/3/82, RTD, box 24, subseries 1.3, SGPB.

${ }^{86}$ Ibid., 446.

${ }^{87}$ North Carolina, among a handful of other southern states, was also beginning to look to regionally diffuse high tech "technical assistance" programs. These programs were called Western North Carolina Tomorrow and Northeastern North Carolina Tomorrow. See, Jesse L. White Jr., to Senator Ted Little, March 26, 1985, folder Staff Memos from Jesse (1985 back), box 20, subseries 1.2.3, SGPB.

${ }^{88}$ Quoted in Ibid., 46.
} 
Cebul

The link with Tech's EES system and the high tide of growth liberalism was not metaphorical. Wayne Hodges, a Tech engineer, headed up Tech's new incubator, and he got his start in expert led economic development at an Area Planning and Development Commission. Hodges moved on from his Commission to join the Industrial Development Branch in Carrolton, Georgia. The Rome Engineering Experiment Station was the first Industrial Development Branch, and as Hodges later recalled, it was the "genesis of everything." Indeed, in the early 1980s, Hodges and his Tech allies explicitly viewed their work as a high tech update of the older model of industrial technical assistance that had predominated in the $1950 \mathrm{~s}$ and $1960 \mathrm{~s} .{ }^{89}$ As Busbee put it, the state government's "alliance with business" would offer a path "to escape the current economic contraction" by "building a base of high technology employment."90

As in the 1960s, Governors across the South viewed growth as a panacea, offering nonredistributionary solutions to poverty, unemployment, stagnant wages, and slackening productivity. ${ }^{91}$ In its 1980 report, "The Future of the South," the Southern Growth Policies Board so emphasized economic growth as a panacea for all measure of social ills they drew criticism

\footnotetext{
${ }^{89}$ Author interview with Wayne Hodges, August 14, 2012, Atlanta, Georgia. McMath, et al., corroborate Hodges’ linking of the ATDC with the earlier Industrial Development Branches. McMath, et al, Engineering the New South, 446.

${ }^{90}$ Quoted in McMath, et al, 439.

91 James J. Gosling, "Patterns of Stability and Change in Gubernatorial Policy Agendas," State \& Local Government Review, Vol. 23, No. 1 (Winter, 1991), 3-12. For an overview of the high tech, University-base growth agenda of states across the country, see Louis G. Tornatzky, Paul G. Waugaman, and Dennis O. Gray, "Innovation U: New University Roles in a Knowledge Economy," Southern Growth Policies Board, 2002.
} 
Cebul

from some of their academic consultants. Southern historian and Board consultant George

Tindall, for instance, complained the Board overemphasized "economic development as the

thing." While the Board had initially formed to avoid some problems faced by the industrial

North, the UNC professor worried the South was "well on the way" to the same mistakes. ${ }^{92}$

Nevertheless, for Democrat Joe Frank Harris, George Busbee’s successor as Georgia’s

Governor, the primary job of any state executive was economic development. In his campaign,

the small town businessman and longtime state representative emphasized two major themes,

education and high tech development. He argued, "As a businessman, I can bring the business-

like management and steady hand to state government that will make a difference when a

corporation looks at us." 93 "The first tenet of my platform," Harris said, deploying market speak,

"is that Georgia must be run in a tight businesslike manner ... We must operate State

government in accordance with sound business principles, facing the realization that we cannot

spent money we do not have and that we cannot borrow ourselves out of debt."94

After the brief spasm of ideological fervor in the early 1980s, by the middle of the decade

business and state government were of one mind about government's proper role in the

economy. The Georgia Chamber of Commerce called on all candidates for state office to

\footnotetext{
92 “South’s blueprint for 1980s looks sketched by Reagan,” CSM, February 24, 1981.

${ }^{93}$ Harris Announces Economic Development Proposals, June 24, 1982, DOC-3862, GAA.

${ }^{94}$ CURE Questionnaire, undated, DOC-3862, GAA.
} 
Cebul

"provide additional funds . . . for . . . a Georgia equivalent of the Research Triangle." 95 In

response, and citing enthusiasm over the early track record of Tech's incubator, Harris proposed

creating a public-private "consortium, coordinated by a joint committee of the University System

of Georgia" that would "better coordinate and amass our advanced research capabilities" - a

state-based, high tech version of the National Resources and Planning Board. Harris had initially

hoped to spend more time studying the matter, but, as part of his efforts to recruit a

microcomputer company, the Governor fast-tracked the Georgia Research Consortium, a \$30

million public investment that would "link and coordinate research and high technology projects

of the state's public and private colleges and universities in cooperative ventures with business

and industry." ${ }^{96}$ Though his recruit ultimately chose Austin, Texas, Harris secured enthusiastic

private sector contributions that funded half of the Consortium's initial costs. The Consortium,

housed at Tech's business incubator, would be "a public/private cooperative venture . . . to build

a high technology industrial base in Georgia." 97 At the peak of Reaganism, the state of Georgia

was generating high tech industrial policy.

By the spring of 1984, Tech's incubator had "graduated" six companies, and 30 more had

entered the program. The kinds of product developments the Advanced Technology

\footnotetext{
${ }^{95}$ Questionnaire for Gubernatorial Candidates, DOC-3862, GAA.

96 “Harris Announces \$30 Million Research Consortium,” May 27, 1983, RCB-1392, GAA.

97 Ibid.
} 
Cebul

Development Center supported ranged far and wide, "from missiles to pole beans," as one staff member put it. ${ }^{98}$ Ahmed Nahgat F. Abdel-Fattah's company Control Factors produced a Muslim prayer clock, which utilized a microcomputer and a compass to help Muslims identify the correct time to pray and the direction to Mecca. While Fattah was there, Control Factors was among 19 incubating companies, some of which were creating using Tech's expertise in electromagnets, biotech, and aerospace. Six years into its work, the Center had 53 "member companies," 34 of which had graduated from the incubator offices. As of 1986, the most successful graduate was Digital Transmission Systems whose high-speed computer modems landed the company an $\$ 8$ million contract with telecommunications giant MCI. Not all of the incubator's clients were fledgling businesses. Lockheed-Georgia, for instance, the massive defense and aerospace firm, often found that its researchers developed ideas for new products that had no practical application in their existing contracts. A Lockheed engineer approached the Center for help developing a business plan. Soon, a newly established subdivision of Lockheed, Getex, was in residence. Among the products Getex worked on with Tech's engineers were an evaluation system that tested for subtle damage to aircraft and a secure modem to better protect computer communications. Getex also struck a deal with Nahgat Abdel-Fattah to license and produce 100,000 of his prayer clocks.

\footnotetext{
98 "From Missiles to Pole Beans," Georgia Trend, May 1986.
} 
Cebul

One of the main lessons Tech's experts taught fledgling entrepreneurs was to develop a "product stream." Ben Hill, an incubator team member, stressed that the "average life cycle of a high-tech product is around 18 months to two years." Tech hoped to prevent its clients from becoming one hit wonders. If "a company is going to manufacture and introduce products into a specific market," Hill said, "it has to very quickly begin thinking about follow-up products." 99 By the second half of the 1980s hundreds of entrepreneurs a year applied for 20 annual slots. Despite the considerable state and federal resources that underwrote their work (in 1985, Tech received over half of its $\mathrm{R} \& \mathrm{D}$ funding from federal sources, $\$ 50,349,000$ out of its total R\&D budget of $\$ 90,445,000^{100}$ ), Tech's staff took pains to emphasize their businesslike processes and institutional culture. Indeed, incubator staff stressed the ways in which the public University incubator's culture was nothing like that of a standard government agency. 'It's much easier for us to be of benefit to (member companies), because we understand how they work," he said. "We try to act as little like a bureaucracy as possible, so that we are able to relate better to entrepreneurs who have no interest - much less inclination - to try to deal with bureaucrats." ${ }^{101}$ The Center soon expanded Tech's Industrial Extension Service to extend the incubator concept throughout the state. "We will go to these areas when asked and put on a program for a

\footnotetext{
99 Ibid.

${ }^{100}$ Candice Brisson and Chilton Rodgers, "Science and Technology in the Sunbelt, 1987," Southern Technology Council, 16, box 92, subseries 3.3, SGPB.

101 “From Missiles to Pole Beans," Georgia Trend, May 1986.
} 
Cebul

chamber of commerce," said an official. As it had in the 1960s and 1970s for the Southern

manufacturing economy, Tech partnered with business to design an industrial policy for the new

high tech, innovation economy. A 1985 McKinsey report credited the ATDC's and Tech's

development efforts as "a national model for technology transfer." 102 By 2002 Tech operated 18

incubator and research and development centers throughout the state, and the entire Georgia

Research Alliance system drew upon \$276 million in state funds. Tech's Atlanta-based research

institute - the central hub of the incubator system - employed nearly 1,000 researchers and

staff. $^{103}$ As of 2002, a survey conducted by the Southern Growth Policies Board ranked Georgia

Tech number one "by a comfortable margin" in relation to other entrepreneurial University-

based public private partnerships. Compared to institutions including Stanford and Carnegie

Mellon, Tech, analysts found, is "a unique example of external partnering. Virtually every

combination of industry relationship or economic development activity can be found at Georgia

Tech, and in a very real sense the school is an operating partner with Georgia state government

in the implementation and management of a variety of technology-focused initiatives."

Financing the New Economy

\footnotetext{
${ }^{102}$ McKinsey findings summarized in “Beginning Thoughts on Georgia's Economy and Capital Markets,” June 14, 1989, 10, folder Growth Strategies Commission, Capital Markets - June, 1989, RCB-14937, GAA.

${ }^{103}$ Tornatzky, et al., "Innovation U: New University Roles in a Knowledge Economy,” 28-31.

${ }^{104}$ Ibid., 28.
} 
Cebul

Despite Georgia's investments in innovative high tech R\&D and private sector

incubators, the longstanding hindrance of Southern development - capital formation, especially

for smaller businesses - continued to dog efforts to grow indigenous companies. ${ }^{105}$ While

Governor Harris invoked the "free market" in his opposition to creating a public venture capital

fund (as states such as Massachusetts, North Carolina, and Rhode Island were doing), one of his

first moves was to implement SGPB recommendations for regional banking. Harris partnered

with Florida and North Carolina to create banking accords to generate new private sector capital

opportunities for Georgia businesses. ${ }^{106}$ Formerly, Georgia firms could secure loans from out of

state banks, but the process was cumbersome and involved additional costs. Though the move

would result in a number of mergers that might see out of state banks take over Georgia banks,

as Harris put it, "This is an economic development issue, not a banking issue." Soon, as the Wall

Street Journal put it, "Merger mania [was] sweeping Southeast banking.” During the summer of

1985, eight of the region's ten largest banks moved across state lines and acquired other

institutions. $^{107}$

\footnotetext{
105 On the South's historic entrepreneurial weakness and its connection to capital, see William Graves, "The Southern Culture of Risk Capital: The Path Dependence of Entrepreneurial Finance," Southeastern Geographer, Volume 51, number 1, Spring 2011, 49-68.

${ }^{106}$ On the SGPB and regional banking, see "Rationale for Regional Banking Statutes," Excerpts from the Report of the Southern Regional Banking Committee, November 14, 1982, folder DC Office - '81 Correspondence, box 18, subseries 1.2.3, SGPB.

107 “3 States Hold Bank Talks,” NYT, September 2, 1983; “Georgia leads a move toward Southern regional banking," CSM, March 16, 1984; and “Regional Banking Grows Rapidly in South,” WSJ, October 3, 1985.
} 
Cebul

Expanded opportunities for private lending promised to generate a bit of new capital liquidity, but the vast majority of Georgia's fledgling businesses, the kind where real innovation would be found, were largely sealed off from these markets. As his second term began, Harris established his Growth Strategies Commission - a group of leading business interests, higher education experts, and state politicians - to identify best practices for freeing capital for the state's high tech economy. ${ }^{108}$ Small and medium sized firms (those with up to 499 employees) were critical to Georgia's growth and constituted the vast majority of the state's businesses and industries. ${ }^{109}$ In rural areas especially, Harris' Growth Strategies consultants found, firms of this size struggled to secure private credit and financing. ${ }^{110}$ Large cap investors, such as public pension funds, dominated venture capital markets. These large-scale investors drove "up the size of limited partnerships, which in turn induce[d] venture capital fund managers to make larger investments." In the quest for greater stability in returns, these larger investors tended to seek out later stage investments, bypassing more risky, but perhaps more innovative, early stage innovators. As a result, funds for start-ups and smaller, perhaps more innovative firms, was scarce. Indeed, the average venture capital investment in Georgia was around \$3.5 million, while

\footnotetext{
108 "Georgia Capital Markets: Preliminary Analysis and Supporting Data," May 1, 1989, 9, folder Growth Strategies Commission, Capital Markets - May, 1989, RCB-14937, GAA.

109 "Finance for the Future: Capital Markets Analysis and Action to Enhance Georgia's Economic Development," November 30, 1989, 18, folder Growth Strategies Commission, Capital Markets - November, 1989, RCB-14937, GAA.

${ }^{110}$ Ibid., 20-21 .
} 
Cebul

small, quickly growing firms needed smaller increments, perhaps $\$ 500,000$ and faster intervals.

Harris' consultants found less than $5 \%$ of venture capital invested in Georgia "was start-up of

early stage. All other Georgia investments are third stage or expansion financings" concentrated

in well-established areas such as "transportation, communications, computer hardware, and

medical services."111 The state needed to generate ways to finance smaller, younger start-ups.

The Reagan Administration made innovation even more difficult for small companies

when it eliminated tax exemption for Industrial Development Bonds (IDB). IDBs enabled local

governments to back private bank loans to provide low interest long-term financing for new or

expanding businesses. ${ }^{112}$ “Georgia communities,” Harris’ consultants found, “made very

aggressive use of IDBs," and "more of Georgia's bank assets are concentrated in smaller, rural

banks with less capacity for long-term industrial lending than in other highly industrialized states

such as North Carolina, Connecticut or Massachusetts."113 When, in 1986, however, the Reagan

Administration closed this tax loophole, the market for the bonds vanished practically overnight.

In 1985, local governments in Georgia issued $\$ 859$ million in tax-free development bonds. In

1986, only \$25 million were issued. States moved quickly to fill the void by offering publicly

\footnotetext{
${ }^{111}$ Ibid., 5.

${ }^{112}$ Minutes, Governor's Advisory Committee on Capital Markets, June 21, 1989, folder Growth Strategies Commission, Capital Markets - June, 1989, RCB-14937, GAA.

${ }^{113}$ Ibid., 23.
} 
Cebul

securitized bundles of development bonds, but Governor Harris was initially hesitant to pursue

similar initiatives in Georgia. ${ }^{114}$

As a result of such federal retrenchment, Georgia's businesspeople intensified their

pressure on state politicians to provide positive inducements to business. In contrast to the

Reagan Administration, which developed primarily negative inducements for business (e.g., targeted tax and regulatory relief), Georgia's businesses reminded state leaders that public finance and regularly updating infrastructure were the most important factors in business development. Gene Dyson, president of the Business Council of Georgia, advised Harris' Commission that tax credits could be a useful tool for growth, but only as part of a broader program of such public investments: "we believe any tax credit should be tied to new investments as well as to new jobs. $" 115$ Likewise, at a business sponsored legislative forum, the Council surveyed 708 business people. The overwhelming consensus signaled business peoples' preferences for pragmatism and industrial policy. Ninety-six percent "agree that 'managing growth through coordinated planning at the local, regional, and state level is important to Georgia's future." Eighty-three percent agreed that state taxes, perhaps on fuel, should be raised

\footnotetext{
114 “No More Small Development Bonds,” Georgia Trend, January 1988.

${ }^{115}$ Gene Dyson to Joel Cowan, August 29, 1988 attached to Gene Dyson to John Sibley, October 5, 1988, folder Growth Strategies Commission: Correspondence - October, 1988, RCB-14935, GAA
} 
Cebul

"to fund developmental highways and [provide] . . . money for education." ${ }^{\text {"16 }}$ Dyson and his

business allies got what they wished. As John Sibley, Harris' chief Growth Strategies consultant, put it, brushing aside Reagan-style negative inducements, "the Commission will not specifically endorse jobs tax credits or any other adjustments to the tax structure. Instead the Commission will emphasize a stronger state role in financing local infrastructure, providing grants for local economic development needs, and making private capital more accessible throughout the state." $" 117$ The Growth Strategies Commission would focus on ways the state could "Finance efforts that generate income growth for the people of Georgia where the value to the State is clear but the project would not qualify for private financing." ${ }^{118}$ The state of Georgia would finance its own developmental state.

Governor Harris was reluctant to get the state involved in providing capital, but, in 1988, John Sibley employed a New Deal analogy to sell the Governor on creating bond issues and public venture capital pools for industrial and high tech development. The instruments, he wrote, "would pool long-term (7-20 year) loans by local banks and sell them on the public markets. It's sort of a Fannie Mae for industrial finance." As he put it, "The main advantages are that the

\footnotetext{
${ }^{116}$ John Sibley to Joe Frank Harris, December 2, 1988, folder Growth Strategies Commission: Correspondence December, 1988, RCB-14935, GAA

117 John Sibley to Gene Dyson, October 21, 1988, folder Growth Strategies Commission: Correspondence October, 1988, RCB-14935, GAA

118 James S. Balloun to Belden Hull Daniels, June 22, 1989, folder Growth Strategies Commission, Capital Markets - June, 1989, RCB-14937, GAA.
} 
Cebul

borrower gets a lower rate of interest and the local banker gets a secondary market for loans that he or she may prefer not to carry on the books." Sibley was sure firms in rural areas like Floyd County would especially benefit. ${ }^{119}$ Harris acquiesced. The new bond instruments would be rolled out along with a seed capital fund with a modest initial state investment of \$2.5 million routed through Tech's incubator. In so doing, Sibley wrote, "the state [would] become a private investor in a seed capital fund that is designed to make a market rate of return on investment, not to make grants. ${ }^{" 120}$ Sibley's goal was to make the seed fund self-perpetuating, requiring no further tax payer investments. The state's program blended old style New Deal risk abatement measures and liberal entrepreneurial state policies (such as Urban Renewal or UDAG), which directed public capital to create new markets. ${ }^{121}$ The new initiative garnered coverage from the Southern Growth Policy Board, which touted the business like approach to development: the state would make "investments" ranging from $\$ 100,000$ to $\$ 500,000$ "in return for an equity position" in the business. ${ }^{122}$ By putting "a world class private seed capital organization in total

\footnotetext{
${ }^{119}$ John Sibley to Joe Frank Harris, December 7, 1989, folder Growth Strategies Commission, Capital Markets December, 1989, RCB-14937, GAA.

${ }^{120}$ Ibid.

${ }^{121}$ On Urban Development Action Grants, see chapter 10, "Public Private Governance in an Era of Neoliberal Policy Prescriptions."

${ }^{122}$ Southern Technology Council Newsletter, May, 1988, 3, Vol. 2, No. 3, folder SGPB, box 92, subseries 3.3, SGPB.
} 
Cebul

control of a public/private pool of $\$ 10$ million or more" the state merely took the next step in the evolution of public-private developmental partnerships.

The state's investment in high tech paid dividends. Letters of support poured in for Tech's regional field offices, especially. One small businesswoman in Rome described the help she received from Tech, and she hoped they might establish a new office in Dalton for its struggling textile firms:

The great American free enterprise system continues to tell us: ... [ellipses in original] 'only in America, and better still . . IN GEORGIA', are these ventures not only possible, but ultimately successful! Many thanks again for the remarkable services of the Georgia Tech Research Institute here in Rome. Here's hoping we can share them . . but please, not lose them entirely ... to Dalton. ${ }^{123}$

The Brunswick Chamber of Commerce lobbied for a field office, and so did the Chambers in Madison and Valdosta. ${ }^{124}$ Despite business' role in propagating the free market rhetoric of the early Reagan years, in the emerging new economy, and under the guise of persistent "free market" rhetoric, local Chambers of Commerce well understood the value of public interventions in the market.

Sharing the Innovation Economy?

\footnotetext{
${ }^{123}$ Julie V. Ouseley to Joe Frank Harris, November 7, 1988, folder GA Tech Reg. Office, RCB - 1506, GAA.

${ }^{124}$ D. Kenneth Darnell to Joe Frank Harris, November 7, 1988, folder GA Tech Reg. Office, RCB - 1506, GAA.
} 
Cebul

Despite new forms of technology transfers and publicly structured avenues for finance,

Southern politicians wrestled with the plain fact that many metropolitan regions were full-

fledged members of the Sunbelt, while non-metropolitan and rural areas languished. Moreover,

the dirty secret of the "new" economy was that high tech manufacturing might pay higher wages,

but it very often employed fewer workers. In 1985-86, Arkansas Governor Bill Clinton chaired

the Southern Growth Policies Board, and he hoped to focus on high tech research and

development and public to private technology transfers while also unraveling the paradox of

employment. At Clinton's recommendation, the Board created a subcommittee, the Southern

Technology Council, whose mission was to develop robust public private partnerships to unite

the "technological and scientific resources of business, government, labor, and educational

institutions" in order to "contribute to technology based development." ${ }^{125}$ One of their first

initiatives, published in a report titled "Turning to Technology," focused on strengthening

research and technology transfer between publicly funded universities and private business. ${ }^{126}$

But, as Clinton put it while presiding over an STC panel on technology and economic

development, the STC had to wrestle with the fact that, while "technology helps us raise

\footnotetext{
${ }^{125}$ Stuart Rosenfeld to Southern Technology Council, May 16, 1986, folder STC Minutes, box 92, subseries 3.3, SGPB.

126 "Regional Science and Technology Centers of Excellence, A Report from the Southern Technology Council of the Southern Growth Policies Board, September 1987, box 92, subseries 3.3, SGPB.
} 
Cebul

productivity," it also "almost always means doing some things with fewer people."127 To address

these sorts of labor market concerns, within the STC, the Policies Board created a regional

consortium that mirrored the Georgia Tech's incubator model in "demonstration" areas across

the South. The consortium would "expand the mission of technical and community colleges by

developing ... efforts to learn about, evaluate, and use new process technologies and

innovations." ${ }^{\prime 28}$ Predominantly focused on productivity, the program, funded largely by the

Tennessee Valley Authority and the Appalachian Regional Commission, also aimed to help rural

regions and workers transition to the high tech economy. ${ }^{129}$ New Deal and Great Society

programs were underwriting New Democrats' programs.

Likewise, however, in Georgia, Governor Harris was confronted by mounting concerns

that "two Georgias" were diverging - the Atlanta boom region and the rest of the state. Indeed,

only the Atlanta area enjoyed wage levels above the national average, while 58 of the state's 159

counties struggled with income levels less than two thirds the national average. ${ }^{130}$ The "Two

Georgias" controversy was touched off by a highly publicized report by a U.Ga. scholar who

\footnotetext{
${ }^{127}$ Southern Technology Council Newsletter, November 1987, 2, Vol. 1, No. 4, folder SGPB, box 92, subseries 3.3, SGPB.

${ }^{128}$ See, for example, A Project of the Southern Technology Council of the Southern Growth Policies Board, Regional Consortium of Advanced Manufacturing Technology, Training, Development, and Demonstration Centers, folder SGPB CMC Minutes / Process Reports, box 92, subseries 3.3, SGPB.

${ }^{129}$ Southern Technology Council Newsletter, May 1988, Vol. 2, No. 3, folder SGPB, box 92, subseries 3.3, SGPB.

130 “The Issue All the Politicians Love to Tout," Georgia Trend, October 1985.
} 
Cebul

found that that only 14 counties in the state had a per-capita income above the state average.

Meanwhile, Atlanta and its neighbors continued to grow at an astonishing rate. Indeed, the

Bainbridge and Decatur County Chamber of Commerce appealed for help to the Southern

Growth Policies Board to identify "areas in the North where recent industrial closures or

cutbacks have left high numbers of unemployed workers." "During the past" decade, they wrote,

"numerous industries have ... added many millions of dollars to our local economy" and they

were "concerned that we may be reaching the bottom of our pool of available labor.",131

Workforce development thus emerged as an economic development and antipoverty issue

that appealed to booming and struggling communities alike. As the Growth Strategies

Commission warned Harris, "Some issues, especially in rural Georgia, start out looking like

capital market issues, but are really employment development and training, education or

infrastructure issues." ${ }^{132}$ Similarly, in 1983, the Southern Growth Policies Board developed a

work plan on "Human Resource Development" and found that "The primary objective of

elementary and secondary education in the South should be the imparting of functional literacy

to Southern children." Education, they emphasized, "offers the best hope for reducing poverty,

\footnotetext{
${ }^{131}$ David W. Booker to Blaine Liner, May 31, 1979, folder Other, box 18, subseries 1.2.3, SGPB.

${ }^{132}$ James S. Balloun to Belden Hull Daniels, June 22, 1989, folder Growth Strategies Commission, Capital Markets - June, 1989, RCB-14937, GAA.
} 
Cebul

unemployment, and underemployment in these communities."133 As the president of the Atlanta

Federal Reserve Bank told Georgia Trend, in his global travels, "The thing I'm asked all the time about economic development in Georgia is, 'What kind of education facilities do you have?',134

As it had in the 1950s and early 1960s, education policy was again viewed as a good bet for economic development. ${ }^{135}$ But, Georgia's worker training program was primarily geared toward the old, low-skilled "smokestack chasing” economy. Its QuickStart program aided industrial recruitment and expansion efforts with publicly subsidized rapid industrial training tailored to fit recruits' needs. ${ }^{136}$ In the second half of the 1970 s, for instance, the program supported 21,000 jobs and, as one of its advocates asserted, over $\$ 1$ billion in capital investments from 621 new or expanding companies. In his 1982 campaign, Harris pledged to upgrade and expand the program through "a new State effort to meet a booming demand in high technology jobs in Georgia." 137 The state Chamber of Commerce was one of Quick Start's staunchest supporters and actively supported Harris' new emphasis on high tech training. ${ }^{138}$ Said one of

\footnotetext{
${ }^{133}$ Work Plan for the Southern Growth Policies Board for the Program Year, 1983-1984, July 16, 1983, folder Work Plan (SGPB), box 20, subseries 1.2.3, SGPB.

134 “Why Georgia’s Politicians Need Some Remedial Economic Reading," Georgia Trend, February 1986.

${ }^{135}$ On this trend more broadly, see Claudia Goldin and Lawrence Katz, The Race between Education and Technology (Cambridge: Belknap, 2010), and W. Norton Grubb and Marvin Lazerson, The Education Gospel: The Economic Power of Schooling (Cambridge: Harvard University Press, 2006).

${ }^{136}$ On Quick Start in Georgia, see David Paul Bunnell, “The Development of Postsecondary Technical Education in Georgia,” 2009, PhD Dissertation, University of Georgia, Proquest Dissertation Database.

${ }^{137}$ Elect Joe Frank Harris, undated campaign flyer, DOC-3862, GAA.

${ }^{138}$ Questionnaire for Gubernatorial Candidates, DOC-3862, GAA.
} 
Cebul

Harris' aides, “At least $50 \%$ of an industrialist's decision about where to locate a new plant depends on the education level of the local work force." "We have a lot of catching up to do.",139

There were other material reasons for governors' growing emphasis on education: it was one policy area that saw expanded federal spending during the Reagan decade. As federal funding for community and economic development waned, the Administration and Congress bid up federal education spending, authorizing well over the budget request each year of Reagan's two terms. ${ }^{140}$ While Congress passed the measures, OMB director David Stockman placed much of the blame on Reagan's Education Secretary, Terrel Bell. Much to the Administration's surprise, during the first term, Bell deftly leveraged his humdrum position as education secretary in a conservative administration into a bully pulpit for increased attention to the failures and opportunities of public education. Bell shepherded a blue ribbon commission on the state of American public education that produced the landmark report, A Nation at Risk. Like the Growth Policies Board, A Nation at Risk invoked national economic competitiveness to make the case for investments in education. It began: "Our nation is at risk. Our once unchallenged preeminence in commerce, industry, science, and technological innovation is being overtaken by

\footnotetext{
139 “Inventors, Take Notice,” Georgia Trend, May 1989.

${ }^{140}$ In 1982 and 1988, the percentage difference between the budgeted request and the amount appropriated was 55 percent and 44.6 percent; in the nine years of budgeting overall, it was never overshot by less that 9.3 percent, and averaged 25.6 percent above the requested total. Figures in Gareth Davies, See Government Grow: Education Politics from Johnson to Reagan (Lawrence, KS: University Press of Kansas, 2007), 268-9.
} 
Cebul

competitors throughout the world." Education "undergirds American prosperity, security, and

civility." Written in plain language as a letter to the American people, the report deployed stark

Cold War imagery: "We have, in effect, been committing an act of unthinking, unilateral

educational disarmament." ${ }^{141}$ The positive media coverage that attended A Nation at Risk's clear

and urgent appeal encouraged Reagan's adoption of the issue. It worked - poll numbers on his

education policies reversed in his favor. Soon Republicans identified education policy,

particularly the ongoing expansion of policies set in motion during the Great Society, as a way to

demonstrate their compassion. Indeed, historian Gareth Davies found that Republican support for

renewal and extension of 1965 's Education and Secondary Education Act grew until it was

practically monolithic: in 1965, only 26 percent of House Republicans supported the Act. In

1974, 74 percent voted in support. By 1988, the Great Society's cornerstone education bill

received 99 percent of House Republicans' support. As Davies put it, "Rather than fight the

expanded federal role, Republicans increasingly sought a share of the political credit."

Southern Governors especially appreciated increased federal education spending because

the "Two Georgias" issue was salient in states across the Sunbelt: boom regions attracted

innovative firms and high skilled workers, often from the North, but much of the rest of the

region was being left behind. Across Appalachia, ARC investments in education had paid

\footnotetext{
${ }^{141}$ Ibid., 273.

142 Ibid., 282.
} 
Cebul

dividends, but the gap was still wide. Between 1965 and 1980, the proportion of Appalachian

adults over twenty five with a high school education increased from 57 to 83 percent, but one in

three Appalachian adults were still functionally illiterate. ${ }^{143}$

Bill Clinton was especially aware of this growing divide. During his term as Growth

Policies Board Chairman, Clinton focused the Board's Commission on the Future of the South

on the issue. In June 1985, at his inaugural address as Chairman in Atlanta, at which he

appointed the Commission, Clinton explained his rationale:

In Hot Springs, Arkansas, twenty-three years ago, as a boy of seventeen I saw Dr. Martin Luther King, Jr. make his 'I Have a Dream Speech' on television. I will never forget one thing he said that now means more to me than anything else. He said he hoped one day his four little children would be judged not by the color of their skin but by the content of their character. I would like to see the people who live in my state and in my region judged by the content of their character, but it will never happen until every child, by dint of his or her effort, can get a decent education and a decent nationally competitive set of economic opportunities. And that is why we ought to do our best to chart the future of the South in $1986 .{ }^{144}$

As Clinton put it, the main focus of the Report would be to "mobilize support for those public policies and public-private partnerships which will increase the per capita income, reduce

\footnotetext{
${ }^{143}$ Ronald D. Eller, Uneven Ground: Appalachia Since 1945 (Lexington, KY: University Press of Kentucky, 2008), 204.

${ }^{144}$ Bill Clinton, "Charge to the Board in Establishing the 1986 Commission on the Future of the South," June 1985, excerpted as forward to "Halfway Home and A Long Way to Go," (Research Triangle Park, NC: Southern Growth Policies Board, 1986), 5.
} 
Cebul

poverty, and reduce unemployment by Southerners by 1992."145 Education and the economy

were fundamentally linked. With appropriate funding of public education and individual effort,

there would be no need to address structural impediments within the nation's political economy.

Clinton's Commission's report, "Halfway Home and a Long Way to Go," diagnosed the

problems and prescribed solutions. ${ }^{146}$ Echoing the "two Georgias," Clinton identified "two

Souths which are rapidly growing farther apart."147 Too many, the report found, "are left behind

with education and skills which better prepare them to function in Henry Grady's Atlanta of

1886 than in Andrew Young's" of 1986. "They can read the ripeness of a tomato or the sky's

forecast of rain, but not the directions for installing new machinery." Deflecting traditionalist's

apologias, the Board report argued, "To honor the past is one thing. To prefer it will cost us the

future." ${ }^{148}$ Invoking the more austere fiscal federalism of the Reagan era, the Commission also

deployed the era's market speak. "The South has never had its own money to burn, and no longer

has Washington's. With too much need and too little money, the South must spend local, state, and federal money where return will be highest ... Where are the South's best investments?

\footnotetext{
${ }^{145}$ Ibid., 4.

146

${ }^{147}$ Ibid.

${ }^{148}$ Ibid., 7-8.
} 
Cebul

After long study, the Commission concludes that the best way to buy shares of the future with guaranteed profit is to invest in the interdependent lives of Southerners themselves."149

This meant making investments in education as a form of economic development, and, by extension, poverty alleviation. "While higher education can be the power station that energizes an entire society, with a few shining exceptions the South has an inadequate system," Commissioners concluded. "If courses are not correlated with changes in area businesses, the relevance of higher education to the state's economy can be easily lost." ${ }^{\prime 150}$ In rural areas especially, where the public school system was "the only game in town," this was especially true. “Once schools are perceived as a way to create and hold jobs and as contributing to local development, cities and towns may think differently about bond issues and school taxes and realize that the future of their community could very well rest on the schools." 151 The Board called to politically reframe schools as growth engines.

While Joe Frank Harris had been a quiet presence as Governor, his Democrat successor, Zell Miller, was an outspoken mainstay of Georgia politics. Miller had been elected Mayor of Young Harris, Georgia in 1959, and the one time college professor had always made improving public education his signature issue. Miller served for sixteen years as the state's Lieutenant

\footnotetext{
${ }^{149}$ Ibid., 9.

${ }^{150}$ Ibid., 19.

${ }^{151}$ Stuart Rosenfeld, Looking Back to the Future: Economic Roles for Public Schools, September, 1982, 10-11, folder Staff memos from Jesse (1985 back), box 20, subseries 1.2.3, SGPB.
} 
Cebul

Governor, first under Lester Maddox in the late 1960s and then under each subsequent governor.

From this position, Miller had a front row seat to the politics of austerity, and had watched (and criticized) as Governor Harris struggled, ultimately in vain, to secure resources to fund his Quality Basic Education program. With Harris term-limited out of office, Zell set his sights on the 1990 Governor's race, and over the 1988 and 1989 developed a new strategy for funding secondary and higher education for economic development.

In 1988, the state of Florida established a lottery, and some estimates suggested that by 1990 Georgians spent \$200 million annually on lotto tickets across their southern border. Indeed, seven of Florida's ten highest grossing sales points were along the Georgia border. ${ }^{152}$ The Georgia Constitution of 1868 had specifically banned state lotteries, and that provision had been recapitulated in the subsequent constitutional revisions of $1877,1945,1973,1981$, and $1983 .{ }^{153}$ As recently as 1984, Miller himself argued, "a lottery would undermine morals more than parimutuel betting" such as horseracing. By 1990, however, Georgia was one of only 16 states without a lottery. After the Florida lottery was established, and with the pragmatic realization that Georgians near Florida were spending considerable sums on tickets, Miller saw a viable path toward funding new education programs.

\footnotetext{
${ }^{152}$ Michael Nelson and John Lyman Mason, "The Politics of Gambling in the South," Political Science Quarterly, Vol. 118, No. 4, 2003-04, 661.

${ }^{153}$ Hyatt, Zell, 238.
} 
Cebul

Miller reached out to two young Democratic strategists who had recently made a name for themselves by winning improbable victories in Pennsylvania and Kentucky. For Paul Begala and James Carville, winning the Georgia gubernatorial race would be their biggest coup yet.

While the Texas and Louisiana Democrats worried that Zell's long career and voting record might hurt him, they agreed the lottery issue would help Miller stand out as a dynamic force for modern, "progressive" change. In the Democratic primary, the lottery issue functioned as a wedge - no other Democrat supported the proposal. Miller successfully used the measure to thread the needle of American political culture: Americans wanted better services, but they did not want to feel coerced into paying for them. As Miller liked to say, "Thomas Jefferson once said a lottery 'is the fairest tax of them all, because it taxes only the willing.' That's the point Georgians need to understand: the alternative to creative revenue sources like the lottery is taxes. And folks, in the climate we live in today, taxes ain't much of an alternative." "New resources are not going to come along and bail us out." 154

For Miller, the appeal of the lottery came down to a simple matter of choice. He used it to deflect the question of whether the lottery would disproportionately and regressively rely on poor purchasers: "When they stop at a gas station or walk into a grocery store, every Georgian will have a choice about whether to buy a lottery ticket. But they have no choice about paying

\footnotetext{
${ }^{154}$ Hyatt, Zell, 242 and 276.
} 
Cebul

taxes." ${ }^{\text {"155 }}$ Miller explicitly invoked the "Two Georgias" issue, arguing that lottery-funded education reform would "close that gap." "I see the Georgia that is," Miller said, "and the Georgia that can be." ${ }^{\prime 156}$ Moreover, Miller said, "Education" was "the key to economic development." "The state cannot offer a good business climate without good schools"157

With the funds from the lottery, Miller planned to offer optional pre-kindergarten for all Georgians, improved facilities, and, he hoped, scholarships for high achieving high school students to attend Georgia's universities to stem outmigration and brain drain. As he put it, "Families in Georgia have struggled long enough to provide their children with a college education ... Just think of it. Not only will this program ease the financial burden on those families, but it will give virtually every child in Georgia the opportunity to complete for tomorrow's jobs." ${ }^{.158}$

Racial resentment, however, threatened to derail Miller's education and lottery plan. Having won the 1996 Olympics, Atlanta and state politicians faced pressure from civil rights groups to change the state's flag. In 1956, as part of the flap over Brown, petulant Georgia lawmakers changed the state flag to include the Confederate stars and bars. The flag, opponents

\footnotetext{
${ }^{155}$ Hyatt, Zell, 241-3.

${ }^{156}$ Hyatt, Zell, 243.

157 “The Georgia That Can Be: A Blueprint for the 1990s,” folder 39, box 3, Series III, Zell Miller Papers, Richard

B. Russell Library for Political History, University of Georgia, Athens, Georgia [hereafter ZMP].

158 “Zell Miller signs new HOPE law,” Catoosa County News, May 4, 1994.
} 
Cebul

argued in the early 1990s, had no place flying at the Olympics. Miller believed the controversy

offered him a simple way to demonstrate progressive values to a national political audience that, he hoped, might soon see him as a viable Senator or even Vice Presidential candidate. Moreover, Miller reasoned that many Georgians, particularly those in suburban areas, had been born elsewhere, and the issue might appeal to their moderate sensibilities.

He grossly miscalculated. Race relations were a near constant theme during the summer of 1992, which saw the nation convulsed by footage of Rodney King's beating by Los Angeles police officers. Thanks in part to CNN's Atlanta headquarters, the flag issue was soon national news, too. Miller appeared on Larry King Live to debate a representative of the Sons of Confederate Veterans who argued on prime time television that Georgia would have been better off "if not for the loss of a few battles as a result of the [North's] invasion." "159 A JournalConstitution poll found that 76 percent of white Georgians "saw the Confederate battle flag as a sign of Southern pride."160 The response was swift and unequivocal. "A lot of people up here feel betrayed by Zell," reported a small business owner in Blue Ridge, Georgia, near Zell's hometown. He signed a petition opposing the change. In Fannin County, one resident explained why he was signing the petition. "I don't think the blacks have a right to take our flag away . . It stands for our way of life, sir, for the courage of our forefathers." "All of my people fought for

\footnotetext{
${ }^{159}$ Hyatt, Zell, 339.

160 “Fight unfurled over Confederate emblem," Star-News, April 25, 1992.
} 
Cebul

the Confederacy," explained another white Georgian, as he signed the petition. The owner of a grocery thought, "Zell would have better things to be concerned about then the flag." ${ }^{\text {, }}$ Even Jimmy Carter, Miller recalled, questioned his decision, saying, "What do you want to do that for? I've always thought that was a pretty flag." "162 Miller quickly regretted his move. "There was no way I could pass that bill," he told a biographer, "and once I saw that I should have pulled the plug on it much sooner than I did ... I left the situation where it cannot even be discussed calmly for years to come." 163 A small business owner explained why Miller lost so definitively: "People just don't like minorities or authorities telling them what to do." 164

Miller backed off the flag issue and focused instead on resuscitating his beleaguered image through the lottery and education plan. While polling prior to the flag fiasco indicated overwhelming support for a constitution amendment allowing a lottery, by the fall of 1992 Georgians had soured on Miller, and the same polls showed a drop in support from 70 to 52 percent. ${ }^{165}$ Moreover, lottery opponents had mobilized, and particularly influential were clergy, including some from Miller's Methodist denomination who called for his excommunication.

\footnotetext{
161 "Former backers call governor a traitor in flag fight," Tuscaloosa News, June 21, 1992.

${ }^{162}$ Hyatt, Zell, 328.

${ }^{163}$ Ibid., 343.

164 "Former backers call governor a traitor in flag fight," Tuscaloosa News, June 21, 1992.

${ }^{165}$ Nelson and Mason, 664.
} 
Cebul

Nevertheless, Miller's amendment eked through with a slim 52 percent majority. By the following year, Georgians had spent $\$ 300$ million on lottery tickets. While some revenue went for pre-kindergarten and school construction, the most notable program was the HOPE scholarships (Helping Our People Educationally): full tuition to any Georgia public university or vocational school for any Georgia high school student who maintained a B average or better. While the state initially restricted recipients to households with annual income below $\$ 66,000$, they quickly lifted the restriction. Between 1993 and 1999, nearly 5,000 Floyd County students, received over $\$ 7$ million in HOPE grants. County schools and universities benefited, too. Over 3,000 students attended Berry College on HOPE scholarships, generating more than \$9 million in tuition revenue. At Coosa Valley Tech, $\$ 4.2$ million in HOPE funds covered vocational tuition for 5,765 students. In its first six years, 319,472 Georgians used \$580.7 million in lottery revenue to attend Georgia institutions of higher education. An editorial by the Rome News Tribune's Business Editor glowed: HOPE “alone has had an impact far beyond what even the lottery's most loyal supporters could have dreamed." "We all owe" Zell "a great deal."166 While the moral uproar faded with time, other critics charged that HOPE was a highly regressive program. Because poor and minority groups were more likely to purchase lottery tickets and less likely to perform as well in school as middle and upper class students, detractors

\footnotetext{
166 “Forget the 'Zig-Zag,' Zell was swell for Georgia’s children,” RNT, January 17, 1999.
} 
Cebul

argued the program stole from the poor to benefit the better off. Miller fired back at the "thinktank elitists who make a living finding fault with anything." Said the Governor, "They can keep criticizing this program, and I'll just keep giving a free college education to deserving Georgia students." ${ }^{167}$ Nevertheless, subsequent analysis found, "a highly regressive pattern of net benefits." Households that made under $\$ 25,000$ spent far more on lottery tickets than they received in education benefits, while households with income over $\$ 50,000$ had the opposite trend. They spent far less on lottery tickets and enjoyed much higher rates of subsidies. White households spent the least on the lottery but enjoyed "substantially higher benefits from lottery funded programs, on average." 168

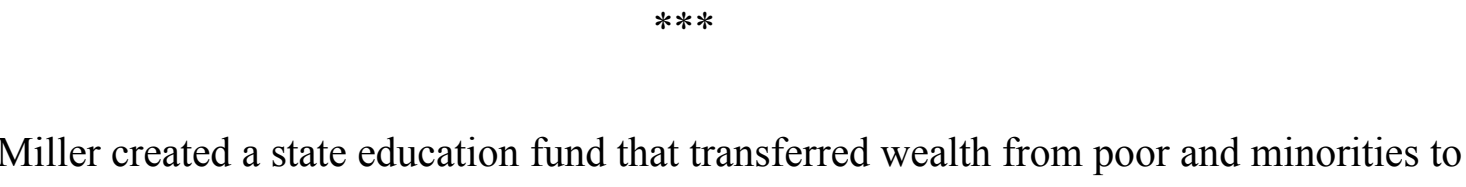
predominantly white, middle class Georgians. By emphasizing the "deserving" nature of HOPE recipients and willfully ignoring well-founded concerns about its regressive quality, Miller repeated one of the central themes of twentieth century developmental state building. He justified public action that benefited the majority and middle class by emphasizing the ways a policy might alleviate poverty and offer opportunity for "deserving" individuals. Miller sold these

\footnotetext{
167 “Governor reacts to HOPE critics," RNT, June 3, 1997.

${ }^{168}$ Ross Rubenstein and Benjamin Scafidi, "Who Pays and Who Benefits? Examining the Distributional Consequences of the Georgia Lottery for Education," National Tax Journal, Vol. LV, No., 2, June $2002,236$.
} 
Cebul

elements, as had other developmental state builders sold programs like Urban Renewal or Block

Grants, as a way to grow the economy and create opportunity without redistributing wealth. They

had all, in fact, redistributed wealth - from the bottom up. 
Cebul

\section{Epilogue}

In 1991, the Democratic Leadership Council held its annual convention in Cleveland,

Ohio. By calling the gathering a Convention, the Council made a tactical decision, drawing the ire of unaffiliated Democrats. DLC leaders aimed to endow the gathering with the gravitas that might propel its major figures - chief among them Al Gore, Bill Clinton, Tom Daschle, and Sam Nunn - to positions of greater influence within the broader Party in the lead up to the 1992 presidential nomination season. Dominated by Southern Democrats, the DLC hoped its convention would demonstrate that its vision for the Democratic Party resonated beyond the Sunbelt's "New" Democrats. Contrary to contemporary news coverage, this vision for the party was not particularly new, though it had been dormant within the national party, in particular its Congressional leadership, for some time. Over the 1980s and early 1990s, however, Southern governors like George Busbee, Bill Clinton, and Zell Miller had nurtured this strain of Democratic growth liberalism through structural economic changes and national electoral realignment. As Democrats had during the high tide of growth liberalism, "New" Democrats emphasized universalist language and growth policies rather than redistribution; investing in programs that purported to offer equality of opportunity rather than equality of outcomes; and 
Cebul

they possessed an outsized faith in the transformative power of technology to drive economic development and social reform.

Leaders on the left of the party blasted the DLC for its obvious lack of diversity. Jesse

Jackson implied on a number of occasions that the DLC was little more than an updated version

of the Dixiecrats. ${ }^{1}$ While he was wrong to equate modern DLC Democrats with the racist cadre of Southern Democrats of 1948, he was absolutely correct that this group resisted poverty or minority-targeted redistribution. Jackson and others on the left charged that DLC members borrowed their ideas from Republicans, but this brand of New Democrat had its roots in the growth liberalism of politicians like John F. Kennedy. DLC Democrats had come of age in the "new" south and embraced the optimistic, some charged naïve, ethos articulated across the region in the 1970 s by the Southern Growth Policies Board - racial reconciliation and social reform could be driven by economic growth. More pragmatically, too, Clinton and DLC leaders like Al From understood that winning national elections and pushing issues like structural reform on behalf of poverty alleviation had essentially become mutually exclusive endeavors.

Their faith in economic growth made them Pollyannaish on structural racism but also politically potent. Cleveland, then, was appealing for two main reasons. Northeast Ohio was home to white, male "Reagan Democrats," whom the DLC aimed to bring back to their father's

\footnotetext{
${ }^{1}$ Kenneth S. Baer, Reinventing Democrats: The Politics of Liberalism from Reagan to Clinton (Lawrence, KS: University of Kansas Press, 2000),185.
} 
Cebul

party. But Cleveland was also a majority minority city headed by African American Mayor

Michael White, who was an outspoken supporter of the DLC.

White sat just behind Bill Clinton while the Arkansas Governor gave the keynote address before hundreds of DLC members in Cleveland's Convention Hall. Since nominating Michael Dukakis at the 1988 Democratic National Convention, it was the biggest speech Clinton had given. It would turn out to be the opening salvo in his successful run for the presidency. Clinton forcefully articulated the themes that animated his campaign and that crystalized the DLC's resurgent force within the Democratic Party. "[O]ur burden," Clinton said, "is to give people a new choice, rooted in old values, a new choice that is simple, that offers opportunity, demands responsibility, gives citizens more say, provides them responsive government." And, Clinton said, "Opportunity for all means first and foremost a commitment to economic growth." To get there, he argued for "investment in emerging technologies, and more incentives to invest by U.S. companies in their own country." He urged the development of "world-class skills, for people who live here while money and management may fly away." This was a message that resonated in Cleveland.

Clinton sought to reclaim cooperative rather than categorical federalism as a Democratic, not conservative initiative. He pledged "to reinvent government, to make it work." Clinton deployed market speak to do so, saying "We believe that we should follow the successes of our 
Cebul

greatest corporations in eliminating middle levels of bureaucracy, pushing decisions down to the

lowest possible level, empowering people, increasing accountability, and treating our citizens

like they were our customers and our bosses - because they are." Decisions "handed down on

high by government bureaucracies are not always the best way to go.” And Clinton explicitly

highlighted the "false choice" of determining whether what he called for was conservative or

liberal. The far left of the party was outraged, however, by Clinton's hard line on welfare. He

demanded "that everybody who can go to work do it." They accused Clinton of merely

repackaging Reagan's Welfare Queen trope, a dog whistle for the racist Reagan Democrats. But, in many ways, Clinton's position - "work is the best social program this country has ever devised" - echoed Franklin Roosevelt's and Lyndon's Johnson's vision of social reform through economic improvement rather than redistribution. Indeed, had Clinton deployed Lyndon Johnson's frequent quip about turning "tax eaters into tax payers," the left might have eaten the Arkansas Democrat alive.

Cleveland's Mayor Michael White was a natural ally for Clinton and the DLC. In 1989, the African American Democrat, then a state senator, ran as the tough on crime candidate, pledging to hire 250 new police officers in an effort to escalate the war on drugs. For black residents, who were the silent victims of drug abuse and criminality and simultaneously the victims of the punitive turn in crime policy, the prospect of an African American who had grown 
Cebul

up in their neighborhoods leading a new drug war seemed promising. As a conservative

Democratic City Councilman, who had voted for Reagan and Bush but had pledged his support

to Clinton, described it, White's “message that I hear in the black community is that you can't go

blaming people anymore ... Some black leaders have taken issue with that, but I don't think

people are listening to them anymore. There comes a point where people have got to take control

of their own destiny.” "2 Indeed, like Council President George Forbes before him, White had

undergone a significant political transformation, evolving from a firebrand, redistributional

councilman, to a political power broker who moved seamlessly from ward halls to corporate

boardrooms. White called for individuals in the black community to stand up and save

themselves while he went to work on continuing the city's downtown redevelopment. ${ }^{3}$

White's and Clinton's emphasis on growth, individual "empowerment," and taking a hard

line on crime also played well with Cleveland's business leadership, which, during the

Voinovich years, had essentially taken over the city's developmental planning. Mayor White

radically extended the suburban-oriented, bricks and mortar downtown development of his

predecessor. Indeed, between 1980 and 1996, a period during which $\$ 3.7$ billion was invested in

building contracts, the top five biggest years for investment in downtown occurred under

\footnotetext{
2 “Clinton Gains From Eased Race Tensions in Big Cities,” WP, October 8, 1992.

${ }^{3}$ On this new black political class that pursued its own self interest, see especially, Adolph Reed, Jr., Stirrings in the Jug: Black Politics in the Post-Segregation Era (Minneapolis, MN: University of Minnesota Press, 1999). See also, Nathan D. B. Connolly, A World More Concrete, forthcoming.
} 
Cebul

Michael White. New bond issues and some state and federal funding were crucial for the redevelopment of the harbor and other projects, but the city's biggest undertaking - a massive new sports complex to house the baseball Indians and basketball Cavaliers - was funded through a county-wide sin tax on alcohol and cigarettes. As Zell Miller's lottery had in Georgia, White's sin-tax funded stadium projects overwhelmingly benefitted suburban whites, who spent less per capita on cigarettes and alcohol than did poorer city residents. ${ }^{4}$ Many of the new corporate office towers, too, the new Key Bank building especially, the city's tallest, received significant tax abatements, which directly transferred wealth from the city's abysmal schools to big business. ${ }^{5}$

While groups like the Cleveland Roundtable joined with the Mayor in focusing on downtown development, an offshoot - Cleveland Tomorrow - turned its attention to deeper structural issues in Cleveland's flagging industrial sectors. Though it eventually expanded to include lawyers and investment bankers, Cleveland Tomorrow was initially comprised solely of the chief executive officers of Cleveland corporations with revenues exceeding \$250 million. Its young executive director, Richard Shatten, was a former McKinsey consultant. Under Shatten's leadership, Cleveland Tomorrow's primary goal was encouraging the city's businesses to reform, modernize, and to generate a more focused industrial strategy for the city. For these

\footnotetext{
${ }^{4}$ Edward W. Hill, "Comeback Cleveland by the Numbers," in David C. Sweet, Kathryn Wertheim Hexter, and David Beach, eds., The New American City Faces its Regional Future: A Cleveland Perspective (Athens, OH: Ohio University Press, 1999), 79-81.

${ }^{5}$ Ibid, 84-5.
} 
Cebul

constituencies, Clinton's calls for new federal investments in R\&D driven economic growth had significant producerist appeal.

Under Shatten, Cleveland Tomorrow spearheaded the Cleveland Advanced

Manufacturing Program (CAMP), a business partnership with new technology transfer centers at Case Western Reserve University, Cleveland State University, and Cuyahoga Community College. ${ }^{6}$ CAMP would "develop computerized manufacturing methods, demonstrate their effectiveness in plants and train or retrain people in the new skills." ${ }^{, 7}$ While the Program did not receive direct federal funds during the Reagan years, Ruben Mettler, the chairman of TRW, urged Ohio Governor Richard Celeste to appropriate \$16 million to develop "advanced technology centers" throughout the state under a new "Thomas Alva Edison Partnership Program” through the Ohio Economic Development Department. Retired Eaton Corp vice president Robert G. Brown said the grant was crucial to getting Cleveland's new partnership “off to a good, healthy fast start." As Governor Celeste put it, "The Edison Program will act as a magnet to attract new industries that can leverage what they have, and it builds on the strengths of the state." By the end of 1985, the Ohio legislature had committed $\$ 67$ million to develop six

\footnotetext{
${ }^{6}$ For an overview of the various new developmental initiatives in Cleveland and Northeastern Ohio during the 1990s and early 2000s, see Edward Hill, et al, “Economic Shocks and Regional Economic Resilience,” in Margaret Weir, Nancy Pindus, Howard Wial, and Harold Wolman, eds., Urban and Regional Policy and its Effects, Volume IV (Washington, DC: Brookings Institution Press, 2012).

7 “3 college here form advanced-tech centers," PD April 17, 1984.
} 
Cebul

public-private-University partnerships throughout the state, which included subsidies for

Universities as well as seed development funds. By early 1986, too, Cleveland Tomorrow

established the Center for Venture Development, an incubator organized through CAMP. It had

51 clients, including small fledgling firms as well as big companies like GE and Bailey

Controls. ${ }^{8}$ Said one executive, the bottom line was that "technical assistance helps companies

survive." 9 As Governor Richard Celeste put it, the program was about "learning to create jobs"

for "a new generation of ... manufacturing." "This was "not an ivory tower exercise" Celeste

said. As Brown put it, "The name of the whole game is job creation and job saving."

another supporter, "Full employment for all our citizens" is the "No. 1 priority."12 To deliver the

jobs, Shatten said the city must "Make love to our entrepreneurs."13

Shatten understood that underlying Cleveland's structural decline was a set of cultural

impediments to embracing the full range of solutions to waning manufacturing productivity.

Cleveland's business leaders had long resisted creating such an arrangement of aggressive public

to private technology transfer programs, because, as one executive noted, they feared losing

\footnotetext{
8 “"Edison Program: Invention is jobs, $P D$, October 27, 1985.

9 “Tool industry on ropes," PD, February 16, 1985, and “Edison Program: Invention is jobs, PD, October $27,1985$.

10 "Industry-university partnership to help manufacturers compete," $P D$, March 13, 1985.

11 “'Edison Program: Invention is jobs, PD, October 27, 1985.

12 “On Woodland, the same hopeful word,” $P D$, October 6, 1986.

13 “Richard Shatten," Crain's Cleveland Business, May 24, 2010.
} 
Cebul

proprietary know-how. ${ }^{14}$ As one Plain Dealer columnist put it, "many of our . . . companies are slow to reach out for technological self-improvement, with some saying it costs too much. Such an attitude in today's marketplace, of course, is deadly." ${ }^{15}$ As the director of the workforce training program put it, "The shocker was that many companies still have not come to terms with the need to invest in new technologies." ${ }^{, 16}$ In the context of globalizing industrial competition and Japan's strides in productivity and technological advancement, a management consultant at Arthur Andersen explained the stakes for Cleveland's business. "If they are to get an advantage over their competitors, they must" take action. The vice president of CAMP agreed: "some industries are doomed to be second rate if they don't do more." Japan's progress "requires that people change things that have been taken for granted for many years." ${ }^{\prime 17}$ All of this meant accepting - even demanding - a greater public sector role in enhancing private sector productivity and competitiveness.

Nearly three decades after Georgia established Area Planning and Development Commissions and the state of North Carolina funded the Research Triangle Park, Cleveland's business and political leadership at last understood that developing a regional industrial policy was essential for growth - indeed survival. CAMP, Cleveland Tomorrow, and the Cleveland

\footnotetext{
14 “Tool industry on ropes," $P D$, February 16, 1985.

15 “Edison Program: Invention is jobs,” $P D$, October 27, 1985.

16 “CCC tech center gives firms a boost," $P D$, October 3, 1986.

17 “Manufacturing: Self improvement is called top priority,” $P D$, January 12, 1987.
} 
Cebul

Foundation collaborated on a report that emphasized biotech as the city's area of greatest potential. In 1987, the state responded by injecting another $\$ 1.5$ million to help establish the Edison Biotechnology Center (now BioOhio) ${ }^{18}$ As a laudatory editorial in the Plain Dealer put it, the funding offered the city "Renewal through research." "A targeted program is recommended" and "Linkups should be made to medical and government reservoirs of brainpower," editors argued, "as well as to industries and state-federal programs that provide most research funding." As former corporate CEO and head of CAMP Robert Brown, put it, "Our economic base can weaken even more if left to itself." ${ }^{, 19}$ But the economic base also depended on an intellectual base. Indeed, in the disastrous late 1970s, while Georgia Tech and the Southern Growth Policies Board were emphasizing the move to high tech innovation, Cleveland lost 2,600 engineers and scientists, many of whom fled to the Sunbelt. ${ }^{20}$ A 1988 CAMP report found that Cleveland lagged the nation considerably in engineering and science research, despite having Case Western Reserve University, a national leader in engineering and scientific research, within the city limits. Building on CAMP's emphasis on biotech, the report called for the creation of a $\$ 60$ million biomedical research center at Case. ${ }^{21}$ Cleveland's

\footnotetext{
18 "Ohio aid given to biotech center," $P D$, November 25, 1987. See also http://www.bioohio.com/membership/

19 "Renewal through research," $P D$, December 27, 1987.

${ }^{20}$ Ibid.

21 "Here comes the high-tech wonder," PD, January 19, 1988.
} 
Cebul

business, political, and academic leadership was at last partnering on behalf of creating a targeted industrial policy

By the following year, Edison had identified hundreds of biotech and high tech related firms in the region, but found that many were gravely undercapitalized. As Scott Rickert, the founder of a nanotech firm and a former Case professor put it, though their sales could top $\$ 1$ million in 1988, his firm would "lose money because of research and development expenditures." "It's very difficult to get into the manufacturing business," he said, because the "start-up costs . . . are enormous." Said Rickert, CAMP and other publicly funded R\&D programs make it so "a small company can get the resources of a big company." Said Bill Sanford, whose medical technology startup Steris had just turned three, "People in start-up businesses tend to underestimate the amount of time and money involved in starting a business." Cleveland's incubators and public to private technology transfers, he said, could help generate faster, more cost effective starts. In 1988 Steris celebrated hiring its $38^{\text {th }}$ employee. ${ }^{22}$ By 2014, Steris was a publicly traded company with $\$ 2.71$ billion in market capitalization.

In 1988, South Carolina's original "New Democrat" Senator Fritz Hollings pushed hard to create a national system of technology transfer and $R \& D$ to support national economic competitiveness. Hollings introduced the Technology Competitiveness Act of 1987 to set up

\footnotetext{
22 "Entrepreneurs temper thrill of own business with reality," PD, October 4, 1988.
} 
Cebul

federally funded regional technology transfer centers. He drew upon South Carolina's own R\&D

transfer programs, but he also cited a Navy program, the Automated Manufacturing Research

Facility, which had successfully partnered with a variety of companies and Universities to

promote "dual use" technologies - developing military oriented R\&D that could be rapidly

transferred to and scaled up for the civilian economy. ${ }^{23}$ To avoid Reagan's veto - with which the

President threatened anything that smelled of industrial policy - Hollings bundled his legislation

into the politically safe Omnibus Trade and Competitiveness Act of 1988. Three initial

Manufacturing Technology Centers were designated in January 1989, the Northeast MTC, based

in Albany, and run jointly by New York State and Rensselaer Polytechnic Institute, the Southeast

MTC, run by the University of South Carolina at Columbia, and the Great Lakes MTC, operated

by Cleveland Tomorrow's Cleveland Advanced Manufacturing Program. The public private

R\&D vehicle Cleveland's business leadership had created had become a branch of the federal

developmental state. Though its initial outlay was a mere $\$ 1.5$ million in federal grants (matched

by another $\$ 1.5$ in state grants), the National Institute of Standards and Technology, the branch

\footnotetext{
${ }^{23}$ On the origins of dual use, see Shelley L. Hurt, “The Military's Hidden Hand: Examining the Dual-Use Origins of Biotechnology in the American Context, 1969-1972," in Block and Keller, eds., State of Innovation. See also, "Manufacturing and Automation Systems: Techniques and Technologies," Part 1 of 5 (San Diego, CA: Academic Press, Inc., 1992), pp. 310-5. Accessed online, http://books.google.com/books?id=oEcBE_5xDI0C\&pg=PA317\&lpg=PA317\&dq=AMRF+hollings\&source=bl\&ot $s=1$ REDC2iKLd\&sig=vZ2ApBtJtIne2Zv7eWG-

TcilZYs\&hl=en\&sa=X\&ei=9AcmU_P2G9CEkQfCtIDYCA\&ved=0CC0Q6AEwAQ\#v=onepage\&q=AMRF\%20hol lings $\& \mathrm{f}=$ false
} 
Cebul

of the U.S. Department of Commerce that oversaw CAMP, touted CAMP's success in its first year of federal funding, having established "working relationships with more than 400 firms." In 1994, President Clinton expanded the program, upping its budget by 79 percent. $^{24}$

While Cleveland's business leadership was finally forging industrial policy in partnership with local, state, and national governments, the potent regionalism that had played such a formative role in building developmental state capacity was unraveling across Georgia and the broader South. Local coverage of the Coosa Valley Area Planning and Development Commission's $25^{\text {th }}$ anniversary celebration - an event keynoted by Governor Joe Frank Harris was buried beneath the fold on page three of the July 22, 1983 edition of the News Tribune. An editorial salute to the Commission revealed the waning enthusiasm for its regional planning and development work. In contrast to the florid optimism of the 1950s and 1960s, the News

Tribune's editors were muted. "The years" since its founding "have seen changes, of course," but "it's encouraging to know that the original purpose is still there and today, as in the late 1950s, the commission continues to serve simply as an extension of local government." This narrative completely missed the Commission's origins in the private sector. Without touting its specific successes, the editorial noted "the commission deals with such complex area-wide problems as

\footnotetext{
${ }^{24}$ Joan M. Zenzen, Automating the Future: A History of the Automated Manufacturing Research Facility, $1980-$ 1995 (Gaithersburg, MD: U.S. Department of Commerce, 2001), pp. 68-71. For a concise overview of Clinton's technology policy, see Marian Negoita, "To Hide or Not to Hide? The Advanced Technology Program and the Future of U.S. Civilian Technology Policy," in Block and Keller, State of Innovation, 78-84.
} 
Cebul

water and sewage, jobs training and economic development." As they weakly concluded, "We

feel the area is mighty fortunate to have the Coosa Valley Area Planning and Development

Commission working hand-in-hand with local governments." 25

At that 1983 meeting, the Commission swore in its first female Chairperson, Anne Rigas.

A Republican, Rigas had been very active in Rome and Floyd County developmental politics in the 1970s, having served on the Floyd County Commission. While Rigas had gotten a taste of city-county acrimony in the 1970s - she had witnessed Roy Knowles’ populist Wallace-ite campaigns against, among other regional organizations, the Coosa Commission - years of inflation, tax revolts, and deepened mistrust of public institutions set the stage for far worse fragmentation and city-county and interregional acrimony. Such was the case in regions across the country. As the director of the Advisory Council on Intergovernmental Relations later put it, Reagan's budget cuts engendered a "fend-for-yourself" federalism that fostered a heightened sense of municipal and regional competition. ${ }^{26}$ Most issues came down to taxing and spending authority, questions of representation, and collapsing regionalism - all of which had been tenuously held together by federal spending that had underwritten a loose consensus on developmental priorities.

${ }^{25} R N T$, July 21, 1983.

26 "Looking at the Reagan Record on Federalism," NYT, June 14, 1987. 
Cebul

The same year she was named Coosa Commission chairwoman, Rigas chaired the Floyd County Commission, which asked voters to approve a $\$ 3.4$ million bond issue for a new County library as part of Rome's downtown revitalization effort. Rigas' vision of civic progress reflected popular currents sweeping the state and nation: investments in education and educational facilities would generate economic development and signify a community on the move. ${ }^{27}$ In the preceding decade or so, however, the County Commission repeatedly sought voters' support for new civic buildings. Increasingly, the county's electoral majority, bolstered by new suburban developments, overwhelmed city voters' support. In a period of rapid inflation, County voters feared new debt would mean increased property tax assessments to cover interest payments. In the context of the late 1970s and 1980s, such debt instruments were nonstarters for Floyd County voters. In 1974 and 1976, County Commissioners sought bond issues to replace the outmoded County courthouse. Both times, county voters defeated the measure. Then, in 1979, they sought bond support for a new jail. The current jail, a federal judge warned, was so bad it "violates the constitutional mandate that cruel and unusual punishment shall not be inflicted." Again, voters defeated the measure. It should not have been a great surprise, then, in 1983, when Floyd County residents overwhelmingly defeated city voters and their library bond. ${ }^{28}$

\footnotetext{
27 “Study begins on new-library plan,” RNT, February 28, 1985.

28 “It's now easy to see what voters turned down," RNT, June 29, 1992.
} 
Cebul

After so many defeats it might have seemed irrational for the County Commission to again go to voters for support, but the library measure was merely the first step in a dance that developmentally minded Romans had learned over a decade of Floyd County resistance. Some city residents ruefully called county voters "ginners" - in a Southern drawl, they were "aginst" everything. ${ }^{29}$ Following the defeat of the prison measure, Commissioners secured an order from the federal judge who stipulated that Commissioners renovate, rebuild the jail, or simply stop making so many arrests. The jail was ultimately built with County revenue. In the case of the courthouse, the Commissioners turned to federal funding, securing more than $\$ 2$ million in federal grants to carry out the necessary renovations and expansion. And so, when the voters predictably turned down the Commission's request for locally sourced funding, Commission members met behind closed doors and secured $\$ 3$ million in state funds and unilaterally moved to float over $\$ 3$ million in matching revenue bonds to be repaid at 10 percent interest over 15 years. The library was completed three years later. At that point, all of the Commissioners who secured its construction had been voted out of office. At its ribbon cutting, the library's architect let a Freudian slip sneak into his remarks: "These are men and women who put their political rears - careers - on the line for causes in which they believe."30

\footnotetext{
${ }^{29}$ Interview with George Harper, August 9, 2012, Rome, Georgia.

30 “Library: Community pleased with results," RNT, December 19, 1988.
} 
Cebul

Such behind the scenes moves that defied popular referendums, however, only stoked a potent and vitriolic antigovernment populism among rural voters. "THE DAY DEMOCRACY DIED IN FLOYD COUNTY” boomed one political ad. "TOMORROW will be your last opportunity for 4 years," a county candidate exhorted voters, "to return the government of Floyd County back to the people and stop this runaway spending that can only lead to higher property taxes, deficits and less jobs. This serious act against approximately $60 \%$ of the voters by C.T. Blankenship, Anne Rigas, and Howard Smith is unacceptable in this country."31 "REMEMBER THE LIBRARY?" asked another ad. "What happened to DEMOCRACY in Floyd County. What we have now is an unelected dictatorship!"32

A new seat opened on the County Commission in 1990, and Rigas again threw her hat in the ring. So too did Roy Knowles, by then 75 years old and suffering from the early stages of emphysema and, soon, lung cancer. His campaign slogan that year was "YOUR TAX DOLLARS VS. THE SPECIAL INTERESTS. $" 33$ Despite his advanced age, infirmity, and cyclical returns to and expulsions from Floyd County elected office, Knowles' campaign against “wasteful and foolish spending” won the day, besting Rigas' good government developmental optimism. ${ }^{34}$ Rigas said she and her supporters “fear we've lost the prestige of progress." She

\footnotetext{
31 . “THE DAY DEMOCRACY DIED IN FLOYD COUNTY,” RNT, August 8, 1988.

32 “'REMEMBER THE LIBRARY?” RNT, August 4, 1988.

${ }^{33}$ Knowles Ad, RNT, October 28, 1990.

34 “Tumult, controversy enliven election year," RNT, December 30, 1990.
} 
Cebul

hoped "that the citizens will unite in an effort to bring back dignity and professionalism into county government." She won all of Rome's precincts, but Knowles won the county. Knowles' election, the News Tribune editors wrote, augured "A time for reckoning," particularly for a long proposed civic center project and future developments along Rome's downtown riverfront. The fact that Rome overwhelmingly supported Rigas meant, as the News Tribune later put it, Romans were effectively "disenfranchised. They are not allowed to have their voice or choice in the operations of county government by an election system that has been bent to ensure rural domination. ${ }^{35}$ In their first move on the Commission, Knowles and his County allies sought to fire County Manager Richard McCullough, who had supported Rigas' developmental agenda. McCullough, however, was out of the country, having been called to active duty in Kuwait for Operation Desert Shield. ${ }^{36}$ Their ouster would have to wait until he returned from serving his country.

This fragmenting sense of regionalism found potent national expression, too, in the Congressional elections of 1994. That year, Newt Gingrich deployed his "Contract with America," a ten point action plan aimed at getting government off Americans' back. As he had for nearly two decades, Gingrich forcefully differentiated his policies from Democrats, though in truth, a number of his proposals had bipartisan support (e.g., targeted tax cuts, some form of

\footnotetext{
${ }^{35} R N T$, June 23, 1992.

${ }^{36}$ Ibid.
} 
Cebul

welfare reform). Nevertheless, by unifying their message, a new and insurgent generation of

Republican candidates, many of whom were under 45 and had come of political age in an era of antigovernment, free market pronunciations, wholeheartedly embraced Gingrich's message. The result was a nearly opposite political appeal to that which had knitted together the growth-based Democratic coalition: rather than understated federal support for a range of pragmatic local developmental issues, Gingrich's New Majority advanced an outspoken assault based on fundamentally abstract grievances about national overreach. The Contract with America, historian Steven Gillon noted, "turned Tip O'Neill's dictum that 'all politics is local' on its head." ${ }^{37}$

In Northwest Georgia, young conservative firebrand Bob Barr took the incumbent Democrats' seat in the $7^{\text {th }}$ Congressional District thanks to overwhelming support from rural county voters (he lost in Rome by a wide margin). ${ }^{38}$ As Barr put it, "It would be difficult to overstate" Gingrich's role in the Republican landslide. "He provided the vision that allowed us to win. ${ }^{39}$ Most gratifying for Gingrich was that most of the new Republicans came from districts, like Georgia's $7^{\text {th }}$, that had tended over the last decade to vote Republican in Presidential elections but had maintained support for their Democratic incumbents. Indeed, the $7^{\text {th }}$ District's

\footnotetext{
${ }^{37}$ Steven M. Gillon, The Pact: Bill Clinton, Newt Gingrich, and the Rivalry that Defined a Generation (New York: Oxford University Press, 2008), 125.

${ }^{38} 1994$ General Election Results, U.S. Congress, $7^{\text {th }}$ District, Georgia Secretary of State.

${ }^{39}$ Gillon, 130.
} 
Cebul

Buddy Darden had weathered Republican challengers since 1983, despite the Reagan

Revolution. Gingrich's contract, however, had given a new generation of conservatives a unified voice. As one of the many new freshman members of Congress put it, "The freshmen see themselves as different." Like local political actors such as Floyd County’s Roy Knowles, they viewed themselves as outsiders, sent to Washington to tame an out of control beast. ${ }^{40}$

The year of Gingrich's New Majority, 1994, the Clinton Administration announced plans to expand the number of Manufacturing Technology Centers, from the three original outposts in Albany, Cleveland, and Columbia, South Carolina, to one hundred. Indeed, by the close of 1994, Clinton had already raised the funding for the MTC's parent agency, the Advanced Technology Program, from $\$ 68$ million to $\$ 441$ million. But, as the Washington Post reported, the New Majority quickly targeted the programs "as particularly worthy of extinction" since the new generation "reserve[s] a special circle in their political hell for anything that remotely smacks of 'industrial policy.",41 “If federal revenues go away," said the director of the Cleveland center, "we'd have to focus our energies on larger companies. The casualties would be the very small companies with 20 to 100 employees," the kind that most depended upon federal R\&D and technology support. ${ }^{42}$ By 1995 , the Cleveland center had worked on over 800 technical

\footnotetext{
${ }^{40}$ Ibid., 129.

41 “Look for the New Majority in Congress to Shake Up High-Tech Partnerships,” WP, November 11, 1994.

42 “U.S. Program Preaches Profit Through Technology,” Philadelphia Inquirer, July 28, 1995.
} 
Cebul

assistance projects, using over $\$ 21$ million in federal and state funds to offer the programming

free or at very low cost to area businesses.

Despite the enthusiasm in Cleveland for publicly funded technical assistance, killing the Commerce Department, through which the MTCs were funded, became Republicans' leading target in the symbolic quest to slay an executive agency. Emboldened by the New Majority, as a key ally of Gingrich's put it, referring to the ATP and MTC programs, "We're trying to promote technological freedom and opportunity, as opposed to a Federal command-and-control system." While some conservatives invoked such ideologically motivated justifications, others simply evinced parochial jealousy. "I note that no South Dakota firm has ever received a grant from the Advanced Technology Program," said one South Dakota Congressman, ignoring Clinton's pledge to expand the program. None "of [its] Manufacturing Technology Centers provide any technical assistance to any company in my state. ${ }^{, 44}$ To some freshman, cutting federal programs for cutting's sake was justification enough. Said one, “Abolishing the Commerce Department, abolishing some part of the federal government, is really important to reducing the federal deficit." As Commerce Department Secretary Ron Brown put it, "It's an absolutely ludicrous idea, at a time of intense global competition ... to think the United States of America would be

\footnotetext{
43 “Outlook 1995: Technology and Media: Congress and White House Split on High Tech,” NYT, January 3, 1995.

44 "Tech budget faces congressional fire," Computerworld, February 20, 1995.
} 
Cebul

the only country in the world where the private sector has no seat at the Cabinet table." ${ }^{45}$ Despite the onslaught, the ATP eventually survived Republicans' assault, and Clinton restored much of its funding. But, in a renewed push to end government's practice of picking "winners and losers," President Bush killed the program in 2007.

While Cleveland's political economic infrastructure and institutions had worked hard to function a bit more like those in the Sunbelt, the South's major business and political institutions had begun to function a little bit more like those in the North. In Rome and Floyd County, and, indeed, across Georgia, a broader range of interests competed to steer regional developmental agendas, and many were slowly but surely making modest inroads. In Rome, however, race and representation continued to be persistently thorny issues. A 1987 incident shook Rome's business associations in particular. The Rome Business and Professional Women's Club invited Xernona Clayton, vice-president of public affairs at Atlanta's Turner Broadcasting, to speak at one of their gatherings. Upon receiving her headshot and biography, however, the Rome women's group canceled. They were shocked to find out their guest was, in fact, African American. Clayton was told a majority of the committee had decided, "Rome was not ready for a black speaker. ${ }^{, 46}$ Club member Amy Plimper resigned over the racist snub, rejecting other

\footnotetext{
45 “High-tech programs in lawmakers' sights,” San Jose Mercury News, September 24, 1995.

46 “Residents Differ on Whether Flap Over Black Speaker Exposed Racism in Rome,” Associated Press, May 18, 1987.
} 
Cebul

members' claims the kerfuffle was not about race. Race "was the whole discussion," she said. "It was nothing else." ${ }^{47}$ County Commissioner Howard Smith and Kiwanis members, worried about business, explained that the women's club was "not representative of this community" and invited Clayton to speak before the Kiwanians. ${ }^{48}$ Chamber Director Bruce Schlosberg worried "the attention given the incident has obscured strides the city has made in establishing good race relations." Yet, the Chamber's "race relations," its means of inclusion, like those of many Chambers across the country, was wholly token, such as giving awards to minority business owners. In 1987, for instance, Bill Collins, the African American owner and operator of Collins Auto Clean Up, was given the Chamber's Small Business of the Year Award. As part of his prize, Collins was named an ex-officio member of the chamber's board of directors and given plane tickets. ${ }^{49}$ It is telling that such awardees were named "ex-officio.,"50

Indeed, by 1992, Rome and Floyd County's political elite embraced the notion that, at the very least, token minority representation was necessary. That year, when a mid-term seat opened on the County Commission, the four commissioners appointed African American Samuel Burrell, Sr. to fill the seat. Burrell had worked for decades in education, having served as

\footnotetext{
47 “B\&PW's rejection of speaker continuing to trigger fallout," RNT, April 21, 1987.

48 “Kiwanis Club Invites Xernona Clayton to Speak in Rome,” AP, April 28, 1987.

${ }^{49}$ RNT, January 16, 1987, folder Chamber of Commerce: 1980s, RFL / HRA

50 “Residents Differ on Whether Flap Over Black Speaker Exposed Racism in Rome," Associated Press, May 18, 1987.
} 
Cebul

principal of the segregated Main High School before its closure. ${ }^{51}$ Still, it hadn't been easy. In an episode that recalled Cleveland's balkanized city council, the Floyd County Commission had been deadlocked, casting 26 secret ballots in its failure to decide between Burrell and Lucian Oldham, a retired white business owner. But, after a frustrated commissioner forced the votes into the open, Burrell won after just two rounds. ${ }^{52}$ Despite the drawn out process, Rome's African American community believed they had finally turned a corner, at least in terms of representation. Alvin Jackson, vice president of the Rome NAACP, felt it meant "we can begin to see equal treatment in government." Homer Bryan, a retired schoolteacher who had also been considered for the seat, said the vote "overwhelms me." Indeed, the seat Burrell was to fill was that of the late Roy Knowles, who had, in 1992, succumbed to lung cancer. Among those who called his widow to offer condolences was Lester Maddox. ${ }^{53}$

New representation for African Americans and a variety of new competing interest groups, including suburbanites' NIMBY politics, however, reinforced the degree to which Georgia's early developmental effectiveness had come thanks largely to undemocratic institutions and marginalized interest groups. As one elegiac article in Georgia Trend put it, "In the past 20 years, power has splintered . . . So many more people have a say that no public

\footnotetext{
51 “Blacks: Action a turning point," RNT, June 28, 1992.

52 “Black Member,” RNT, June 28, 1992.

53 “Knowles known for strong stands," RNT, May 14, 1992.
} 
Cebul

project can be accomplished without the painstaking building of coalitions." Developmental

leaders "have to fret about satisfying outsiders, ranging from housing-project residents who

demand a MARTA rail connection to middle-class whites protesting highways that slice through

their neighborhoods." ${ }^{54}$ As the CEO of SunTrust Bank put it, "The days when a few guys could decide what went on are over." Georgia Trend pointed to a 2.4 mile stretch of highway that had "the backing of nearly every important business and political leader in the state," but "neighborhood activists have repeatedly brought construction to a halt." "Choosing public officials once seemed as easy as promoting corporate executives." With greater democratic engagement and points of access, developmental politics had simply become more difficult.

In part, however, the political fragmentation was also the result of business growth. "The executives," Georgia Trend pointed out, "worry more about Wall Street than Peachtree Street."

With the globalization of Georgia businesses, the biggest movers and shakers had "interests

[that] span the globe." The magazine worried, for instance, that Anne Cox Chambers, the billionaire owner of Cox Enterprises, might move her "art collection ... to New York, where she is a trustee of the Museum of Modern Art." On the flip side, outside investors increasingly took the lead in a variety of developments. "Canadians and Texans often count for more than Georgians in ... area real estate" where they financed new malls, housing developments, and

\footnotetext{
${ }^{54}$ Allen Myerson, "The Currents of Power," Georgia Trend, February 1987.
} 
Cebul

Atlanta skyscrapers. The banking sector, too, "succumbed to outside investment." First Atlanta, for instance, had been gobbled up by First Wachovia Corp. based in Winston-Salem, North Carolina. Two other venerable Georgia banks had been acquired by out of state interests. Such was the case in Rome, as well, where smaller banking and retail concerns were bought up or crowded out by regional, national, and international concerns. ${ }^{55}$

In manufacturing and retail, too, outside conglomerates or larger corporations were taking ownership positions in Georgia companies. Richard Rich had been one of Atlanta's most influential businesspeople in the 1950s and 1960s on the strength of his Georgia department store empire. 56 "It's no accident," Georgia Trend, noted, "that the Five Points MARTA station is right next to his downtown store." Federated Stores of Cincinnati, Ohio, however, had acquired Rich's empire. As another leading Atlanta businessman put it, Rich's local successor has "to check in with Cincinnati before he can do anything . . . Dick Rich didn't have to call anyone." ${ }^{, 57}$ Lawrence Gellerstedt, the President of the construction firm Beers, Inc., longed for "the old Camelot" days under "our benevolent dictatorship" of business leaders. As Georgia Trend put it, "corporate mergers have drained some Atlanta institutions." ${ }^{, 58}$ Indeed, a similar fracturing of corporate civic leadership occurred in Cleveland, too, as over the 1980s and into the 1990s, the Roundtable and

\footnotetext{
55 Author Interview with Buster Wright, August 15, 2012, Rome, Georgia.

${ }^{56}$ On Rich, see, for example, Clarence Stone, Regime Politics, 51-4, and Kevin Kruse, White Flight, $185-92$.

${ }^{57}$ Myerson, “The Currents of Power,” Georgia Trend, February 1987.

58 “Twelve Who Run Georgia,” Georgia Trend, February 1987.
} 
Cebul

Cleveland Tomorrow underwent changes in personnel. As the Plain Dealer put it, retirements

and company takeovers "led to an unusually high turnover in the membership of Cleveland

Tomorrow, the congress of city chief executives." Richard Shatten reported, in just four years, 50

percent of the elite CEOs who comprised its membership turned over. Younger, and with

backgrounds in law and finance rather than business development, the new executives were also

not native Clevelanders. In 1986, for instance, just two of the 22 new executive members of

Cleveland Tomorrow were Northeastern Ohioans. ${ }^{59}$

The result of the "benevolent dictatorship," once it was established in Cleveland, and for decades in Georgia, had been relatively smooth implementation of massive projects subsidized by the federal developmental state that created vast economic opportunities for some, but that often came at great costs for others. As a later piece by the editor of Georgia Trend argued, the increasing governmental regulation, interest group mobilization, and antigovernment sentiment all conspired to undermine these sorts of developments going forward. The business-government partnership, combined with a "quiescent" public had once led to significant developments: the "rebuilding of Hartsfield International Airport, the freeing of the freeways ... Still to come is Georgia 400 and the Georgia Dome." "The federal government," Georgia Trend, noted, "has added to the complexity by requiring public hearings for federally funded activities." Greater

\footnotetext{
59 "New faces in the board rooms," $P D$, July 8, 1986.
} 
Cebul

democratic access to developmental decision-making had even "been extended to some state and local projects." Meanwhile, much of the middle class had come to feel "that public works are a burden best borne by someone else." Georgia Trend's managing editor pointed to the wealthy homeowners in Buckhead who had successfully blocked efforts to build Georgia 400, a highway that would benefit the "million people on the north side of Atlanta," including Romans. "For one reason or another, Atlantans were once willing to make those sacrifices. Now they are not." "Enjoy these public works projects while you can," Georgia Trend concluded. Given the fractured political climate and dwindling federal spending, "We may not see their likes again." While there was "nothing wrong ... with public hearings ... even small groups of opponents use such hearings - and the courts - to endlessly obstruct projects that would benefit the community."

But benefit whom and whose community? In Cleveland as in Georgia, the rhetoric of community and of fighting poverty had been invoked for decades to justify massive public subsidies for developmental projects repeatedly meant to bring the private sector "back in" to community development projects. But, in both regions, structural impediments to overcome poverty had never been surmounted despite sunny optimism that investments in technology or education would deliver a brighter future for all. The Developmental State was a powerfully

\footnotetext{
60 “The End of an Era for Public Works," Georgia Trend, August 1989.
} 
Cebul

productive model of economic development for some. But its most effective application came at the cost of democratic access and equal opportunity for millions of Americans - in whose name it was very often invoked. It is a bitter irony that, with the collapse of a more moderate political rhetoric that advanced public private partnerships for growth, even those who stood to benefit the most from the Developmental State - business and the middle class - stand to suffer now thanks to a more dogmatic, misguided, zero sum appraisal of public and private initiative. The greatest fruits of the developmental state were always denied to a minority, but a majority of Americans will share its loss. 
Cebul

\section{Bibliography}

\section{Archival Collections:}

\section{Alderman Library, University of Virginia, Charlottesville VA}

Southern Regional Council Papers

\section{Annie Belle Weaver Special Collections, Ingram Library, University of West Georgia,} Carrolton, GA

Newt Gingrich Papers

\section{Georgia Archives, Morrow, GA}

George Busbee Administration Papers

Jimmy Carter Administration Papers

Growth Strategies Commission Records

Joe Frank Harris Administration Papers

Zell Miller Administration Papers

Southern Growth Policies Board Papers

Georgia Institute of Technology Archives, Atlanta, GA

Engineering Experiment Station - Industrial Extension Division Papers

\section{Georgia Power Corporate Archives, Atlanta, GA}

Advertisements and Community Development Files

Annual Reports

Better Home Towns Files

Economic Development Files

Preston Arkwright Speeches and Early Company Collection

\section{Ford Foundation Archives, New York, NY}

Records of McGeorge Bundy

Target City Cleveland Project Records

\section{Hagley Museum and Library, Wilmington, DE}

Chamber of Commerce of the United States Papers

National Association of Manufacturers Papers 
Cebul

Hargrett Special Collections Library, University of Georgia, Athens, GA

Coosa Valley Area Planning and Development Commission Annual Reports

Rome-Floyd County Chamber of Commerce Newsletter

The Forum

Hoover Institution Archives, Stanford University, Stanford, CA

Carla A. Hills Papers

Richard P. Nathan Papers

Gerald R. Ford Presidential Library, Ann Arbor, MI

James Cannon Files

Myron B. Kuropas Papers

David O. Meeker Papers

Jimmy Carter Presidential Library, Atlanta, Georgia

Jimmy Carter Papers, Pre-Presidential Series, 1962-1976

White House Central Files: Federal Aid

Public Administration Library, City Hall, Cleveland, OH

City of Cleveland Papers, 1940-1949

City Planning Commission Papers

John T. Howard, "City Planning in Cleveland," unpublished manuscript

Regional Association of Cleveland Papers

George V. Voinovich Administration Records

Richard M. Nixon Presidential Library, Yorba Linda, CA

Michael Balzano Papers

Frederick Malek Papers

White House Central Files: Local Governments

White House Subject Files: Federal Aid

Richard B. Russell Library for Political Research and Studies, University of Georgia, Athens, GA

James W. Davis Papers

Mack F. Mattingly Collection

Zell Miller Papers

Richard B. Russell Papers 
Cebul

William S. Stuckey Papers

Herman Talmadge Papers

Ronald Reagan Presidential Library, Simi Valley, CA

Federal Government: Office of Policy Development

Edwin Meese Files

M.B. Oglesby Files

Dan Smith Files

White House Office of Records Management: Federal Aid

White House Office of Records Management: Federal Government

White House Office of Records Management: States

White House Staff Member and Office Files: Media Relations

White House Subject Files: Business - Economics

David Wright Files

Sarah Hightower Special Collections Library, Rome, GA

Chamber of Commerce Vertical File

Coosa Valley Area Planning and Development Commission Newsletter

Coosa Valley Area Planning and Development Commission Papers

Numan Battey, A History of Rome and Floyd County, manuscript

Rome Chamber of Commerce Papers

Southern Historical Collection, Wilson Library, University of North Carolina, Chapel Hill, NC

Southern Growth Policies Board Papers

Western Reserve Historical Society, Cleveland, OH

Buckeye Woodland Community Congress Papers

Harold Hitz Burton Papers

Greater Cleveland Growth Association Papers

Fannie M. Lewis Papers

Ralph J. Perk Papers

Carl B. Stokes Papers

George V. Voinovich Papers

Government Publications: 
Cebul

Advisory Commission on Intergovernmental Relations, Revenue Sharing - An Idea Whose Time has Come. December 4, 1970.

. Federalism in 1973: The System Under Stress. January 1974.

. Public Opinion and Taxes. May 1972.

. General Revenue Sharing: An ACIR Re-Evaluation. October 1974

Annual Report of the Appalachian Regional Commission. Washington: Appalachian Regional Commission, 1965.

Appalachian Regional Commission, The Appalachian Experiment, 1965-1970. Washington: Appalachian Regional Commission, 1972.

Hearing Before the United States Commission on Civil Rights, Transcript, April 1-7, 1966, Cleveland, Ohio. Washington: GPO.

Financing New Communities: Government and Private Experience in Europe and the United States, A report prepared by the U.S. Department of Housing and Urban Development, Office of International Affairs, May 1973. Washington: GPO.

Security, Work, and Relief Policies: A Report by the National Resources Planning Board, 1942

The Role of Commercial Banks in the Finances of the City of Cleveland, Staff Study by the Subcommittee on Financial Institutions Supervision, Regulation, and Insurance of the House Committee on Banking, Finance and Urban Affairs, June 1979.

Testimony of Margaret Foster before the Senate Banking Committee on Neighborhood Preservation, June 1976, Congressional Record, GPO.

Testimony of Margaret Foster before the House Committee on Banking, Currency, and Housing, September 29, 1976, Congressional Record, GPO.

Troubled Local Economies and the Distribution of Federal Dollars, August 1977, Congressional Budget Office. Washington: GPO. 
Cebul

\section{Author Interviews:}

Kenneth Cormany, August 2, 2012, Rome GA.

George Harper, August 15, 2012, Rome, GA.

Andrew Hudak, December 22, 2010, East Cleveland, OH.

Norman Krumholz, January 4, 2011, Cleveland, OH.

Richard Pogue, December 29, 2010, Cleveland, OH.

Vladimir Rus, January 5, 2011, Woodmere, OH.

Taras Szmagala, December 23, 27, and 29, 2010, Cleveland, OH.

Buster Wright, August 15, 2012, Rome, GA.

Newspapers, Periodicals, and Newsletters:

Americus Times-Recorder

Atlanta Constitution

Bainbridge Post-Searchlight

Call and Post

Catholic Universe Bulletin

Catoosa County News

Chicago Tribune

Christian Science Monitor

Cleveland Magazine

Cleveland Plain Dealer

Cleveland Press

Computerworld

Crain's Cleveland Business

Daily Standard

Decatur-Dekalb News

Gadsden Times

Georgia Business

Georgia Trend

Harper's

Laurens County News

Los Angeles Times 
Cebul

Macon Telegraph and News

National Journal

Neighborhood News

Newsweek

New York Times

Philadelphia Inquirer

Pittsburgh Post-Gazette

Rome News Tribune

San Jose Mercury News

Star-News

Time Magazine

Toledo Blade

Ukrainian Weekly

U.S. Chamber of Commerce Newsletter

Vidalia Advance

Wall Street Journal

Washington Post

\section{Online Sources:}

The African American Experience in Ohio, The Ohio Historical Society: http://dbs.ohiohistory.org/africanam

The American Presidency Project, University of California, Santa Barbara:

http://www.presidency.ucsb.edu/index.php

City Planning Commission of the City of Cleveland:

http://planning.city.cleveland.oh.us/cwp/pop trend.php\#11

Cleveland Memory Project:

http://www.clevelandmemory.org

The Living New Deal:

https://livingnewdeal.berkeley.edu/

Lyndon Johnson Oral History Project, Miller Center of Public Affairs: 
Cebul

http://web2.millercenter.org/lbj/oralhistory

John F. Kennedy Presidential Library Oral History Program:

http://www.jfklibrary.org/Research/About-Our-Collections/Oral-history-program.aspx

John F. Kennedy Presidential Library, White House Staff Files of Lee C. White:

http://www.jfklibrary.org/Search.aspx?nav=N:4294902018

Nation's Business, Hagley Museum and Library Digital Collections:

http://www.hagley.org/2012/04/digital-collections-nations-business-online.

Walter J. Brown Media Archives \& Peabody Awards Collection, University of Georgia: http://crdl.usg.edu/cgi/crdl?format= video\&query=id\%3Augabma wsbn $64077 \&$ cc $=1$

Women's Comprehensive Program Oral History Project, Ethnic Women of Cleveland:

http://clevelandmemory.org/ewc/index.html

\section{Secondary Sources:}

Adams, Stephen B. Mr. Kaiser Goes to Washington: The Rise of a Government Entrepreneur. Chapel Hill: University of North Carolina Press, 1997.

Applebome, Peter. Dixie Rising: How the South is Shaping American Values, Politics, and Culture. New York: Random House, 1997.

Aycock, Roger. All Roads to Rome. Roswell, GA: W.H. Wolfe Associates, 1981.

Ayers, Edward L. The Promise of the New South: Life After Reconstruction. New York: Oxford University Press, 2007.

Baer, Kenneth S. Reinventing Democrats: The Politics of Liberalism from Reagan to Clinton. Lawrence, KS: University of Kansas Press, 2000.

Balogh, Brian. Chain Reaction: Expert Debate and Public Participation in American Commercial Nuclear Power, 1945-1975. Cambridge: Cambridge University Press, 1991. 
Cebul

. "Reorganizing the Organizational Synthesis: Federal-Professional Relations in Modern America.” Studies In American Political Development, Vol. 5, Issue 1, (1991): 119-72.

. A Government Out of Sight: The Mystery of National Authority in Nineteenth Century America. New York: Cambridge University Press, 2010.

Bartley, Numan V. The Creation of Modern Georgia. Athens: University of Georgia Press, second edition, 1990.

. The New South: 1945-1980. Baton Rouge: Louisiana State University Press, 1995.

Bensel, Richard Franklin. Sectionalism and American Political Development, 1880-1980. Madison: University of Wisconsin Press, 1984.

. The Political Economy of American Industrialization, 1877-1900. New York:

Cambridge University Press, 2001.

Bergin, Angus. The Great Persuasion: Reinventing Free Markets since the Depression. Cambridge: Harvard University Press, 2012.

Berman, Elizabeth Popp. Creating the Market University: How Academic Science Became an Economic Engine. Princeton: Princeton University Press, 2012.

Biles, Roger. The Fate of Cities: Urban America and the Federal Government, 1945-2000. Lawrence, KS: University Press of Kansas, 2011.

Black Earle and Merle Black, The Rise of Southern Republicans. Cambridge: The Belknap Press of Harvard University Press, 2002.

Block, Fred and Matthew R. Keller, eds. State of Innovation: The US Government's Role in Technology Development. Boulder, CO: Paradigm, 2011.

Bradshaw, Michael. The Appalachian Regional Commission: Twenty-Five Years of Government Policy. Lexington: University Press of Kentucky, 1992.

Brattain, Michelle. The Politics of Whiteness: Race, Workers, and Culture in the Modern South. Athens, Georgia: University of Georgia Press, 2001. 
Cebul

Brenes, Michael. "For Right and Might: The Militarization of the Cold War and the Remaking of American Democracy.” PhD. Dissertation, The City University of New York, 2013.

Brinkley, Alan. Voices of Protest: Huey Long, Father Coughlin and the Great Depression. New York: Vintage, 1982.

. The End of Reform: New Deal Liberalism in Recession and War. New York: Vintage, 1995.

. "Conservatism as a Growing Field of Scholarship," Journal of American History (2011) 98 (3): 748-751.

Brownlee, W. Elliot and Hugh Davis Graham, eds., The Reagan Presidency: Pragmatic Conservatism and its Legacies. Lawrence: University Press of Kansas, 2003.

Brunori, David. Local Tax Policy: A Federalist Perspective. Washington, DC: The Urban Institute Press, 2007.

Bullock III, Charles S. and Mark J. Rozell, eds. The New Politics of the Old South: An Introduction to Southern Politics. Lanham, MD: Rowman and Littlefield, 2007.

Burns, Jennifer L. Goddess of the Market: Ayn Rand and the American Right. New York: Oxford University Press, 2009.

Candeloro, Dominic. “The Single Tax Movement and Progressivism, 1880-1920.” American Journal of Economics and Sociology, Vol. 38, No. 2, Apr. 1978.

Carlton, David L. and Peter A. Coclanis. The South, the Nation, and the World: Perspectives of Southern Economic Development. Charlottesville: University of Virginia Press, 2003.

Carpenter, Daniel. Reputation and Power: Organizational Image and Pharmaceutical Regulation at the FDA. Princeton: Princeton University Press, 2010.

. The Forging of Bureaucratic Autonomy: Networks, Reputations and Policy Innovation in Executive Agencies, 1862-1928. Princeton: Princeton University Press, 2001. 
Cebul

Chang, Ha-Joon. Kicking Away the Ladder: Development Strategy in Historical Perspective: Policies and Institutions for Economic Development in Historical Perspective. London: Anthem Press, 2002.

Chappell, Marisa. The War on Welfare: Family, Poverty, and Politics in Modern America. Philadelphia: University of Pennsylvania Press, 2010.

Cho, Yong Hyo. "City Politics and Radical Polarization: Bloc Voting in Cleveland Elections," Journal of Black Studies 4.4, Jun., 1974.

Clavel, Pierre. Activists in City Hall: The Progressive Response to the Reagan Era in Boston and Chicago. Ithaca, NY: Cornell University Press, 2010.

Clemens, Elisabeth S. and Doug Guthrie, eds. Politics and Partnerships: The Role of Voluntary Associations in America's Political Past and Present. Chicago: University of Chicago Press, 2010.

Cobb, James C. The Selling of the South: The Southern Crusade for Industrial Development, 1936-1990. Urbana, IL: University of Illinois Press, 2nd ed., 1993.

. Industrialization and Southern Society, 1877-1984. Lexington: University of Kentucky Press, 1984.

and Michael Namorato, eds. The New Deal and the South. Jackson: University of Mississippi Press, 1984.

Cohen, Lizabeth. Making a New Deal: Industrial Workers in Chicago, 1919-1939. New York: Cambridge University Press, 1990.

. A Consumer's Republic: The Politics of Mass Consumption in Postwar America. New York: Vintage, 2003.

Collins, Robert M. More: The Politics of Economic Growth in Postwar America. New York: Oxford University Press, 2000.

Conlan, Timothy. From New Federalism to Devolution. Washington, D.C.: Brookings Institution Press, 1998. 
Cebul

Connolly, Nathan D.B. A World More Concrete: Real Estate and the Remaking of Jim Crow South Florida. Chicago: University of Chicago Press, 2014

Cowie, Jefferson. Capital Moves: RCA's Seventy-Year Quest for Cheap Labor. New York: The New Press, 1999.

. Stayin'Alive: The 1970s and the Last Days of the Working Class. New York: The New Press, 2010.

and Joseph Heathcott, eds. Beyond the Ruins: The Meanings of Deindustrialization. Ithaca, NY: Cornell University Press, 2001.

and Nick Salvatore, "The Long Exception: Rethinking the Place of the new Deal in American History," International Labor and Working-Class History, 74, 2008, 1-32.

Crespino, Joseph. In Search of Another Country: Mississippi and the Conservative Counterrevolution. Princeton: Princeton University Press, 2007.

. Strom Thurmond's America. New York: Hill and Wang, 2012.

Critchlow, Donald T. Phyllis Schlafly and Grassroots Conservatism: A Woman's Crusade. Princeton: Princeton University Press, 2005.

. The Conservative Ascendancy: How the GOP Right Made Political History. Cambridge: Harvard University Press, 2007.

Cummings, Scott. Business Elites and Urban Development: Case Studies and Critical Perspectives. Albany: SUNY Press, 1988.

Darko, Morrell Johnson. The Rivers Meet: A History of African-Americans in Rome, Georgia. Kearney, NE: Morris Publishing, 2003.

Davies, Gareth. From Opportunity to Entitlement: The Transformation and Decline of Great Society Liberalism. Lawrence: University Press of Kansas, 1996. 
Cebul

. See Government Grow: Education Politics from Johnson to Reagan. Lawrence:

University Press of Kansas, 2007.

Derthick, Martha, Dilemmas of Scale in America's Federal Democracy. Cambridge: Woodrow Wilson Center Press and Cambridge University Press, 1999.

Dilworth, Richardson ed. The City in American Political Development. New York: Routledge, 2009.

Dreier, Peter, John Mollenkopf and Todd Swanstrom, Place Matters: Metropolitics for the Twenty-first Century. Lawrence: University Press of Kansas, 2004.

Edling, Max. A Revolution in Favor of Government: Origins of the U.S. Constitution and the Making of the American State. New York: Oxford University Press, 2008.

Eisinger, Peter K. The Rise of the Entrepreneurial State: State and Local Economic Development Policy in the United States. Madison: University of Wisconsin Press, 1988.

Eller, Ronald D. Uneven Ground: Appalachia Since 1945. Lexington, KY: University Press of Kentucky, 2008.

Elmore, Bartow. Citizen Coke: The Making of Coca Cola Capitalism. New York: Norton, 2014.

Farber, David ed. The Sixties From Memory to History. Chapel Hill: University of North Carolina Press, 1994.

Feiss, Carl. "The Foundations of Federal Planning Assistance: A Personal Account of the 701 Program," Journal of the American Planning Association, Volume 51, No. 12, 1985.

Ferguson, Niall, Charles S. Maier, Erez Manela, and Daniel J. Sargent, eds. The Shock of the Global: The 1970s in Perspective. Cambridge: The Belknap Press of Harvard University Press, 2010.

Ferguson Ronald F. and William T. Dickens, eds. Urban Problems and Community Development. Washington, D.C.: Brookings Institution Press, 1999. 
Cebul

Field, Gregory B. “'Electricity for All': The Electric Home and Farm Authority and the Politics of Mass Consumption, 1932-1935.” The Business History Review, Vol. 64, No. 1, 1990.

Flamming, Douglas. Creating the Modern South: Millhands and Managers in Dalton, Georgia, 1884-1984. Chapel Hill: The University of North Carolina Press, 1992.

Fraser, Steve and Gary Gerstle, eds. The Rise and Fall of the New Deal Order. Princeton: Princeton University Press, 1989.

Frederickson, Kari. Cold War Dixie: Militarization and Modernization in the American South. Athens: University of Georgia Press, 2013.

Free Lloyd and Hadley Cantril. The Political Beliefs of Americans: A Study of Public Opinion. New Brunswick, NJ: Rutgers University Press, 1967.

Freund, David M.P. Colored Property: State Policy \& White Racial Politics in Suburban America. Chicago: University of Chicago Press, 2007.

Frieden Bernard J. and Marshall Kaplan. The Politics of Neglect: Urban Aid from Model Cities to Revenue Sharing. Cambridge: MIT Press, 1975.

Friedman, Tami J. "Exploiting the North-South Differential: Corporate Power, Southern Politics, and the Decline of Organized Labor after World War II," Journal of American History, September 2008, 323-346.

Frug, Gerald. City Making: Building Communities without Building Walls. Princeton: Princeton University Press, 1999.

Funigiello, Philip. The Challenge to Urban Liberalism: Federal-City Relations during World War II. Knoxville: University of Tennessee Press, 1978.

Galambos, Louis. "The Emerging Organizational Synthesis in Modern American History." Business History Review, 44, Autumn 1970.

Galvin, Daniel. Presidential Party Building: Dwight Eisenhower to George W. Bush. Princeton: Princeton University Press, 2010. 
Cebul

Gerstle, Gary. American Crucible: Race and Nation in the Twentieth Century. Princeton:

Princeton University Press, 2002.

Gillon, Steven M. The Pact: Bill Clinton, Newt Gingrich, and the Rivalry that Defined a Generation. New York: Oxford University Press, 2008.

Glad, Betty. Jimmy Carter: In Search of the Great White House. New York: W.W. Norton, 1980.

Glasberg, Davita Silfen. The Power of Collective Purse Strings: The Effects of Bank Hegemony on Corporations and the State. Berkeley: University of California Press, 1989.

Goldin, Claudia and Lawrence Katz, The Race between Education and Technology. Cambridge: Belknap, 2010.

Goldstein, Alyosha. Poverty in Common: The Politics of Community Action During the American Century. Durham, NC: Duke University Press, 2012.

Gordon, Colin. New Deals: Business, Labor, and Politics in America, 1920-1935. New York: Cambridge University Press, 1994.

Gosling, James J. "Patterns of Stability and Change in Gubernatorial Policy Agendas," State \& Local Government Review, Vol. 23, No. 1, Winter, 1991.

Green, Elna C. ed. The New Deal and Beyond: Social Welfare in the South since 1930. Athens, GA: University of Georgia Press 2003.

Griffin, Patrick. American Leviathan: Empire, Nation, and Revolutionary Frontier. New York: Hill and Wang, 2008.

Grisinger, Joanna. The Unwieldy American State: Administrative Politics Since the New Deal. New York: Cambridge University Press, 2012.

Grubb, W. Norton and Marvin Lazerson, The Education Gospel: The Economic Power of Schooling. Cambridge: Harvard University Press, 2006.

Guglielmo, Thomas. White on Arrival: Italians, Race, Color, and Power in Chicago, 1890-1945. Chicago: University of Chicago Press, 2003. 
Cebul

Hacker, Jacob. The Divided Welfare State: The Battle over Public and Private Social Benefits in the United States. New York: Cambridge University Press, 2002.

and Paul Pierson, "Business Power and Social Policy: Employers and the Formation of the American Welfare State," Politics and Society, 30, April 2004.

Hale, Grace Elizabeth. A Nation of Outsiders: How the White Middle Class Fell in Love with Rebellion in Postwar America. New York: Oxford University Press, 2011.

Hall, Jacqueline Dowd. Like a Family: The Making of a Southern Cotton Mill World. Chapel Hill: The University of North Carolina Press, 1987.

Hamilton, Shane. Trucking Country: The Road to America's Wal-Mart Economy. Princeton: Princeton University Press, 2008.

Hart, David M. Forged Consensus: Science, Technology, and Economic Policy in the United States, 1921-1953. Princeton: Princeton University Press, 1998.

. "Herbert Hoover's Last Laugh: The Enduring Significance of the 'Associative State' in the United States," Journal of Policy History. Volume 10, Issue 04, October 1998.

Hawley, Ellis W. The New Deal and the Problem of Monopoly: A Study in Economic Ambivalence. New York: Fordham University Press, Reissue Edition, 1995.

. "Hebert Hoover, the Commerce Secretariat, and the Vision of an 'Associative State."' Journal of American History 61 (1974): 116-40.

. "The Discovery and Study of a 'Corporate Liberalism."” Business History Review (Autumn 1978), 52:312.

Hays, Samuel P. “The Social Analysis of American Political History, 1880-1920,” Political Science Quarterly. 80, September 1965.

Hines, Thomas S. "The Paradox of 'Progressive' Architecture: Urban Planning and Public Building in Tom Johnson's Cleveland.” American Quarterly, Vol. 25, No. 4 (Oct., 1973). 
Cebul

Hirsch, Arnold R. Making the Second Ghetto: Race \& Housing in Chicago 1940-1960. Chicago: University of Chicago Press, Second Edition, 1998.

Hogan, Michael J. A Cross of Iron: Harry S. Truman and the Origins of the National Security State, 1945-1954. Cambridge: Cambridge UP, 1998.

Holmes, Michael S. The New Deal in Georgia: An Administrative History. Westport, CT: Greenwood Press, 1975.

Howard, Christopher. The Hidden Welfare State: Tax Expenditures and Social Policy in the United States. Princeton: Princeton University Press, 1999.

Huyssen, David. Progressive Inequalities: Rich and Poor in New York, 1890-1920. Cambridge: Harvard University Press, 2014.

Hyatt, Richard. Zell: The Governor Who Gave Georgia Hope. Macon, GA: Mercer University Press, 1997.

Jacobs, Meg. Pocketbook Politics: Economic Citizenship in Twentieth-Century America. Princeton: Princeton University Press, 2005. and William J. Novak, and Julian Zelizer, eds. The Democratic Experiment. Princeton: Princeton University Press, 2003.

Jacobson, Matthew Frye. Roots Too: White Ethnic Revival in Post-Civil Rights America. Cambridge: Harvard University Press, 2006.

Jackson, Kenneth. Crabgrass Frontier: The Suburbanization of the United States. New York: Oxford University Press, 1985.

Jenkins, William D. "Before Downtown: Cleveland, Ohio and Urban Renewal, 1949-1958," Journal of Urban History, 2001, 27:41.

Jones, Daniel Steadman. Masters of the Universe: Hayek, Friedman, and the Birth of Neoliberal Politics. Princeton: Princeton University Press, 2012. 
Cebul

Judge, Davis, Gerry Stoker and Harold Wolman, ed. Theories of Urban Politics. London: Sage, 1995.

Kaiser Edward J. and David R. Godschalk. "Twentieth Century Land Use Planning," Journal of the American Planning Association, 61, 3, 1995.

Katz, Michael B. The Undeserving Poor: From the War on Poverty to the War on Welfare. New York: Pantheon Books, 1989.

Katznelson, Ira. When Affirmative Action was White: An Untold History of Racial Inequality in Twentieth-Century America. New York: Norton, 2005.

. Fear Itself: The New Deal and the Origins of Our Time. New York: Liveright, 2013.

Kazin, Michael. The Populist Persuasion: An American History. Ithaca: Cornell University Press, 1995.

Keating, W. Dennis, Norman Krumholz, and David C. Perry, eds. Cleveland: A Metropolitan Reader. Kent, Ohio: Kent State University Press, 1995.

Kennedy, David. Freedom From Fear: The American People in Depression and War, 19291945. New York: Oxford University Press, 1999.

Kerr, Daniel. Derelict Paradise: Homelessness and Urban Development in Cleveland, Ohio. Amherst, MA.: University of Massachusetts Press, 2011.

Kettl, Donald F. Managing Community Development in the New Federalism. New York: Praeger Special Studies, 1980.

Kloppenberg, James T. The Virtues of Liberalism. New York: Oxford University Press, 1998.

Krippner, Greta R. Capitalizing on Crisis: The Political Origins of the Rise of Finance. Cambridge: Harvard University Press, 2011.

Krugman, Paul. Geography and Trade. Cambridge: MIT Press, 1991. 
Cebul

Kruse, Kevin M. White Flight: Atlanta and the Making of Modern Conservatism. Princeton: Princeton University Press, 2005.

Kytle Calvin and James A. Mackay. Who Runs Georgia? Athens, GA: University of Georgia Press, 1948 and 1998.

Lagemann, Ellen Condliffe ed. Philanthropic Foundations: New Scholarship, New Possibilities. Bloomington: Indiana University Press, 1999.

Lassiter, Matthew D. The Silent Majority: Suburban Politics in the Sunbelt South. Princeton: Princeton University Press, 2006.

. "Political History Beyond the Red Blue Divide," Journal of American History (2011) 98 (3): 760-764.

and Joseph Crespino, eds. The Myth of Southern Exceptionalism. New York: Oxford University Press, 2010.

Lewis, Robert. "World War II Manufacturing and the Postwar Southern Economy," The Journal of Southern History. Vol. 73, No. 4, Nov. 2007.

Liner, Blaine and Lawrence K. Lynch, eds., The Economics of Southern Growth. Durham, NC: Southern Growth Policies Board, 1977.

Lipartito, Kenneth. The Bell System and Regional Business: The Telephone in the South, 18771920. Baltimore: Johns Hopkins / AT\&T Series in Telephone History, 1989.

. "Connecting the Cultural and Material in Business History," Enterprise \& Society, December 2013, Vol. 14, No. 4, 686-704.

Logan, John R. and Harvey L. Molotch. Urban Fortunes: The Political Economy of Place. Berkeley: University of California Press, 1987.

Malczewki, Joan. "Weak State, Stronger Schools: Northern Philanthropy and Organizational Change in the Jim Crow South.” The Journal of Southern History, Vol. 75, No. 4. 
Cebul

Marschall, Dan ed. The Battle of Cleveland: Public Interest Challenges Corporate Power. Washington, DC: Ohio Public Interest Campaign, Conference on Alternative State and Local Politics, 1979.

Martin, Isaac. The Permanent Tax Revolt. Stanford: Stanford University Press, 2008.

Massey Douglas S. and Nancy A. Denton, American Apartheid: Segregation and the Making of the Underclass. Cambridge: Harvard University Press, 1993.

McCraw, Thomas. TVA and the Power Fight, 1933-1939. New York: J.B. Lippincott Company, 1971.

McGirr, Lisa. Suburban Warriors: The Origins of the New American Right. Princeton: Princeton University Press, 2001.

McGreevy, John T. Parish Boundaries: The Catholic Encounter with Race in the TwentiethCentury Urban North. Chicago: University of Chicago Press, 1996.

McKee, Guian A. The Problem of Jobs: Liberalism, Race, and Deindustrialization in Philadelphia. Chicago: University of Chicago Press, 2008.

. "Blue Sky Boys, Professional Citizens, and Knights-in-Shining Money: Philadelphia's Penn Center Project and the Constraints of Private Development," Journal of Planning History, 2007 6: 48.

McMath, Robert C., Ronald H. Bayor, James E. Brittain, Lawrence Foster, August W. Giebelhaus, and Germaine M. Reed, ed., Engineering the New South: Georgia Tech, 1885-1985. Atlanta: Georgia Institute of Technology Press, 1986.

McQuaid, Kim. Uneasy Partners: Big Business in American Politics, 1945-1990. Baltimore: Johns Hopkins University Press, 1994.

Meier, August and Elliott Rudwick. CORE: A Study in the Civil Rights Movement. Urbana, IL: University of Illinois Press, 1975.

Mellow, Nicole. The State of Disunion: Regional Sources of National Partisanship. Baltimore: Johns Hopkins University Press, 2008. 
Cebul

Mettler, Suzanne. Soldiers to Citizens: The G.I. Bill and the Making of the Greatest Generation. New York, Oxford University Press, 2005.

. The Submerged State: How Invisible Government Policies Undermine American Democracy. Chicago: University of Chicago Press, 2011.

Michelmore, Molly C. Tax and Spend: The Welfare State, Tax Politics, and the Limits of American Liberalism. Philadelphia: University of Pennsylvania Press, 2012.

Michney, Todd. "Constrained Communities: Black Cleveland's Experience with World War II Public Housing," Journal of Social History, Vol. 40, No. 4, Summer, 2007.

Milkis, Sidney M. and Jerome M. Mileur, eds. The Great Society and the High Tide of Liberalism. Amherst, MA, 2005.

Mirowski, Philip, and Dieter Plehwe, eds. The Road from Mont Pelerin: The Making of the Neoliberal Thought Collective. Cambridge: Harvard University Press, 2009.

Mollenkopf, John H. The Contested City. Princeton, NJ: Princeton University Press, 1983.

Moore, Leonard N. Carl B. Stokes and the Rise of Black Political Power. Urbana, IL: University of Illinois Press, 2002.

Moss, David A. When All Else Fails: Government as the Ultimate Risk Manager. Cambridge: Harvard University Press, 2002.

Mossberger, Karen. "State-Federal Diffusion and Policy Learning: From Enterprise Zones to Empowerment Zones," Publius, 29:3, Summer 1999.

Moynihan, Daniel P. Maximum Feasible Misunderstanding: Community Action in the War on Poverty. New York: The Free Press, 1970.

Murphy, John C. “General Revenue Sharing’s Impact on County Government,” Public Administration Review, Vol. 35, No. 2, March - April, 1975. 
Cebul

Murray, Charles. Losing Ground: American Social Policy: 1950-1980. New York: Basic Books, 1984.

Nathan, Richard P., Paul R. Dommel, Sarah F. Liebschtz, and Milton D. Morris, "Monitoring the Block Grant Program for Community Development," Political Science Quarterly, Vol. 92, No. 2, Summer, 1977.

Nathan, Richard P. and Jerry A. Webman, eds. The Urban Development Action Grant Program: Papers and Conference Proceedings on Its First Two Years of Operation. Princeton: Princeton Urban and Regional Research Center, 1980.

Nelson, Michael and John Lyman Mason, "The Politics of Gambling in the South," Political Science Quarterly, Vol. 118, No. 4, 2003.

Nisbet, Robert. The Degradation of the Academic Dogma: The University in America, 19451970. New York: Basic, 1971.

Novak, William J. “The Myth of the 'Weak' American State," American Historical Review, 113, no. 3 (June 2008): 752-772.

Nye, Jr., Joseph S., Philip Zelikow, and David C. King, eds., Why People Don't Trust Government. Cambridge: Harvard University Press, 1997.

O'Connor, Alice. Poverty Knowledge: Social Science, Social Policy, and the Poor in TwentiethCentury U.S. History. Princeton: Princeton University Press, 2001.

O’Donnell, John. "Public Finance in a Growing Economy: Some Postwar Trends in Municipal Bond Financing." The Journal of Finance, Vol. 17, No. 2, May, 1962.

Olson, Mancur, The Rise and Decline of nations: Economic Growth, Stagflation, and Social Rigidities. New Haven: Yale University Press, 1982.

O'Mara, Margaret P. Cities of Knowledge: Cold War Science and the Search for the Next Silicon Valley. Princeton: Princeton University Press, 2005.

Onuf, Peter. Jefferson's Empire: The Language of American Nationhood. Charlottesville: University of Virginia Press, 2000. 
Cebul

Orleck, Annelise and Lisa Gayle Hazirjian, eds. The War on Poverty: A New Grassroots History. Athens, GA: University of Georgia Press, 2011.

Orren, Karen and Stephen Skowronek, The Search for American Political Development. New York: Cambridge University Press, 2004.

Patterson, James. The New Deal and the States: Federalism in Transition. Princeton: Princeton University Press, 1969.

. Grand Expectations: The United States, 1945-1974. New York: Oxford, 1996.

Patton, Randall L. with David B. Parker, Carpet Capital: The Rise of a New South Industry. Athens: University of Georgia Press, 1999.

Peterson, Paul E. City Limits. Princeton: Princeton University Press, 1980. . The Price of Federalism. Washington: Brookings Institution Press, 1995.

Phillips-Fein, Kimberly. Invisible Hands: The Making of the Conservative Movement from the New Deal to Reagan. New York: W.W. Norton, 2009.

. "Conservatism: A State of the Field," Journal of American History. December 2011, Vol. 98, No. 3. . and Julian E. Zelizer, ed. What's Good For Business: Business and American Politics since World War II. New York: Oxford University Press, 2012.

Pierson, Paul P. Dismantling the Welfare State?: Reagan, Thatcher and the Politics of Retrenchment. New York: Cambridge University Press, 1995.

. Politics in Time: History Institutions, and Social Analysis (Princeton: Princeton University Press, 2008 and Theda Skocpol, eds. The Transformation of American Politics: Activist Government and the Rise of Conservatism. Princeton: Princeton University Press, 2007. 
Cebul

Prasad, Monica. The Politics of Free Markets: The Rise of Neoliberal Economic Policies in Britain, France, Germany, and the United States. Chicago: University of Chicago Press, 2006.

Reed, Jr., Adolph ed. Without Justice for All: The New Liberalism and Our Retreat from Racial Equality. Boulder: Westview Press, 1999.

. Stirrings in the Jug: Black Politics in the Post-Segregation Era. Minneapolis:

University of Minnesota Press, 1999.

Reed, Ingrid W. "The Life and Death of UDAG: An Assessment Based on Eight Projects in Five New Jersey Cities,” Publius, (1989) 19 (3): 93-109.

Robertson, David Brian, ed., Loss of Confidence: Politics and Policy in the 1970s. University Park, PA: Pennsylvania State University Press, 1998.

Rodgers, Daniel. Age of Fracture. Cambridge: Belknap, 2012.

Rose, William Ganson. Cleveland: The Making of a City. Kent, Ohio: Kent State University Press, Second Edition, 1990.

Rosenfeld, Sophia. Common Sense: A Political History. Cambridge: Harvard University Press, 2011.

Rubenstein Ross and Benjamin Scafidi. "Who Pays and Who Benefits? Examining the Distributional Consequences of the Georgia Lottery for Education," National Tax Journal, Vol. LV, No., 2, June 2002.

Rubin, Elihu. Insuring the City: The Prudential Center and the Postwar Urban Landscape. New Haven: Yale University Press, 2012.

Russell, Judith. Economics, Bureaucracy, and Race: How Keynesians Misguided the War on Poverty. New York: Columbia University Press, 2004.

Safire, William. Before the Fall: An Inside View of the Pre-Watergate White House. New York: Transaction Publishers, 2005. 
Cebul

Sawers, Larry and William K. Tabb, eds. Sunbelt / Snowbelt: Urban Development and Regional Restructuring. New York: Oxford University Press, 1984.

Schaefer, Axel. Piety and Public Funding: Evangelicals and the State in Modern America. Philadelphia: University of Pennsylvania Press, 2012.

Schrecker, Ellen. Many are the Crimes: McCarthyism in America. New York: Little Brown, 1998.

Schulman, Bruce J. From Cotton Belt to Sunbelt: Federal Policy, Economic Development, and the Transformation of the South, 1938-1980. Raleigh: Duke University Press, $2^{\text {nd }}$ ed. 1994.

. The Seventies: The Great Shift in American Culture, Society, and Politics. New York: Da Capo Press, 2001.

and Julian E. Zelizer, eds. Rightward Bound: Making America Conservative in the 1970s. Cambridge: Harvard University Press, 2008.

Scott, Daryl Michael. Contempt and Pity: Social Policy and the Image of the Damaged Black Psyche, 1880-1996. Chapel Hill: University of North Carolina Press, 1997.

Scott, James C. Seeing Like a State: How Certain Schemes to Improve the Human Condition Have Failed. New Haven: Yale University Press, 1999.

Scranton, Philip. The Second Wave: Southern Industrialization from the 1940s to the 1970s. Athens, GA: University of Georgia Press, 2001. and Patrick Friedenson, Reimagining Business History. Baltimore: Johns Hopkins University Press, 2013.

Self, Robert. American Babylon: Race and the Struggle for Postwar Oakland. Princeton: Princeton University Press, 2003. . All in the Family: The Realignment of American Democracy Since the 1960s. New York: Hill and Wang, 2012. 
Cebul

Selznick, Philip. TVA and the Grass Roots: A Study in the Sociology of Formal Organization. Berkeley: University of California Press, 1949.

Shapiro, Ian, Peter A. Swenson, and Daniela Donno Panayides, eds. Divide and Deal: The Politics of Distribution in Democracies. New York: NYU Press, 2008.

and Stephen Skowronek, and Daniel Galvin, ed. Rethinking Political Institutions: The Art of the State. New York: New York University Press, 2006.

Shermer, Elizabeth Tandy. Sunbelt Capitalism: Phoenix and the Transformation of American Politics. Philadelphia: University of Pennsylvania Press, 2013.

Sklar, Martin. The Corporate Reconstruction of American Capitalism, 1890-1916: The Market, the Law, and Politics. New York: Cambridge University Press, 1988.

Smith, Jason Scott. Building New Deal Liberalism: The Political Economy of Public Works: 1933-1956. New York: Cambridge University Press, 2006.

Smith, Rogers. Civic Ideals: Conflicting Visions of Citizenship in U.S. History. New Haven: Yale University Press, 1997.

Sparrow, James T. Warfare State: World War II Americans and the Age of Big Government. New York: Oxford University Press, 2011.

Squires, Gregory ed. Unequal Partnerships: The Political Economy of Urban Redevelopment in Postwar America. New Brunswick, NJ, 1989.

Stein, Judith. Pivotal Decade: How the United States Traded Factories for Finance in the Seventies. New Haven: Yale University Press, 2010.

Stokes, Carl B. Promises of Power: A Political Autobiography. New York: Simon and Schuster, 1973.

Stone, Clarence N. Regime Politics: Governing Atlanta, 1946-1988. Lawrence: University Press of Kansas, 1989. 
Cebul

Sugrue, Thomas J. The Origins of the Urban Crisis: Race and Inequality in Postwar Detroit. Princeton: Princeton University Press, 1998.

. Sweet Land of Liberty: The Forgotten Struggle for Civil Rights in the North. New York: Random House, 2008.

Swanstrom, Todd. The Crisis of Growth Politics: Cleveland, Kucinich, and the Challenge of Urban Populism. Philadelphia: Temple University Press, 1985.

Sweet, David C., Kathryn Wertheim Hexter, and David Beach, eds. The New American City Faces its Regional Future: A Cleveland Perspective. Athens, OH: Ohio University Press, 1999.

Teaford, Jon C. The Rough Road to Renaissance: Urban Revitalization in America, 1940-1985. Baltimore: Johns Hopkins University Press, 1990.

. "Urban Renewal and Its Aftermath,” Housing Policy Debate, Vol. 11, No. 2, 2000.

Tindall, George B. The Emergence of the New South. Baton Rouge: Louisiana State University Press, 1967.

Tompkins, Richard F. "'All the Necessary Services the People Need and Deserve': Federal Grants in Cleveland During 1978." Washington, DC: Brookings Institution and Cleveland Foundation, 1979.

Tornatzky, Louis D., Paul G. Waugaman, and Dennis O. Gray, "Innovation U: New University Roles in a Knowledge Economy," Southern Growth Policies Board, 2002.

Tuck, Stephen N.G. Beyond Atlanta: The Struggle for Racial Equality in Georgia, 1940-1980. Athens: University of Georgia Press, 2001.

Wall, Wendy. Inventing the "American Way": The Politics of Consensus from the New Deal to the Civil Rights Movement. New York: Oxford University Press, 2008.

Wallerstein, Immanuel. World-Systems Analysis: An Introduction. Durham, NC: Duke University Press, 2004. 
Cebul

Warf Barney and Brian Holly. "The Rise and Fall and Rise of Cleveland." Annals of the American Academy of Political and Social Science, Vol. 552, May, 1997.

Waterhouse, Benjamin. Lobbying America: The Politics of Business from Nixon to NAFTA. Princeton: Princeton University Press, 2014.

. "Mobilizing for the Market: Organized Business, Wage-Price Controls, and the Politics of Inflation, 1971-1974." Journal of American History. Vol. 100, No. 2, September 2013.

Weaver, Timothy Paul Ryan. "Neoliberalism in the trenches: Urban policy and politics in the United States and the United Kingdom.” PhD Dissertation, University of Pennsylvania, 2012.

Weinberg, Kenneth G. Black Victory: Carl Stokes and the Winning of Cleveland. Chicago: Quadrangle Books, 1968.

Weir, Margaret. "States, Race, and the Decline of New Deal Liberalism." Studies in American Political Development Vol. 19, no.2, October 2005.

. "'Beyond the Plant Gates': Postwar Labor and the Organizational Structure of Liberalism," Institute for Research on Labor and Employment Working Paper Series, University of California, Berkeley, 2009.

, Nancy Pindus, Howard Wial, and Harold Wolman, eds. Urban and Regional Policy and its Effects, Volume IV. Washington, DC: Brookings Institution Press, 2012.

Weiss, Penny A. and Marilyn F. Friedman, eds. Feminism and Community. Philadelphia: Temple University Press, 1995.

Wiebe, Robert. The Search for Order, 1877-1920. New York: Hill and Wang, 1967.

Wilentz, Sean. The Age of Reagan: A History, 1974-2008. New York: Harper, 2008.

Williams, Mason B. City of Ambition: FDR, LaGuardia, and the Making of Modern New York. New York: W.W. Norton, 2013. 
Cebul

Wilson, David E. The National Planning Idea in U.S. Public Policy. Boulder, CO: Westview Press, 1980.

Wilson, Gregory S. Communities Left Behind: The Area Redevelopment Administration, 19451965. Knoxville: University of Tennessee Press, 2009.

Wright, Gavin. Old South / New South: Revolutions in the Southern Economy Since the Civil War. New York: Basic Books, 1986.

. "The New Deal and the Modernization of the South." Federal History, 2010.

Zannes, Estelle. Checkmate in Cleveland. Cleveland, OH: The Press of Case Western Reserve University, 1972.

Zelizer, Julian E. "Reflections: Rethinking the History of American Conservatism," Reviews in American History. June 2010, Vol. 38, No. 2.

Zenzen, Joan M. Automating the Future: A History of the Automated Manufacturing Research Facility, 1980-1995. Gaithersburg, MD: U.S. Department of Commerce, 2001. 